\title{
AMBIENTE ESCOLAR INFANTIL
}

TATIANA GENTIL MACHADO

DISSERTAÇÃO APRESENTADA À FACULDADE DE ARQUITETURA E URBANISMO DA UNIVERSIDADE DE SÃO PAULO PARA OBTENÇÃO DE TíTULO DE MESTRA.

ÁREA DE CONCENTRAÇÃO PROJETO, ESPAÇO E CULTURA ORIENTADOR PROF. DR. GIORGIO GIORGI JR.

SÃO PAULO 2008 
Autorizo a reprodução e divulgação total ou parcial deste

trabalho, por qualquer meio convencional ou eletrônico,

para fins de estudo e pesquisa, desde que citada a fonte.

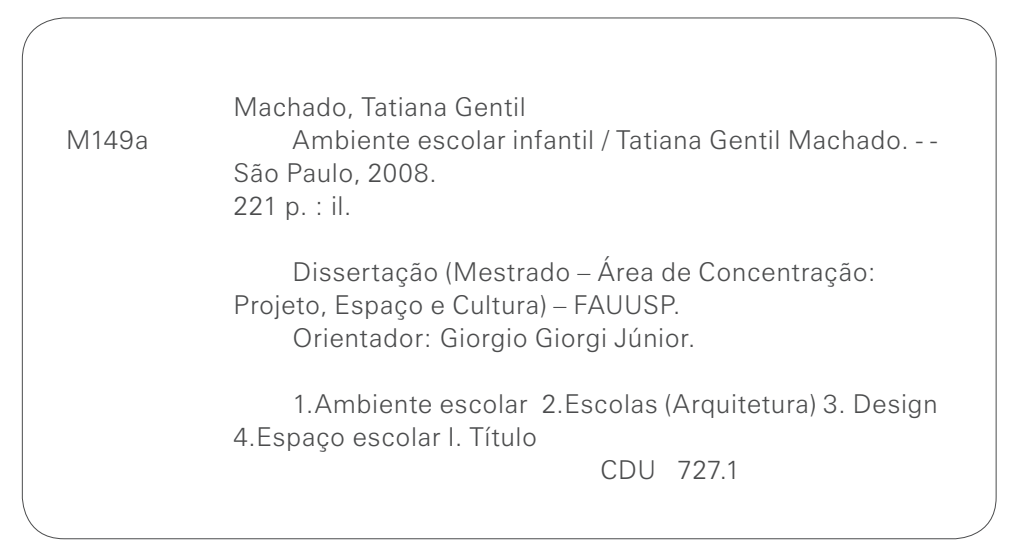




\section{AGRADECIMENTOS}

Agradeço a todos aqueles que dividiram comigo momentos e idéias ao longo de todos esses anos e me fizeram refletir sobre nossas identidades e projetos. A Chico Homem de Melo, Clice Mazzilli, Luís Antônio Jorge e a todos aqueles que me incentivaram a seguir adiante neste projeto; a toda a equipe das escolas que me receberam e a todos com os quais pude expor minhas inquietações sobre o universo enorme e extremamente rico da criança e sobre nossa atuação diante de tudo isso; a Eveline Bouteiller, pela leitura dos textos e pelas sugestões; a Andrea Castro, pela ajuda com as imagens. Especialmente, a Giorgio Giorgi Jr., meu orientador, que sempre me deu força nessa empreitada e me "cutucou" sempre que necessário. Aos meus pais e amigos, que me acompanharam todo esse tempo e me deram suporte para a realização deste trabaIho; aos meus "parceiros" de mestrado, com os quais compartilhei idéias, angústicas, ansidedades e descobertas. E, por fim, a Paulo Mattos, meu companheiro e incansável incentivador de novos desafios e da busca de paixão e sentido nas coisas desse mundo. 



\section{RESUMO}

A temática do Ambiente Escolar para a Infância vem recentemente ganhando mais espaço e tendo reconhecida sua importância na discussão sobre o desenvolvimento infantil. No entanto, as características físicas destes ambientes continuam sendo geralmente negligenciadas no planejamento de espaços infantis coletivos. Atendidas as necessidades mínimas e cumpridas as exigências de segurança, acessibilidade, manutenção, etc., faz-se necessário projetar além da funcionalidade, da praticidade e da usabilidade, concebendo o ambiente não apenas como pano de fundo ou cenário para a interação, mas como estrutura de oportunidades para a aprendizagem. Questiona-se aqui a usual primazia do espaço em detrimento do ambiente, feita tanto por parte de arquitetos como de educadores, entendendo a complexidade como um aspecto fundamental no desenvolvimento de projetos ambientais escolares.

\section{ABSTRACT}

Although the discussion on the significance of School Environment for the child development has gained importance, the physical aspects of these environments are still neglected when they are planned. Once basic needs are supplied and security, accessibility and maintenance demands are fulfilled, environments should be developed not as merely backdrops to children interaction, but as structures of opportunities for the process of learning (taking into account more than functional and practical issues). In this work, the usual supremacy of space over environment (commonly granted by architects as much as by educators) is called in question, while the concept of complexity is presented as an essential aspect on the development of school environment projects. 
Criança e a idéia de infância

A idéia de escola infantil: conquistas e descompassos

Educação infantil e os desafios de hoje

\section{CAP 2. CRIANÇA, DESENVOLVIMENTO E PROJETO DE AMBIENTES}

A criança e seu desenvolvimento

Espaço, ambiente e percepção ambiental

Percepção ambiental e meio ambiente percebido

Ambiente percebido e qualidade ambiental

Percepção e compreensão do ambiente

Legibilidade e complexidade

Complexidade ambiental e projeto de ambientes

Considerações finais

CAP 3. EDUCAÇÃO INFANTIL: PROJETOS E EXPERIÊNCIAS ESCOLARES FORA DO BRASIL

O projeto para a escola Delftse Montessorischool (Holanda)

A experiência das escolas infantis municipais de Reggio Emilia (Itália)

89

CAP4. EDUCAÇÃO INFANTIL: PROJETOS E EXPERIÊNCIAS ESCOLARES NO BRASIL

A experiência da Escola Viva

O projeto da Escola Infantil do Colégio Santa Cruz

O projeto de escolas infantis da Pedagogia Waldorf

197 CAP 5. AMBIENTE ESCOLAR INFANTIL: ESTRUTURAÇ̃̃O DE OPORTUNIDADES PARA O DESENVOLVIMENTO DA CRIANÇA

218 CRÉDITOS DAS IMAGENS

219 BIBLIOGRAFIA 
Conservare lo spirito dell'infazia

Dentro di sé per tutta la vita

Vuol dire conservare

La curiosità di conoscere

Il piacere di capire

La voglia di comunicare

BRUNO MUNARI
Produzir espaço não é construção;

\section{é intervenção cultural}

que não está à procura de uma coerência visual, mas

exige uma operação cognitiva para se tornar visibilidade.

LUCRÉCIA FERRARA 


\section{INTRODUÇÃo}

A temática do Ambiente Escolar para a Infância vem recentemente ganhando mais espaço e tendo reconhecida sua importância na discussão sobre o desenvolvimento infantil. No entanto, as características físicas destes ambientes continuam sendo geralmente negligenciadas no planejamento de espaços infantis coletivos, sejam eles creches, escolas, hospitais, parques e outros.

Podemos observar que existe consciência da importância do papel do ambiente (físico-social) no desenvolvimento infantil tanto por parte dos educadores quanto por parte dos arquitetos e projetistas. No entanto, de um lado, estes desconhecem as especificidades do processo de desenvolvimento da criança, e em que medida e como os elementos do ambiente influenciam a percepção do mesmo por esta, e, de outro, aqueles em geral não têm a dimensão concreta de como o projeto ambiental pode enriquecer as vivências cognitivas, sociais e motoras das mesmas - apenas sabem que este deve ser rico e estimulador.

Não são raros os estudos, teses e dissertações sobre espaços infantis, mas, na realidade, a pesquisa acadêmica pouco tem alimentado a produção concreta dos mesmos. Parece não só haver uma distância entre pesquisa e pro jeto dentro do próprio campo da arquitetura e do design, como também praticamente inexistir o diálogo entre este e o campo da pedagogia.

Grande parte dos textos e discussões existentes acaba ficando restrita às dimensões teóricas e conceituais ou, quando se faz uma tentativa de materializar o discurso, freqüentemente se cai em soluções programáticas, já conhecidas, pouco atentas aos detalhes, à dimensão do conjunto e da relação entre os elementos que constroem um ambiente (arquitetura, mobiliário, equipamentos, e de todas as suas variações).

Muitos são os trabalhos feitos sobre as exigências básicas e ideais de infra-estrutura, conforto, adequação dimensionamento, os estudos sobre a organização espacial dos ambientes (das salas "de aula" principalmente), ou ainda as retomadas e revisões sobre a história da educação infantil e das linhas pedagógicas existentes.

Poucas foram as análises mais aprofundadas sobre experiências concretas (sob o ponto de vista do ambiente escolar propriamente dito) que encontramos. Se os estudos realizados no campo da pedagogia concentram-se principalmente na observação dos programas arquitetônicos, das atividades aí desenvolvidas e dos brinquedos (existência ou não destes e suas tipologias), as análises na área da arquitetura são em geral superficiais, também muitas vezes apenas programáticas, ou fragmentadas, raramente se fazendo uma reflexão sobre os valores, simbologias, conceitos e objetivos por trás do projeto, nem tampouco sobre as relações estabelecidas tanto entre os elementos do ambiente, quanto - e principalmente - entre estes e seus usuários.

Uma vez já conhecidas e destrinchadas as questões técnico-funcionais (ainda que não sejam sempre atendi- 
das), pretendemos, nesta dissertação, abordar o tema do ambiente escolar infantil sob um outro enfoque, o qual, principalmente no Brasil, não nos pareceu ter obtido ainda a atenção merecida. Hoje, se percebe claramente a importância de conceber escolas infantis como espaços estimuladores dos desenvolvimentos afetivo e cognitivo, e não apenas como espaços assistencialistas, voltados para satisfação de necessidades de guarda, higiene e alimentação. Atendidas as necessidades mínimas e cumpridas as exigências de segurança, acessibilidade, manutenção, etc., acreditamos que se faz necessário projetar além da funcionalidade, da praticidade e da usabilidade, concebendo o ambiente não apenas como pano de fundo ou cenário para a interação, mas como estrutura de oportunidades para a aprendizagem.

Como observa Ana Beatriz Goulart', seguindo códigos e legislações seculares, muitos projetos, principalmente na esfera pública, ainda resultam em espaços, cuja pedagogia silenciosa, inscrita em suas paredes, nos ensina a disciplina, a segregação, o controle e a punição. E assim não acolhem nem promovem a autonomia, a criatividade, as múltiplas linguagens, a curiosidade, o imprevisto e a liberdade das crianças e dos adultos.

Diante da realidade atual e das novas demandas que vêm sendo propostas em relação à criança e ao seu papel social na sociedade, faz-se necessário um novo olhar sobre a educação infantil e os espaços e ambientes em que esta acontece.

Este trabalho pretende, então, trazer para discussão alguns projetos e experiências de escolas infantis que de alguma forma apresentaram uma preocupação com o ambiente onde suas propostas pedagógicas se realizam, a fim de aprofundar a reflexão feita sobre a importância e influência deste no processo de desenvolvimento da criança, e extrair destas abordagens, proposições, e elementos concretos de projeto para ambientes escolares infantis. Estruturada em cinco partes, a dissertação, além das análises, traz e amplia as questões intrínsecas ao tema, tanto no campo da arquitetura como no da educação (este em menor profundidade, dada a abordagem proposta e a área em que se insere a pesquisa).

No primeiro capítulo, procuramos situar o trabalho na discussão que vem sendo realizada sobre a idéia de criança e de infância, e sobre os desafios de hoje na educação infantil, a fim de compreender o contexto no qual estamos inseridos e a partir do qual devemos olhar as experiências existentes e conceber as novas posturas de projeto.

No capítulo 2, apresentamos as fundamentações teóricas e conceituais que nos auxiliaram a definir os parâmetros norteadores das análises das escolas. Na primeira parte, procuramos, na condição de arquitetos-designers compreender as especificidades do processo de desenvolvimento da criança, principalmente na fase em que ela se encontra nos grupos aqui estudados (dos 3/4 aos 6 anos de idade), e da relação desta com ambiente. Na segunda parte, buscamos nos estudos sobre percepção visual, semiótica, percepção e cultura, e outras áreas afins, uma complementação às leituras feitas sobre arquitetura e educação, a fim de enriquecer a reflexão sobre o tema, uma vez que, apesar do aumento de produções nessa área, sentimos a ausência do olhar sobre a percepção ambiental e sobre os processos cognitivos na busca da compreensão das inter-relações do homem (da criança, mais especificamente, neste caso) com o ambiente.

Nos dois capítulos seguintes, debruçamo-nos sobre a análise de cinco projetos escolares, dois estrangeiros e três brasileiros - trazendo ainda rapidamente duas outras referências de experiências que resgatam a questão pública para a discussão do ambiente escolar infantil no Brasil.

Feito um recorte temporal - as décadas de 60/70, quando as discussões em torno da figura e da identidade da criança e da sua inserção na sociedade começam a se materializar em propostas concretas, marcando um momento de mudança no panorama do ensino infantil no mundo em geral -, procuramos selecionar algumas experiências, dentre inúmeras outras também significativas, que trouxessem algum tipo de reflexão sobre o tema pesquisado e que apresentassem abordagens e construções
1 FARIA, Ana Beatriz Goulart de.Pedagogia do Lugar: Pequena coleção para colaborar na construção e ocupação dos territórios da infância. In: Territórios da Infância: linguagens, tempos e relações para uma pedagogia para as pequenas. Ana Lúcia Goulart de Faria, Suely Amaral Mello (orgs.). Araraquara, SP: Junqueira\&Marin, 2007, pp.97-117. 
diferentes umas das outras, justamente para alimentar a discussão e ampliar a visão sobre os princípios de concepção e projeto de ambientes escolares.

Inicialmente proposta para o estudo de experiências apenas nacionais, a pesquisa passou a englobar algumas escolas fora do território brasileiro em função da relevância de projetos e experiências que vêm sendo desenvolvidos no mundo, e que vêm, inclusive, influenciando novas propostas pedagógicas e ambientais no Brasil. A seleção das escolas também levou em consideração a disponibilidade e a possibilidade e/ou facilidade de acesso a informações e materiais sobre as experiências, muitas vezes difícil de alcançar, ainda que o número de publicações em torno destas questões tenha aumentado nos últimos anos.

No caso das escolas estrangeiras, infelizmente não nos foi possível acompanhar as experiências de perto, o que impossibilitou uma análise mais profunda das mesmas. Todas as reflexões foram então elaboradas a partir de publicações, conversas com arquitetos e pedagogos conhecedores dos projetos, e informações fornecidas pelas próprias instituições. Já às escolas brasileiras pudemos fazer algumas visitas, sendo recebidos mais abertamente em umas e menos em outras - em alguns casos, por exemplo, não pudemos observar os ambientes enquanto estes estavam sendo utilizados pelas crianças.

Por este motivo, resultam diferentes os graus de aprofundamento das análises. Apesar de tais limitações, porém, ainda consideramos importante a apresentação de todas estas experiências a fim de trazer mais elementos para o enriquecimento e a ampliação da discussão sobre o tema.

Além das experiências apresentadas, inúmeras outras poderiam ser mencionadas e trazidas para a discussão, como o trabalho que vem sendo desenvolvido pelo grupo francês NAVIR, principalmente em solo europeu, ou o projeto dos arquitetos Takaharu, Yui Tezuka e Kashiwa Sato para a escola Fuji Kindergarten em Tachikawa, ou o projeto desenvolvido pela arquiteta Ana Beatriz Goulart de Faria para o Centro de Cultura e Educação Infantil (CECEI) da CAASP
(Caixa de Assistência dos Advogados de São Paulo), ou ainda o projeto da escola infantil TeArte, entre muitos outros que apresentam propostas diferenciadas de organização espacial e ambientação, reforçando a necessidade e a importância do desenvolvimento conjunto e participativo de tipologias ambientais que atendam aos interesses das crianças e às suas especificidades. Em função do tempo e/ou das condições disponíveis, porém, não nos foi possível aprofundar suas análises, e optamos por não incluí-las neste trabalho.

Procuramos concentrar o foco das análises no ambiente construído e nas relações aí estabelecidas, não fazendo juízo ou qualquer questionamento ideológico ou conceitual sobre as propostas pedagógicas ali colocadas. Além de, como já mencionado, não entrarmos em questões estruturais, de detalhamento técnico, nem tampouco de adequação técnica dos elementos arquitetônicos. Estas devem, sem dúvida, ser avaliadas em qualquer situação, porém, neste trabalho, pretendemos apresentar outros critérios de análise e discussão sobre projeto, que devem ser complementares aos funcionais, ergonômicos e de segurança.

Por fim, no último capítulo, retomamos as experiências apresentadas por meio de diagramas de referências perceptivas, os quais servem de ponto de partida para uma reflexão final mais abrangente sobre o ambiente escolar infantil de forma geral.

Apesar de a maior parte das escolas analisadas pertencer à rede privada de ensino, pretendemos que as reflexões aqui colocadas se ampliem para todo e qualquer projeto de ambiente educativo. Não podemos nos furtar, especialmente no Brasil, de pensar a questão pública e buscar melhorar a qualidade tanto de nossas escolas quanto das políticas públicas voltadas para estas.

De forma alguma pretendemos esgotar, neste trabaIho, a discussão das questões referentes ao ambiente escolar infantil, mas, ao menos, chamar a atenção para sua importância e urgência, procurando apresentar alguns pontos iniciais para reflexão. 



\section{CRIANÇA E EDUCAÇÃO INFANTIL}

\section{Criança e a idéia de infância}

A idéia de infância não existe desde sempre, e tampouco da mesma maneira. Durante muito tempo, até praticamente o final do século XIX, as crianças eram tidas como miniaturas dos adultos, constituindo-se historicamente como repositório dos desejos dos mesmos (Bullivant 1997), o que se refletia não só nos brinquedos e móveis destinados a elas, mas, acima de tudo, em sua educação.

"Demorou muito tempo até que se desse conta que as crianças não são homens ou mulheres em dimensões reduzidas - para não falar do tempo que levou até que essa consciência se impusesse também em relação às bonecas. É sabido que mesmo as roupas infantis só muito tardiamente se emanciparam das adultas. Foi o século XIX que levou isso a cabo. (...) Isso se deve mais ao fato de que até o século XIX adentro o bebê era inteiramente desconhecido enquanto ser inteligente e, por outro lado, o adulto constituía para o educador o ideal a cuja semelhança ele pretendia formar a criança" (Benjamin 2002, p.86).

Retomando o percurso da história, estudos apontam

1 FRABBONI, Franco. "A Escola Infantil entre a Cultura da Infância e a Ciência Pedagógica e Didática". In: Qualidade em Educação Infantil, Miguel A. Zabalza, 1998, pp.63 a 92 três momentos principais de mudanças na concepção da infância: primeira identidade, da "criança-adulto" ou a infância negada; segunda identidade, da criança "filho-aluno" ou a infância institucionalizada; e terceira identidade, da criança "sujeito social" ou a infância reencontrada'. Foi somente na segunda metade do século $X X$ que de fato legitimou-se o direito da criança ao conhecimento e à criatividade.

A primeira identidade, considerada o período desde a Idade Media até o início da Idade Moderna, parece não ter apresentado nenhum conceito intencional de educação. A criança, nesse período, uma vez desmamada, deveria tornar-se a "companheira natural do adulto" (Frabboni 1998). Aos sete anos, inclusive, já recebia a carteira de identidade "jurídica" de adulto, pois considerava-se que seu desenvolvimento e "metamorfose" para adulto só seria possível se fosse inserida na sociedade dos adultos precoce e forçosamente.

$\mathrm{Na}$ segunda identidade, com o avanço da Idade Moderna, a infância sofre um processo de redefinição social e cultural, que traz não só uma nova imagem da mesma, como também uma nova experiência desta etapa da vida. Com o surgimento da família moderna, a criança torna-se o centro das atenções e o símbolo das necessidades que precisam ser atendidas e devido às quais a própria família constitui-se como tal: afetividade, cuidados, reconhecimento, continuidade. A família, assim, aos pou cos, assume uma função moral e espiritual, e a nova mora impõe dar aos filhos uma educação e prepará-los para a vida. A criança, assim, desprende-se da imagem de adulto 
miniaturizado, mas ainda se encontra inserida e manipulada por duas instituições: a família e a escola. Ainda nesse momento the é negada a possibilidade de autonomia, e sua infância agora passa a ser institucionalizada.

Então, é só na terceira identidade, que segue até os dias de hoje, que a criança começa a se constituir como figura social, e como sujeito de direitos. Esta mudança é possível somente na medida em que escola e família são capazes de se "desinstitucionalizarem" e de quebrarem o isolamento existente entre ambas e em relação à realidade existente (Frabboni 1998).

Se, em um primeiro momento, foram fatores como a rápida industrialização, o trabalho infantil e o moralismo da classe média que constituíram as razões para o início de uma transformação da concepção e da atenção voltada à criança, ao longo do tempo estes foram sendo substituídos por uma crescente preocupação com a infância propriamente dita, o que pode ser constatado com o surgimento de inúmeras pesquisas em torno do processo de desenvolvimento da criança e de suas especificidades, transformando-as em objeto pedagógico.

A história da criança de marginalização social, cultura e, inclusive, educativa, em que esta não podia viver em um mundo próprio, nem tampouco integrar-se ao mundo ao seu redor, começa, então, a dar sinal de transformação nessas últimas décadas, quando se tem buscado criar as condições necessárias para que se possa alcançar o pleno desenvolvimento pessoal de cada criança individualmente.

Além de sujeito de direitos, a criança passa a ser vista também como ser "competente" (Frabboni 1998), portador de vivências e competências diversas, e não mais um ser incompleto a ser completado com os conhecimentos científicos que o adulto possui.

A criança não deve ser mais vista como "aluno", mas sim como sujeito social produtor de cultura, e a escola infantil, conseqüentemente, não deve "construir novas aprendizagens", mas "enriquecer os âmbitos da experiência" da mesma, tirando proveito do repertório de recursos com os quais os indivíduos têm acesso ao ensino, à apren- dizagem, e utilizá-los para completar o seu leque de experiências (Zabalza 1998).

Podemos perceber, então, como a idéia de infância é dinâmica, se transforma e cada vez mais ganha relevância social. Porém, como ela antecede a idade adulta, do ponto de vista do tempo cronológico, acaba gerando uma interpretação dúbia, o que produz uma confusão entre a natureza biológica e o papel social ocupado pela criança nas diferentes culturas. Se, por um lado, a idéia de criança se explica pelo período cronológico precedente à idade adulta, por outro, a infância está permeada de significações ideológicas que determinam o seu papel na sociedade em que vive. A idéia de infância só tem sentido, portanto, se percebida de acordo com as relações de produção da sociedade em determinada época. Logo, não se pode mais tratar a criança como um ser desprezível e de pouca idade, mas como alguém em desenvolvimento, que vive em um determinado contexto e contribui para a cultura de sua época (Carneiro s/d).

\section{A idéia de escola infantil: conquistas e descompassos}

Ao longo de todo esse tempo, como conseqüência das transformações sociais, culturais e econômicas, pedagogos, psicólogos, intelectuais e pensadores da educação de forma geral procuraram rever as propostas de ensino e seus instrumentos de forma a, cada vez mais, defender uma educação direcionada especificamente à criança e ao universo infantil que lhe é próprio.

Em meados do século XIX, quando inicia-se um processo de reconhecimento da criança não mais como um pequeno adulto, mas como um indivíduo em desenvolvimento, com suas especificidades, Fröebel ${ }^{2}$ introduz a brincadeira no contexto infantil com a proposta de criação dos jardins de infância (que influencia a educação infantil de todos os países). Ali, predominariam atividades práticas auto-geradas pelos interesses e desejos das crianças (acompanhadas pelas professoras "jardineiras"), dado o
2 Friedrich Fröbel foi um pedagogo alemão, cujas idéias reformularam a educação. A essência de sua pedagogia eram as idéias de atividade e liberdade. Em 1837, Fröbel abriu o primeiro jardim de infância, onde as crianças eram consideradas como plantinhas de um jardim, do qual o professor seria o jardineiro. A criança se expressaria através das atividades de percepção sensorial, da linguagem e do brinquedo. A linguagem oral se associaria à natureza e à vida. 
${ }^{3}$ Ainda que apontando novos rumos na educação, a própria pedagogia não menciona o espaço como um elemento didático, concentrando suas observações basicamente sobre mobiliário e brinquedos. Algumas pesquisas apontam a influência do espaço no comportamento humano, porém poucas são as análises e relações estabelecidas diretamente entre espaço e aprendizagem. poder de criar que Fröebel defendia como sendo inato à criança. Fröebel acreditava que o brincar deveria ser uma atividade livre e espontânea da criança, e exerceu um importante papel naquele momento ao apontar aquele como uma "atividade" responsável pelo desenvolvimento físico, moral e cognitivo da criança.

Na virada do século XIX para o XX, Maria Montessori traz uma nova maneira de olhar a criança, propondo um novo conceito de educação: uma educação "para a liberdade". O jardim de infância passa a ser a "casa das crianças", onde se busca principalmente desenvolver a autonomia e a responsabilidade das mesmas. Enfatizando o aspecto biológico do crescimento e do desenvolvimento infantil, sua grande marca foi a criação de materiais voltados à exploração sensorial pelas crianças, além da exigência de adaptação do mobiliário usado nas pré-escolas à dimensão das crianças (e da miniaturização dos objetos domésticos cotidianos para que fossem usados na casinha de boneca).

A partir de então, ao longo do século $X X$, foram elaboradas inúmeras teorias, linhas pedagógicas e propostas de ensino, cada qual introduzindo novos conceitos e novas idéias sobre os elementos constituintes ou influenciadores do desenvolvimento infantil. John Dewey foi o primeiro apontar a importância do contexto sociocultural e do ambiente educativo para o processo de aprendizagem. Vygotsky retomou e importância da brincadeira apontada por Fröebel, complementando-o com a idéia do jogo, sempre com o suporte do adulto. Piaget, um dos pensadores mais referidos pelas escolas em geral, pesquisou e definiu as fases de desenvolvimento da criança, apontando a relevância da experiência através do próprio corpo nesse processo. A pedagogia Waldorf trouxe a aproximação com a natureza, dando ênfase às artes e às atividades práticas e sensoriais. A.S. Neill, com as escolas democráticas (Summerhill foi a primeira delas), criou a idéia de espaços com multi-atividades. Mais recentemente, após a Segunda Guerra Mundial, Freinet trouxe a importância das oficinas, ateliês, jornais, etc., conhecida como "pedagogia do traba-
Iho". High Scope, uma proposta americana dos anos 60 criou as salas com divisão por áreas de interesse, levada pela idéia de learn by doing. Na década de 70, Malaguzzi, na Itália, reforçou o conceito de "conhecimento como prática", procurando fazer da escola um laboratório de experimentação. Howard Gardner, de certa forma dialogando com o princípio de "cem linguagens da criança" de Malaguzzi aponta as "múltiplas inteligências" da mesma, talvez uma das mais recentes referências das novas propostas pedagógicas que vêm sendo colocadas nos últimos anos.

Inúmeras e extremamente significativas foram as mudanças na maneira de entender a criança, seu desenvolvimento e o processo educativo, como já apontado acima (sobre as etapas da infância). Não pretendemos aqui traçar um panorama dos estudos, propostas e experiências realizadas ao longo da história, nem tampouco apontar a maior ou menor importância de qualquer uma delas (as citações acima são apenas uma retomada rápida e superficial de algumas das correntes que marcaram e marcam até hoje a história da educação infantil de forma geral). Uma revisão destas, no entanto, é importante para se observar que ainda que a criança tivesse passado a ser vista sob uma nova ótica, e que algumas propostas pedagógicas introduzissem a importância do conhecimento por meio da prática e da experiência e da experimentação, sempre houve um descompasso entre estas e os projetos de espaços, ambientes, brinquedos, brincadeiras e mobiliário. Estes demoraram muito tempo para levar em consideração as suas especificidades, constituindo-se por um longo período (até os dias de hoje) não só como miniaturizações de objetos do universo adulto, mas também como concepções inadequadas e mesmo "infantilizadas" da idéia do universo infantil ${ }^{3}$

"Rodeadas por um mundo de gigantes, as crianças criam para si, brincando o pequeno mundo próprio: mas o adulto, que se vê acossado por uma realidade ameaçadora, sem perspectivas de solução, liberta-se dos horrores do real mediante a sua reprodução miniaturizada. A banalização de uma existência insuportável contribuiu considera- 
velmente para o crescente interesse que jogos e livros infantis passaram a despertar após o final da guerra [ $1^{\mathrm{a}} \mathrm{GM}$ ]

Nem todos os novos estímulos direcionados então à indústria de brinquedos foram-lhe úteis. A melindrosa silhueta das figuras laqueadas que, entre tantos produ tos antigos, representam a modernidade, não constitui propriamente nenhuma vantagem para esta; tais figuras caracterizam antes aquilo que o adulto gosta de conceber como brinquedo do que as exigências da criança em relação ao brinquedo. E ao imaginar para crianças bonecas de bétula ou de palha, um berço de vidro ou navios de estanho, os adultos estão na verdade interpretando a seu modo a sensibilidade infantil" (Benjamin 2002, p.85-86).

Somente nas últimas décadas o conceito de projeto para criança começou a ganhar uma nova dimensão, a partir do estudo e entendimento dos processos de percepção e cognição da mesma e das relações que esta estabelece com o ambiente ao seu redor.

Desde a primeira metade do século XX, Walter Benjamin apontava o poder de criação da criança, mas pouco ou quase nada destas reflexões chegavam a se concretizar nos brinquedos e/ou ambientes destinados às crianças: "Hoje talvez se possa esperar uma superação efetiva daquele equívoco básico que acreditava ser a brincadeira da criança determinada pelo conteúdo imaginário do brinquedo, quando, na verdade, dá-se o contrário. criança quer puxar alguma coisa e torna-se cavalo, quer brincar com areia e torna-se padeiro, quer esconder-se e torna-se bandido ou guarda. (...) Se (...) fizermos uma reflexão sobre a criança que brinca, poderemos falar então de uma relação antinômica. De um lado, o fato apresentase da seguinte forma: nada é mais adequado à criança do que irmanar em suas construções os materiais mais heterogêneos - pedras, plastilina, madeira, papel. Por outro lado, ninguém é mais casto em relação aos materiais do que crianças: um simples pedacinho de madeira, uma pi nha ou uma pedrinha reúnem na solidez, no monolitismo de sua matéria, uma exuberância das mais diferentes figuras" (Benjamin 2002, p.93). Colocadas há muito tempo por pensadores e profissionais da educação, apenas agora questões como funcionalidade, ergonomia, conforto, flexibilidade, etc. começam a ser repensadas a partir de novos paradigmas, que requerem uma abordagem interdisciplinar, e que consideram a capacidade e a riqueza de imaginação e transformação, ou recriação, da realidade pela criança.

Portanto, esta nova postura em relação aos projetos direcionados à criança, supõe a visão desta como construtora do seu próprio conhecimento. Se até então as poucas conquistas em relação à infância tinham sido "dadas" à mesma em função de uma maior ou menor sensibilidade dos adultos, agora coloca-se a urgência de considerá-la uma fase essencial ao desenvolvimento da criança, em que esta é um ator ativo, transformador e criador de novos cenários. Isto implica criar oportunidades para que ela possa participar da construção de processos, e a possibilite experimentar, pensar, criar. E, conseqüentemente, significa desenvolver projetos - sejam eles de brinquedos, mobiliário ou espaço e ambiente - que estimulem o envolvimento da criança, levando-Ihe novos desafios e descobertas, deixando "espaço suficientemente pensado para estimular a curiosidade e a imaginação da criança, mas incompleto o bastante para que ela se aproprie e transforme esse espaço através de sua própria ação" (Lima 1989, p.72).

Podemos perceber, portanto, que se colocam hoje novas demandas e novos paradigmas de educação e de projeto para todo e qualquer elemento direcionado à criança. "Não se trata apenas de que a criança seja feliz e esteja sendo cuidada durante esses anos [infância]. Trata-se de fazer justiça ao seu potencial de desenvolvimento durante anos que são cruciais. Ou seja, de colocar em andamento os seus recursos para enriquecê-los, de percorrer com ele um ciclo de desenvolvimento de capacidades e construção de recursos operacionais (...)" (Zabalza 1998, p.20).

Como podemos observar, nada disso é novidade no conjunto de pensamento pedagógico referente à educação infantil. Porém, continuam sendo em relação às práticas cotidianas. O ambiente da escola e de equipamentos 
destinados à criança é um material pedagógico e didático rico para o desenvolvimento global da criança (compreendendo aqui desde a sua dimensão física e funcional, até a dimensão temporal e a relacional), e o grande desafio está em fazer com que seus projetos apreendam "o que é necessário para estimular a iniciativa e a curiosidade da criança, sem querer adiantar-se aos próprios projetos de apropriação da criança" (Lima 1989, p.102)

\section{Educação infantil e os desafios de hoje}

Atualmente, encontramo-nos em um momento em que, mesmo que se trabalhe com um conceito ainda difuso e muitas vezes paternalista de "direito", já começa a ser configurado um mapa de direitos da infância cada vez mais preciso e comprometedor (já desde a última Convenção Internacional sobre os Direitos da Infância, em 1998, são descritos os diferentes compromissos que a sociedade atual deveria assumir em relação à infância, estabelecendo-se o direito da criança a ser educada em condições que permitem alcançar o pleno desenvolvimento pessoal) (Zabalza 1998)

Hoje, exige-se pensar além dos conteúdos formativos da etapa da infância, questionando-se qual a verdadeira contribuição da Educação Infantil para o desenvolvimento do indivíduo como um todo, por completo. Exige-se perceber que a infância não se restringe à fase dos 0 aos 7 anos apenas, e que é essencial que se dê continuidade ao processo de formação da criança quando esta passa da pré-escola para o Ensino Fundamental, tomando-a como ser social e não como "aluno" a ser "preenchido" e "completado".

A continuidade é um grande desafio nos dias de hoje e a Educação Infantil exerce um papel importante nesse processo. Nenhuma proposta de ensino se efetivará com qualidade sem que haja o estabelecimento de alicerces firmes nessa primeira etapa de desenvolvimento. E aí torna-se imprescindível, inclusive, o compromisso do poder público para que esta concepção e a proposta educacional aconteçam de fato.

Nesse novo contexto, a escola infantil deve, então, caminhar para a construção de uma proposta aberta, em diálogo com o seu tempo, com a nova sociedade e com o novo papel social que exerce hoje a criança na comunidade. Deve, antes de mais nada, ser uma escola para a criança (e não para o adulto, como há muito vem sendo), onde se procura trabalhar o desenvolvimento de sua autonomia, identidade, competência, responsabilidade $e$ aprendizagem (aguçar a curiosidade, despertar o gosto pela aprendizagem e o prazer da descoberta, e incentivar a atitude criativa). Por conseguinte, deve ser uma escola aberta a experiências, e à multidimensionalidade e polivalência das áreas formativas. Deve construir formas de integração a partir da pluralidade destes conhecimentos e experiências e, assim, estar em permanente transformação. E deve, ainda, integrar-se à comunidade e à cidade buscando construir o que hoje se coloca como a "cidade educadora". 

CRIANÇA, DESENVOLVIMENTO E PROJETO DE AMBIENTES

Proxêmica é um conceito desenvolvido por Edward T. Hall em seu livro, A dimensão oculta e diz respeito à inter-relação entre observações e teorias do uso que o homem faz do espaço como uma elaboração especializada da cultura.
Diante de todas as questões e novas demandas que vêm sendo colocadas em relação à criança e ao seu papel social na realidade atual, como observamos no capítulo anterior, faz-se necessário um novo olhar sobre a educação infantil e os espaços e ambientes onde esta acontece.

Este trabalho pretende trazer para discussão alguns projetos e experiências de escolas infantis que de alguma forma apresentaram uma preocupação com o ambiente onde suas propostas pedagógicas se realizam, a fim de aprofundar a reflexão sobre a importância e influência deste no processo de desenvolvimento da criança.

Para tal, além de compreender o momento em que nos encontramos, os desafios que estão sendo colocados à educação infantil e os contextos em que estão inseridas as propostas analisadas, procuramos conhecer um pouco (na medida do possível, considerando-se o fato de não constituir exatamente esta a área de interesse desta dissertação) as especificidades do processo de desenvolvimento da criança, principalmente na fase em que ela se encontra nos grupos aqui estudados (dos 3/4 aos 6 anos de idade).

De forma um pouco mais aprofundada, buscamos ainda retomar estudos e reflexões que vêm sendo feitos sobre percepção ambiental, proxêmica', semiótica e outras áreas afins, a fim de complementar a fundamentação da análise das experiências e projetos.
A partir de todos estes entendimentos, não só foram definidos alguns parâmetros para análise e comparação dos estudos de caso, como também foram levantadas questões para uma posterior reflexão mais ampla e abrangente sobre o projeto de ambientes escolares de forma geral.

\section{A criança e seu desenvolvimento}

Inúmeros foram e são os pesquisadores que contribuíram e continuam contribuindo para um melhor entendimento da criança, de suas fases de desenvolvimento e dos elementos influenciadores do mesmo. Porém, nenhum influenciou tanto a Psicologia Evolutiva e foi referência para tantas propostas pedagógicas como Jean Piaget, psicólogo suíço conhecido principalmente por organizar o desenvolvimento cognitivo em uma série de estágios.

"Até Piaget e seus colaboradores realizarem um minucioso estudo do desenvolvimento do pensamento de crianças, do nascimento à adolescência, acreditava-se que algumas percepções, pelo menos, ou uma noção de tempo ou mesmo alguns conceitos poderiam ser inatos. Acompanhando o trabalho de Piaget descobriremos que as crianças só vagarosamente aprendem a reconhecer formatos e tamanhos, enquanto na primeira infância (até 
aproximadamente dezoito meses) nem sequer percebem que os objetos são permanentes" (Beard 1999, p.38).

Dada a importância que este psicólogo exerceu de forma geral no processo de descoberta e entendimento do processo de desenvolvimento da criança, optamos por adotá-lo aqui como referência principal para a compreensão do usuário principal dos ambientes escolares em análise. Isto não significa desconsiderar as demais linhas de pensamento em torno da infância, nem tampouco fecharse para as considerações e descobertas feitas por estas, que, sem dúvida foram igualmente importantes para a compreensão da figura da criança tal como ela acontece hoje. Pelo contrário, ao longo da dissertação, o leitor poderá observar como novas visões da criança são ressaltadas como grandes conquistas para a reflexão e abordagem da mesma, muitas vezes, inclusive, apontando as lacunas da teoria piagetiana. De forma geral, no entanto, pode-se observar que as críticas feitas à sua teoria devem-se mais à rigidez de definição dos estágios de desenvolvimento da criança, e ao seu olhar essencialmente voltado para o crescimento intelectual da mesma, do que propriamente às descobertas e afirmações colocadas por ele. Assim, Piaget continua sendo uma importante referência de base para uma primeira aproximação ao universo da criança $e$ de seu processo de desenvolvimento, e passaremos aqu por alguns conceitos e observações trazidas por ele que consideramos importantes para o estudo das questões colocadas por este trabalho.

Dentre os processos que Piaget considera que servem de base a toda aprendizagem, dois são apontados como essenciais: a adaptação ao ambiente e a organização da experiência por meio de ação, memória, percepções, ou outros tipos de atividades mentais. Mais adiante, veremos como se dá o desenvolvimento destas capacidades, mas já podemos ressaltar, a partir da colocação de Piaget, a importância da relação e interação com o ambiente e da vivência de experiências diversas para a formação do indivíduo, especialmente nas suas primeiras fases da vida.
Como já mencionado acima, as crianças não herdam capacidades mentais prontas, mas apenas um modo de reagir ao ambiente. Na busca de adaptar-se ao ambiente, a criança vive e revive experiências, o que faz com que ela comece a desenvolver ações habituais. Essas seqüências bem definidas de ações são denominadas por Piaget como "esquemas", cuja principal característica é ser conjuntos totais organizados e freqüentemente repetidos, que podem ser facilmente reconhecidos entre outros comportamentos diversos e variáveis (Beard 1999, p.40).

A criança pequena tem esquemas só de ações e percepções, mas, com a incorporação de objetos ou experiências novas aos esquemas existentes ("assimilação"), começa a representar uma coisa por outra, empregando palavras e símbolos e, assim, constrói esquemas repre sentacionais. A assimilação, portanto, estende o alcance de um esquema, o qual, em geral, tende a estabilizar a percepção. Para que a criança seja provocada e estimulada a buscar novas maneiras de adaptação e de comportamentos e ações bem-sucedidas, portanto, o meio deve romper o seu equilíbrio através de constantes estimulações, ou diferenças perceptivas. Ou seja, deve apresentar novas informações que coloquem o organismo em estado de alerta (Rapoport 1978, p.172; Pignatari 1977, p.58)

Exceto em crianças muito pequenas, a acomodação (o processo de modificar esquemas para resolver problemas que resultam de experiências novas dentro do ambiente) é um processo ativo que acontece por meio da exploração, indagação, tentativa e erro, realização de experiências ou reflexão. A criança tenta combinações de esquemas ou realiza experiências e procura informações, até chegar a esquemas novos e bem-sucedidos. Assim, cada indivíduo fica adaptado a seu ambiente, desenvolvendo um repertório suficiente para lidar com a rotina comum de acontecimentos. Porém, trata-se de uma adaptação temporária, que se modifica à medida que o ambiente se altera ou que o indivíduo estende o seu raio de ação (Beard 1999, p.42) Por isso, mais uma vez, fica clara a necessidade de pro- 
duzir ou criar oportunidades de modificações no ambiente infantil para que ocorram "desequilíbrios" na rotina e nos esquemas conhecidos, estimulando a busca de novas adaptações e, conseqüentemente, promovendo o desenvolvimento pessoal.

\section{Os principais períodos de desenvolvimento}

Piaget distingue três principais períodos de desenvolvimento: o primeiro é o "período de inteligência sensóriomotora", que se estende do nascimento até o aparecimento de linguagem, durante aproximadamente os dezoito primeiros meses de vida; o segundo, que se estende dessa época até por volta dos onze ou doze anos, consiste na preparação para "operações concretas de classes, relações e números" e sua realização; e o terceiro período, que começa aproximadamente aos doze anos, é o das "operações formais" (Beard 1999; Castro 2000).

Quando falamos de educação infantil, estamos lidando principalmente com crianças na primeira infância e em parte da segunda (até os seis ou sete anos, aproximadamente). São períodos, portanto, essenciais e de fundamental importância para o desenvolvimento de qualquer indivíduo. Após o período de inteligência sensório-motora o primeiro momento do segundo período, dos dezoito meses até por volta dos quatro anos, caracteriza-se por ser um "estádio pré-conceitual". O segundo, dos quatro aos sete anos aproximadamente, já é um "estádio intuitivo". A partir dos sete anos, até a adolescência, entra-se no denominado "período de operações concretas" (Beard 1999). Portanto, por exemplo, para que ocorra um bom desenvolvimento das operações concretas, é fundamental que os estádios pré-conceitual e intuitivo sejam bem explorados e trabalhados.

"Se a ordem dos períodos de desenvolvimento tende a ser constante, a idade em que se atinge um estádio não pode ser absolutamente fixada, pois é sempre relativa ao ambiente, que pode encorajar, atrapalhar, ou mesmo impedir seu aparecimento". Já está comprovado, portanto, por meio de inúmeras pesquisas, que esses desenvolvimentos são em grande parte determinados social e educacionalmente (Beard 1999, pp.62-63, grifos nossos).

Conhecer e compreender quais os processos pelos quais as crianças passam nos primeiros anos de vida é essencial, então, para entender como o ambiente se insere no seu contexto de desenvolvimento. Já sabemos que este, de fato, exerce um papel fundamental no processo de aprendizagem. Resta-nos saber de que maneira esse processo pode ser enriquecido.

A criança entre os $2 / 3$ e os 7 anos de vida (período em que a criança usualmente freqüenta a escola infantil) passa de um estádio pré-conceitual para um estádio intuitivo, vindo de uma fase de forte exploração sensório-motora. Reafirmando a importância, apontada no capítulo anterior, de continuidade do processo de formação da criança - e do ser humano de forma geral -, fica claro que não se deve considerar esses períodos isoladamente, e, portanto, ao pensar em projetos de qualquer natureza para a infância, deve-se ter em mente a relevância da contínua experimentação sensorial como mecanismo de descoberta do mundo, e a intrínseca relação desta com o processo de compreensão e reflexão sobre o mesmo.

No estádio intuitivo, há um desenvolvimento da criança que permite que esta comece a apresentar razões para suas ações e a formar alguns conceitos, mas seu pensamento ainda não é operacional, e é dominado por percepções imediatas, que variam conforme a situação e contexto (Beard 1999). Os estímulos e desafios colocados a ela, então, devem buscar um equilíbrio entre o conhecido/habitual e o desconhecido, levando, por um lado, a sensação de segurança e de conforto e, por outro, criando expectativas e provocando a curiosidade por novas descobertas. Criando rotinas e, ao mesmo tempo, quebrando a sua monotonia.

Pode-se observar o começo do pensamento conceitual, quando começam a imitar a realidade (ao invés de usar uma coisa para representar outra em fantasia) e a 
transferir os conceitos do mundo e de causalidade física de si própria para os objetos. Nesse contexto, o papel do ambiente é, então, o de proporcionar possibilidades de aumento de repertório, permitindo assim o desenvolvimento do conhecimento, do vocabulário e da compreensão da relação entre as coisas.

Na ausência de operações mentais, mas em meio ao processo de desenvolvimento das mesmas, as crianças dependem de julgamentos perceptuais. Por esse motivo, os processos perceptivos são essenciais nessa fase de vida e fundamentais para a formação o indivíduo como um todo. Estes devem, portanto, ser constantemente estimulados, introduzindo-se, inclusive, sempre novos desafios perceptivos para que não ocorra a estagnação dos esquemas, como já observado anteriormente ${ }^{2}$.

\section{Espaço, ambiente e percepção ambiental}

Estando constatadas a influência do ambiente e a importância dos processos perceptivos no processo de desenvolvimento da criança, principalmente nos primeiros anos de vida, quando a exploração sensório-motora é um mecanismo de apreensão do mundo e de construção da sua compreensão, faz-se necessário refletir sobre quais e como variáveis deste ambiente podem contribuir para um maior ou menor enriquecimento deste processo. Para isso, recorreu-se a estudos nas áreas de percepção ambiental, proxêmica, semiótica e outras afins, a partir dos quais foi possível compreender algumas questões referentes às relações de interação entre o homem e o ambiente.

Antes de iniciar a discussão sobre processos perceptivos propriamente ditos, cabe aqui esclarecer os conceitos de espaço e ambiente e a razão de se optar pelo uso do termo "ambiente" ("ambiente escolar") como um conceito mais abrangente, que engloba a própria idéia de espaço.

Muitas são as pesquisas e discussões em torno de "espaço" e "ambiente", nas mais diversas áreas, como filosofia, psicologia, antropologia, geografia, arquitetura, etc. e, em conseqüência, diversas são as concepções apresentadas.

Freqüentemente, pode-se observar que o termo "espaço" refere-se a algo físico apenas, impessoal e existindo independentemente de qualquer interação. É importante observar, porém, que este está no coração do ambiente construído, constituindo-se como uma extensão tridimensional do mundo que nos cerca: intervalos, relações entre pessoas, entre pessoas e coisas e entre coisas. O espaço físico, os equipamentos, mobiliários e objetos em geral constituem o grande suporte para que as pessoas se relacionem e qualifiquem o espaço, fazendo-o adquirir a condição de ambiente (Mazzilli 2003, p.43). A idéia de espaço como vazio, como volume ou caixa, portanto, é apenas uma abstração, e todo espaço organizado ou construído é mediado, qualificado, completado ou alterado pela relação que nele estabelece o indivíduo consigo próprio ou com outros indivíduos (Mayumi 1989, p.14).

Sendo assim, ao se adotar aqui o termo "ambiente", trabalhamos não só com a idéia de espaço, mas com o conceito de uma estrutura espacial (e não apenas um conjunto de elementos unidos ao acaso) qualificada pelo uso. Ou seja, um arranjo de significados e uma dimensão do próprio homem.

Se, então, toda organização espacial expressa qualidades de sensação, as quais, por meio de um processo de filtragem (em função de um dado repertório), são transformadas em informação e significado, ao projetar qualquer ambiente, deve-se ter conhecimento de como se dão tais relações de interação entre homem e ambiente ${ }^{3}$ a fim de compreender até que ponto e de que forma o meio ambiente físico influencia o comportamento daquele.

Neste capítulo, procuraremos esclarecer como se dá este processo, desde a percepção do ambiente pelo homem, até a compreensão do mesmo e a construção de esquemas cognitivos e mapas mentais (que explicaremos a seguir). Tendo como foco da pesquisa especificamente o ambiente escolar, buscaremos apontar em que medida se dá a relação entre cognição e experiência sensorial,
${ }^{2}$ Cabe aqui observar, como veremos adiante, a importância do equilíbrio entre homeostase e tensão de estímulos, que deve constituir o processo de percepção (Rapoport 1978, p.172; Pignatari 1977, p.58), assim como do diálogo entre estes estímulos e a curiosidade ilimitada das crianças. Ao mesmo tempo em que a estimulação da criança é fundamental para o seu processo de desenvolvimento, o hábito faz-se necessário para que se estabeleçam pontos de referência mais estáveis nos quais esta encontra segurança para construir a sua compreensão da realidade. $O$ excesso de estímulos e/ou o excesso de diversificação, desconectividade e imprevisibilidade dos mesmos pode resultar em desconcentração e, conseqüentemente, em não -comunicação, não desencadeando processos de associação e raciocínio.

${ }^{3}$ Lucrécia Ferrara, em seu livro Design em Espaços, 2002, considera o espaço como território interdisciplinar de investigação, pois, segundo ela, sua complexidade demanda interpretações que decorrem da experiência humana tecida e tramada nas filigramas da vivência cotidiana. Dessa forma, não se pode pensar ou interpretar o espaço senão através da experiência cotidiana do homem, no tempo e no espaço. 
monstrando que, de fato, o homem aprende por meio da experiência e que, portanto, o diálogo e a coerência entre ambiente educativo e proposta de ensino são essenciais para a eficiência e a clareza do processo de aprendizagem.

\section{Percepção ambiental e meio ambiente percebido}

Desde a década de 70 já se afirma que o meio ambiente construído é capaz de facilitar ou de inibir comportamentos e ações, chegando inclusive a atuar como catalisador ou como desencadeador de comportamentos latentes (sem nunca poder, no entanto, gerá-los ou determiná-los) (Rapoport 1978, p.43).

Porém, antes que possam ser organizadas em esque-

${ }^{4}$ Nenhum processo de percepção ambiental pode, portanto, ser analisado independentemente da inserção cultural de cada indivíduo, pois esta, por meio de valores, crenças, estruturas soc e formas de entender o mundo, influi fortemente na compreensão e inter-relação entre homemambiente (Rapoport 1978; Hall 2005).

${ }^{5}$ Pignatari trabalha com o conceito de teor ou taxa de informação. Esta é uma propriedade ou potencial dos sinais e está intimamente ligada à idéia de seleção, escolha e discriminação. Na Teoria da Informação e da Comunicação, o que importa, essencialmente, é a medida do conteúdo de informação (a taxa de informação). Esta visão dialoga com a visão apresentada por Rapoport e Hawkes, a ser desenvolvida nos sub-capítulos seguintes.

${ }^{6}$ Consideramos aqui a definição de repertório dada por Pignatari: a soma de experiências e conhecimentos codificados de uma pessoa ou grupo. Segundo ele, a comunicação pressupõe a existência de um repertório e de um código comuns a transmissor e receptor, e o repertório necessita constantemente de informação nova para combater a sua própria tendência entrópica,

ou seja, a sua tendência a estados uniformes. A introdução de signos novos implica o alargamento do repertório e permite reduzir a taxa de redundância do sistema (Pignatari 1977, p.58) mas e avaliadas, as informações precisam ser percebidas. A percepção, portanto, é o mecanismo desencadeador do processo que relaciona os homens com o seu meio ambiente: o homem experimenta ambientes por meio de seus sentidos (Rapoport 1978; Hall 2005), e qualquer informação chega a ele por meio da percepção (o termo percepção vem do latim percipere e significa compreender, dar-se conta [Rapoport 1978, p.171]). De fato, diversas pesquisas realizadas nas últimas décadas apontaram a importância da captação dos estímulos ambientais pelos sentidos no processo de percepção e compreensão do es-

Portanto, como afirma Rapoport, quando trabalhamos com seres humanos como indivíduos, devemos dar grande atenção à sua capacidade sensorial, pois é por meio destas vias (os sentidos) que os homens, como usuários ativos e exploradores do meio, o percebem e lhe dão significado (constituem-se em vias de percepção, de uso e de compreensão ou interpretação).

Como pudemos ver no início deste capítulo, mais atenção ainda se deve dar à capacidade sensorial das crianças pequenas (até 6/7 anos), uma vez que estas, ainda não tendo desenvolvido por completo as operações concretas, e o processo de abstração, relacionam-se com o mundo e paço e do ambiente. apreendem a realidade fundamentalmente por meio da exploração sensorial.

No entanto, apesar de a percepção ser um dos primeiros processos de interação entre o indivíduo e o seu ambiente, e a sua experiência mais imediata, não se trata de um processo passivo. Os efeitos do meio ambiente são sempre mediados por filtros, pois "os homens e os grupos humanos (...) só absorvem a informação de que sentem necessidade e/ou que lhes seja inteligível" (Pignatari 1977, p.12). A percepção é um processo ativo no qual o indivíduo transforma os estímulos potenciais em efetivos (Rapoport 1978), em que as mensagens interagem com aquele que as percebe, em função das suas motivações, expectativas, conhecimentos e hipóteses (Rapoport 1978; Hall 2005; Ferrara 2002).

Apesar de as pessoas verem o mundo de um modo mais ou menos equivalente (Rapoport 1978), estruturamno e avaliam-no de formas muito diferentes ${ }^{4}$, pois "não é a quantidade de informação emitida que é importante para a ação, mas antes a quantidade de informação capaz de penetrar o suficiente num dispositivo de armazenamento e comunicação, de modo a servir como gatilho para a ação" (Norbert Wiener apud Pignatari 1977, grifos nossos) ${ }^{5}$.

Processo perceptivo e produto percebido, portanto, são diferentes: enquanto a percepção ambiental é uma propriedade mental, o meio ambiente percebido é algo que supõe "a superfície total a partir da qual as decisões vão se definindo e que incluem elementos naturais e arti ficiais, reais e irreais, geográficos, políticos, econômicos e sociológicos" (Brookfield 1969, p.53 apud Rapoport 1978, p.43). Um único processo de percepção ambiental pode conduzir a produtos diferentes ou a meio percebidos dis tintos, o que nos leva a deduzir que é o ambiente percebido que constitui o espaço de ação do indivíduo (e não o ambiente construído), pois só o que se percebe pode ser objeto de oportunidades para atuar (Rapoport 1978, p.43)

Todo e qualquer projeto de ambientes deve necessariamente trabalhar com a dimensão de repertório ${ }^{6}$ do público ao qual se destina. A análise da percepção do meio 
ambiente é importante porque introduz variabilidades culturais e pessoais e modifica a noção de um ambiente único com características imutáveis ${ }^{7}$. Ao considerar o meio ambiente como uma forma de comunicação não-verbal deve-se atentar para as duas dimensões aí envolvidas: de um lado, o ambiente construído constitui-se um instrumento de análise para compreensão de seu(s) usuário(s) com seus diferentes códigos e valores; de outro, deve ser projetado com a consciência de que meio ambiente percebido é muito diferente em função de quem o percebe: diferentes grupos de usuários podem elaborar (mentalmente) meios ambientes perceptivos distintos, assim como projetistas muitas vezes percebem os ambientes de forma diferente daqueles que não o são.

\section{Ambiente percebido e qualidade ambiental}

Ao partir da idéia de ambiente percebido, e de que a percepção de um ambiente não é única e apresenta uma variabilidade cultural e pessoal, deve-se conseqüentemente considerar variáve/ o conceito de qualidade ambiental assim como se deve colocar em discussão a relação estrita entre função e uso. Sendo os processos de percepção, cognição e avaliação pessoais e individuais, não se pode projetar qualquer ambiente de forma a determinar usos e funções, e, sim, deve-se estabelecer o diálogo com o(s) usuário(s), abrindo possibilidades de uso dentro de um sistema de linguagens conhecido.

No entanto, apesar de a noção de qualidade de um ambiente variar segundo cada indivíduo ${ }^{8}$, é possível isola certas características físicas que resultam em maior diversidade e riqueza ambiental (independente do contexto cultural), e levantar parâmetros de comparação entre ambientes, de forma a analisar e compreender suas estruturas e relações e em que medida e de que maneira estas afetam o comportamento de seus usuários ${ }^{9}$
O presente trabalho se propõe, portanto, a explicitar a importância da influência destes sobre as pessoas, mostrando as suas variáveis e como a definição dos elementos e da inter-relação estabelecida entre os mesmos resulta em meios mais ou menos complexos e ricos (os conceitos que serão expostos e discutidos ao longo deste capítulo).

\section{Percepção e compreensão do ambiente}

Apesar de o processo de percepção-cognição-avaliação ambiental variar com a cultura e as experiências e expectativas pessoais de cada indivíduo, sua estrutura essencia tende a ser universal (Rapoport 1978). Portanto, a fim de entender como se dá o processo de inter-relação entre ambiente e usuário, podemos trabalhar a partir do conhecimento de funcionamento deste processo, sua natureza e suas características

"A percepção ambiental é a experiência sensitiva mais direta e imediata do meio ambiente e, ainda que influenciada pela memória e pela cognição, é tão independente quanto possa sê-lo. Sempre se relaciona com a ação, é multimodal e diz respeito a todo o meio, não só a partes dele" (Rapoport 1978, p.172)

Talvez exatamente por ser a experiência mais direta e imediata, a percepção ambiental nem sempre é um processo consciente. Na verdade, a maior parte dos dados não é recebida conscientemente por nós, porém, a informação que não se seleciona também se recebe e se classifica, afetando as pessoas além da consciência (Rapoport e Hawkes 1970; Rapoport 1978, p.172), pois, além do sistema nervoso consciente, que processa apenas os dados selecionados (por meio de filtros), apresentamos o sistema nervoso subliminar, mais primitivo, o qual percebe todo o estímulo.

Se é pela percepção subliminar que percebemos as coisas fora dos esquemas cognitivos sedimentados (Rapoport 1978), portanto ela é essencial para explicar a
Cultura, experiência pessoal e aprendizagem afetam o significado da informação fornecida por objetos e eventos (Rapoport e Hawkes 1970).

${ }^{8}$ Pois pressupõe um juízo de valor, intrinsecamente ligado ao repertório (cultural, social, pessoal).

${ }^{9}$ Apesar de fatores pessoais e culturais afetarem a percepção do espaço, estes podem apenas modificar a informação que o ambiente físico fornece a todos (Rapoport e Hawkes 1970). 
${ }^{10}$ A definição de esquema é dada por Rapoport, no livro Aspectos humanos de la forma urbana, 1978. Segundo ele, conhecer implica usar esquemas, noções, etc., os quais são muito variáveis conforme a cultura. A noção de esquema imaginativo (schemata) também é importante na psicologia do desenvolvimento de Piaget (apud Rapoport 1978), que demons-

trou que os esquemas variam de cultura a cultura e que as recordações não se organizam segundo o tempo e o espaço cronológicos, mas seguem esquemas imaginativos - por isso, cada grupo recorda-se de um ponto distinto do mesmo relato. Estes esquemas, portanto, são meios pelos quais o homem organiza o seu comportamento presente e são resultado de sua experiência e do ajuste de suas expectativas e predisposições. Os esquemas permitem combinar a memó-

ria com situações atuais para resolver problemas.

11 estado normal do homem é o de uma homeostase entre percepção e cognição, e os estímulos são conscientizados quando saem deste estado como novidade única - com a idade, os esquemas ganham importância, e os estímulos devem apoiar-se neles.

${ }^{13} \mathrm{O}$ conceito de legibilidade foi definido por Kevin Lynch, no seu livro A imagem da cidade, de 1960 como a facilidade com a qual as partes do ambiente urbano podem ser reconhecidas e organizadas em uma estrutura coerente. riqueza do meio ambiente, pois possibilita a captação de informações ricas do meio ambiente que escapam a qualquer representação que poderíamos fazer.

Esta informação é de grande importância para o presente trabalho, uma vez que permite afirmar e reforçar a importância de um ambiente educacional rico em estímulos, pois esta riqueza, ainda que inconsciente em um primeiro momento, possibilita um aumento de repertório que se fará significativo na construção e desenvolvimento pessoal de cada indivíduo.

Em geral, os esquemas ${ }^{10}$ tendem a estabilizar a percepção, fazendo com que, com o tempo, haja uma tendência a acabar em uma percepção totalmente subliminar e homeostática. Por isso, o meio deve romper este equilíbrio por meio de constantes estimulações - diferenças perceptivas - ou seja, deve apresentar novas informações que coloquem o organismo em estado de alerta. A percepção deve, então, constituir-se como uma combinação entre homeostase e tensão, com certos níveis recomendados de novidade (Rapoport 1978, p.172; Pignatari 1977, p.58).

Em crianças bem pequenas, existem pesquisas que apontam a existência de uma percepção de objetos antes da cognição dos mesmos (Bower 1971 apud Rapoport 1978; Beard 1999). Portanto é essencial que seu desenvolvimento seja constante, e, desde o início, enriquecido por meio de estímulos perceptivos diversos e variados, pois estes alimentarão o repertório de cada criança, constituindo material para a construção posterior de seus esquemas ${ }^{11}$.

Por esse motivo, entre outros já apontados, podemos reafirmar a importância e a urgência de se projetar ambientes em que se explora a natureza polivalente da percepcão. O conjunto de sentidos exerce um papel fundamental no processo perceptivo, pois a informação visual sobre a qual as pessoas se apóiam se correlaciona com o som, o odor, o tato, a sinestesia, as correntes de ar e a temperatura. Assim se reforça ou não a percepção visual e se selecionam as informações, esquematizando as diferenças perceptivas (Rapoport 1978, pp.180-185). Todos os sentidos, portanto, contribuem para uma maior riqueza da experiência perceptiva, e daí novamente a necessidade de se trabalhar os ambientes de forma polissensorial.

De forma geral, enquanto se movimenta pelo espaço, o ser humano conta com mensagens recebidas de seu corpo para estabilizar seu mundo visual (Hall 2005). A informação recebida pelos receptores como olhos, ouvidos e nariz, no entanto, desempenha um papel tão importante em nossa vida diária que acabamos não nos dando conta da atuação dos demais receptores (tato, sensações que recebemos pela pele, membranas e músculos) como importantes órgãos dos sentidos. Principalmente nas crianças, os outros sentidos além da visão são muito importantes, podendo se falar inclusive de espaços acústicos, olfativos, táteis, etc. (Hall 1966; Rapoport 1978). Na percepção ambiental, portanto, o emprego de todos os sentidos enriquece a experiência e facilita a compreensão do ambiente. Olfato, mudanças na temperatura, umidade, luz, sombra, textura, cor, etc. devem ser então trabalhados em conjunto, de forma a estimular o uso do corpo inteiro como órgão sensorial.

\section{Legibilidade e complexidade}

Segundo Rapoport, ao mesmo tempo que as pessoas de forma geral desejam entender cognitivamente o meio, também desejam perceber sua riqueza sensorial. A complexidade de um ambiente está justamente neste jogo entre o cognitivo e a sua superação (Rapoport 1978 p.195). Não existe, portanto, contradição entre legibilida $\mathrm{de}^{13}$ e complexidade (Rapoport e Kantor 1970). Estas, na verdade, são complementares e, enquanto a legibilidade depende da cognição, a complexidade depende da percepção (em grandes escalas, a claridade é insubstituível; em pequenas escalas, é a complexidade que não pode deixar de existir [Rapoport 1978]) 
Investigações psicológicas recentes demonstram que os homens (incluindo as crianças) preferem as configurações complexas dentro de seu campo visual. Como já comentado anteriormente, a percepção é dinâmica em si mesma, e, por isso, a mudança de estimulação é importante para que ocorra o processo perceptivo. Porém, tanto o campo excessivamente simples quanto o excessivamente caótico não agradam, e quando a estimulação é excessivamente constante, os ambientes tornam-se indesejados e desfavoráveis à percepção (Rapoport e Hawkes 1970; Rapoport 1978).

A complexidade de um ambiente está, então, relacionada com as variações dentro de uma ordem, ou seja, com as diferenças percebidas ${ }^{14}$. A informação admissível depende dos estímulos que se detectam como variáveis em um sistema de expectativas: são as mudanças nos estímulos que são percebidas, e não os estímulos por si só (Gibson 1968; Rapoport e Hawkes 1970; Rapoport 1978).

A própria idéia de "informação" está ligada à idéia de surpresa, de inesperado, de originalidade. Portanto, quanto menos previsível, ou mais rara, uma mensagem, maior a sua informação. Esta, assim, só começa a existir onde houver um mínimo de diferenciação, pois só pode haver informação onde há dúvida. E dúvida implica existência de alternativas. E, por conseguinte, escolha, seleção, discriminação (Pignatari 1977, pp.45 e 55; Ferrara 2002). A complexidade depende, assim, mais das relações entre os elementos do que dos elementos em si mesmos, e é a variação dentro de uma ordem que deve ser captada (Rapoport e Hawkes 1970; Rapoport 1978, p.199).

Estas constatações sugerem, então, a importância de renovação constante daqueles ambientes freqüentados pelos mesmos usuários de forma rotineira, a fim de que estes não se tornem desinteressantes e desestimulantes (pois apresentarão poucas novidades, ou uma taxa de informação pequena, com o passar do tempo; e o desconhecido tornar-se-á conhecido). Por renovação, entendese aqui transformações, acréscimos e/ou reduções de elementos a partir de uma estrutura já existente, sem que se perca de vista a essência e identidade do lugar e com o cuidado de não promover o excesso ou a escassez de estímulos (que provocam, respectivamente, a perda de referência espacial e o caos ou a monotonia). Este é o caso, por exemplo, de ambientes escolares, onde as crianças (além dos professores, diretores e funcionários em geral) passam boa parte de seus dias, cinco dias por semana.

\section{Complexidade ambiental e projetos de ambientes}

Como pudemos ver até aqui, a complexidade pertence a um processo informativo, fenomenológico e significativo, e caracteriza-se pela polissensorialidade, pela "perceptividade" (pelas diferenças perceptivas) e pela justaposição organizada de grande número de elementos (Rapoport 1978: Mazzilli 2003). Sua criação, portanto, se dá por meio da manipulação da variedade, com base no princípio de construção de expectativas e no jogo de estímulos perceptivos a partir destas (Rapoport e Hawkes, 1970).

O excesso de estimulação ou a escassez da mesma dependem da quantidade e da relação que se estabelece entre os elementos do meio ${ }^{15}$. De forma geral, Rapoport e Hawkes consideram que um nível baixo de informação utilizável deve-se a quatro causas: 1. os elementos não são ambíguos: 2. existe pouca variação entre os elementos; 3. os elementos variam, porém de maneira previsível, não existindo portanto informação; e 4. Os elementos conformam um caos super-estimulante e insignificante (Rapoport e Hawkes 1970).

A fim de evitar tanto a monotonia quanto o caos, tanto a pobreza quanto a saturação de informação, os projetos de ambientes podem, portanto, explorar de forma consciente e estruturada os múltiplos fatores que promovem a complexidade (em função, principalmente, da relação estabelecida entre eles), como diferenças físicas, sociais e temporais: mescla e mudanças de usos e atividades, alternância entre desenhos abertos e fechados, influência da natureza, manipulação de itinerários, jogo de relações
${ }^{14} \mathrm{~A}$ complexidade ambiental foi primeiramente definida em um trabalho desenvolvido por Rapoport em parceria com Ron Hawkes. A definição é baseada no conceito de índice de informação utilizável (informação que é recebida e processada por uma pessoa em qualquer momento), a qual leva em consideração tanto os contextos social e cultural, como a experiência e a aprendizagem.

${ }^{15}$ A percepção da quantidade, da diversificação e da variação dos elementos, por sua vez, está relacionada ao repertório de cada indivíduo, pois, como diz Décio Pignatari (1978), os homens só absorvem a informação que Ihes seja inteligível. 
${ }^{16}$ A noção de informação utilizável, que depende de diferenças perceptíveis e descontinuidades, inevitavelmente sugere que algumas áreas não devem ser complexas, uma vez que a transição de um ambiente simples para um complexo torna-se uma experiência clara e marcada e, portanto, significativa. entre diferentes áreas, exploração de texturas variadas, cores, formas, pesos, sons, odores, luzes, polissensorialidade, entre inúmeros outros já mencionados ao longo desse trabalho.

A redundância, trabalhada em diferentes canais de comunicação (ritmo, padrões de organização, cores, etc.), e mesmo o baixo nível de estimulações em algumas áreas pode também ser importante para a percepção quando o objetivo é reforçar uma mensagem, passar a sensação de segurança ou ainda criar maiores expectativas e mais impactantes surpresas no jogo com outros ambientes. Quanto melhor trabalhado o conjunto, o ritmo e o equilíbrio (que não exclui contrastes) das relações entre seus elementos, da variedade e das variações entre os mesmos, mais se notará a diferença entre as zonas, mesmo que nem todos estes indícios sejam percebidos conscientemente.

Se, então, como apresentado ao longo deste trabalho, a percepção deve constituir-se como uma combinação de homeostase e de tensão, com certos níveis recomendados de novidade ${ }^{16}$ (Rapoport e Hawkes 1970; Rapoport 1978 , p.172: Pignatari 1977, p.58), e a percepção através dos sentidos enriquece a experiência e a memória (Rapoport 1978 , p. 195), pode-se afirmar que qualquer proposta de ambientes deve ter como objetivo o projeto de áreas perceptíveis, tendo em mente que a riqueza de um ambiente e, por conseguinte, a riqueza de uma experiência ambiental estão diretamente relacionadas à sua complexidade. Esta, enfatizada pela diferenciação de seus elementos dentro de uma ordem estabelecida, e pelas transformações de seus usos e atividades ao longo do tempo (variedade a partir do número de elementos discerníveis [Rapoport 1978, p.201]) não é, por sua vez, produto do acaso e, por isso, deve ser projetada e estimulada (a própria possibilidade de intervenções pelos usuários deve ser projetada pelo arquiteto e/ou designer, constituindo-se tanto como uma postura quanto como um partido de projeto).

A seguir, retomaremos, de forma resumida, os pontos e conceitos considerados mais relevantes para o desen- volvimento deste trabalho, os quais nortearão as análises dos ambientes escolares selecionados, definindo alguns parâmetros de comparação entre os mesmos.

\section{Considerações finais}

Podem ser ressaltadas, das colocações feitas ao longo desse capítulo, as seguintes idéias que fundamentarão o desenvolvimento da dissertação de mestrado:

1. O ambiente construído é capaz de facilitar ou de inibir comportamentos e ações, chegando a atuar como catalisador ou como desencadeador de comportamentos latentes (sem nunca poder, no entanto, gerá-los ou determiná-los);

2. O homem experimenta ambientes por meio de seus sentidos (experiência multissensorial), e qualquer informação chega a ele por meio da percepção, o que confirma a importância da captação dos estímulos ambientais pelos sentidos no processo de percepção e compreensão do es paço e do ambiente (pois a percepção enriquece a experiência e a memória).

3. Especificamente com relação ao processo de desenvolvimento da criança, dentre os processos que Piage considera que servem de base à toda aprendizagem, dois são apontados como essenciais: a adaptação ao ambiente e a organização da experiência por meio de ação, memória, percepcões, ou outros tipos de atividades mentais.

4. Ainda especialmente para a criança, é de extrema relevância a continuidade da experimentação sensorial pois este é o seu principal instrumento de descoberta do mundo, sendo intrínseca a relação desta com o processo de compreensão e reflexão sobre o mesmo.

5. O processo de percepção varia com a cultura, mas a sua estrutura essencial tende a ser universal, por isso talvez possamos projetar ambientes a partir do conhecimento das relações de interação entre homem e ambiente, atentando para as questões culturais locais: 
6. Considerando que os processos de percepção, a cognição e a avaliação são pessoais e individuais, não podemos projetar qualquer ambiente de forma a determinar usos e funções, e, sim, devemos estabelecer o diálogo com o(s) usuário(s), abrindo possibilidades de uso dentro de um sistema de linguagens mutuamente compartilhado

7. A complexidade é uma qualidade desejável para ambiente urbano (Rapoport e Hawkes 1970);

8. Apesar de a noção de qualidade de um ambiente variar segundo cada indivíduo, é possível isolar certas características físicas que resultam em maior diversidade e riqueza ambiental (independente do contexto cultural), e levantar parâmetros de comparação entre ambientes, de forma a analisar e compreender suas estruturas e relações e em que medida e de que maneira estas afetam o com portamento de seus usuários.

Abaixo, estão relacionadas as principais considerações que podem nortear todo projeto de ambientes, e que servirão de parâmetros para comparação dos ambientes escolares analisados nessa pesquisa e para uma maior reflexão sobre projetos de ambientes de forma geral:

1. O meio deve romper o equilíbrio a que tendem os esquemas cognitivos mediante constantes estimulações diferencas perceptivas;

2. A criança pequena tem esquemas só de ações e percepções, mas, com a incorporação de objetos ou experiências novas aos esquemas existentes ("assimilação"), constrói esquemas representacionais. Para que a criança seja provocada e estimulada a buscar novas maneiras de adaptação e de comportamentos e ações bem-sucedidas, o meio deve romper o seu equilíbrio. Ou seja, deve apresentar novas informações que coloquem o organismo em estado de alerta (Rapoport 1978, p.172; Pignatari 1977, p.58).

3. Um dos papéis do ambiente é proporcionar possibilidades de aumento de repertório, permitindo assim o desenvolvimento do conhecimento, do vocabulário e da compreensão da relação entre as coisas.
4. O conjunto de sentidos exerce um papel fundamental no processo perceptivo, por isso deve-se explorar a natureza polivalente da percepção.

5. Tanto a estimulação excessiva (campo muito caótico) quanto a escassez da mesma (campo muito simplório) convertem seus ambientes em indesejados e desfavoráveis à percepção:

6. A complexidade está diretamente relacionada com a idéia de expectativas violadas e diferenças perceptíveis ou seja, com as variações dentro de uma ordem (e a percepção deve constituir-se como uma combinação de homeostase e de tensão, com certos níveis recomendados de novidade - são as mudanças de estímulos que são percebidas, e não os estímulos por si só):

7. Em grandes escalas, a claridade (legibilidade) é insubstituível; em pequenas escalas, é a complexidade que não pode deixar de existir (Rapoport 1978):

8. Um nível baixo de informação utilizável se deve a quatro causas: 1 . os elementos não são ambíguos; 2 . existe pouca variação entre os elementos; 3 . os elementos variam, porém de maneira previsível, não existindo portanto informação; e 4. Os elementos conformam um caos super-estimulante e insignificante.

9. A complexidade pode ser criada a partir da exploração estruturada e relacional de/entre:

- variação (dentro de uma ordem)

- polissensorialidade

- polivalência

- ambigüidade

- mistério/surpresa/novidade/ incongruência

que, em termos mais concretos, podem ser trabalhados nos seguintes elementos e relações de projeto:

- organização espacial

- campos visuais (abertos, fechados) ${ }^{17}$

- relação entre domínios público e privado

- relação (mescla) entre usos, funções e atividades

- jogo de (diferenciação) densidades
17 Quanto maior o número de mudanças de direção no campo visual, maior a quantidade de informação significativa disponível. Curvas acentuadas são mais perceptíveis e causam maiores expectativas, portanto, fornecem mais informação utilizável e maior complexidade do que uma série de curvas suaves. Quando a mudança de direção é inclusive um ponto de escolha, o significado da informação ê ainda maior, uma vez que o indivíduo deve observar antes de escolher o caminho correto a seguir, além de poder variar o percurso em outros momentos (Rapoport e Hawkes 1970, p.7) 
- relação entre desenhos abertos e fechados

- interação com a natureza

- sugestão/indução de itinerários

- jogo de relação entre diferentes áreas (e mudança

da quantidade de estímulos e, conseqüentemente, de

informação)

- diversificação de formas, materiais, cores, texturas,

escalas, pesos, luzes, sons, odores, temperaturas

Fica implícita, aqui, a idéia de que a complexidade é fundamental no desenvolvimento de projetos de ambientes, principalmente escolares, a fim de que estes se constituam como ambientes-estruturas de aprendizagem.

$\mathrm{E}$ de que esta complexidade deve ser planejada e projetada

E constantemente revista e re-projetada em função das novas intervenções realizadas por seus usuários ${ }^{18}$, pois, como diz Lucrecia Ferrara, produzir espaço não é construção; é intervenção cultural que não está à procura de uma coerência visual, mas exige uma operação cognitiva para se tornar visibilidade ${ }^{19}$

${ }^{18} \mathrm{~A}$ freqüência destes processos varia de acordo com o contexto e atividade (Rapoport 1978).

19 FERRARA, Lucrecia D'Alessio. Design em Espaços

São Paulo: Edições Rosari, 2002. O conceito de visibilidade, da qual decorre a elaboração reflexiva do dado visual, com a sua transformação em fluxo cognitivo, vem se opor ao de visualidade, que corresponde à simples constatação do visual como dado. 



\section{EDUCAÇÃO INFANTIL \\ PROJETOS E EXPERIÊNCIAS ESCOLARES FORA DO BRASIL}

Ao longo da história, inúmeras foram as propostas pedagógicas colocadas para a infância, e diversos foram os ambientes construídos para o desenvolvimento das mesmas.

No entanto, poucos foram os projetos que pensaram de fato no ambiente como uma estrutura de oportunidades e de possibilidades para o desenvolvimento da criança. Este continua sendo muitas vezes pensado ou trabalhado em contraponto às concepções pedagógicas. Mesmo que a intenção seja promover o aprendizado, com base nas colocações feitas pelos diversos estudos ao longo das últimas décadas, apontando a inter-relação entre desenvolvimento infantil e ambiente, este ainda reflete antigas concepções e ideologias advindas do ensino tradicional.

Muitas das propostas analisadas ao longo da pesquisa - e que não são apresentadas aqui - reduziram ou reduzem suas reflexões sobre novas formas de abordar e trabalhar com a criança a propostas meramente programáticas (número de salas, tipos de ambientes, etc.) ou instrumentais (relação de objetos, materiais, equipamentos, etc.), ou não chegavam/chegam a concretizar os seus discursos no ambiente construído.

Apesar do crescente reconhecimento da importância da influência do ambiente sobre o desenvolvimento da criança, as características físicas deste continuam sendo negligenciadas no planejamento e no projeto de ambien- tes infantis de forma geral, sejam eles escolas, hospitais, parques, etc. Quando não é caracterizado por um alto grau de controle e organização externa, de rotina de comportamentos e de limitações de oportunidades para escolhas pessoais, é, em geral, considerado simplesmente como um cenário ou pano de fundo para a interação e o desenvolvimento das atividades programadas.

Várias são as dimensões implícitas no ambiente escolar e estas se configuram como uma linguagem a ser decifrada. A leitura destas diferentes dimensões se faz necessária, então, não só para a compreensão da instituições educativas, mas também para a reflexão sobre a inter-relação entre homem e ambiente e entre arquitetura, design e educação como construções sociais, culturais e históricas.

Neste capítulo, retomamos experiências a partir das décadas de 60/70, quando as discussões em torno da figura e da identidade da criança e da sua inserção na sociedade começam a se materializar em propostas concretas, marcando um momento de mudança no panorama da ensino infantil no mundo em geral. Foram destacados alguns projetos e experiências considerados importantes referências para a reflexão sobre o ambiente escolar, independentemente da linha de pensamento pedagógico adotada.

Não pretendemos aqui traçar um panorama da história das experiências de ambientes escolares, nem tampouco 
apresentar uma seleção dos projetos mais significativos existentes até hoje. A partir de um recorte temporal, como mencionado acima, buscamos selecionar algumas experiências, dentre inúmeras outras também significativas, que trouxessem algum tipo de reflexão sobre o tema pesquisado e que apresentassem abordagens e construções diferentes umas das outras, justamente para alimentar a discussão e ampliar a visão sobre os princípios de concepção e projeto de ambientes escolares. Levamos também em consideração a disponibilidade e o acesso a informações e materiais sobre as experiências, muitas vezes difícil de alcançar, ainda que o número de publicações em torno destas questões tenha aumentado nos últimos anos.

Em nenhum dos casos, foi possível acompanhar as experiências de perto, o que impossibilitou uma análise mais profunda das mesmas. Todas as reflexões colocadas aqui foram elaboradas a partir de publicações, conversas com arquitetos e pedagogos conhecedores dos projetos, e informações fornecidas pelas próprias instituições. Notar-se-á que os graus de aprofundamento das análises também diferem de uma para outra escola, em função da quantidade e qualidade dos materiais conseguidos para a realização das mesmas. Apesar de tais limitações, ainda consideramos importante a apresentação destas experiências a fim de trazer mais elementos para o enriquecimento e ampliação da discussão sobre o tema.

O primeiro projeto apresentado é o de uma escola montessoriana desenvolvido pelo arquiteto holandês Herman Hertzberger, em Deflt, na Holanda, no início dos anos 60. Como já mencionado nos capítulos anteriores, Maria Montessori, na passagem do século XIX para o século XX, trouxe um novo método pedagógico, que, mais do que um sistema educativo alternativo, estabelecia uma nova visão da criança e de vida. Foi uma das primeiras a ressaltar mais clara e enfaticamente a importância do ambiente arquitetônico no desenvolvimento da infância, conceituando e concretizando esta preocupação no que ela chamou de Prepared Environment (Oldiges 1997, pp.175-182). No projeto analisado neste trabalho, Hertzeberger faz uma leitura da proposta montessoriana, inserindo-a no contexto da época, e interpretando-a a partir do seu modo próprio de conceber a arquitetura. Nesta tentativa de diálogo entre proposta pedagógica e proposta espacial, pode-se observar uma série de reflexões em torno da relação da arquitetura, e do espaço em geral, com o homem, ou com a criança, mais especificamente neste caso.

A segunda análise traz a experiência das escolas municipais de Reggio Emilia, na Itália. Este país tem se destacado pelos diversos estudos e experiências que vem desenvolvendo sobre a infância e a educação infantil. As escolas municipais de Reggio Emilia são uma entre várias outras referências italianas significativas, como as que vêm sendo realizadas em Milão, Modena, Bologna, entre outras, e sua escolha se deve à maior disponibilidade de material publicado e acessível sobre as questões pesquisadas. 

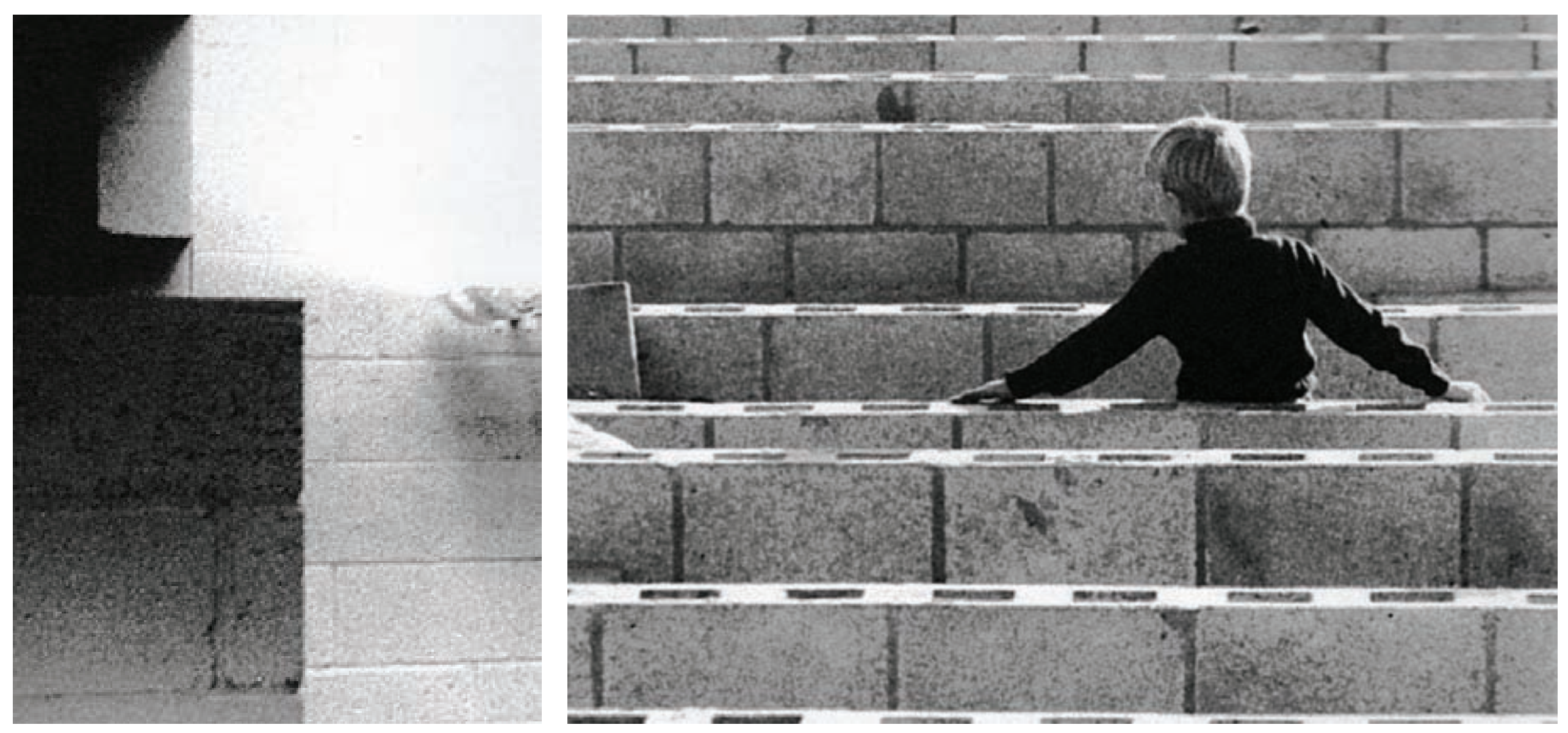


\section{O projeto para a escola Delftse Montessorischool (Holanda)}

As observações e análises desse projeto são feitas a partir de informações pesquisadas em publicações e na internet, uma vez que não nos foi possível visitar a escola e sentir experimentar o espaço e tampouco observar a sua dinâmica e a forma como seus usuários o utilizam.

Portanto, baseando-se em textos do próprio arquiteto e outros críticos, inevitavelmente trabalharemos com informações subjetivas e filtradas, o que impõe limites a uma análise mais consistente e imparcial (no sentido de ser feita diretamente a partir do olhar do pesquisador).

A escassez de informações, fotos e materiais em geral sobre o projeto e a escola também prejudica o trabalho de análise dos mesmos, sendo esta feita, então, a partir do que nos foi possível coletar.

É importante ressaltar ainda que a escola aqui como

Projeto de arquitetura Herman Hertzberger

Local e Ano Delft, Holanda, 1960

Escola analisada educação infantil dos 3 aos 6 anos de idade

Total de crianças sem dados

Total de salas sem dados objeto de estudo insere-se em uma realidade socioeconômica e cultural diferente da encontrada em nosso país enquanto a Holanda encontra-se na $9^{a}$ posição em relação ao Indice de Desenvolvimento Humano e apresenta um PIB per capita de US\$38 mil, o Brasil encontra-se na 70a posição e tem um PIB per capita de US\$11 mil - o que certamente influi na concepção de criança, de educação, na disponibilidade de recursos, e nas condições ambientais e de trabalho (número de crianças por sala, tempo das mesmas na escola, infra-estrutura, etc.).

\section{A proposta da escola}

Projetada por Herman Hertzberger, a escola Delfse Montessorischool segue o método pedagógico montessoriano, cuja proposta principal é uma educação com base no desenvolvimento natural da criança, em que autonomia e responsabilidade são construídas em meio a um processo de progresso gradual e próprio de cada uma.

Partindo da afirmação de que qualquer indivíduo deveria educar e agir por si mesmo - ou nunca mais o faria -, e de que, portanto, deve-se cultivar na criança o desejo próprio de aprender segundo a sua própria escolha (e não obrigá-la a fazer exaustivamente estudos preestabelecidos), a escola baseia sua proposta pedagógica em três fundamentos principais: o "ambiente preparado" (Prepared Environment), os "materiais" e a figura do professor. Estes constituem os elementos essenciais de um "ambiente montessoriano" e são os instrumentos que devem facilitar o desenvolvimento autônomo e natural de cada criança, incentivando a curiosidade e a busca de conhecimento característicos das mesmas. Entende-se que, ajudando a aperfeiçoar seus instrumentos de aprendizagem naturais, sua capacidade será assim maximizada durante as situações de aprendizagem futuras. 
O conceito de "ambiente preparado" traz a idéia de que "a casa das crianças" (como Maria Montessori identificava a escola infantil) é como um laboratório científico, onde as crianças são os cientistas. Daí, o ambiente deve ser bem organizado e ordenado e deve ser também interessante e dinâmico, a fim de encorajar as crianças nas suas buscas.

Já os "materiais" constituem o principal instrumento de trabalho das crianças e dos professores na proposta montessoriana. Segundo esta, toda aprendizagem começa com a experiência concreta, pois Montessori acreditava que as crianças aprendem principalmente com suas mãos, ou seja, fazendo. Cada material, então, isola um conceito particular (por exemplo, comprimento), a fim de que a criança concentre-se em uma única problemática enquanto trabalha ${ }^{1}$ com cada material. Todos os materiais Montessori são auto-corretivos, exigindo um mínimo de intervenção do professor.
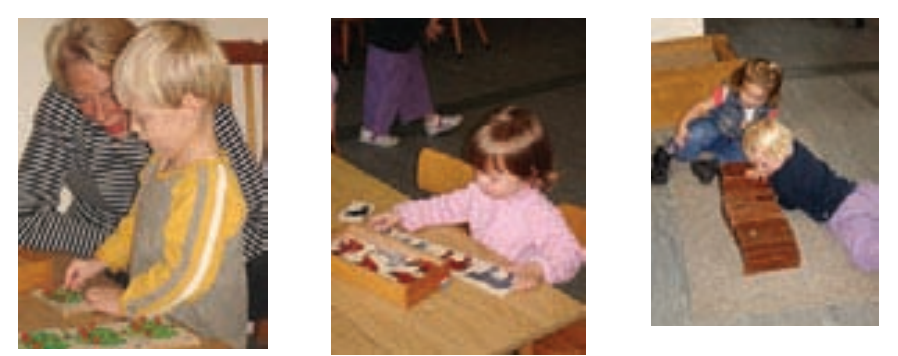

Os "materiais", como são denominados os instrumentos de trabalho das crianças.

O professor deve ser amigável, atencioso e estar sempre disponível para a criança, uma vez que seu papel é o de despertar a curiosidade da mesma e estimular o seu potencial. Até os seis anos de idade, a criança aprende diretamente do contato com seu ambiente, através de todos os sentidos e por meio do movimento: a criança literalmente absorve o que existe no ambiente e, por isso, ao invés de direcioná-la, o professor deve preparar e continuar a adaptar o ambiente de forma a estabelecer uma ligação entre este e a criança, facilitando a exploração deste e a criatividade daquela.

Uma vez que a criança é um "espírito absorvente" (nas palavras de Maria Montessori), a utilização dos materiais está baseada sobre a aptidão única da criança de aprender. Ela aprende tudo sem saber que está aprendendo e, ao fazer isso, passa aos poucos da percepção inconsciente para o pensamento consciente. Montessori acredita que a inteligência é construída a partir de experiências concretas, por meio de movimentos livres, e através dos sentidos, e que esta é um passo vital para o pensamento abstrato.

Ao ter como elementos fundamentais de sua proposta pedagógica e didática o ambiente preparado, os materiais e a figura do professor, o método montessoriano considera indiferente o espaço no qual é implantada a escola. Escolas Montessori podem localizar-se em igrejas, grandes edifícios escolares e até casas: o ambiente físico é secundário em relação à habilidade natural da criança e ao treinamento dos adultos-professores. O projeto analisado neste trabalho, portanto, é quase uma exceção na realidade das escolas montessorianas que, em sua maioria, fazem adaptações de casas com o intuito, inclusive, de criar as novas "casas das crianças".

Por meio da pesquisa sobre outras escolas montessorianas, constatamos que o projeto desenvolvido por Hertzberger, ainda que buscando estabelecer o diálogo com a proposta pedagógica, traz características muito próprias de seu trabalho e do seu conceito de arquitetura. A relevância deste projeto está justamente na postura crítica, colaborativa e construtiva do arquiteto em relação à proposta da escola, o qual parte da compreensão da mesma para não só atender suas necessidades, mas também propor novos olhares, novas soluções e novas maneiras de desenvolver e estender os seus princípios norteadores. Além de garantir a coerência do ambiente escolar, Hertzberger procura reforçar e inovar os seus paradigmas. O projeto, porém, apresenta alguns limites que observaremos a seguir.
1 Montessori sempre se referiu às atividades das crianças como "trabalho" ao invés de jogo, brincadeira com o objetivo de enfatizar a seriedad por trás das mesmas. Segundo ela, o trabalho de desenvolvimento da personalidade de uma criança equivale ao trabalho de um adulto. 


\section{O ambiente escolar}

Uma das idéias de Maria Montessori era a de estimular crianças a aprender oferecendo a elas uma grande gama de escolhas dentro de uma estrutura clara e organizada.

Hertzberger $^{2}$ parece ter cruzado essa idéia com o seu próprio conceito de arquitetura, desenvolvendo todo o projeto a partir da figura do indivíduo - principalmente da criança - como personagem ativo e transformador do espaço que utiliza. Segundo ele, a arquitetura deveria oferecer um incentivo para que os usuários a influenciassem sempre que possível, não apenas para reforçar a sua identidade, mas especialmente para realçar e afirmar a identidade de seus usuários: "deveríamos fazer projetos de tal modo que o resultado não se referisse abertamente a uma meta inequívoca, mas que ainda admitisse a interpretação, para assumir sua identidade pelo uso. O que fazemos deve constituir uma oferta, deve ter a capacidade de provocar, sempre, reações" traçou um paralelo com a cidade, projetando a escola com seus espaços "públicos", "privados" e intermediários ("semi-públicos" ou "semi-privados"). A sala de aula, como já definia Montessori, é a casa, enquanto o hall é a "praça", o espaço coletivo. Entre a casa e a praça, existem os "quintais" ou "vestíbulos", espaços semi-privados onde as crianças podem desenvolver algumas atividades individuais independentemente da dinâmica de suas salas, além de constituírem espaços para exposição dos trabalhos das turmas, criando e demarcando a identidade das mesmas. Segundo Hertzberger, os "intervalos", transições entre áreas com demarcações territoriais divergentes, constituem a condição espacial para o encontro e diálogo entre áreas de ordens diferentes.

As salas de aula, seguindo a idéia de que as crianças devem ser independentemente ativas, devem apresentar a escala correspondente ao tamanho das mesmas ${ }^{3}$. Hertzberger trabalha, então, com pés-direitos baixos (em toda a escola, não apenas nas salas de aula, com exceção
A partir da proposta de "casa das crianças", Hertzberger

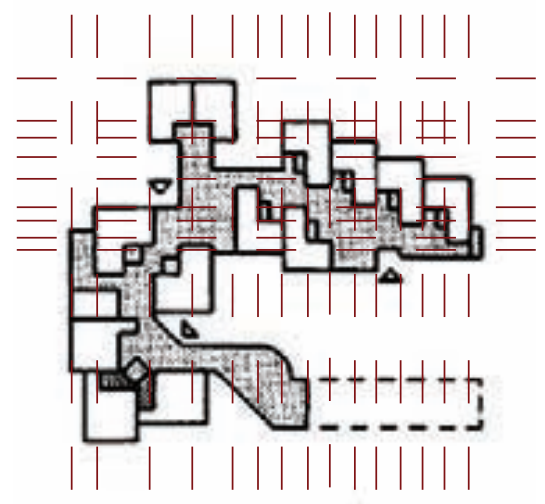

Planta da escola (desatualizada, porém única encontrada), na qual se pode observar a construção da mesma a partir de eixos que são "quebrados" a fim de dar uma maior complexidade ao espaço, criando ambientes de diferentes tamanhos e graus de privacidade.

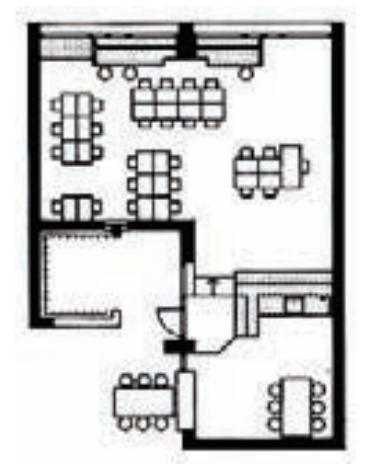

Planta de uma sala de aula padrão, na qual se observa o formato em "L" do ambiente principal, composto com a área de "quintal", "vestíbulo" e abertura para comunicação com a "rua comunitária". 
de algumas áreas, onde há mudança de pé-direito com entrada de luz zenital), e todo o mobiliário da mesma é adequado às dimensões e proporções das crianças (o mobiliário não é projetado pelo arquiteto). Mesas, cadeiras e pias são pequenas, banheiros e seus equipamentos apresentam dimensões reduzidas, carpetes, toalhas e louças também são adaptados para a estatura infantil. Todos os objetos devem ser leves a fim de que a criança mais nova possa carregá-los, e as prateleiras devem ser colocadas em alturas apropriadas para que todas possam alcançálas. Acima de tudo, segundo Montessori, o mobiliário deve ser simples e claro, bonito e harmonioso em traços e cores e deve ser pintado em cores claras. E, por fim, deve ser lavável, não apenas por motivo de higiene, mas com o objetivo de dar à criança a oportunidade de limpá-lo (Montessori observou que crianças demonstravam desde pequenas grande prazer em fazer tarefas de casa, como limpeza, por exemplo)."A casa das crianças deve ser bonita e agradável até o último detalhe, porque a beleza incentiva a atividade e o trabalho"4

O projeto de Hertzberger, no entanto, não engloba o desenho dos mobiliários dentro das salas de aula, os quais, em escolas montessorianas em geral, são produzidos por fornecedores específicos e conhecedores das exigências dessa filosofia. Na escola analisada, porém, estes parecem ter sido comprados de produções industrializadas de mercado, nem sempre seguindo as diretrizes em relação a cores e materiais

Em função das diferentes dinâmicas dentro de cada sala de aula - uma vez que as atividades são escolhidas e desenvolvidas individualmente por cada criança -, estas apresentam diferenças de níveis, além de um formato em "L", possibilitando a realização simultânea de atividades diversas e que requerem diferentes níveis de concentração e ruído, sem prejudicar a visibilidade do professor, que pode manter o olhar sobre todas as crianças ao mesmo tempo (Hertzberger 1996). Parece não haver uma separação em "cantos" específicos (relacionados a atividades específicas), mas todos os materiais são organizados segundo
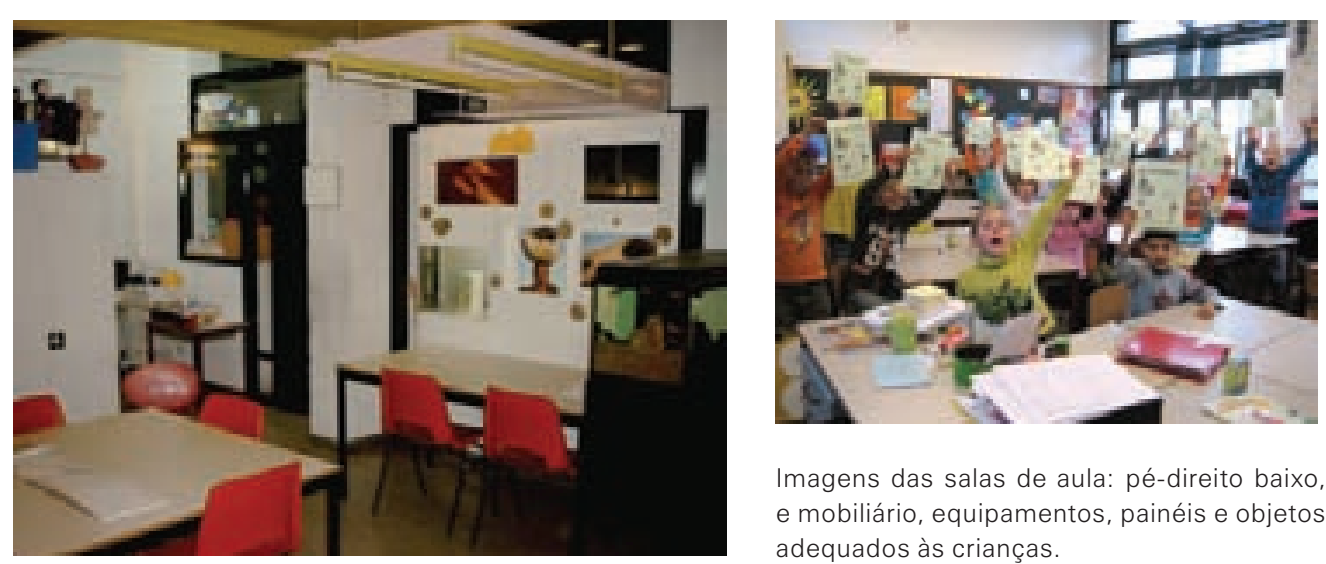

Imagens das salas de aula: pé-direito baixo e mobiliário, equipamentos, painéis e objetos adequados às crianças.

áreas de conhecimento e/ou tipos de atividades. A ordem é um elemento considerado essencial pelo método montessoriano, pois facilita a autonomia da criança, ao permitir que ela localize e reorganize seus elementos: "a ordem estabelecida é benéfica à agilidade mental da criança" (Oldiges 1997, p.180). Portanto, segundo Montessori, um ambiente com poucos elementos e com materiais cuidadosamente escolhidos chama a criança para o trabalho e para a concentração, enquanto um ambiente cheio e caótico pode causar stress e pode dissipar a energia da criança.

Todo o ambiente da escola Montessori é organizado em áreas de assuntos - desde a sala de aula até os espaços da escola como um todo. Se interiormente as salas estão organizadas segundo os materiais, exteriormente, a escola se organiza em áreas de cozinha, limpeza, jardinagem, artes, canto da biblioteca, área dos animais, etc. Ao ter domínio de onde se encontram os materiais para cada atividade, as crianças são sempre livres para mover-se na sala (em vez de ficarem sentadas em cadeiras e mesas), e não há limite de quanto tempo uma criança pode trabalhar em alguma coisa que ela tenha escolhido. Ao longo do dia, em algum momento todos os assuntos (trabalho prático, matemática, linguagem, ciências, história, geografia, artes, música, etc.) serão estudados, em todos os níveis, por crianças de diferentes idades, aprendendo umas com
${ }^{3}$ Nas escolas montessorianas, crianças de 3 a 6 anos convivem em uma mesma classe. Segundo essa proposta pedagógica, a mistura de crianças fornece aos pequenos uma série graduada de modelos de imitação, e aos mais velhos, a oportunidade de reforçar seus próprios conhecimentos ajudando os menores. O mobiliário, portanto, deverá atender todas as crianças entre esta faixa etária.

${ }^{4}$ Montessori 1993 apud Oldiges 1997. 
as outras, facilitadas pela observação e ajuda cuidadosa dos professores e de lições individuais ${ }^{5}$.

A classe Montessori é, portanto, concebida para deixar a criança à vontade, com liberdade em meio a um ambiente organizado com materiais atrativos. Quando não estão sobre mesas e cadeiras, as crianças trabalham sobre pequenos tapetes, onde elas se sentem à vontade. Os materiais de classe utilizados nas atividades podem ser divididos em cinco grupos principais: materiais de vida prática (primeiros exercícios para crianças de 3 a 4 anos); materiais sensoriais (podem ser usados por todas as idades da classe); materiais de matemática; materiais de linguagem e materiais acadêmicos, que atendem ao momento de aprendizagem de ciências, história e geografia.

Como podemos observar, a maior parte dos trabalhos realizados pelas crianças concentra-se no desenvolvimento de atividades direcionadas, que acontecem em áreas específicas e que requerem concentração e foco nos objetos e materiais. Ao sublinhar que a mão sempre foi o principal professor da criança, e que, para aprender, é preciso concentração, sendo a melhor maneira de fazer uma criança concentrar-se e fixar sua atenção em alguma tarefa é fazer com que ela trabalhe com as mãos, o método montessoriano acaba restringindo a experiência das crianças às percepções primordialmente visual e tátil, dando menor ênfase à percepção pelos demais sentidos. Estes, quando instrumentos de aprendizagem (assim como todos os outros concebidos por esta metodologia) são estimulados de forma extremamente direcionada, sendo explorados apenas por meio de recipientes e/ou objetos de estudo. A importância dada ao ambiente por esta linha pedagógica, portanto, fica claramente representada pelo conceito de "ambiente preparado", denominação criada pela própria Montessori, onde os principais elementos didáticos constituem-se de materiais e objetos (cuidadosamente preparados pelos adultos para as crianças) - e não da relação estabelecida e construída a partir da arquitetura, do mobiliário, dos equipamentos, da comunicação visual, e, enfim, de todos os elementos decorrentes destes campos.
Hertzberger procura extrapolar os limites das salas de aula e demais salas de atividades, propondo a expansão das experiências exploratórias para os espaços coletivos da escola. Cria, assim, elementos inusitados nas áreas de hall internas e nos espaços de lazer externos.

Em um dos halls da escola, o ponto central da mesma é demarcado por um podium, um elemento construído a partir de blocos de tijolo, o qual é usado para diversas finalidades, desde assembléias formais até brincadeiras espontâneas. Estando fixo ao piso, sua permanência, imobilidade e o fato de "estar no meio do caminho" constituem a sua essência e o elemento provocador, pois é justamente a sua presença inescapável que contém sugestões e incentivos para respostas em cada situação que aparece.

O bloco torna-se assim um "obstáculo", que deve ser utilizado e transformado de alguma forma a fim de ganhar algum significado. Dessa forma, acaba aumentando a gama de possibilidades de uso do espaço, que deixa de ser apenas um espaço livre. Em cada situação, a plataforma evoca uma imagem particular, e uma vez que ela permite uma variedade de interpretações, pode exercer uma variedade de papéis. As próprias crianças também são estimuladas a exercer uma variedade de papéis nesse espaço, e o fazem, utilizando o bloco ora para sentar, ora para pular, ora para colocar materiais durante aulas de trabalho manual e aulas de música, entre outras coisas.

A plataforma também pode ser estendida em todas as direções por meio de um conjunto de peças de madeira, as quais podem ser retiradas do interior do bloco para transformá-lo em um palco próprio para espetáculos de teatro, dança ou música. As crianças podem fazer isso elas mesmas, sem a ajuda de professores, uma vez que as peças são leves e de fácil encaixe. Durante o recreio, crianças jogam em cima e ao redor do bloco, ou se amontoam ali para ver fotos, etc. Apesar de todo o espaço existente no hall da escola, a maior parte das atividades acaba se desenvolvendo próxima ao bloco. Este torna-se, assim, uma referência e uma marcação significativa. Como diz Hertzberger ${ }^{6}$, é "uma ilha em um mar de espaço de chão brilhante". 


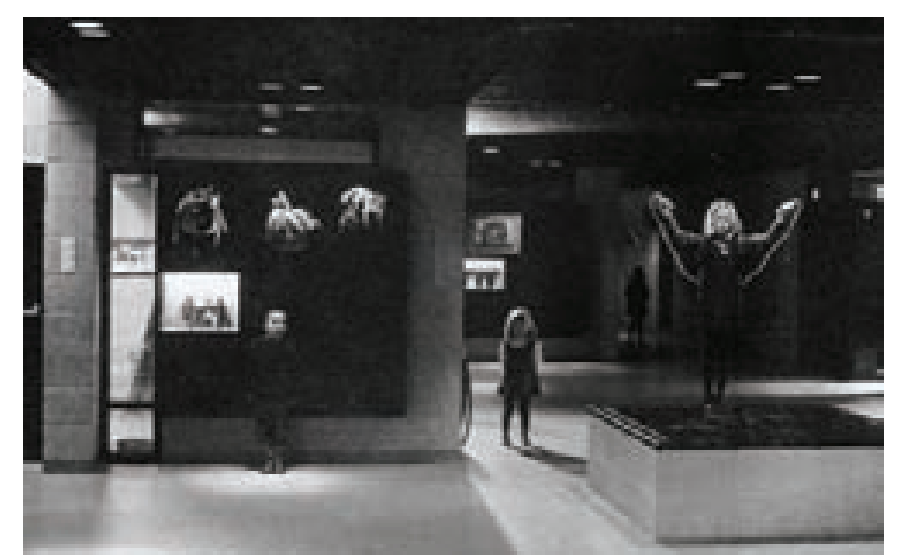

Um dos halls da escola com podium "no meio do caminho", sendo utilizado como palco imaginário por uma criança.

No outro hall da escola, o piso apresenta uma depressão quadrada no meio, a qual é preenchida com blocos de madeira soltos. Estes podem ser retirados e colocados em volta do quadrado para formar um "círculo" de assentos. Os blocos são construídos como pequenos tocos, que podem ser facilmente movidos pelas crianças pelo espaço do hall. Em função de sua forma polivalente, cada um dos blocos pode ser interpretado individualmente como uma cadeira, um banco para sentar ou um bloco para subir, e, se combinado com os demais, pode ser empilhado formando uma torre, ou pode ser usado para construir trens, carros e inúmeras outras coisas. Como se pode observar, o quadrado é o oposto da plataforma de tijolo, no outro hall: enquanto o bloco evoca imagens e associações com escalar uma montanha para se ter uma vista melhor, o quadrado dá uma sensação de segregação, de vácuo, e evoca associações com descida de um vale ou um buraco - se a plataforma é uma ilha no mar, o buraco é um lago, que as crianças transformaram em uma piscina, colocando um trampolim (Hertzberger 1996).
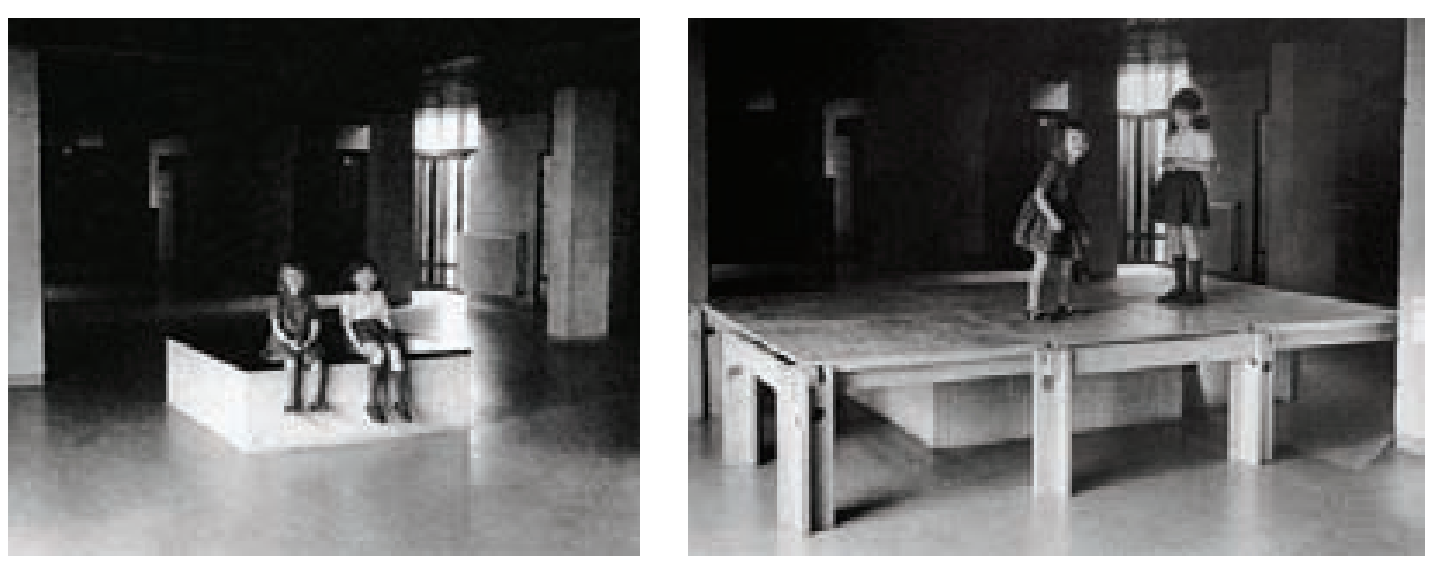

Podium e peças de madeira retiradas de seu interior, sendo utilizadas pelas crianças como um segundo piso.
${ }^{6}$ HERTZBERGER, Herman. Lições de Arquitetura. Trad. Carlos Eduardo Lima Machado. São Paulo: Martins Fontes, 1996 

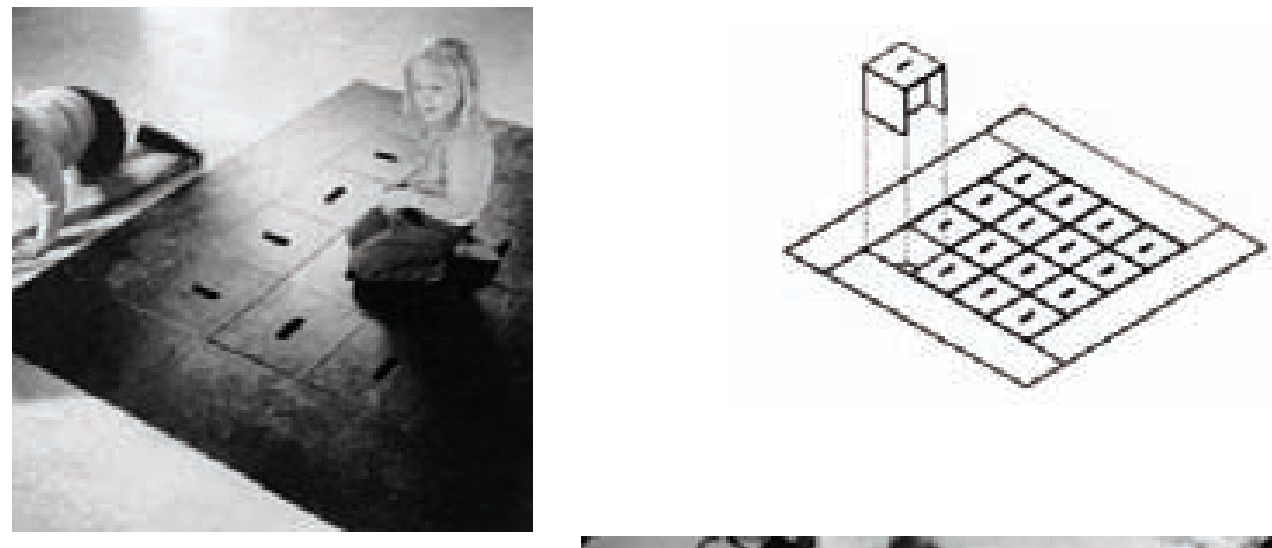

Externamente, seguindo os mesmos princípios dos elementos dos halls internos, Hertzberger cria uma malha de blocos de tijolo, que, assim como o podium, são fixos no chão. Organizados em fileiras ou em malhas quadriculadas, os blocos acabam criando situações e espaços inusitados, mais uma vez provocando e estimulando a apropriação por parte das crianças a fim de que adquiram algum significado. Estes são transformados, então, em vasos, suporte para tendas e até mesmo em banheiras ou piscinas.
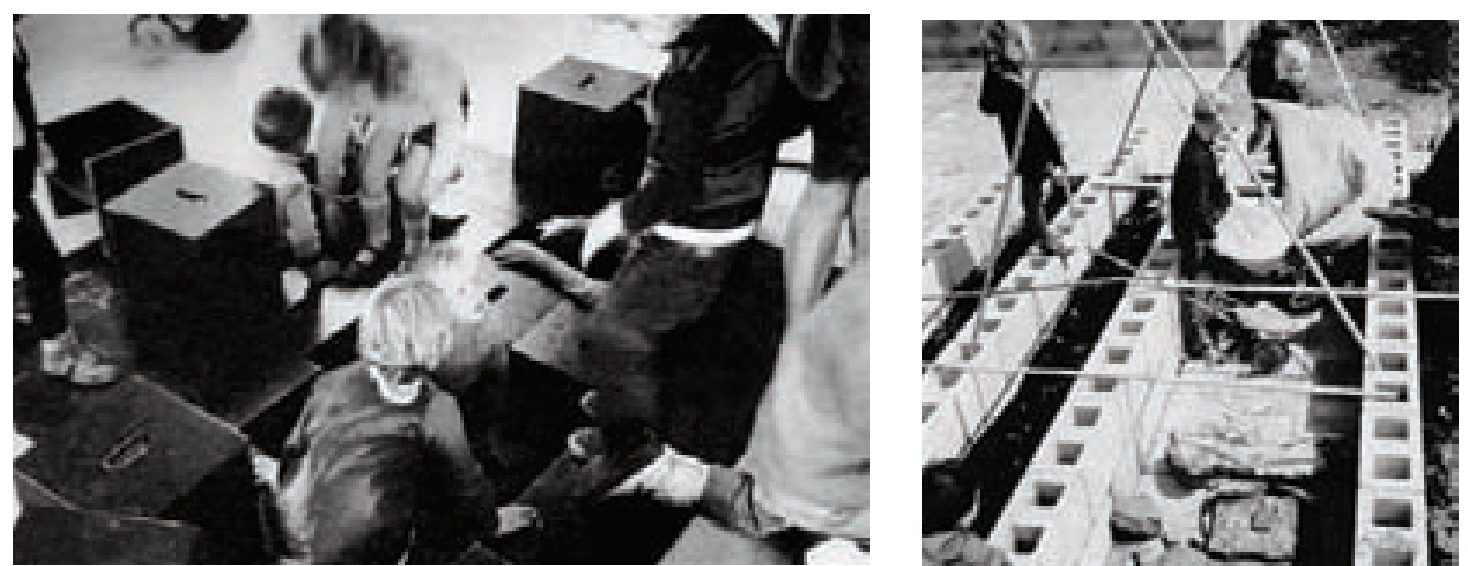

Muretas com blocos de tijolo sendo apropriadas pelas crianças, que criam e recriam situações diver-

Piso com quadrado em destaque; crianças desconstruindo o quadrado-piso e transforvários outros ambientes.
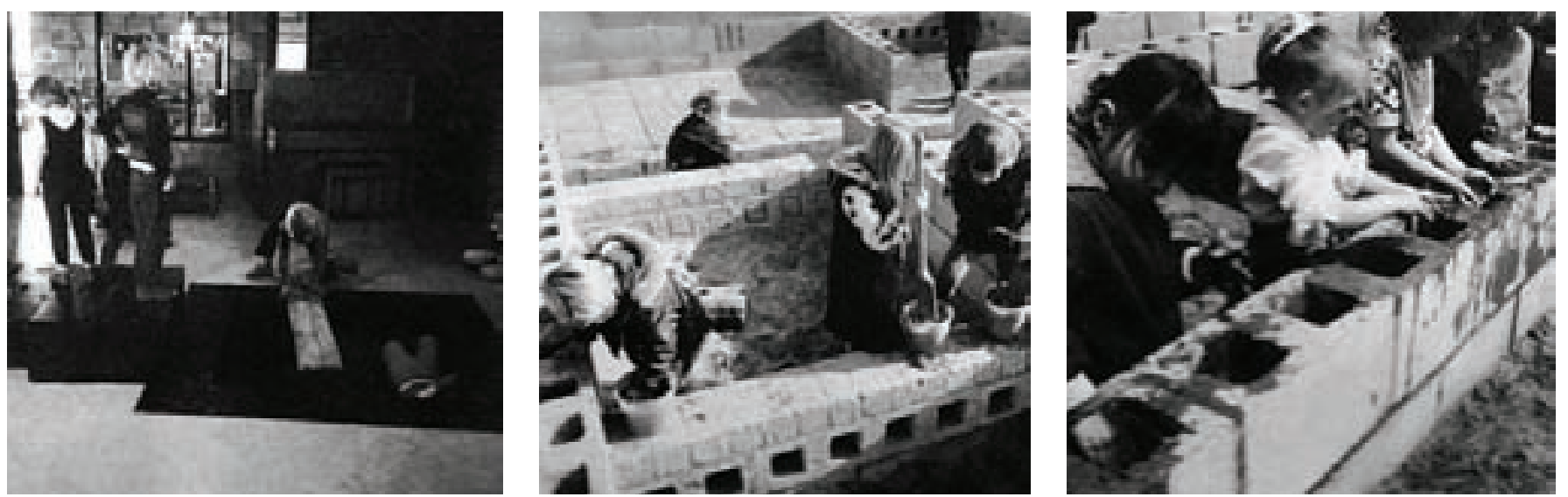
De forma geral, podemos observar que em todo o projeto, desde a organização em planta (disposição dos ambientes uns em relação aos outros) até os desenhos dos equipamentos, o arquiteto explora o jogo de formas sempre a partir de eixos ou "malhas" estruturais - que são também, e propositalmente, quebradas para que se possa criar uma maior gama de possibilidades de uso. Todo o trabalho do arquiteto encontra-se na relação entre estrutura e liberdade e entre público e privado. Seguindo o conceito de arquitetura estruturalista, da qual foi um dos principais condutores $^{7}$, e segundo a qual deve-se projetar a partir das necessidades dos usuários e criar uma estrutura social que pode ser preenchida de diferentes formas, Hertzberge procura criar a ordem mínima necessária para possibilitar o máximo de liberdade e inclusive estimular esse efeito, com o objetivo de criar espaço de oportunidades.

Hertzberger está mais interessado em "criar espaço" do que "produzir lugares"8 (fazendo um jogo entre "criar espaço" e "deixar espaço"). Segundo ele, estimular a influência dos usuários sobre seu ambiente depende de questões como, entre outras coisas, graus de acesso e demarcações territoriais. Por isso, desde a entrada da escola o projeto procura encorajar a interação humana. Segundo ele, a entrada de uma escola, mais do que uma abertura através da qual as crianças são "engolidas quando as aulas começam e expelidas quando elas terminam", deveria ser um lugar que oferecesse algum tipo de conforto para as crianças que chegam cedo e para os alunos que não querem ir logo para casa depois das aulas. Um pequeno espaço público como local de encontro, o qual exerce uma importante função social. "Paredes baixas onde se pode sentar é o mínimo que se pode oferecer: uma esquina coberta (sheltered) é melhor, e a melhor coisa seria uma área inteira coberta para quando chovesse."9
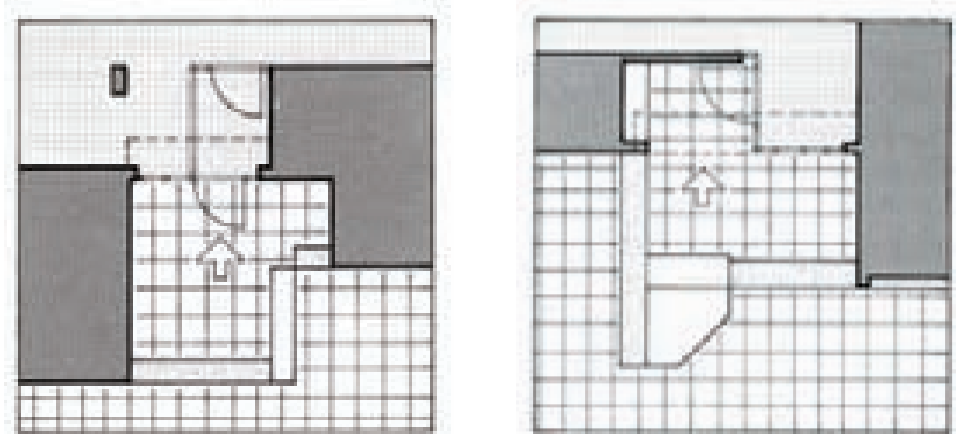

Acima, plantas com opções de acesso à escola; abaixo, foto de um dos acessos construídos, buscando criar o espaço-ambiente intermediário, o "intervalo", o espaço social.

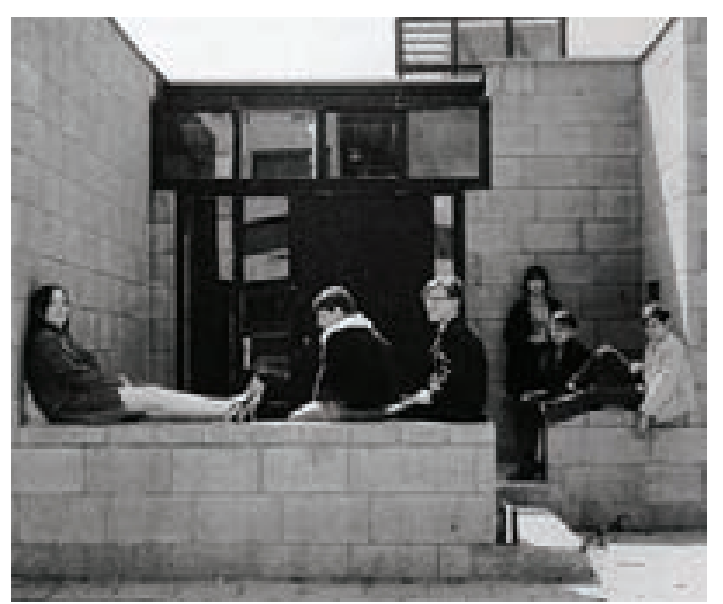

7 Inspirada nas investigações do antropólogo Levi-Strauss sobre relações entre as estruturas que regem os processos culturais, a arquitetura estruturalista, segundo Hertzberger, não deveria apresentar soluções prontas, e sim estruturas espaciais que o usuário pudesse administrar para deixar sua marca pessoal (informação retirada do site Vitruvius, www.vitruvius.com.br)

BERGEIJK, Herman Van e Deborah Hauptmann. Notations of Herman Hertzberger. Netherlands: NAi Publishers, 1998

9 HERTZBERGER, Herman. Lições de Arquitetura. Trad. Carlos Eduardo Lima Machado. São Paulo: Martins Fontes, 1996 
Até mesmo a escolha do método construtivo e do acabamento - alvenaria estrutural visível de blocos sem revestimento - deveu-se à finalidade de interação com as crianças, fazendo com que estas compreendessem o processo de construção do edifício: "que as crianças entendam que o edifício nasceu do trabalho de empilhar e unir inúmeros blocos, como elas fazem com seus jogos pedagógicos durante as aulas" (Hertzberger 1998).

Hertzberger trabalhou com psicólogos, procurando entender como as pessoas utilizam os espaços. "A questão é como trazer as pessoas junto sem forçá-las. Você pode estimular comportamentos sabendo como pessoas se comportam". "Sou uma daquelas velhas pessoas que desesperadamente conecta forma e significado" (Hertzberger apud Bergeijk 1996).

Como em muitos dos seus trabalhos, Herzberger pensa o projeto desta escola em termos de mini cidades, onde interiores imitam ruas e espaços públicos, com as suas "piazze" (grande influência da arquitetura italiana) fora das classes, em oposição aos corredores, e com algumas paredes feitas de grandes extensões de vidro (área de entrada das salas e, principalmente, área de transição entre espaço interno e espaços externos de lazer), promovendo a comunicação entre áreas diferentes.

Atento já anteriormente a questões relacionadas ao ensino, tendo realizado pesquisas sobre diferentes métodos de educação para crianças, o arquiteto procurou trabalhar com conceitos que humanizassem e facilitassem a integração do pequeno usuário. Predominam em seus edifícios escolares a transparência e a organização espacial, com a valorização das áreas sociais (o hall é a parte mais valorizada da edificação): espaços para alunos, professores ou visitantes são tratados da mesma maneira; em oposição ao esquema de organização tipo corredor ele propõe salas de aula agrupadas ou conectadas para torná-las mais adaptáveis a outras atividades; ou unidades autônomas (as pequenas "casas" já mencionadas) com entrada pelo hall de acesso. Para Hertzberger, "já que nós, arquitetos, não temos influência no ensino propriamente dito, podemos tentar fazer um ambiente em que isso ocorra da maneira mais convidativa possível" 10 .

\section{Ambiente escolar como estrutura de oportunidades}

A fim de compreender melhor os princípios que estão por trás da elaboração do projeto de Hertzberger (e dos demais projetos analisados), e baseados em pesquisas sobre a inter-relação entre ambiente e comportamento humano entre ambiente e desenvolvimento infantil (ver capítulo "Criança, desenvolvimento e projeto de ambientes" e estudos feitos por Lina Iglesias Forneiro sobre a organização dos espaços na educação infantil), levantamos alguns pontos essenciais para a análise de ambientes escolares infantis que servirão como parâmetros de reflexão e dis cussão sobre as possibilidades e maneiras de trabalhar os mesmos como estruturas de aprendizagem: organização espacial e campo visual; clima, recursos do ambiente, arquitetura, materiais, equipamentos e brinquedos; salas de aula (elementos estruturais, formato e dimensões, mobilário, materiais, decoração, etc.); e a relação destes elementos todos com atividades, usos e funções.

\section{A. Organização espacial}

O projeto da escola desenvolve-se inteiramente a partir da idéia de mini-cidade, e suas relações entre espaços públicos e privados, dando-se maior ênfase aos ambientes coletivos, como os halls internos, as áreas intermediárias ("semi-públicas-privadas") e as áreas externas de lazer. 
Hertzberger propõe uma concepção "nuclear" da escola, onde o hall é o ambiente principal, que articula todos os demais espaços, evitando a presença de corredores. A construção deste núcleo (na verdade, são dois os núcleos principais), no entanto, se faz não a partir da delimitação de uma área regular, mas acontece a partir do deslocamento de cada sala de aula em relação ao eixo da sala vizinha, formando assim uma área central maior e pequenas áreas adjacentes e intermediárias entre as salas de aula mais privativas e as áreas de uso coletivo.
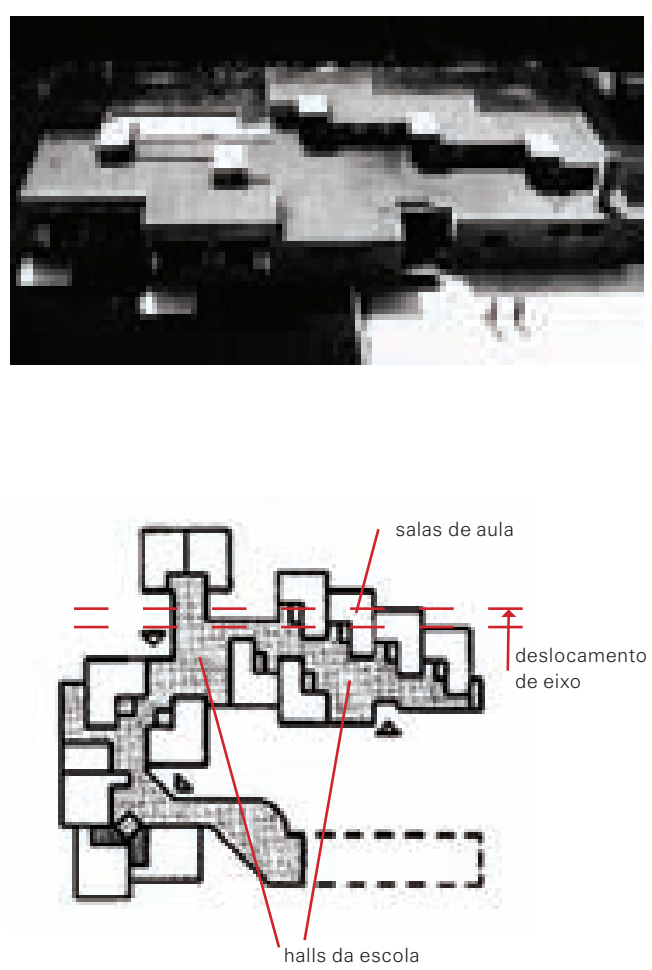

Na busca constante de diferentes articulações espaciais, Hertzberger dá ênfase ao sistema estrutural, ao detalhe, à passagem entre o espaço público e o privado, e à dialética do espaço, embora proponha uma separação precisa de cada área por meio de uma definição formal.

O arquiteto procura sempre trabalhar não somente com os espaços construídos, mas também com os es paços "entre" eles ou "deixados" por eles. Assim, acaba explorando não apenas os cheios, mas também os vazios: os elementos construtivos e constitutivos dos espaços são em geral concebidos a partir da exploração de suas formas, da construção e desconstrução das mesmas, do jogo entre cheios e vazios, entre recuos e avanços, entre volumes e superfícies, entre solidez e transparência, etc.

A idéia de "projeto aberto" (às intervenções e recriações dos usuários) constrói-se a partir das estruturas espaciais. Todas as "provocações" para que os usuários se apropriem do espaço da escola, que estimulam a curiosidade e a descoberta, são construídas a partir da ambigüidade entre forma, função e uso, "soltando", "desprendendo" estes de uma leitura e de uma relação linear e direta.

Na configuração em torno de "praças" e na proposta de evitar corredores, procurando criar "ruas comunitárias" transparece a atenção do arquiteto em relação à dinâmica da escola e à possibilidade de encontros e relações acontecerem neste espaço (ênfase nos conceitos de público e coletivo). Sem deixar que a reclusão, a privacidade e a concentração, tão caras ao método montessoriano, sejam prejudicadas. Esta é garantida, inclusive em diferentes níveis, à escolha do usuário, que pode desenvolver atividades tanto dentro das salas de aula, como nas áreas "semiprivadas"ou "semi-públicas" - os "quintais" ou "vestíbulos", espaços semi-abertos (com paredes mais baixas e criando fechamentos parciais) nos quais as crianças dispõem de uma mesa e algumas cadeiras.

Apesar de todo ambiente de uma escola Montessori ser organizado em áreas por assuntos (áreas de cozinha, limpeza, jardinagem, artes, canto da biblioteca, área dos
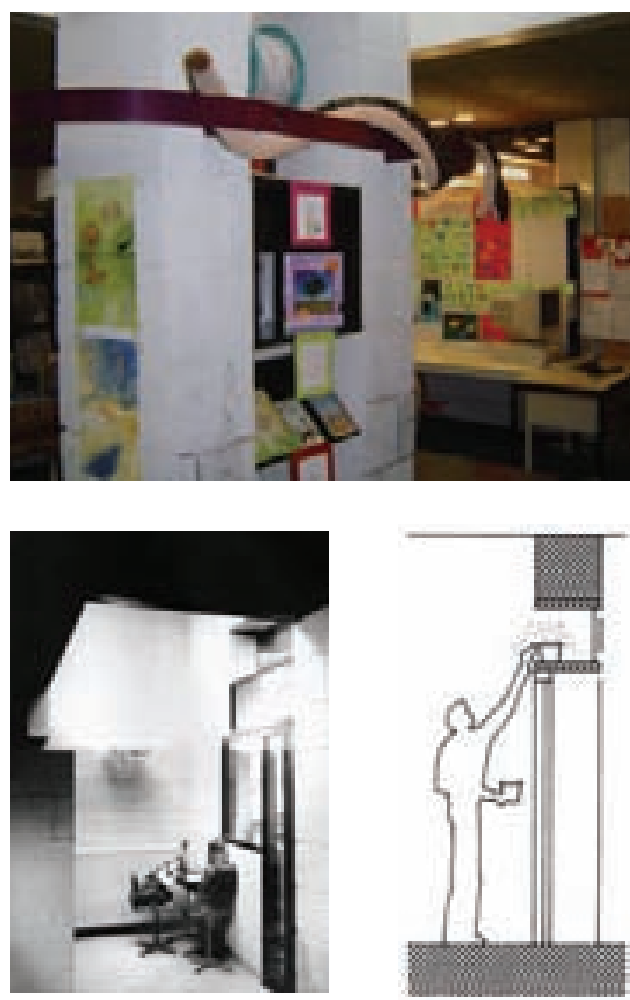

Recuos nas portas, janelas e pilares, formando pequenos nichos que podem ser preenchidos pelos usuários. 
animais, etc.) - desde a sala de aula até os espaços comuns da escola -, com o intuito de facilitar o domínio espacial e a orientação das crianças na escola, Hertzberger procura evitar soluções demasiadamente específicas, pois acredita que estas cairiam inevitavelmente na rápida obsolescência, conduzindo não só à disfuncionalidade como também a uma grave falta de eficiência.

Devido à escassez de materiais (plantas, descrições, etc.) sobre a escola analisada neste trabalho, não podemos dizer ao certo como estão distribuídos e dispostos os espaços para cada atividade. Talvez algumas delas tenham sido incorporadas ao interior das salas de aula, uma vez que, pela observação da única planta encontrada, não parecem existir muitos ambientes além das classes. Se a rigidez da divisão em áreas específicas não foi quebrada pelo arquiteto, parece-nos que houve uma tentativa de desconstrui certos paradigmas no projeto das áreas de uso comum (halls internos e áreas externas de lazer), onde jogou-se com os conceitos de pisos, muretas e áreas livres, criandose elementos inusitados que põem em questão as funções e usos dos mesmos.

Podemos dizer, portanto, que Hertzberger vai além do re-arranjo espacial ao repensar os paradigmas mencio nados acima, propondo uma revisão das funções e usos de ambientes e equipamentos de uma escola, e criando contra a idéia de soluções prontas, estruturas espaciais que o usuário possa administrar, a fim de deixar sua marca pessoal. É por meio de elementos incidentais, elementos "surpresa" (dentro de um determinado padrão perceptivo) e, acima de tudo, elementos polivalentes, que o arquiteto acredita que o espaço possa e deva abrir possibilidades variadas de uso ao longo do tempo.

\section{B. Campo visual}

Apesar de apresentar dois núcleos principais (halls) mais abertos, estes, como já mencionado, são formados a partir do deslocamento do eixo de uma sala de aula em relação à vizinha, o que resulta em espaços irregulares, com inúmeros avanços e reentrâncias.
Não existe, portanto, um único campo visual, ou um ponto da escola onde se possa visualizá-la por inteiro. Cada "praça" (hall) abre espaço para a visualização dos elementos e ambientes ao seu redor e, apesar de não existirem corredores, alguns pontos da escola constituem-se como passagens mais estreitas, fechando o campo visual e dividindo a escola em áreas diversas.

Assim, a escola, ainda que apresentando uma estrutura lógica e racional de organização espacial, deve se percorrida nos seus diferentes ambientes para ser descoberta e compreendida. A alternância, ainda que pequena, entre espaços abertos e fechados - e, conseqüentemente, campos visuais abertos e fechados - acaba enriquecendo a experiência de seus usuários, propiciando uma alternância de sensações. Como diz Rapoport, em seu livro Aspectos humanos de la forma urbana, de 1978, são as mudanças e diferenciações de estímulos, ou melhor, as variações dentro de uma ordem que criam a complexidade de um espaço e, conseqüentemente, resultam em sua riqueza ambiental.

Na Delftse Montessorischool, no entanto, esta alternância de estímulos, nos espaços de uso comum, acaba se dando quase que exclusivamente pelas diferenças de campos visuais e pela imprevisibilidade dos elementos construídos nos halls. Não há, por exemplo, a exploração de texturas, cores, intensidades e tipos de luz, materiais etc. Os elementos construtivos e materiais utilizados sãos os mesmos em todas as partes da escola, apresentando variações apenas nas formas e nas estruturas.

\section{Atividades, usos e funções}

Não nos foi possível compreender exatamente como se dá a distribuição das atividades na escola e se realmente existem ambientes específicos para a realização de alguns determinados trabalhos (como cozinha, sala de artes, biblioteca, etc.), ou se alguns destes foram incorporados às salas de aula.

A partir do estudo da metodologia montessoriana, porém, podemos ter uma idéia como se dá a dinâmica de 
uma escola com esta proposta. Segundo esta, a aplicação prática do método Montessori é baseada em tendências humanas: explorar, movimentar-se, dividir com um grupo, ser independente e tomar decisões, criar ordens, desenvolver autocontrole, extrair idéias a partir de experiências usar imaginação criativa, trabalhar duro, repetir, concentrar e aperfeiçoar seus erros ${ }^{11}$.

A utilização dos materiais, portanto, implica uma série de movimentos - andar, carregar, virar, despejar, falar e, mais precisamente, utilizar constantemente as mãos. "ambiente preparado", como um todo, é direcionado às crianças e ao seu desenvolvimento, procurando fortalece a atividade motora e estimulá-las sensorial, intelectual e emocionalmente.

Tendo o professor como guia, uma vez que a estimulação para o aprendizado viria do ambiente global, e não da figura do professor, as crianças entram em contato com o ambiente por meio das seguintes atividades: "exercícios da vida prática", "exercícios sensoriais", "exercícios de matemática", "exercícios de linguagem" e "exercícios acadêmicos" (ciências, história e geografia).

Como exercícios da vida prática, Montessori estruturou muitos exercícios para a classe a fim de ajudar a criança a satisfazer suas necessidades de atividades significativas. Para esses exercícios, ela utiliza objetos familiares, como botões, broches, vasilhas, água e muitos outros objetos que a criança conhece de sua experiência em casa, além de "quadros" (que isolam uma única técnica) para desenvolver atividades como lavar a louça, cortar legumes, amarrar os sapatos, etc. Montessori afirma que a criança tem necessidade de imitação nos seus primeiros anos de vida, que está sempre querendo realizar as mesmas tare fas de seus pais ou de qualquer pessoa mais velha.

Já nos exercícios sensoriais, a criança, que conhece o mundo que a rodeia pela utilização constante de seus sentidos - para examinar um novo objeto, um bebê o olha, o pega nas mãos para sentir a textura e o peso, o sacode, o lambe e o morde -, experimenta materiais que aguçam os seus sentidos. Cada material sensorial isola uma quali- dade, como cor, forma, textura, temperatura, cheiro, etc. O material sublinha uma dessas qualidades particulares, eliminando ou minimalizando as demais. O objetivo destes materiais é ajudar a criança a distinguir, a classificar e a associar uma nova informação àquilo que ela já conhece. Segundo Montessori, o espírito precisa de educação e de treino para ser capaz de distinguir e apreciar e, mais do que perceber, o importante é ser capaz de compreender o que percebe.

Os inúmeros exercícios sensoriais são também uma preparação para os aprendizados acadêmicos, e os materiais geométricos são igualmente importantes para fazer aprender a linguagem que ajuda a criança a se concentrar sobre as formas diferentes. É muito mais fácil para a criança aprender o que é uma pirâmide ou uma esfera quando ela pode tocá-las do que por um processo abstrato. Fica clara, mais uma vez, a importância dada ao tato pelo método montessoriano, mais do que os demais sentidos.

As crianças são constantemente estimuladas pela vasta gama de escolhas de materiais e suas numerosas utilizações, mas, trabalhando na maior parte das vezes individualmente com seus materiais, estas podem seguir o ritmo próprio de cada uma. A utilização individual dos materiais permite um ritmo variado adaptado aos inúmeros níveis de aptidões dentro da classe.

Apesar de ter como instrumento de trabalho principal o conjunto de "materiais", com formas e estruturas bem específicas, e de dar ênfase à atividade individual, o método montessoriano também propõe atividades em grupo e abre espaço para que novos materiais sejam utilizados. Alguns professores utilizam apenas o material concebido por Maria Montessori; outros acrescentam novos materiais educativos; e trabalhos em grupo, como música, poesia, artes e jogos, podem complementar as atividades individuais com o material Montessori. Se os novos materiais propostos seguirem os princípios Montessori, podem enriquecer o ambiente da classe.

Além das atividades desenvolvidas em sala de aula também acontecem atividades nas áreas de uso coletivo. 
Imagens de outras escolas montessorianas, mostrando os "materiais" utilizados por esta metodologia de ensino (estas fotos foram colocadas aqui a fim de mostrar mais claramentte o que são os "materiais", uma vez que não foi possível encontrar imagens específicas da Delftse Montessorischool).
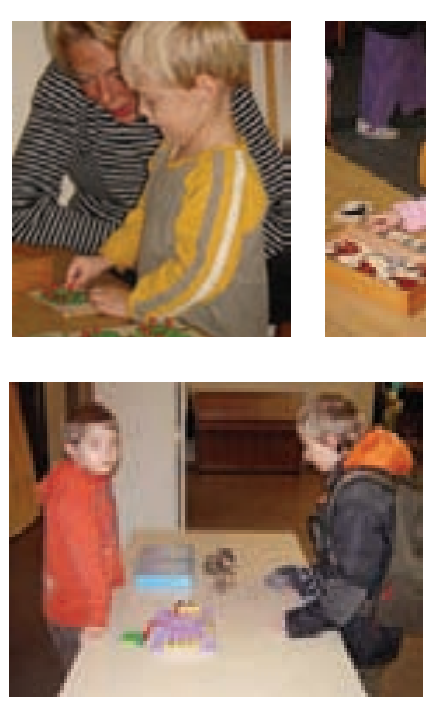
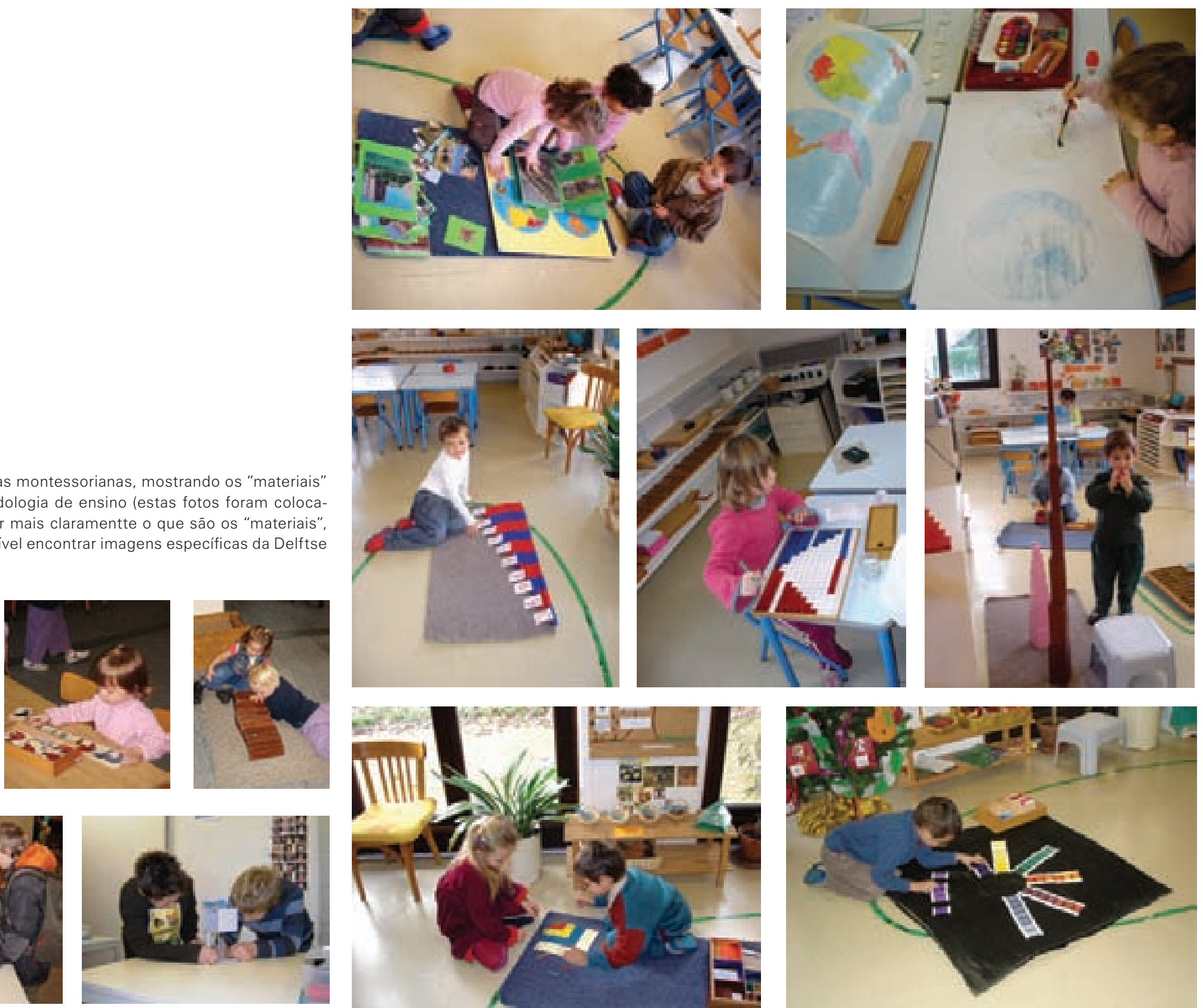
Estas parecem apresentar alguma variedade de uso - como vimos anteriormente, o podium é utilizado como local de assembléias, formais, peças teatrais, suporte para exposições, ou mesmo como ponto e referência para a realização de lições e para conversas informais. Externamente, a área de lazer com as muretas baixas de blocos de tijolo também abrigam atividades diferentes.

De forma geral, no entanto, praticamente não se vê a presença ou a marca das crianças na escola como um todo, a não ser em cada sala de aula e seu respectivo "quintal" (que possui uma área projetada pelo arquiteto para exposição dos trabalhos das crianças). Os materiais desenvolvidos por estas acabam sendo expostos quase que unicamente em painéis ou em áreas reservadas para esta finalidade. A possibilidade de transformação dos espaçoambientes da escola acaba ficando restrita em função da quase ausência de elementos (objetos, brinquedos, ma teriais, equipamentos, etc.) disponíveis para as crianças brincarem. O direcionamento de grande parte das atividades acaba deixando pouco espaço para a espontaneidade, para a fantasia e para a invenção (a não ser internamente à situação preparada).

A escola, portanto, apresenta uma dinâmica pequena e pouca constância de alternância e mudança de atividades e usos, mas explora em alguma medida a mescla de espaços e equipamentos mais definidos e espaços e equipamentos menos definidos quanto às suas funções usos, o que resulta em um certo grau de polivalência e flexibilidade, importantes para a abertura a interpretações $e$ apropriações variadas (fornecendo quantidades variáveis de estímulos e, portanto, de informação).

\section{Materiais, recursos do ambiente, equipamentos,}

\section{móveis e brinquedos}

Como já observado anteriormente, Hertzberger desenvolve o projeto da escola a partir de estruturas espaciais que permitem e incentivam o usuário a manipulá-las, para que deixem suas marcas pessoais. Os espaços e equipamentos projetados por ele procuram abrir possibilidades variadas de uso ao longo do tempo. Assim, o usuário defrontase com alternativas, sobre as quais deve posicionar-se de alguma maneira a fim de que os espaços tornem-se lugares, ou os equipamentos e objetos adquiram significado. A partir principalmente da exploração da ambigüidade das formas e da ruptura da relação direta entre forma-usofunção, o arquiteto trabalha a polivalência das mesmas, abrindo espaço, portanto, para a participação.

Com relação aos materiais utilizados na escola e aos estímulos que estes provocam, podemos observar que tanto os materiais didáticos criados pelo método montessoriano como os elementos projetados por Hertzberger estimulam principalmente a percepção visual e o tato, em detrimento dos demais sentidos. A maioria dos mobiliários e equipamentos da escola é feita em madeira natural, e poucos outros materiais são utilizados no acabamento ou na decoração dos ambientes, ou mesmo nos objetos e "materiais" fornecidos às crianças (a não ser quando se trabalha com objetos e elementos industrializados e comprados no mercado padrão e quando há a necessidade de exploração de outros materiais). A arquitetura também apresenta poucas variações de texturas, cores e acabamentos, aparecendo como um fundo homogêneo e relativamente neutro (em termos "videotáteis"12, nos aspectos
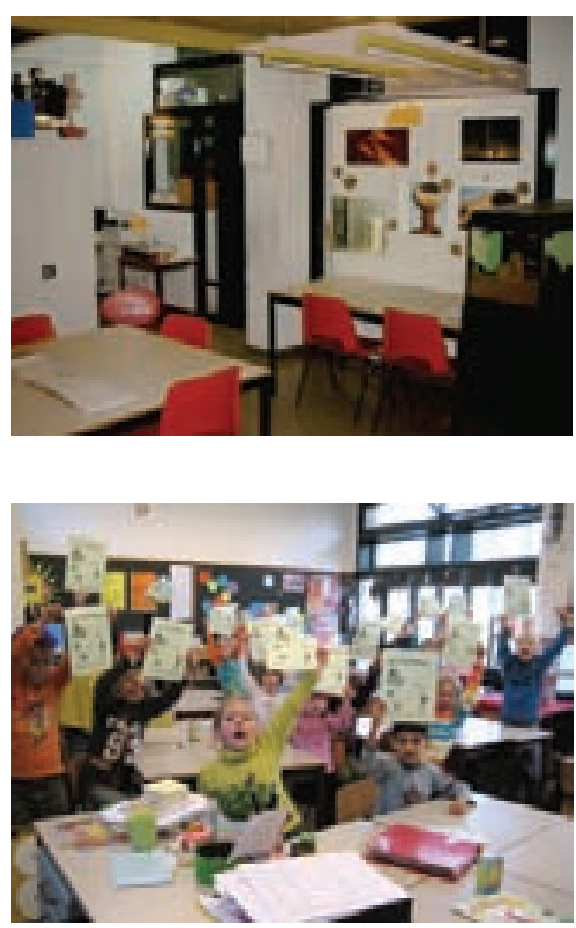

Salas de aulas com painéis onde ficam exposto os trabalhos das crianças.

12 Termo cunhado por McLuhan, no livro Os Meios de Comunicação como Extensões do Homem, na tradução de Décio Pignatari. 


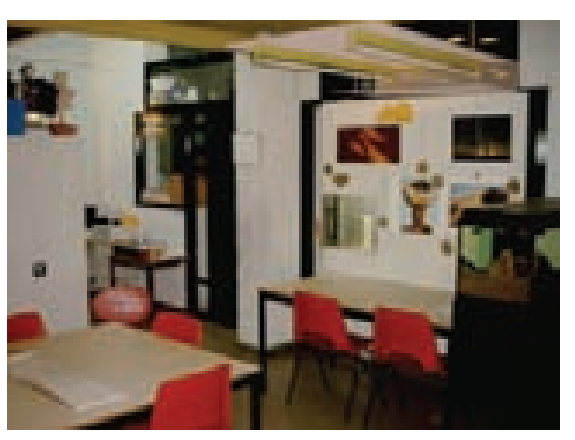

Materiais e acabamentos das paredes e pisos são iguais em toda a escola, não havendo exploração de cores, nem tampouco variação de texturas; as luminárias também são as mesmas em todos os ambientes; algumas áreas têm iluminação natural zenital, criando uma mudança nesses ambientes; a maior parte da arquitetura construída acaba constituindo-se como elemento neutro, servindo de suporte para a exposição de trabalhos das crianças.
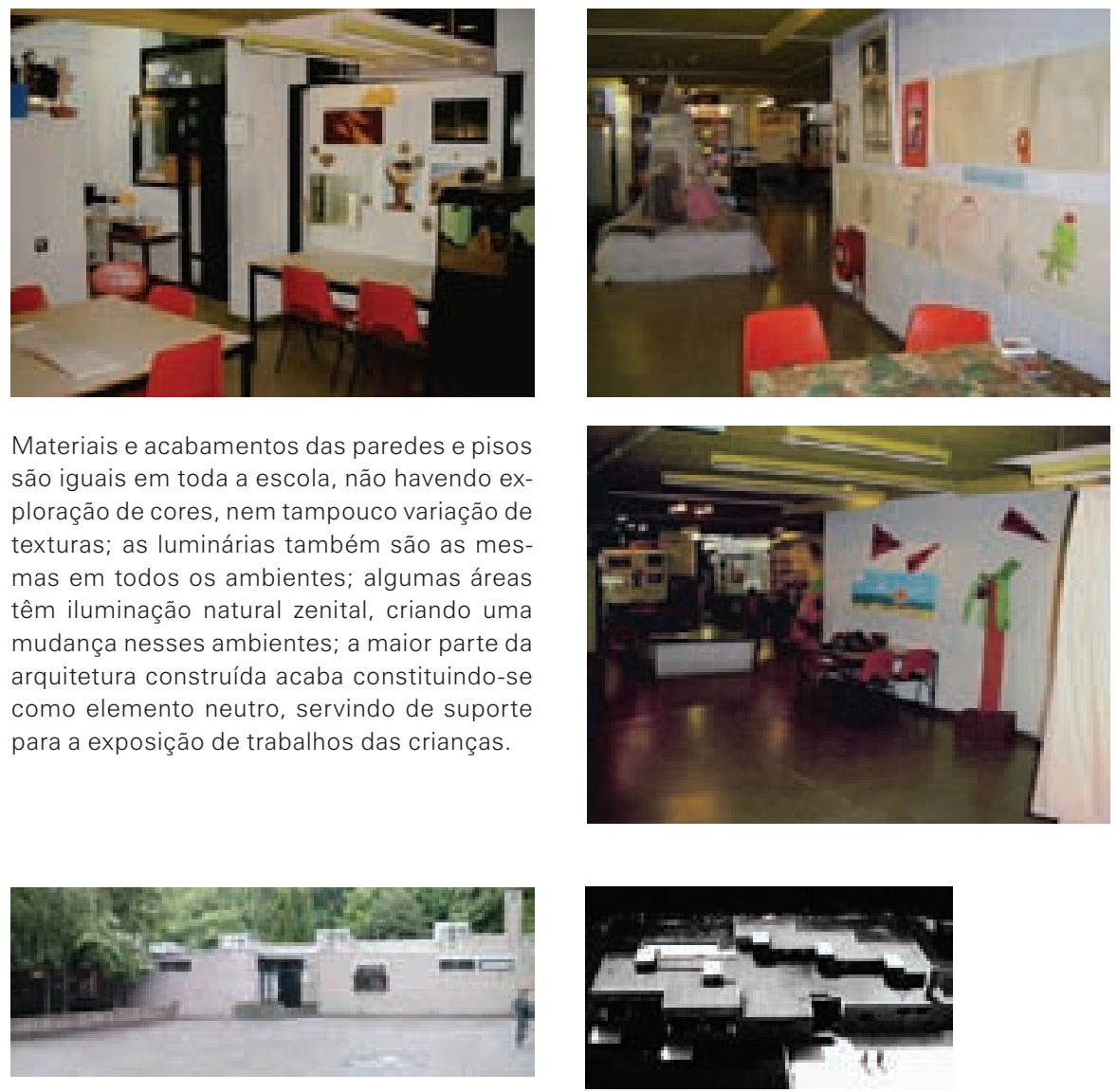

Uma das fachadas da escola: paredes externas, construídas também a partir de blocos estruturais, foram mantidas na cor natural do material (cor fria), não apresentando pintura; nas três imagens seguintes, podemos observar as aberturas para iluminação zenital, e a delimitação e diferenciação de ambientes em função desta. que acabamos de mencionar), só apresentando algumas poucas variações de transparência e luminosidade, em função da construção de algumas aberturas de vidro (zenital e lateral).

A integração ou interlocução com a natureza não acontece, o que pode ser explicado em parte pelo clima loca - frio na maior parte do ano, que exige ambientes mais fechados - e, talvez, também por um fator cultural. Inserida em um terreno rodeado de árvores, a escola, porém, não se integra às mesmas, e o que existe de vegetação mais próxima ao edifício da escola está implantado em uma área específica e claramente delimitada.

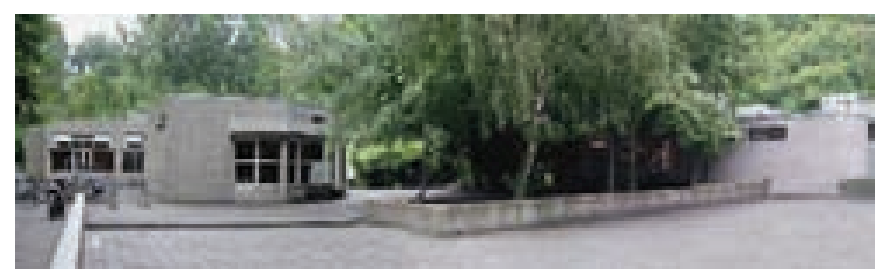

Árvores inseridas em canteiros delimitados.

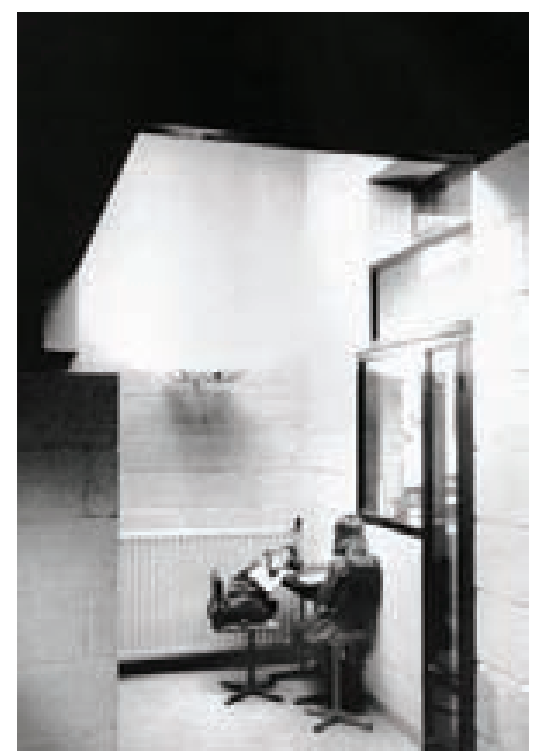


Não parece haver sequer a utilização de materiais naturais ou reciclados (além da madeira) mesclados a materiais artificiais nos objetos e "materiais" fornecidos às crianças. O contato desta com a natureza parece ocorrer apenas nas atividades de jardinagem e cuidado com os animais, mais uma vez atividades direcionadas e com finalidades específicas

A riqueza (complexidade) da experiência sensorial acaba ficando reduzida, sendo explorada primordialmente nas lições com os "materiais".

\section{E. Salas de aula}

[análise de: relação com demais espaços da escola; elementos estrutuais; formato; dimensões; organização espacial e das atividades; materiais, cores, texturas de pisos, paredes; iluminação; decoração; flexibilidade; mobiliário, equipamentos, objetos e brinquedos]

Todas as salas de aula da Delftse Montessorischool apresentam formatos e tamanhos iguais, tendo sido projetadas por Hertzberger no formato de um "L", diferentemente dos formatos tradicionais, quadrados ou retangulares, com o intuito de criar ambientes e "cantos" diferentes, onde atividades diversas pudessem ser desenvolvidas concomitantemente (sem que uma interferisse na outra e sem que o professor perdesse controle das crianças, ou a visão do conjunto). Reforçando esta idéia, foi criado um desnível na sala, dividindo-a em dois ambientes maiores: um com uma mesa e uma área molhada (pia e bancada) e outro com as demais mesas e materiais.

O formato em "L" também permitiu a criação dos espaços intermediários entre as salas de aula e as "ruas comunitárias", os quais formaram-se a partir da "extração" de uma área retangular do retângulo "original" da sala de aula (ver figuras acima)

Como já pudemos observar em outros momentos, todo o projeto de Hertzberger é desenvolvido a partir do jogo entre criação de uma malha estrutural e sua "quebra", por meio da extração, deslocamento ou rebatimento de elementos construtivos ou constitutivos.

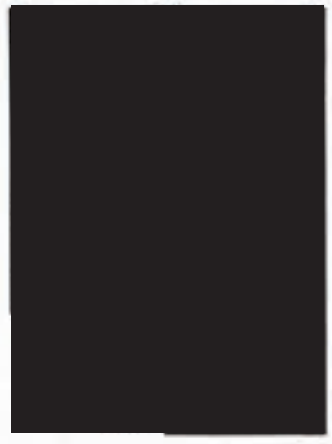

Área retangular "original".

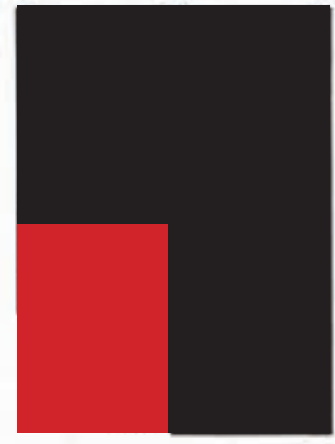

"Extração" da primeira área, correpondente à área total do vestíbulo.

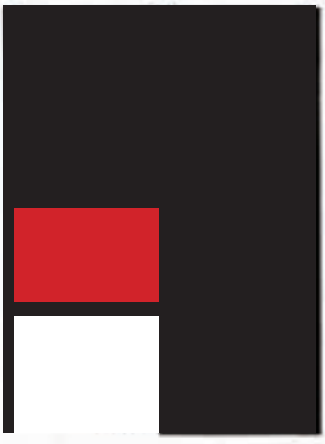

"Extração" da segunda área, correpondente à mais íntima e resguardada do vestíbulo.

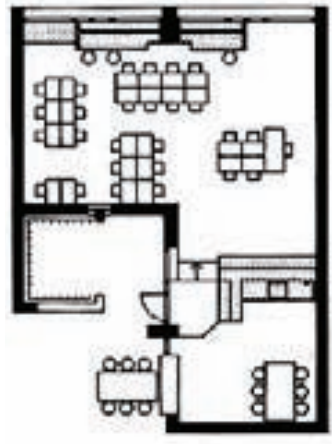

Planta da sala de aula e área do "vestíbulo".
A partir desse jogo, podemos também apontar como regra geral o conceito de espaços complementares com graus de privacidade e abertura que modificam-se gradualmente: todas as turmas dispõem de uma sala mais resguardada e fechada e uma sala intermediária semi-aberta, todas cobertas e internas.

Interiormente às salas de aula, uma vez que as crianças devem cuidar de suas próprias classes e mantê-las limpas (dando expressão a esse espaço por meio do envolvimento cotidiano), o método Montessori propõe que todos os materiais devam ser organizados de forma lógica, ficando acessíveis às crianças (garantindo-Ihes autonomia) e facilitando o trabalho das mesmas, que aprendem onde ficam cada um dos objetos da sala. Se, por um lado, isso auxilia o reconhecimento da sala e a orientação da criança, por outro, diminui o dinamismo do ambiente que, com o tempo, passa a não apresentar mais nenhuma novidade nesse aspecto. Todo indivíduo necessita de um certo grau de estabilidade para que se sinta seguro e pertencente ao lugar. Quando as mudanças são realizadas pelos próprios usuários não se perde a noção de orientação, nem tam- 
pouco a sensação de "pertencimento", mas, ao contrário, fortalece-se a identidade do ambiente.

Com relação aos materiais constituintes e presentes, as salas apresentam, em geral, pisos frios e lisos (pelas fotos não é possível dizer ao certo qual é o material, mas parece ser cimento queimado), não havendo diferenciação em nenhuma área da sala ou mesmo na passagem da sala para as áreas de uso coletivo. O "relaxamento" e outras atividades que requerem pisos mais confortáveis e de temperatura mais quentes acabam tendo que ser realizados sobre tapetes, em função da ausência de áreas mais quentes e confortáveis.

As paredes são pintadas de branco (pintura diretamente sobre blocos, sem massa, o que deixa transparece a textura do tijolo), e as cores do ambiente são exploradas principalmente em alguns equipamentos e nos materiais montessorianos. Paredes e armários constituem-se como elementos praticamente neutros (pintura branca ou ma-
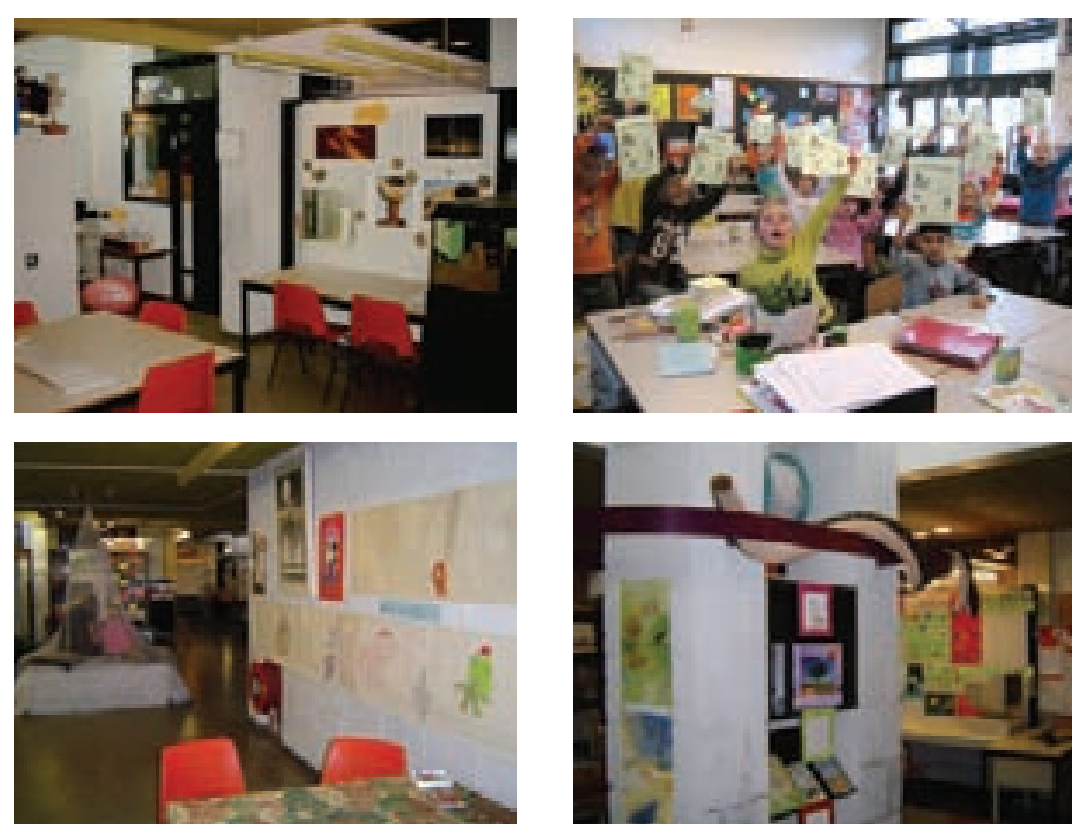

deira natural), servindo basicamente como suportes para os materiais e os trabalhos feitos pelas crianças ao longo do ano. Os armários em geral são abertos para que os materiais fiquem à vista e facilmente acessíveis pelas crianças. Trabalhando com painéis, sempre ao alcance das crianças, pode-se dizer que nas salas de aula a presença da criança é mais fortemente notada (do que em relação aos demais espaços da escola).

Os pés-direitos das classes parecem variar de altura: em algumas partes são baixos, proporcionais à estatura das crianças, enquanto em outras, e também nas áreas de "quintais", parece haver uma elevação da cobertura, criando uma iluminação zenital, conseguida por meio da construção de caixas de vidro. Esta variação de altura e iluminação resulta na delimitação e diferenciação de ambientes, que produzem sensações diferentes (conforto e privacidade, por exemplo), o que é importante para o enriquecimento da experiência ambiental.

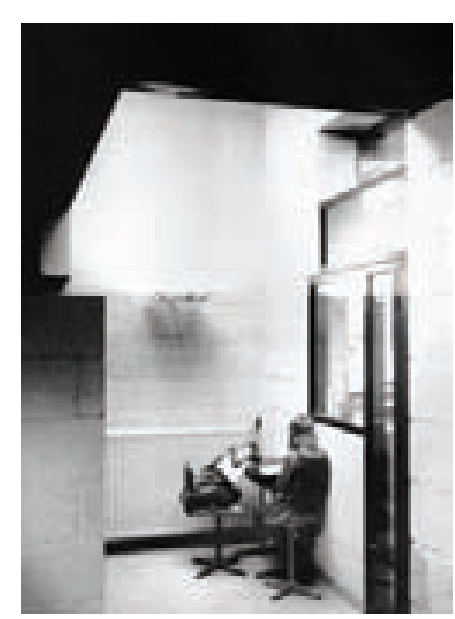

Arquitetura neutra, dando espaço para a comunicaça dos equipamentos e materias montessorianos, e dos trabalhos das crianças; pés-direitos dos ambientes variam, criando ritmos e sensações diferentes ao longo da escola. 
Uma situação que chama a atenção nas salas de aula é a grande quantidade de mesas e cadeiras. Apesar de parecer haver uma grande dinâmica e liberdade das crianças dentro de uma sala montessoriana, pudemos observar que, na maioria das fotos apresentadas nos diferentes materiais pesquisados, as crianças estão quase sempre sentadas ao redor das mesas ou no chão, se relacionando específica e diretamente com o "material". Não se nota a existência de uma interação maior com o ambiente como um todo, e tampouco de uma intervenção das mesmas sobre este, a não ser na manipulação e transformação imaginária dos elementos dos halls internos (podium e quadrado). A grande influência possível do ambiente sobre o desenvolvimento, apontada por Montessori, acaba reduzida à necessidade que este seja proporcional à criança, com mobiliário flexível e materiais acessíveis para sua autonomia (e estimulantes de seu desenvolvimento) - explicitado na denominação "ambiente preparado", como já observado anteriormente.
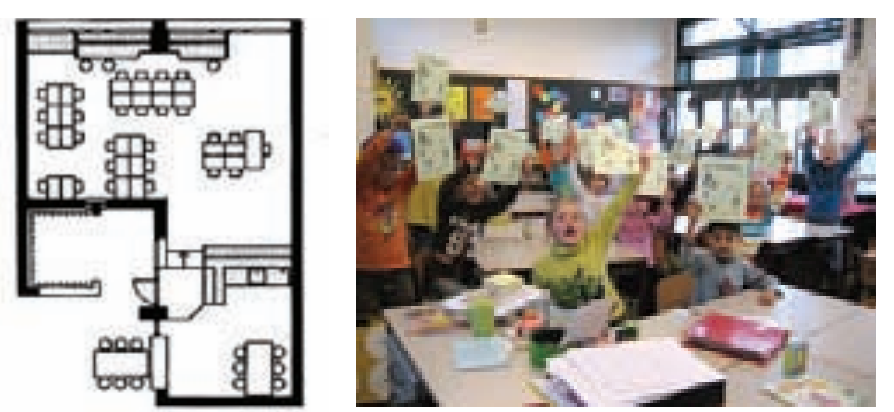

Apesar de o material ser o mesmo, cada classe Montessori é única, pois cada uma delas reflete as características individuais do professor e das crianças. Alguns professores utilizam apenas o material concebido po Maria Montessori; outros acrescentam novos materiais educativos; e trabalhos em grupo, como música, artes, poesia, e jogos, podem complementar as atividades individuais com o material Montessori.

\section{Considerações finais}

Desenvolvendo um projeto para uma escola, Hertzberger procurou estabelecer um diálogo entre a proposta pedagógica e a sua concepção de arquitetura. O conceito montessoriano de "ambiente preparado" e de "casa das crianças", então, materializa-se na proposta de uma escola configurada como uma mini-cidade, que representava, no fundo, a tentativa de fundir a idéia de um laboratório científico (colocada pela proposta pedagógica) com a preocupação e a busca do arquiteto em oferecer ali uma diversidade de espaço, onde fossem possíveis interpretações individuais, em virtude de sua capacidade de acomodar, absorver e instigar usos, apropriações e alterações desejadas.

Se todo indivíduo deveria educar e agir por si mesmo, como dizia Montessori, nada mais adequado do que uma arquitetura que colocasse as crianças como interventoras e construtoras de sua própria identidade. Jogando com a rigidez da "ordem" montessoriana e com a sua proposta estruturalista, Hetzberger se propôs a evitar a racionalidade funcionalista e a neutralidade, as quais considera justamente a ausência de identidade, buscando construir um ambiente convidativo à intervenção de seus usuários. E para tal, procurou conceber seu projeto de forma a estar aberto às possibilidades de mudança, pois é este, ao seu ver, o princípio que contribui para a criação de significado de cada forma individualmente.

Assim, "para fazer frente à mudança, as formas construídas devem ser feitas de tal modo que permitam múltiplas interpretações" (Hertzberger 1996) e a única abordagem construtiva vista por ele para uma situação que está sujeita à mudança é uma forma que parta da própria mudança como fator permanente: uma forma que seja polivalente, que se preste a diversos usos sem que ela própria tenha que sofrer mudanças, de maneira que uma flexibilidade mínima possa produzir uma solução ótima.

No projeto de Hertzberger, portanto, forma e função produzem-se mutuamente, e é a interpretabilidade que deve constituir-se como característica inerente à forma. 
Tenta-se não só ir ao encontro das exigências da função no sentido estrito, mas também fazer com que o objeto construído possa cumprir mais de um propósito: "as formas dependem de como são 'lidas' e das imagens que são capazes de suscitar para o 'leitor'. Uma forma pode evocar imagens diferentes em pessoas diferentes, e, deste modo, assumir um significado diferente" (Hertzberger 1996).

Talvez pela sua própria arquitetura, ou talvez pela própria proposta montessoriana, Hertzberger acabou explorando primordialmente a percepção visual e a manipulação (tato) como conseqüência e complementação daquela. Poucos são os estímulos que atingem os demais sentidos da criança, os quais são essenciais para a percepção do ambiente, principalmente nesta fase em que a experimentação sensorial é o seu mecanismo de descoberta do mundo.

Ainda, em função da ênfase dada pela escola à atividade individual, os elementos e materiais disponíveis para manipulação das crianças acabaram ficando restritos às salas de aula e, apesar de Hertzberger ter procurado extrapolar esse limite, expandindo a proposta dos materiais para fora das classes, com o podium e o quadrado nos halls, estes acabaram configurando-se como intervenções pontuais e isoladas.

Apesar, portanto, da aproximação entre propostas pedagógica e ambiental, parece ter havido um desencontro entre o foco no desenvolvimento individual e concentrado (pela escola) e a busca de uma coletividade (pelo arquiteto), e entre a importância dada aos materiais próprios da metodologia proposta e a tentativa de dar presença e transformar o ambiente construído com um todo em uma estrutura de aprendizagem.

Não podemos avaliar se (e como) os espaços, objetos e equipamentos propostos por Hetzberger foram de fato apropriados e ampliaram as possibilidades de intervenção e exploração pelas crianças. No entanto, este projeto levanta um importante questionamento sobre a relação entre forma, função e uso, entre projeto e apropriação do mesmo, e sobre os limites entre "criar espaço" e "deixar espaço". O estudo e análise de suas intervenções e de seus princípios norteadores para pensar a inter-relação entre criança e ambiente podem ser um rico estímulo para a revisão das maneiras como vêm sendo concebidos os ambientes infantis, e mesmo os projetos de arquitetura em geral. 

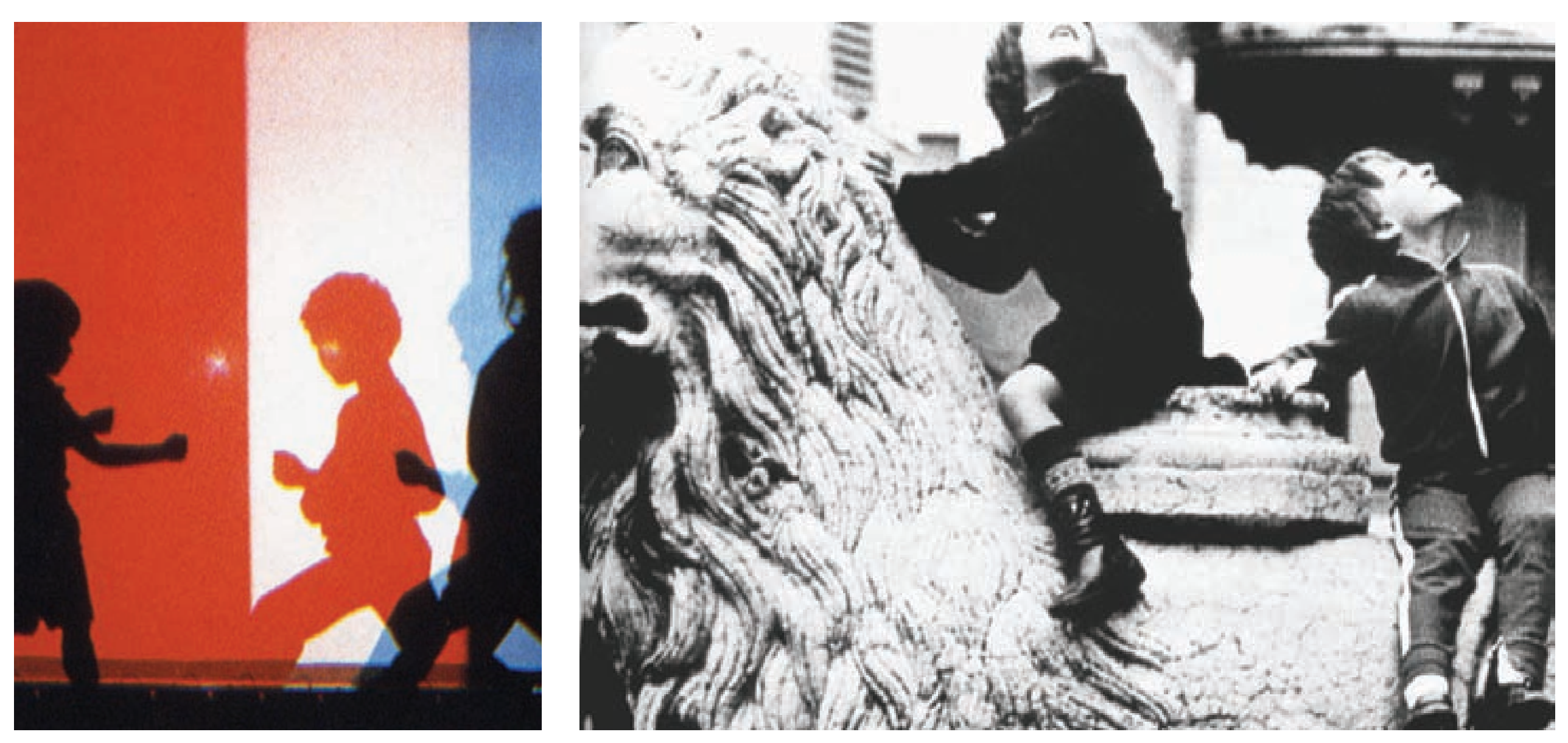


\section{A experiência das escolas infantis municipais de Reggio Emilia (Itália)}

Projeto de arquitetura autoria desconhecida

Local e Ano Reggio Emilia, Itália, 1963

Escola analisada educação infantil dos 3 aos 6 anos de idade

Total de crianças 75 crianças (tempo integral, na maioria)

Total de salas

3 salas ( 1 sala de cada idade)
A análise deste projeto é feita a partir de informações pesquisadas em publicações, na internet, e a partir de conversas com pessoal do Centro Internazionale Loriz Malaguzzi, em Reggio Emilia, na Itália, e com representantes elou estudiosos, no Brasil, da experiência italiana, uma vez que não nos foi possível visitar nenhuma das escolas municipais e sentir, experimentar e tampouco observar a dinâmica do espaço e a relação deste com as crianças e seus usuários em geral.

Mais uma vez, como na análise da escola montessoriana projetada por Hertzberger, devemos levar em consideração e estar cientes das limitações e possíveis equívocos de uma análise realizada nestas condições.

É importante ainda observar que a experiência e projeto aqui apresentados inserem-se em uma realidade socioeconômica e cultural muito particular, diversa da realidade brasileira, e são frutos de um percurso histórico também muito próprios da história italiana. O que faz com que sejam experiências únicas, não reproduziveis, que devem ser analisadas dentro de um contexto específico. No entanto, trazem uma série de questões, abordagens e proposições interessantes para a discussão do ambiente escolar infantil em qualquer parte do mundo.

\section{A proposta da escola}

Antes de analisarmos as escolas municipais da Reggio Emilia, devemos colocá-las em contexto a fim de compreender o meio sociocultural e histórico no qual se construiu e se constrói esta proposta e a realidade urbana e social em que acontece esta experiência.

A primeira escola municipal reggiana surge em 1963 em meio a um período de grandes mudanças na mundo em geral e mais especificamente, na sociedade italiana. Se a concepção da infância e da figura da criança passava por transformações ao longo do século XX, nesse momento de pós-II Guerra Mundial e governo fascista, na Itália, ela ganhava uma nova dimensão ainda mais forte, passando a representar um novo caminho a ser construído e uma liberdade em relação ao rígido pensamento e ao ensinamento do racionalismo. A criança surgia como oposição, como reforma, como anti-autoritarismo. Uma série de reorganizações político-culturais tomavam conta do país, novos valores e demandas eram estabelecidos.

Crescia, então, nos anos 50 e 60, a conscientização da urgência de uma educação infantil de melhor qualidade e mais abrangente. Novas idéias e propostas pedagógicas chegavam à Itália, vindas de outras partes da Europa, fazia-se necessária uma mudança na abordagem educa- 
cional das crianças. Com a força de grupos feministas protestos por melhores serviços sociais, escolas e cuidados infantis ganharam as ruas, e, nas localidades com uma forte tradição de iniciativa local, surgiram tentativas espontâneas para o estabelecimento de escolas coordenadas pelos pais, tais como a da Reggio Emilia.

Fundamentada na imagem de uma criança com enorme potencialidade e sujeito de direitos, a proposta de Loris Malaguzzi, pedagogo e psicólogo, figura principal na fundação e no desenrolar do projeto educacional reggiano, procurou ir além da idéia de transmissão de conhecimentos, buscando, acima de tudo, o desenvolvimento, no indivíduo, da capacidade analítica para compreender o mundo, e a capacidade criativa para transformá-lo. L'infanzia, si sa, è un'interpretazione ed una costruzione culturale. Ogni società, ogni periodo storico definisce la sua infanzia, ciò che intende, dedica e si aspetta dall'infanzia... Credo sia ormai familiare a tutti i presenti l'immagine del bambino competente, su cui fonda la stessa esperienza dei nidi delle scuole reggiane. Competente a che cosa? A relazionarsi col mondo (Reggio Children s/d, p.12).

Estabelecendo desde o início uma visão fortemente inserida em um contexto de mudanças, o projeto educativo procurava promover, assim, a formação do indivíduo como um todo, sensível, atento, observador, responsável, ativo, questionador e criativo. Acreditava-se que a educação deveria liberar a energia e as capacidades infantis e promover o desenvolvimento harmonioso da criança como um todo, em todas as áreas - comunicativa, social, afetiva e também em relação ao pensamento crítico e científico.

Tendo surgido este sistema a partir de um movimento de colaboração entre os pais, houve, desde o início, um reconhecimento explícito da importância da relação ou da parceria entre pais, educadores e crianças. Inserido em uma cidade de apenas 130.000 habitantes, o projeto de escolas municipais de Reggio Emilia primou desde o início pelo diálogo contínuo entre administradores, professores, oficiais eleitos e a participação de toda a cidade e da comunidade de forma geral no desenvolvimento educacional da primeira infância. A participação das famílias na vida e na gestão dos serviços de infância municipais sempre fez, e ainda faz, parte da história da experiência, e é um dos elementos que marca fortemente a identidade desta proposta educativa.

Não podemos deixar de considerar, então, este contexto muito específico de desenvolvimento das escolas mu nicipais reggianas, que, como veremos a seguir, influencia significantemente o desenrolar do projeto, tanto no que se refere ao diálogo estabelecido com a comunidade, quanto com relação à inserção física e à interação concreta que se dá entre escolas e cidade, nas suas variadas dimensões (cultural, física, social, etc.). Deve haver um processo de "osmose" com a cidade: la scuola non deve essere un contro-modo, ma essenza e distillato della società. La realtà contemporanea può e deve permeare la scuola, filtrata da un progetto culturale di interpretazione che funge da membrana e interfaccia (Ceppi e Zini 1998, s/ p.).

\section{Criança e ambiente nas escolas municipais reggianas}

Entre os principais objetivos do enfoque colocado pela proposta reggiana está o de reforçar a idéia de identidade de cada criança. A criança é vista como portadora e construtora de culturas próprias e participante da organização de suas identidades, autonomia e competências, através da relação com outras crianças, adultos, coisas, idéias, fatos e eventos, etc.

Considerando que ela passa por um longo e laborioso trabalho para construir a sua própria identidade, para dotar a si mesma de cara, corpo, gesto, palavra, pensamento, emoção e imaginação, a proposta das escolas de Reggio Emilia acredita que este processo deve ser desenvolvido a partir de experiências concretas e de suas comunicações. Deste modo, procura promover nas crianças a ampliação das redes de comunicação e de domínio e a experimentação e expressão por meio de linguagens em todos os níveis. Segundo Loris Malaguzzi, a criança tem "cem linguagens" (ver texto ao final do capítulo) e é preciso, portanto, encontrar as conexões entre a "escola do saber" e a 
"escola da expressão", a fim de abrir as portas para estas cem linguagens (Edwards, Gandini e Forman 1999, p.87)

Por meio de projetos que investigam fenômenos reais o trabalho da escola é visto como um meio de "desempacotar" ou tirar a familiaridade de objetos e de eventos do cotidiano (Edwards, Gandini e Forman 1999) despertando a curiosidade e a atenção das crianças como um estímulo ao questionamento e à posterior experimentação e compreensão do mundo que as cerca. Acredita-se que as crianças têm uma força inata que as impulsiona, mas que esta força se multiplica ainda mais quando se dão conta que ação e idéias são um recurso importante. Por isso, a presença das outras crianças e dos professores, em um trabalho conjunto de elucubração, imaginação, experimentação e descoberta, é também considerada essencial para o processo de aprendizagem.

Se a criança é um sujeito construtor de conhecimentos, deve então ser protagonista do ato cognitivo, vivendo o conhecimento como prática. Daí, o conceito de escola como "laboratório", como "oficina de saber e de conhecimento" (Ceppi e Zini 1998, s/ p.), onde as crianças são incentivadas a explorar o ambiente e a expressar a si mesmas através de todas as suas linguagens ou modos de ex pressão, sejam elas verbais ou não-verbais.

Nas escolas da Reggio, não há um currículo fixo, nem uma rotina preestabelecida, o que não quer dizer que não haja um planejamento ou uma reflexão sobre os processos de ensino e aprendizagem. A cada ano, cada escola delineia uma série de projetos relacionados, alguns de curto, outros de longo prazo, os quais são entremeados por atividades mais pontuais e direcionadas. Estes temas servem como apoios estruturais principais, mas o dia-a-dia das crianças se desenvolve de acordo com as decisões tomadas tanto pelos professores quanto pelas crianças. De forma geral, no entanto, as crianças não são encaminhadas seqüencialmente de uma atividade para outra diferente, e são encorajadas a repetir experiências fundamentais, e a observar, considerar e representar muitas das coisas mais de uma vez, procurando aprofundar o processo de conhecimento por meio da experimentação concreta.

Sua abordagem incentiva, então, o desenvolvimento intelectual das crianças por meio, principalmente, da representação simbólica. A partir de hipóteses e teorias que dão significado aos acontecimentos e coisas do mundo que as rodeiam, as crianças partem para a exploração e pesquisa dos elementos e fenômenos envolvidos, e, posteriormente, procuram representar os "resultados" e descobertas alcançadas utilizando-se de diversos meios suportes (palavras, movimento, desenhos, pinturas, montagens, escultura, teatro de sombras, colagens, dramatizações, música, etc.). Acredita-se que todas as teorias, das mais simples às mais complexas, devem ser verbalizadas ouvidas e representadas para poderem existir. Enquanto as representam, as crianças começam a conhecê-las e entendê-las melhor, e esse processo permite que suas imagens e intuições tomem forma e evoluam por meio da ação, da emoção, da expressão, da iconização, da representação simbólica e das centenas e milhares de linguagens com que narram e explicam o mundo e a si mesmos (Instituto Tomie Ohtake 2007).

Para que todos esses processos aconteçam de forma rica, permitindo interconexões e relações as mais variadas possíveis, o ambiente deve estar organizado de maneira a sustentá-los. A proposta das escolas municipais de Reggio Emilia dá, desde o seu início, muita atenção ao contexto físico da educação, colocando o espaço como um interlocutor da aprendizagem, e é principalmente por este motivo que trazemos esta experiência para discussão neste trabalho. Apesar de esta experiência italiana ser extensamente conhecida entre pedagogos, psicólogos pesquisadores e estudiosos da educação em várias partes do mundo, não nos pareceu haver ainda uma análise mais detalhada e aprofundada do ambiente escolar como um todo, abordando desde os seus elementos constitutivos até a sua dimensão inter-relacional. O livro Bambini, Spazi, Relazioni: metaprogetto di ambiente per l'infanzia, publicado pela Reggio Children (Centro internazionale per la 
difesa e la promozione dei diritti e delle potenzialità dei bambini e delle bambine), em que as "palavras-chave" para a concepção de um ambiente escolar, e as indicações de projeto para o mesmo são apresentadas, nos pareceu constituir mais uma pesquisa desenvolvida e proposta pelo Domus Academy Research Center em torno do tema (ambiente escolar) do que propriamente um estudo sobre o projeto das escolas da Reggio Emilia. Alguns elementos da proposta reggiana acabam sendo pouco explorados, enquanto outros tópicos de projeto acabam sendo discutidos de forma mais genérica e abstrata.

Tentaremos, a seguir, destrinchar um pouco mais como se concretizam o projeto e a experiência reggiana em uma de suas escolas, a Escola Diana, localizada na Viale Allegri, em meio aos Jardins Públicos do centro histórico da cidade1.

\section{O ambiente escolar}

Acreditando na importância da reflexão e revisão constante do trabalho educacional, as escolas de Reggio Emilia desde o início procuram desenvolver pesquisas baseadas em observações "de campo" (da prática cotidiana) a fim de promover mudanças e garantir a sintonia entre o ambiente e a realidade e a construção cultural de seus usuários. Realizada por pedagogos, professores e atelieristas (como são designados os responsáveis pelo ateliê, que será explicado mais à frente), a primeira pesquisa de comportamento, apropriação e percepção dos espaços pelas crianças, que visava modificações do ambiente escolar, foi desenvolvida no começo dos anos 70, quando se percebeu como este não se adequava mais à filosofia e às metodologias educativas daquele momento. As observações foram levadas para discussão junto a um arquiteto, e, depois de inúmeras discussões e reflexões, resultaram na individualização de novas identidades dos espaços da escola, prefigurando novos mobiliários e funções e tornando-os mais coerentes com o projeto pedagógico.
Naquele momento, tendo a escola Diana como primeiro projeto a ser reformulado, foram apontadas algumas diretrizes gerais, que podem ser observadas ainda hoje no ambiente existente (e que tornaram-se referências para o desenvolvimento das demais escolas, sem a supressão de suas identidades próprias). O salão central se transformou em uma praça capaz de fornecer múltiplos encontros; a entrada tornou-se um espaço convidativo à chegada na escola, com apresentações e informações da mesma; cozinha e banheiros ganharam importância e metaforicamente foram deslocadas da periferia para uma zona central; e transparência e conexões entre os vazios e com a parte externa tornaram-se testemunhas visíveis da relação e da comunicação (Reggio Children 2002). Desde então, as escolas procuram refletir internamente e com os pais das crianças sobre os seus ambientes, chegando a projetar, com eles, seus mobiliários, instrumentos, equipamentos, etc., a partir dos resultados das pesquisas².

Observando algumas das escolas do sistema municipal reggiano (dentro do possível, dada a impossibilidade de visitá-las), podemos dizer que há de fato uma identidade forte da proposta, que se reconhece nos vários projetos, que comunicam claramente seus princípios e acabam utilizando muitos equipamentos e instrumentos de trabalho comuns. Isso não resulta, no entanto, em escolas idênticas, tampouco em um modelo único e reprodutível de espaço. Cada uma das escolas construiu sua própria identidade, desdobrando os mesmos princípios fundadores em arquiteturas e ambientes diversos.

Mais do que definir quais e como os ambientes escolares devem ser, ou mais do que procurar reproduzir a casa familiar ou qualquer outro lugar, a verdadeira preocupação da proposta reggiana é construir a identidade da escola como um espaço de experimentação, que pode ser desdobrado de diversas formas, conforme aqueles que o constroem no dia-a-dia.

Neste capítulo, procuraremos analisar como acontece concretamente esta experiência por meio da análise de uma das escolas, a escola Diana, trazendo uma ou outra
1 A escolha da Escola Diana se deve à maior quantidade e de informações e imagens encontradas sobre esta escola, que, freqüentemente, acaba representando o sistema de escolas municipais.

2 Nos últimos anos, como apontado na referência ao livro Bambini, Spazi, Relazioni, estas reflexões e projetos parecem estar sendo desenvolvidos em parceria com outras instituições, como universidades, institutos de pesquisa e empresas italianas e de diversas partes do mundo. 


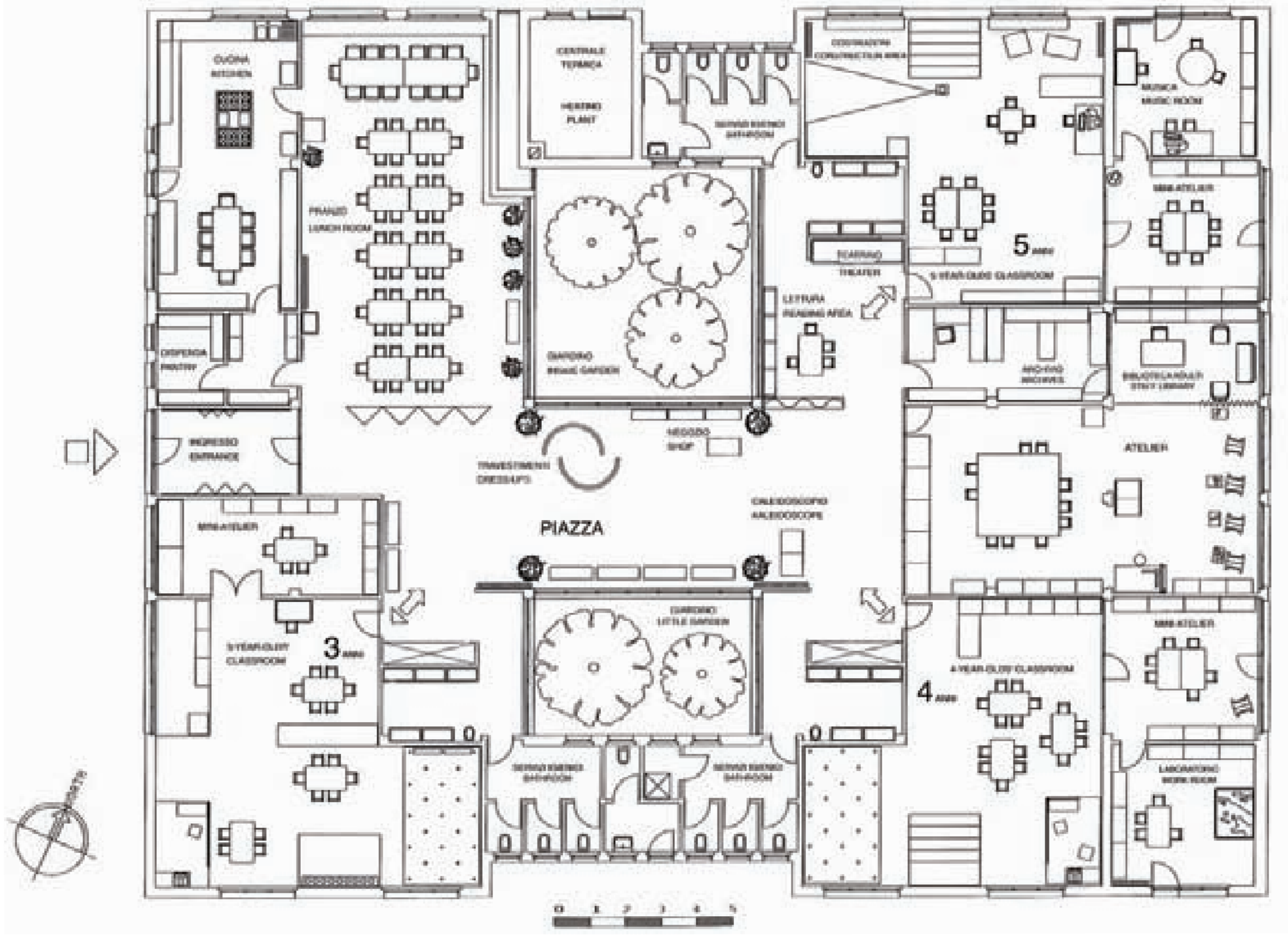

Planta baixa da escola Diana, com sua praça central, a piazza, entorno da qual se distribuem os demais ambientes; podemos ver, sinalizadas, as salas de cada uma das turmas, com suas diferentes dimensões e organizações espaciais; todas têm acoplado um mini-ateliê e, nas salas das turmas de 4 e de 5 anos, também podemos ver um terceiro ambiente, próprio para a idade em que se encontram as crianças daquela sala. 
informação e imagens de outras escolas que sejam importantes para exemplificar ou esclarecer práticas comuns a todas elas.

Como pudemos observar pelas diretrizes acima, a escola Diana, e a maioria das demais escolas municipais reggianas, organizam-se a partir de uma praça central, a piazza, em torno da qual se distribuem as salas de aula, separadas, em geral, em turmas por faixas etárias (3, 4 e 5 anos).

Cada uma das salas apresenta materiais, equipamentos e brinquedos próprios, que variam em função da idade (medidas e adequação ao momento de desenvolvimento) e dos interesses das crianças e dos seus professores. De maneira geral, as salas são os pontos de referência para cada uma das turmas, mas todas estas utilizam os vários espaços comuns da escola, assim como estabelecem in tercâmbios entre si (crianças da turma dos 3 anos visitam e "espiam" a sala e as crianças de 4 ou 5 anos, por exemplo). As atividades de cada turma também são desenvolvidas em diferentes ambientes, não se restringindo ao uso da sala de aula.

Um outro ambiente considerado uma marca da experiência reggiana é o ateliê, uma grande sala onde são exploradas inúmeras linguagens e realizados diversos experimentos, todos inseridos em projetos maiores desenvolvidos pelas crianças em conjunto com os professores. $\mathrm{O}$ ateliê não representa o que comumente se define, aqui no Brasil, como "sala de artes". Mais do que isso, o ateliê é um espaço de experimentação, um laboratório de idéias. Ali as crianças não produzem apenas "trabalhos de arte", mas experimentam modalidades, técnicas, instrumentos e materiais alternativos a partir de temas escolhidos por elas ou sugeridos pelos professores, sempre procurando descobrir, entender, provar hipóteses e questões levantadas com o grupo ou individualmente.

Além da praça central, das salas e do ateliê, as escolas reggianas apresentam também o refeitório, a cozinha, os banheiros e os jardins internos. Não há uma área específica para a administração (diretores, coordenadores mesmo professores). Todos os espaços da escola podem

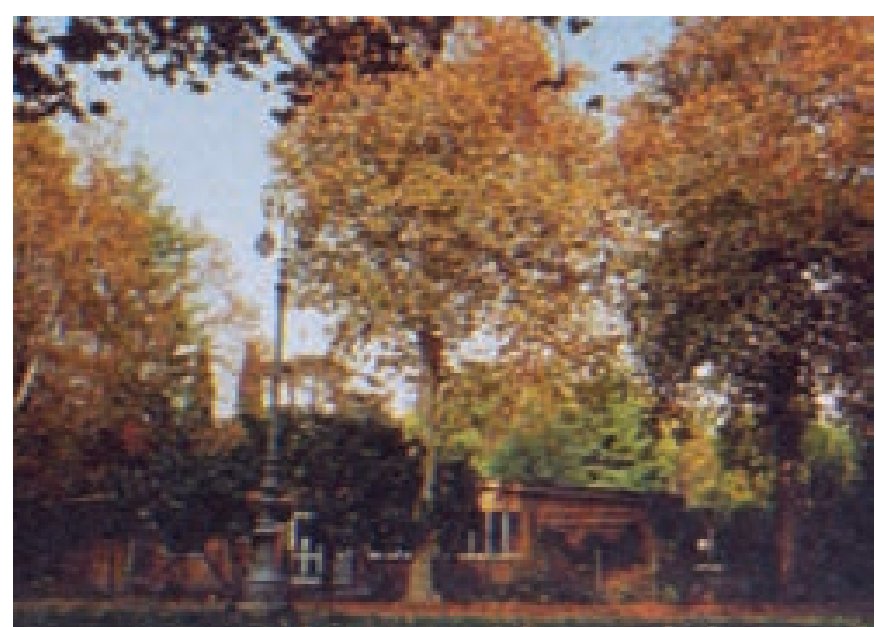

Vista da escola a partir de um dos lados dos Jardins Públicos: a escola quase que se camufla em meio à vegetação do parque.

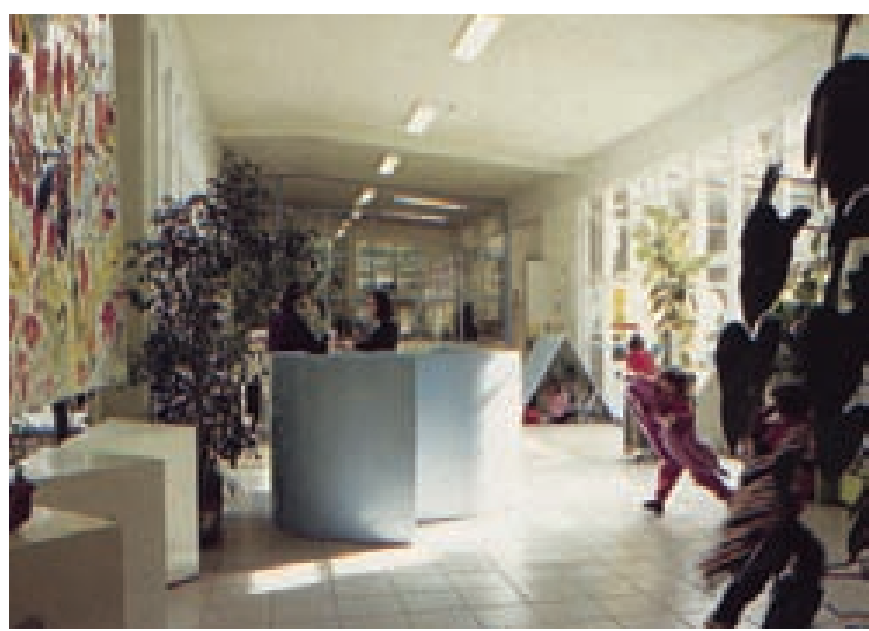

Vista a partir da entrada da escola Diana, com sua praça central e com seus jardins internos (acesso pelos painéis de vidro à esquerda e à direita da praça); a praça é o ponto de encontro e o espaço coletivo interno por excelência, constituindo a maior área livre da escola.

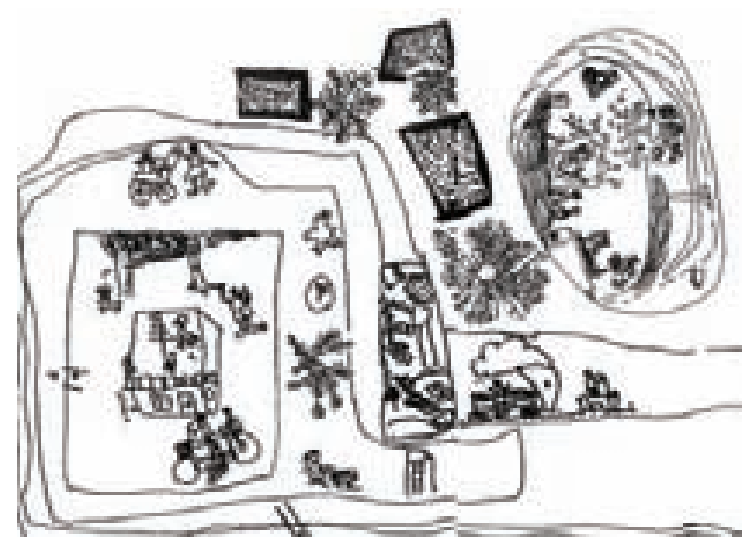

Desenho da escola e de seu entorno, feito por uma das turmas de crianças de 5/6 anos: a escola fica pequena diante de todo o universo que se apresenta ao redor.

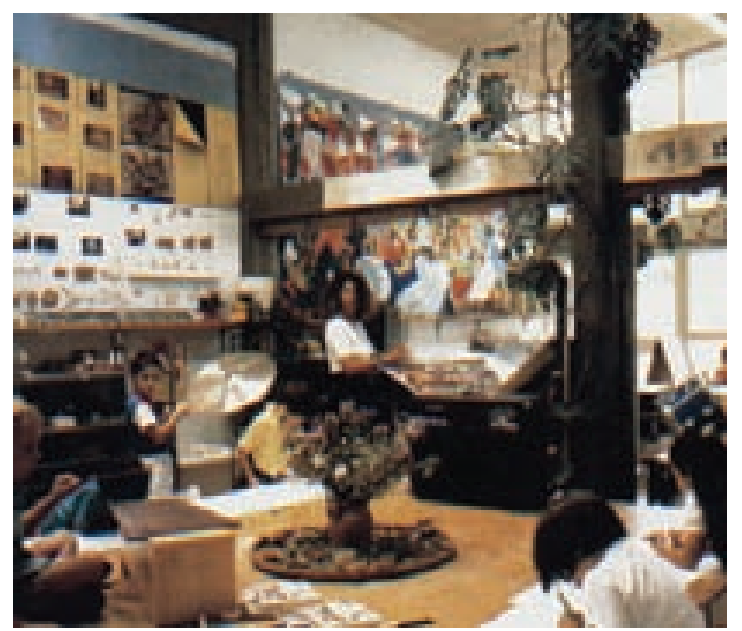

Ateliê, a grande sala coletiva onde são realizadas inúmeras e diversas experimentações pelas crianças, junto a seus professores e à atelierista: com variados materiais, equipamentos e trabalhos à vista, parece de fato um "laboratório". 


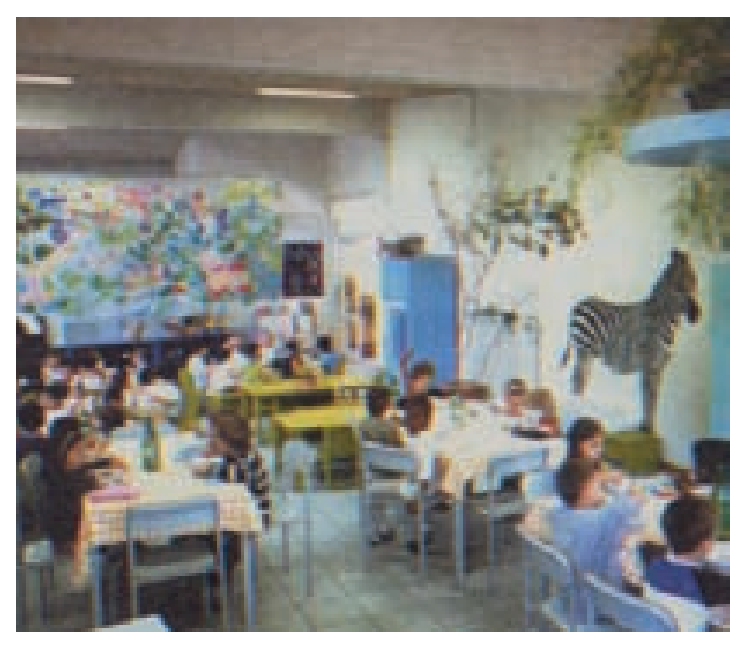

Refeitório da escola Diana, ambiente que pode servir também para reuniões; o refeitório é separado da praça central por um painel de plástico feito por um grupo de crianças; na parede, a zebra, pintada numa visita por um artista convidado, é a figura que dá hoje a identidade desta escola.

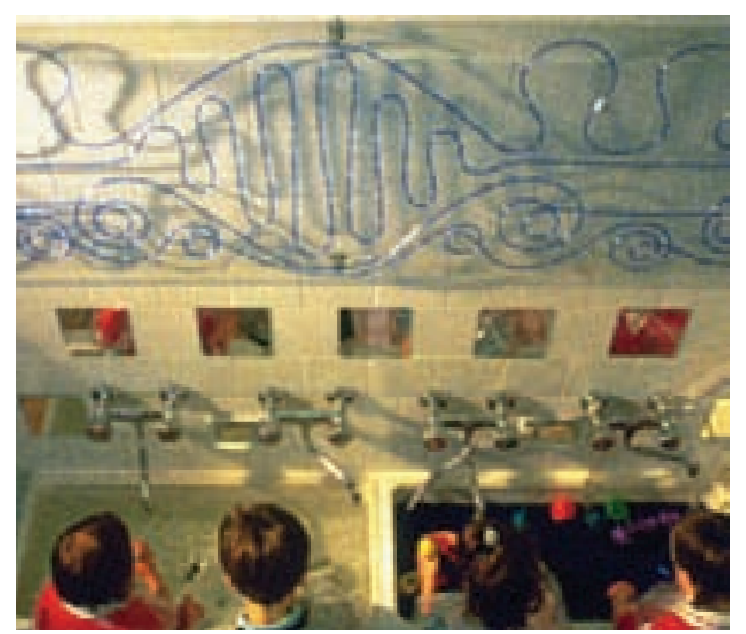

Área das pias, próximas a cada uma das salas das crianças: o momento de lavar as mãos também pode ser divertido e experimental - espelhos em ângulos diferentes ficam espaIhados pelo ambiente para que as crianças se descubram e se transformem.

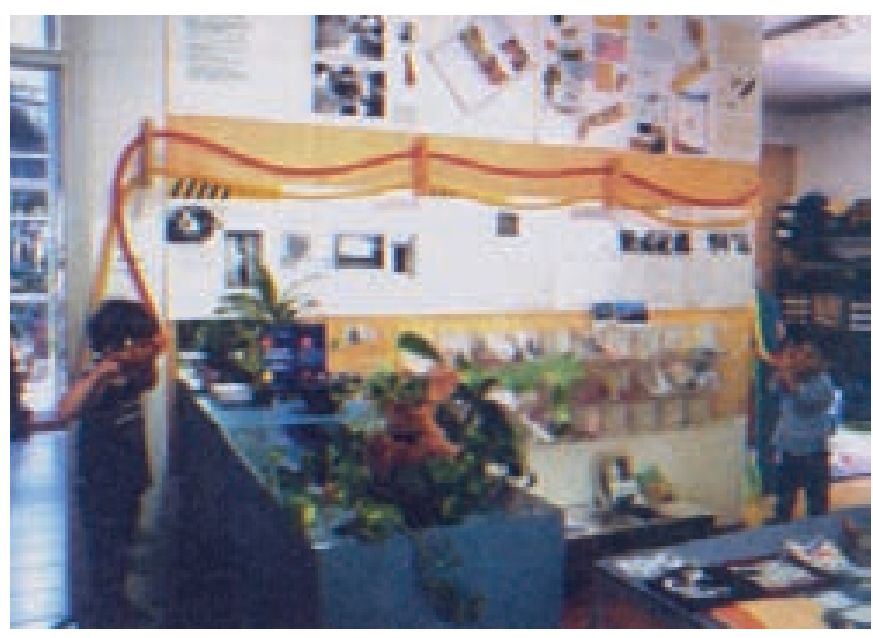

Sala da turma de três anos: à esquerda, ao fundo, vê-se o painel de vidro da praça central, de onde se acessa este ambiente: em primeiro plano, crianças brincam de telefone sem fio; é notável a diversidade de materiais, equipamentos e brinquedos presentes na sala - os quais variam de acordo com a idade da turma.

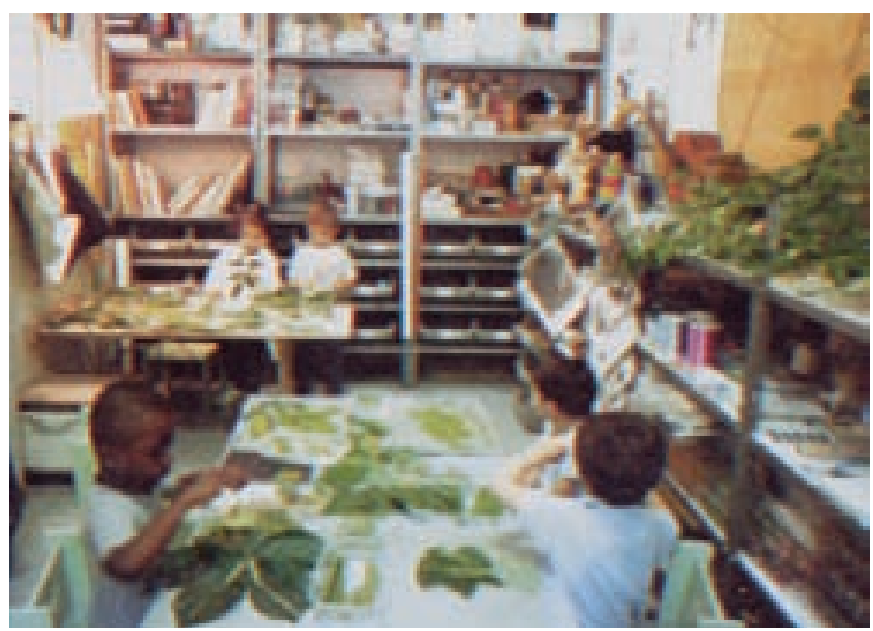

Mini-ateliê da sala da turma dos 3 anos: aqui se misturam os universos naturais e artificiais, e se exploram suas características e especificidades com a ajuda dos inúmeros materiais e instrumentos que ficam à disposição das crianças nos armários e prateleiras abertas. e devem ser utilizados por todos os seus usuários, sejam eles crianças, professores, funcionários ou pais. O refeitório e a praça central, por exemplo, são ambientes que podem ser transformados conforme a atividade ou a necessidade do momento.

De forma geral, as escolas de Reggio Emilia são de pequeno porte, horizontais (um único piso), e apresentam uma estrutura enxuta como a descrita acima. Complementando a área de cada escola, no entanto, procura-se sempre que possível inserir o seu edifício em algum terreno público maior, como uma praça ou um parque. Podemos dizer que a escola Diana é uma escola privilegiada, pois encontra-se em meio a um grande parque, conhecido como os Jardins Públicos da cidade. Apesar de apresentar uma área não muito extensa, extrapola os seus limites para o parque, incorporando-o (além de toda a cidade, como veremos adiante) ao seu universo de pesquisa e experimentação.

Como já mencionado, o dia-a-dia das crianças acontece em volta dos projetos de curto e longo prazo, combinados com algumas atividades mais pontuais e direcionadas. Toda a organização da escola e dos materiais acontece em função dos trabalhos em andamento. A cada manhã, por volta das 9 horas, quando todas as crianças já chegaram à escola, cada classe tem uma reunião. Depois, uma vez que as crianças tenham optado por uma das atividades disponíveis ou por continuar com um dos projetos em andamento, suprimentos e ferramentas necessárias são colocados sobre mesas, bancadas iluminadas e cavaletes, ou colocados em espaços convenientes. Os materiais são selecionados com antecedência e colocados de um modo organizado em recipientes transparentes, com o auxílio dos professores. Além disso, tudo o mais que precisam as crianças pode ser encontrado em prateleiras abertas, or ganizadas, cheias de materiais reciclados e não-reciclados (Edwards, Gandini e Forman 1999).

Segundo a proposta reggiana, todos os aspectos da organização diária devem se derivar diretamente das es colhas educacionais, e o projeto arquitetônico deveria ele 
mesmo se constituir como um "projeto de pesquisa" e uma "metáfora do conhecimento" (Reggio Children 1996).

\section{O ambiente escolar como interlocutor da aprendizagem}

A análise a seguir é feita com base nos mesmos parâmetros apontados na análise da escola montessoriana projetada por Hertzberger, parâmetros estes levantados a partir dos estudos e questionamentos desenvolvidos no capítulo 2. Respeitando a identidade e as especificidades do projeto da escola Diana, algumas alterações podem, no entanto, ter sido feitas com relação aos critérios de avaliação ou mesmo à ênfase dada a cada um destes.

\section{A. Organização espacial e campo visual}

Como já observado, a escola Diana organiza-se em torno de um núcleo central, conhecido como a piazza, "lugar público da escola, que exerce no edifício o mesmo papel da praça da cidade" (Ceppi e Zini 1998, s/ p.), e que vem justamente exemplificar a colocação da escola como reflexo da sociedade na qual está inserida.

Além de se apresentar como um espaço que se abre e convida aquele que adentra a escola, depois de passar por uma área relativamente estreita e mais fechada, a praça central reforça um dos conceitos da proposta reggiana de que o processo de aprendizagem só se dá por meio da interação e da troca entre crianças, entre estas e os objetos e entre estas e os adultos. Nela estão colocadas as noções de coletividade, de público e privado, de integração, de reunião. E acaba, assim, se constituindo como um ponto de referência importante, facilitando inclusive a compreensão do espaço da escola por parte das crianças.

A organização espacial nuclear, evitando o uso de corredores, traz também a opção por um espaço mais fluido e integrado, que permite e estimula um ambiente relacional, sem hierarquia, com mais liberdade e menos controle. As crianças podem circular pela escola sem a ajuda ou a vigilância dos adultos, e são incentivadas a tal, uma vez que
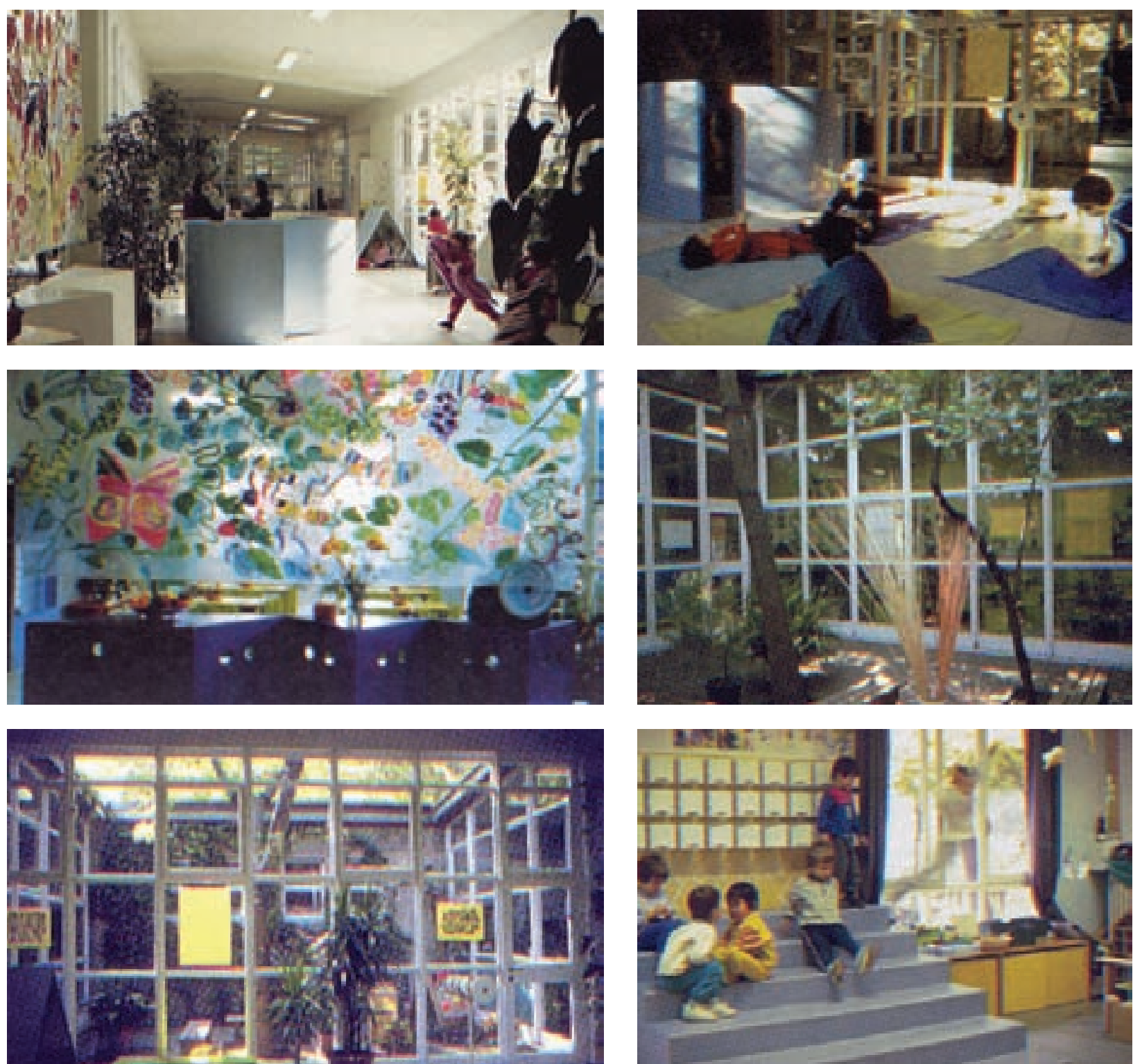

A praça e suas relações de integração: centralidade, fluidez dos espaços e comunicação com outros ambientes por meio de elementos móveis de separação (armários e painéis); transparência (vidros), etc.; trocas com a natureza por meio dos jardins internos: zonas intermediárias entre condições climáticas externas e internas (controle de abertura, luminosidade, ventilação, cor, temperatura, etc.) - permite uma série de experiências sensoriais (cheiros da comida, luz do sol, água da chuva, etc.). 


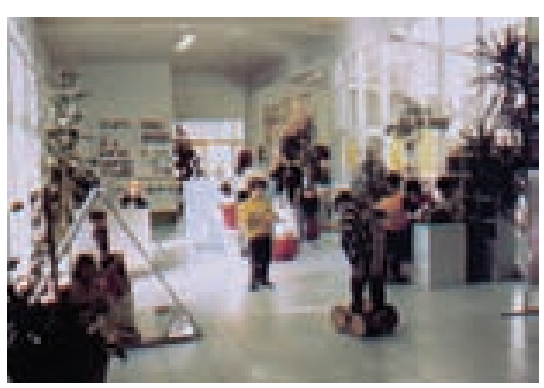

Os vários momentos da praça - usos e apropriações variadas, criando ambientes diferentes em cada momento: momentos livres e momentos de atividades mais direcionadas; simulação de uma "multidão", modelo vivo, música; explorações de expressão corporal e musical, por exemplo, não acontecem apenas nas salas específicas para as mesmas (apesar da existência de uma sala junto à sala de aula das crianças de 5 anos), e podem ser realizadas em vários am bientes da escola (os instrumentos musicais ficam no ateliê grande e podem ser deslocados para qualquer lugar pelas crianças).
Pela planta da escola, podemos observar onde acontecem as mudanças de campos visuais, as quebras, barreiras, etc, que impedem que a escola seja vista por inteiro e se esgote um único olhar; com pés-direitos, larguras e áreas diferentes, os ambientes provocam sensações diferentes, que podem ser ressaltadas ou amenizadas conforme a relação que se estabelece entre estes e seus elementos.
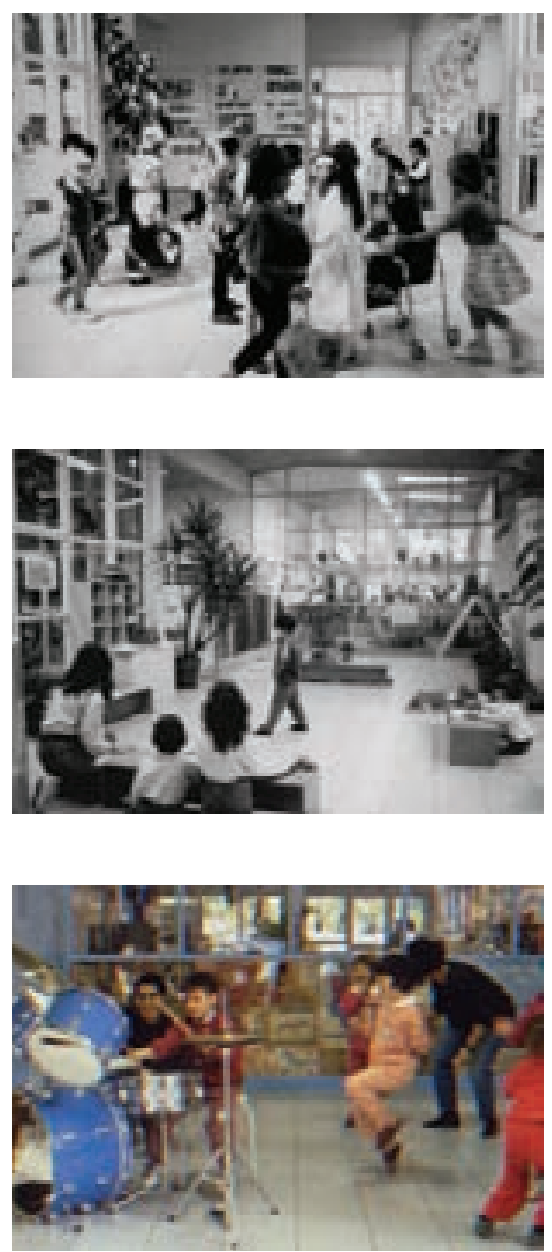

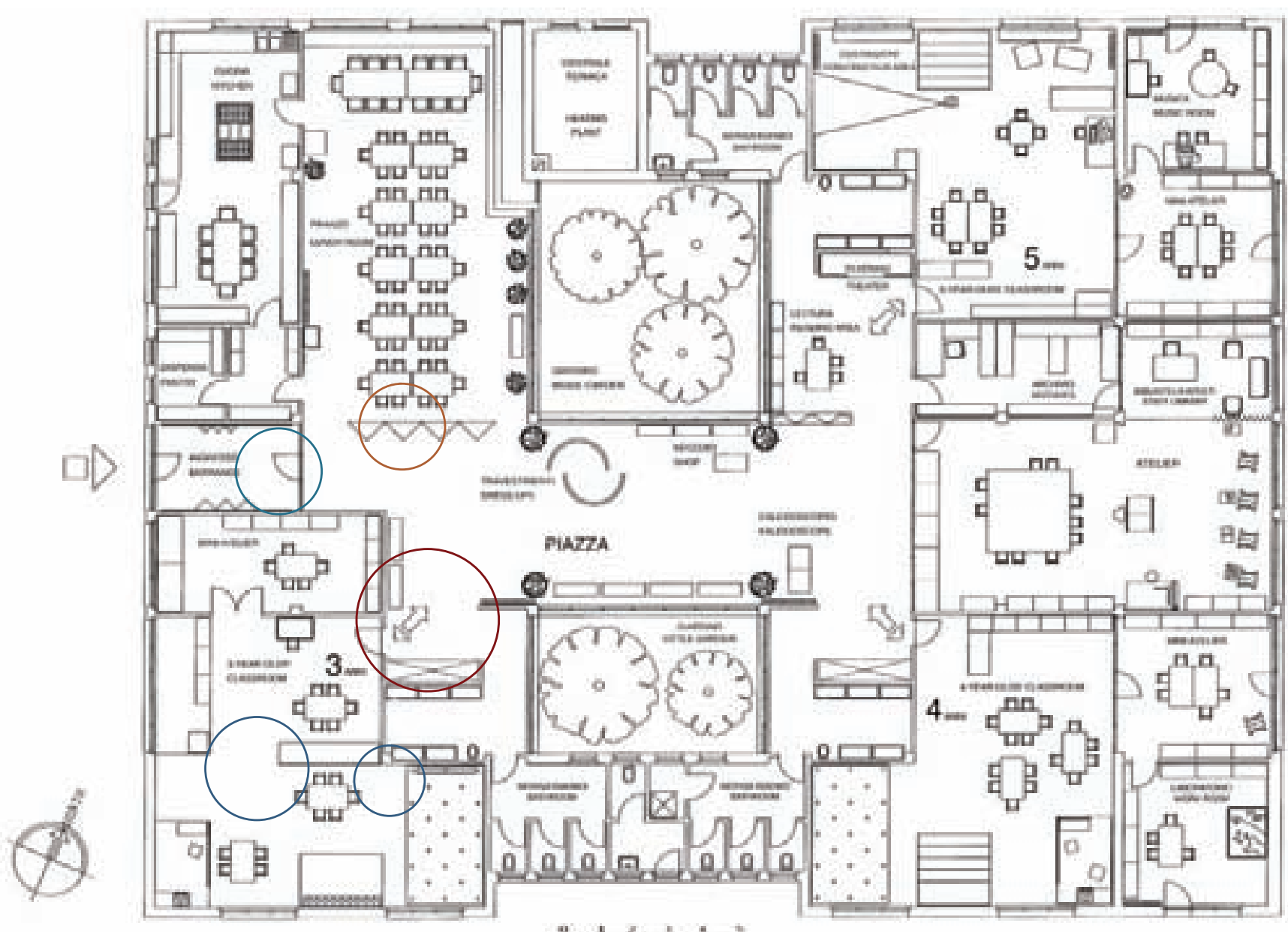


seus espaços são bem definidos, distribuídos a partir de uma lógica clara e facilmente compreendida por aquelas, e acessíveis, tanto pela sua localização, quanto pelas características arquitetônicas de seus elementos.

Toda a escola é permeada por vidros, reforçando ainda mais a idéia de integração e troca, e possibilitando a visão do conjunto da mesma de vários pontos. Janelas, divisórias e portas acabam se transformando em membranas de inter-relação entre os diferentes ambientes internos e entre o exterior e o interior.

Estando rodeado por jardins, que podem ser acessados por vários pontos, inclusive por cada uma das salas de aula individualmente, o edifício escolar está sujeito a constantes trocas com o meio ambiente e os seus habitantes (pássaros, gatos, insetos, etc.). E, inserido ainda no terreno dos Jardins Públicos, dialoga e abre seu campo de visão e observação para um imenso universo. Ao mesmo tempo, as cercas vivas que circundam o terreno da escola garantem a privacidade e a sensação de conforto e segurança necessárias às crianças nessa fase da vida.

No entanto, apesar de um núcleo central, de uma planta compacta que se desdobra a partir dele, e da presença significativa de vidros e transparências, a escola não se esgota em um único olhar, apresentando uma série de cantos e ambientes que somente são desvendados à medida que se desbravam os seus espaços, tanto internos quanto externos. Principalmente para as crianças, cuja linha do horizonte é mais baixa, a escola é feita de inúmeros cantos e esconderijos, que proporcionam experiências e sensações diversas.

Além da riqueza e da complexidade dos espaços externos e da relação entre estes e o edifício da escola, acontecem também significativas mudanças de ambientes e quebras de ritmos internamente à escola, o que podemos observar principalmente na passagem da área de recepção para a praça e da praça para as salas de aula (e mesmo no interior destas)

Ao entrar na escola, o usuário depara-se com uma pequena área que o recepciona com textos, imagens e alguns
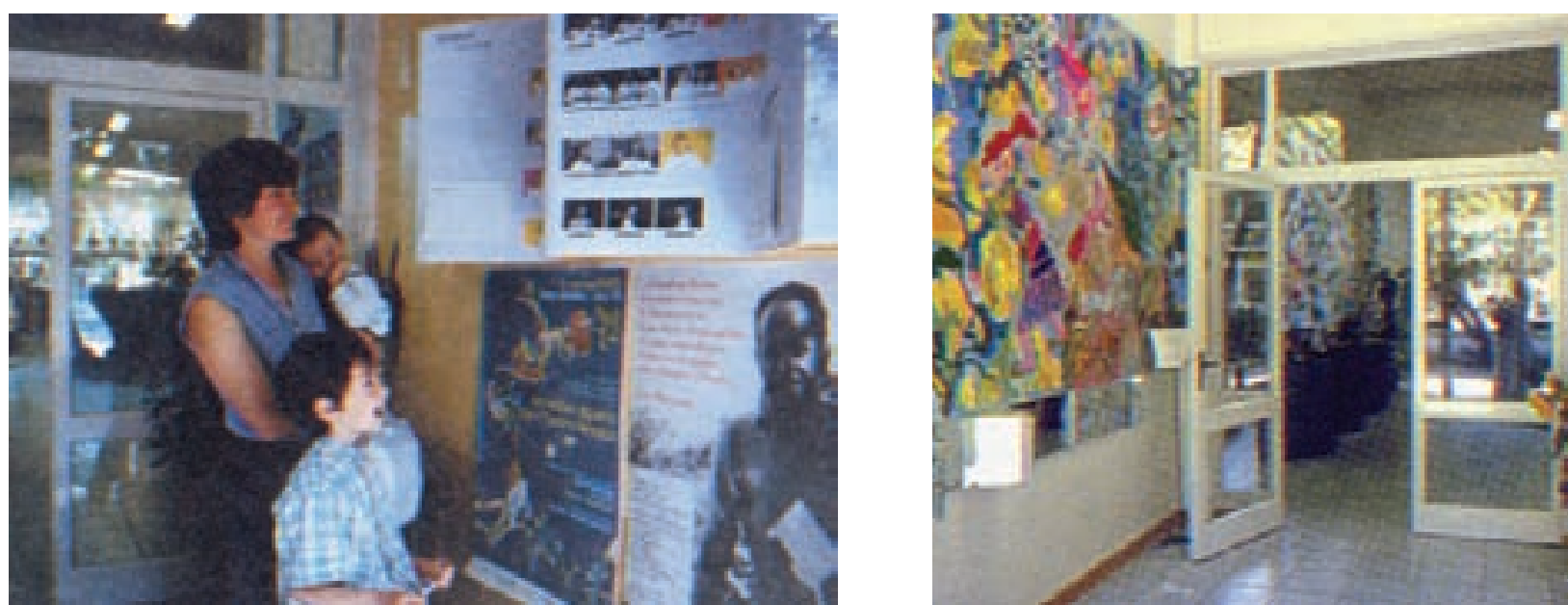

A área-corredor de recepção, e a praça, ao fundo, após as portas de vidro: passagem de um ambiente mais estreito, menor com pédireito mais baixo, para um outro mais amplo, mais aberto, maior e com pé-direito mais alto, provocando sensações diferentes.
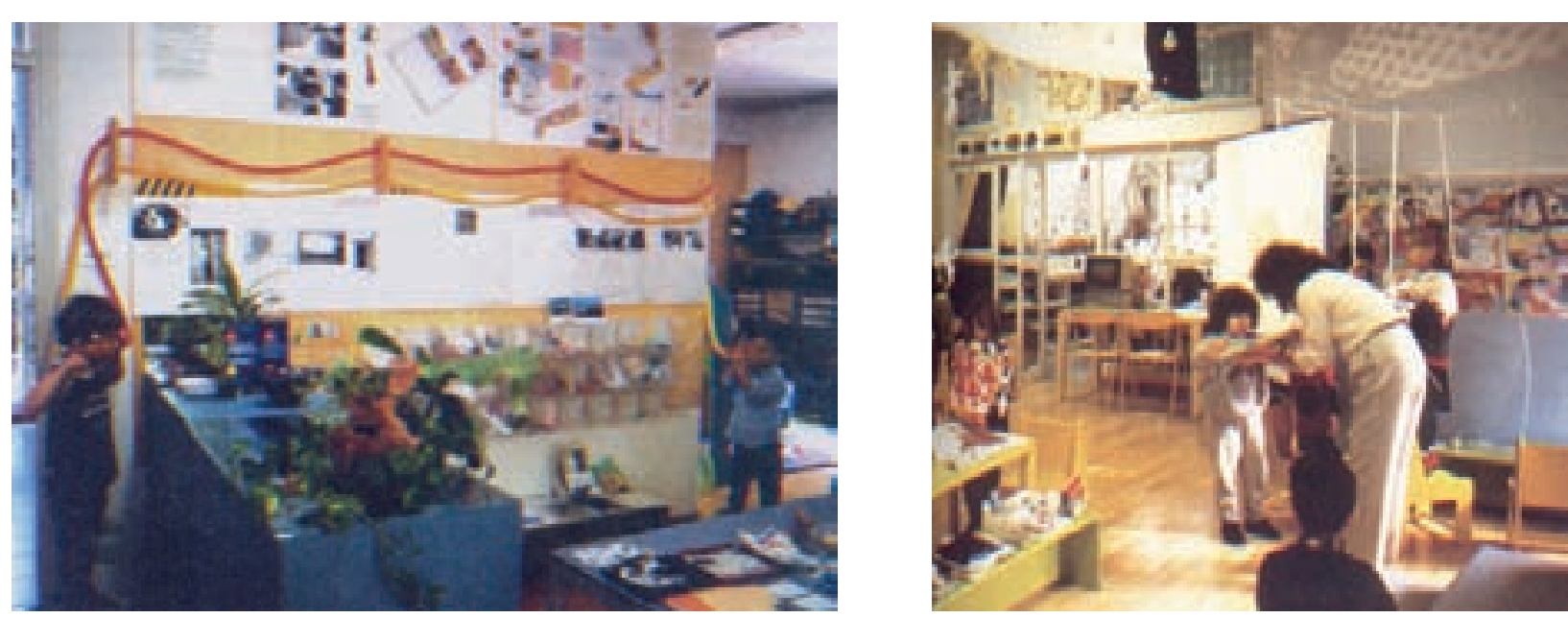

Móveis, panos, painéis, elementos da arquitetura e equipamentos são utilizados para a criação de cantos, ambientes e campos visuais diferentes, estabelecendo ritmos e sensações de privacidade variadas dentro das salas. 

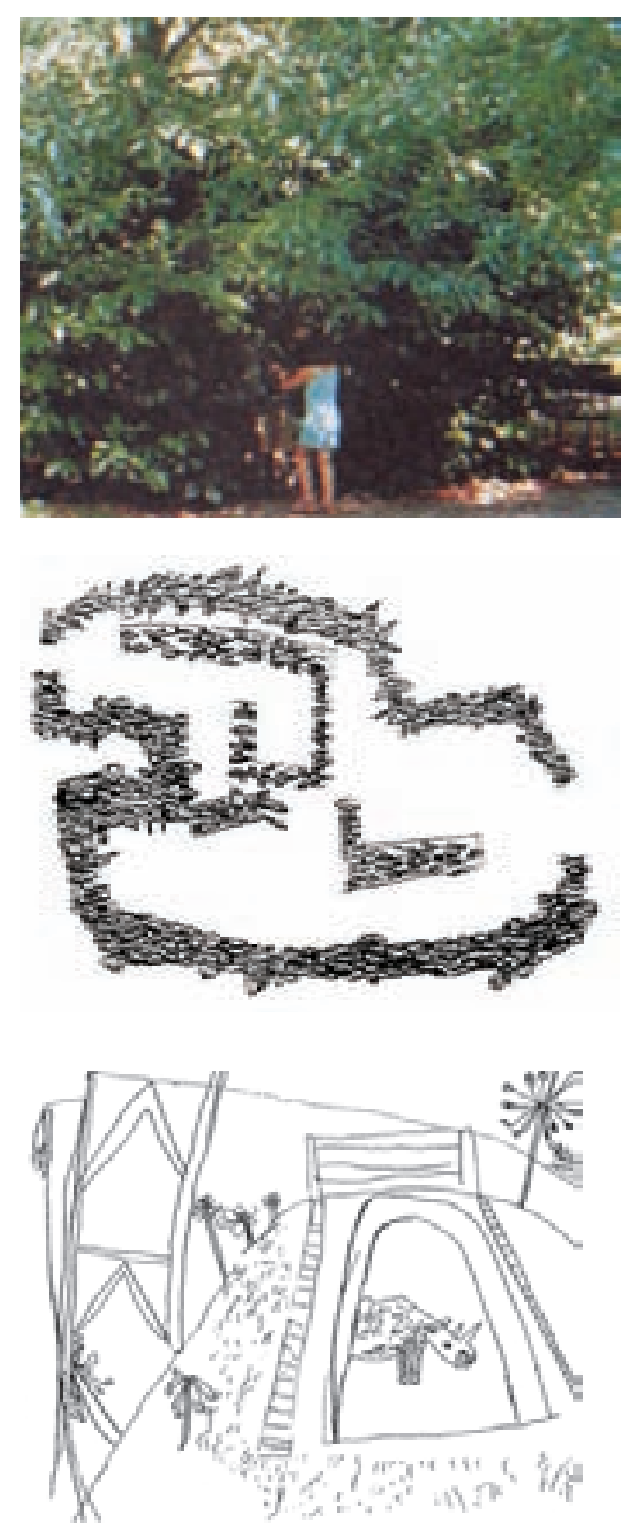

As variações de campos visuais acontecem principalmente no espaço externo da escola, através da vegetaçåo e da construção de "buracos" na terra, "labirintos" de árvores e etc. elementos que estimulam a interação das crianças, como espelhos, por exemplo. Esta área acolhe e "recolhe" quem vem de fora, que então sente-se abrigado e convidado a adentrar o edifício. Ao deixar este primeiro espaço de contato com a escola, o usuário é então recebido mais abertamente por um segundo espaço, amplo e iluminado (luz natural), que passa a ser mais impactante justamente em função do contraste causado pela diferença entre os campos visuais

Mais adiante, de um espaço aberto e amplo, passase para um espaço intermediário semi-fechado ("semipúblico") e chega-se a uma das salas de aula, cujo formato em "L" e a composição de cantos e áreas variadas criam ritmos e sensações bem diferentes dos encontrados naqueles primeiros espaços coletivos.

Esta alternância entre espaços abertos e fechados e, conseqüentemente, entre campos visuais abertos e fechados, é extremamente importante para dar dinamismo e evitar a monotonia da escola.

Em algumas das escolas reggianas, faz-se uso também de mezaninos, que possibilitam às crianças novos ângulos de visão e de compreensão do espaço e das coisas em geral.

B. Atividades, usos e funções e sua relação com os recursos do ambiente, a arquitetura, os materiais, equipamentos e brinquedos

Apesar de localizada em uma região onde as diferenças de temperaturas são grandes e chegam a baixar significativamente durante o inverno, a escola Diana apresenta um espaço construído e coberto relativamente pequeno e procura estabelecer uma intensa relação de troca com o ambiente externo ao longo de todo o ano.

Grande parte das atividades e projetos desenvolvidos pelas crianças acontece em algum momento fora do edifício da escola ou pelo menos estabelece algum tipo de diálogo com o mundo externo.

Tendo a realidade e as coisas do cotidiano como objeto de pesquisa e base para tudo o que é desenvolvido junto às crianças, a escola procura sair de seus limites e explorar o que acontece na cidade ou no campo, ou, ao contrário e/ou simultaneamente, trazer o universo exterior para dentro das suas paredes. Todo esse universo é considerado uma extensão da sala de aula e, portanto, parte do currículo da escola envolve levar crianças para que explorem as vizinhanças e os marcos da cidade. O espaço familiar da cidade pode tornar-se o palco e o tema de atividades e de explorações construtivas. A escola tem seu espaço de experimentação ampliado significativamente.

A própria arquitetura denuncia essa postura, tendo a maior parte de seus fechamentos em vidro, permitindo, assim, a interação constante com a natureza e seu tempo, seus ritmos, e suas variações.

Inseridos no perímetro do edifício, encontram-se também dois jardins internos, que, além de permitirem o contato das crianças com o ar livre de forma um pouco mais protegida e íntima do que no ambiente externo, figuram como dois mini-laboratórios de exploração sensorial e científica (pesquisa dos fenômenos naturais).

Escola e território, interno e externo, portanto, estabelecem uma estreita relação. O objetivo é que aquela seja, e que parece de fato acontecer, um lugar que "sinta fortemente aquilo que acontece fora, do clima às estações, da hora do dia ao ritmo da cidade" (Ceppi e Zini 1998, s/ p.). Parque, natureza e cidade são os grandes objetos de estudo das crianças - as chuvas, os animais, o vento, o sol, a arquitetura, as pessoas, os sons, etc. Os desafios estão aí; o espaço da escola fica pequeno perto disso e acaba se constituindo mais como local onde se dá o aprofundamento das pesquisas a partir da observação externa, ou a produção da comunicação das mesmas.

Com um currículo de natureza informal, então, como já pudemos observar, em que há uma grande flexibilidade de tempo e as crianças são livres para brincar e trabalhar em atividades as mais variadas, a escola procura oferecer uma rica gama de possibilidades de escolha de equipamentos e materiais a serem explorados e utilizados para 
as mais diversas experimentações, o que podemos ver acontecendo na maior parte de seus ambientes.

Considerada um "recipiente" (como a própria escola aponta) que abriga e dá suporte aos processos de aprendizagem, podemos observar que a arquitetura é relativamente neutra, comunicando os valores e princípios da escola por meio da sua simplicidade, clareza (sem cair na obviedade), transparência, permeabilidade, centralidade e ausência de hierarquia, mas, acima de tudo, dando espaço para que a transformação aconteça, por meio da apropriação, criação e manipulação dos elementos móveis e semifixos que compõem os ambientes.

$\mathrm{Na}$ escola Diana e, pelo que nos pareceu, em todas as escolas reggianas, são os equipamentos, mobiliários, brinquedos, materiais e, significativamente, os trabalhos das crianças que exercem o papel principal na construção do ambiente educativo. Buscando estabelecer o que eles chamam de "normalidade rica", trabalha-se com a idéia de que se deve conferir à nomalidade um valor novo e positivo, e não criar um outra realidade extraordinária, e desconexa do mundo contemporâneo existente. Por isso, uma arquitetura simples, que, no entanto, cria, sugere e possibilita diferentes situações e ambientes e é capaz de abrigar e se sujeitar a mudanças.

Acredita-se que o objetivo de ensino é oferecer condições para a aprendizagem, e podemos dizer que uma das grandes riquezas da experiência reggiana está justamente na abertura para receber e interagir com tudo, seja com o mundo natural como com o mundo artificial, que faz com que seu ambiente seja pensado de forma a proporcionar a infra-estrutura necessária e a disponibilidade constante de materiais para estas diversas explorações.

Vários são os tipos de materiais e equipamentos que ficam à disposição das crianças para que desenvolvam suas pesquisas, experiências e brincadeiras, como argila, madeira, tintas, lápis, papel, tela, projetor, slide, lanterna, fontes de luz diversas, instrumentos musicais diversos, computador, gravador, filme, máquina fotográfica, etc. sempre sob o olhar e a orientação, ou diálogo, com o
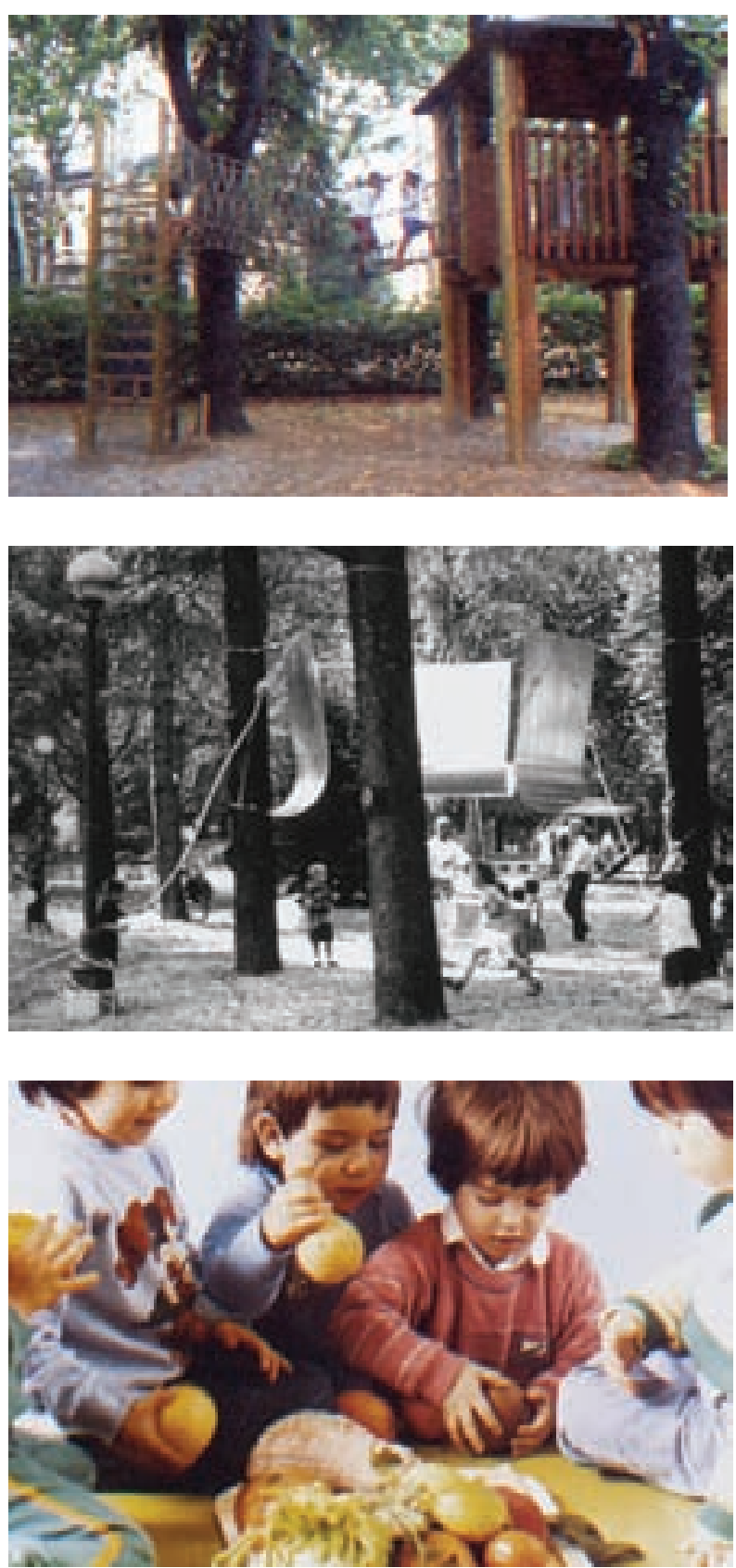

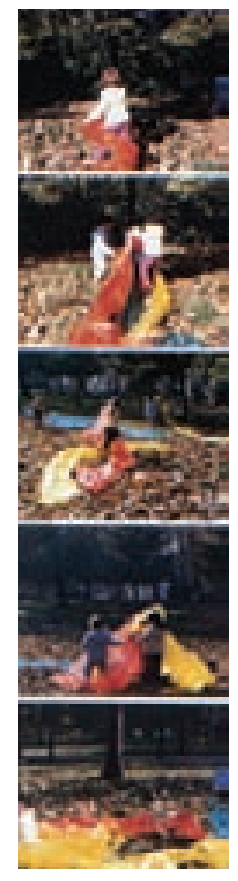

scola para o parque, para a natureza, para a cidade; trabalhos livres e dirigidos pelos professores de atenção/compreensão do som, da luz, da cor, dos cheiros e de suas variantes;
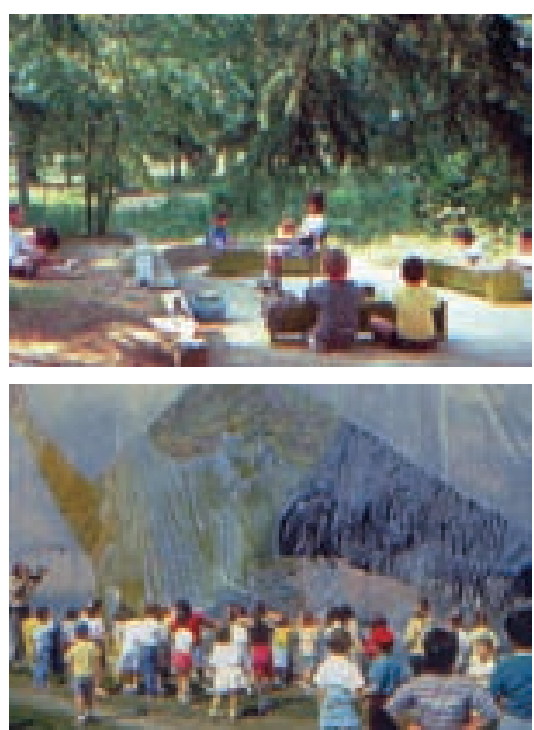

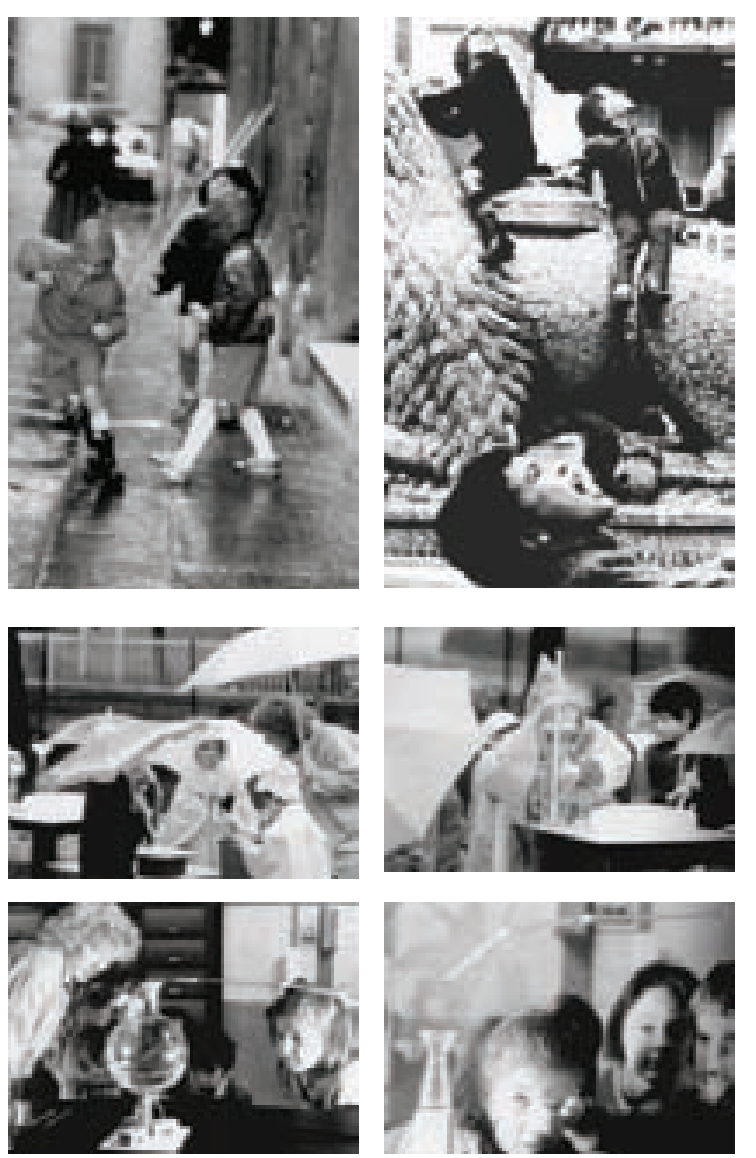

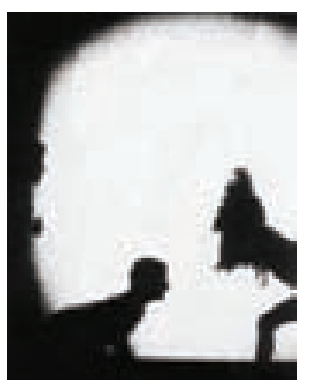

Da natureza e da cidade para a escola: depois de algumas experimentações ao ar livre, as crianças levam materiais, objetos, bichos e suas descobertas em geral para o interior da escola e partem para explorações no "laboratório interno" - procurando entender como se forma a chuva, ou a sombra quais as formas, cores e cheiros das plantas, etc.
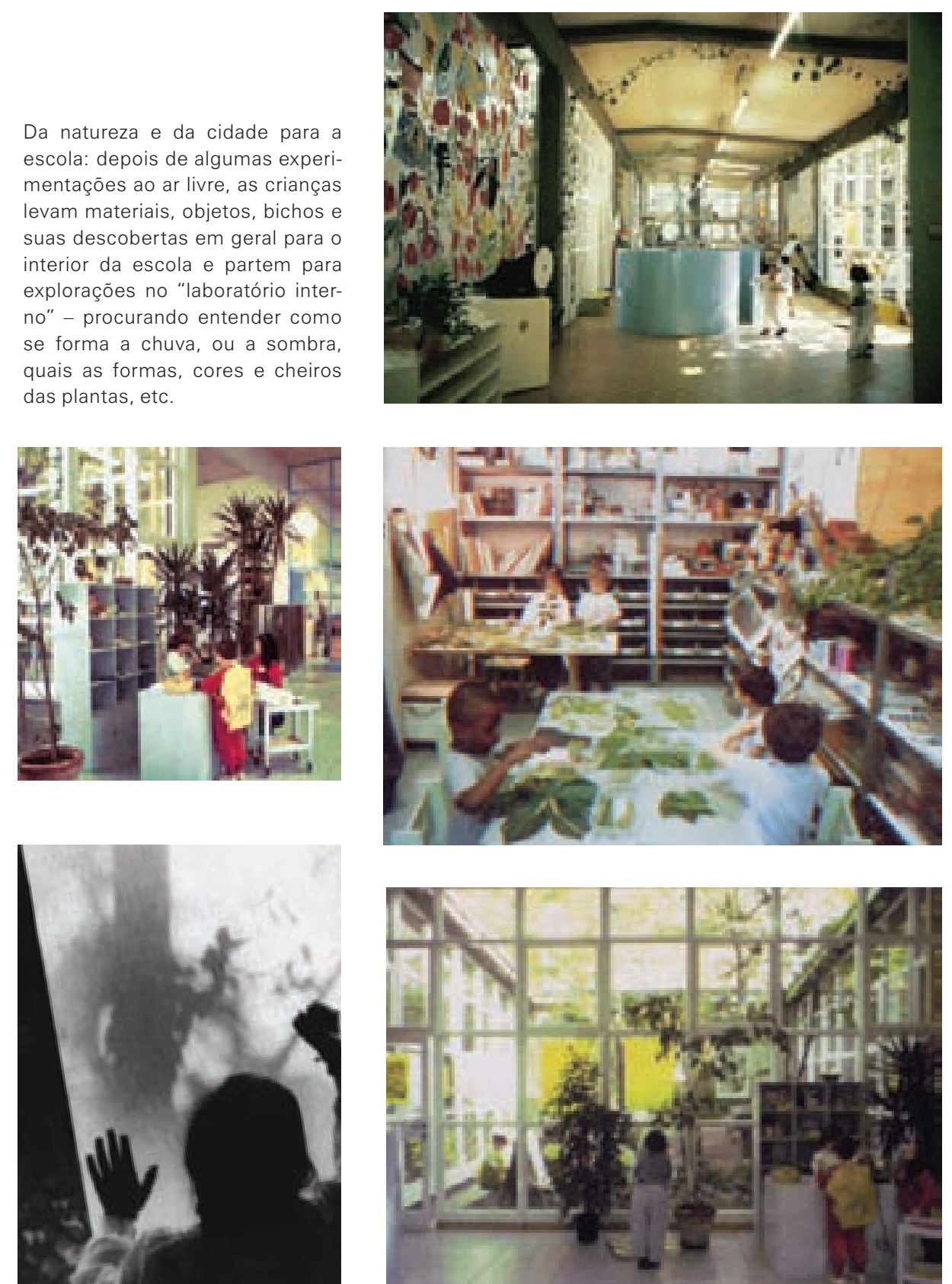
professor. E a arquitetura da escola, assim, é coberta e transformada por uma segunda camada construída pelos trabalhos das crianças.

Uma segunda camada porque, na verdade, as crianças não chegam a interferir definitivamente em nenhum elemento da arquitetura escolar. Toda as intervenções realizadas são sobrepostas aos elementos fixos do ambiente, ou modificam apenas os elementos semi-fixos e móveis. Nenhum piso, vidro ou parede, por exemplo, recebe alguma pintura definitiva ou tem sua estrutura ou elementos constituintes modificados. Por isso, mais uma vez, a arquitetura é projetada de forma neutra ("intencionalmente neutra", por isso não indiferente ou sem identidade), permitindo que os ambientes sejam modificados freqüentemente, de acordo com seus usuários. Paredes claras (nem sempre brancas, porém), janelas e portas de vidro, esquadrias, batentes, testeiras e elementos estruturais aparentes e neutros, com supefícies lisas, tudo isso serve como suporte para intervenções diretas das crianças e dos professores, ou é ainda complementado por painéis semi-fixos, ganchos e outros elementos que são utilizados para intervenções indiretas.

Desenhos, fotos, trabalhos em argila, pinturas, móbiles, painéis de papel, tecido, plástico, etc. são alguns dos elementos que recobrem a arquitetura do edifício, estabelecendo um diálogo com esta, às vezes direto e pontual, às vezes indireto ou apenas estrutural.

Nem todas estas "sobreposições" trabalham com a idéia de intervenção específica e direcionada para o local onde são instaladas. Muitas vezes, a arquitetura serve apenas como suporte para a comunicação das crianças, das suas descobertas e dos seus feitos, como é o caso dos painéis e trabalhos expostos nas paredes. Em outras, há uma maior exploração das características físicas dos elementos arquitetônicos e das possibilidades que estas oferecem, como, por exemplo, no uso dos vidros para observação dos efeitos da luz sobre os desenhos, as formas e as cores. As janelas, tanto das salas quanto do ateliê e da praça central se transformam com os trabalhos das
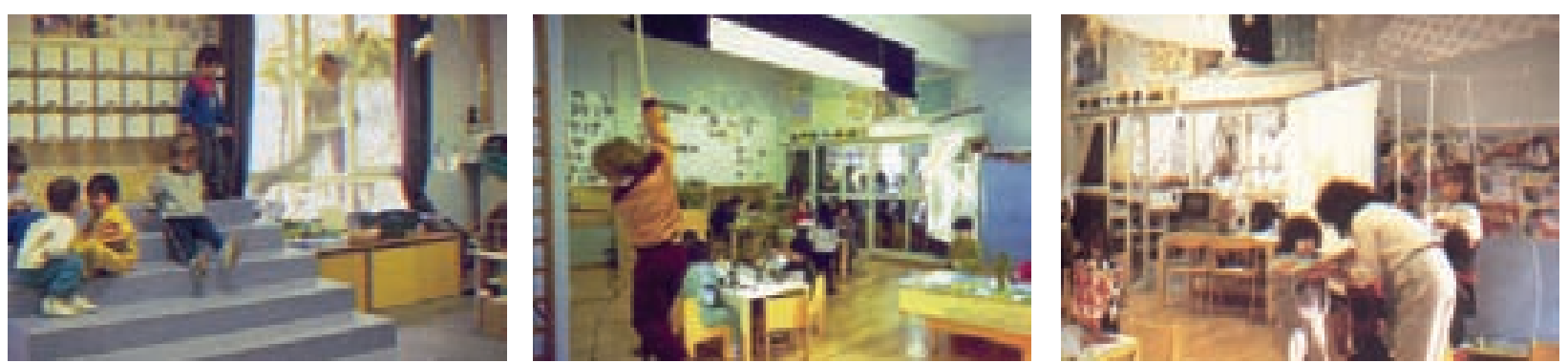

Arquitetura "neutra": paredes na cor branca ou em cores claras e quentes, como amarelo, azul e verde; esquadrias, testeiras, e elementos estruturais aparentes na cor branca; painéis semi-fixos que praticamente somem na paisagem da sala; elementos semi-fixos, colados, perfurados e fixados de diversas formas, a fim de permitir mudanças.
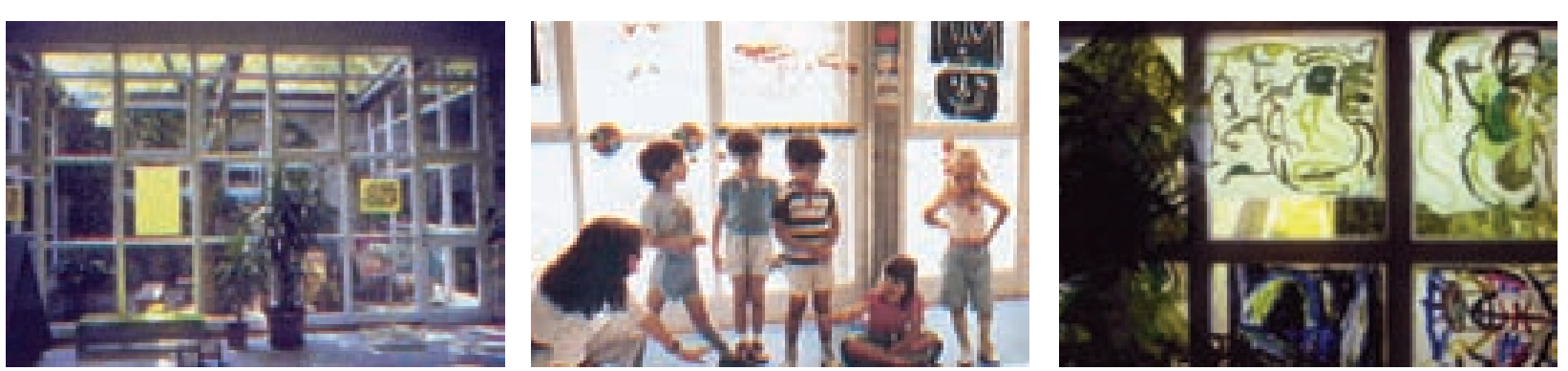

Arquitetura por sobre a qual se constrói uma "segunda camada", feita pelas crianças e pelos professores; é notável a inter-relação entre elementos fixos, semi-fixos e móveis; aqui, vidros como suporte e como membranas que possibilitam a passagem de luz, dando espaço para cores e sombras que são investigadas pelas crianças na interação com seus trabalhos;
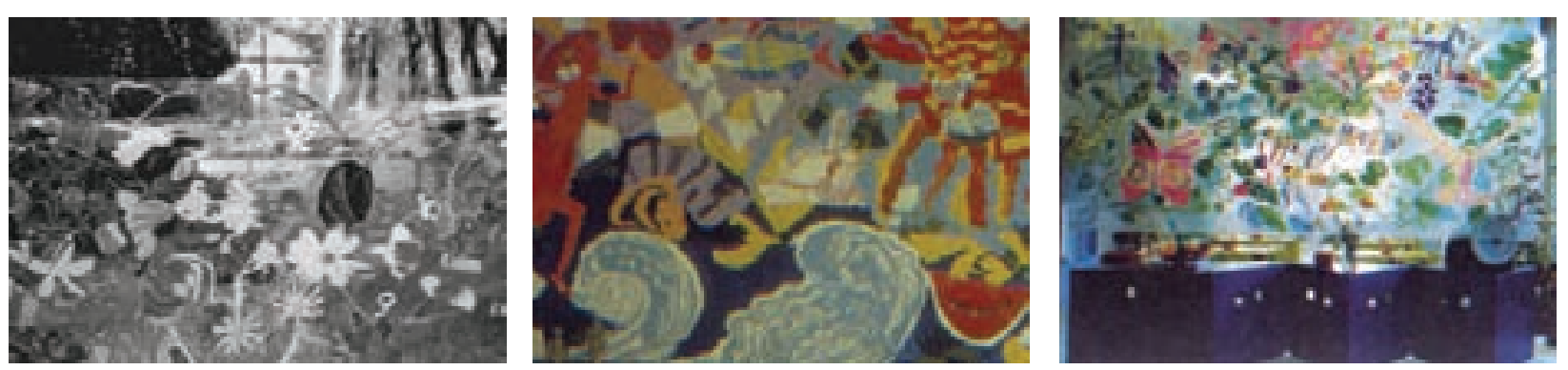

Painéis produzidos pelas crianças, e inseridos no ambiente da escola; alguns painéis, como o que separa o refeitório da praça central foram projetados especificamente para aquele local, servindo como elemento arquitetônico e ambiental, além de explorar a presença marcante de luz natural, que atravessa o plástico transparente e "liberta" os insetos ali desenhados, que então parecem voar no espaço da escola. 


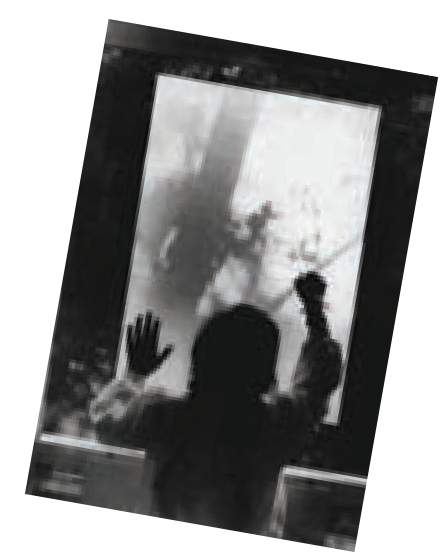

crianças, ora ganhando mais luzes e cores, ora tornandose mais escuras, ora deixando a luz natural entrar livremente, ora filtrando-a de formas diferentes. Nesses casos, as intervenções das crianças chegam a modificar mais fortemente o ambiente da escola, pois influem em aspectos como luminosidade, temperatura, textura, etc., o que não acontece quando a arquitetura é utilizada apenas como suporte para a comunicação. Além disso, a idéia de trabaIhar com um direcionamento do olhar para um lugar, um objeto ou uma situação específica pode ser interessante para desenvolver, nas crianças, uma percepção mais aguçada de espaço, de identidade e da relação que este estabelece com os demais espaços e ses usuários. Este trabalho, no entanto, parece acabar acontecendo pouco dentro das escolas reggianas, ficando mais evidente nas explorações externas.

Não pudemos saber tampouco qual a dinâmica de transformação destes ambientes da escola. Percebe-se que muitos pequenos trabalhos são colocados e retirados, conforme o andamento das pesquisas e observações mas não ficou claro se o mesmo se dá para os projetos de maior escala que ganham papel arquitetônico e ambiental como é o caso do painel plástico que divide o refeitório da praça central. Em todas as imagens analisadas, é o mesmo painel que aparece, o que nos leva a perguntar se há um processo de transformação da escola nesse âmbito maior e mais a médio ou longo prazo (anual, por exemplo) ou se as mudanças acontecem mais superficialmente (nos elementos móveis, mais do que nos semi-fixos) e mais rapidamente, seguindo o ritmo dos projetos.

Outra questão que podemos levantar e que não nos foi possível observar é se há espaço para intervenções livres das crianças, uma vez que nos pareceu que pelo menos a maior parte delas acontece inserida em um contexto de projeto ou atividade direcionada. Ainda que neste contexto a liberdade da criança seja estimulada e garantida, há um certo direcionamento por trás de suas ações. Cabe aqui perguntar se as manifestações espontâneas e livres de investigações das crianças: vidro da janela e uma folha de papel se juntam para captar as sombras do mundo exterior. tidas (mesmo que temporariamente) e até mesmo estimuladas (dando-se espaço para as mesmas acontecerem)

Para oferecer condições para a aprendizagem, portanto, e se abrir para o mundo, a escola conta com vários elementos: o espaço e a arquitetura, o mobiliário e os equipamentos de maior porte (como escadas, casa da fantasia, triângulo de espelhos, etc.), os equipamentos e instrumentos de menor porte e fixos (como as caixas de mensagens, os grandes espelhos, as telas fixas, os instrumentos musicais, etc.); e os materiais e instrumentos de menor porte que são mais fortemente manipulados transformados pelas crianças.

A qualidade do ambiente é então resultado da multiplicidade destes fatores e do diálogo estabelecido entre eles. Quanto mais ampla a gama de possibilidades que se oferece às crianças, maiores serão as alternativas de escolhas e mais ricas serão as suas experiências, pois como vimos no capítulo 2, a complexidade de um ambiente, e conseqüentemente a sua riqueza, estão diretamente ligadas às relações que se estabelecem entre os seus elementos, e às variações dentro de uma ordem. Por isso, por parte das escolas de Reggio Emilia, a busca de amplia a variedade de tópicos e objetivos, os tipos de situações que são oferecidas e seu nível de estrutura, os tipos e as combinações de recursos e materiais e as possíveis interações com objetos, companheiros e adultos (Edwards Gandini e Forman 1999).

Segundo a escola, todas estas interações deveriam acontecer através do corpo das crianças. Em função da importância dos sentidos na construção e elaboração do conhecimento e da memória pessoal (Ceppi e Zini 1998), muita atenção, então, se dá à construção de um ambiente e de experiências ricas sensorialmente, onde o questionamento e a descoberta acontecem de forma corporal.

Para descobrir e entender as cores, por exemplo, plásticos coloridos e translúcidos são disponibilizados para as crianças para que os experimentem e os combi nem das mais diversas formas, vendo e sentindo o que acontece com elas e com os elementos ao seu redor à 
medida que se cruzam e são atingidos pelos raios solares. O primeiro momento é de experimentação livre, de descobertas sensoriais e, em geral, acontece em lugares externos, como, nesse caso, no parque próximo à escola. Assim, dá-se espaço também para a diversidade, para a mudança, para o imprevisível. Natural e artificial se misturam e se transformam.

Essa experiência passa, então, por fases diferentes, que procuram ajudar as crianças a materializar e a desmaterializar a luz e as cores e fazê-las sentir suas características, provocando situações diversas de interação sensitiva e perceptiva: visuais, olfativas, auditivas, espaciais, temporais, estéticas e, posteriormente, representativas, lógicas, lingüísticas, imaginativas e etc. Depois de experimentálas fora do edifício da escola, as crianças e os professores "levam a cor" para dentro de suas salas e ateliês e passam a explorá-las a partir de fontes diferentes. Perguntas e inquietações que surgem procuram, assim, ser investigadas por meio das ferramentas disponíveis na escola. Ao lado, podemos ver momentos diferentes de exploração da cor e da luz (não necessariamente nessa seqüência, ou realizada pelas mesmas crianças), utilizando até mesmo técnicas mistas para o cruzamento das suas diversas manifestações (como na sobreposição do que parecem ser colagens e desenhos na parede, desenhos projetados e os próprios corpos das crianças, com suas cores naturais e de suas roupas). Do contato com a natureza à sua investigação, a escola fornece os espaços e os instrumentos para o seu desenvolvimento.

Outras experiências interessantes são as de descobertas da luz e das sombras, que podem ser desdobradas em inúmeras formas. Na página ao lado, podemos ver alguns desses experimentos, durante as quais as crianças brincam com papéis opacos, translúcidos, transparentes, com luz natural, artificial, direta, difusa, com fontes variadas de luz (projetor, sol, mesa de luz, etc.) e com suportes e técnicas diferentes. Novamente, tanto a variedade de espaços e ambientes, com fontes de luz diferentes, quanto a variedade de equipamentos e ferramentas disponíveis
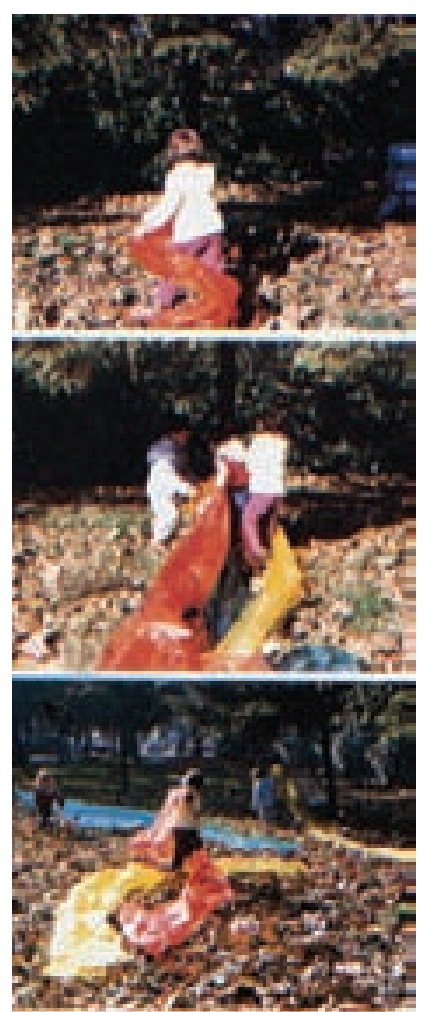

s.
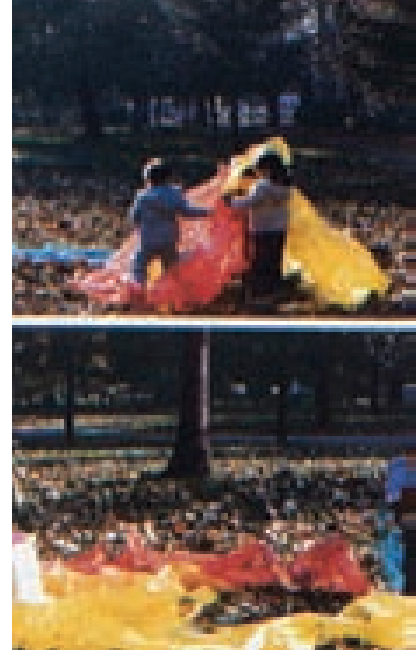

Diversas processos de descobrir e experimentar, fazendo uso de diferentes instrumentos e materiais: além de observar as cores da própria natureza e experimentálas através de suas frutas e folhas, por exemplo, as crianças podem também brincar com plásticos, projeções, desenhos, papéis, e outros materiais; com simplicidade, mas diversidade, pode-se enriquecer as vivências das crianças na escola. 
Com materiais simples como papéis, plásticos, tecidos e películas diversas, as crianças podem criar, junto com seus prosituacões diferentes que thes ermitam investigar os fenômenos da natureza, como a luz, a sombra, o reflexo, etc., e, posteriormente, Ihes possibilitem maginar e criar novos universos.
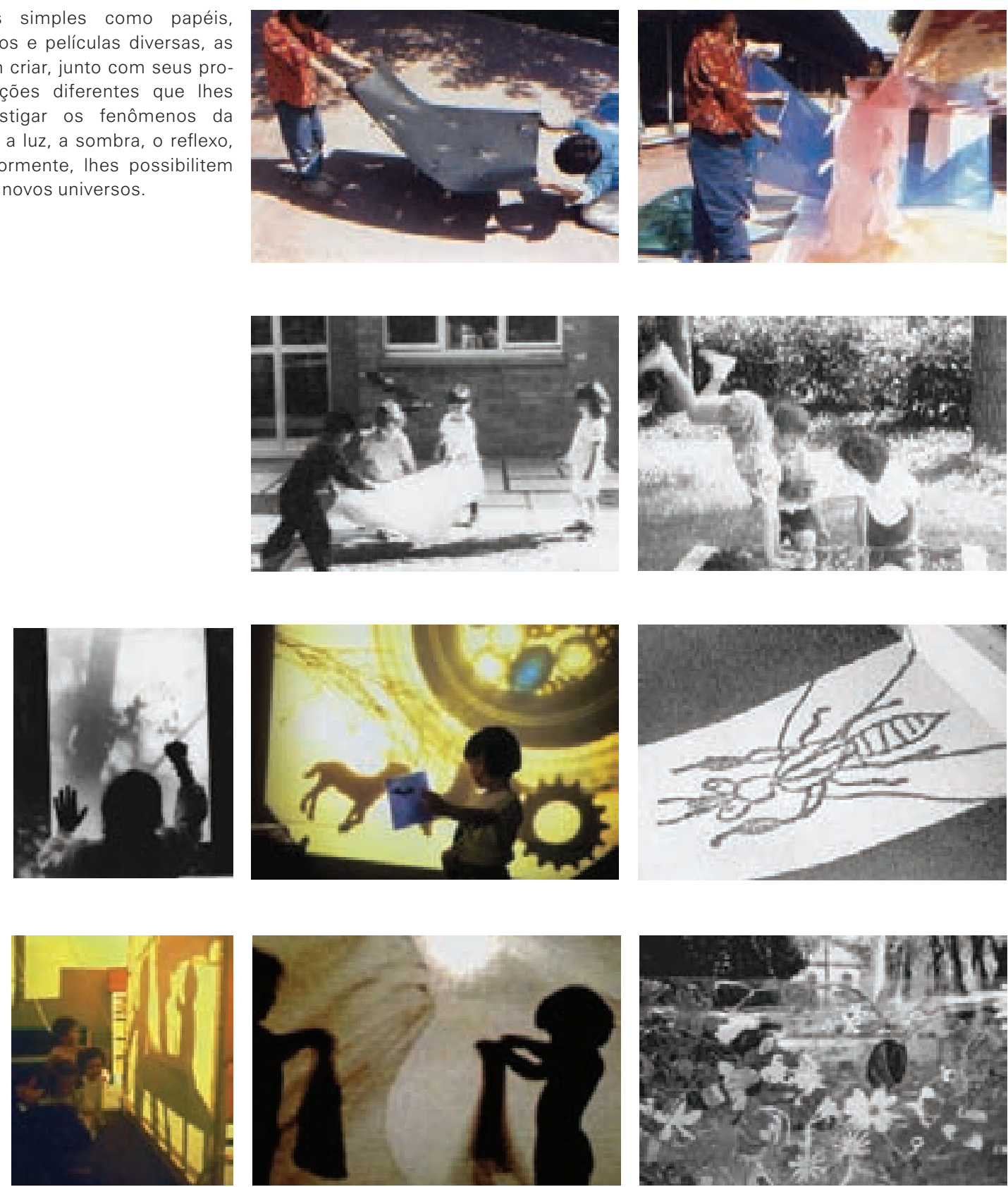

possibilitam e propiciam a riqueza dos processos investigativos e de aprendizagem

Como podemos observar, nada é considerado espaço ou elemento marginal, nem externamente, tampouco in ternamente ao edifício da escola. Desde a planta nuclear sem hierarquia, até o branco do teto, tudo contribui para os experimentos das crianças. E todos os elementos influenciam-se uns aos outros e a dinâmica da escola: desde a forma dos espaços até o conjunto de percepções sensoriais (luz, cor, acústica, temperatura, texturas, odores, etc.). Atividades, usos e funções estão, então, intrinsecamente ligados à disponibilidade de recursos, materiais, equipamentos, ferramentas. Alguns, como veremos adiante, mais direta e definitivamente, outros menos.

As salas de aula da escola, portanto, mais do que espaços e ambientes isolados, são "pequenos" (diante da cidade e do parque, por exemplo) universos de exploração que dialogam com todos os demais ambientes, mas que garantem uma maior privacidade e uma maior adequação às crianças nas suas diferentes fases de desenvolvimento. Analisaremos mais detalhadamente, a seguir, como isso se concretiza na escola Diana.

\section{Salas de aula}

Como já mencionado, a proposta das escolas reggianas é a de tornar possível a escolha de diferentes modos de trabalho e interação. Pequenos grupos de crianças trabalham simultaneamente e podem ser encontrados por toda a escola, organizados de modo a facilitar o desenvolvimento das atividades e do processo de aprendizagem. Variadas são as possibilidades de escolhas, então: locais onde possam estar a sós, em um pequeno grupo, em um grupo grande, com os professores ou sem eles, no ateliê, no mini-ateliê, na grande piazza ou, se o tempo está bom no jardim fora da escola.

Seguindo este mesmo princípio, a sala de aula é transformada em um grande espaço com pequenos agrupamentos e cantos, cada um com suas próprias crianças e seus próprios projetos e atividades. 
Todas as salas da escola Diana são em forma de "L", o que já sugere e propicia a criação de mais de um ambiente. Ao lado, podemos ver a perspectiva da sala das crianças de 3 anos com a simulação dos ambientes e alguns dos seus objetos. Não pudemos saber exatamente em que medida essa distribuição é mantida e por quanto tempo ou se ela se transforma conforme as crianças e os professores que a utilizam. Comparando o desenho da planta baixa, apresentado na página 63, com a perspectiva ao lado, pudemos observar algumas pequenas mudanças, principalmente em função do deslocamento de alguns móveis, mas a estrutura parece permanecer a mesma.

Cada uma das salas de aula apresenta uma organização espacial própria e é composta por mobiliários, equipamentos e elementos em geral diferentes em relação umas às outras, em função das diferentes fases de desenvolvimento das crianças. Procura-se adaptar cada uma delas aos seus interesses, características e ao que se considera importante e adequado como exploração para cada período.

De forma geral, todas são compostas por cantos (não só cantos, mas áreas) diferenciadas, que apresentam níveis de privacidade, conforto, luminosidade, complexidade, etc. diversos. Apesar das especificidades de cada sala, parece sempre haver uma combinação de desafios físico-motores com áreas de "construção", áreas de trabaIho sobre mesas, áreas para brincadeiras mais intimistas (como "casinha", no caso das crianças de 3 anos), canto das mensagens, entre outros. Podemos notar que há uma riqueza de possibilidades de escolha para as crianças brincarem e trabalharem.

Todos esses "cantos" e ambientes são ainda complementados com a presença do mini-ateliê, uma segunda sala conectada a esta principal, em geral menor, que dispõe de ainda mais materiais e ferramentas para as investigações das crianças (como argila, plantas, papéis, materiais de pintura, etc.). Nas salas de 4 e 5 anos, além do mini-ateliê, também encontramos um laboratório e uma sala de música, respectivamente. Todos esses ambientes formam o núcleo próprio de cada turma.

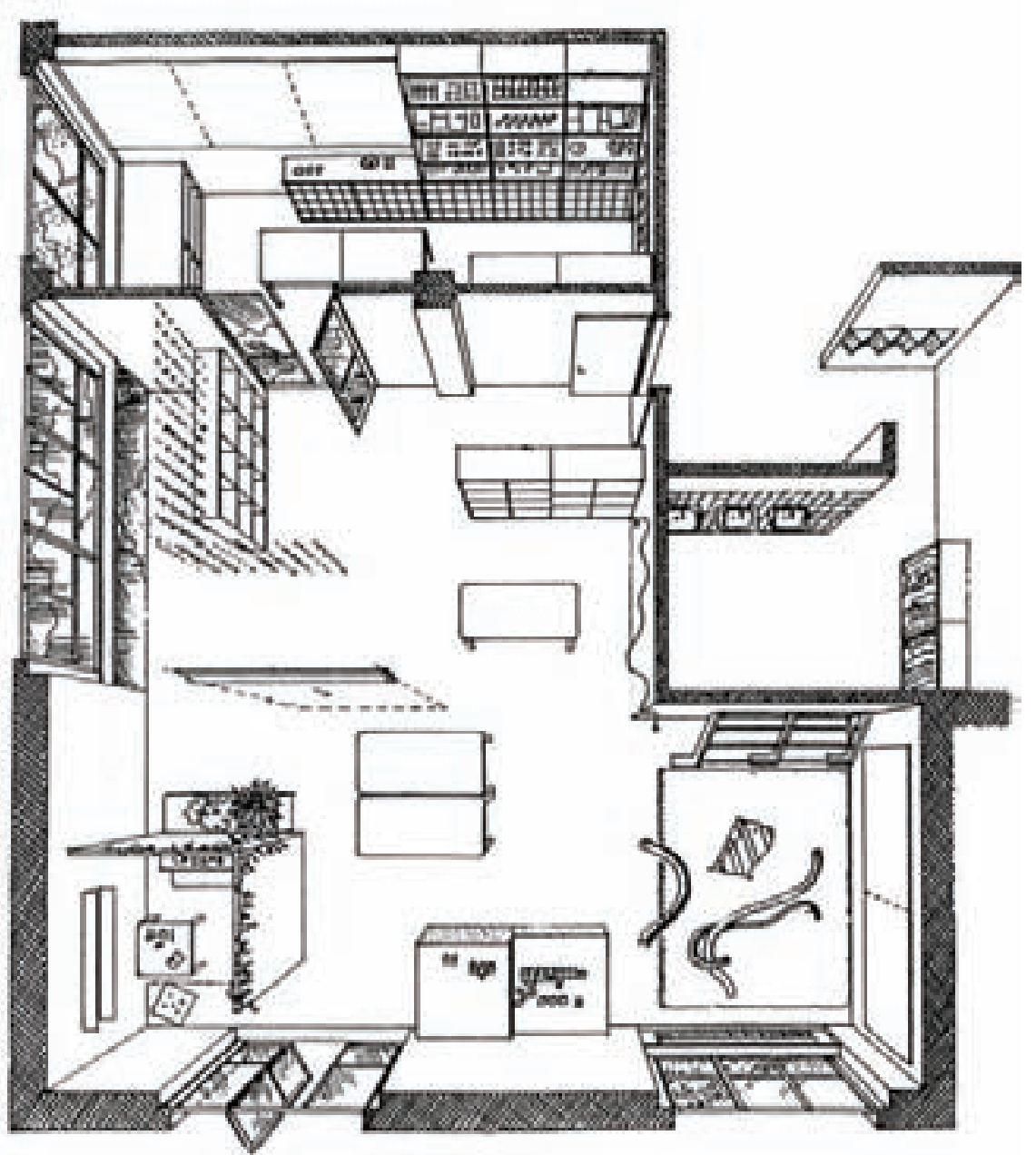

Perspectiva da sala das crianças de 3 anos, com uma possível organização de seus espaços e atividades/equipamentos (apesar de termos percebido algumas mudanças na organização desta sala no conjunto de fotos analisadas, a estrutura essencial, no entanto, pareceu-nos ter permanecido a mesma ao longo dos anos, sendo feitas apenas algumas alterações pontuais). Na sala das crianças menores, em geral, é deixado mais espaço para que o grupo brinque com materiais não estruturados como blocos, legos, animais de brinquedo e materiais reciclados. A área coberta com tapetes é maior para permitir que as crianças brinquem no chão; além disso, existe uma outra área, ampla, rica de pequenas réplicas de panelas e louças geralmente encontradas nas casa e potes de macarrão de diferentes tamanhos e feijões de diferentes cores. Entrando no mini-ateliê, podemos observar materiais como argila, papel, arame, entre outros. Durante todo o ano, enquanto as crianças adquirem mais autoconfiança, elas realizam explorações e projetos também no ateliê principal (Reggio Children 2002). 

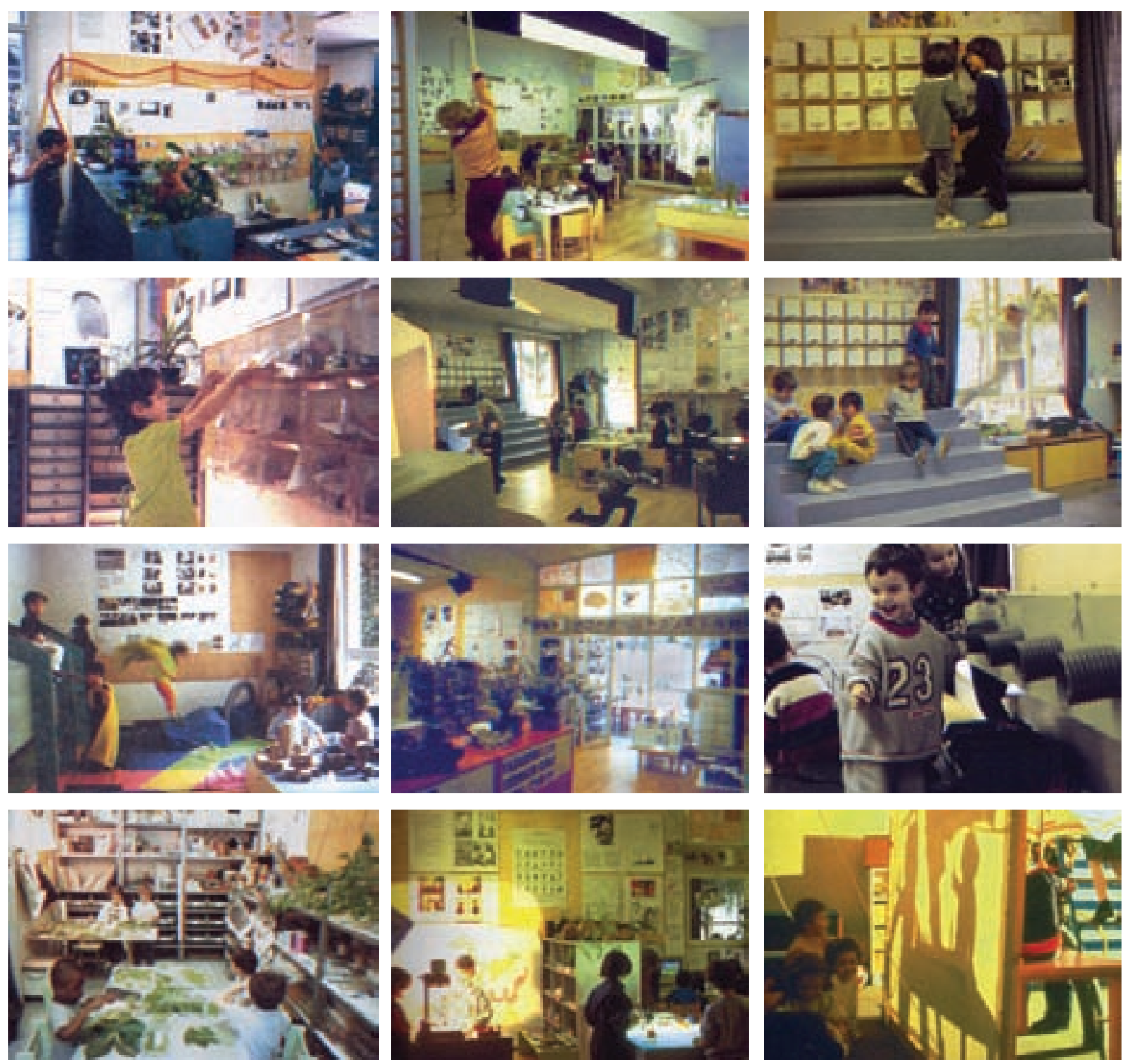

Imagens das salas das crianças (aqui, estão apresentadas as salas das três turmas - de 3 a 6 anos); mudam os equipamentos, mas a essência do projeto da sala permanece: arquitetura neutra, sobre a qual são sobrepostos elementos semi-fixos e móveis (na maioria) telefone sem fio, caixas de mensagens, degraus-escada-banco, tapetes, telas removíveis, cordas, fantasias, etc.
Grande parte dos materiais, ferramentas e equipamentos fica ao alcance das crianças, podendo ser utilizados a qualquer momento pelas mesmas. Em todas as salas também parece haver o "canto das mensagens", onde caixas transparentes fixadas na parede são utilizadas como recipientes para a comunicação entre as crianças e entre estas e os adultos. Recados, fotos, presentes, etc. são trocados entre todos por meio destas caixas. Cada uma delas tem o nome e a foto da criança na frente, permitindo a identificação da mesma pela própria criança e por seus colegas. $\mathrm{O}$ fato de serem transparentes permite que cada um saiba quando tem algo a receber, o que estimula mais a troca, criando um clima de expectativa e dando uma dinâmica a este tipo de relação entre as crianças.

Com relação às características físicas das salas, estas em geral são trabalhadas de forma bem neutra e simples. As paredes são lisas (sem textura), pintadas em cores claras (azuis, amarelas, verdes), o teto é, quase sempre, branco, e o piso, de madeira clara (material quente). Todo o mobiliário e os demais elementos de apoio às atividades, como painéis, mesas, cadeiras, escadas, degraus, etc são de madeira, que pode ser deixada ao natural, ou pintada nas mesmas cores utilizadas para as paredes: amarelo, azul e verde claros, em geral (tonalidades um pouco mais densas que as paredes, mas cores semelhantes, procurando estabelecer um equilíbrio cromático entre os elementos). As cores mais fortes dos ambientes acabam sendo dadas pelos materiais explorados pelas crianças (de várias proveniências), pelos trabalhos das mesmas, pelos brinquedos, tecidos, colchões e elementos móveis em geral. Não há nenhum tipo de diferenciação do piso, e a definição das áreas acontece principalmente pela disposição dos móveis, pelo uso de colchões e de elementos de madeira que estabelecem variações de nível.

Todas as salas dão acesso direto ao jardim externo e apresentam uma boa iluminação natural, devido à presença de portas e janelas de vidro. Para a criação de ambientes diferentes, controla-se também a luminosidade da sala com a ajuda de cortinas opacas ou outros elementos 

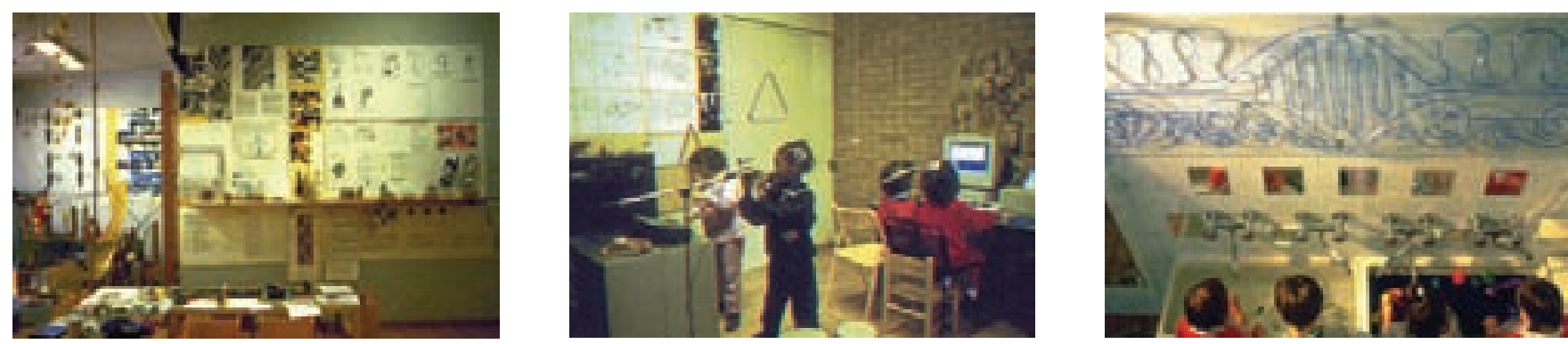

Ainda, a diversidade de elementos com os quais as crianças podem brincar: desde a sala, passando pelo mini-ateliê, até os banheiros, a disponibilidade de materiais e equipamentos variados é grande: a experiência sensorial começa logo na porta da sala, que traz um espelho na altura do olhar da criança; no interior dos ambientes, espelhos, instrumentos musicais, tintas, colchões, mesas de luz, almofadas, computadores, e outros, podem ser manipulados de várias maneiras.

encontrados pelas crianças e pelos professores - como papéis - que permitem a passagem de níveis diferentes de luz. Quando a luz ambiente da sala é eliminada, diferentes fontes de luz ficam à disposição das crianças para que (re)criem os ambientes e efeitos desejados, e tentem "captar" a luz e desvendar os raios solares.

Como todas as salas encontram-se ao redor da praça central, criaram-se espaços intermediários entre esta última e aquelas, os quais representam ambientes de transição. Estes são mais estreitos e dão acesso tanto para as salas quanto para os banheiros e "vestiários" de cada turma, que ficam logo ao lado de cada sala (ver planta p.63). Esta relação de exterioridade e proximidade dos banheiros, permeada por uma área de transição "semi-privada", é interessante para que as crianças ganhem autonomia e, ao mesmo tempo, sintam-se protegidas e à vontade.

Além das salas de aula, outro grande ambiente freqüentado pelas crianças da escola toda (crianças de 3 anos mais ao fim do ano, em geral) é o ateliê (o grande, coletivo, e não o mini-ateliê, próprio de cada sala). Considerado um dos elementos marcantes da proposta reggiana, o ateliê nada mais é do que uma grande sala onde todos os materiais, técnicas e linguagens podem ser experimentadas pelas crianças. É um espaço complementar às salas de aula, e não independente. Como já comentamos, grande parte dos projetos desenvolvidos junto às crianças utiliza os vários lugares da escola. Os trabalhos feitos no ateliê não se restringem a experimentações artísticas, mas são parte de processos investigativos que começam nas salas de aula, nas discussões freqüentes entre as crianças e seus professores.

Tanto o ateliê quanto o mini-ateliê são entendidos como possibilidades cotidianas de encontro com vários materiais, várias linguagens, pontos de vista, de combinação do trabalho com as mãos, o pensamento e as emoções (Reggio Comune 2005). Ali as crianças podem experimentar modalidades, técnicas, instrumentos e materiais alternativos; explorar temas escolhidos por elas ou sugeridos pelos professores; talvez trabalhar em um grande mural em grupo; talvez preparar um pôster com palavras e ilustrações; talvez até mesmo dominar pequenos projetos em uma escala reduzida, entre outras coisas (Reggio Children 1996).

Pelo que pudemos perceber, o ateliê, mais do que um espaço de experimentação, representa um espaço de coletividade e troca, por onde crianças de todas as idades circulam e têm contato com projetos e propostas de trabaIhos de naturezas e níveis diferentes. Manifestações das 

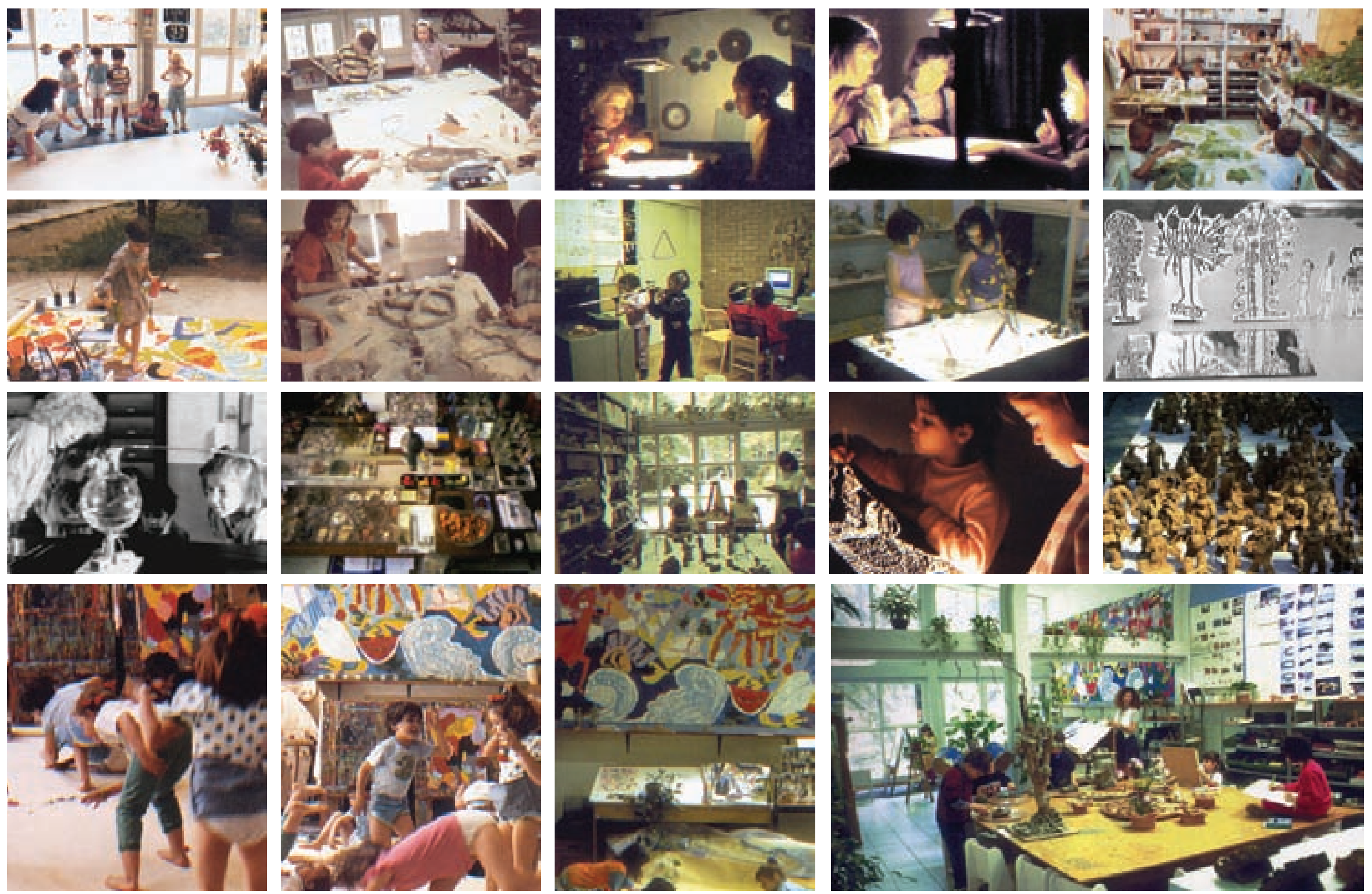

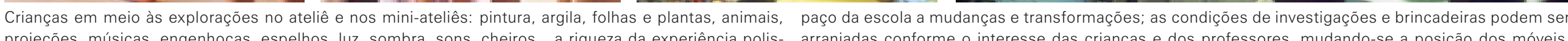
projeções, músicas, engenhocas, espelhos, luz, sombra, sons, cheiros... a riqueza da experiência polis- arranjadas conforme o interesse das crianças e dos professores, mudando-se a posição dos
sensorial, possibilitada pela variedade de materiais e equipamentos disponíveis, e pela abertura do es- controlando-se a quantidade e o tipo de luz incidente, escolhendo-se ou criando-se espaços. 
turmas de 4 anos podem ser vistas, sentidas e acompanhadas tanto pelas crianças de 3 quanto pelas de 5, estimulando a integração e a interação entre todos.

Com uma área generosa e duas de suas faces repletas de vidros, voltando-se, de um lado, para a praça central, e de outro, para o jardim externo da escola, o ateliê estabelece de fato relações de integração, interação, intercone xão, reunião, encontro, troca, permeabilidade.

Além disso, por ser um espaço mais amplo, com pé direito mais alto e móveis mais espaçosos e diferenciados daqueles das salas de aula, pode abrigar projetos de maior escala e talvez uma maior liberdade de movimento das crianças. Ali acontecem coisas que em nenhum outro lugar da escola podem acontecer

\section{Considerações finais sobre a estrutura e} sobre as relações do ambiente escolar reggiano

Ao analisarmos as escolas reggianas, mais especificamente aqui, a escola Diana, podemos notar como é forte o discurso e a relação que de fato acontece entre estas e a natureza e a cidade, e como é a partir desta premissa que o espaço da escola passa a configurar um "laboratório de experimentação". Se o material a ser explorado está fora da escola e se os instrumentos e ferramentas para a investigação dos mesmos são móveis e podem existir e ser utilizados em qualquer situação e ambiente, podemos nos perguntar em que medida o espaço, a arquitetura, o mobiliário e os equipamentos são importantes para o processo de aprendizagem proposto por estas escolas e onde estes elementos entram na construção de sua identidade. Se uma das grandes riquezas da experiência reggiana se concretiza nos materiais, instrumentos e equipamentos disponibilizados para as crianças, quais são os papéis exercidos pelo espaço, pela arquitetura, pelo mobiliário e pelos equipamentos de maior escala?

Podemos talvez desmembrar, apenas para fins de análise e compreensão, o ambiente escolar reggiano em quatro grandes grupos: espaço e arquitetura; mobiliário e equipamentos maiores; equipamentos e instrumentos menores fixos e semi-fixos; e, por fim, materiais e instrumentos menores, em geral móveis (que podem ser transformados pelas crianças).

Se, por um lado, poderíamos dizer que os experimentos realizados pelas crianças com papéis, argila, projetores, mesas de luz, etc. podem de fato acontecer em qualque lugar, por outro, como pudemos ver ao longo do capítulo 2, sabemos que inúmeros são os aspectos do ambiente que influenciam a percepção, compreensão e construção da realidade pelas crianças (pelos homens em geral).

A arquitetura, portanto, aqui apontada como neutra, tem seu papel na relação com os demais elementos do ambiente. Sua neutralidade é intencional e não representa a ausência de identidade, mas, sim, a abertura para receber intervenções dos usuários da escola. Há uma preocupação em garantir um ambiente harmonioso, confortável, seguro, que se comunica com o universo ao redor e que dá espaço para a comunicação e o intercâmbio.

Para isso, há um cuidado com o equilíbrio de cores nos ambientes, procurando-se mesclar cores mais quentes (a maioria) com algumas levemente mais frias, ou mais fechadas. As estruturas são deixadas aparentes, mas também ficam rebaixadas no ambiente, sendo pintadas de branco, ou cores bem claras, ou ainda deixadas ao natural (como o concreto, em algumas situações) para que não interfiram muito nos trabalhos das crianças, que as revestem ao longo do ano. Muitos fechamentos e divisões são feitos em vidro, mas também se trabalha um jogo entre transparência e opacidade, entre permeabilidade e restrição, entre campos visuais abertos e fechados, que se dá com a alternância entre os vidros e as paredes.

Todos os vidros são transparentes e incolores, novamente com o objetivo de não interferir, de forma definitiva e imutável, nos projetos e nos ambientes da escola. Esta "neutralidade" aceita (no sentido de permitir) variadas transformações momentâneas feitas pelas mãos das crianças (ganha cor e forma, tem sua luminosidade
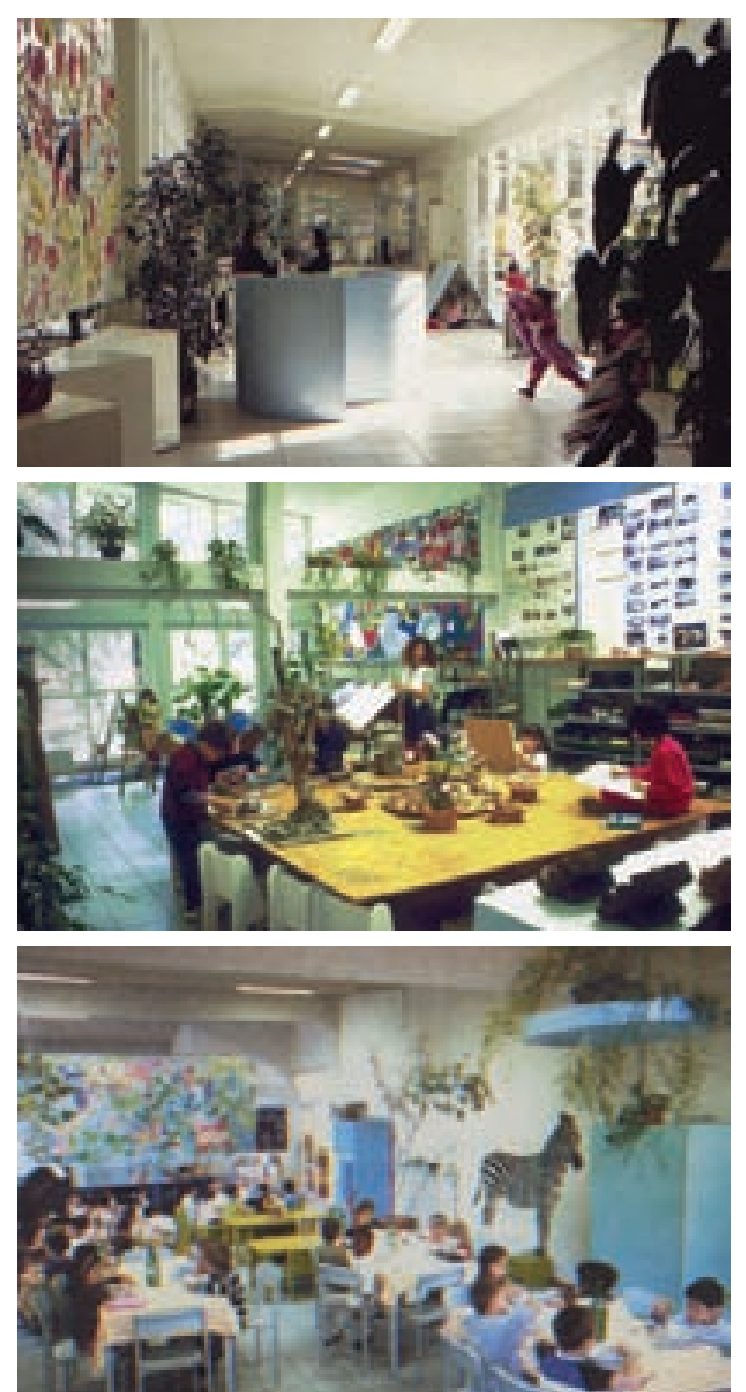

Percebemos a recorrência da cor branca nos elementos estruturais da arquitetura dos ambientes coletivos, os quais ganham cor por meio dos móveis e trabalhos das crianças. Nos móveis, predominam as cores amarela, azul e verde. quentes e claras, deixando espaço para a vibração das cores dos desenhos (talvez a variação de cor pudesse ser um pouco mais explorada nos móveis, a fim de diferenciar alguns ambientes). 

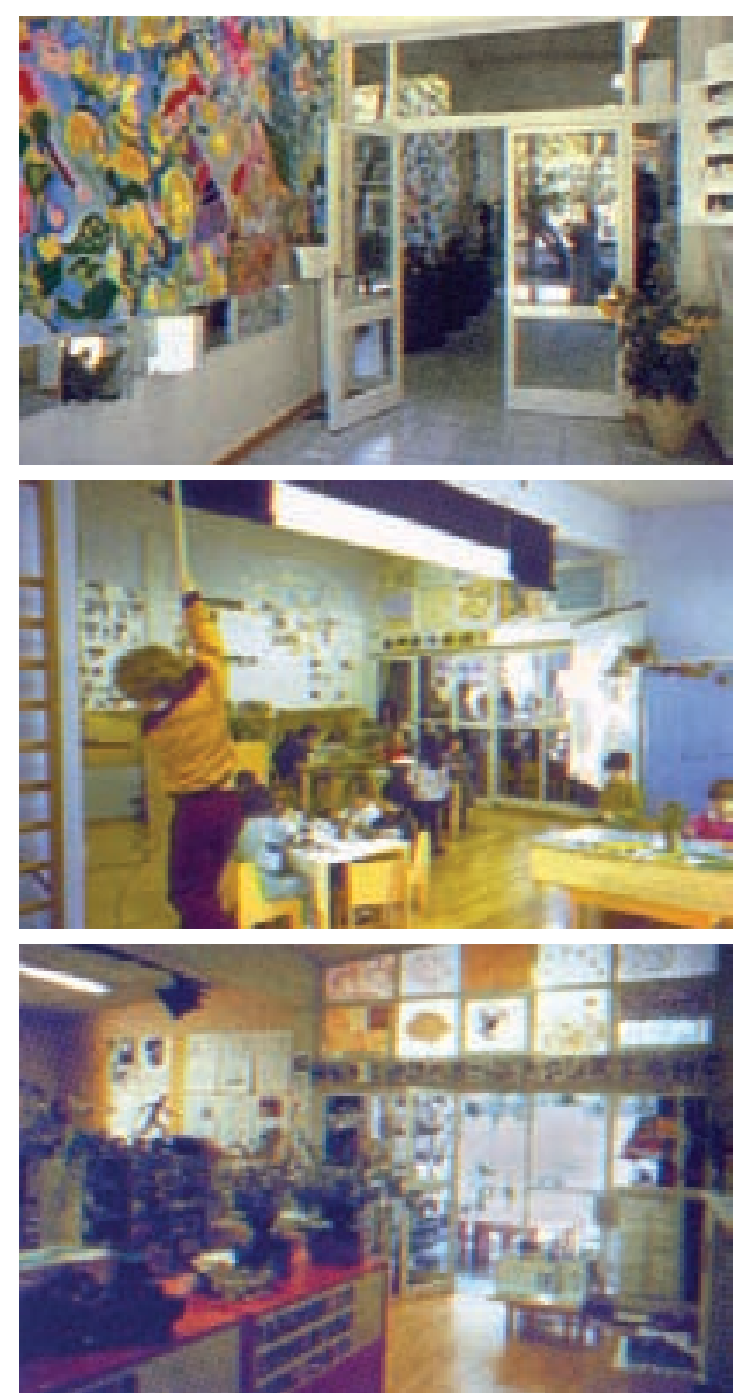

Nas salas, o branco das paredes passa a ser complementado por outras cores, também claras - sempre a mesma paleta de cores de todos os equipamentos da escola: amarelo, azul e verde. Parece haver pisos sâo nẫo no pédireito (diminui) e os pisos são mais quentes, de madeira. Podemos observar na imagem logo acim como os vidros recebem intervenções e influem na ambientação geral como filtros de cor e de luz. controlada, forma cheios e vazios, cria sombras, texturas, entre outras coisas).

Há também uma alternância entre pés-direitos de alturas diferentes, o que diferencia os ambientes, criando sensações de segurança e privacidade mais fortes na área de recepção e nas salas de aula, por exemplo, e de maior liberdade e amplitude na praça central e no ateliê. Os pisos também variam um pouco, sendo mais frios nos espaços coletivos e de maior circulação e movimentação, e mais quentes nos espaços mais privativos, como as salas de aula, onde parece haver a intenção de se criar uma sensação de aconchego maior.

Como podemos observar, as sensações de conforto, segurança, intimidade e o estímulo à imaginação não se dão de forma figurativa, mas sim por meio do trabalho de cores, luzes, formas, etc. O uso de imagens e/ou arquiteturas temáticas, por exemplo, e a definição rígida de usos e funções não só não são a única forma de levar as sensações de reconhecimento, pertencimento ou intimidade às crianças, como tampouco se constituem como um estímulo rico à imaginação. Ao contrário, o uso de elementos figurativos e simbólicos, com significados e leituras predefinidas socialmente, deixa menos espaço para a interpretação, para a fantasia e para a imaginação das crianças. Uma arquitetura singela, portanto, pode se constituir, quando combinada com outros elementos, como um importante convite à experimentação e à imaginação.

Espaço e arquitetura nas escolas reggianas, portanto, são trabalhados de forma a garantir a adequação às crianças (tamanhos, alturas, amplitudes, campos de visão, etc.) propiciar a neutralidade que se abre para a intervenção garantir (pela organização espacial) a ausência de hierarquia, a fluidez, a sensação de coletividade, de reunião, de responsabilidade e de cuidado; sugerir e/ou facilitar a criação de diferentes ambientes, com ritmos, campos de visão, privacidades e identidades próprias; possibilitar (por meio da transparência) a permeabilidade dos espaços, sua percepção e compreensão pelas crianças, a integração (e não o isolamento), a comunicação, a experimentação e a investigação dos fenônemos da natureza; entre inúmeras outras coisas.

Apesar de fixos, espaço e arquitetura devem ser pensados e projetados como partes importantes da dinâmica da escola, pois, como vimos, sugerem, ou pelo menos influenciam, uma série de relações e sensações e são os primeiros elementos que orientam a construção da identidade da mesma, desde a solução de sua planta e de sua relação com o mundo exterior.

O mobiliário e os equipamentos maiores, e, juntamente com eles, os equipamentos e instrumentos de menor porte, então, constituem uma outra camada que vem complementar e estabelecer relações com a arquitetura e seus espaços, trazendo uma outra dinâmica às mesmas, ao se apresentarem como elementos semi-fixos e móveis.

Como mobiliário e equipamentos maiores, entedendemos os armários, mesas, cadeiras, escadas, degraus, triângulo espelhado (ver figura na página seguinte), círculo da fantasia (idem), caleidoscópio, e externamente ao edifício, casa da árvore, "casa-esconderijo", tirolesa, etc. Estes, por não serem fixos, podem ser manipulados pelas crianças, quando possível, e/ou pelos professores (no caso das peças mais pesadas), servindo como ins trumentos para a criação de ambientes, cantos e áreas diferentes, em uma escala diversa daquela da arquitetura Além disso, podem também ser utilizados como desafios físico-motores, como as escadas, os degraus e os elementos de escaladas em geral. Ainda, por possibilitarem manipulação, podem ser apropriados de formas diversas e podem abrigar situações as mais varidas: o triângulo espelhado, por exemplo, pode ser explorado apenas como uma caixa de espelhos, mas também pode ser transformado em uma casa para receber amigos, ou ainda virar um abrigo para uma boa soneca.

Não se trabalha aqui, como na escola montessoriana de Hertzberger, com a idéia de polivalência ou ambigüidade das formas, nem na arquitetura nem tampouco no mobiliário. O triângulo, o caleidoscópio, o círculo da fantasia criam ambientes, mas não se modificam; podem ser deslocados 

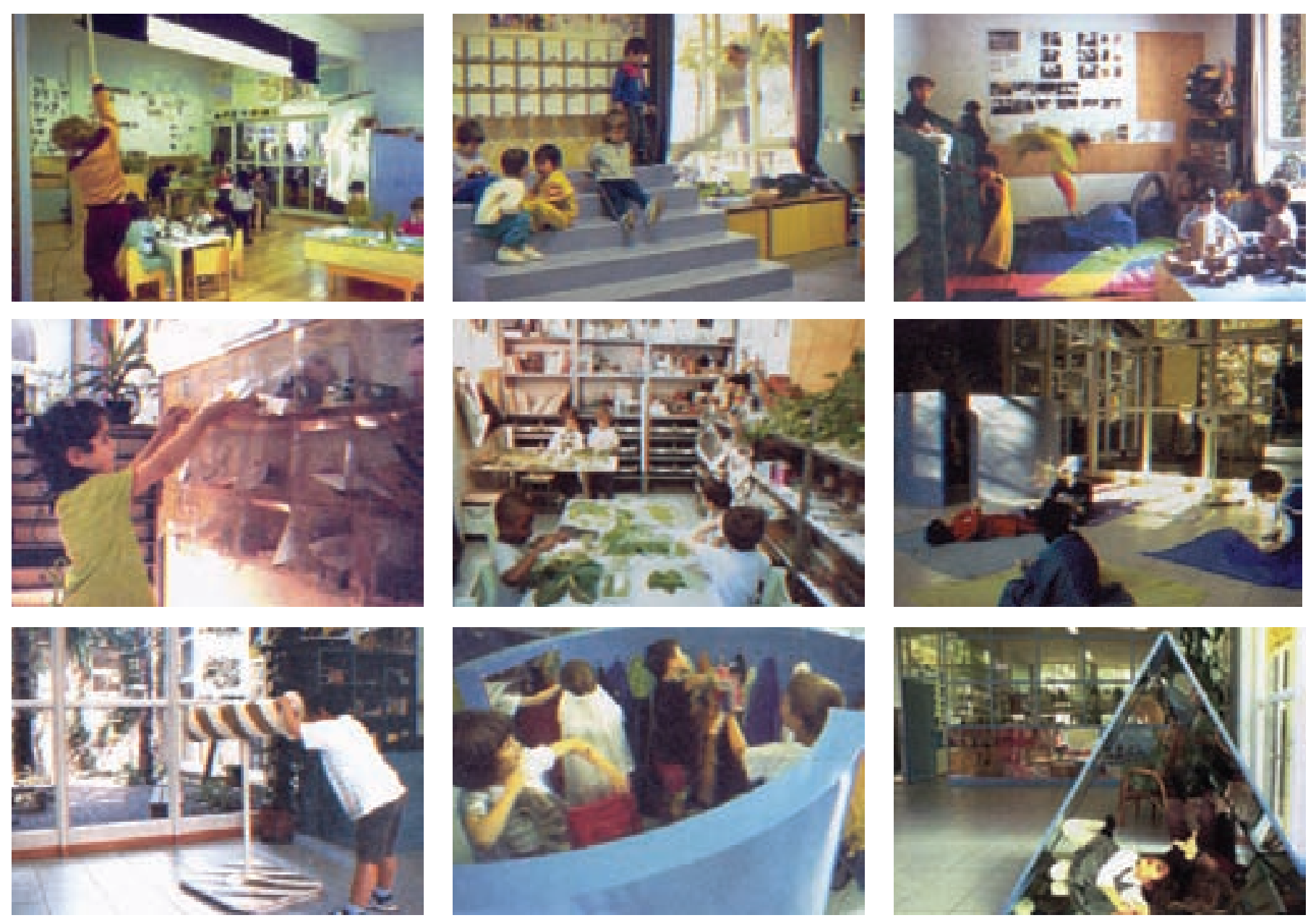

Mobiliário e equipamentos maiores: podem ser manipulados pelas crianças e pelos professores, servindo como instrumentos para criação de obstáculos, desafios físico-motores, cantos, esconderijos, etc O triângulo de espelhos forma uma quantidade infinita uma casa com cozinha e tudo o mais, ou simplesmente virar uma teto para uma soneca; o caleidoscópio permite a visualização de um universo incrí vel não possível de ser visto simplesmente com nossos olhos; os colchões, tapetes, com nossos ol hos; os colchoes, tapetes, casas, esconderijos, lugares de descanso, amortecedores de quedas, obstáculos, ou dar margem a outras imaginações com a ajuda de fantasias e outros equipamentos; a casa da árvore, com sua ponte e demais casa da arvore, com sua ponte edem elementos, pode ser um abrigo para inumeras brincadeiras, ou pode ser um mirante ou ainda um refúgio, pode ficar aberta ou ser coberta por panos e papéis, opacos ou transparentes. 

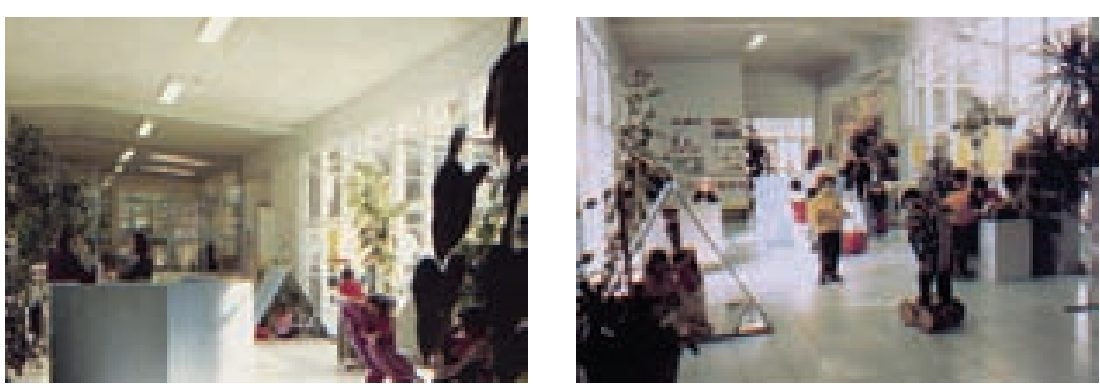

A praça central e seus elementos: o caleidoscópio, o mercado, o triângulo e o círculo da fantasia
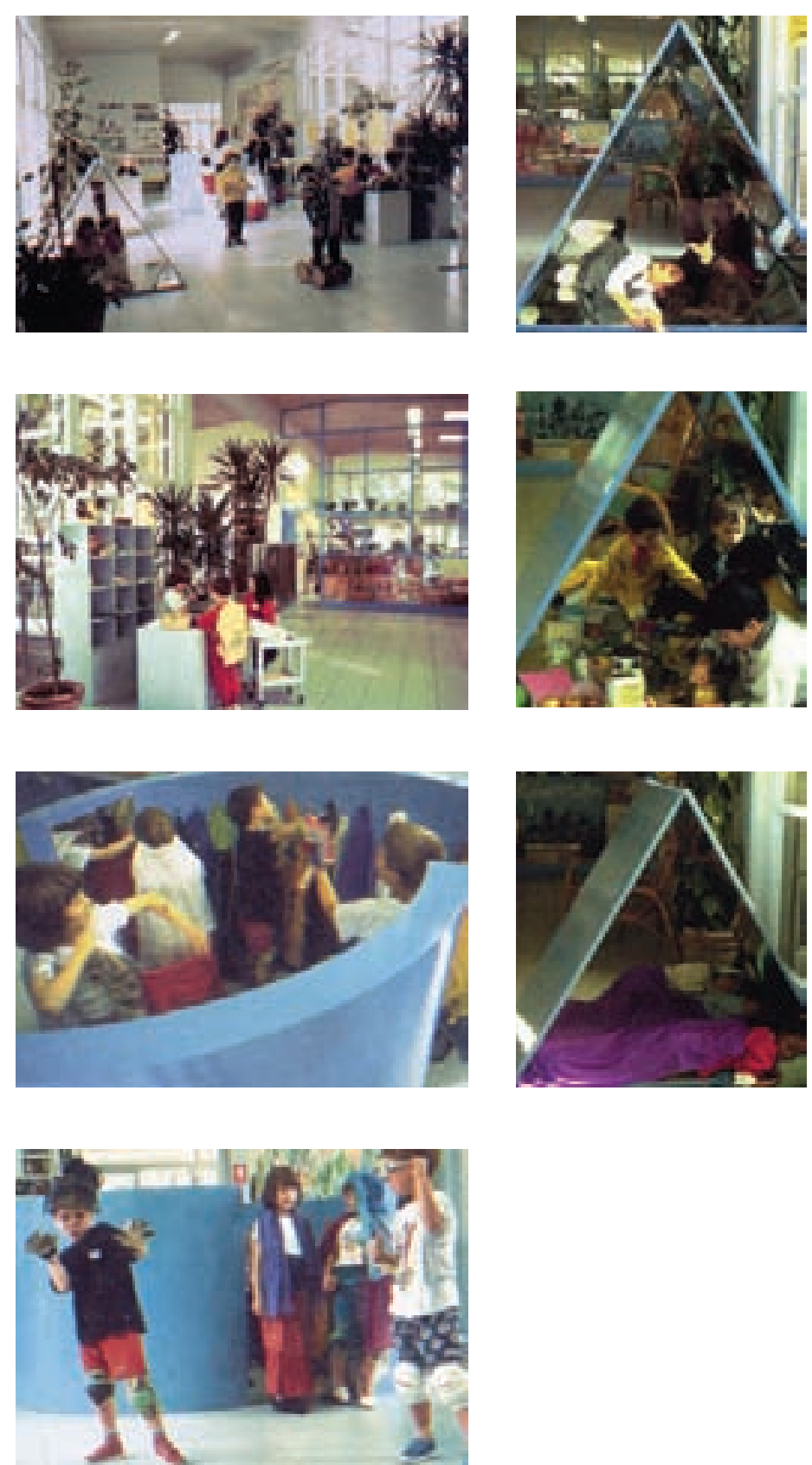

de seus lugares, mas não podem ser utilizados em diferentes posições nem tampouco se desmembrados em peças menores (como os cubos e o podium de Hertzberger). Estes não permitem modificações ou manipulações de suas formas ou estruturas, mas dão suporte para que transformações ocorram e novas situações apareçam

Por apresentarem funções ou usos melhor sugeridos ou mais ou menos predefinidos (caleidoscópio e círculo de fantasia, este último menos), ou por carregarem formas simbólicas (triângulo espelhado), alguns destes equipamentos acabam abrindo poucas possibilidades de reinterpretação. Talvez aqui, principalmente na praça central, onde parecem predominar os equipamentos de maior porte (de usos geralmente mais restritos), fosse possíve enriquecer ainda mais as experiências das crianças, se estas, por exemplo, conseguissem manipular e/ou descolar as peças do "círculo de fantasia" ou do triângulo (criando um jogo de transparência e opacidade, permeabilidade e impermeabilidade, escalando-os com a ajuda de reentrâncias, etc.). Elementos que dessem margem a interpretações e apropriações variadas, ou mesmo a presença de um material mais flexível, por exemplo, poderiam ampliar as possibilidades de uso e recriação destas peças.

Por outro lado, é sempre importante mesclar objetos e equipamentos com funções mais definidas com outros de menor definição, a fim de tentar alcançar um equilíbrio entre certezas e indefinições, entre o familiar e o desconhecido. E a fim de sugerir uma ordem a partir da qual a criança pode ter uma referência e uma sensação de segurança para, então, lidar com suas variações (lembrando sempre da capacidade de imaginação da criança).

Pouca variação de material e cor é encontrada no mobiliário e nos equipamentos da escola, predominando superfícies lisas, nas cores azul, amarelo e verde, e materiais duros e inflexíveis. Desde a arquitetura até os equipamentos de pequeno porte, podemos observar a ausência de plasticidade e de flexibilidade. Estas são encontradas apenas na vegetação e nos elementos móveis, como colchões, tecidos, papéis, argila e outros materiais do gênero. 
Por último (apenas por ordem de apresentação, sem juízo de importância), então, complementando a relação de elementos que constituem o ambiente das escolas reggianas, estão os equipamentos e instrumentos menores fixos e semi-fixos e os materiais e instrumentos menores, em geral móveis. Os primeiros são as caixas de mensagem, a caixa "advinha" (ver imagem), o telefone sem fio, os instrumentos musicais, as telas removíveis, os espelhos maiores, etc. Os segundos são a mesa de luz, o projetor, o slide, as tintas, telas, papéis, argila, pequenos espelhos, entre outros.

Aqueles possibilitam a manipulação parcial das crianças. Também não se modificam, porém possibilitam a vivência de novas realidades, que podem ser vistas, sentidas, ouvidas, tateadas, mas não reconstruídas ou transformadas concretamente: caleidoscópio possibilita a visão de realidades alteradas; as telas permitem a formação de sombras e efeitos inimagináveis, os espelhos podem ser usados para deformações (côncavos e convexos) e distorções das coisas e dos objetos, ou podem servir para o cruzamento e sobreposição de imagens.

Não chegam a ser moldados ou transformados em um novo objeto, o que acaba sendo possível, enfim, com os materiais e instrumentos menores, elementos "soltos", móveis, que podem ser apropriados das mais diversas formas. Estes são objetos "prontos", sem qualquer tipo de indefinição ou ambigüidade de forma, que, no entanto, permitem usos diversos e podem ser considerados polivalentes. Sem usos predeterminados, papéis, argila, espelhos, projetores e telas podem ser transformados ou transformar coisas e situações.

Procurando nos afastar um pouco desta análise mais minuciosa dos elementos constituintes do ambiente escolar reggiano, e retomando uma visão mais ampla da sua estrutura e das relações aí estabelecidas, podemos observar que, como mencionado no início deste texto, uma das grandes riquezas da proposta está na configuração da escola como um "laboratório de experimentação", que
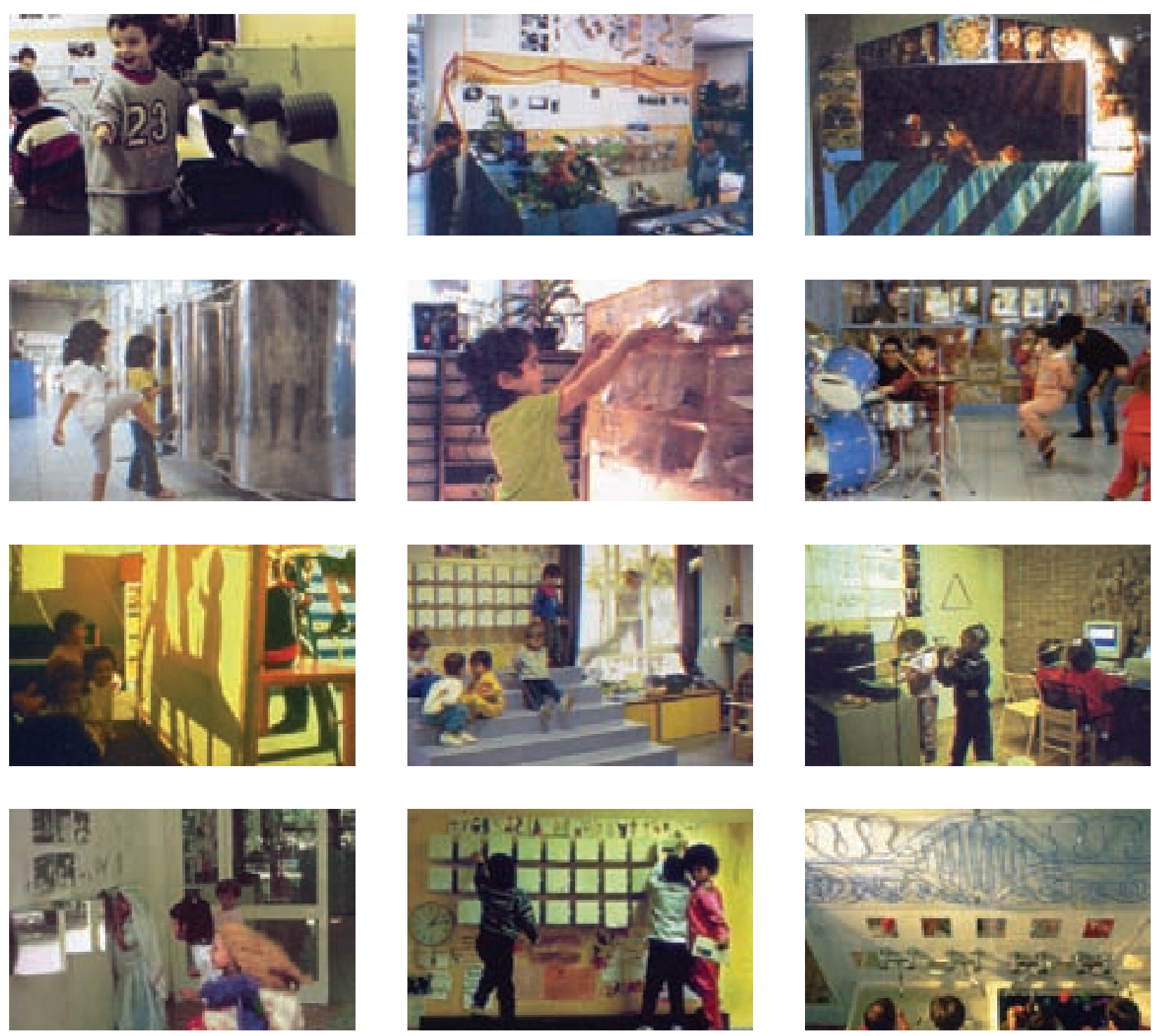

Equipamentos e instrumentos menores fixos e semi-fixos: espelhos, telefone sem fio, caixa de mensagens, molas, degraus-escadabanco, tapetes, telas removiveis, cordas, instrumentos musicais, teatro, fantasias, etc. a criança modifica a si mesma e transforma o ambiente momentaneamente, criando estados diferenciados do mesmo (em relação a ruído, luminosidade, movimentação, cor, etc.) 

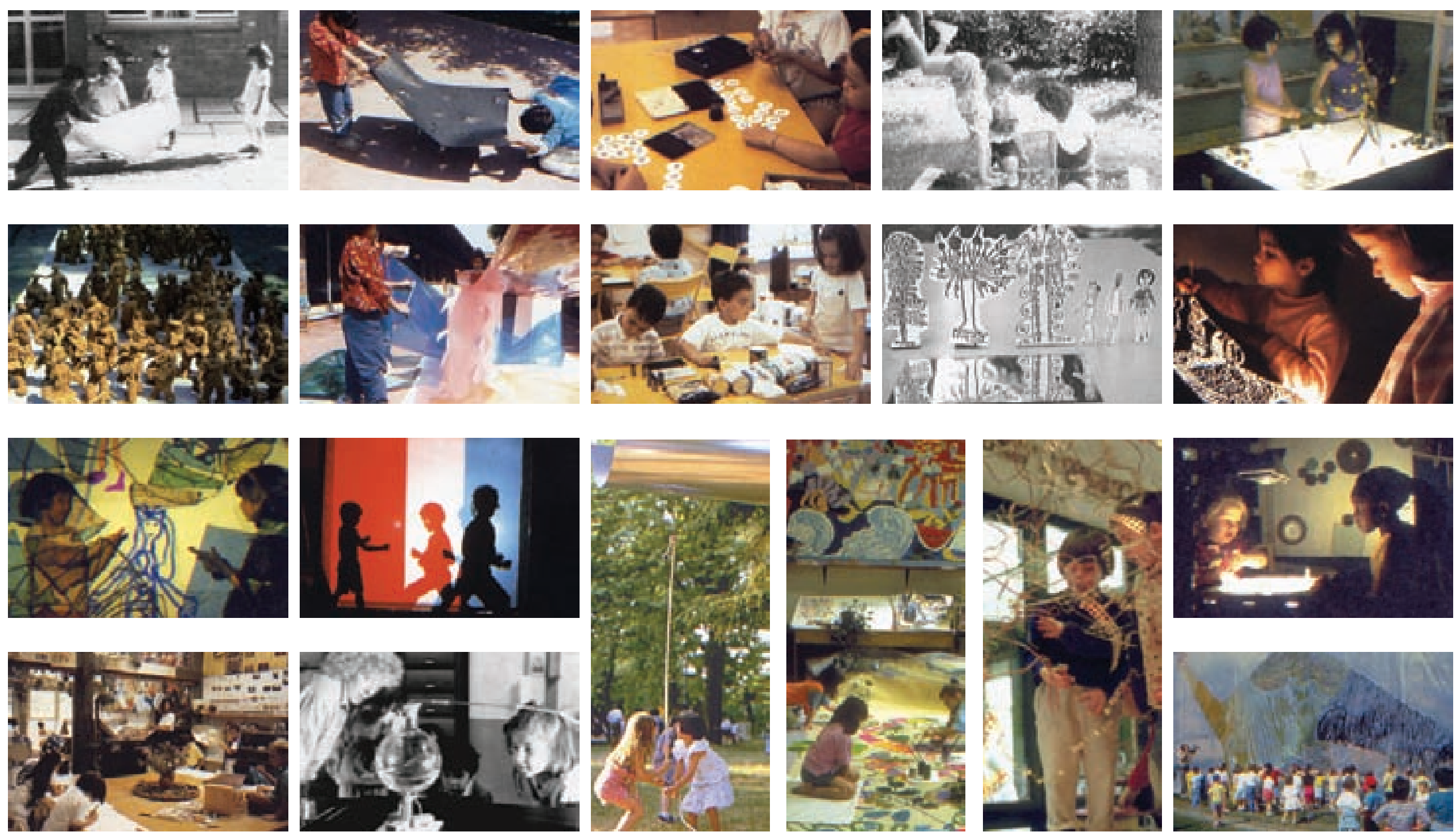

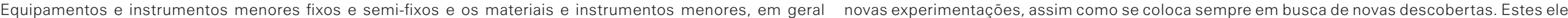

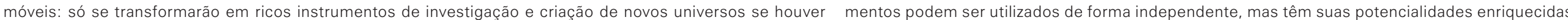

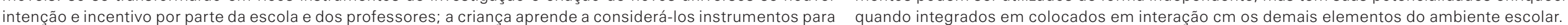


não considera a realidade como alguma coisa de estaticamente dada, um limite construtivo ao qual é necessário adaptar-se, mas como uma matéria fluida da qual é necessário apreender as leis para poder transformá-la.

Há, por trás de todas as atividades e vivências que acontecem ali, um estímulo à percepção mais aguçada, à observação, à investigação, ao questionamento, à iniciativa, ao aprofundamento de questões e ao envolvimento profundo com os projetos, à solução de problemas, à atitude ativa e propositiva, e à capacidade de execução.

Ao considerar, porém, o ambiente como um "interlocutor" educativo, ou um "recipiente" que favorece a interação social, a exploração e a aprendizagem, os educadores em Reggio Emilia acabam enxergando-o mais como um elemento comunicativo, que carrega códigos, mensagens educacionais, que está carregado de estímulos e que dá suporte e abriga transformações.

A idéia de "transformabilidade", de um ambiente manipulável pelas crianças e pelos adultos, que permite mudanças ao longo dos dias e dos anos, de fato acontece, mas é resultado principalmente das sobreposições de trabalhos feitas pelos seus usuários.

O ineditismo, a imprevisibilidade, as mudanças e variações, tão valorizados e respeitados no mundo exterior, acabam ficando principalmente a cargo da natureza, e poucos destes princípios e das experiências aí possibilitadas são levados para os objetos e equipamentos da escola. Como vimos, há pouca exploração da polivalência e pouca variação de cores, texturas, materiais e aspectos como maciez, porosidade, etc. naqueles.

Podemos nos perguntar se há uma busca de encontrar o equilíbrio entre todos esses estímulos ao redor das crianças. Mas também se não é importante que o inedistismo, a imprevisibilidade e a capacidade de transformação estejam presentes no mundo artificial produzido pelo homem. 
Invece il cento c'è.

\begin{tabular}{ll} 
Il bambino & Gli dicono: \\
è fatto di cento. & di scoprire il mondo che già c'è \\
Il bambino ha & e di cento \\
cento lingue & gliene rubano novantanove. \\
cento mani & Gli dicono: \\
cento pensieri & che il gioco e il lavoro \\
cento modi di pensare & la realtà e la fantasia \\
di giocare e di parlare & la scienza e l'immaginazione \\
cento sempre cento & il cielo e la terra \\
modi di ascoltare & la ragione e il sogno \\
di stupire di amare & sono cose \\
cento allegrie & che non stanno insieme. \\
per cantare e capire & \\
cento mondi & Gli dicono insomma \\
da scoprire & che il cento non c'è. \\
cento mondi & II bambino dice: \\
da inventare & invece il cento c'è. \\
cento mondi & \\
da sognare. & \\
II bambino ha & Loris Malaguzzi \\
cento lingue & I Cento Linguaggi dei Bambini 1996 \\
(e poi cento cento cento) & \\
ma gliene rubano novantanove. & \\
La scuola e la cultura & \\
gli separano la testa dal corpo. & \\
Cli dicono: & \\
di pensare senza mani & \\
di fare senza testa & \\
di ascoltare e di non parlare & \\
di capire senza allegrie & \\
di amare e di stupirsi & \\
solo a Pasqua e a Natale. & \\
& \\
\hline
\end{tabular}





\section{CAP4 \\ EDUCAÇÃO INFANTIL \\ PROJETOS E EXPERIÊNCIAS ESCOLARES NO BRASIL}

Como vimos no primeiro capítulo, vem crescendo nos últimos anos a importância conferida à educação infantil. Diversos são os motivos que podemos apontar, como as profundas mudanças ocorridas no papel da mulher na sociedade moderna e, conseqüentemente, no cuidado e educação dos filhos; as transformações nas condições de vida nas cidades e na forma como as crianças vivem suas infâncias; e o avanço nas pesquisas científicas sobre o desenvolvimento infantil (que apontaram a enorme importância dos primeiros anos de vida para o desenvolvimento físico, cognitivo, afetivo e social dos seres humanos). Podemos destacar, talvez como o mais recente movimento e o que mais tenha incutido mudanças concretas na atenção dada à educação infantil, o reconhecimento internacional dos direitos da criança, que incluem o direito à educação de qualidade desde os primeiros anos de vida (Campos s/d).

No Brasil, mudanças importantes nesse sentido foram introduzidas nas décadas de 80 e $90 \mathrm{com}$ a nova Constituição de 1988 e com a Lei de Diretrizes e Bases da Educação (LDB), de 1996, as quais estabeleceram pela primeira vez a educação infantil como um direito da criança (de 0 a 6 anos) e como parte integrante do sistema educacional (primeira etapa da educação Básica, que compreende também o Ensino Fundamental e Médio) (Campos s/d;
Revista Criança 2007). Esta nova concepção de educação infantil que se instaurava é a mesma que persiste até os dias atuais e está retratada na seguinte citação extraída da LDB:

"A educação infantil, primeira etapa da educação básica, tem como finalidade o desenvolvimento integral da criança até seis anos de idade, em seus aspectos físico, psicológico, intelectual e social, complementando a ação da família e da comunidade." (Brasília 1996, art. 29)

Ao considerar a educação infantil como a primeira etapa do ensino básico, fazendo com que se integrasse definitivamente no sistema escolar, a LDB procurou enterrar definitivamente sua visão assistencialista, adotando uma visão mais educativa, caracterizada pela existência de uma proposta pedagógica (Carneiro 2004). Por muito tempo, as creches brasileiras haviam sido idealizadas com base em princípios assistencialistas e higienizadores, e os serviços prestados pelo poder público ou por entidades religiosas e filantrópicas não eram considerados um direito das crianças e de suas famílias, mas sim uma doação que se fazia sem grandes investimentos. A Constituição de 1988 e a LDB de 1996 representaram, então, um grande avanço (em termos formais), ao estabelecer a obrigação 
do Estado, por meio dos municípios, em oferecer educação infantil, integrada ao sistema educacional.

Apesar das mudanças legais introduzidas nessas décadas, poucas foram as transformações efetivas na educação infantil, e muitos são os problemas que ainda permanecem, alguns dos quais podemos destacar com base em um diagnóstico realizado pela comissão da Unesco/ OCDE2, em 2005: não efetivação da transição de creches para os sistemas educacionais; omissão dos governos estaduais em relação às suas responsabilidades quanto à educação infantil; baixo conhecimento sobre o desenvolvimento infantil na faixa de 0 a 6 anos; pequena preocupação nas escolas com a programação de atividades com as crianças, avaliada como pouco diversificada, rígida e presa a rotinas empobrecidas e empobrecedoras; insuficiente integração entre pré-escola e $1^{\text {a }}$ série do Ensino Fundamental; e descaso, desconhecimento ou dificuldade de adequação, investimento e cuidado com o espaço escolar, instalações, materiais, pessoal, cuidados com a saúde, proporção adulto/criança de acordo com os grupos de idade, currículo e gestão das unidades (Campos s/d, p.3).

Se as instituições de educação infantil passaram a não ser mais vistas como espaços meramente assistencialistas, como anteriormente, não conseguiram, no entanto. conquistar de fato o papel de educadoras. Até hoje, muitos as vêem mais como centros de recreação e "ainda predomina uma visão de que para a criança pequena qualquer coisa serve: não se valoriza o profissional que trabalha com ela, não se julga que livros, materiais pedagógicos e brinquedos são necessários no dia-a-dia e não existe preocupação com crianças passando longas horas em ambientes insalubres, longe do contato com a natureza e forçadas a contínuos períodos de ociosidade" (Campos s/d, p.3).

Conseqüentemente, o espaço destas instituições continua relegado ou pensado em contraponto às novas concepções pedagógicas. Apesar de estas terem sofrido mudanças diversas durante a história da educação, pouco mudou na estrutura física das escolas ao longo desses anos (Romão 2006). Principalmente se olharmos para a rede pública escolar, veremos a adoção de projetos padronizados, sem que haja qualquer tipo de questionamento sobre sua concepção. Na rede privada, a situação parece ser um pouco diferente, e, desde a década de 70, começamos a observar algumas propostas atentas ao ambiente escolar. Porém, mesmo nessa esfera, muitas vezes há descaso, desconhecimento ou incoerência no tratamento do espaço.

Portanto, apesar do crescente reconhecimento da influência do ambiente sobre o desenvolvimento da criança, não se vê um reflexão concreta sobre suas características físicas e as relações entre estas. Recomenda-se sempre que estes sejam ricos e estimuladores, mas as discussões em torno destes aspectos não são aprofundadas e raramente passam do plano abstrato e teórico para o concreto e prático. Quando isso acontece, em geral cai-se em propostas que ficam restritas ao programa arquitetônico, às atividades desenvolvidas, à existência ou não de brinquedos (e de que tipos) e à adequação e atendimento das necessidades básicas e funcionais.

No início dos anos 2000, com o intuito de tentar reverter este quadro, partindo de um diagnóstico apresentado no Plano Nacional de Educação (PNE-2001), em que se concluía que ainda havia sérios problemas a se enfrentar nesse campo, definiu-se como meta do governo a elaboração de padrões de infra-estrutura para o funcionamento das instituições de educação infantil. Uma equipe de profissionais de arquitetura, engenharia, pedagogos e psicólogos, o Grupo Ambiental Educação (GAE), foi chamada então, para participar como consultora, junto à equipe da Secretaria Municipal de educação de Belo Horizonte, da discussão e elaboração do documento Parâmetros básicos de infra-estrutura para Instituições de Educação Infantil (DPE/SEB). Depois de debatido com dirigentes estaduais e municipais de educação e representantes da sociedade civil, o documento começou a ser distribuído no início de 2007 em todo o país (Revista Criança 2007, pp.19-20), procurando oferecer referências para as secretarias de educação constituírem ou reformarem os prédios das institui- 
ções de educação infantil, a partir do que denominou-se de "metodologias participativas", que deveriam incluir "as necessidades e os desejos dos usuários, a proposta pedagógica e a interação com as características ambientais" (Parâmetros MEC 2006, p.9)

O que poderia representar mais uma conquista e um avanço na conscientização da importância do ambiente para o desenvolvimento infantil e na materialização de seu discurso, acabou, no entanto, ficando reduzido a uma relação de orientações em relação a infra-estrutura, materiais, sala-ambientes, iluminação, ventilação, conforto, higiene, segurança, etc. O espaço físico é apontado como "um suporte que possibilita e contribui para a vivência a expressão das culturas infantis" (Parâmetros MEC 2006 p.16). Porém, a proposta não é aprofundada e fica restrita questões técnicas, funcionais, programáticas e práticas, não considerando a inserção do espaço em uma rede de relações, que envolve não só elementos físicos, mas também pessoas, e que produz estímulos e desencadeia processos de percepção, apreensão, compreensão e ação (ver capítulo 2). Pouco se fala sobre o ambiente como estrutura de oportunidades para a aprendizagem, ou isso pouco aparece na discussão dos parâmetros definidos. Como o próprio título do documento já aponta, colocam-se ali essencialmente parâmetros básicos de infra-estrutura para instituições de educação infantil, como podemos observar nos tópicos a seguir:

- “janelas com abertura mínima de 1/5 da área do piso, permitindo a ventilação e a iluminação natural, visibilidade para o ambiente externo (...):

- portas com visores, largas, que possibilitem a integração entre as salas de repouso e de atividades, facilitando o cuidado com as crianças

- paredes revestidas em material impermeável até uma altura mínima de 1,50m, de fácil limpeza e manutenção;

- piso liso, mas não escorregadio, de fácil limpeza e que propicie conforto térmico para as crianças engatinharem; (...)" (Parâmetros MEC 2006, p.14, grifos nossos).
Esta definição de parâmetros chega até mesmo, às vezes, a ser excessivamente redutiva, quando, por exemplo, determina o material dos equipamentos sugeridos, ou quando apresenta a listagem de objetos que devem estar presentes nas escolas, desconsiderando qualquer contexto onde estas estejam inseridas e/ou direcionando a escolha dos equipamentos sem deixar espaço ou mesmo incentiva a reflexão por parte dos diretores, educadores e pessoas envolvidas na construção dos ambientes escolares.

Transcrevemos abaixo mais alguns trechos também extraídos do documento Parâmetros básicos de infra-estrutura para Instituições de Educação Infantil (DPE/SEB), do Ministério da Educação, que mostram estas colocações:

"Sugestões para aspectos construtivos:

(...) quadro e cabides acessíveis às crianças e, quando possível, contemplar também quadro azulejado onde os trabalhos das crianças possam ser afixados (...)" (Parâmetros MEC 2006, p.17)

\section{"XI. Área externa}

Deve corresponder a, no mínimo, 20\% do total da área construída e ser adequada para atividades de lazer atividades físicas, eventos e festas da escola e da comunidade. Contemplar, sempre que possível, duchas com torneiras acessíveis às crianças, quadros azulejados com torneiras para atividades com tinta lavável, brinquedos de parque, pisos variados, como, por exemplo, grama, terra cimento. Havendo possibilidade, deve contemplar anfiteatro, casa em miniatura, bancos, brinquedos como escorregador, trepa-trepa, balanços, túneis, etc. (...)" (Parâmetros MEC 2006, p.26)

Antes mesmo da elaboração deste documento desenvolvido pelo governo, no entanto, já podiam ser encontrados, desde o final dos anos 80, textos, análises e discussões sobre a questão do espaço físico em escolas de ensino infantil. Com o aumento significativo destas instituições e da importância dada aos seus ambientes, 
aumentavam os estudos e pesquisas sobre o tema, nas mais diferentes abordagens e recortes. Consultando inúmeras destas publicações, porém, pudemos perceber, por um lado, novamente a quase ausência de transposição do discurso para a prática (e redução deste a tópicos a serem seguidos) e, por outro, o retrato de uma realidade, da rede pública brasileira, em que os esforços ainda concentram-se no atendimento das necessidades programáticas (programa de atividades, salas, etc.) e da infra-estrutura básica.

Ainda que as condições socioeconômicas e os contextos político-culturais sejam precárias e complexas no Brasil, acreditamos que a discussão sobre o ambiente escolar infantil possa e deva ir além das questões de adequação e de atendimento das necessidades básicas e funcionais. Foi-nos possível observar que, muitas vezes, independentemente da disponibilidade de recursos, o problema do debate em torno dos espaços educativos e da posterior concretização de suas propostas estava, na realidade, na forma fragmentada de abordar o ambiente, que era pensado e estruturado a partir de listas (tópicos) de materiais, objetos, brinquedos, equipamentos e algumas orientações, desconsiderando que são as relações estabelecidas no espaço que constroem o ambiente, e não os elementos e as pessoas isoladamente.

Se, então, os ambientes infantis continuam sendo pobremente planejados, e muitas vezes ainda orientados para atender as necessidades do adulto e/ou a partir da concepção adulta de criança e infância, podemos nos perguntar até que ponto a inclusão da educação infantil na legislação representou de fato um avanço, e o estabelecimento dos parâmetros de infra-estrutura pode garantir ou pelo menos orientar, em direção à construção de ambientes de qualidade. No Brasil, pudemos observar que as políticas públicas ainda estão muito distantes de tratar a infância com a devida importância e seriedade, e que mesmo na esfera privada, muito ainda falta para que se perceba e se tenha domínio sobre a dimensão da importância e da influência do ambiente no processo de desenvolvimento infantil.
Em meio a este cenário de deficiência, porém, podemos observar alguns caminhos traçados. Neste capítulo, pretendemos apresentar alguns projetos e experiências que apontaram algum tipo de preocupação em relação aos espaços e ambientes onde estas aconteciam. Mais uma vez, não há aqui a pretensão de se traçar um panorama da educação infantil brasileira nem tampouco de apontar as melhores propostas de projeto, mas sim de trazer para discussão e para uma análise mais profunda princípios, questões, mecanismos e relações seguidos, utilizados e criados para o projeto de ambientes infantis. O recorte, como colocado no início desta dissertação, continua sendo a cidade de São Paulo, em função dos motivos já expostos.

Devido à escassa existência de propostas na rede pública paulistana que conseguiram levar adiante e concretizar projetos de ambiente que fugissem ao modelo padrão, optamos por selecionar três experiências do universo privado de escolas infantis para uma análise mais detalhada, procurando apresentar formas muito próprias de trabalhar os espaços e diferentes umas das outras.

Antes de partirmos para estas análises, porém, gostaríamos de destacar e comentar rapidamente duas das poucas iniciativas públicas que marcaram a história da educação infantil antes da Constituição de 1988 (uma delas) e da Lei de Diretrizes e Bases de 1996 e que trouxeram elementos para a reflexão sobre a concepção da criança, da infância e dos espaços destinados a elas, cada uma em seu momento e contextos específicos: os Parques Infantis da década de 30 e as EMEls do início dos anos 90.

\section{Parques infantis}

Como sabemos, até a década de 30, a infância foi ignorada pelo poder público. É somente a partir de 1930, com a tendência democratizante, que surge mais intensamente a necessidade de assistência à criança de até seis anos de idade. Com o movimento de expansão industrial que 
começava no Brasil naquele momento, crescia a absorção do trabalho feminino pelas fábricas, e, conseqüentemente, aumentava a demanda por espaços que recebessem $e$ assistissem as crianças pequenas (Campos s/d, p.1).

Na cidade de São Paulo, o então secretário da Cultura Mário de Andrade, cria, em 1935, os Parques Infantis, localizados nos bairros operários, com o intuito de atender as crianças em período integral. Com uma proposta educacional, cultural e ambiental bastante inovadora, estes parques integravam um projeto governamental maior de educação não-escolar para as crianças pequenas de família operária, por meio da qual se procurava garantir-lhes o direito à infância. Estas instituições, apesar de não-escolares, podem ser consideradas a origem da rede de educação infantil paulistana e o embrião das atuais EMEIS - Escolas Municipais de Educação Infantil (Campos s/d; Faria 1999).

Apesar de atender crianças de até 12 anos, consideramos importante a análise deste projeto, pois ele se destinava também a crianças de 3 a 6 anos, o foco do nosso trabalho. Muitos são os estudos e teses já apresentadas sobre a proposta e experiência dos Parques Infantis (PI) por este motivo, procuraremos aqui destacar os pontos que consideramos constituir importantes contribuições para a discussão em torno do ambiente escolar infantil, abordando-os também sob o ponto de vista arquitetônicoambiental, e não apenas pedagógico-cultural.

A proposta do $\mathrm{PI}$ era de um resgate da infância, indo além do que se entendia como educação nas escolas da época. Seu projeto se dirigia de forma crítica à escola e se propunha a complementá-la, considerando também as formas não-científicas de produção do conhecimento, como a arte, o folclore e o conhecimento espontâneo da criança, construído através de jogos, brincadeiras e relações de interação entre crianças entre estas e os adultos (Faria 2002).

Colocando-se como complemento escolar, o PI oferecia às crianças o espaço e a oportunidade de continuarem crianças, enriquecendo e diversificando a vivência que lhes era colocada nas escolas, na figura de "alunos". A criança era entendida como um sujeito produtor de cultura e, portanto, o PI deveria promover as melhores condições para que lhe fosse garantido o direito de brincar e criar a cultura infantil. Assim, enquanto as crianças estavam no parque, não trabalhavam, mas conviviam com a natureza, com o folclore brasileiro, e com variadas formas de expressão.

Os Pls foram construídos em grandes terrenos escoIhidos entre os bairros operários (as primeiras unidades localizavam-se no Parque D. Pedro, na Lapa e no Ipiranga). Eram grandes espaços abertos, com uma pequena edificação coberta. Esta, que ocupava em geral por volta de apenas $15 \%$ do área do PI, e abrigava os vestiários, a cozinha e o depósito (não havia salas de aula - ver planta na página seguinte), implantava-se na extremidade do terreno, liberando o gramado para as atividades lúdicas e eventos. Havia sempre um vasto espaço livre, ocupado por um playground e, em um segundo momento, quando possível, foram incorporados também pistas de corrida, locais para jogos atléticos, campos de ginástica e piscinas. Profissionais de recreação e higiene social revezavam-se na organização e supervisão das atividades ali oferecidas, que não incluíam atividades escolares convencionais (Niemeyer 2005, p.12).

Com um tríplice objetivo, de assistir, educar e recrear, o PI procurava integrar a criança, o jogo, a cultura, a edu cação e a saúde. Podemos ter uma dimensão do que se passava ali quando lemos os relatos e relatórios sobre o dia-a-dia das crianças, descrevendo suas atividades: teatrinho, desenho, marcenaria, jardinagem, modelagem, trabalhos manuais (bordados, tapeçaria), aulas de música exposição dos trabalhos das crianças; valsa, dança indígena, recorte de gravuras, bailado da Nau Catarineta, lei tura, biblioteca, prateleira de livros, carrossel, joguinho -0 pulo do canguru, joguinho - corrida com batatas, voleibol, balanço, passo de gigante, escorregador, jogo de construção, gangorra, pingue-pongue, corda, tanque de areia, jogos tranqüilos, jogos de damas e jogo de dominós, fila indiana, ginástica, ginásticas com bastões, corrida, peteca, bicicleta, carrinho, piscina, banho de sol, quebra-cabeças, 
lanches, histórias, comemorações cívicas; tudo isso fazia parte da proposta educacional de Mário de Andrade (Faria 1999; Faria 2002; Niemeyer 2005).

Baseada na produção cultural, então, estava sendo criada ali uma alternativa às pré-escolas existentes, assim como uma alternativa para os espaços filantrópicos voltados para as crianças pobres. A concepção de criança como ser total era bem diferente das usuais concepções da época, e por isso o PI era tão diferente das outras instituições infantis, marcando uma mudança importante na história da educação infantil e na abordagem de seus espaços. Apesar de não se constituir como escola propriamente dita, o projeto tinha, por trás de suas atividades, uma proposta educativa, e, por isso, podemos inseri-lo no debate sobre ambientes escolares, considerando-se as devidas ressalvas e diferenças.

A experiência dos Parques Infantis, portanto, levantou uma série de questionamentos em relação à abordagem da criança e da infância existente até então e propôs novas formas de enxergá-las, que são válidas ainda hoje. Unindo cuidado, educação e cultura, a proposta de Mario de Andrade colocou a criança em um plano até então desconsiderado no Brasil, o de portadora e produtora de cultura, e, mais do que deu espaço para isso, estimulou a diversidade de formas de produção de conhecimento, e a troca entre as diferentes culturas existentes no país. Valorizou a criança no seu processo de construção da própria identidade, e a inseriu como uma das protagonistas na construção da identidade nacional (que englobava todas as faixas etárias e todas as camadas sociais). Recuperou a importância das manifestações folclóricas, e aproximou, assim, educação e realidade, educação e contexto socioeconômico e cultural. Mostrou, acima de tudo, que educação e lazer não se contrapõem e tampouco se separam, principalmente na fase dos primeiros anos de desenvolvimento da criança - chegando, inclusive, a registrar aspectos da brincadeira como etapa importante na criação de uma "cultura infantil". Ao mesmo tempo, apontou a importância do equilíbrio entre liberdade e direcionamento
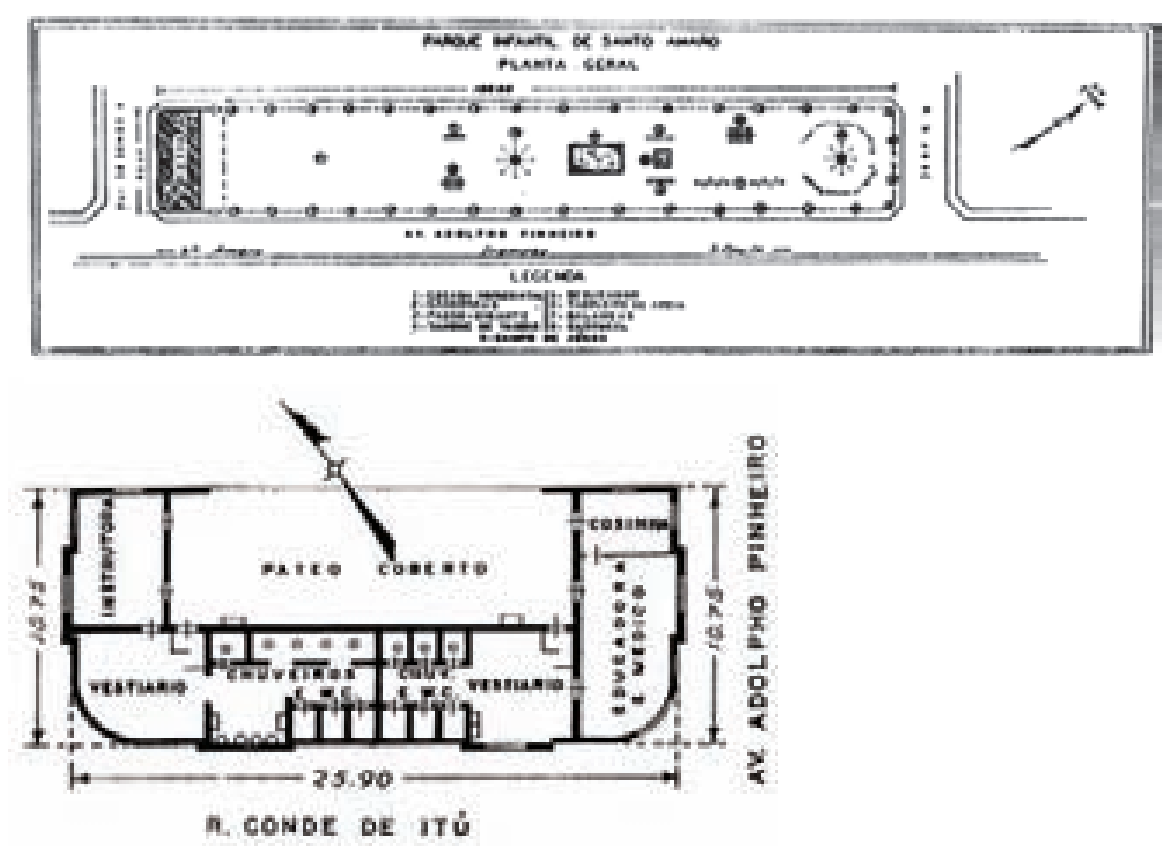

Acima, planta de situação do Parque Intanfil de Santo Amaro: abaixo, planta da edificação coberta da mesma unidade.

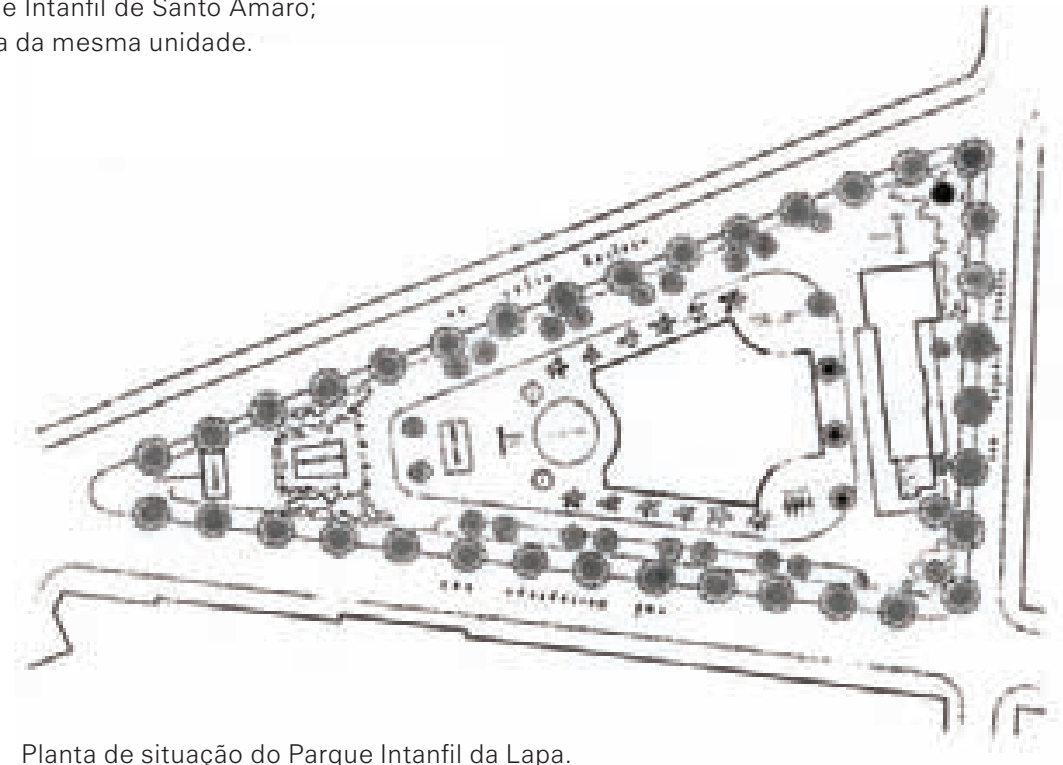

Planta de situação do Parque Intanfil da Lapa. 

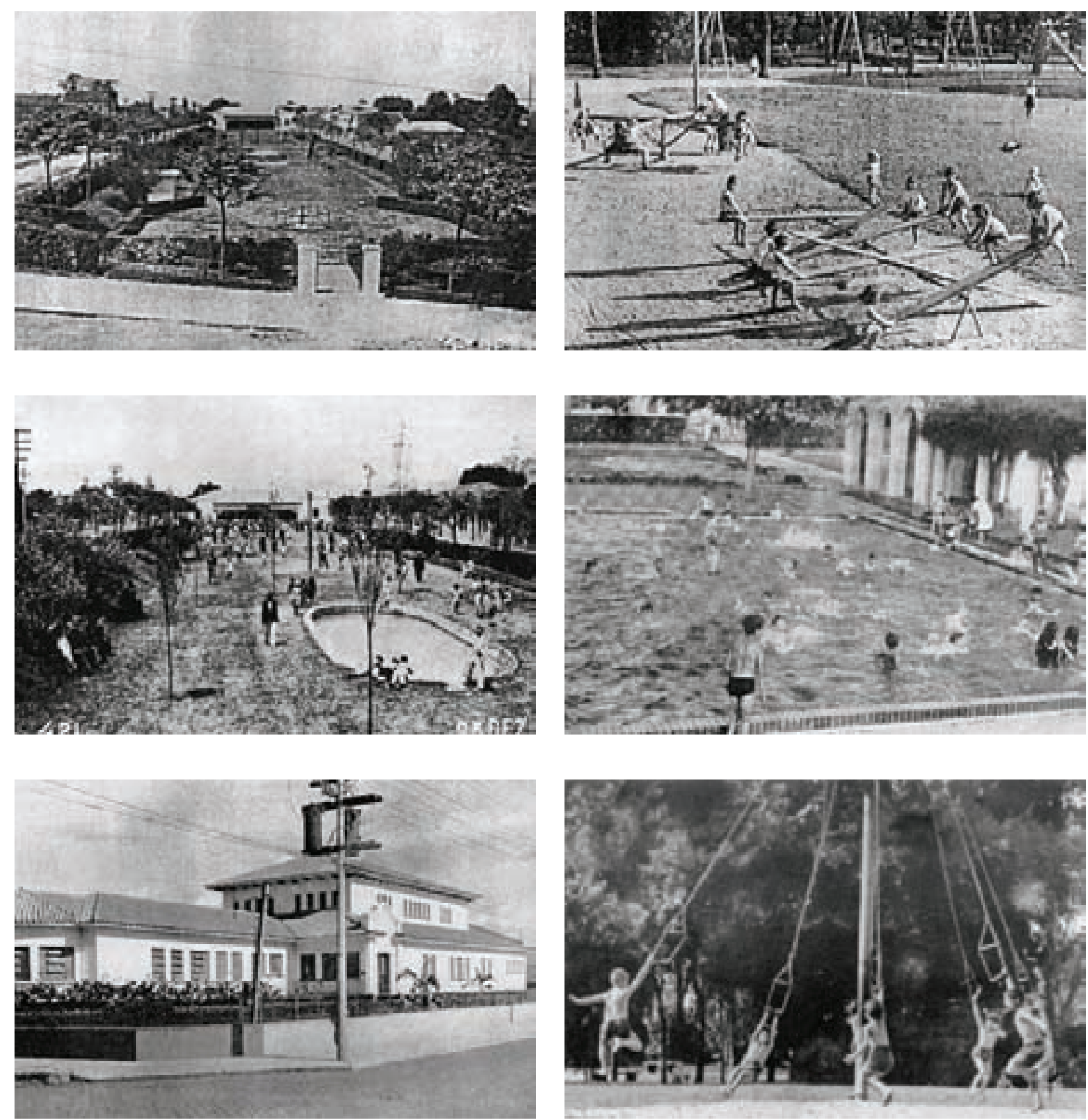

no processo de aprendizagem e, por fim, procurou concretizar tudo isso em espaços amplos, generosos, abertos, em contato com a natureza, que trouxessem o espírito de emancipação, troca, coletividade, compartilhamento, abertura, fluidez.

Os espaços do PI representaram, assim, um rompimento com os espaços concebidos na época para a educação, em geral fechados e organizados em torno de salas de aula, que traduziam as preocupações com segurança, controle e higiene das crianças. A presença de espaços livres, a extensão e diversidade dos espaços descobertos e dos equipamentos disponíveis, e o contato com a natureza constituíam um novo universo para a infância dentro da esfera pública brasileira, mais especificamente, paulistana.

Podemos dizer que esta proposta foi essencial para colocar em dúvida os parâmetros e ações voltadas para a educação infantil naqueles anos. Não podemos deixar de considerá-la, porém, dentro de um contexto e um momento histórico muito específicos. Se recuperarmos alguns textos e declarações oficiais da época, e analisarmos um pouco mais de perto os ambientes dos Pls, podemos observar que, apesar da liberdade e da riqueza de atividades propostas às crianças, havia ainda ali um forte controle e direcionamento das ações realizadas nos parques.

Se naquele momento os grandes gramados representavam uma conquista em relação aos espaços destinados à infância, hoje podemos questionar o seu arranjo, sua extensão e amplitude, sua relação com a vegetação, entre outros pontos. Ainda que tenhamos perdido muito dessa generosidade de espaço nas instituições de educação ao longo desses anos, colocam-se hoje novas questões e demandas, novos valores e princípios, novas entendimentos em relação ao que pode ser o ambiente escolar infantil.

A quase ausência de diferenciação entre ambientes na extensão dos gramados dos Pls, a concentração das árvores e da vegetação em geral nas bordas do terreno, a existência apenas de equipamentos padrão de mercado (como gangorra, gira-gira, escorregador, etc.), a pouca variação de campos visuais, entre outras coisas, são algumas 
das características e relações que hoje podemos apontar como empobrecedoras do ambiente educativo, pois deixam de criar a complexidade tão cara ao processo de desenvolvimento da percepção e, conseqüentemente, da compreensão e da ação. Como vimos no capítulo 2, para que a criança seja provocada e estimulada a buscar novas maneiras de adaptação e de comportamentos e ações bem-sucedidas, o meio deve romper o seu equilíbrio por meio de constantes estimulações, ou diferenças perceptivas; ou seja, deve apresentar novas informações que coloquem o organismo em estado de alerta (Rapoport 1978, p.172; Pignatari 1977, p.58), o que não nos pareceu acontecer nos Pls, em função da regularidade, da permanência e da delimitação muito clara dos equipamentos ali dispostos e disponibilizados para as crianças, dificultando a integração e interação entre os elementos, e a apropriação livre ou transformação destes por parte das crianças ${ }^{1}$.

O marco, sob o ponto de vista arquitetônico-ambiental, dos Parques Infantis se encontrava, assim, muito mais na conquista de espaços, amplos, ao ar livre, em contato com a natureza, que dispunham de uma infra-estrutura capaz de dar suporte à sua diversidade de suas atividades, com os variados materiais e objetos do folclore brasileiro que eram levados e/ou construídos pelas crianças e pelos adultos.

É importante lembrarmos que todas estas observações foram feitas com base apenas em algumas poucas imagens encontradas nos arquivos do Instituto de Estudos Brasileiros da USP e em teses e publicações, que, na maioria das vezes, mostravam os espaços de forma muito ampla e pouco detalhada. De qualquer forma, sem pretender entrar em uma análise mais profunda sobre esta proposta e experiência educativa, consideramos importante trazê-la à tona para recuperar algumas questões levantadas naquele momento, que se perderam nas propostas posteriores de ambiente escolar, principalmente no que se refere ao nosso sistema público.

A riqueza de visão e este caráter avançado da proposta educativa, como projeto sociocultural, e a busca de construção de espaços de coletividade e troca, por exemplo foram e têm sido ignorados pela rede de EMEls, que praticamente eliminaram os objetivos iniciais do PI relacionados ao lúdico, aos jogos tradicionais, às experimentações artísticas, ao contato com a natureza, à produção de cultura, enfim, à idéia de criança criadora. A retomada de valores e princípios como estes, re-contextualizados na realidade atual, é essencial para que não se deixem para trás conquistas já alcançadas e não se perca a dimensão e a importância de se pensar (e repensar) a realidade brasileira.

\section{EMEls inseridas no projeto do CEDEC/Emurb}

\section{(década de 90)}

Outra iniciativa que merece ser recuperada e ter alguns de seus princípios e ações revistos e redimensionados para o contexto atual é o projeto das EMEls desenvolvidas dentro da proposta mais ampla de criação do Centro de Desenvolvimento de Equipamentos Urbanos e Comunitários - CEDEC².

Dando um salto de alguns anos, mas permanecendo ainda no âmbito da rede municipal de educação, chegamos ao início da década de 90, quando é criado o CEDEC, em meio a um momento em que parecia se reforçar a necessidade de se assegurarem os direitos de cidadania à toda a população. Já desde a década de 60 , no estado de São Paulo, procurava-se desenvolver um processo de planejamento de obras públicas, em que as demandas populares passassem a ser consideradas objetivamente, isto é, para além das barganhas político-eleitoreiras (Lima 1995, p.137), mas poucas tinham sido as conquistas nesse sentido. O CEDEC veio, então, no âmbito municipal, buscar justamente assegurar o direito da população aos serviços públicos básicos, no que diz respeito à produção dos equipamentos urbanos, abrindo espaço para a sua participação no processo de construção dos espaços coletivos. Organizado dentro da estrutura da Empresa Municipal de Urbanização - Emurb, constituía um setor de pesquisa e
1 Talvez, particularmente para as crianças pertencentes a classes sociais menos favorecidas, a descontinuidade da experiência do PI se desse mais pelo fato de este funcionar como uma uma espécie de "oásis" na experiência perceptiva cotidiana das mesmas (vivenciadas em casa ou na cidade). E, por isso, a importância dos espaços amplos, organizados, limpos.

2 O CEDEC, Centro de Desenvolvimento de Equipamentos Urbanos e Comunitários, constitui-se no núcleo de pesquisas e de produção industrial de componentes urbanos e de equipamentos comunitários, implantado na Diretoria de Desenvolvimento de Equipamentos Urbanos da Empresa Municipal de Urbanização, e tem como objetivo principal encaminhar soluções adequadas às demandas sociais do município. seguindo as diretrizes políticas do Governo Municipal. 
de produção industrial de componentes de construção de equipamentos sociais e urbanos.

O direcionamento de suas atividades em três frentes principais - participação crescente do usuário nas decisões de planejamento e de uso; busca de qualidade dos espaços, ambientes e instalações oferecidas; e oferta de informações claras e objetivas - tinha como objetivo, assim, romper com o quadro de deficiência e má qualidade dos equipamentos sociais e urbanos e introduzir - através de ações concretas - novos processos de produção do espaço urbano.

Tendo a arquiteta Mayumi de Souza Lima à frente do projeto de criação do CEDEC, procurou-se colocar uma nova postura da administração municipal com relação ao papel que esta desempenha na criação de espaços e oportunidades para as ações coletivas e para o aparecimento de uma rede autônoma de informações e troca de experiências nas comunidades para a construção do seu espaço. Os equipamentos e a própria cidade não deveriam mais ser entendidos apenas como prédios construídos e, sim, como uma relação de espaços cheios e vazios que, isoladamente e em conjunto, têm um significado e constituem coordenadas culturais e históricas de toda a população. Isso significava uma nova postura de projeto, cujo ponto de partida era o usuário e o ponto de chegada a melhoria na qualidade do ambiente que a ele é oferecido (Lima 1995, p.127)

Uma escola ou uma creche, assim, não deveria ser mais uma construção de baixo custo, mas a "arquitetura de um lugar" (Lima 1995, p.138) destinado às crianças e, portanto, necessariamente alegre, clara, com áreas projetadas para as necessidades específicas de cada faixa etária. Inserido em um momento histórico em que a concepção da criança como sujeito de direitos estava se consolidando e em que crescia significativamente a importância dada à educação infantil, o projeto, por meio principalmente da arquiteta Mayumi, procurava incorporar as novas reflexões sobre os espaços destinados às escolas. Depois de uma fase de rápido crescimento da rede escolar pública, em que a normatização, a sistematização e a padronização dos edifícios resultaram na queda da qualidade dos seus espaços, fazia-se necessária uma revisão dos projetos destinados às crianças.

Para a concepção dos espaços educacionais das EMEls, quatro elementos básicos passaram a ser considerados pelo CEDEC: a criança, a proposta pedagógica, as condições do terreno e o entorno da área onde a escola seria inserida. A idéia era que a escola deveria refletir, no seu aspecto exterior e nos seus espaços internos, a sua concepção educativa, que, para a equipe do CEDEC, deveria ser democrática, aberta, em que a criança é protagonista na sua descoberta do mundo, através do brincar.

Não pudemos analisar que tipo de propostas pedagógicas foram seguidas nestas escolas, nem tampouco como estas foram apropriadas, ou que tipo de atividades foram ali realizadas. O que trazemos aqui é apenas a proposta de projeto, os princípios que estavam por trás da mesma e um rápido olhar sobre os espaços construídos. Ainda que seja uma análise superficial e sem referências das experiências concretas destes projetos, consideramos importantes o conhecimento e a reflexão sobre alguns dos pontos levantados por eles, os quais veremos adiante.

Podemos dizer que os dois pontos de partida principais para a concepção de toda a proposta são o entendimento de que o espaço da escola é, por excelência, espaço público e, mais do que isso, espaço da cidadania, e de que a criança se desenvolve e enriquece a sua experiência por meio da brincadeira e da observação. É a partir destas duas idéias que o projeto arquitetônico-ambiental se desenvolveu, desde a organização espacial até a comunicação visual.

Partindo do pressuposto que a escola deveria se integrar ao bairro onde ela se insere, procurou-se evitar o seu isolamento por trás de grandes muros, optando-se pelo uso de alambrados de cor neutra, os quais permitiam a "troca" entre o mundo "interior" e o "exterior". Ainda com o intuito de envolver a comunidade local e estabelecer um ponto de referência espacial para a mesma, foram criadas 
marcas próprias para cada unidade escolar, resgatando o nome do bairro onde se localizava, e aplicando-as no espaço, a fim de fortalecer a relação de identidade entre bairro e escola. A caixa d'água, ponto mais alto destes edifícios, passou, assim, a carregar a marca de cada projeto, destacando-se na paisagem urbana.

A organização espacial das escolas procurou também sugerir a relação e a integração entre as crianças e os usuários em geral e a estimular a troca e o convívio em espaços coletivos abertos, ao abrir todas as salas de aula para fora do edifício e criar caminhos e pontos de encontro em toda a área externa. O equilíbrio e a noção dos conceitos de público e privado eram dados, entre outras coisas, pela presença de terraços junto às salas, constituídos como espaços de transição entre os ambientes mais fechados e intimistas de cada turma e o ambiente aberto e amplo dos jardins.

Novamente com a intenção de reforçar a idéia de integração, as áreas externas foram concebidas como extensões da área edificada, desenvolvendo-se ao longo de um caminho, já mencionado acima, que passava pelo interior do escola. Este caminho não só interligava os elementos

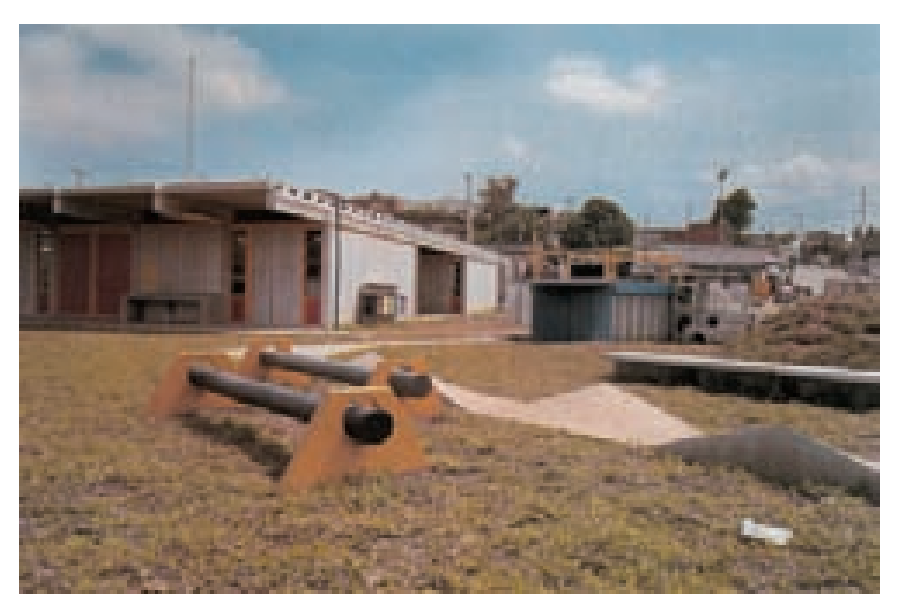

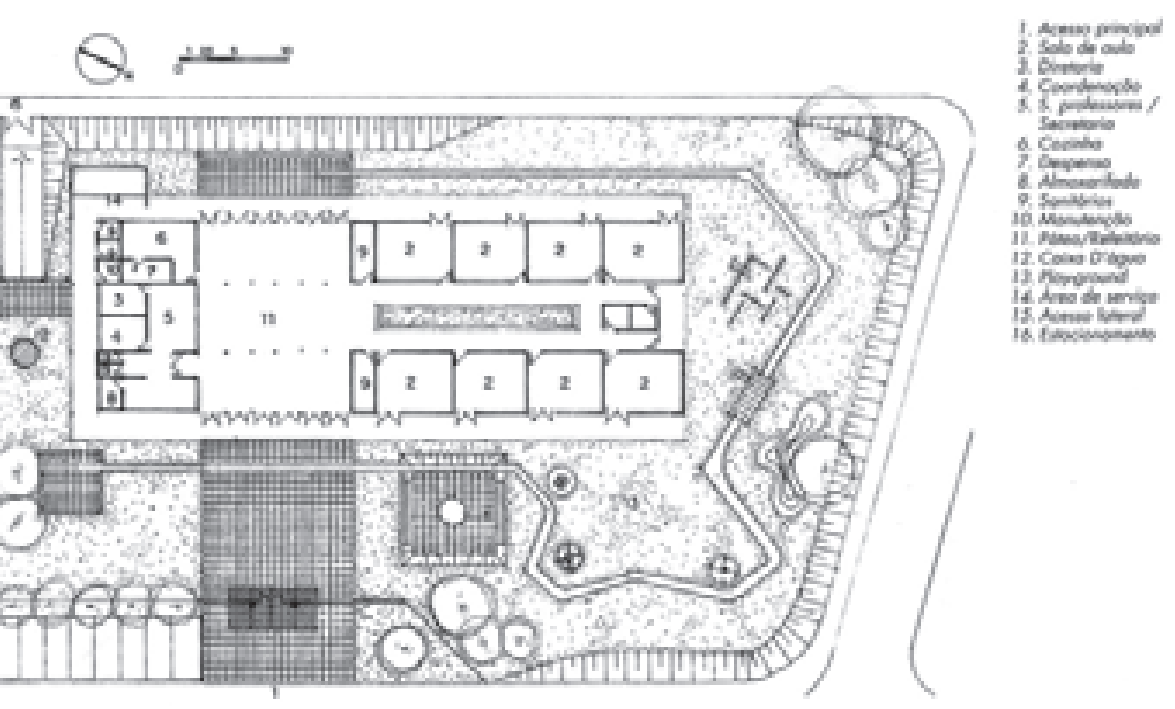

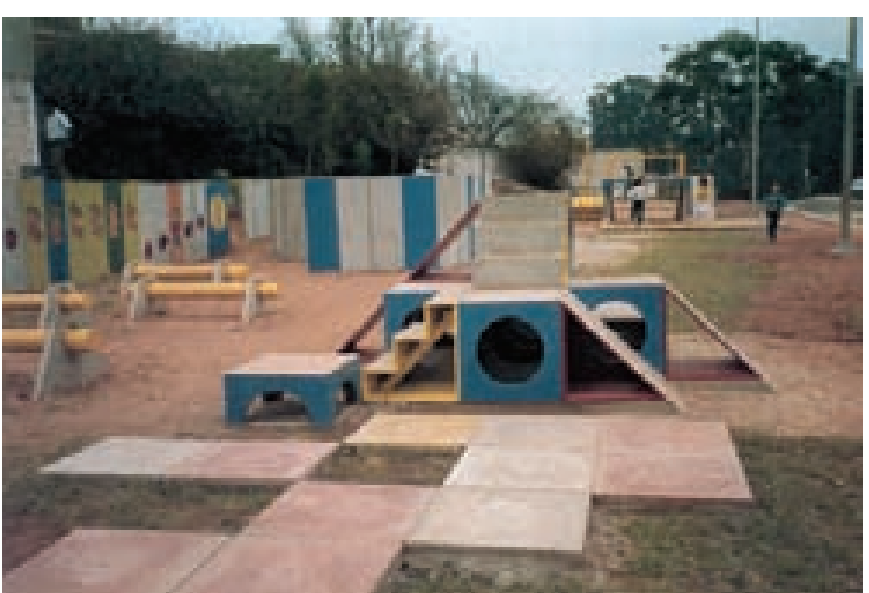

A planta acima, da EMEl Jardim Robru (São Paulo, Brasil), representa o esquema padrão que rege a organização espacial de todas (sempre que possível) as EMEIs projetadas.

As imagens ao lado e nas próximas páginas são fotografias de diferentes escolas da rede e nos mostram a utilização dos modelos de equipamentos pré-fabricados (produzidos na fábrica do CEDEC). Nesta página, podemos ver o caminho que estabelece a ligação entre todos os espaços e ambientes da escola. 
que compõem a área externa; constituía também um percurso onde iam aparecendo diversas situações e brincadeiras, como amarelinha, fita métrica, pegadas, mãos, e desafios, como planos inclinados, seixos rolados, lombadas, etc. (tirando-se proveito da conformação do terreno).

Aqui podemos observar a importância dada ao brincar, que, ao ser considerado no seu sentido abrangente de aprender, divertir, descobrir, inventar, fantasiar, estimular e aperfeiçoar o domínio da criança nas suas relações com o mundo e com as demais pessoas, acabou regendo o desdobramento do projeto nos seus equipamentos, objetos e elementos visuais.

Procurando criar um outro universo, diferente do estabelecido pelo mercado padrão e encontrado em qualquer lugar, e fazendo uso da estrutura e proposta construtiva do CEDEC $^{3}$, buscou-se fugir dos equipamentos e brinquedos tradicionais, construindo-os a partir da combinação de elementos de argamassa armada (como cubos, escadas, triângulos, cambotas de lixeiras, peças de canalização e divisórias) com elementos naturais (troncos de eucalipto e cordas, por exemplo) e sucatas. Túneis, trepa-trepas, labirintos, e outros, eram formados e distribuídos pela área externa da escola. Junto aos equipamentos e brinquedos, a vegetação compunha os espaços externos das escolas, procurando enriquecer ainda mais esse universo, com sua variedade de flores e plantas, cores e texturas, com a marcação das estações do ano e com a configuração de ambientes diferentes.

A intenção por trás da concepção destes equipamentos e dos elementos visuais e do diálogo com a natureza era a de "despertar a capacidade da criança descobrir por trás da primeira aparência, um mundo complexo que se revela a cada nova indagação", buscando "primeiro despertar a curiosidade, portanto, fazer uma pergunta e, segundo, encontrar uma resposta diferenciada em cada nível de aprofundamento da própria pergunta, feita individualmen-

${ }^{3}$ Constituindo-se como um núcleo de pesquisa e de produção industrial, o CEDEC tinha em sua estrutura uma fábrica onde eram produzidos componentes urbanos e equipamentos comunitários (em argamassa armada). 1995, p.145). 

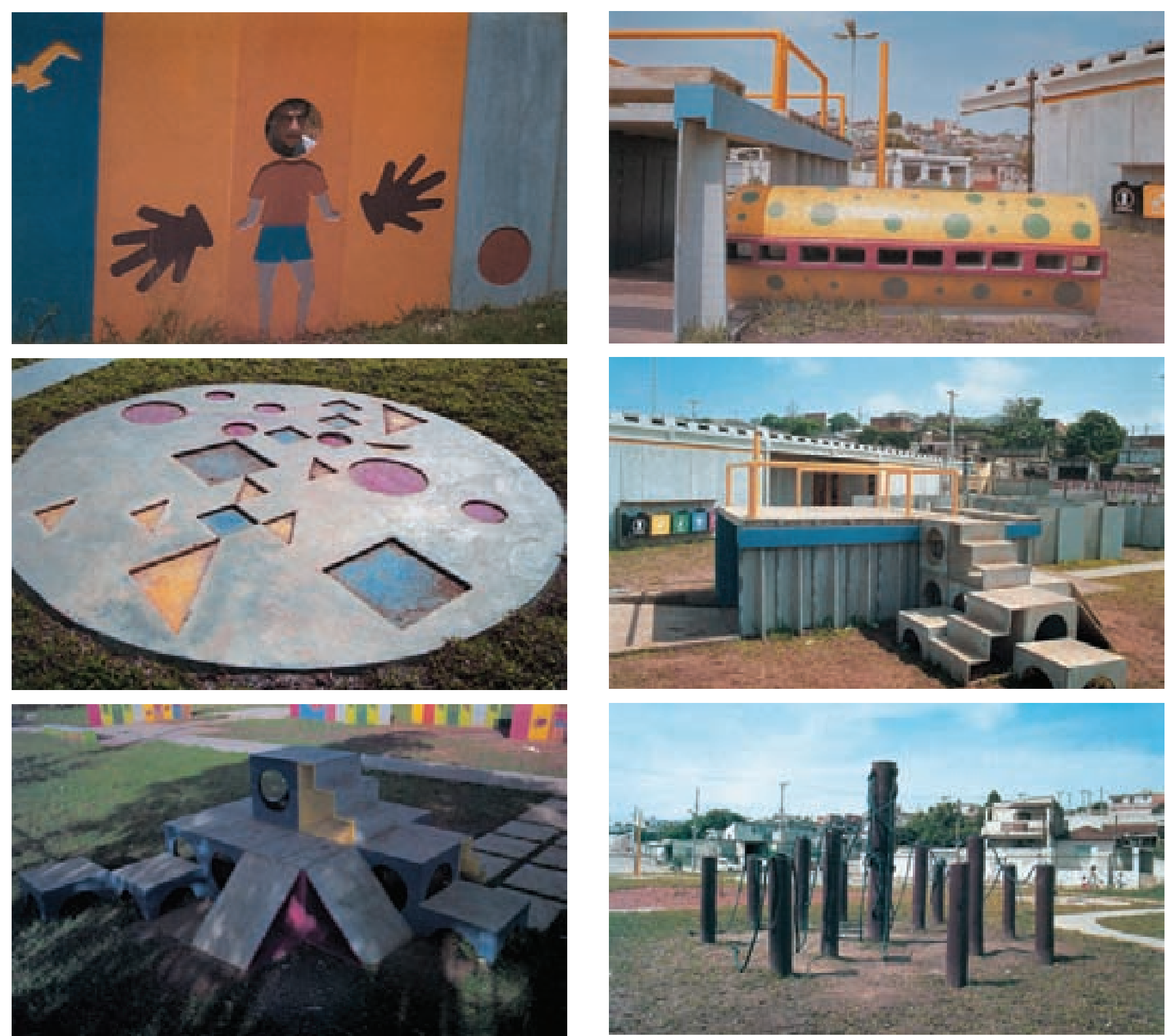
As EMEls projetadas nestes anos do projeto CEDEC eram fortemente identificadas por seus espaços diferenciados, rompendo com uma história marcada pelo freqüente descaso com o ambiente escolar. Propunha-se naquele momento que projetos de escolas e creches fossem repensados dentro de uma concepção mais ampla, além da programação funcional, construtiva e curricular, apontando para as novas demandas e valores que se apresentam já há algum tempo. O intuito era de "fazê-las repensar os espaços por elas ocupados, como e porque eles são organizados, como é possível alterá-los. Permeando tudo isto estava a tentativa de colocá-las como sujeitos de sua realidade, capazes de transformá-la a partir do seu entendimento, através de sua ação e na direção da satisfação de suas necessidades... 'Não há educação mais revolucionária do que aquela que ensina a considerar o mundo não como uma realidade já feita, inexorável, mas como uma obra a ser criada'" (CONESP 1984, pp.18-19).

Hoje, fazendo uma análise mais minuciosa do projeto, podemos apontar suas lacunas e limitações. Podemos observar como a intenção de criar o espaço da descoberta acaba ficando enfraquecida com a fixação, a rigidez e a pouca maleabilidade ou flexibilidade de seus elementos, cujas surpresas se esgotam rapidamente por não permitirem a transformação por parte das crianças; como a sinalização excessiva ou muito precisa da escola, numa situação onde esta é relativamente pequena, pode empobrecer o processo de descoberta de seus espaços, havendo outras formas de "sinalizar" a escola e localizar a criança que façam com que esta se sinta segura e, ao mesmo tempo, livre para explorar o seu entorno; como o trabalho com elementos visuais predominantemente simbólicos reduz as possibilidades de (re)interpretação e, conseqüentemente, de criação; como a construção da identidade de uma escola não se constrói de fora para dentro, mas de dentro para fora, ou seja, deve nascer da apropriação de seus espaços (físicos e virtuais) e da transformação dos mesmos; entre outras coisas.
No entanto, ainda que delimitada no tempo, no espaço e no contexto de deficiência da rede pública brasileira e paulistana, esta proposta - e talvez mais o seu discurso do que sua realização - é importante para que reflitamos sobre o conceito de "arquitetura do lugar" e sobre a necessidade e urgência de pensar e projetar espaços educativos de qualidade, independentemente da situação econômica existente. Como a própria Mayumi afirmava, "a superação dessas condições exige transformações sociais, econômicas e políticas mais profundas", porém, "a dimensão e a complexidade das transformações necessárias não podem constituir-se em pretextos para que mudanças imediatas não sejam realizadas". (Lima 1995, p.127)

Mesmo que de forma incompleta e superficial, consideramos importante a retomada, nesse capítulo, tanto da experiência dos Parques Infantis da década de 30 quanto do projeto das EMEls em argamassa armada da década de 90, a fim de resgatar a questão pública para a discussão do ambiente escolar infantil. Estas duas propostas, com todas as limitações que podemos apontar, trouxeram uma significativa reflexão sobre a participação e o envolvimento da população e da comunidade local na construção de seus espaços educativos, e procuraram concretizá-la, cada uma à sua maneira. Em ambas, o contexto e a cultura locais eram, ou deveriam ser, pontos fundamentais para o desenvolvimento das propostas pedagógicas e ambientais.

O sentido de voltar o olhar para estes projetos, portanto, está em extrair de suas propostas, questões, reflexões, princípios e ações válidas para os dias de hoje e saber contextualizá-las e revisá-las no debate atual. E, além disso, está também em refletir sobre as conquistas e sobre as limitações apresentadas, que nos dão referências concretas e nos ajudam a esclarecer e a tomar partido de que valores e caminhos de projeto pretendemos construir.

A seguir, partiremos para a análise das experiências de escolas infantis privadas, como havíamos mencionado no início do capítulo: a Escola Viva; o Colégio Santa Cruz; e as escolas Waldorf Rudolf Steiner e São Paulo. 

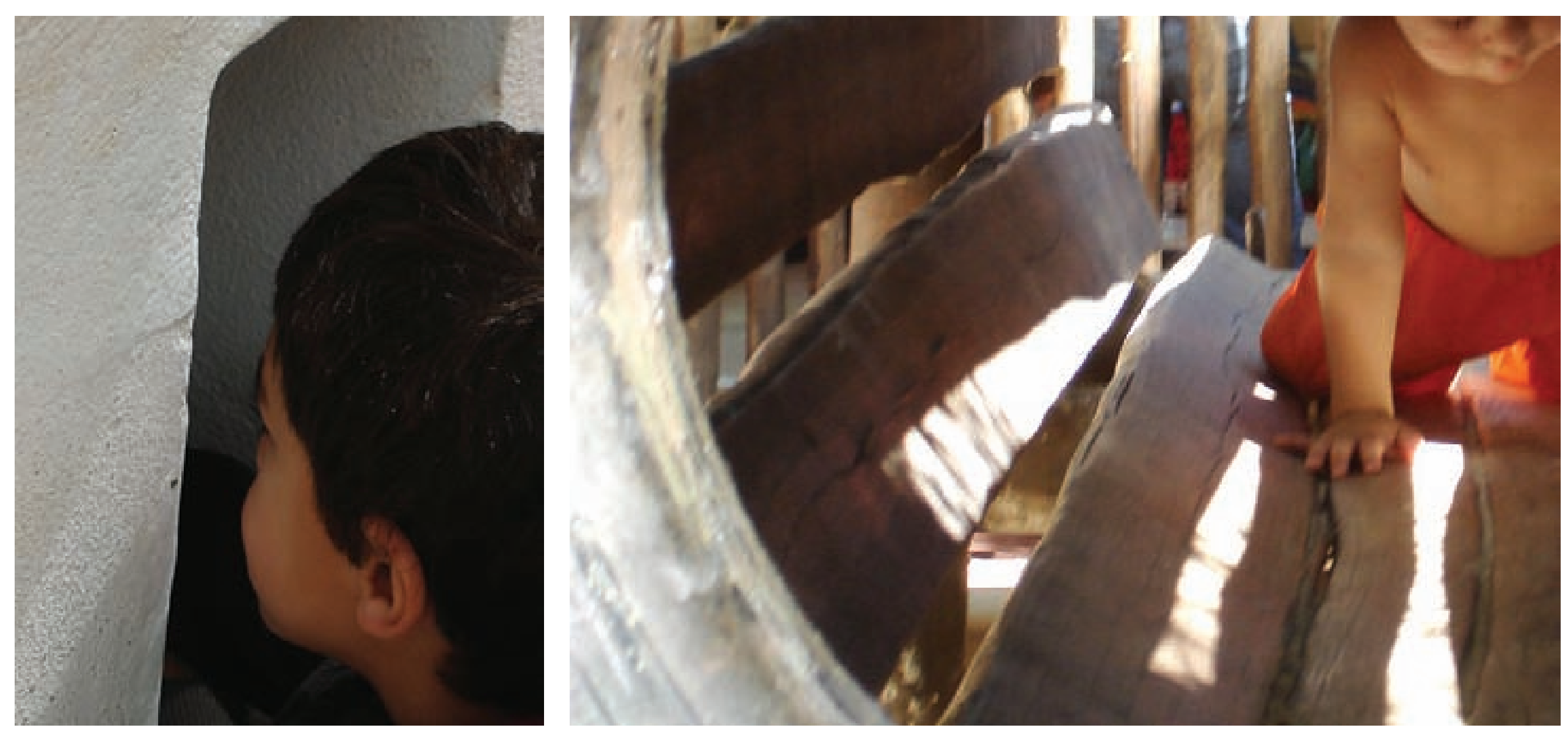


\section{A experiência da Escola Viva}

\section{A proposta da escola}

Projeto de arquitetura Cláudio Furtado

Projeto de comunicação visual Gustavo Piqueira I Rex Design

Local e Ano

São Paulo, Brasil, início da década de 70

Escola analisada educação infantil dos 3 aos 6/ 6,5 anos de idade

Total de crianças 325 crianças por período (manhã/tarde)

Total de salas

3 salas de cada idade por período (geralmente, 16 crianças por turma/sala)

\footnotetext{
** Notas 1 a 6: ver página seguinte
}

Originalmente um ateliê de artes para crianças, a Escola Viva tem desde o seu início uma grande preocupação com a importância do trabalho de artes visuais, música e expressão corporal. Tendo inicialmente como referências principais os trabalhos de Anna Mae Barbosa (escola de arte-educação) e Fanny Abramovich (pedagoga, desenvolveu trabalhos com teatro-educação e criatividade-educação), a escola sempre apresentou uma marcante formação na área de arte-educação, que continua presente até hoje em sua proposta.

Incentivada pela solicitação de pais que procuravam uma alternativa de educação para seus filhos, a coordenação do ateliê decidiu, no início da década de 70, abrir uma escola de educação infantil (separadamente do ateliê de artes, o qual permaneceu aberto, existindo até hoje em frente ao terreno de uma das unidades da Escola Viva). Atualmente a escola tem quatro unidades, localizadas na mesma rua, formando crianças de 1 a 14 anos de idade.

Às referências de arte-educação foram sendo agregadas outras reflexões e propostas pedagógicas, com significativa influência da pedagogia de Freinet ${ }^{1}$, Piaget (por meio das traduções de Emilia Ferreira), Vygostsky², Montessori e, mais recentemente, Howard Gardner ${ }^{3}$.
Em Freinet, a escola buscou principalmente a idéia de texto livre (considerando texto não só o texto literário, mas também todo desenho e qualquer tipo de expressão), e da importância do trabalho não só de grupo, mas individual de cada criança (educação mais individualizada), em que a possibilidade de escolhas era considerada muito importante para o desenvolvimento da criança. Freinet trazia a experiência prática, a transposição do trabalho teórico para o dia-a-dia, propondo um desenvolvimento global da criança (além do trabalho apenas com arte), o qual deveria ocorrer por meio da assistência e da intervenção do adulto - uma proposta diferente, em um momento em que se acreditava no processo educativo a partir da idéia de laisser-faire.

Já por meio do contato com Howard Gardner, a escola complementou e reforçou o trabalho junto às crianças a partir do conceito de "inteligências múltiplas", segundo o qual o indivíduo é dotado de inúmeras inteligências que devem ser exploradas e estimuladas - inteligência espacial, musical, emocional, intrapessoal, corporal/cinestésica, entre outras. Somou-se a esta idéia o contato com a experiência das escolas infantis de Reggio Emilia, na região de mesmo nome no norte da Itália, onde se fala das "100 linguagens das crianças" 4. 
Contra a idéia de seguir uma única linha pedagógica específica, a escola busca acima de tudo, segundo sua declaração, um aprimoramento contínuo, sempre com a ênfase na alfabetização do olhar e do ouvir.

O ambiente escolar, entendido como o conjunto formado tanto pelos objetos e espaço construído como pelas pessoas que o freqüentam, sempre foi considerado um elemento importante para o desenvolvimento da criança. Nas palavras da diretora, "espaço é elemento da didática, é conteúdo". "A idéia não é a beleza pela beleza - mas como ser útil e ao mesmo tempo belo, interessante, instigante - a gente pensa em ter uma colcha, um patchwork bem bacana: com muitas texturas, muitas informações, mas com harmonia. Esse é o objetivo: oferecer oportunidade de ter diferenças, mas com harmonia". "O espaço é um outro educador"5

Segundo ela, o espaço da escola deve oferecer possibilidades, além de estar sempre "em movimento", ser sempre dinâmico. "A gente favorece que [os espaços] sejam flexíveis; os móveis podem ser tirados do lugar... para que também o educador se aproprie desse espaço porque não adianta só o espaço sem ele ser tecido. Os arquitetos e as pessoas ligadas à comunicação visual precisam entender o projeto pedagógico também e os nossos profissionais fazem parte das reuniões para poder fazer com que isso tenha um sentido no trabalho deles. Esse entendimento entre os profissionais acaba sendo muito importante."

Ao longo de toda a trajetória da escola, procurou-se estabelecer um diálogo contínuo com profissionais da arquitetura e do paisagismo - tanto no que se refere à construção do ambiente (arquitetura e mobiliário, principalmente), quanto com relação ao desenvolvimento das atividades com as crianças: a importância dada à integração com a natureza, por exemplo (pois, segundo a escola o homem faz parte desta), levou à realização de um trabaIho junto a paisagistas e biólogas, procurando envolver as crianças no mesmo.

Tendo passado por várias ampliações ao longo dos anos, em função do crescimento do número de turmas e do surgimento de novas necessidades e espaços, a escola se viu impelida a adaptar e rever seu projeto original, processo que foi freqüentemente realizado e/ou acompanhado pelo arquiteto que havia concebido a primeira versão do mesmo (arq. Cláudio Furtado).

De forma geral, a escola se propõe a ser uma comunidade, fazendo com que todos os funcionários façam parte da proposta, envolvendo também os pais das crianças, e promovendo assim um ambiente de integração e interligação. Como diz a diretora, tenta-se reproduzir uma mini-sociedade, tanto do ponto de vista social como espacial, por meio de uma "praçona", outras praças menores, espaços comuns, e salas que dão para essas praças ou qualquer outro espaço coletivo: "é preciso entendimento do que é comum e do que é privado, do equilíbrio entre o indivíduo e o grupo. São vários elementos que estão na concepção pedagógica e que devem ser traduzidos do ponto de vista concreto, do espaço, do material, dos utensílios ...".

\section{O espaço escolar como ambiente de aprendizagem} [dimensões física, funcional, temporal e relacional]

Para que os ambientes fossem adequados às diferentes fases de desenvolvimento (e tamanho) das crianças, estas foram separadas em sedes diferentes (de 1 a 3 e de 4 a 6/6,5 anos de idade -educação infantil), criando-se assim centros menores para que estes fossem ambientados conforme as necessidades e proporções específicas de cada grupo

Cada grupo de crianças da mesma idade é dividido em turmas, que possuem salas próprias (apenas compartilham a mesma sala grupos da mesma idade de períodos do dia diferentes - turma da manhã e turma da tarde). Durante o horário de quintal e de algumas oficinas as turmas se misturam, havendo uma integração inclusive de crianças de diferentes idades.

Cada "ano" do processo escolar é identificado por uma cor (começando pelos amarelinhos, de 1 a 2 anos,
${ }^{1}$ Célestin Freinet: pedagogo, nascido em 1896, na França. Suas publicações constituem uma crítica radical ao sistema educacional público tradicional. A abordagem de Freinet não era apenas teórica e política, mas também muito prática, uma vez que ele integrava as suas idéias no seu trabalho cotidiano dentro da sala de aula.

Lev S. Vygostsky: professor e pesquisador russo, nascido em 1896. Assim como Piaget, tinha como objetivo uma nova psicologia que desse conta de ultrapassar as limitações das visões mecanicista e idealista.

${ }^{3}$ Howard Gardner: psicólogo americano, nascido em 1943. É conhecido pela sua teoria de inteligências múltiplas, segundo a qual todo ser humano tem sete dimensões de inteligência (visual/espacial, musical, verbal/lingüística, lógica/matemática, interpessoal, intrapessoal e corporal/cinestésica).

${ }^{4}$ Loris Malaguzzi: pedagogo e psicólogo italiano, nascido em 1920, fundou o Gruppo Nazionale NidiInfanzia em Reggio Emilia, Itália, a partir do qual propôs e promoveu uma inovadora filosofia da educação, baseada na idéia das "100 linguagens das crianças", que será apresentada na discussão sobre a experiência da escola Diana, na Reggio Emilia.

As informações sobre a proposta pedagógica e a relação desta com o ambiente escola aqui apresentadas provêm de conversa com a diretora da escola. Heloísa Pavan, no dia 11 de agosto de 2006.

${ }^{6}$ Com relação às considerações das "professoras", estas foram feitas pelas professoras de uma das turmas do azul (crianças de 4 anos em geral), Kátia e Nana, durante visita no dia 28 de agosto de 2006. 


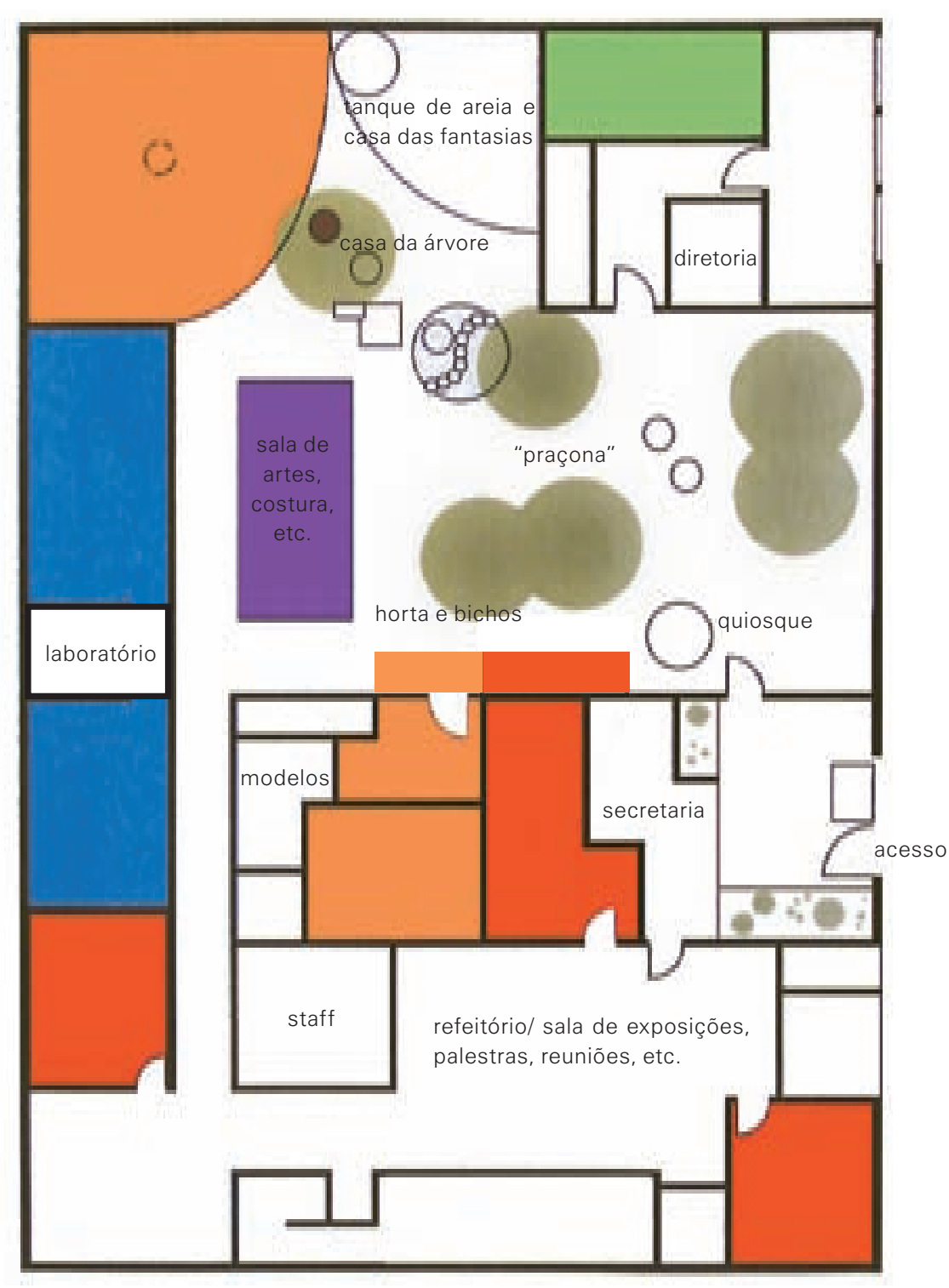

Planta da Escola Viva elaborada pela equipe interna, com demarcação das áreas das turmas por suas respectivas cores. passando pelos amarelos - estes dois localizados em uma outra sede--, laranjas, azuis, verdes e vermelhos, até 6/6,5 anos - estes últimos localizados na sede em análise) e, conseqüentemente, os uniformes e as salas de cada fase são identificadas pelas cores respectivas. Segundo algumas professoras ${ }^{6}$, isso acaba criando um sentimento de pertencimento e uma identidade de turma, além de facilitar a localização dos espaços onde as atividades de cada grupo são desenvolvidas.

Cada turma tem o seu "espaço" na escola e este é constituído por ambientes diferentes, com níveis de privacidade variadas: uma sala mais fechada, onde geralmente acontecem atividades em mesas, rodas e outras brincadeiras no chão (às vezes, esta sala é ainda dividida em dois ambientes); e uma área intermediária, "semi-privada" (o "terraço", onde pode acontecer a mistura das turmas); e, no caso da turma laranja, uma área descoberta, porém cercada, que se configura como uma transição para a área coletiva adjacente à maior parte das salas, conhecida como "praçona".

A "praçona", praça e principal área coletiva da escola, é o núcleo em torno do qual se organiza a escola. Apesar das expansões pouco planejadas, que acabaram desconfigurando um pouco o layout original da escola, no qual se previa a localização de todas as salas "de aula" ao redor desta praça, a idéia do núcleo central se manteve, congregando, inclusive, inúmeros outros "cantos" e ambientes", como o quiosque, a casa da árvore, a cada das fantasias, o espaço dos coelhos e das tartarugas, e vários outros. Salas de música, laboratório, e os ateliês de maquete/modelo e de artes/costura e atividades diversas também foram agrupados ao redor da "praçona", ou mesmo inseridos nela, como é o caso do ateliê de artes, sendo facilmente encontrados e acessados por todas as crianças.

A parte administrativa, também em função das ampliações e adaptações, acabou sendo dividida em duas áreas: diretoria e coordenação localizam-se próximas à praça e as demais salas ficam próximas à área de recepção, no 

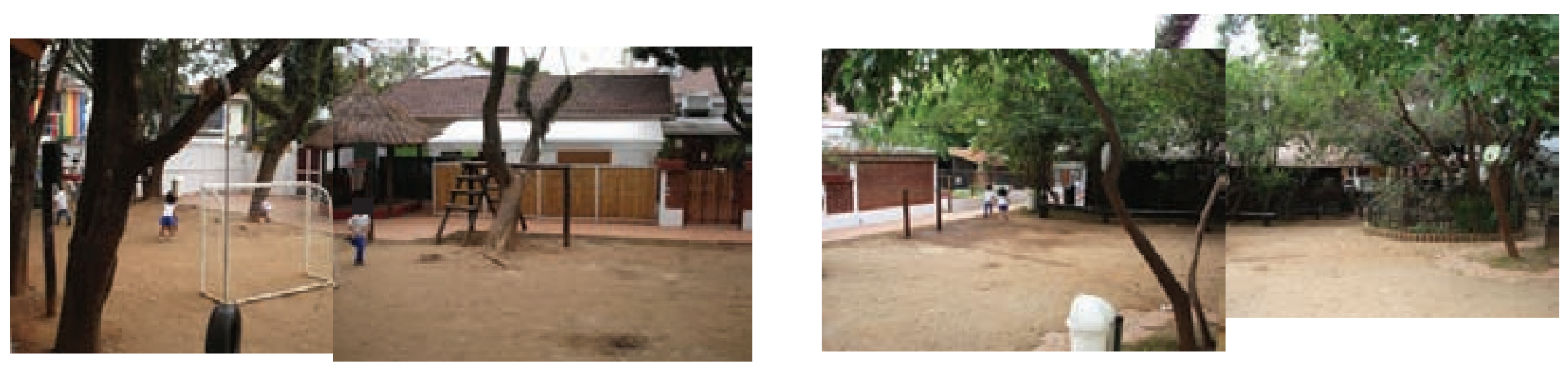

"Praçona", com quiosque e algumas salas do entorno (turma laranja).

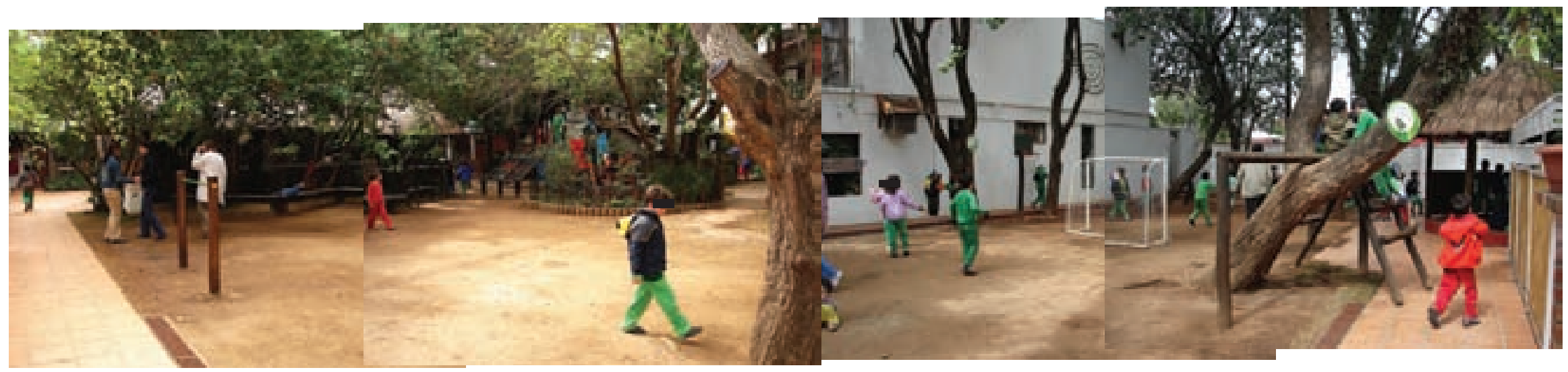

"Praçona"; ao fundo: área de ateliê, casa da árvore, edifício da diretoria e sala de uma das turmas; à direita, quiosque e uma das salas do entorno (turma laranja).

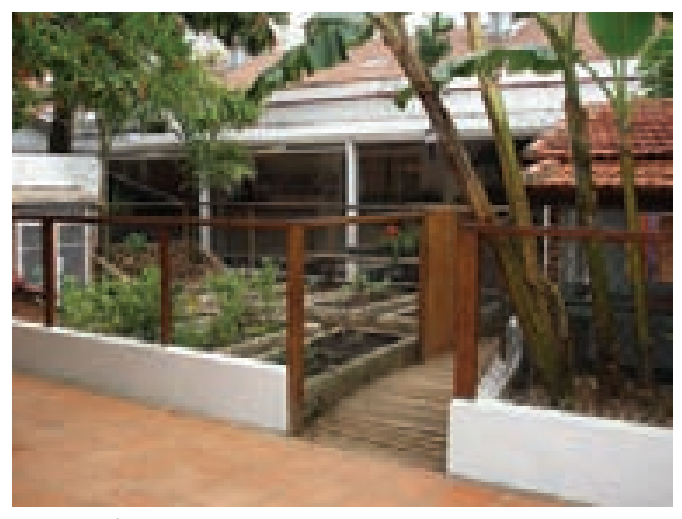

Horta e área dos animais.

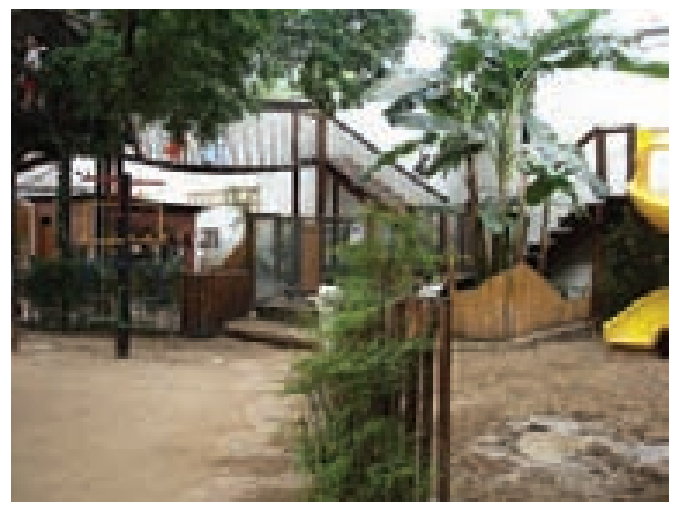

Área da casa da árvore, fantasias e outros equipamentos.

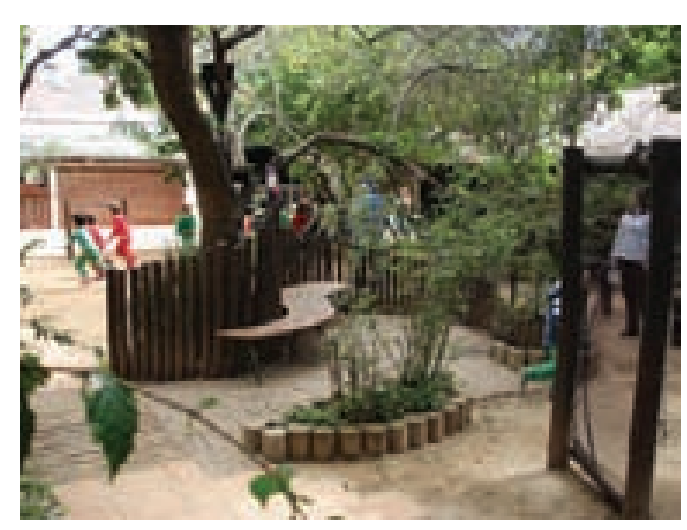

"Cantinho" entre "praçona" e casa da árvore. 


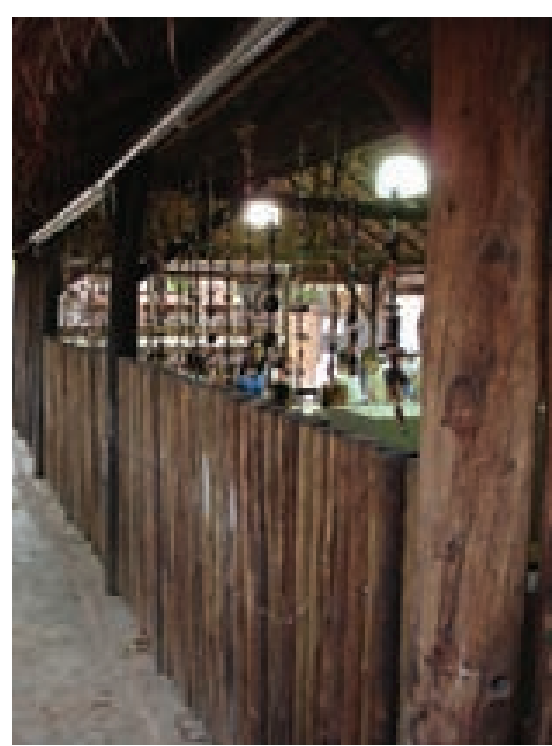

Ateliê de artes e outros.

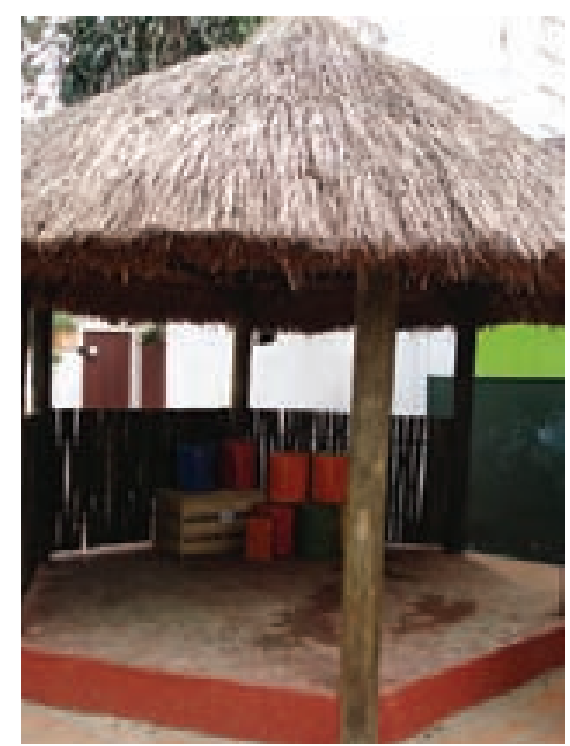

Quiosque.

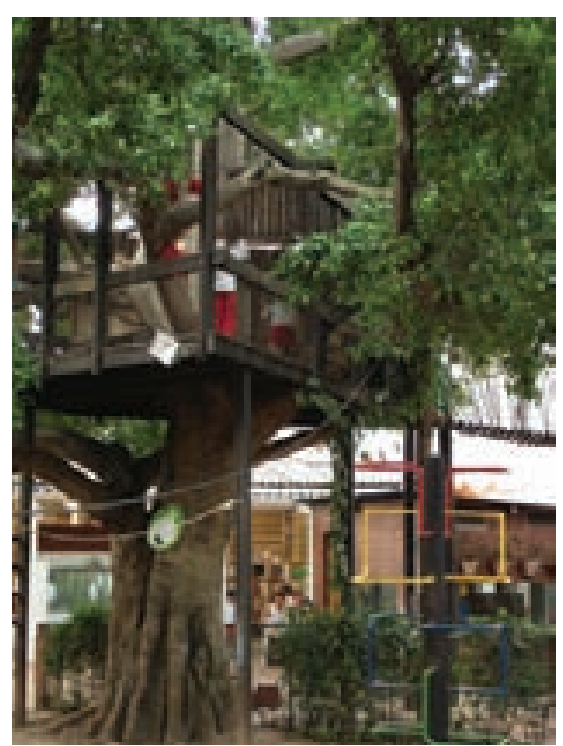

Casa da árvore. outro lado da escola, junto às áreas da cozinha e do refeitório para funcionários.

Por ser uma área livre e extensa, o espaço onde são realizadas as refeições dos funcionários é transformado em alguns momentos em local de reunião, palestras e exposição, o que já transparece uma das propostas da escola: pensar seus espaços de forma flexível e polivalente, o que veremos acontecer também nas salas de "aula" e nos espaços coletivos de forma geral.

Diferentemente das escolas de Reggio Emilia, a rotina da Escola Viva parece ser menos informal, tendo suas atividades de certa forma já predefinidas pelos professores, as quais, em geral, apresentam a programação do dia às crianças e trabalham mais freqüentemente com o grupo todo destas - e menos com grupos pequenos "isoladamente" (em locais diferentes da escola ou da sala), como acontece nas escolas reggianas. Havendo mais de uma turma da mesma idade, os professores procuram mesclar atividades internas e mais "privativas" (entre as crianças da própria turma) e atividades externas e integradas, onde há mistura de crianças da mesma "cor" ou mesmo de "cores" (idades) diferentes

Os primeiros 45 minutos de cada dia (período escolar) são dedicados ao "trabalho pessoal", cuja escolha fica a critério do aluno. Nesse momento, todas as crianças de uma mesma "cor" ficam soltas e espalhadas pelas salas de todas as turmas dessa mesma cor, desenvolvendo atividades como costura, experiência, faz-de-conta, música desenho, entre outras, sempre sob o olhar e a orientação e ajuda dos professores.

Após os 45 minutos, as crianças dirigem-se às suas salas para o início dos trabalhos internos, que, conforme suas características e necessidades de espaços e equipamentos, utilizam as salas mais fechadas, em geral com mesas, ou as mais abertas (ou "semi-abertas"), em geral utilizadas para atividades como relaxamento, quando as 


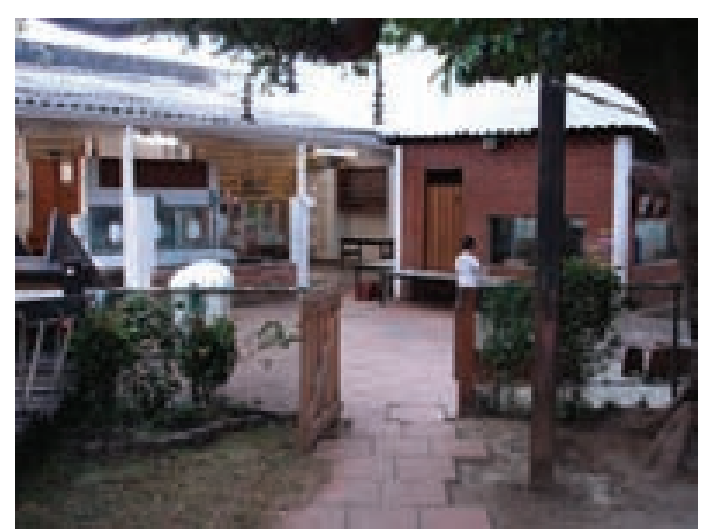

Acesso aos ambientes de uma das turmas laranjas.

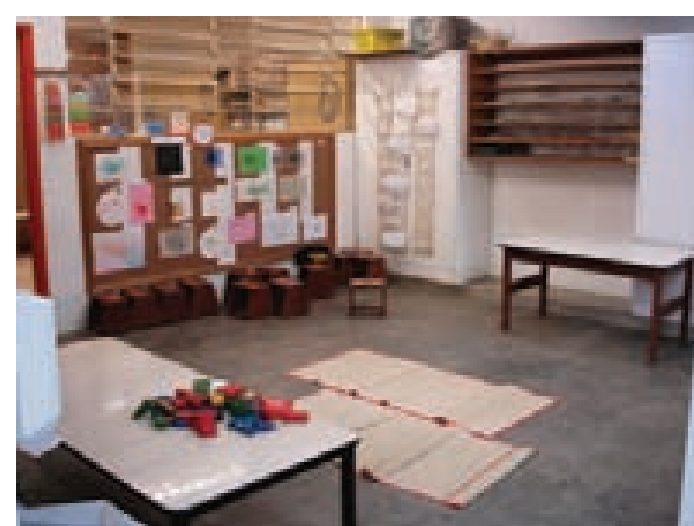

Sala intermediária (roda, relaxamento, etc.).

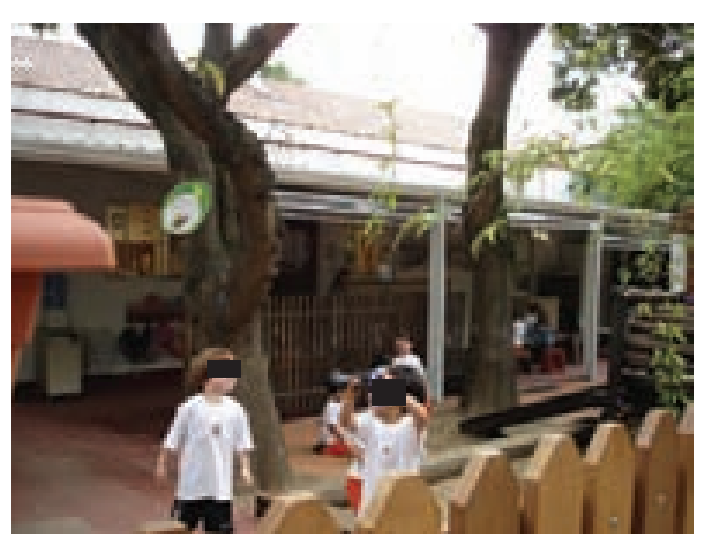

Área semi-aberta: "terraço" de outra turma laranja.

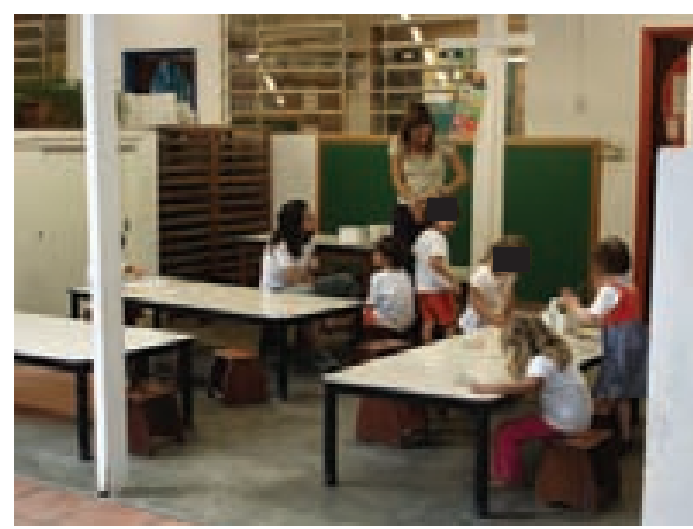

Área semi-aberta: "terraço" de uma das turmas laranjas.

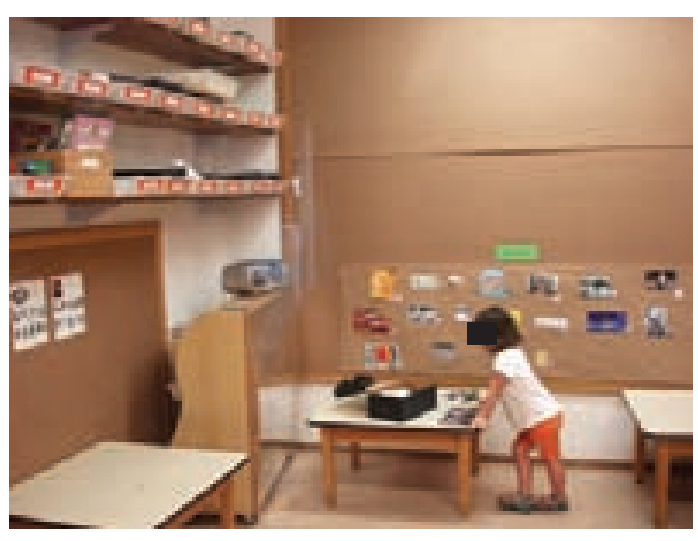

Sala própria de uma das turmas laranjas (mais "fechada").

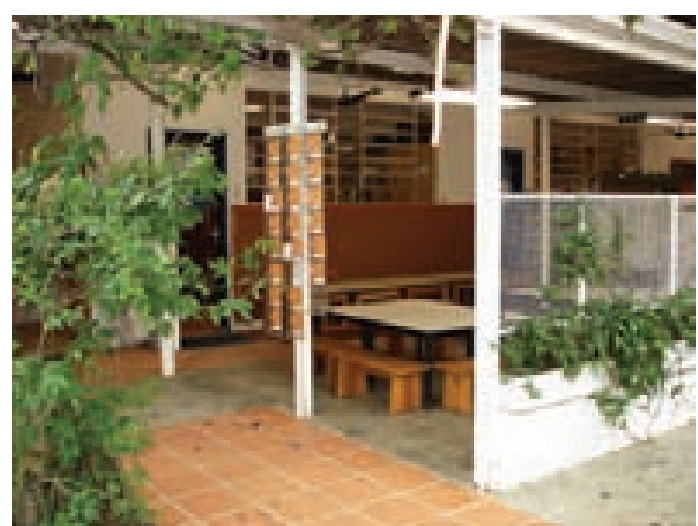

Área semi-aberta: "terraço" de uma das turmas azuis. 
crianças deitam no chão, em cima de esteiras, por exemplo (as crianças e os professores também mexem na organização do mobiliário e elementos das salas para adaptarem-nos a cada atividade proposta).

Prezando pela integração entre as crianças, a escola propicia um segundo momento em que estas se encontram, agora as turmas de todas as idades, o que acontece normalmente no horário do "quintal". A fim de que a integração se dê de forma gradual, faz-se um pequeno intervalo entre os horários de quintal de cada "cor". As crianças mais novinhas (os "laranjas"), portanto, são liberadas para o espaço da praça primeiramente. Depois de alguns minutos chegam os "azuis", depois os "verdes" e, por último, os "vermelhos". Quando as crianças mais velhas se espalham pelos espaços da escola, as pequenas já estão adaptadas e integradas.

Todo o espaço da escola é disponibilizado para as crianças na hora do quintal (todos os espaços coletivos,

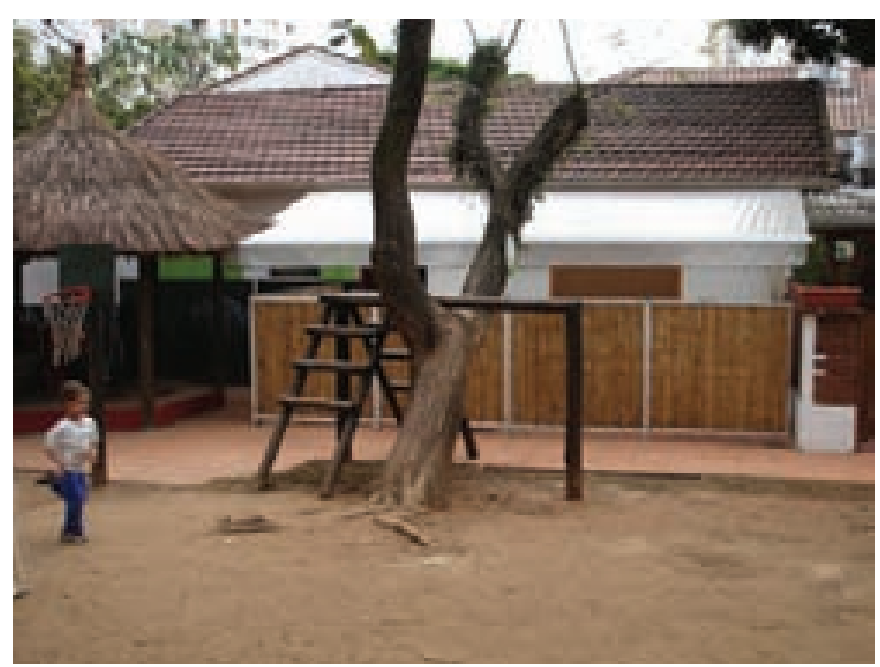

Equipamento de madeira conjugado à árvore, criando ainda mais e mais diversos desafios e pontos de vista do espaço da escola. sem restrição de uso), assim como vários equipamentos e brinquedos, que ficam espalhados por seus vários cantos. Nos espaços coletivos, em geral externos e constituí dos principalmente pela praça principal e seus "cantos", encontram-se equipamentos e elementos em geral que trabalham tanto o desenvolvimento físico-motor das crianças quanto o perceptivo-sensorial. Estão presentes tanto brinquedos de modelos padrão de mercado como outros construídos localmente, principalmente em integração com a vegetação existente.

Todos os equipamentos, mobilários e brinquedos são pensados de forma a atender as necessidades e dimensões das crianças nas suas diferentes fases de desenvolvimento, assim como a facilitar o trabalho dos professores e assistentes. A altura da pia, o tamanho e o peso das mesas e cadeiras, o sistema de fechamento das torneiras, a abertura, a localização e o arranjo dos sanitários e dos locais para que as crianças guardem seus mochilas, escovas de

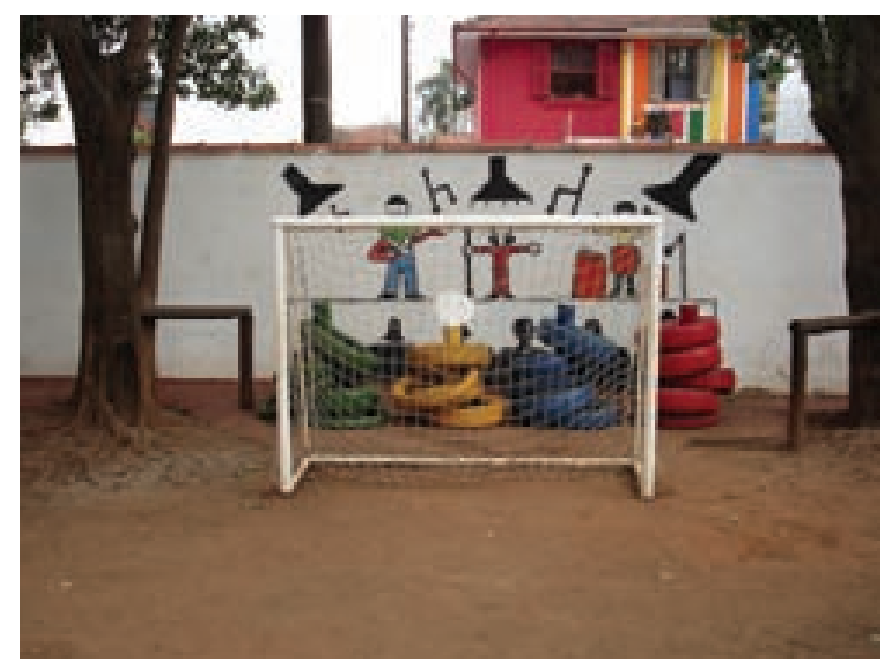

Pneus à disposição das crianças, para que sejam usados e explorados livremente (com o desafio, para as crianças menores em especial, de tirálos e guardá-los por cima do eixo de madeira onde se encontram): aqui também podemos encontrar equipamentos conjugados às árvores. 
dente, trabalhos, ... tudo é projetado com o intuito de possibilitar e incentivar a autonomia e a responsabilidade da criança, sempre sob o olhar atento do professor.

Atendidas as necessidades e as exigências de um espaço escolar, é então necessário criar um ambiente de aprendizagem, o que a Escola Viva procura fazer por meio da integração entre espaço físico e questões funcionais e temporais, e entre estes e os seus usuários.

Analisemos agora como e em que medida este ambiente de aprendizagem torna-se também uma estrutura de oportunidades para o desenvolvimento da criança.

\section{O ambiente escolar como estrutura de oportunidades para o processo de aprendizagem}

Os pontos a seguir, que servirão de linha-guia para a análise de todas as escolas apresentadas neste capítulo, são os mesmos apontados no capítulo anterior, a partir dos quais foram feitas as reflexões sobre o projeto de Hertzberger para uma escola montessoriana e sobre a experiência das escolas municipais de Reggio Emilia. Assim como nestas primeiras, alterações na ordem ou na ênfase dada aos parâmetros de análise podem ocorrer em função das especificidades de cada projeto.

\section{A. Organização espacial e campo visua}

Como já mencionamos, a Escola Viva tem, em seu projeto original, uma proposta de organização espacial a partir de um núcleo central, a "praçona", um espaço coletivo e multifuncional, ao redor do qual localizavam-se todas as salas de aula inicialmente.

Apesar da expansão, que, em função da incorporação de terrenos de forma irregular, fez com que as novas salas de aula acabassem ficando distantes, sem acesso direto à "praçona", o conceito de núcleo central permaneceu, constituindo-se como o principal ponto de referência e espaço coletivo, onde crianças de diferentes idades, professores e funcionários convivem e realizam atividades diversas.
Procurando construir uma espécie de comunidade, como nos colocou a diretora, a escola traz claramente, com a sua configuração em torno de um espaço comum central, uma proposta de reunião, permitinho e estimulando a mistura, integração e convivência, e introduzindo às crianças os conceitos de público e coletivo (ao mesmo tempo que os conceitos de privado e privacidade são dados e garantidos por meio da "demarcação" das áreas e salas específicas de cada turma, onde estas podem desenvolver as atividades que requerem maior concentração, menor espaço, maior controle térmico-acústico, menor número de pessoas, etc.).

A não organização espacial das salas em corredores, e, sim, ao redor de uma área central, resulta também em uma maior liberdade das crianças, uma vez que não há um controle (espacial) rígido do "ir-e-vir" das mesmas (não há um percurso único a ser seguido; pelo contrário, a grande parte dos espaços da escola é permeável, possibilitando facilmente o acesso ou a passagem). Mesmo a saída programada das crianças à "praçona" e a entrada em "sala de aula" não precisam ser encaminhadas e "escoltadas" pelos professores.

Até a implantação de banheiros e pias externas às salas de cada turma, embora próximo às mesmas, constituise como um elemento que propõe a liberdade e exige a responsabilidade da criança em relação às suas ações e comportamentos.

A existência de uma referência espacial forte, portanto, mesmo com o desdobramento da escola em "braços" menos acessíveis (ampliações), constitui-se como um elemento importante para a compreensão do espaço da escola pelas crianças e facilita a noção de localização das mesmas, permitindo, inclusive, como de fato acontece, o desmembramento dos ambientes como sala de "aula", sanitários e ateliês.

Apesar de apresentar um grande e aberto ponto central principal, a escola constitui-se também de uma série de outros espaços menores complementares a esta, os quais, integrando-se ou não a ela, fazem com que o espaço 

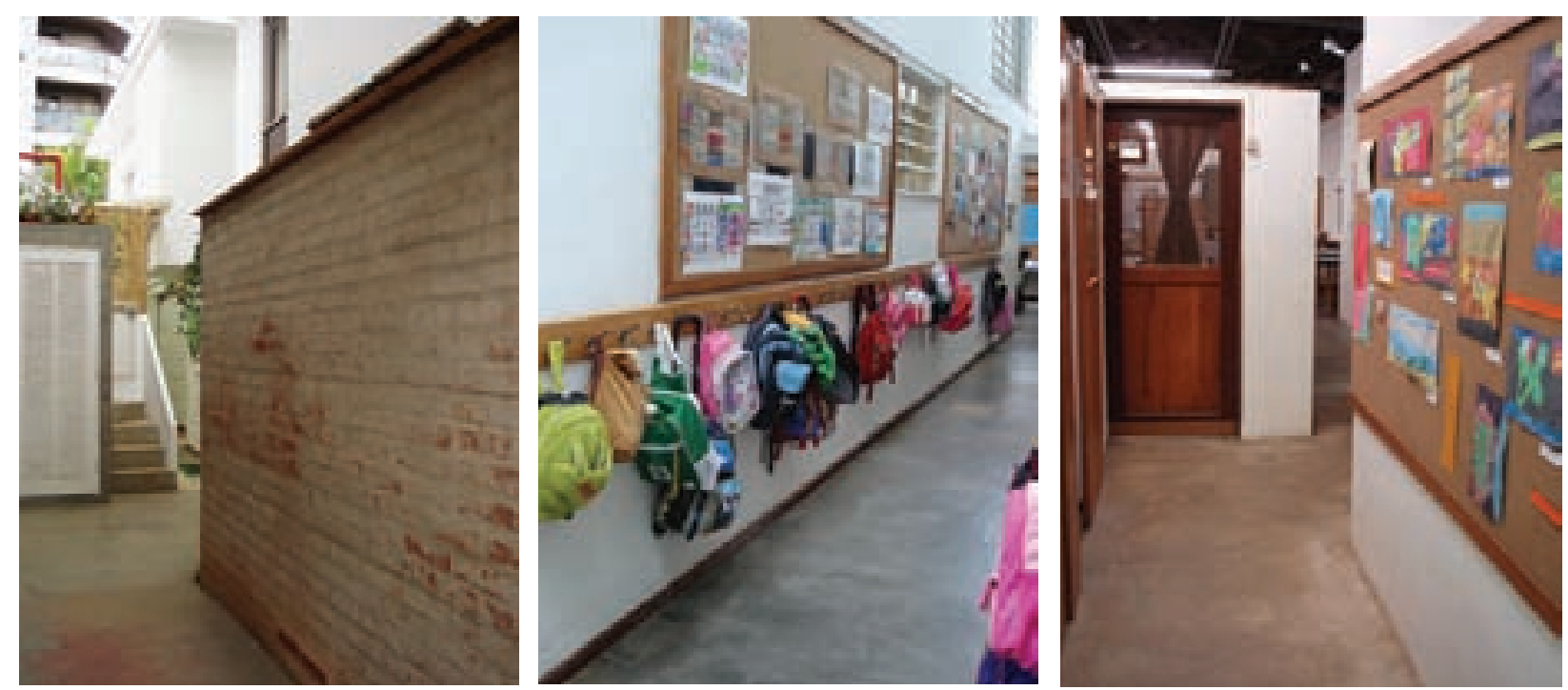

Corredores estreitos, caminhos tortuosos, distanciamento de algumas salas da praça cent tenham que passar pelo refeitório ou áreas administrativas para chegarem às mesmas.

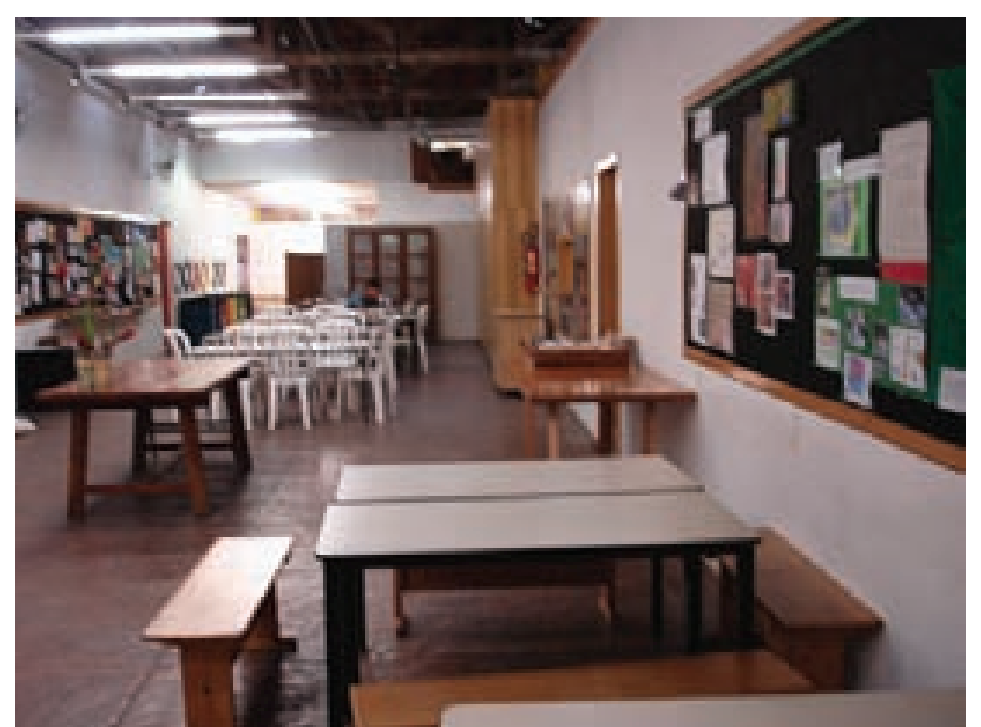

da escola não se esgote em uma única área e em um único ambiente coletivo. Além da própria "praçona" desdobrarse em inúmeros "cantos", alguns "puxadinhos" e "espaços intermediários", criados em função da "não-planificação" de sua expansão, formam, muitas vezes, caminhos tortuosos, estreitos e "labirínticos", que oferecem possibilidades diversas de atividades e proporcionam experiências diferentes, variando em termos de tamanho, formato, cor, textura, intensidade e tipo de luz, materiais, desafios, etc.

Não existem, portanto, um único campo visual e um ponto da escola onde se possa visualizá-la por inteiro. Por um lado, isso pode prejudicar a fluidez e o senso de localização da criança - e conseqüentemente o domínio do espaço por ela -, e pode provocar o isolamento de algumas turmas da dinâmica da escola, prejudicando o sentimento de pertencimento ao grupo. Por outro, essa complexidade do espaço (não somente por seus caminhos tortuosos, mas pela distribuição espaçada e não delimitada dos equipamentos externos e internos e das salas de atividades) pode ser um rico elemento para que ele não se torne monótono. Como vimos no capítulo 2, quanto maior o número de mudanças de direção no campo visual, maior a quantidade de informação significativa disponível, e, quando a mudança de direção é inclusive um ponto de escolha, ainda maior é o significado da informação (Rapoport and Hawkes 1970, p.7)

A variedade de elementos que apresenta e a disposição destes no terreno acabam criando inúmeros "cantos" e "ambientes" que fazem com que a criança, ao longo do tempo que freqüenta a escola, tenha muitas coisas a descobrir. O fato de o espaço não ser facilmente decifrável e percebido e/ou compreendido pode constituir um rico estímulo à descoberta. O que não impede que sua leitura seja feita pelas crianças e por seus usuários em geral, pois, apesar de não seguir uma estrutura ortogonal ou cartesiana, apresenta uma lógica de organização, e possui pontos, espaços e ambientes de referência, assim como áreas de campo visual aberto, que permitem uma visualização mais 

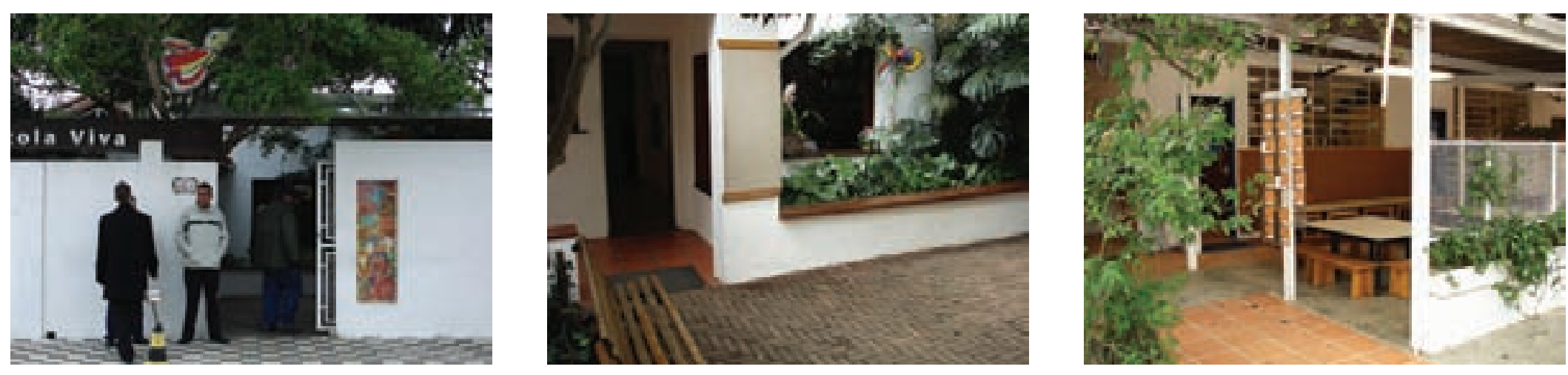

Depois da entrada estreita da escola abre-se uma pracinha convidativa.

Transição da área coberta (esquerda, "terraço") para área descoberta.

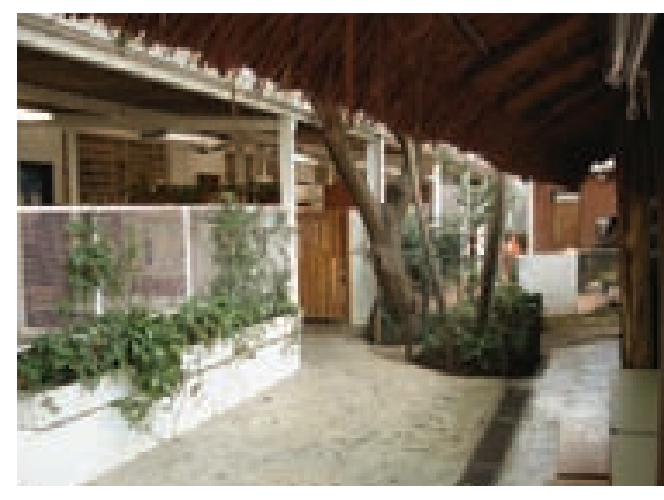

Transição de campo mais coberto e escuro para área descoberta e clara.

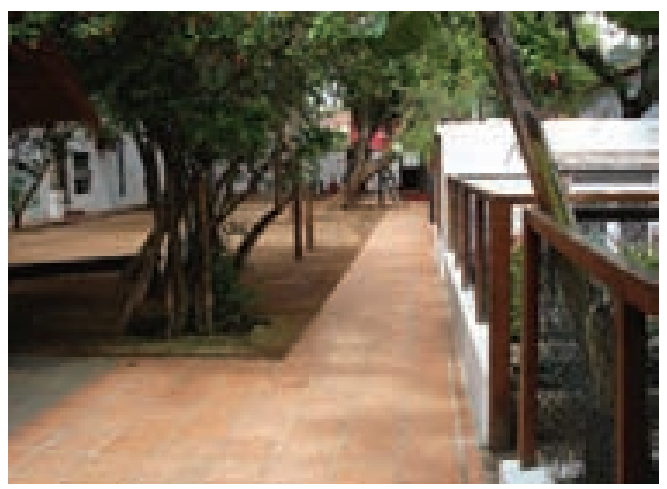

Saindo de uma das áreas de salas, dá-se com a abertura gradual da praça.

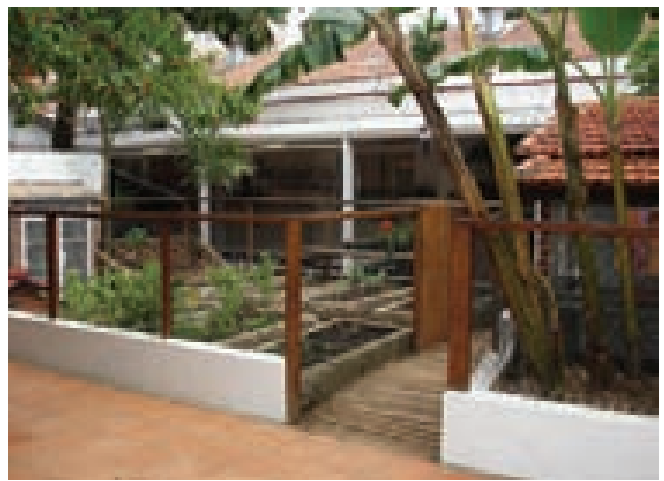

Entrada estreita a partir da amplidão do espaço da praça.

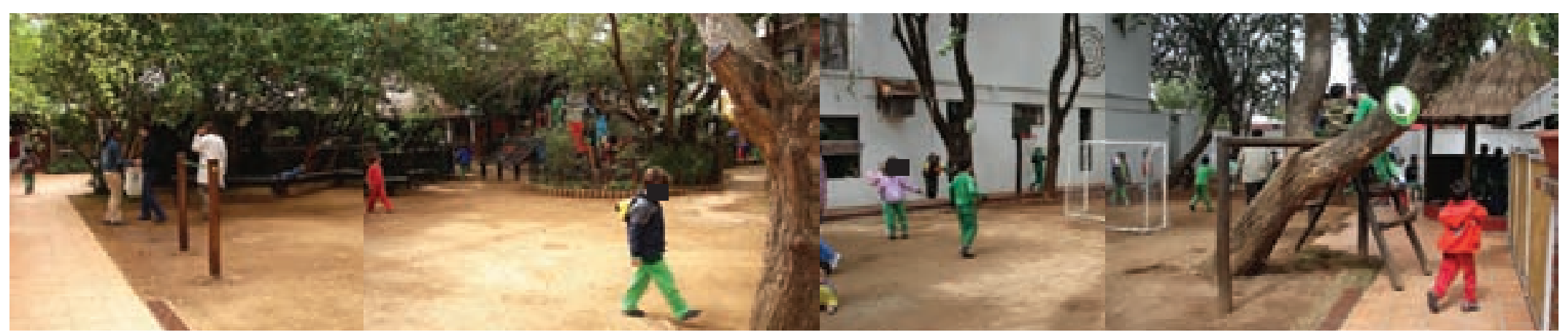

Visão geral da praça a partir de uma das salas da turma laranja - principal referência espacial da escola. 


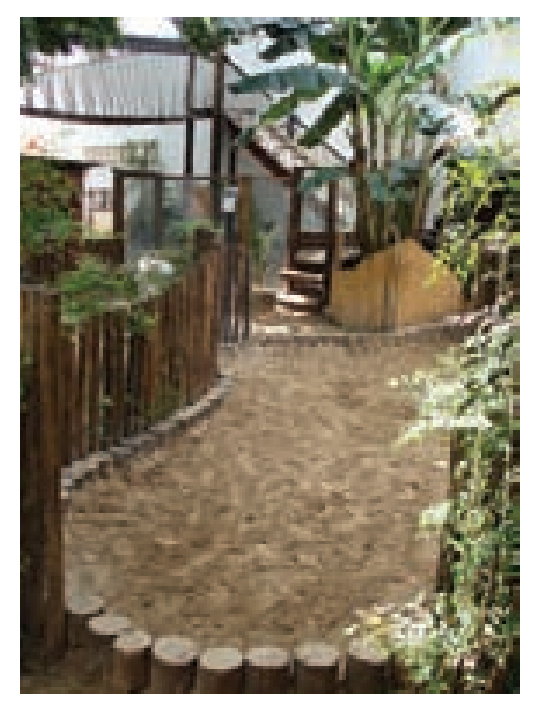

"Cantos" com acesso mais estreito.

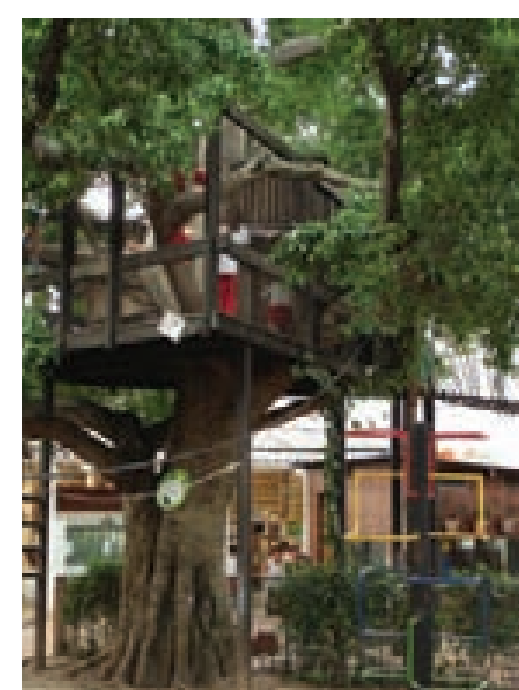

Casa da árvore: um ângulo de visão diferente da escola.

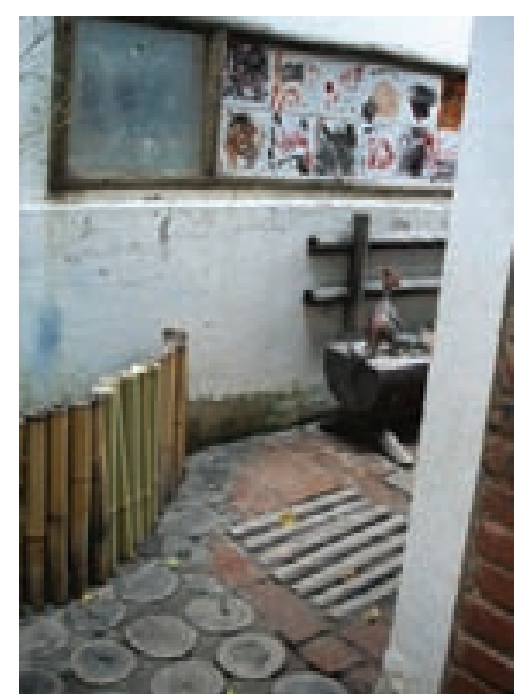

Cantinhos "escondidos" da escola.

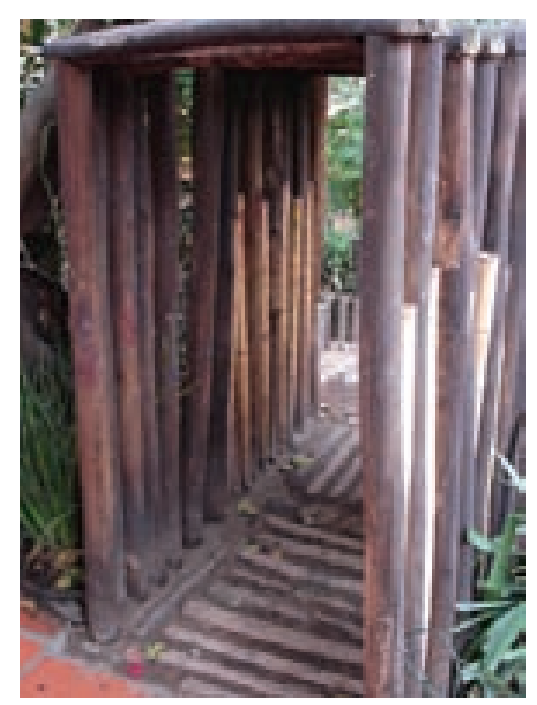

Passagem mais estreita em meio à área externa descoberta.

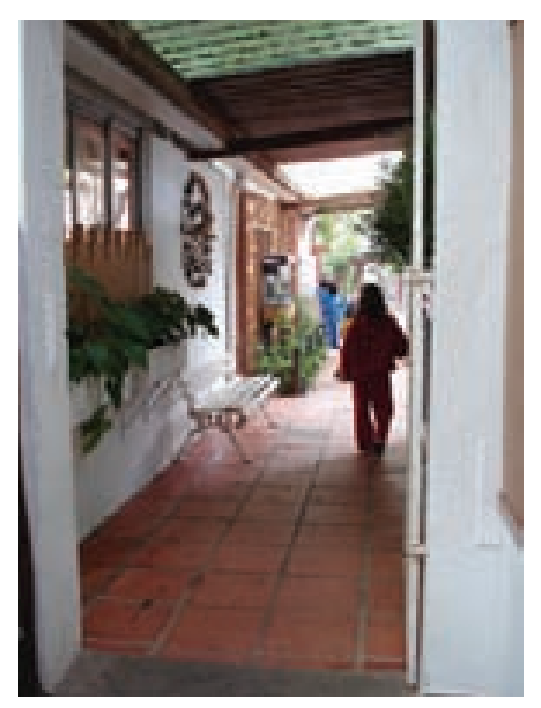

Passagem mais estreita (do galpão para a área externa, descoberta).

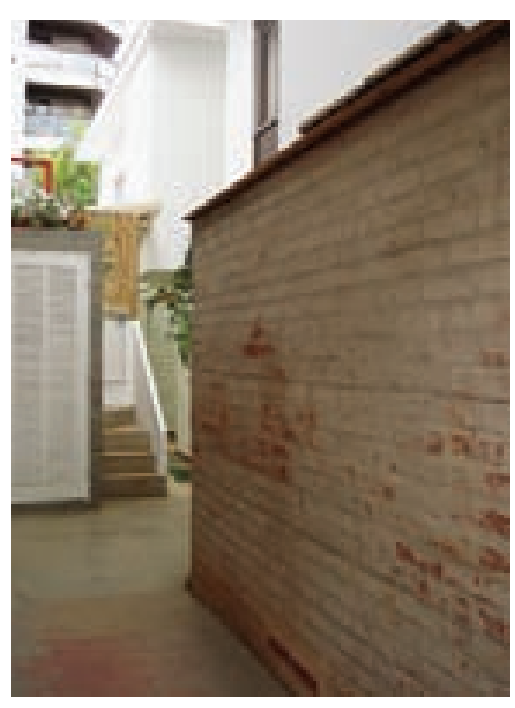

Passagem estreita que dá acesso à diretoria e a uma das salas das crianças. ampla e geral do conjunto, e garantem o reconhecimento e a noção de localização.

A alternância entre espaços abertos e fechados - e, conseqüentemente, campos visuais abertos e fechados - cria, assim, uma complexidade que enriquece a experiência daqueles que utilizam a escola, principalmente de forma cotidiana, pois propricia a criação, alternância e "violação" (termo utilizado por Rapoport, no livro Aspectos humanos de la forma urbana, 1978) de expectativas e a mudança e diferenciação de estímulos (variações dentro de uma ordem)

A organização espacial e o campo visual, portanto, são dois elementos que influem fortemente no ambiente escolar e nas relações ali estabelecidas, uma vez que sugerem relações de integração ou separação, conceitos de público e privado, noções de espaço, conjunto, localização, direção, sentido, e contribuem para a criação de um ambiente rico em experiências e surpresas, ou monótono e sem estímulos a descobertas.

\section{B. Clima e recursos do ambiente, arquitetura, materiais,} equipamentos e brinquedos

Localizada em uma região de clima tropical, quente durante quase todo o ano (temperaturas baixas amenas, não exigindo ambientes fechados e aquecimento interno), a Escola Viva tem grande parte dos seus espaços coletivos abertos e descobertos, procurando promover uma forte interação entre as crianças e a natureza, além de fornecer grandes espaços para que as crianças possam se movimentar com liberdade e amplidão (em dias de chuva, porém, os espaços coletivos acabam ficando restritos aos "terraços" das salas e aos poucos espaços coletivos internos)

Com seu ambiente externo formado principalmente por uma praça central, a "praçona", a escola é construída a partir das relações estabelecidas entre esta e os diversos "cantos" e ambientes que se encontram em sua área ou em sua volta, como o quiosque, a casa da árvore, a horta, o espaço dos coelhos e das tartarugas, o cantinho 
do banco curvo, o escorregador e o tanque de areia, e vários outros (além das salas diversas).

É interessante notar que esses espaços não chegam a ser delimitados ou demarcados claramente, não constituindo áreas específicas para cada tipo ou modalidade de atividade ("o parquinho" ou "o campo de futebol" ou "a área de contrução", etc.). Há, na verdade, uma integração entre esses elementos de maneira que todos formam um todo único, porém diversificado, e é este um dos motivos que faz com que este ambiente seja um dos grandes espaços de exploração das crianças.

Desafios motores, por exemplo, encontram-se espaIhados por toda a escola - nos diferentes pisos, nas árvores e vegetação integradas aos ambientes, nos elementos que possibilitam a transposição das cercas que definem as salas de cada turma, nos brinquedos e equipamentos, nos bancos que transformam-se em "pontes", "barreiras" ou "caminhos no ar", e em inúmeros outros elementos.

Além dos desafios motores, estes espaços oferecem também inúmeras oportunidades para explorações sensoriais. Vários são os elementos que estimulam os sentidos e a percepção da criança: espelhos escondidos em meio à vegetação; passagens mais estreitas; pequenas superfícies em vidro que permitem a transparência e, portanto, a visualização de outros ambientes e atividades, abrindo novas perspectivas e pontos de vista para a compreensão do espaço e da dinâmica da escola; elementos vazados de diferentes formas que exploram também a visibilidade/não visibilidade, acesso/restrição, contato/separação (estimulando brincadeiras de "esconde-esconde", "pegasurpresa", etc.); diferentes acabamentos, fechamentos e coberturas, explorando as nuanças de luz/sombra, transparência e opacidade, entre outras coisas.
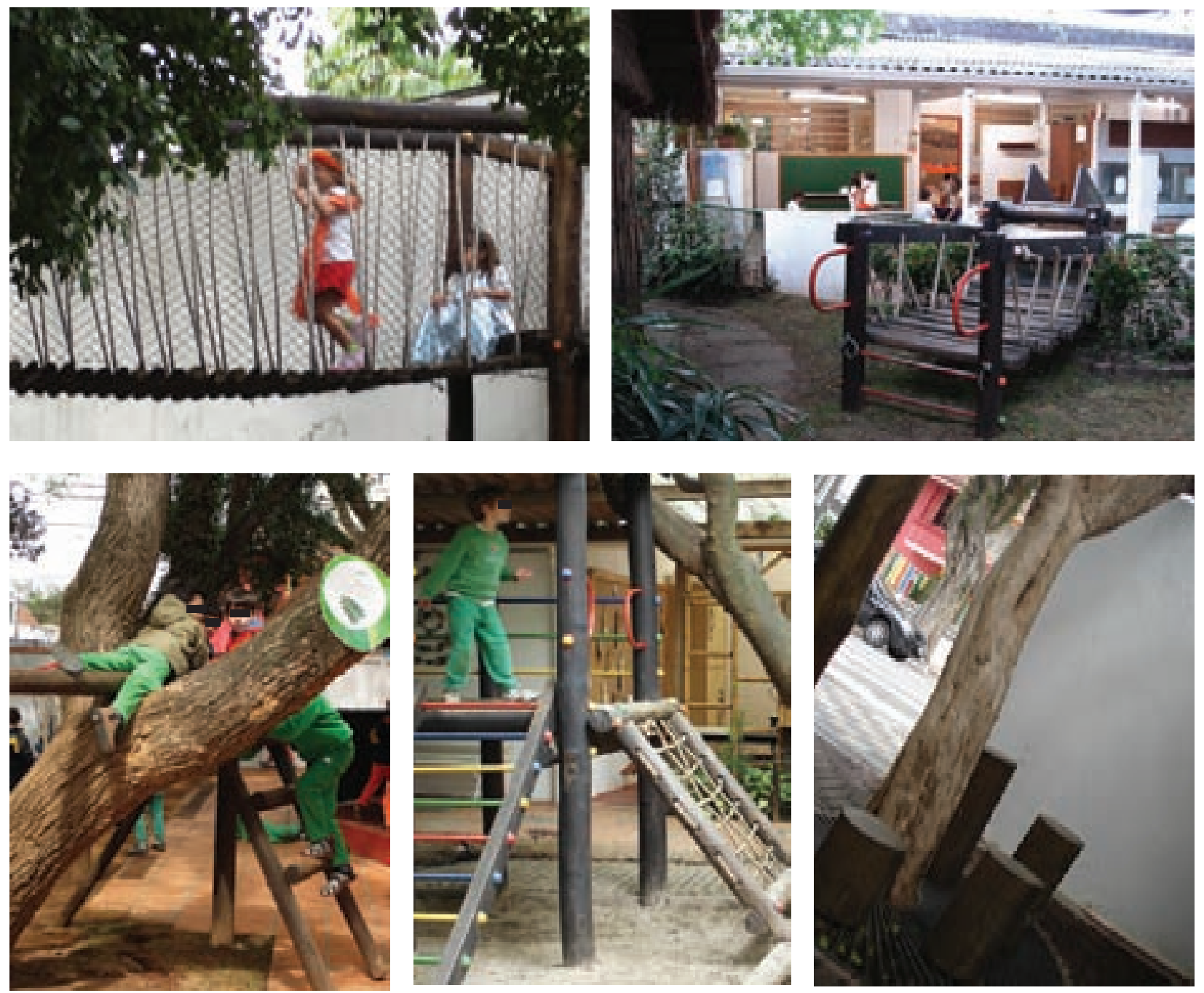

Desafios motores encontram-se em todos os lugares; não há "o parque" ou "a área de equipamentos". 


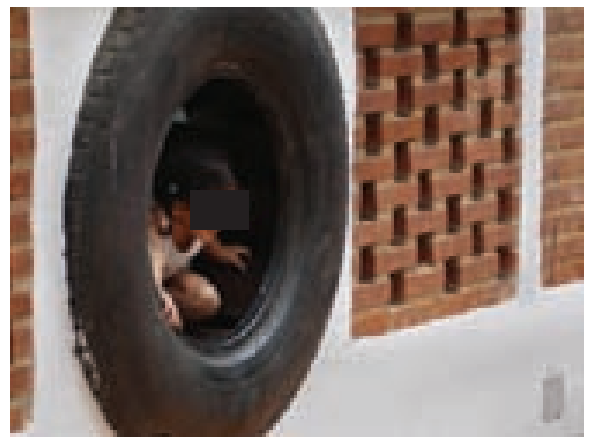

"Túnel" de pneu, um dos "canais de comunicação" entre terraço e "praçona".

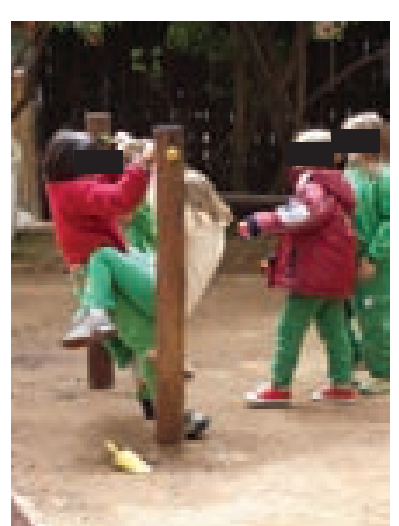

"Barra", apropriada pelas criança das mais diversas formas.

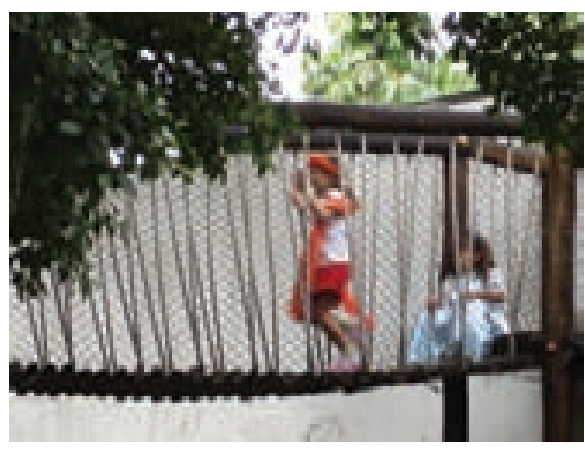

Ponte de acesso à casa da árvore, com piso e balanço que criam um desafio ao equilíbrio.

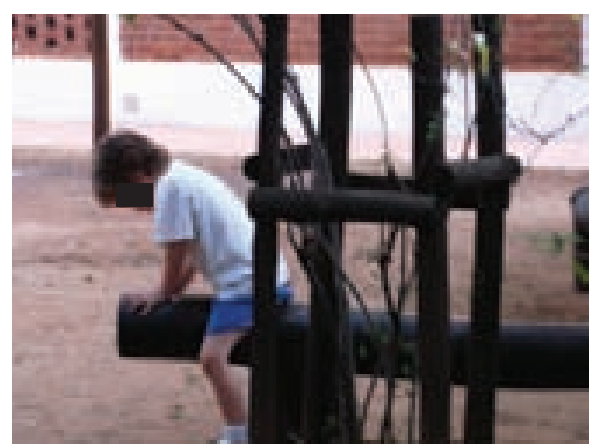

Banco, que se transforma em obstáculo, ponte...

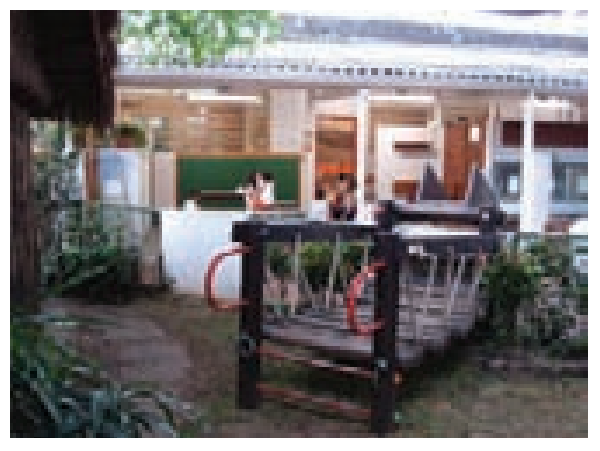

Ponte-escorregador (acesso mais difícil à área de uma das turmas do laranja).

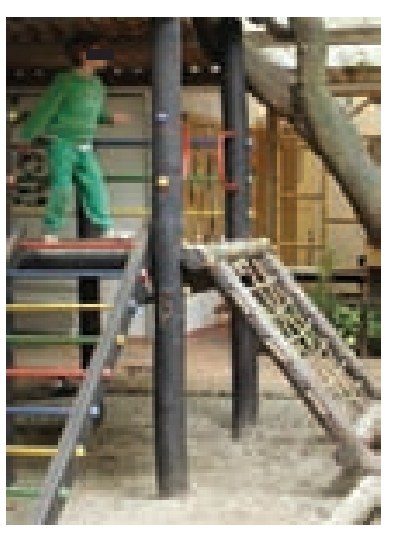

A casa "suspensa" e os desafios Tocos de madeira: um "convite" para chegar lá em cima.

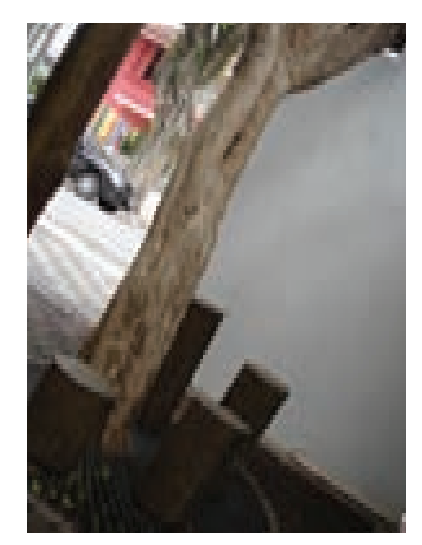

à copa da árvore.

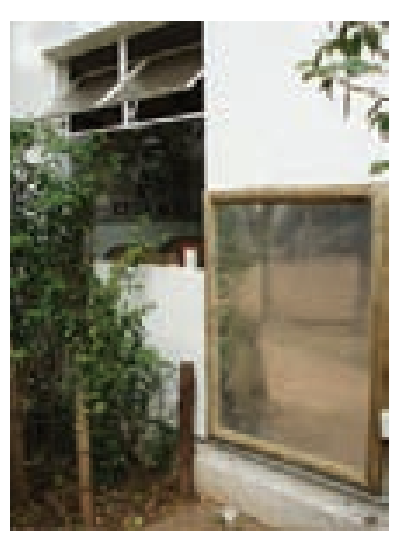

Espelho "escondido" em meio à vegetação.

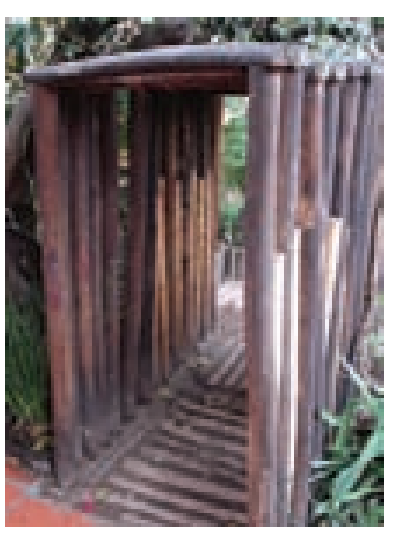

"Túnel-passagem".

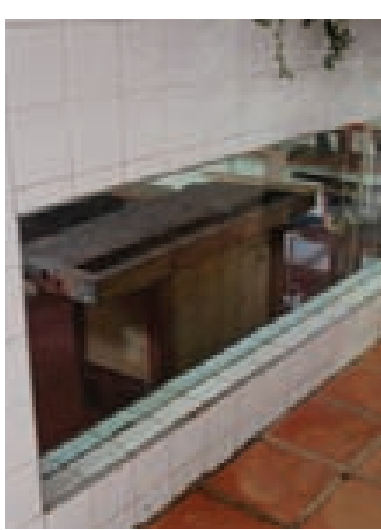

Abertura para visualização do interior do ateliê de maquetes (vista por baixo) 
Percebe-se, então, que em todo o ambiente da escola (principalmente nos espaços coletivos) existem equipamentos, objetos ou elementos que "convidam" as crianças a se apropriarem ou interagirem com os mesmos. Como observado acima, todo o espaço é articulado por barreiras/ fronteiras, ligações/conexões, e desafios que podem e devem ser "ultrapassados" e "vencidos". Não havendo delimitação ou demarcação de cada área de atividade específica, a criança se depara com elementos diferentes por cada local que ela passa, o que proporciona um dinamismo e dificulta o estabelecimento de uma relação automática e programada da criança com o ambiente escolar.

Ainda, com a mescla de equipamentos de finalidade "predefinidas" (escorregador, trepa-trepa, etc.) e de elementos cujos uso e função não são muito bem definidos ou abrem mais de uma possibilidade de leitura, permite-se e se estimula a interpretação e apropriação pessoal de cada criança e do grupo, que pode recriar - e o faz - e reinventar cada uma das situações e propostas ali colocadas.
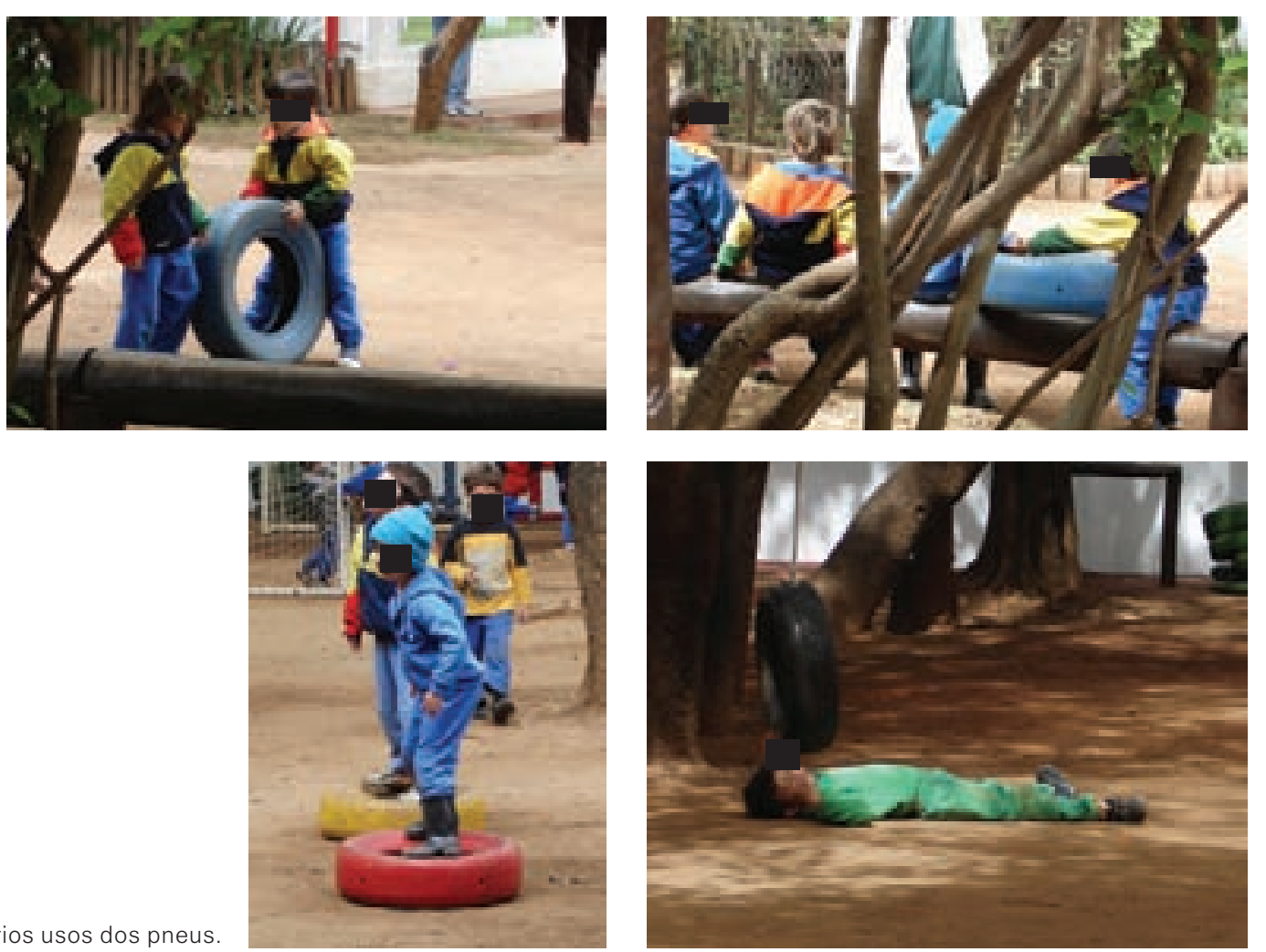

Os vários usos dos pneus.

Os equipamentos e as árvores se misturam e se transformam.
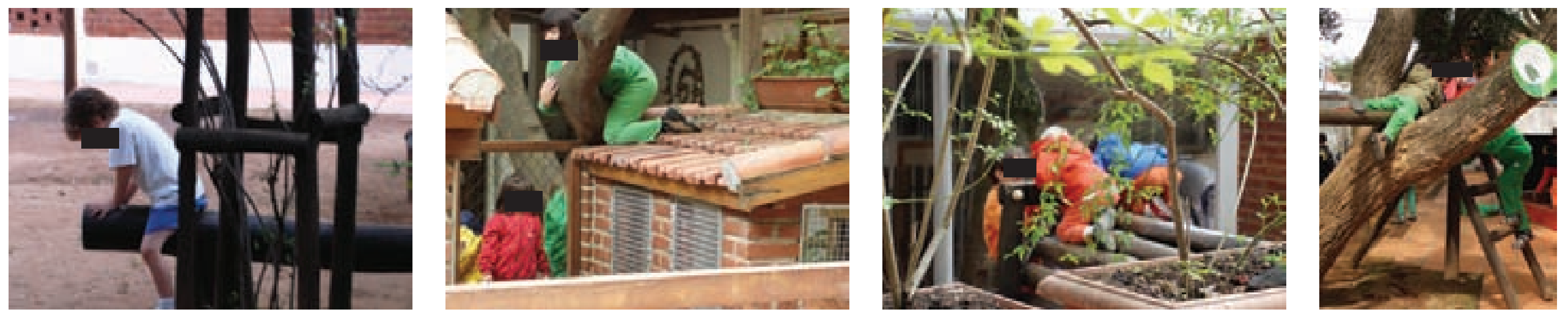

AMBIENTE ESCOLAR INFANTIL CAP 4 PROJETOS NO BRASIL 

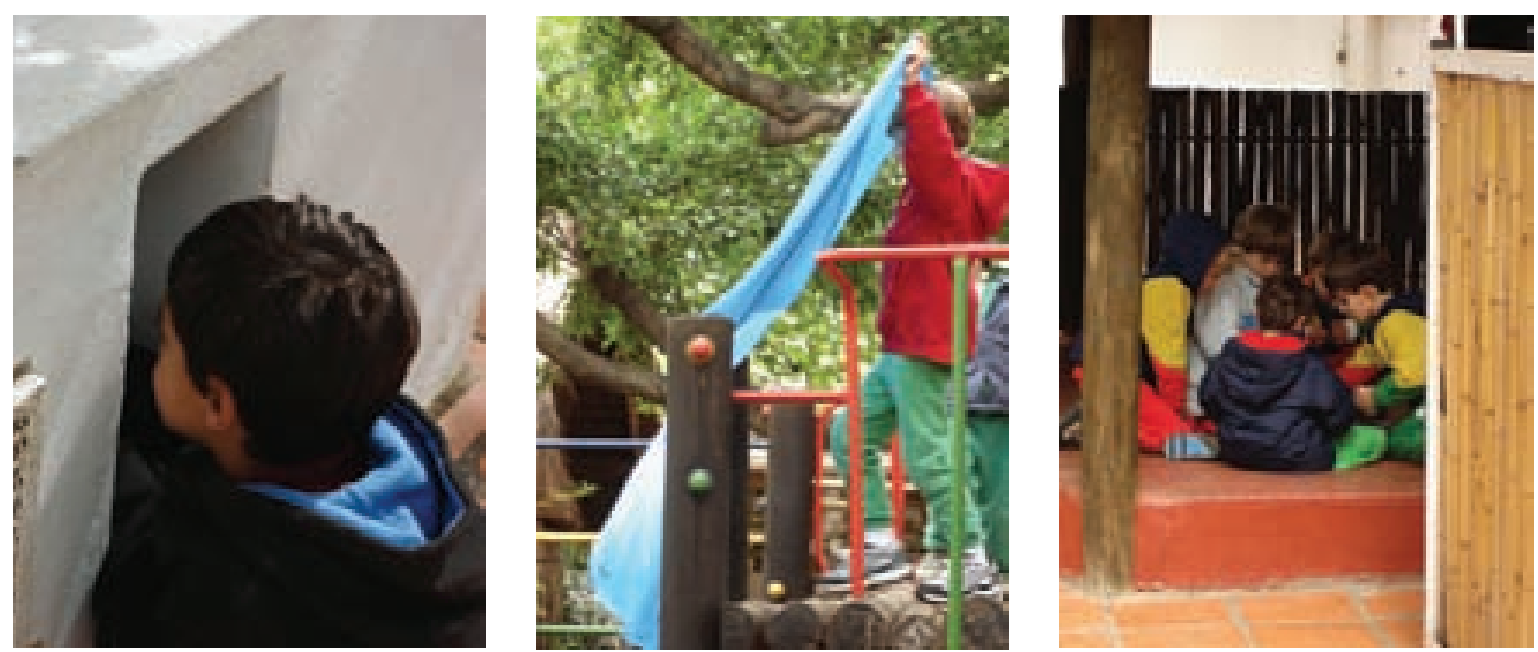

Conseqüentemente, a presença das crianças pode ser notada em toda a escola - não somente dentro de cada sala de aula, mas em todos os espaços, abertos e fechados, inclusive dentro das salas de professores e do pessoal administrativo - o que representa uma grande valorização das crianças e de seus trabalhos, fortalecendo a identidade e auto-estima de cada uma.

Aqui, de forma semelhante (porém diferente) a das escolas de Reggio Emilia, a arquitetura, com seus elementos fixos, procura ser relativamente neutra, a fim de ser "coberta" por uma segunda "pele", construída e reconstruída pelas crianças e pelos professores.

A interferência das crianças ganha, então, espaço e pode ser vista de várias maneiras: na apropriação, recriação, "re-funcionalização" e re-significação dos equipamentos, brinquedos e objetos existentes; na exposição de seus trabalhos, de naturezas e escalas diferentes, em espaços diversos; no desenvolvimento de trabalhos que são inseridos e integrados aos ambientes; e no desenvolvimento de projetos específicos para determinados espaços e ambientes da escola, sendo, inclusive, muitas vezes incorporados na arquitetura e construção do edifício (como "cortinas", pisos, azulejos, etc.). Os trabalhos produzidos pelas crianças, portanto, estão não só expostos em murais, mas também em meio aos equipamentos e à vegetação, a fim de que sejam não apenas contemplados, mas manipulados e apropriados por elas mesmas e todos os usuários da escola. 


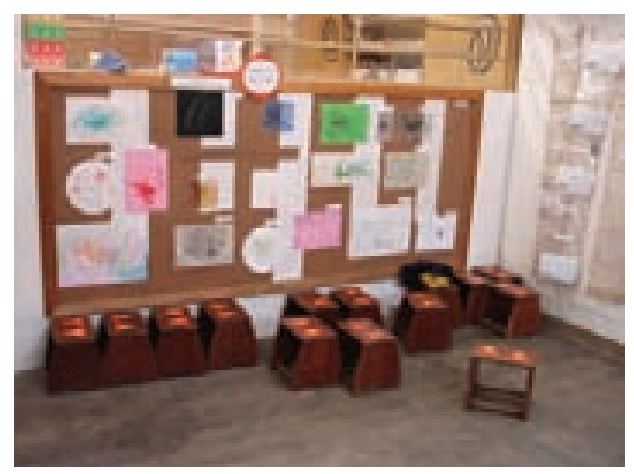

Trabalhos das crianças expostos nas salas (altura

acessível à manipulação e aos olhos de todas).
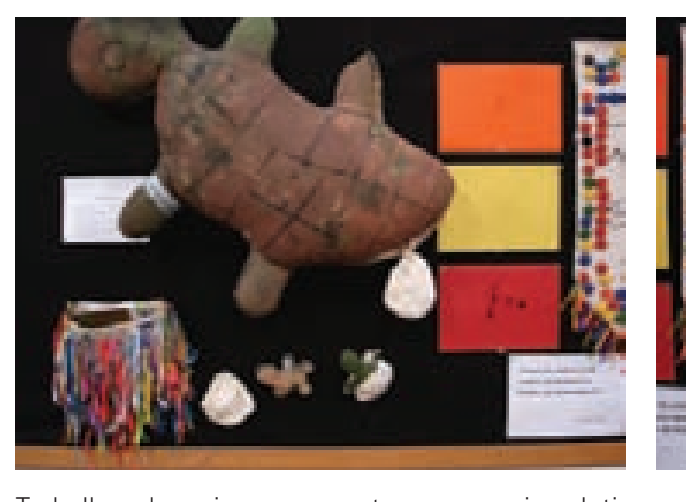

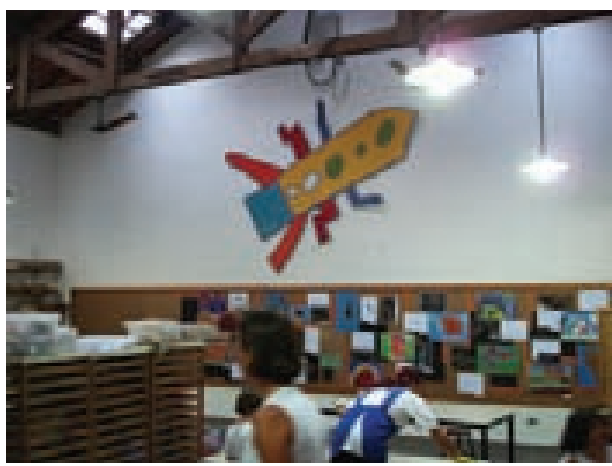

Trabalhos das crianças expostos nas salas - escalas diferentes de inserção no espaço da escola.

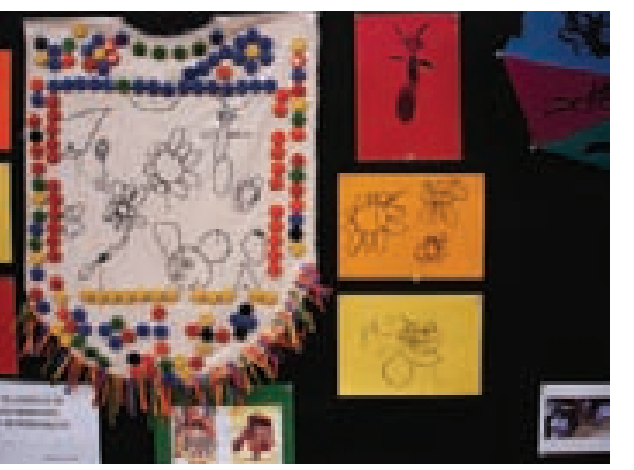

Trabalhos das crianças expostos em murais coletivos.

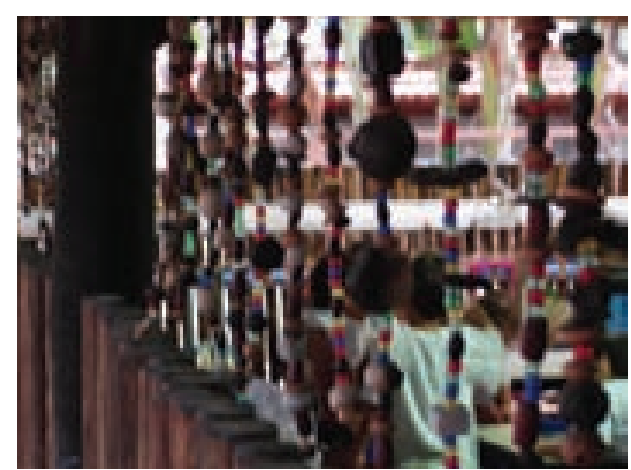

Trabalhos das crianças como elementos de decoração e definição de ambientes.

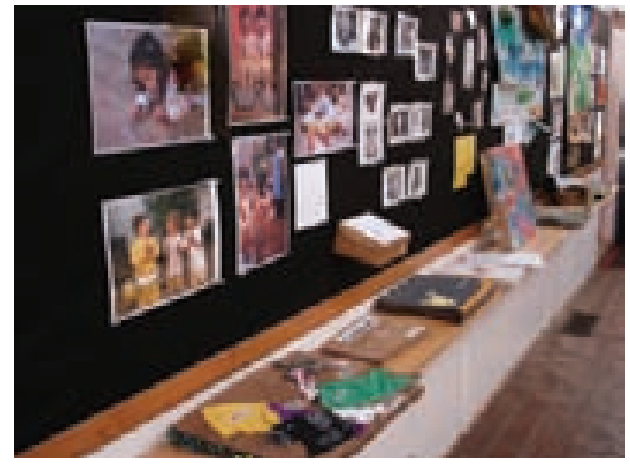

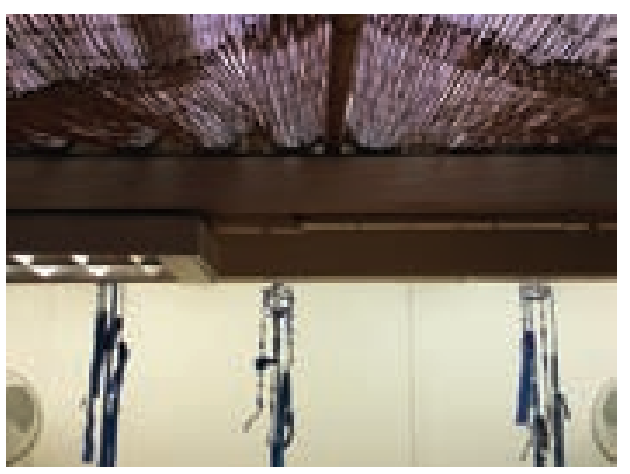

Trabalhos das da decoração e ambientação; integração com mbiente: escala, ponto de vista fixação, etc.

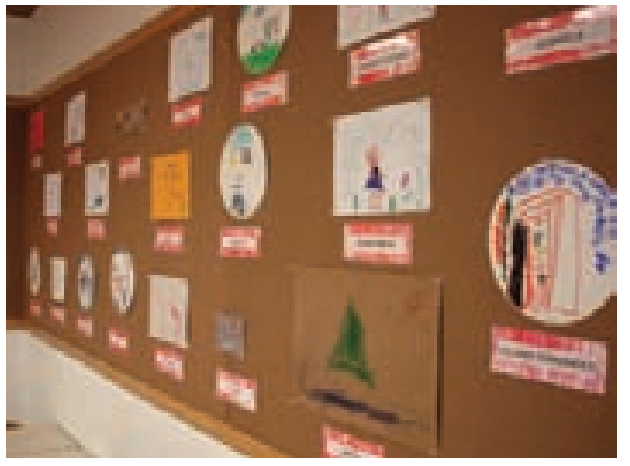

Trabalhos das crianças expostos nas salas. 

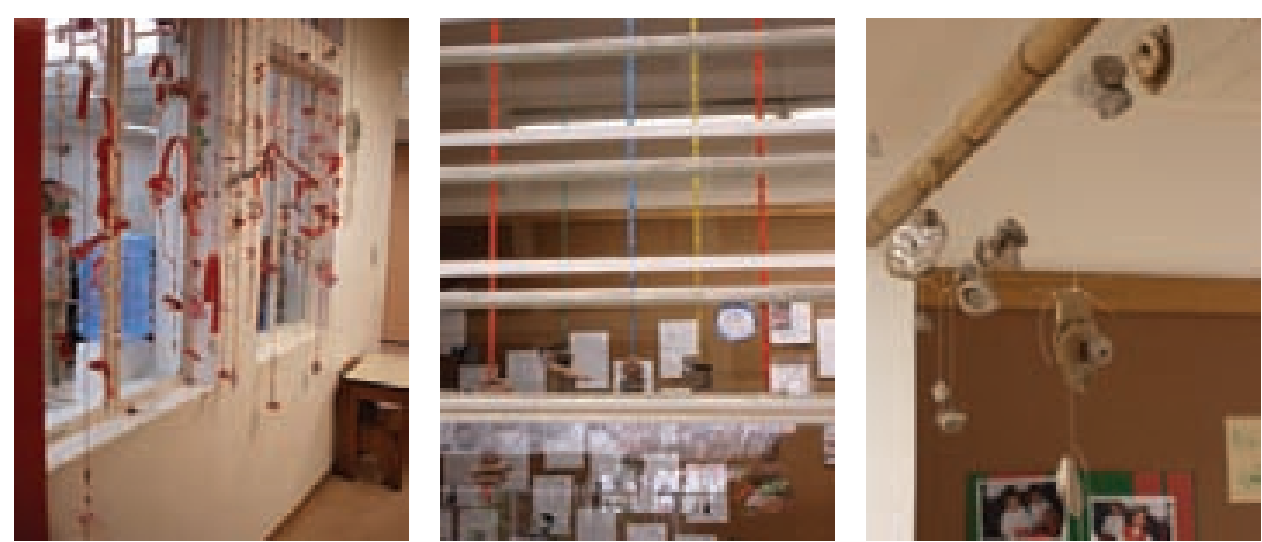

Trabalhos das crianças como ambientação da escola e elemento de manipulação nas diferentes salas.
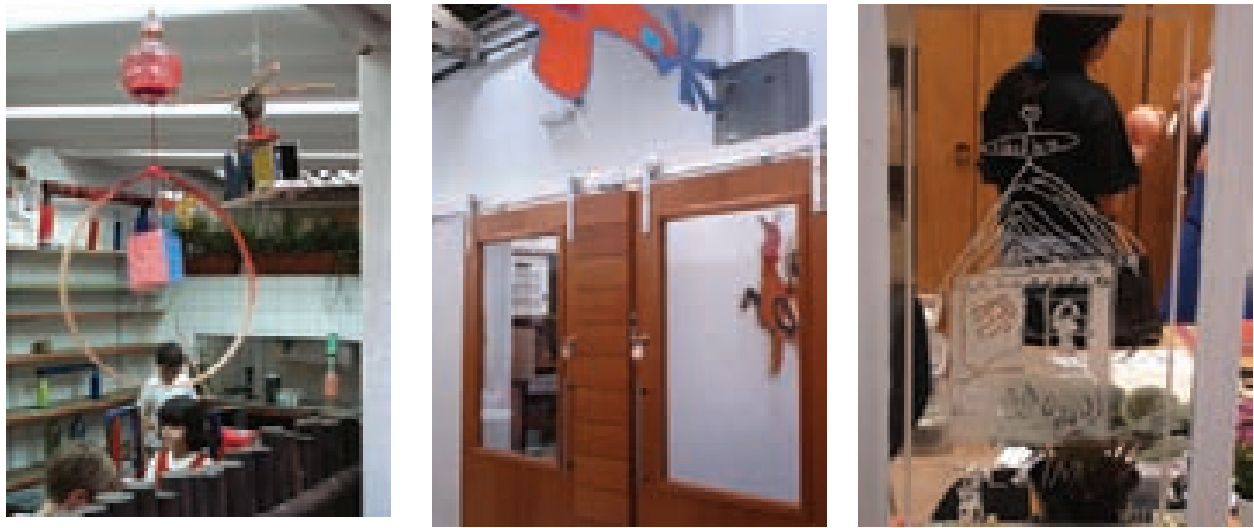

Trabalhos das crianças expostos por toda a escola - inclusive áreas administrativas e de professores.
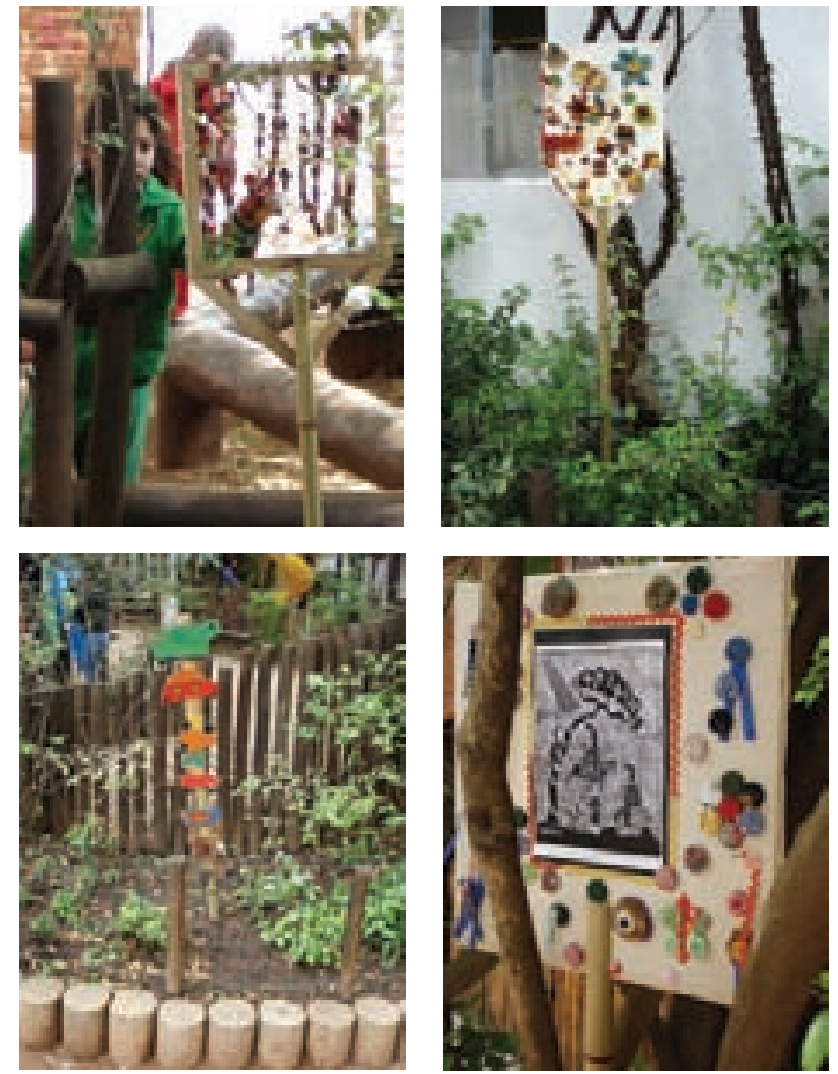

Trabalhos das crianças integrados ao ambiente da escola. 

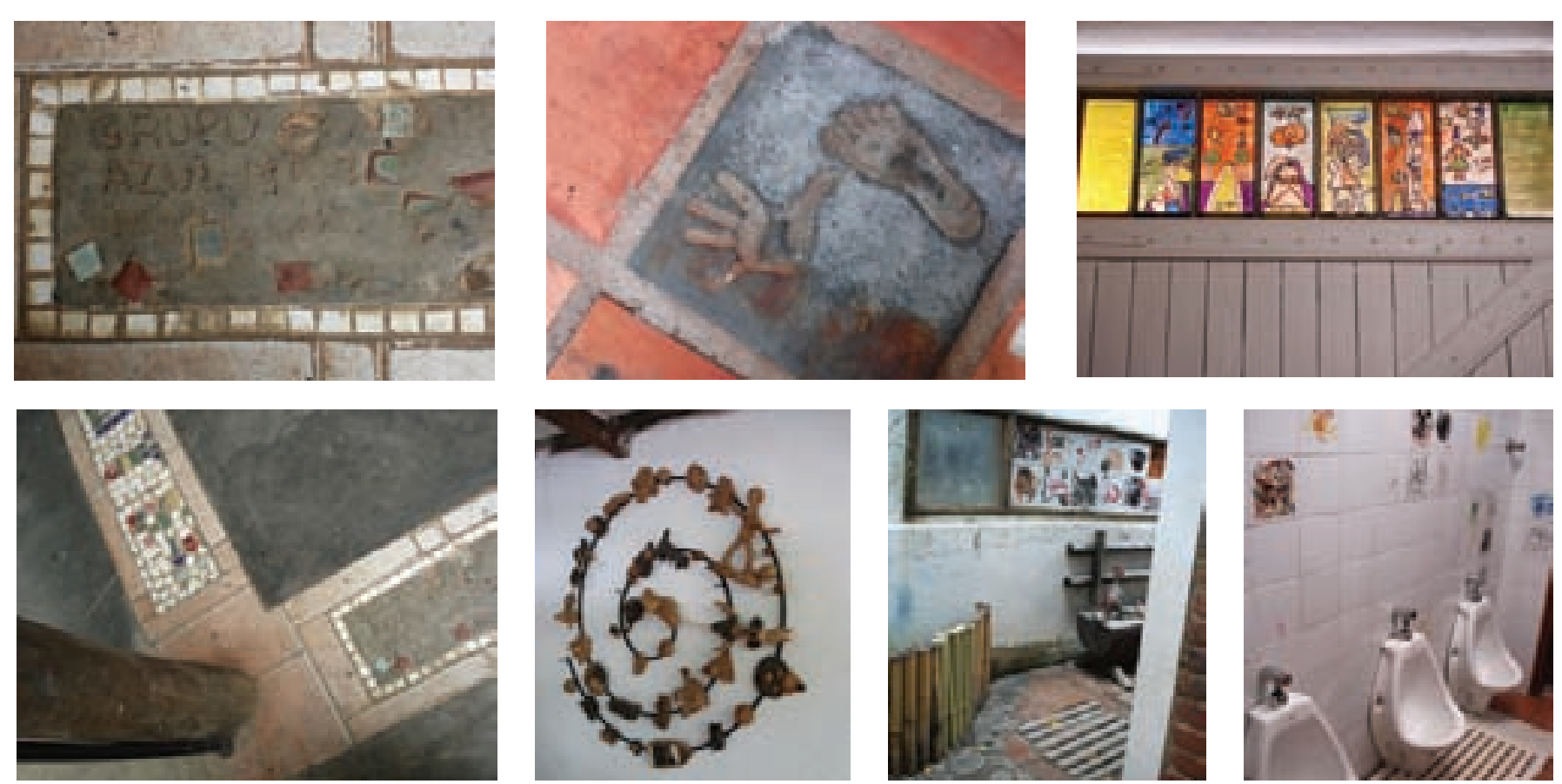

Trabalhos das crianças integrados ao ambiente da escola.

Até mesmo a natureza - a vegetação de forma geral passa a ser apropriada como equipamento pelas crianças. Quase sempre integrada aos brinquedos, mobiliários, equipamentos ou mesmo cercados e muros, cria situações "híbridas" e de inter-relação entre artificial e natural, construído e existente, que enriquecem as possibilidades de interação e interpretação pelos pequenos. Algumas vezes, tocos de madeira de alturas diferentes são colocados próximos às árvores a fim de facilitar e mesmo estimular a subida das crianças; outras vezes, equipamentos de madeira são conjugados aos troncos das árvores, complementando e diversificando os desafios motores apresentados pelos primeiros, além de possibilitar novos desafios e pontos de vista do espaço da escola. Em outras situações ainda, a vegetação chega quase a constituir "instrumento de transgressão" dos limites dos espaços (como, por exemplo, as 
Equipamento-natureza: a natureza como "trampolim" para a transposição dos limites e cercados construídos:

A natureza como integração de espaços e equipamentos.
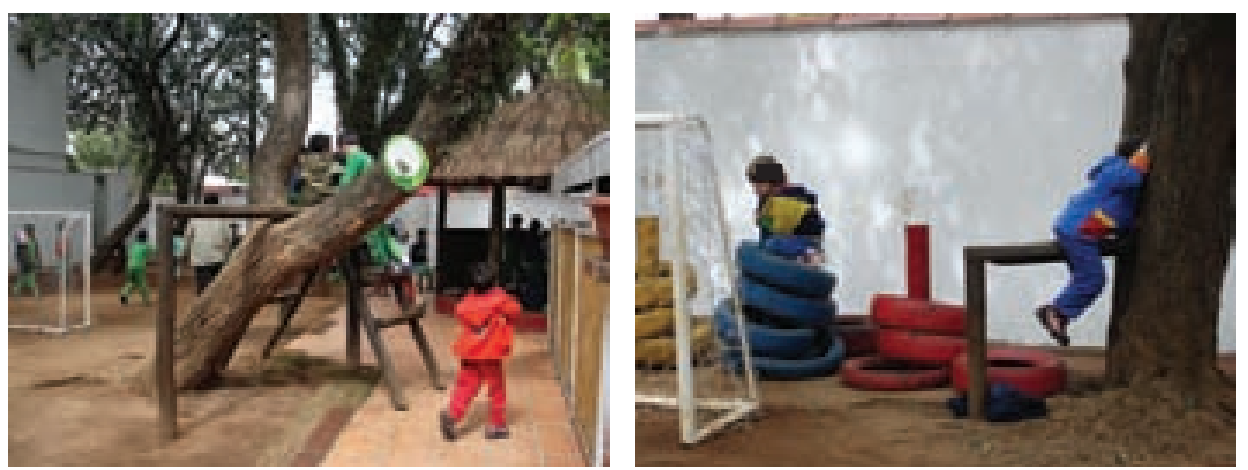

Integração equipamento-natureza: novos desafios Integração equipamento-natureza, artificial-natural. e pontos de vista do espaço da escola.

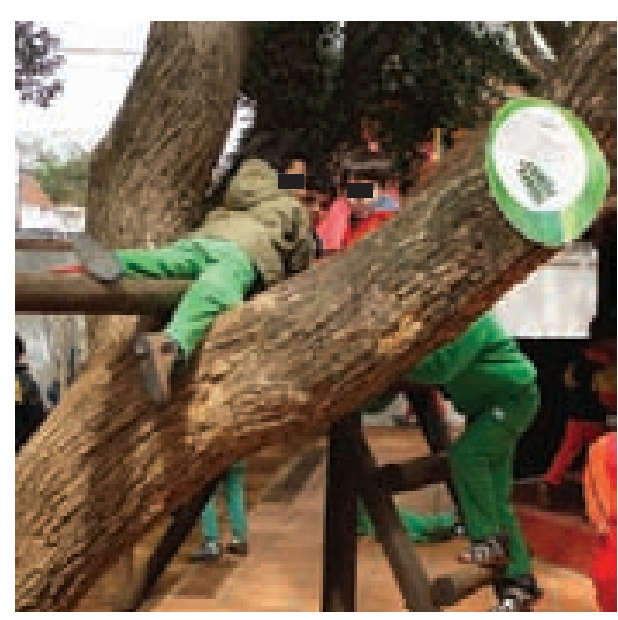

Equipamento-natureza e os novos desafios e possibilidades.

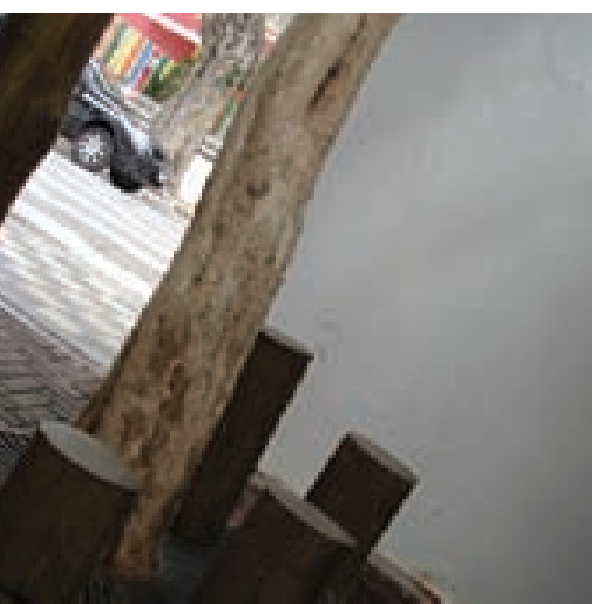

Tocos de madeira: um "convite" à copa da árvore.
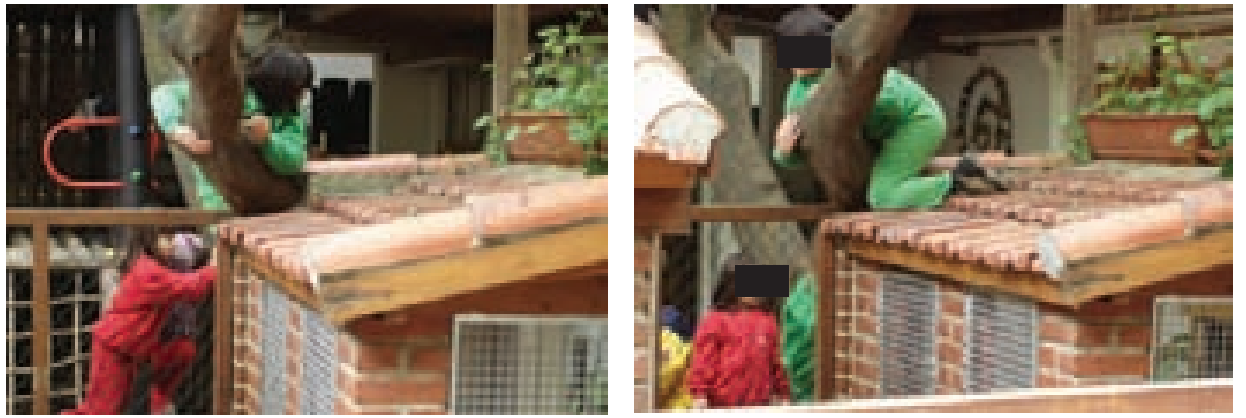
árvores próximas aos cercados das hortas e dos animais que, ao encontrarem-se encostadas nesses cercados, passam a ser "trampolins" para a transposição destes últimos pelas crianças).

Além de "equipamentos", as plantas e árvores em geral também são utilizadas para a criação de diferentes ambientes, por meio da exploração de aspectos como escalas, aberturas/fechamentos, luminosidade/ sombreamento diversos, que definem nichos ou áreas com maior ou menor privacidade, maior ou menor permeabilidade. Ainda, seus frutos, folhas e flores transformam-se em materiais para atividades diversas, desde colagens até a produção de geléias (algumas vezes, porém, feitas apenas pelas professoras)

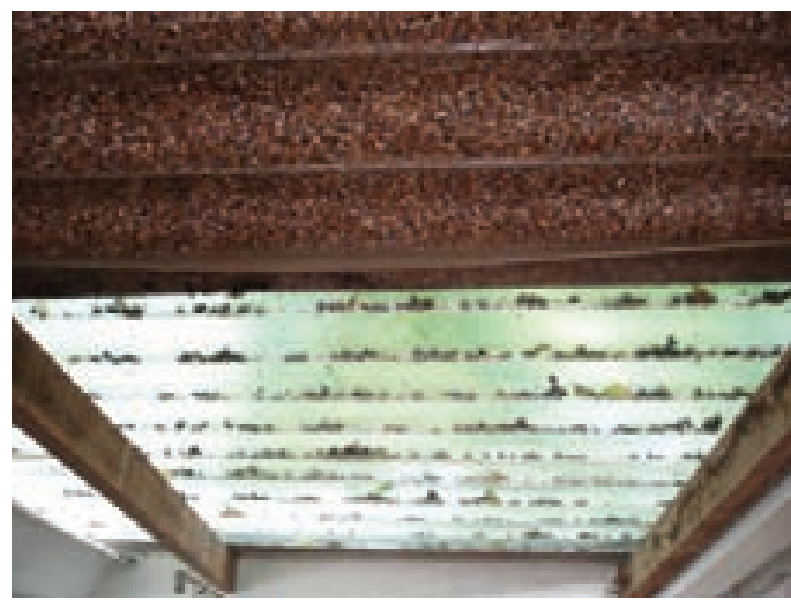

Composição de cobertura opaca e translúcida - mudança de luminosidade e visibilidade; combinação e jogo compositivo entre materiais naturais e industrializados.

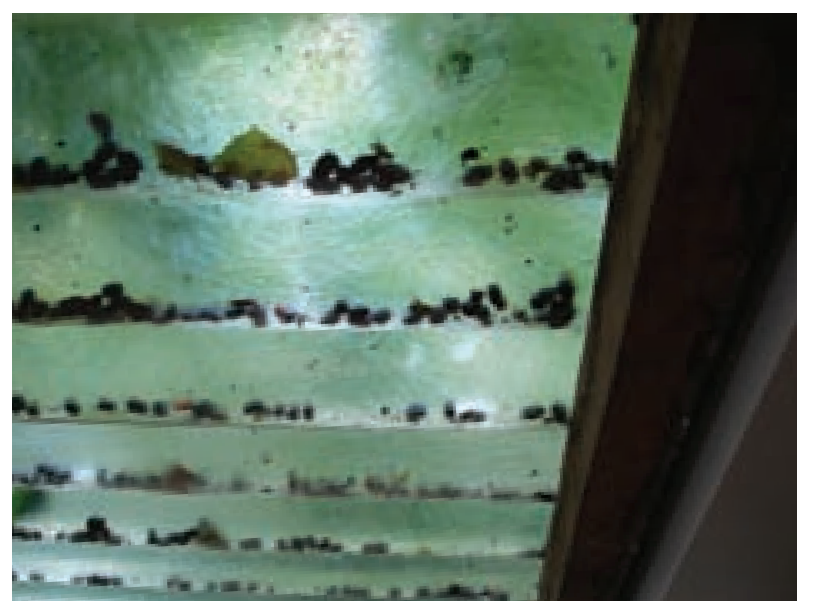

Composição criada pelo acaso: sementes e folhas caídas sobre cobertura ondulada e translúcida: jogo de luz/ sombra, textura, composição
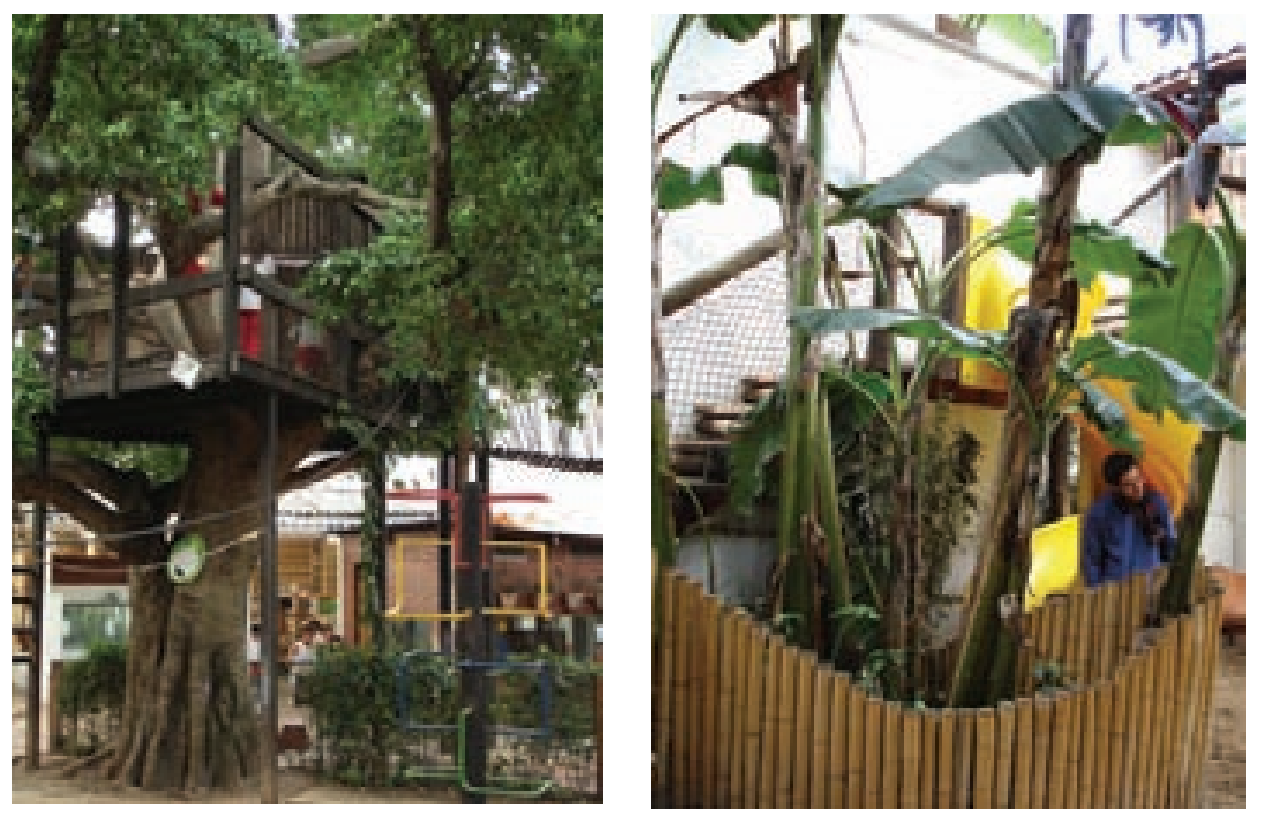

Casa da árvore e "nicho" criado entre tanque de areia e acesso à casa da árvore e casa "da fantasia". 
A integração entre natural e artificial, artesanal e industrial, e os seus diferentes materiais e texturas.
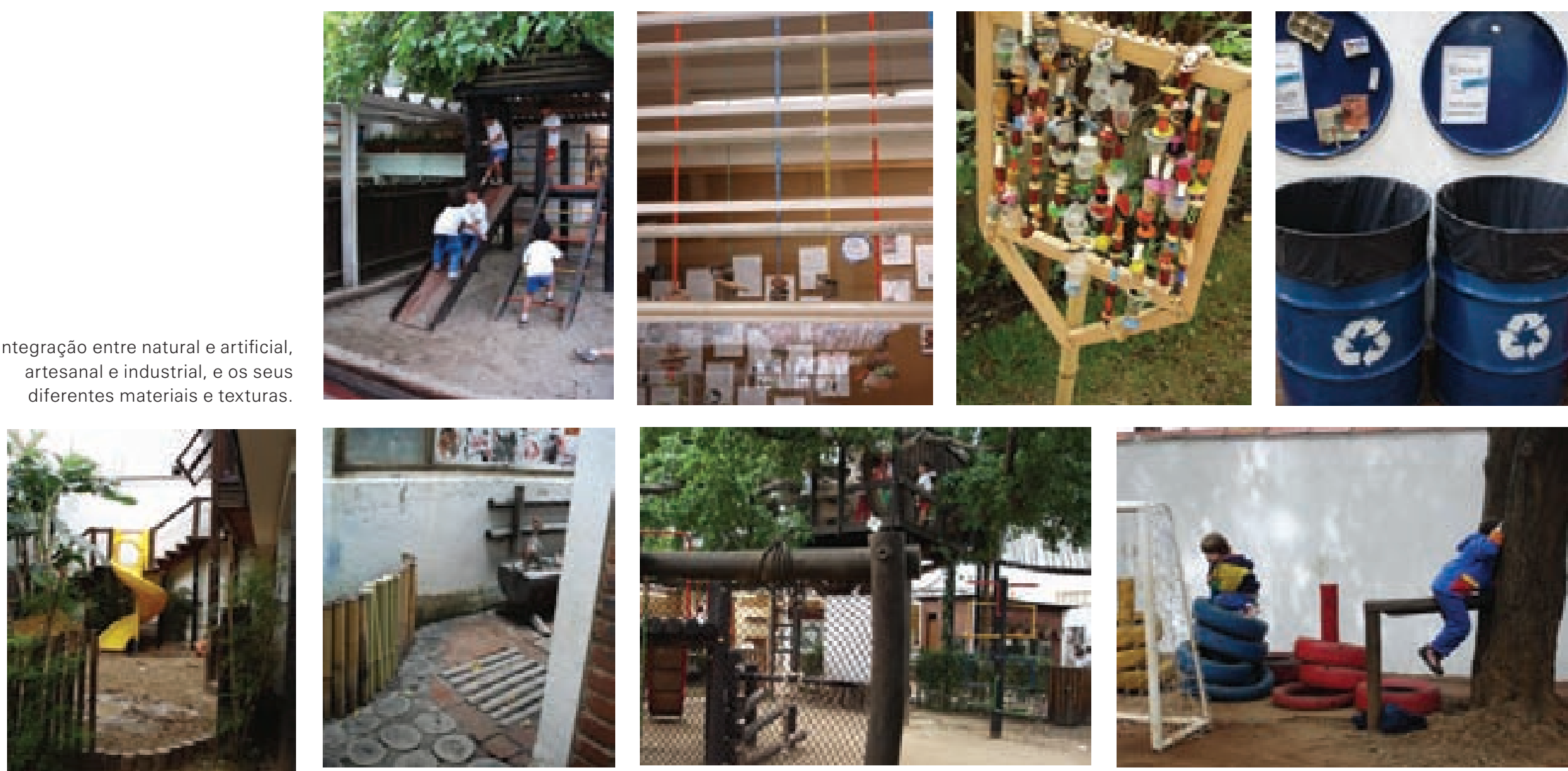

De modo geral, observam-se, portanto, a presença e exploração de uma diversidade de materiais, tanto de naturezas quanto de proveniências diferentes, o que resulta na apresentação de uma gama maior de possibilidades de construções e combinações (ambiente, equipamentos, brinquedos, etc.), enriquecendo o repertório da criança. Materiais industrializados convivem e se misturam a materiais de origem natural (natureza), assim como sucatas, materiais naturais e materiais descartados ou sobras são utilizados para o desenvolvimento de atividades e projetos

- a própria decoração das salas feita pelas crianças, por exemplo, traz essa mistura e integração. 
Também o piso da escola é trabalhado dentro dessa mesma idéia, sendo explorado de diversas maneiras. A variação no material do piso não só delimita áreas de usos e funções diferentes (atendendo, às vezes, necessidades específicas de determinadas atividades), como também é utilizada para oferecer diferentes desafios (de equilíbrio, principalmente) às crianças de diferentes idades e tamanhos, o que é ainda mais acentuado com a existência de degraus, desnivelamentos e irregularidades (de colocação, composição e altura) propositais. Além disso, a variação do piso proporciona também a experimentação de diferentes texturas, a sensação de diferentes temperaturas e a percepção de mudança de ambiente.

Como se tem notado, o ambiente escolar analisado transparece uma preocupação por parte da escola de não apenas atender as necessidades funcionais e de uso dos seus espaços, mas também de fazer com que estes abram novas possibilidades de apropriação, conforme a leitura de cada um de seus usuários. Procura-se ir além da funcionalidade, da adequação, da segurança e da praticidade, e busca-se incentivar a autonomia e a atitude ativa (e conseqüentemente, a responsabilidade) das crianças, professores e funcionários, que são estimulados a se apropriarem e transformarem o ambiente da escola, sempre tendo em vista a coerência e a unidade da proposta pedagógica/ educacional adotada pela escola como um todo.

É visível no ambiente em geral a colocação da criança como figura principal do processo educativo, e a tentativa de estabelecer uma relação de abertura, diálogo e transparência entre diretores, coordenadores, professores e crianças. Mas também é visível que não se perde de vista o papel de cada uma das figuras nesse processo, principalmente o dos professores, que são também usuários e transformadores do ambiente, atuando como orientadores e estimuladores das atividades, experiências e projetos ali desenvolvidos.
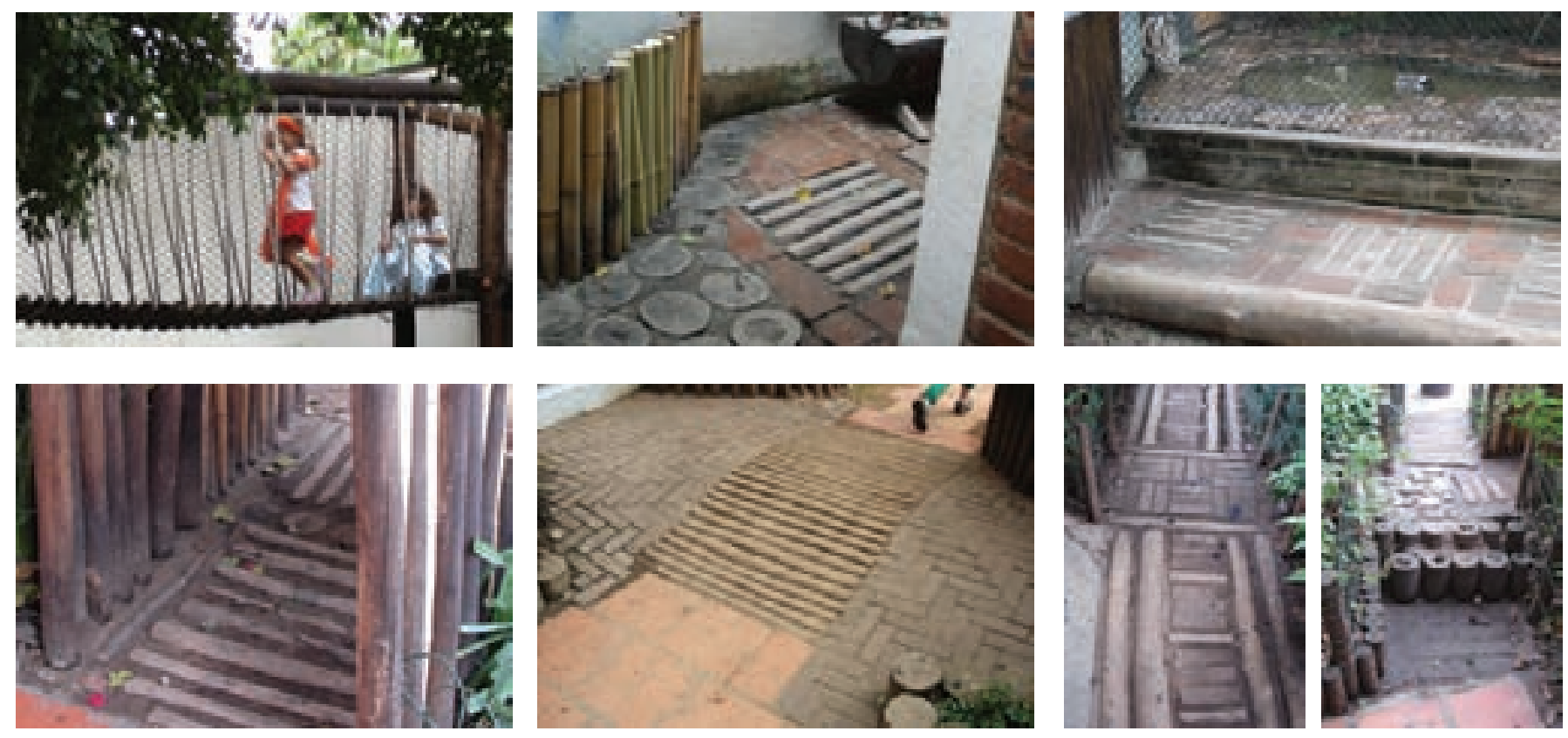

AMBIENTE ESCOLAR INFANTIL CAP 4 PROJETOS NO BRASIL 
Ao mesmo tempo, portanto, em que cria um ambiente fluido, sem hierarquia, integrado e permeável, estabelecem-se também as diferenciações entre público e privado, entre o que é acessível a todos e o que é restrito a alguns. Sem criar separações muito marcadas ou barreiras que intimidem a aproximação, garantem-se a privacidade e a reclusão necessária a algumas atividades e ambientes a partir da exploração do jogo entre visível, "semi-visível", não-visível, feito por meio da alternância entre materiais opacos, translúcidos e perfurados ou transparentes.
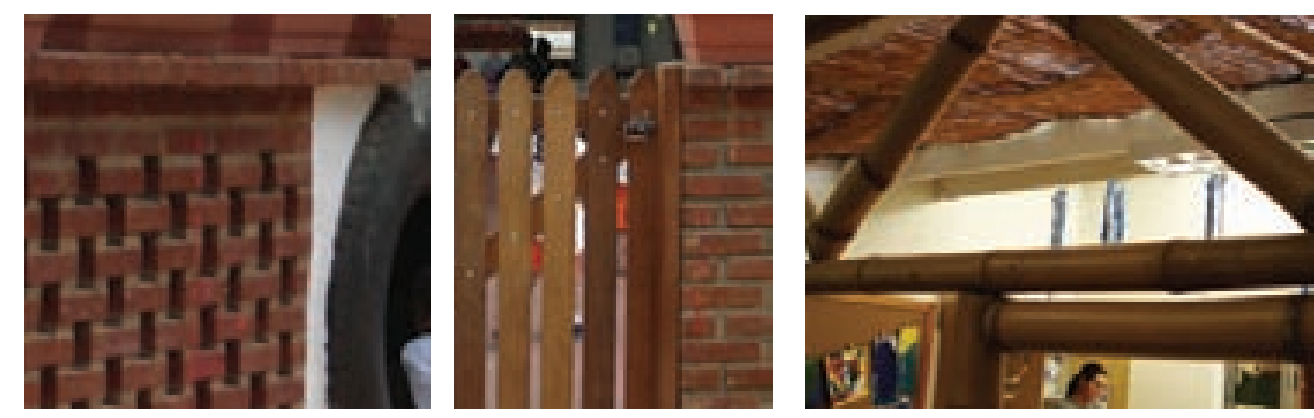

Alternância entre muros de tijolos com e sem vazios intercalados; portões de madeira permitindo frestas de abertura e visibilidade; estruturas permeáveis delimitando as áreas "semi-públicas" (os "terraços" das salas da cada turma).
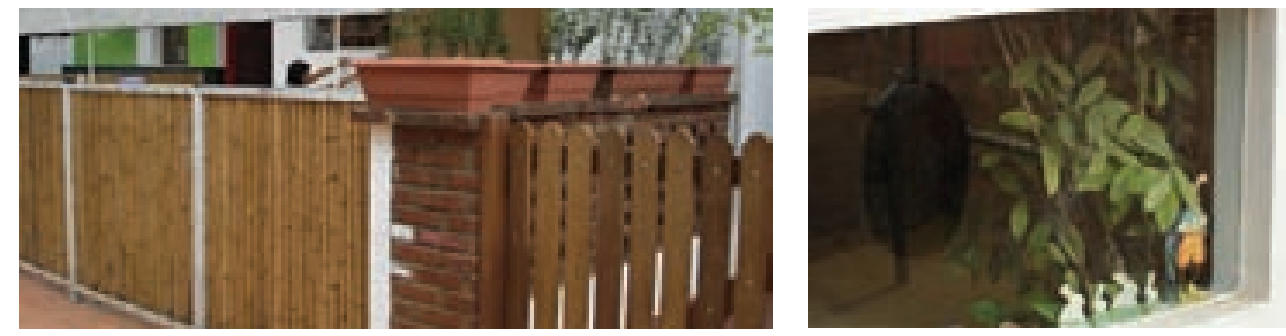

Acima, alternância de materiais e alturas, criando situações de diferentes visibilidades, acesso e privacidade; à direita, acima, sala da diretora: abertura para a "praçona" (abertura de vidro na altura dos olhos das crianças);

à direita, abaixo, salas de professores, coordenadores e pessoal administrativo: uso de materiais perfurados, aberturas transparentes, portas de correr - criação de ambiente de abertura acessibilidade, diálogo, proximidade.
De modo geral, podemos observar que a escola se propõe claramente a criar um ambiente de integração, tanto entre seus usuários como entre estes e a natureza, o que procura ser concretizado tanto no projeto arquitetônico como nas propostas de atividades. Primando por um ambiente harmonioso, embora diversificado e aberto a transformações ao longo do tempo, a Escola Viva procura estabelecer uma relação dinâmica entre elementos fixos e móveis, entre o permanente e o temporário, entre o industrial e o artesanal, entre o planejado e o espontâneo, entre o previsto e o inesperado.

Nesse contexto, tudo pode ser aproveitado, combinado e transformado. Com a intenção de enriquecer o repertório das crianças e dos usuários da escola em geral, leva-se para as experiências do dia-a-dia uma variedade de materiais, cores, texturas, formatos, acabamentos, encaixes, estruturas, odores, temperaturas, etc. que criam e permitem a criação de novas situações, objetos ou sensações.

Percebe-se aqui a intenção de trabalhar o edifício e o espaço da escola como um todo não apenas como suportes para a atividade pedagógica, mas como partes intrínsecas desta.

No entanto, ainda que haja uma interação entre projetos, atividades e ambiente, esta não é explorada em toda sua potencialidade. Apesar de não termos acompanhado o dia-a-dia das crianças por muito tempo, pudemos observar algumas de suas atividades durante algumas visitas, o que nos deu uma pequena, ainda que superficial, idéia de como estas parecem ser encaminhadas. Pelo que nos foi possível investigar, então, nos pareceu que poucos trabalhos, projetos, exercícios ou brincadeiras realizadas pelas crianças junto a seus professores acabam fazendo uso de fato da diversidade e da riqueza do ambiente onde são realizados

Se, por um lado, há um interessante trabalho de procurar desenvolver com as crianças propostas de intervenções e/ou sobreposições para lugares específicos da escola - como "cortinas" para cada um das salas,"móbiles", desenhos nos vidros, estandartes, etc. - (o que não vimos 
acontecer nas escolas da Reggio Emilia, por exemplo), por outro, parece que pouco se extrai das características físicas próprias de cada lugar, ou pouca experimentação se dá a fim de produzir novos efeitos resultantes da interação entre este e os trabalhos das crianças. Exploram-se escalas e suportes diferentes - grandes objetos e desenhos nas paredes, pequenas peças penduradas das mais diversas formas, elementos soltos no espaço, parecendo voar, etc. -, mas o jogo com fenômenos físicos e aspectos como intensidade de luz, cor, som, cheiro, transparência/opacidade, etc. parece acabar não acontecendo ou se dando de forma muito tímida e pouco intencional (o que tivemos a impressão de ver de forma mais significativa na experiência reggiana, com o painel que divide o refeitório da praça principal, com projetos que se propõem a interagir com a flora e a fauna do parque, com a exploração de luzes, sombras e cores a partir da fixação de trabalhos das crianças nos vidros do edifício, entre outras propostas) ${ }^{7}$.

Tampouco a riqueza da natureza, com suas frutas, flores, plantas, bichos, etc., é experimentada ou destrinchada, servindo de base para explorações de cor, textura, densidade, odor, e mesmo para a compreensão dos diversos fenômenos físicos.

Perde-se aqui, talvez, a oportunidade de potencializar a riqueza do ambiente escolar e de aguçar e afinar a capacidade de percepção da crianças. Sem dúvida, a complexidade ali construída e o espaço que se dá para a transformação constante dos seus elementos já criam oportunidades de ampliação do repertório das crianças, rompendo com o equilíbrio da rotina e estimulando a busca por novas adaptações e descobertas. Um maior direcionamento ou uma maior interlocução entre ambiente e atividades, porém, poderiam enriquecer ainda mais o processo de aprendizagem e desenvolvimento das crianças.

\section{Salas de aula}

[análise de: relação com demais espaços da escola; elementos estrutuais; formato; dimensões; organização espacial e das atividades; materiais, cores, texturas de pisos, paredes; iluminação; decoração; flexibilidade; mobiliário, equipamentos, objetos e brinquedos]

As salas de aula da Escola Viva apresentam formatos e tamanhos variados, deixando de haver, inclusive, uma regularidade e uma proporcionalidade entre o espaço disponibilizado para cada turma e a fase de desenvolvimento das crianças. Crianças da mesma "cor", porém de turmas diferentes, podem dispor de diferentes áreas de sala "de aula" e de terraço. Isso se deve às diferentes etapas de expansão da escola, que se fizeram em função da anexação irregular de porções de terreno.

Como regra geral, porém, podemos apontar o conceito de espaços complementares com graus de privacidade e abertura que se modificam gradualmente: todas as turmas dispõem de uma sala mais resguardada e fechada (com janelas e portas que se cerram), uma sala intermediária semi-aberta, semi-coberta, e uma área externa descoberta ainda não coletiva. A maior parte das salas "de aula" (mais fechadas) tem formato retangular e é considerada pequena pelos professores, o que faz com que estes tenham que encontrar soluções para a escassez de espaço.

Se, por um lado, isso prejudica o desenvolvimento de algumas atividades, e a organização dos materiais que, às vezes, acabam ficando inacessíveis às crianças, em locais muito altos -, por outro, resulta em soluções interessantes, na medida em que dinamizam o espaço, o qual deve ser freqüentemente modificado e adaptado aos diferentes momentos da classe. Dessa forma, parte dos armários é móvel e apresenta "face-dupla", criando cantos, ambientes e situações diversas segundo a sua posição na sala; mesas e cadeiras são leves e fáceis de serem carregadas pelas crianças, podendo ser rearranjadas ou retiradas da sala por elas mesmas (a partir dos 4 anos, principalmente); esteiras são colocadas e guardadas conforme as atividades desenvolvidas, modificando a
7 Isto não significa que os espaços e elementos da Escola Viva não sejam explorados livremente e intensmente pelas crianças. Aqui apenas se apresenta para reflexão a idéia de aguçar ainda mais a capacidade de percepção das crianças e promover experiências e vivências diferentes daquelas que estas têm por sí próprias. 
sensação do ambiente, em termos de temperatura e conforto; entre outras coisas.

Com relação aos materiais constituintes, as salas apresentam, em geral, pisos frios, como paviflex e cimento queimado, sendo o primeiro utilizado nas salas "de aula" (mais fechadas, privativas), e o segundo, nas áreas intermediárias, os terraços. O relaxamento e outras atividades que requerem pisos mais confortáveis e de temperatura mais quentes acabam tendo que ser realizados sobre esteiras, em função da ausência de áreas com piso diferenciado.

As paredes são pintadas de branco (acabamento simples, liso, padrão, sem textura), e as cores do ambiente são exploradas no conjunto de equipamentos, decoração, objetos e trabalhos das crianças. Paredes e armários constituem-se como elementos neutros (pintura branca ou madeira natural), servindo como suportes para as intervenções feitas pelas crianças e pelos professores ao longo do ano. Trabalhando com um grande número de painéis de tamanhos variados, sempre ao alcance das crianças (com exceção dos grandes painéis, cuja parte superior fica inacessível às mesmas), o que se destaca em cada uma das salas é a comunicação do conjunto de atividades, projetos e trabalhos realizados ou programados pelas turmas. Podemos notar aí a importância dada à criança e ao seu desenvolvimento: este sobrepõe-se à arquitetura e é ele que dá a identidade de cada classe.

Os pés-direitos são variáveis, chegando a ser excessivamente altos em alguns casos (como o do galpão ao lado de uma das turmas vermelhas - que é, no entanto, uma das turmas maiores, com crianças de 6 a 6,5 anos). Com o objetivo de criar ambientes diferentes, a escola utilizase de recursos variados para fazer o fechamento de cada sala, explorando tipos e intensidades de luminosidade diversas por meio da alternância entre elementos vazados e opacos, transparentes ou translúcidos. Cortinas e elementos presos ao teto ou à cobertura são produzidos pelas crianças para complementar a ambientação e o jogo de luz e sombra. Janelas e/ou aberturas também exercem o papel de controle da luz, e, ao mesmo tempo, são elementos de controle do campo visual, do ruído e do conforto térmico e psicológico (janelas mais altas nas "salas de aula", onde se exige maior concentração).
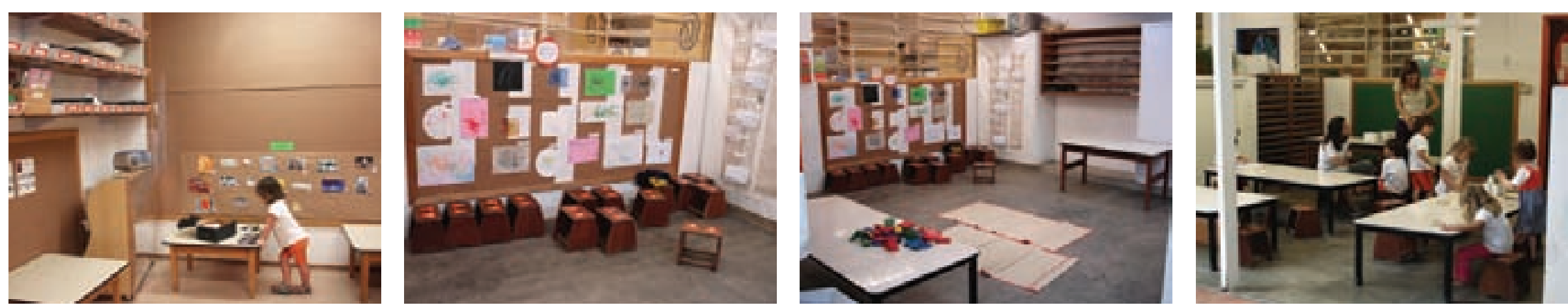

Salas pequenas, mas com diferentes ambientes; a presença das crianças nesses espaços através de seus trabalhos e intervenções; mobiliário: o que pode e o que não pode ser acessível às crianças. 


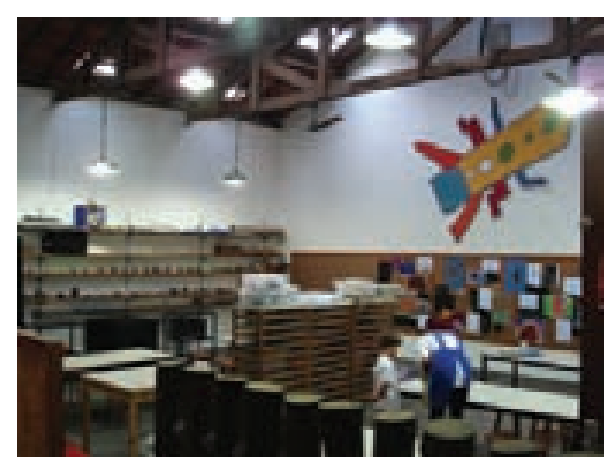

Galpão: pé-direito mais alto da sala de uma das turmas vermelhas (sala de atividades artísticas, principalmente)

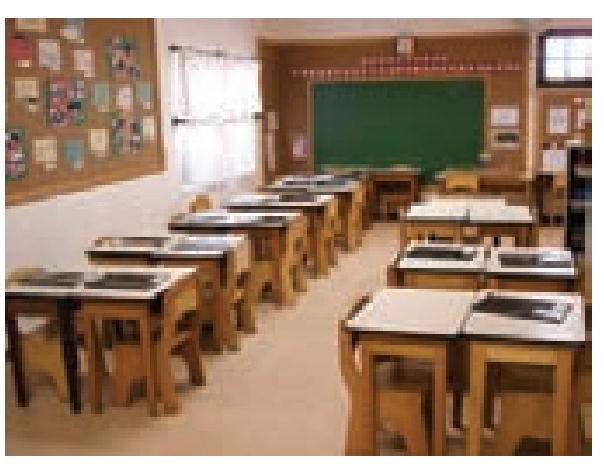

Mobiliário leve, já com um tamanho e arranjo diferente das salas das crianças menores: lousa baixa para alcance das crianças: painéis com trabalhos expostos.

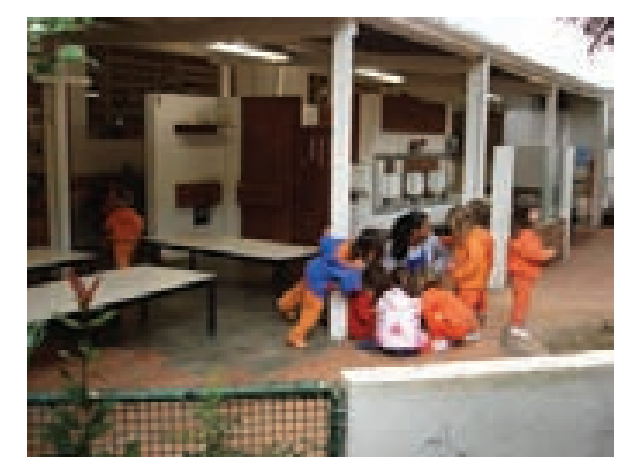

"Terraço", área de pias e banheiros externas às "salas, porém conjugadas às mesmas:

cor da arquitetura: branca, mesclada com elementos em madeira, de forma geral.

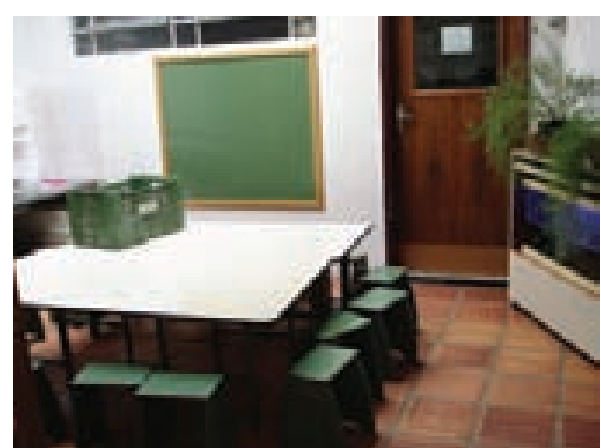

Laboratório de experiências: ambiente neutro, mesclando cores brancas, verdes e madeira; bancos leves para rearranjo da disposição dos alunos; porém, mesa única e pesada, dificultando uma maior flexibilidade do espaço.
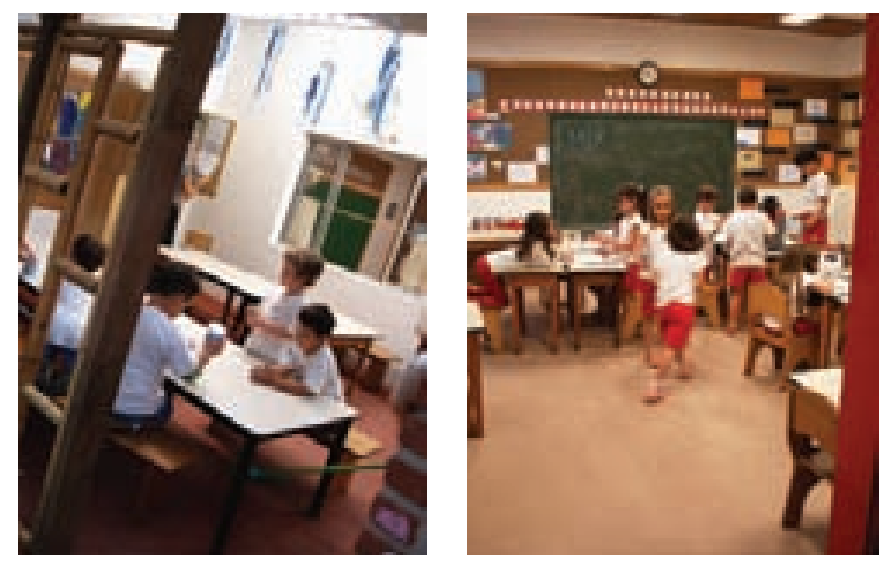

Arquitetura neutra e permeável, destacando as intervenções das crianças no ambiente.
Flexibilidade e polivalências das salas - mobiliário rearranjado de acordo com a atividade proposta.
O mobiliário, como já mencionado, também é neutro, feito em madeira natural, com um ou outro detalhe de composição e recorte, constituindo, com a aquitetura, um elemento silencioso, que dá espaço às intervenções e comunicações das crianças, e contribui para a dinâmica e proposta de transformação e exploração da escola. É móvel, portanto, o que permite que seja manipulado pelas crianças e pelos professores, uma vez que a maioria das salas é pequena e deve ser transformada a cada atividade que ali se desenvolve, não apresentando "cantos" específicos. As salas são orientadas e programadas, quase não havendo espaços nem momentos em que a criança possa ficar sozinha brincando, lendo ou desenvolvendo qualquer outra atividade.

As áreas das salas de aula são em geral pouco estruturadas no que diz respeito à definição de uso e função dos seus espaços, mas existe uma clareza e uma lógica na organização dos materiais e equipamentos, assim como 


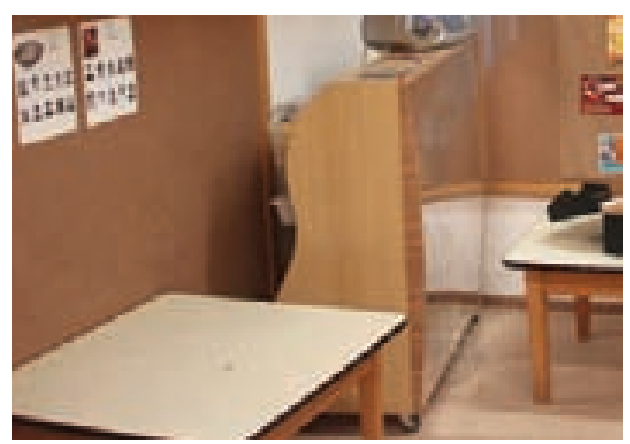

Móvel de uma das salas: de um lado, espelho para as crianças brincarem; de outro, prateleiras para guardar materiais utilizados em classe e que devem ser de fácil acesso às crianças; as mesas são leves a fim de facilitar o manuseio pelas crianças.

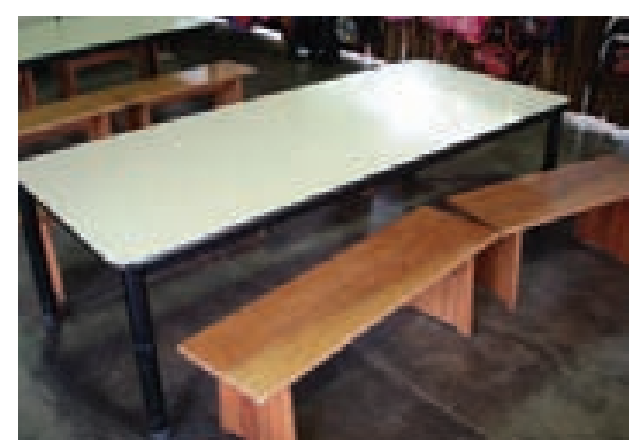

Mobiliário do "ateliê de artes": mesas mais pesada não permitem o manuseio ou deslocamento pelas crianças; já os bancos, apesar de compridos, são relativamente leves e geralmente såo manipulados pelas crianças (de forma a mudar a posição destes).
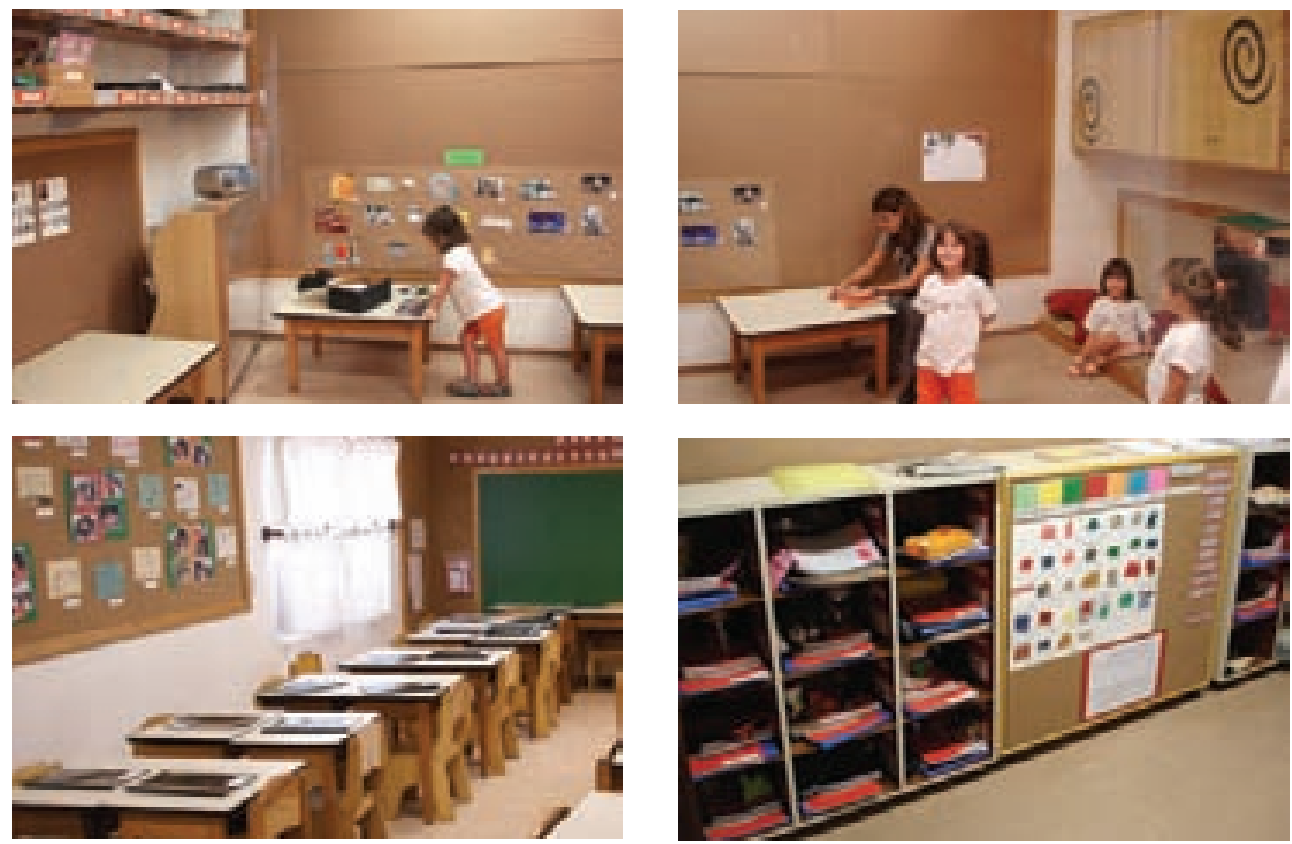

Separação entre o que deve ficar acessível à criança (quadros, lousas, espelhos, móvel com livros e alguns equipamentos, armários, etc.) e o que deve ser controlado pelos professores (prateleiras e armários mais altos) - (nem sempre proposital - às vezes, em função de limitações de espaço). dos armários de cada uma das crianças, os quais devem ser mantidos em ordem por elas próprias.

O tamanho das salas acaba de fato prejudicando a intenção de construir espaços de exploração a mais longo prazo e de disponibilizar seus recursos às crianças de forma mais livre, sendo manipuladas quase todo o tempo para abrigar atividades diferentes, e tendo alguns dos seus móveis e materiais apenas ao alcance dos professores, mas, sempre que possível, parece que há uma tentativa de promover a autonomia e a responsabilidade das crianças. Há também uma alternância entre armários abertos e fechados, sinalizando o que pode e o que não pode ser manipulado pelas crianças.

A lousa é outro elemento que fica ao alcance das crianças, pois, apesar de servir principalmente para a organização das atividades do dia pelos professores, é também utilizada por estas, ainda que sob a coordenação daqueles.

Apesar de apresentarem muitos elementos em comum, cada sala, cada espaço reservado a cada uma das turmas, tem sua própria identidade, construída pelos próprios usuários (crianças e professores). Desta forma, enriquece-se ainda mais a experiência do espaço da escola uma vez que, sem que se deixe de garantir a unicidade da proposta pedagógica, que norteia a lógica e a essência dos ambientes construídos, permite-se a variedade de apropriações, intervenções, adaptações e, por conseguinte, de estímulos diferentes que chegam a cada uma das crianças. Cada uma delas passará por uma classe, por um espaço coerente com os demais, porém com características próprias e uma identidade a ser construída, o que enriquece o seu repertório e a estimula à participação.

Podemos notar, no entanto, que, ainda que o espaço das salas seja flexível e que sejam variadas as atividades aí desenvolvidas, poucos são os instrumentos e ferramentas disponíveis para que as crianças explorem, criem e transformem o universo ao seu redor. A exploração e a experimentação polissensorial acabam, assim, acontecendo mais nos ambientes externos do que propriamente nas salas de atividades. 


\section{Atividades, usos e funções}

Como já mencionamos, além das atividades desenvolvidas em sala "de aula", a escola propõe outras atividades complementares, como artes, maquetes e música, as quais têm espaços próprios para serem desenvolvidas. Apesar da existência desta separação, algumas dessas práticas são desenvolvidas nas próprias salas de cada turma e, muitas vezes, há inclusive um intercâmbio entre turmas e salas, especialmente durante as chamadas "oficinas", nas quais todas as salas "abrem suas portas" e propõem atividades que podem ser realizadas por quaisquer crianças (de uma mesma "fase-cor-idade"), independentemente de suas turmas ("classes"). Em alguns momentos, até as salas de artes, maquetes e música (esta talvez mais raramente) são utilizadas de formas diferentes.

Ainda que haja liberdade de criação, expressão, comunicação e produção nas atividades desenvolvidas nestas salas, em geral, aí são realizados trabalhos e projetos mais direcionados e programados. É nos espaços coletivos, então, que aparecem os usos e apropriações mais livres e diversificados. A "praçona" pode ser tranformada (em parte) em pista de corrida, área de descanso, piscina de lama, ou mesmo campinho de futebol, como acontece muitas vezes. O quiosque, inserido em um canto da praça, é espaço para música, jogos, conversas e muitas outras coisas. A área dos bancos compridos, em outro canto, pode servir para descansar, pode virar uma ponte ou servir de obstáculo a ser ultrapassado. O cantinho da árvore com banquinho é esconderijo, cantinho do descanso ou da "transformação" (com fantasias de pano). Alguns equipamentos ficam espalhados e disponíveis para as crianças brincarem e inventarem os seus espaços e universos. Pneus, latas, bolas, paus, fantasias, entre outras coisas podem ser utilizados da forma como melhor convém às crianças (sob o olhar dos professores, com atenção à segurança), o que faz com que os espaços e ambientes da escola sejam transformados constantemente.

Esta transformação é possível graças à presença de elementos móveis e semi-fixos (equipamentos, mobiliário,
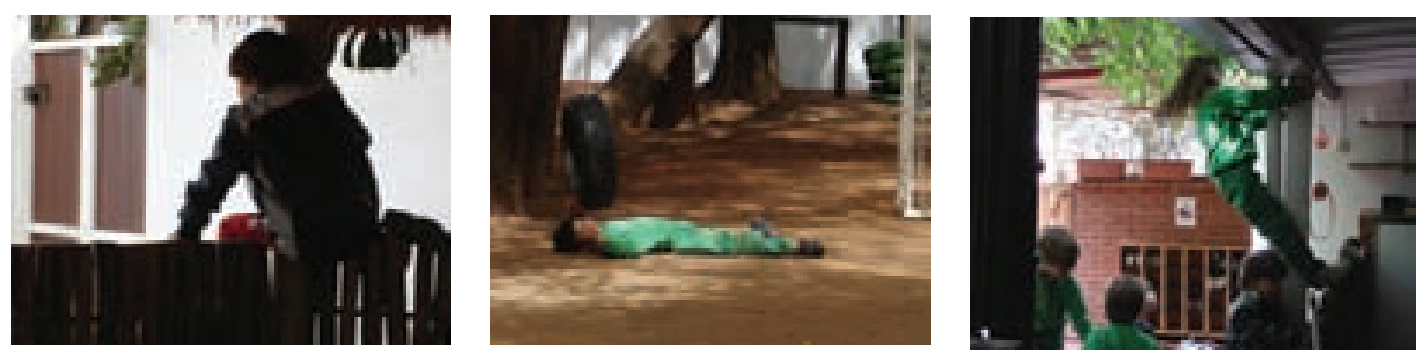

decoração, etc.) que podem ser manipulados pelas crianças e provocam as mudanças em cada momento de utilização dos mesmos. Mas não só estes elementos, como também a própria arquitetura e os elementos fixos do ambiente escolar passam por transformações coordenadas pela diretoria e/ou pelos professores, e algumas vezes produzidas pelas crianças (cerâmicas para piso, peças de vidro para janelas, azulejos para banheiros, etc.).

A escola, portanto, apresenta uma dinâmica de constante alternância e mudança de atividades e usos, assim como trabalha com a mescla de espaços e equipamentos mais definidos e espaços e equipamentos menos definidos quanto às suas funções e usos, o que resulta em um ambiente polivalente, flexível e aberto a interpretações e apropriações variadas. O fato ainda de cada turma ter uma área dividida em espaços mais fechados e privativos até espaços mais abertos e "semi-públicos" cria uma maior dinâmica interna às próprias turmas, que estão em constante movimento e troca de ambientes, e entre os grupos de turmas, que se inter-relacionam nos espaços mais permeáveis e semi-abertos.

Todas estas transformações, no entanto, são contrabalanceadas com a manutenção e constância de certas rotinas e hábitos, que garantem o equilíbrio da dinâmica do ambiente escolar, cuja complexidade é alcançada justamente com o jogo e a relação entre quantidades variáveis de estímulos e, portanto, de informação.
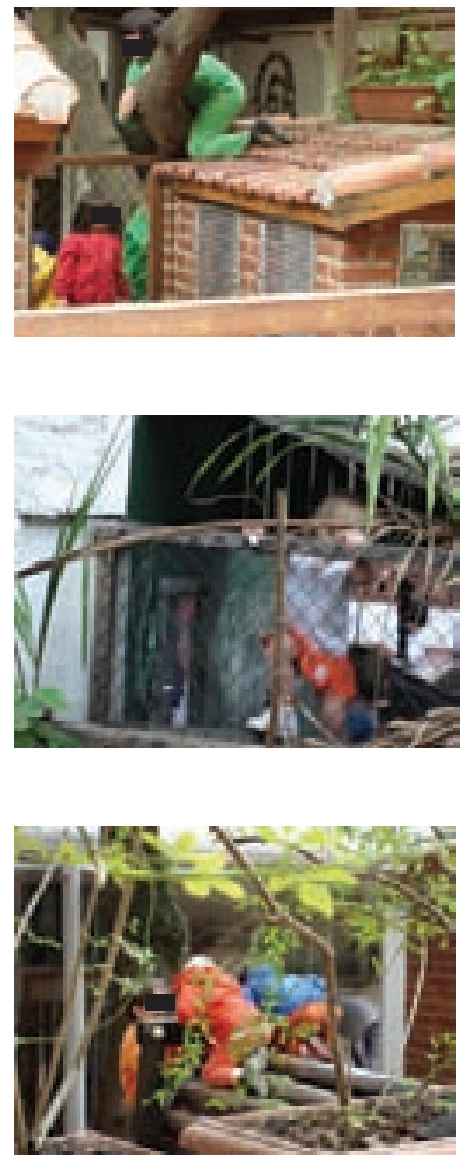


\section{Considerações finais}
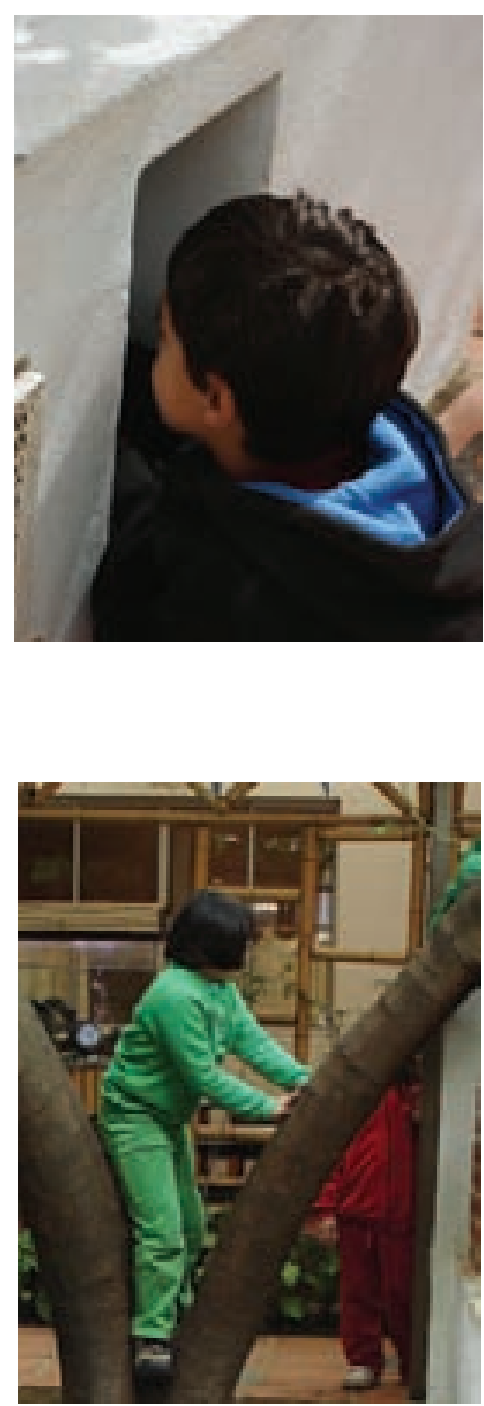

A análise da experiência da Escola Viva permitiu-nos observar que a ausência de um projeto arquitetônico-ambiental único e "completo" (ou pelo menos, que vislumbrasse e planejasse ampliações futuras, e não sem planejamento, feito em etapas, como ocorrido na escola) não prejudicou ou mesmo impediu o desenvolvimento de um ambiente escolar condizente com a proposta pedagógica e, mais do que isso, intrínseco a ela. Ao contrário, o próprio fato de a escola ter sido impelida a repensá-lo inúmeras vezes possibilitou que se criasse uma dinâmica em torno deste, abrindo espaço para questionamentos e revisões das experiências já vivenciadas.

O diálogo constante entre diretora e arquiteto foi essencial para que se construísse o ambiente escolar tal como é hoje, sob um olhar interdisciplinar. É necessário porém, que este diálogo seja ampliado para os demais usuários da escola, e que se mantenha uma dinâmica de reciclagem e transformação da mesma, pois, se ambiente é um espaço mediado, qualificado, modificado ou alterado pela relação que nele estabelece o indivíduo consigo próprio ou com os outros indivíduos (Lima 1989, p.14), todos são construtores e modificam e são modificados por ele.

Se nas palavras da diretora, apresentadas no início do trabalho, pudemos perceber a intenção de conceber o espaço como elemento curricular e educador, na análise do ambiente da escola, pudemos observar como isso de fato acontece (ainda que com algumas ressalvas e problemas não solucionados). Procura-se ir além da funcionalidade, da adequação, da segurança, da praticidade, atentandose para a autonomia e atitude ativa (e conseqüentemente, responsabilidade) das crianças, professores e funcionários, os quais são estimulados a se apropriarem e transformarem o ambiente da escola, sempre tendo em vista coerência e unidade da proposta pedagógica/ educacional colocada pela escola como um todo.

Nesse processo, ainda mais interessante é notar que, ao conceber o ambiente como educador, cria-se espaço inclusive para o "acaso", que muitas vezes pode enriquecer ainda mais a experiência educacional. O espaço, seus equipamentos, mobilários, brinquedos, etc., não direcionam um único comportamento ou ação de seus usuários mas criam uma estrutura de oportunidades. É possível observar que algumas das situações hoje existentes na escola foram construídas inconscientemente, sem planejamento, ou até involuntariamente, como, por exemplo, muitas das interações natureza-edifícios - a incorporação da natureza na paisagem, o jogo de luz e sombra por ela provocado e até mesmo a sua transformação em 'trampolins" para a transposição das barreiras físicas. Pode-se dizer que o espaço e o ambiente, assim, vão além de "convidar à sua apropriação", mas chegam quase a "convidar à sua transgressão" (no sentido de transformação, "re-funcionalização" e "re-signficação").

A riqueza desta experiência está, portanto, na complexidade de sua proposta e na definição de seus usuários (da criança, principalmente) como figuras principais de sua construção. Está na procura de integração e interlocução entre a criança e o universo ao seu redor, seja ele natural ou artificial. E está na busca de promover essa interação por meio de experiências sensoriais, que se renovam com o ambiente, aberto a constantes transformações. Talvez ainda, como já observamos, podendo ser potencializada com um movimento de maior ênfase, direcionamento, ou aprofundamento das experimentações sensoriais nas atividades, trabalhos e projetos desenvolvidos. 

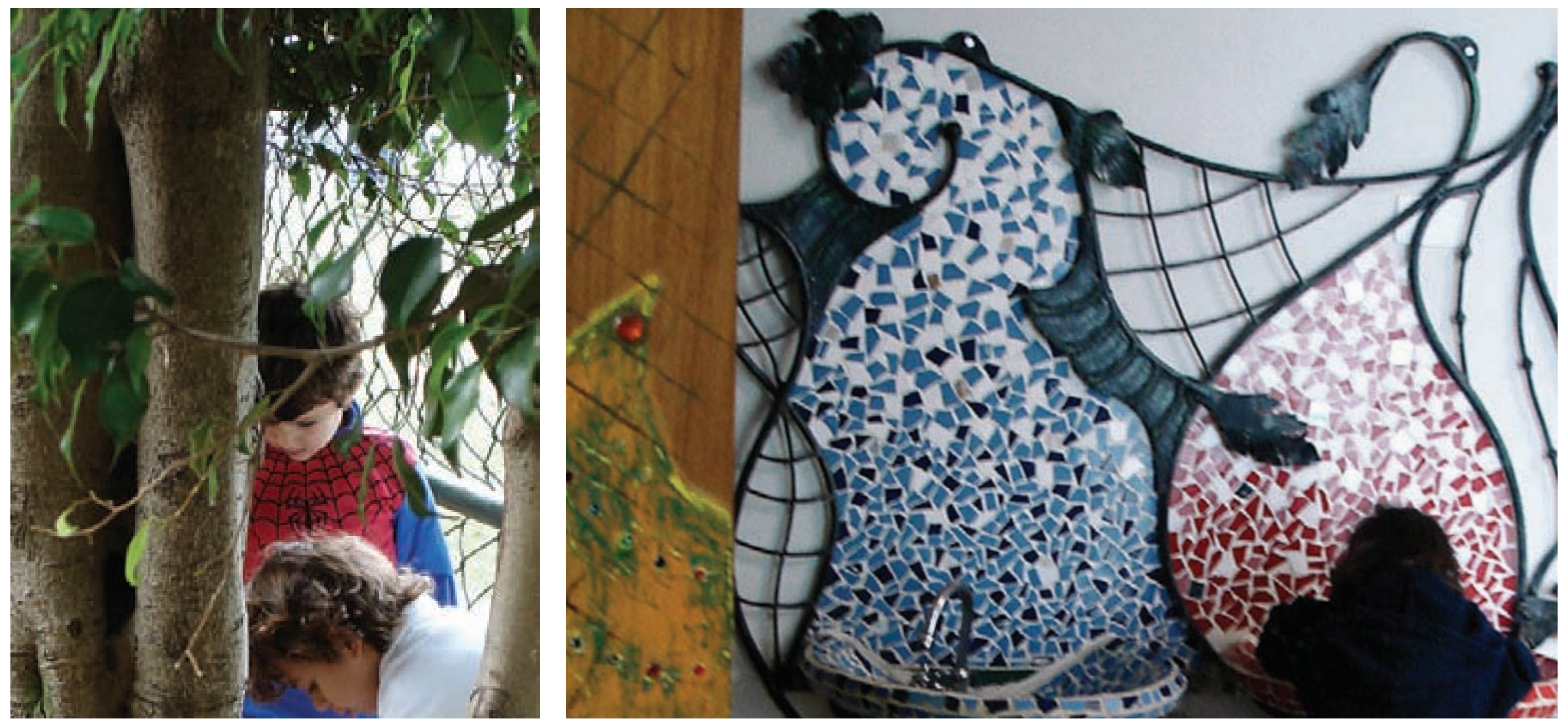


\section{O projeto da Escola Infantil do colégio Santa Cruz}

\section{A proposta da escola}

Inaugurada no final dos anos 90, a escola infantil do colégio Santa Cruz, diferentemente da Delftse Montessorischool, das escolas municipais de Reggio Emilia, e mesmo da Escola Viva, analisadas anteriormente, é concebida em meio a um contexto de passagem de século, nascendo, portanto, imbuída de princípios e questionamentos próprios desse tempo.

Questões como a importância de criar um ambiente

Projeto de arquitetura

Sérgio Vaz Cristóvão

Projeto de ambientação J.C. Serroni

Local e Ano

São Paulo, Brasil, década de 90

Escola analisada educação infantil dos 4 aos 6 anos de idade

Total de crianças 144 crianças por período (manhã/tarde)

Total de salas 6 salas da mesma faixa etária por período (geralmente, 24 crianças por turma/sala) escolar propicio e preparado para a criança (filosofia defendida por Montessori) ou a necessidade de interferência do adulto no processo de desenvolvimento, por exemplo, não estão mais em pauta. A concepção da criança como sujeito social e de direitos já se estabeleceu como princípio norteador da grande parte de propostas de ensino infantil, e a escola passou a ser vista, de forma geral, como agente possibilitador do desenvolvimento das potencialidades e características de cada criança individualmente, sendo o professor uma figura de grande importância no desenrolar do processo de ensino-aprendizagem.

Não se concebe mais uma escola apenas para "abrigar", "atender as necessidades", "proteger" ou "da assistência" à criança, mas, sim, para promover o seu desenvolvimento. E neste contexto, então, a escola é vista pelo colégio Santa Cruz como uma "célula da sociedade, da cultura, da contemporaneidade", e é entendida como o "espaço do aprendizado das competências necessárias à vida", onde "o desafio é saber tecer em conjunto os diversos saberes numa visão de mundo pluralista e multifacetada" (Plano Diretor 2007 p.19).

Em conseqüência dessa nova concepção da criança e do reconhecimento de sua capacidade e riqueza de transformação e/ou recriação da realidade, começa a crescer também, nesse final de século, a conscientização de que não só os brinquedos e equipamentos, mas principalmente o espaço da escola pode ser um grande facilitador ou inibidor desse processo.

A Escola Infantil Santa Cruz acaba, assim, trazendo essas questões para sua proposta, não só colocando como pilares de sua concepção filosófica o "cuidar", o "brincar" e o "conhecer" (não mais apenas o "cuidar"), como também concebendo o seu espaço escolar como o "habitat" da educação proposta (Plano Diretor 2007 p.22).

Vejamos como esse espaço se desdobra e aparece concretamente no dia-a-dia da escola. 


\section{O espaço escolar como ambiente de aprendizagem} [dimensões física, funcional, temporal e relacional]

A escola de Educação Infantil do colégio Santa Cruz com preende duas séries, Pré 1 e Pré 2, atendendo crianças de 4 a 6 anos de idade, aproximadamente. Cada série freqüenta a escola em um período diferente: o Pré 1 de manhã, das 8 h̀ às 12h30, e o Pré 2 à tarde, das 13 h15 às 17 h45.

As séries (grupo de crianças da mesma faixa etária) são divididas, então, em turmas, as quais possuem salas próprias (apenas compartilham a mesma sala grupos da outra série, em períodos do dia diferentes - turma da manhã e turma da tarde). Cada turma é identificada por uma cor e, conseqüentemente, suas salas são identificadas pelas cores respectivas. Segundo a diretora, a proposta foi justamente fazer com que a identificação das salas pelas crianças acontecesse de forma mais lúdica, tendo as cores não só nos nomes, mas também nos próprios ambientes.

Sendo criado muito posteriormente à fundação do colégio, na década de 50, o edifício da educação infanti acabou sendo implantado onde originalmente era a "casa dos padres" (padres da Congregação Santa Cruz que mo ravam no colégio). Apesar de passar por uma reforma, o espaço da escola ficou prejudicado em função de algumas restrições estruturais, de tempo e de verba, as quais acarretaram em limitações principalmente com relação à organização e à distribuição espacial (veremos mais adiante).

A "casa", o edifício, passou então a abrigar as salas de aula, diretoria, administração, cozinha, banheiros e demais salas. O jardim foi transformado em um grande gramado, ao lado do qual foi construída uma quadra coberta. $E$, in corporando parte do terreno da escola fundamental, foi construído também um "parquinho", onde se encontram equipamentos pré-fabricados de madeira que oferecem desafios motores às crianças.

A maior parte das salas de aula foi implantada no piso superior do edifício, uma ao lado da outra ao longo de um corredor comprido'. Este conecta-se à rampa e às escadas que ligam as salas das crianças ao piso inferior, onde localizam-se as salas de artes, jogos dramáticos, cozinha, diretoria, coordenação, administração e recepção.

Assim como a Escola Viva, a rotina da escola Santa Cruz é mais formal (em relação à das escolas reggianas, por exemplo) e estrutura-se a partir de uma grade temporal diária - a mesma tanto para o Pré 1 quanto para o Pré 2: primeiro bloco de aulas (aproximadamente 45 minutos); lanche; recreio e segundo bloco de aulas (duas horas). Cada turma desenvolve suas atividades individualmente em suas salas, havendo a mescla das crianças apenas durante o horário de recreio (ao mesmo tempo para todas) e, eventualmente, durante a visita de uma turma à sala de outra (a mistura acontece apenas entre as turmas da mesma série, não ocorrendo o cruzamento das séries em momento algum).

Durante o recreio, todo o espaço externo da escola é disponibilizado para as crianças (gramado, quadra, parquinho, terraço-corredor externo), que, porém, não devem sair do piso térreo. As salas de artes e jogos dramáticos também ficam abertas, mas as crianças acabam não fazendo uso delas. Além dos equipamentos pré-fabricados existentes no parquinho, alguns outros equipamentos e brinquedos são disponibilizados pelos professores, como cordas, bolas, blocos de construção, etc.

De forma geral, todos os equipamentos, mobiliários e brinquedos foram projetados a fim de atender as necessidades e dimensões das crianças nas suas diferentes fases de desenvolvimento. A altura da pia, o tamanho e peso das mesas e cadeiras, a localização dos sanitários e dos locais para que as crianças guardem seus mochilas, trabalhos..., tudo foi concebido com o intuito de possibilitar e incentivar a autonomia e a responsabilidade da criança, sempre sob o olhar atento do professor.

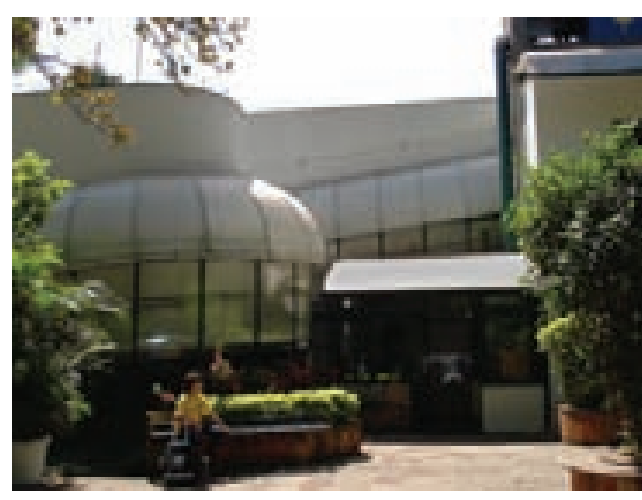

Fachada principal da escola.
1 Em função da área disponível na parte superior do edifício, uma das salas das crianças (laranja) foi implantada no piso térreo, sendo acessada pelo corredor da administração/coordenação/diretoria ou pelo corredor externo, que dá acesso direto ao gramado. 


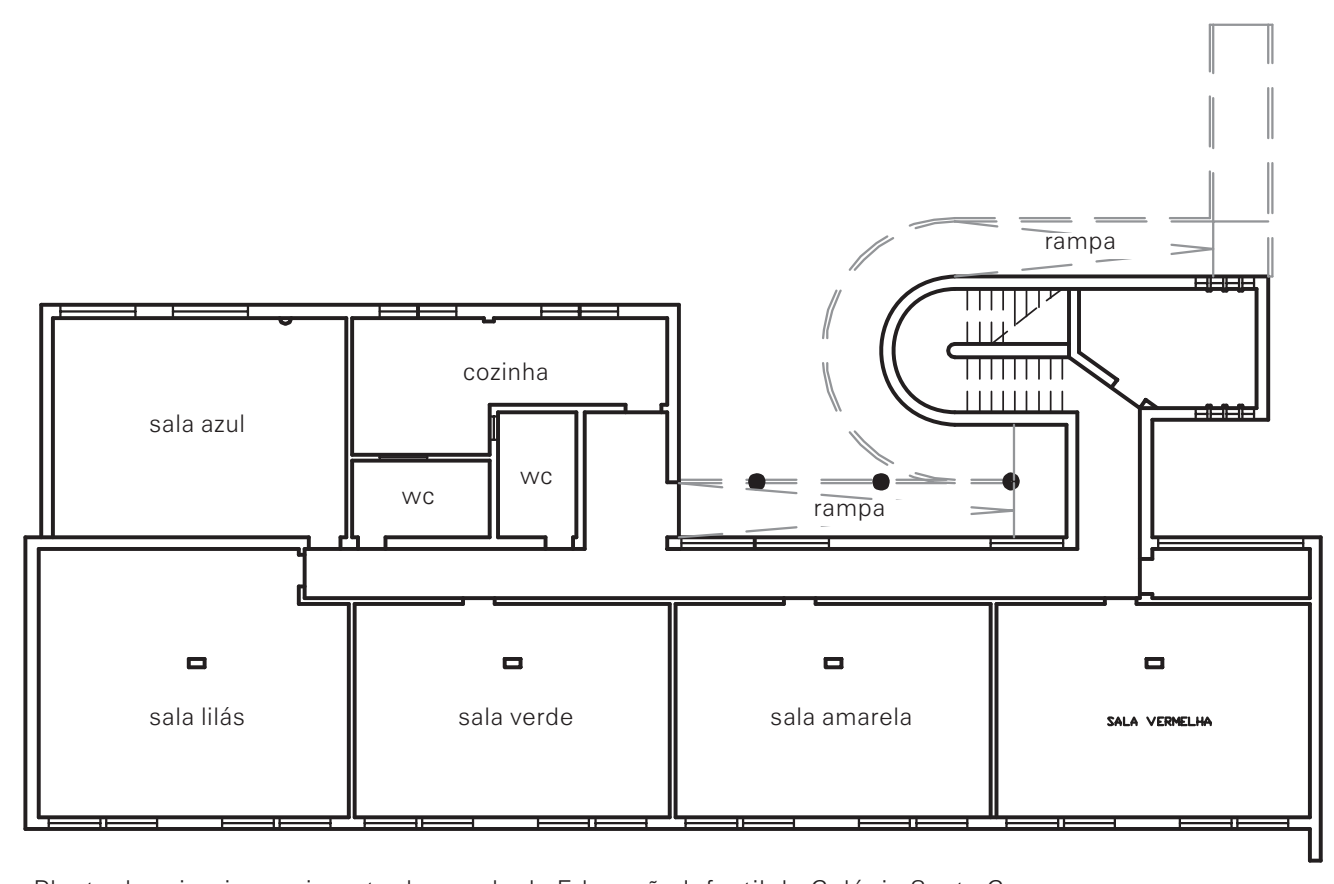

Planta do primeiro pavimento da escola de Educação Infantil do Colégio Santa Cruz. Escala 1:25

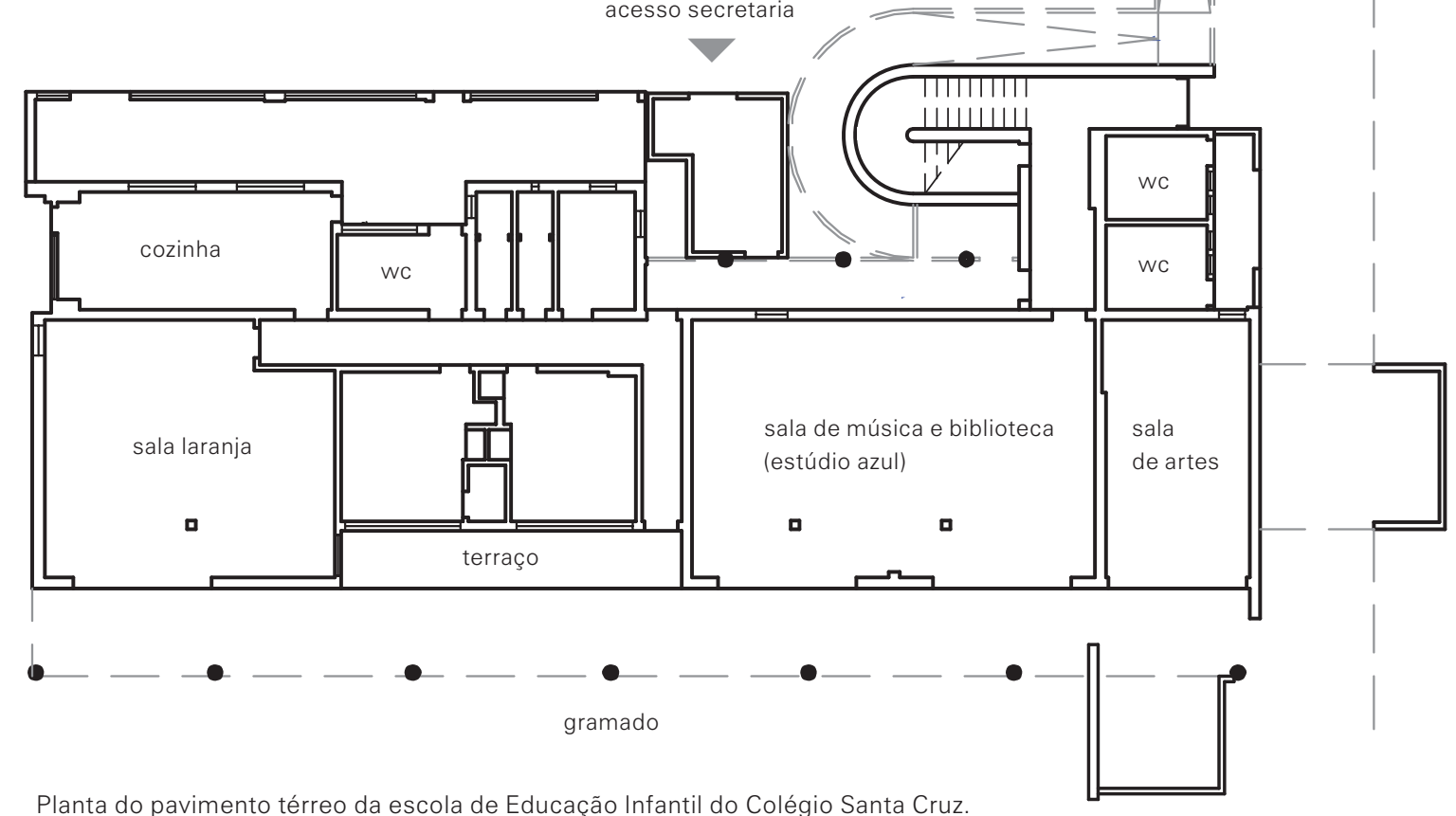



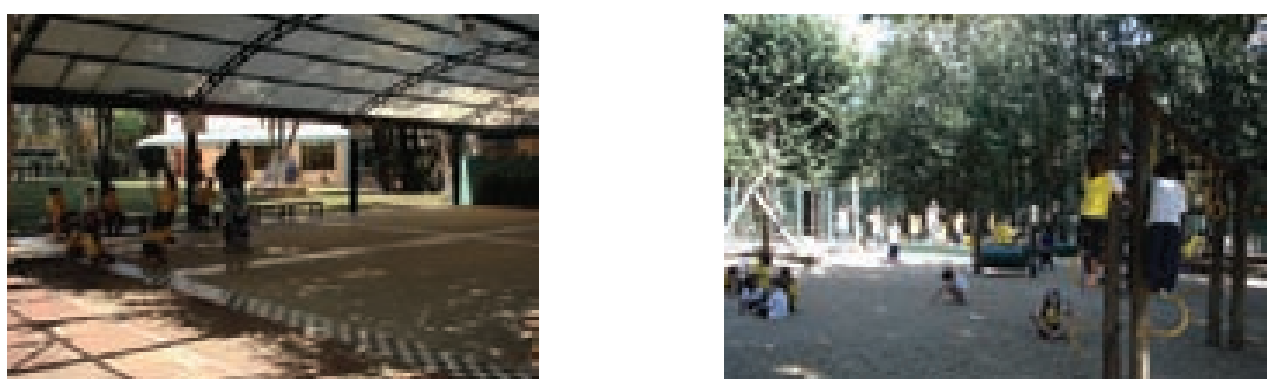

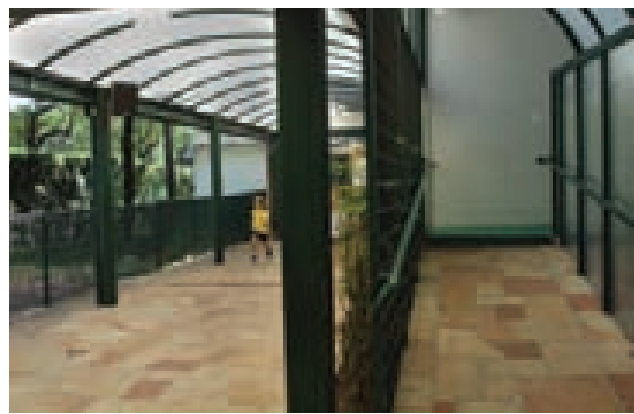

Rampa que liga o térreo às salas de aula.

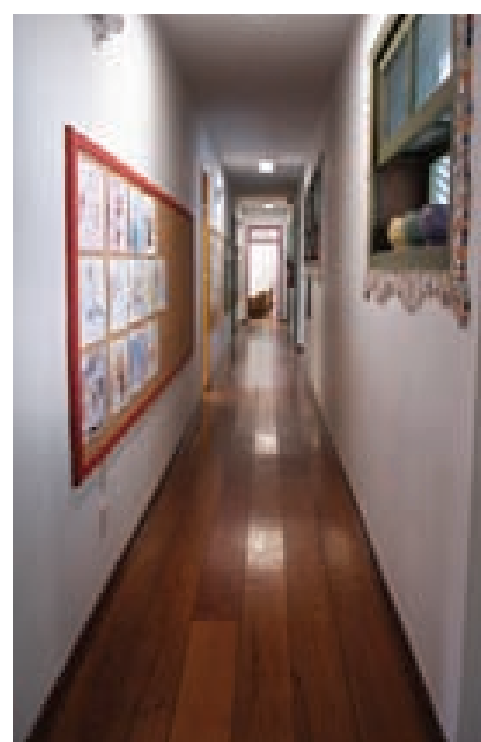

Corredor das salas de aula no piso superior

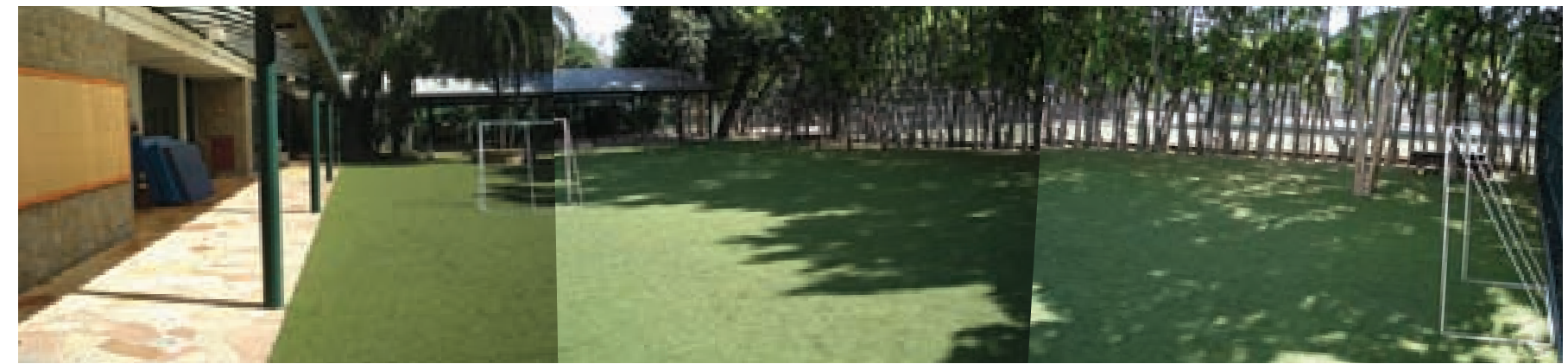

Gramado.

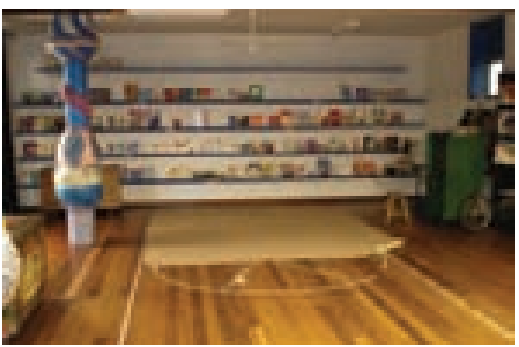

Salas de jogos dramáticos e biblioteca.

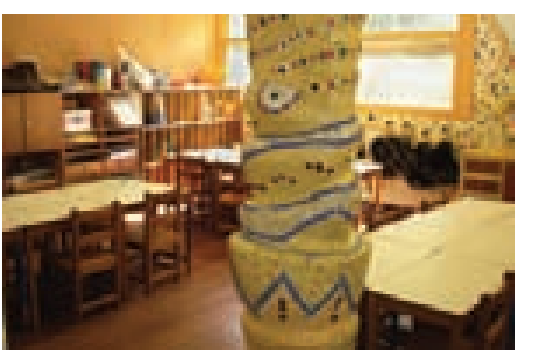

Salas de aula (identificadas pelas cores, fortemente presentes nas colunas).
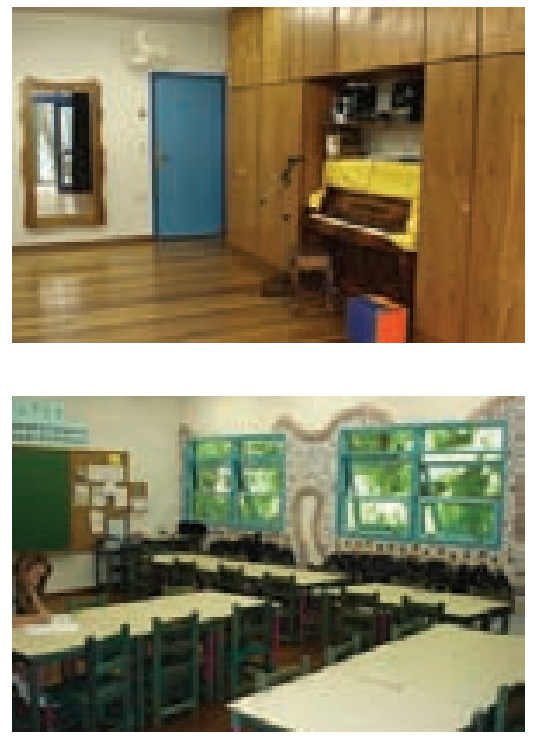

Sala de artes.
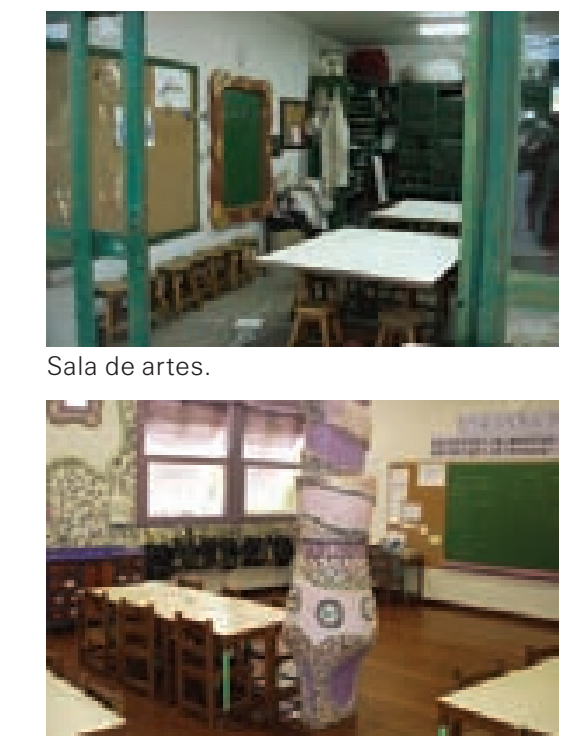
Entendida como se dá a organização do espaço e a dinâmica de atividades da escola, deve-se agora lançar um olhar mais profundo sobre o ambiente aí construído e sobre a relação que se dá entre estruturação espacial e uso, procurando avaliar sua complexidade e conseqüen temente sua riqueza ambiental, e em que medida este se constitui como uma estrutura de oportunidades para o processo de aprendizagem.

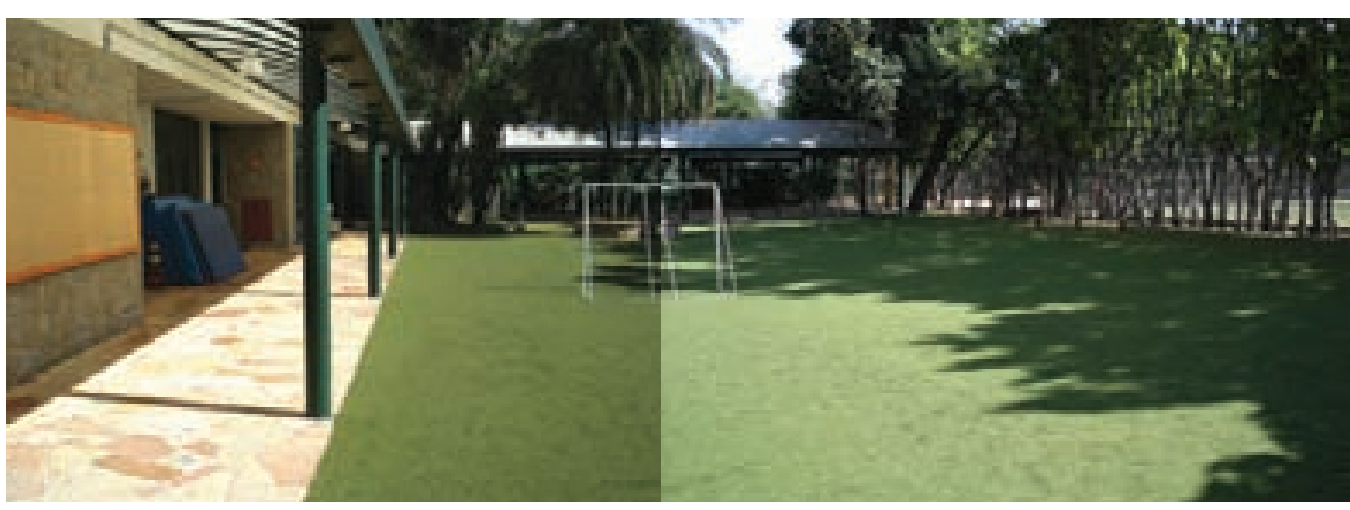

Edifício e gramado, correndo paralelamente um ao outro (ao fundo, quadra dá continuidade ao gramado).

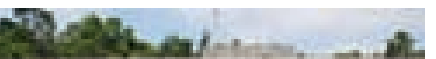

À esquerda

ista do edifício a partir do gramado no piso superior, as salas de aula, dentificadas cada uma por sua cor; eno piso inferior, a sala larania (à esquerda), a diretoria/coordenação e as salas de jogos dramáticos e artes (à direita).

À direita

árvores alinhadas ao longo da lateral do gramado, reforçando o eixo longitudinal.
O ambiente escolar como estrutura de oportunidades para o processo de aprendizagem

\section{A. Organização espacial e campo visua}

Constituindo-se como uma adaptação de uma residência, a escola manteve o layout original do terreno, instalandose inteiramente na casa original, de formato retangular que dá vista para a área externa, também em formato retangular, adjacente à mesma.

Conseqüentemente, toda a organização espacial dos ambientes se dá de forma longitudinal e linear, não havendo um núcleo central irradiante, como na Escola Viva ou nas escolas reggianas, por exemplo.

Apesar de não haver um núcleo central, o gramado acaba se constituindo como uma forte referência, justamente por se estender por toda a lateral do edifício da es cola, acompanhando as janelas de todas as salas de aula.

A configuração linear, e não nuclear, porém, acaba enfraquecendo a idéia de reunião e de coletividade, pois acaba isolando os ambientes uns dos outros, que se configuram lado a lado, de forma independente, voltados para si próprios (fechados em si mesmos, não permitindo a visualização do conjunto). Ainda que o gramado constitua o "espaço coletivo por excelência" e o "núcleo referencial" da escola, este é utilizado apenas em momentos específicos - durante o recreio ou as atividades físico-motoras.

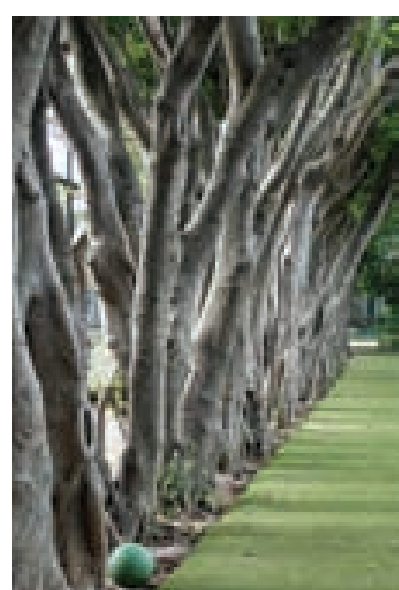

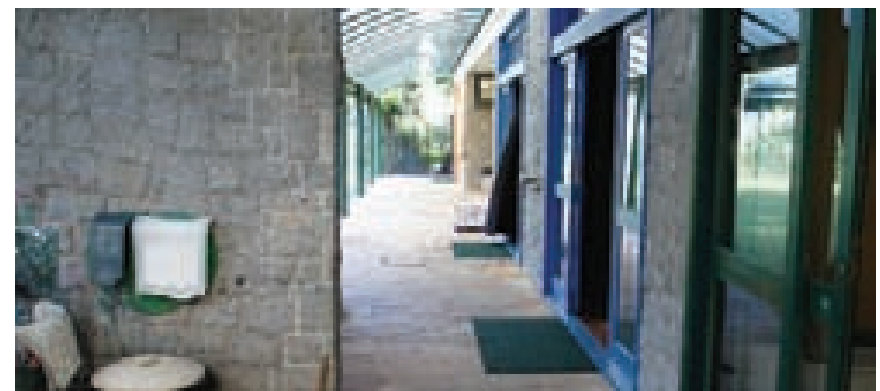

Terraço-corredor, conectando gramado e quadra, à esquerda, e edifício à direita; organização longitudinal fortemente marcada. 
A comunicação entre as salas e, portanto, entre as turmas, se dá, como já mencionado, apenas por um corredor estreito, que acaba se constituindo essencialmente como espaço de passagem, dando acesso aos banheiros das crianças e ao piso inferior. O próprio fato de as salas de aula estarem localizadas no piso superior dificulta o acesso das crianças ao gramado, com exceção da turma Iaranja, cuja sala localiza-se no térreo, em contato direto com a área externa. As crianças desta sala, inclusive, acabam, durante algumas atividades de sala, utilizando-se do espaço do "terraço-corredor externo", o que não acontece com as demais, que só acessam a área externa quando orientadas e direcionadas pelos professores.

Com essa configuração espacial e com a quase ausência de atividades conjuntas, a mistura de turmas acaba acontecendo de forma muito tímida, o que seria importante para o desenvolvimento sócio-interativo das crianças. Por não haver espaços intermediários entre as salas de aula, mais privativas, e os espaços coletivos, "públicos", todas as atividades realizadas pelas turmas acabam acontecendo separadamente e isoladamente umas das outras, mesmo aquelas que não requerem tanta concentração ou silêncio, as quais poderiam ser desenvolvidas em ambientes mais permeáveis ou integrados. A alternância de ambientes pelas crianças poderia ser importante em alguns momentos para evitar a monotonia e propiciar novos estímulos, provocando diferentes sensações.

A organização espacial de salas em corredores acaba também restringindo as possibilidades de caminhos e percursos a serem feitos, o que também reduz a variedade de escolhas oferecidas, de estímulos trabalhados, e aumenta o controle sobre o ir-e-vir das crianças, o que deixa de ser um incentivo ao desenvolvimento da responsabilidade e da autonomia das mesmas.

A implantação dos banheiros externamente às salas, por exemplo, ainda que existam pias internamente a cada uma delas, constitui-se como um simples, porém importante elemento que propõe a liberdade e exige a responsabilidade da criança em relação às suas ações e
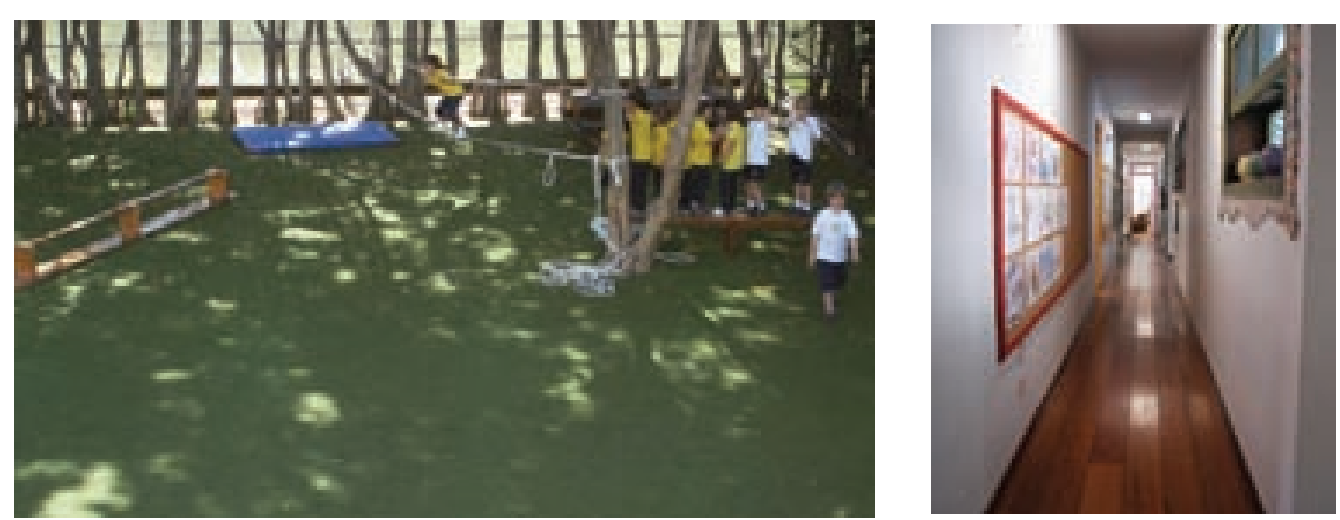

De um lado, as salas de aula voltam-se para o gramado (com exceção da sala turquesa, construída posteriormente, voltada para o lado oposto da escola); de outro, as salas (com exceção da sala laranja, localizada no térreo, logo ao lado do gramado), voltam-se para o corredor interno, estreito, que acaba se constituindo como local de passagem principalmente.
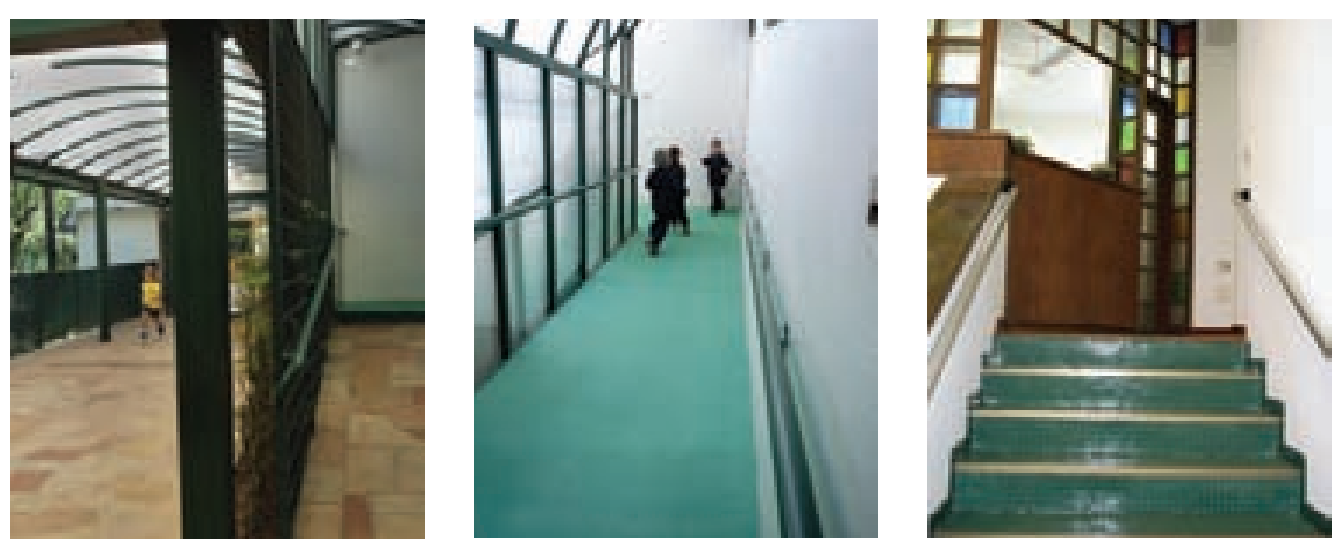

Rampas e escadas, internas e externas, que fazem a ligação entre pisos térreo e superior; à esquerda, no alto corredor das salas de aula: áreas estreitas e fechadas, direcionando o percurso; não há alternativas (a escada é principalmente utilizada pela equipe da escola, reservando-se as rampas para as crianças. 
comportamentos. A sala laranja (localizada no térreo) acaba prejudicada nesse sentido, pois os banheiros inferiores encontram-se do outro lado do edifício, ficando excessivamente distantes da mesma.

No térreo, as salas utilizadas pelas crianças em geral (sala laranja e sala de jogos dramáticos) têm acesso duplo (tanto pelos corredores internos quanto pelo "terraçocorredor" externo), o que é interessante, pois acaba criando uma permeabilidade dos espaços e possibilitando, conseqüentemente, uma maior variedade de caminhos a serem percorridos, uma maior dinâmica de fluxos e uma maior exploração dos espaços pelas crianças.
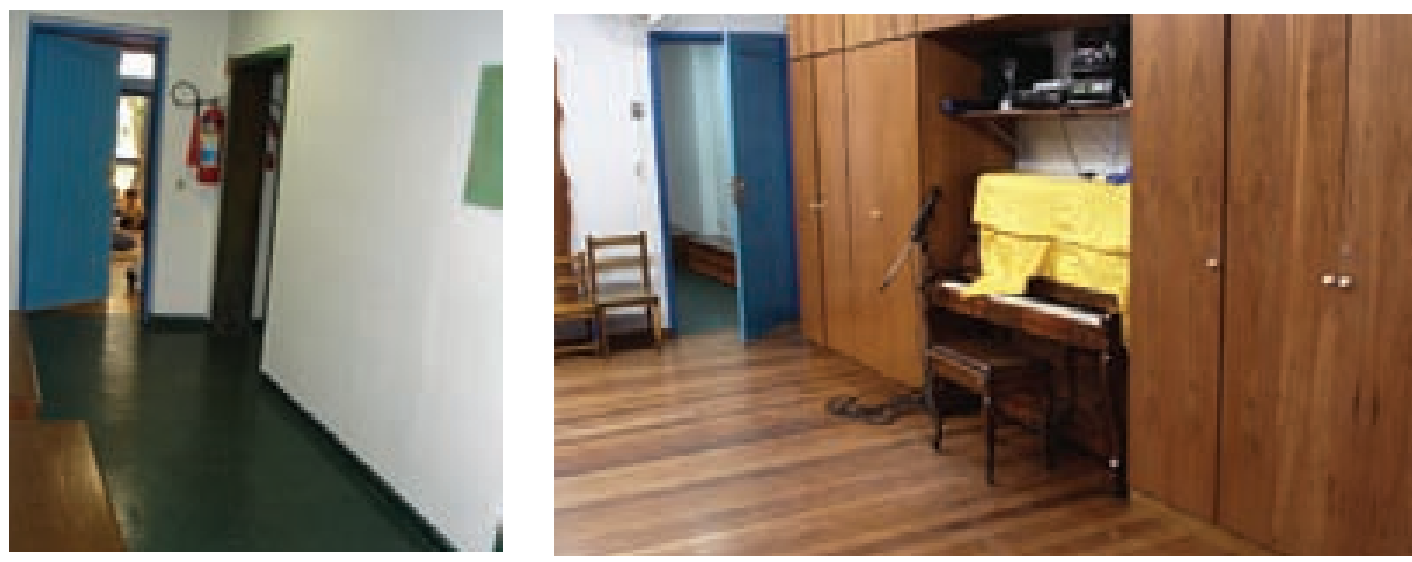

Da esquerda para a direita, de cima para baixo: corredor que dá acesso à sala pela parte interna do edifíco (porta azul, vispala de bibliotecal jogos dramáticos; ao lado, nota-se sutilmente a luz natural entrando pela lateral esquerda da sala, através das portas de vidro que dão acesso direto ao gramado: sala laranja: vê-se, ao fundo, porta de da escola; ao lado, vê-se esquadria e quadro laranjas, pertencentes à sala de mesma cor, que pode ser acessada também pelo terraço-corredor externo.
O jogo entre campos visuais diferentes é outro interes sante instrumento de criação de sensações diversas, condição que enriquece a experiência ambiental das crianças e qualquer usuário desse espaço. Os corredores (estreitos e fechados), nesse sentido, inseridos no conjunto dos espaços da escola, podem constituir-se como elementos de contraponto aos ambientes abertos, espaçosos e iluminados das salas de aula, por exemplo. Quando passam a constituir os únicos e apenas espaços de passagem, porém, têm sua presença empobrecida, pois passam a se monótonos, espaços sem novidade e já tão conhecidos que não despertam mais nenhuma atenção ou sensação.
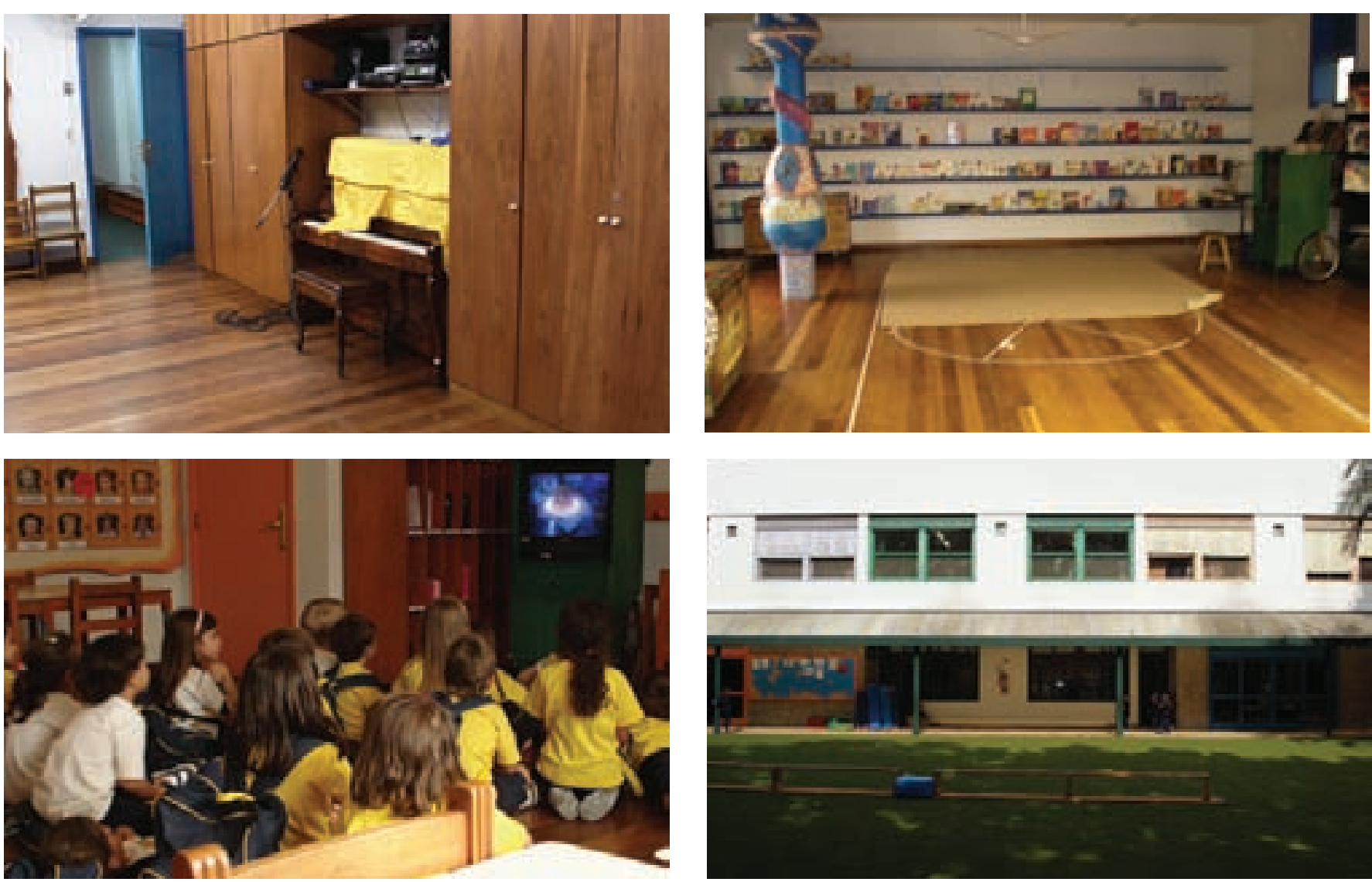
Processo semelhante acontece com os ambientes do gramado e da quadra, por exemplo. Constituindo-se como áreas abertas, com pequena existência de "cantos" ou elementos que as integrem, possibilitam uma leitura direta e fácil de seus espaços, os quais, portanto, uma vez vistos, são imediatamente desvendados. A quase inexistência de desdobramentos dos mesmos resulta em uma pequena variedade de campos visuais. Se, por um lado, isso facilita a compreensão e o domínio do espaço da escola e de sua organização, por outro, diminui sua riqueza ambiental, e a possibilidade de descobertas, surpresas e de experiências variadas.

De uma maneira geral, então, pode-se observar que a organização espacial linear da escola, a partir de corredores internos e fechados (no caso das salas), ou da implantação de espaços paralelos uns aos outros (como do gramado e da quadra, ao longo do edifício), acaba por enfraquecer ou diluir a integração entre as partes, seus usuários e as atividades aí desenvolvidas. Com a pouca variedade e a pouca variação de campos visuais, o espaço da escola acaba, assim, constituindo-se mais como um espaço de suporte e de controle das atividades desenvolvidas pelas crianças do que propriamente um ambiente estimulador da autonomia, da descoberta e da experimentação.

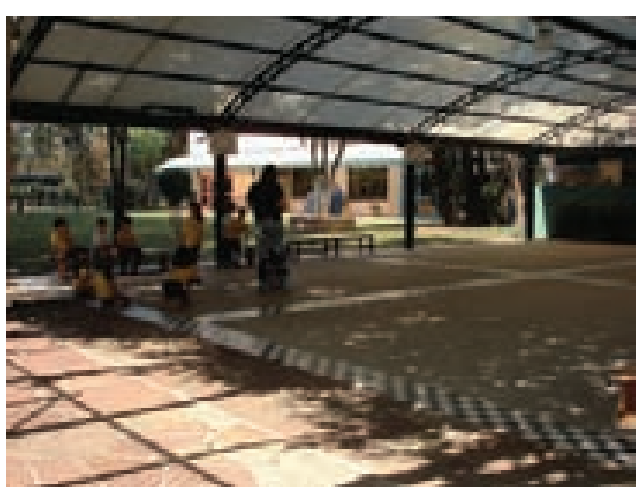

Vista da quadra, em primeiro plano e gramado, ao fundo: leitura imediata, visão completa do conjunto, ocorrendo abertura do campo visual na passagem de um para o outro em função da cobertura da quadra/descoberto do gramado.

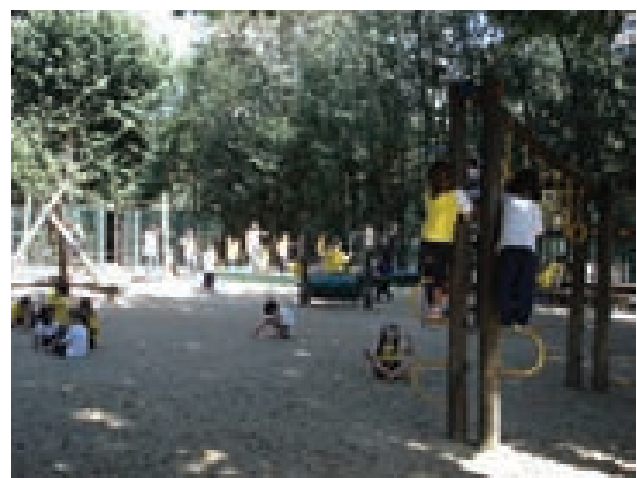

Vista do parquinho: leitura quase imediata: área quadrada/retangular não apresenta cantos claramente delineados, mas a disposição dos equipamentos acaba criando áreas mais abertas e áreas mais fechadas.

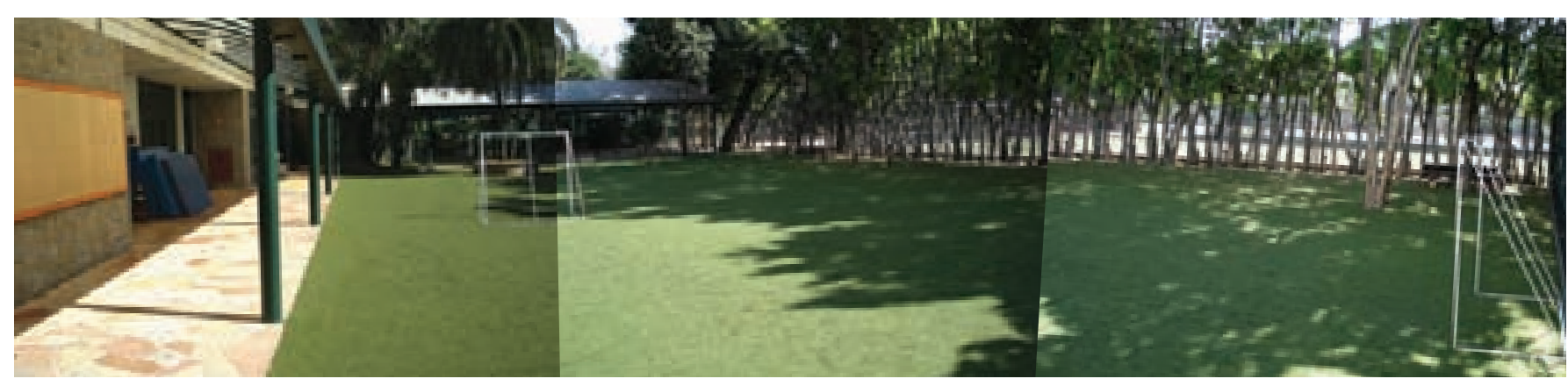

Vista do campo, no centro e à direita; da quadra, ao fundo; e do edifício, à esquerda: quase ausência de "cantos"; leitura quase imediata de todos os ambientes; alternância de campos visuais se dá pela presença ou ausência de coberturas e de algumas poucas barreiras visuais. 

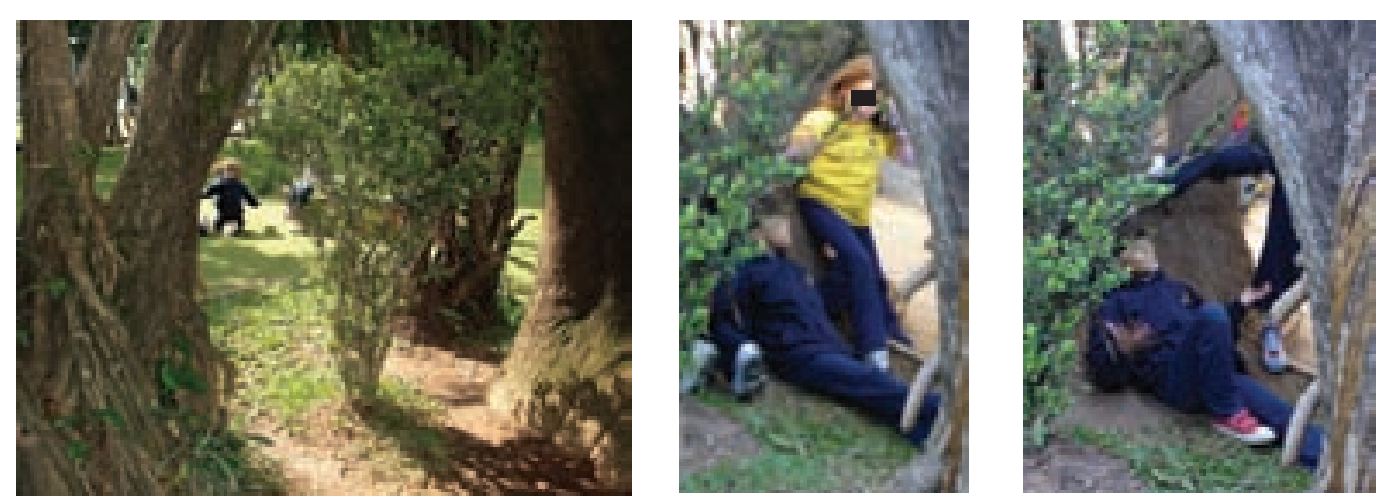

"Canto das árvores": "canteiro" de árvores mais robustas, que criam nichos mais sombreados e de pouca visibilidade - "escondidos", mais intimistas, mais acolhedores... uma área para descanso ou conversas em grupos menores, ou

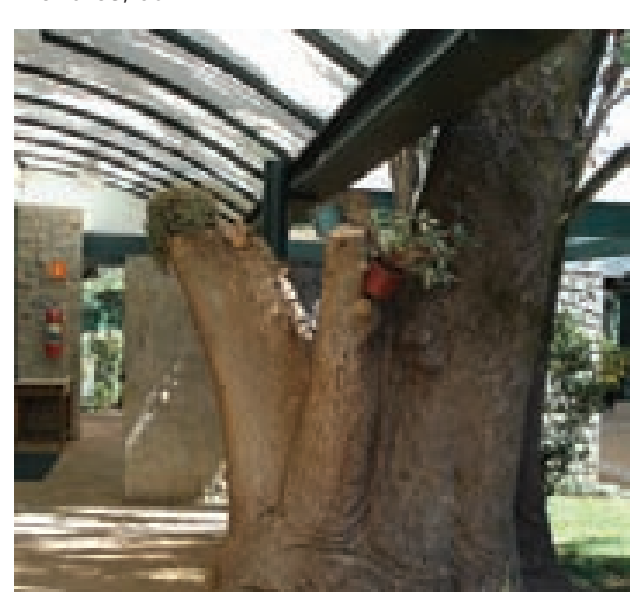

Visto pelo outro lado, o "canto das árvores robustas" cria um segundo ambiente, com a cobertur translúcida: uma área intermediária entre a amplidão do gramado, o "semi-aberto" do terraçocorredor e a intimidade do "miolo do canto das árvores" - outras luzes, outras sombras, outros pontos de vista, outros campos visuais; uma outra possibilidade de ambiente, que pode propiciar outras sensações e estimular outras atividades comportamentos.

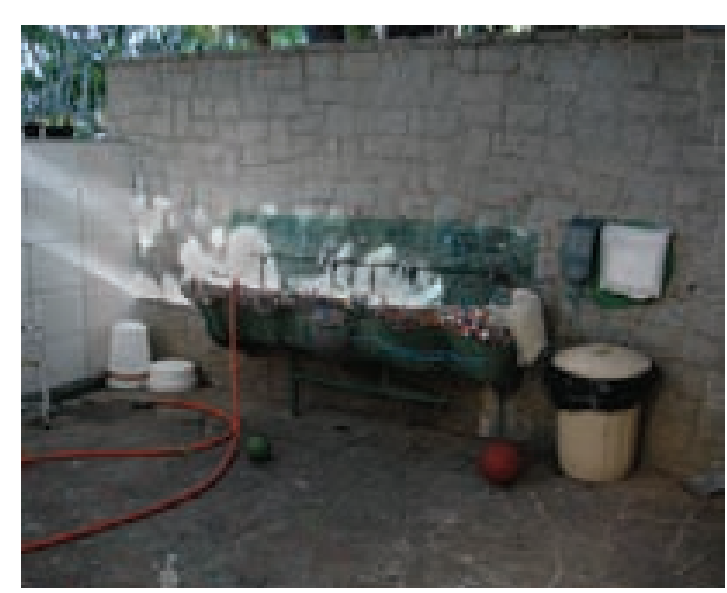

"Canto das artes": área adjacente à sala de artes, criada para o desenvolvimento de atividades como pintura, colagem, etc.: delimitada por paredes de pedra e azulejo. define claramente uma área à parte do restante do espaço externo (quadra e gramado, por exemplo); por ter uma artes), acaba sendo sub-utilizada no recreio ou em outras horas livres. função predefinida (trabalhos e projetos durante a aula de
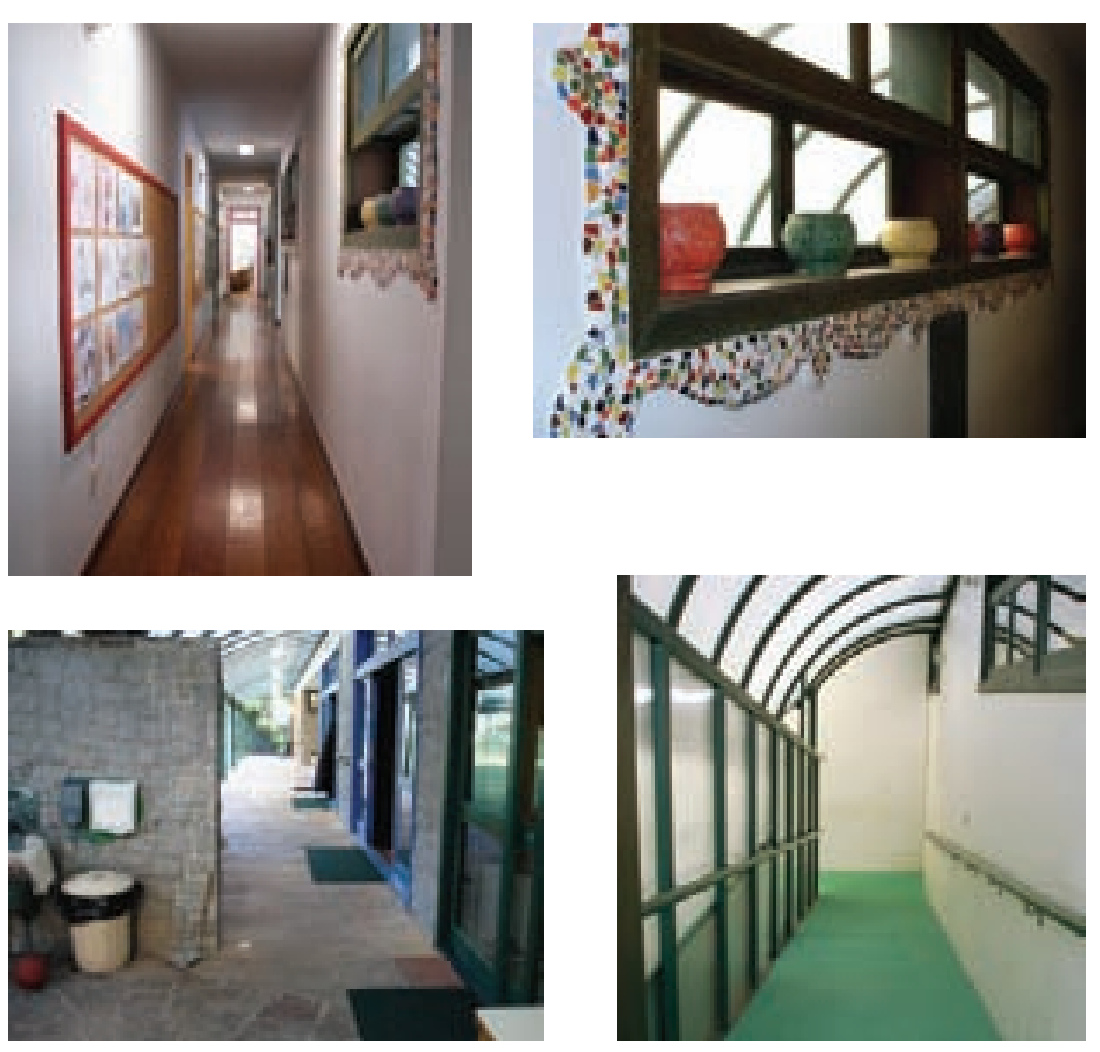

Algumas alternâncias de campo visual, luminosidade, amplitude espacial, etc resultantes de mudanças em pés-direitos, localização das janelas e aberturas em geral, fechamentos/vedações, barreiras visuais e de percursos.
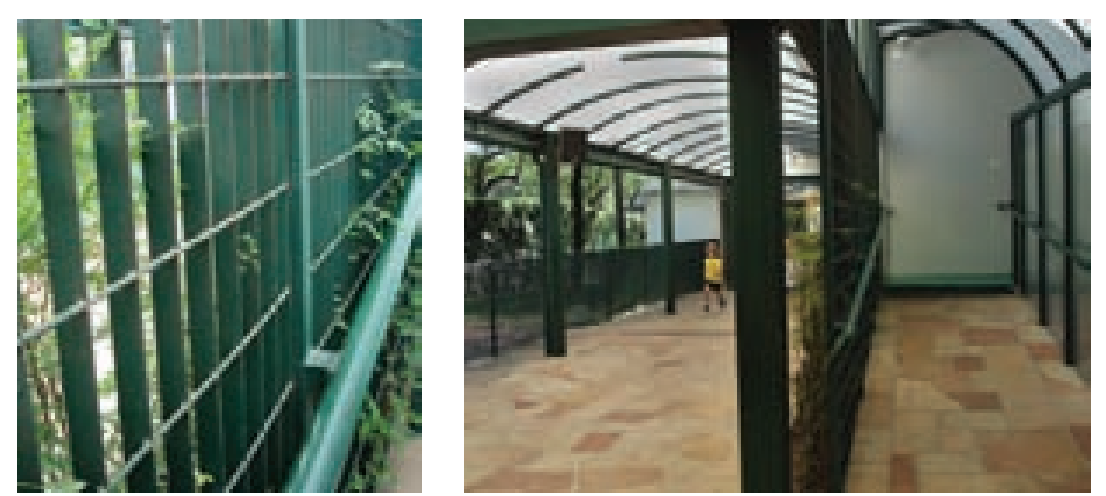
B. Clima e recursos do ambiente, arquitetura, materiais, equipamentos e brinquedos

Assim como a Escola Viva, a Escola Infantil Santa Cruz tem grande parte de seus espaços coletivos descobertos, promovendo um maior contato das crianças com materiais naturais (como árvores e areia, por exemplo) e também uma maior sensação de liberdade. Em dias de chuva, porém, o espaço das crianças acaba ficando restrito à quadra coberta e aos terraços-corredores.

Também em função das chuvas, e da intensa movimentação das crianças, depois de algumas tentativas de manter a grama natural da área do "gramado", a diretoria da escola decidiu substituíla por grama artificial, pois a primeira não resistia e acabava criando grandes espaços de terra, que se transformavam em grandes áreas lameadas. Apesar da existência do problema, perdeu-se aqui a oportunidade de explorar a diversidade de pisos. Mesmo utilizando a grama artificial, poderiam ter sido criadas áreas que possibilitassem diferentes experiências às crianças, não só físico-sensoriais (visuais, táteis e sonoras, etc.), como também com relação ao entendimento das diferenças entre materiais naturais e artificiais e suas implicações.

Ainda que toda esta área coletiva seja aberta e descoberta em grande parte, há uma clara definição de cada um dos seus ambientes, tanto pela presença de portas e portões, estruturas verticais e coberturas (grades na entrada do parquinho e cobertura sobre a quadra), como também pela diferenciação de pisos: o gramado, em grama artificial; a quadra, em pedra e azulejo, e o parquinho, em areia.

Se por um lado a diferenciação de pisos pode criar ambientações diferentes, enriquecer a experiência do usuário e orientá-lo no espaço, por outro, pode ser empobrecedora se passa a limitar as possibilidades de uso deste espaço ou se acaba criando delimitações muito definidas de cada área.

No Santa Cruz, isso acaba acontecendo em certa forma, principalmente em relação ao parquinho (cujo isolamento, porém, não acontece apenas em função do piso, mas acaba sendo reforçado pela grade e pelo portão que

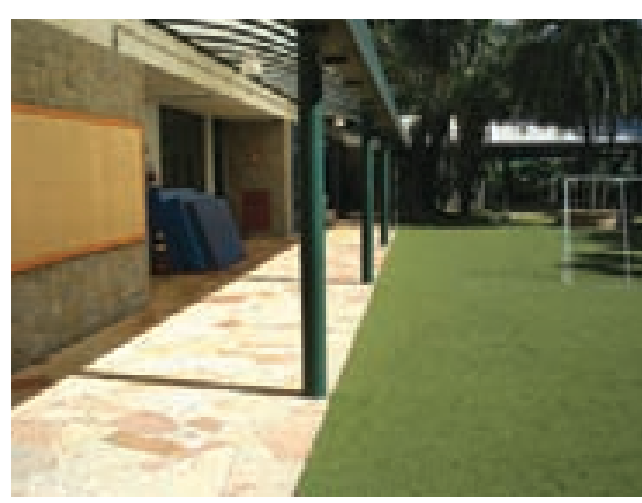

Delimitação dos ambientes por meio de pisos, portões, vegetação... (acima e ao lado: terraço-corredor: gramado; linha de árvores; abaixo: separação do parquinho por meio de portões e gradis).
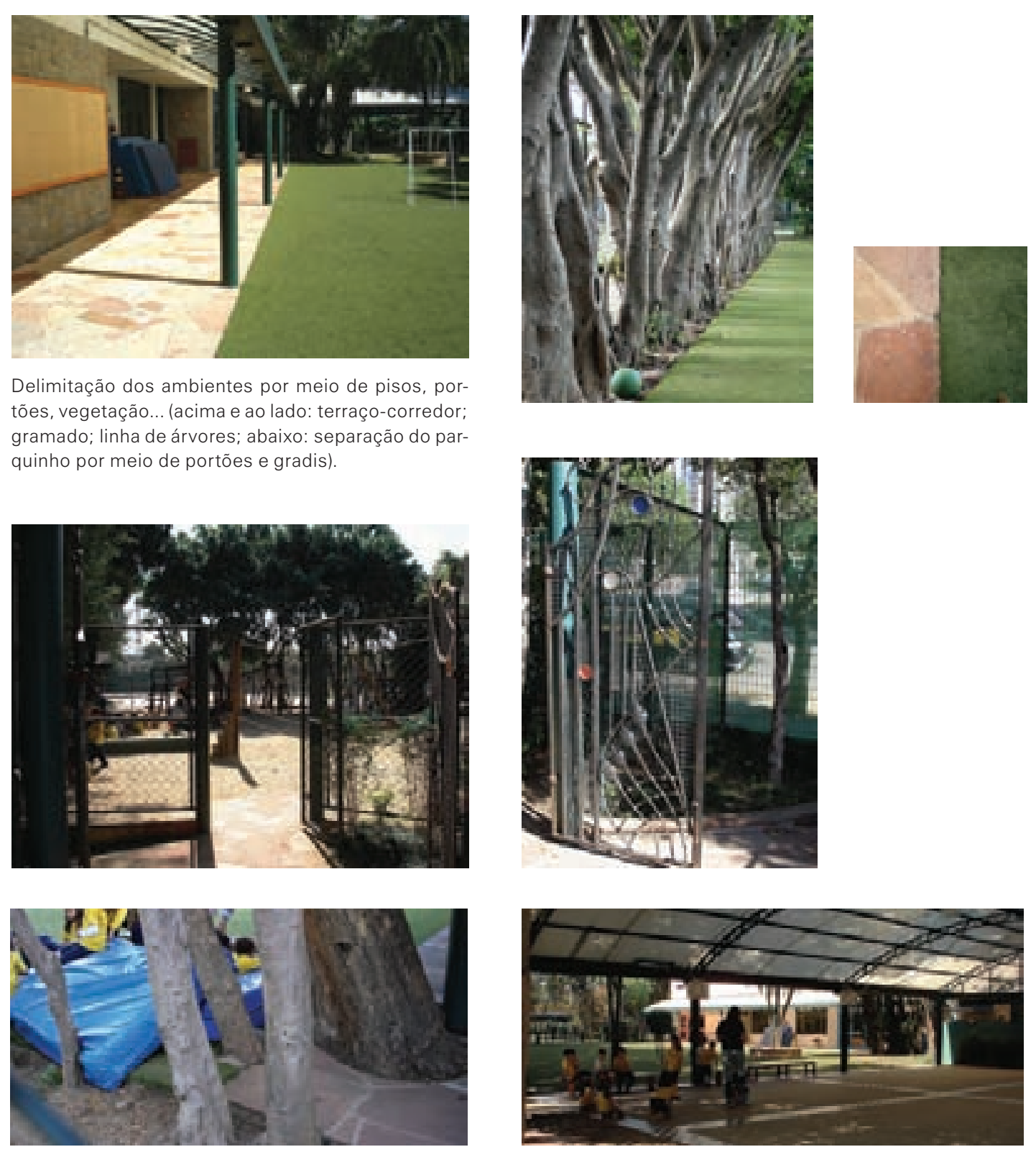

Delimitação exata dos limites do gramado, da quadra e da faixa intermediária entre estes dois ambientes e o parquinho; diferenciação do gramado para a quadra se faz tanto pelo piso quanto pela cobertura. 
o separam do restante do espaço da escola). Sendo projetado para utilização tanto pela educação infantil quanto pelos primeiros anos do ensino fundamental, o parquinho foi cercado e fechado com dois portões que dão acesso a dois lados diferentes do terreno (um para cada escola). Apesar desta problemática, poderia se ter pensado em expandir esse conceito de ambiente - ao invés de concentrálo em uma única área cercada - espalhando equipamentos e desafios físico-motores por toda a escola. A presença destes junto a outros desafios e elementos estimuladores sensório-motores poderia aumentar a complexidade do ambiente da escola como um todo, de forma conjunta e harmônica, não delimitando uma única área onde as crianças exercitassem suas habilidades ou desenvolvessem esse tipo de atividade. Mesclar equipamentos de finalidade "predefinidas" (ponte, trepa-trepa, etc.) e elementos cujos uso e função não são muito bem definidos ou abrem mais de uma possibilidade de leitura pode estimular a in terpretação e apropriação pessoal de cada criança e do grupo, que pode recriar e reinventar cada uma das situações e propostas ali colocadas - e sempre o faz!, como podemos observar nas fotos a seguir.
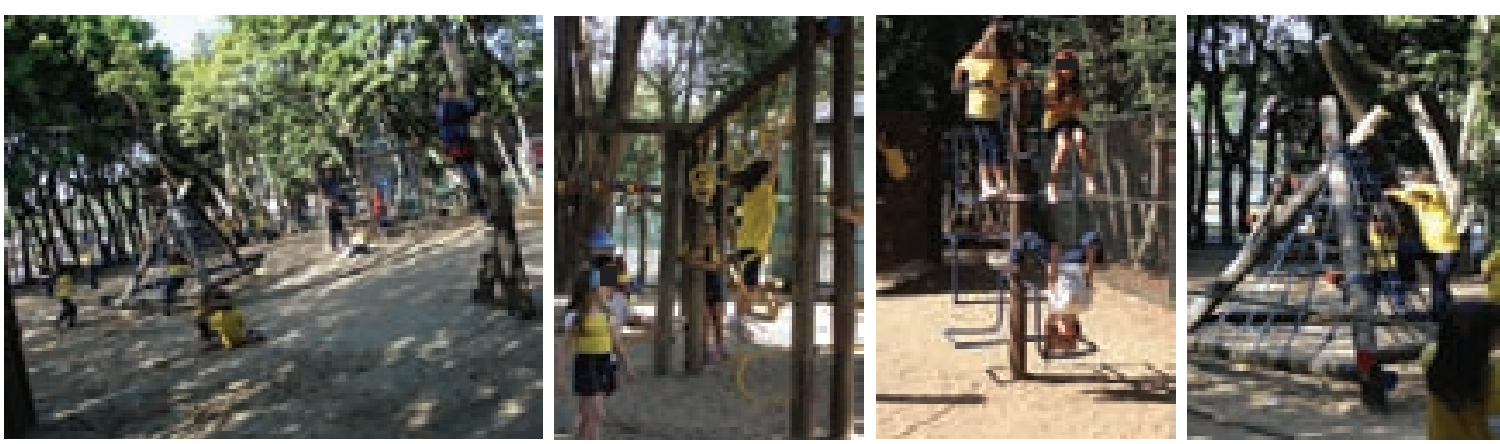

A maior parte dos equipamentos que oferecem desafios às crianças encontra-se delimitada na área do parquinho...

mas assim como as crianças apropriam-se de alguns equipamentos de diversas formas (diferentes das funções para as quais foram "previstas" pelos projetistas), ou desafiam as restrições colocadas pelos mesmos.
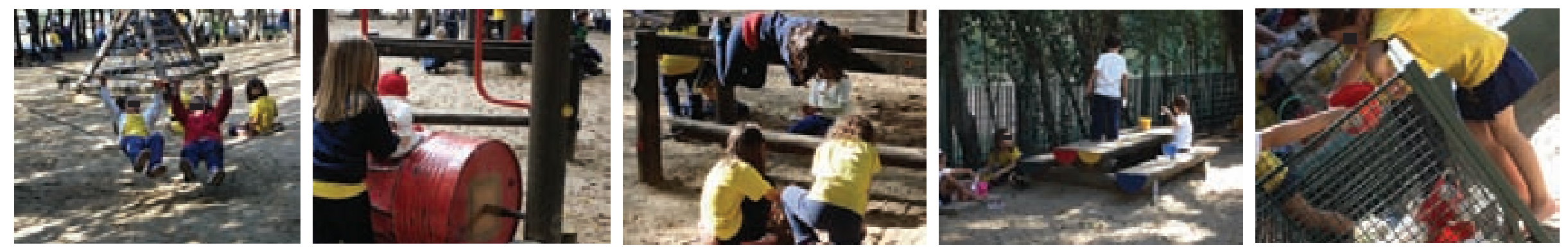

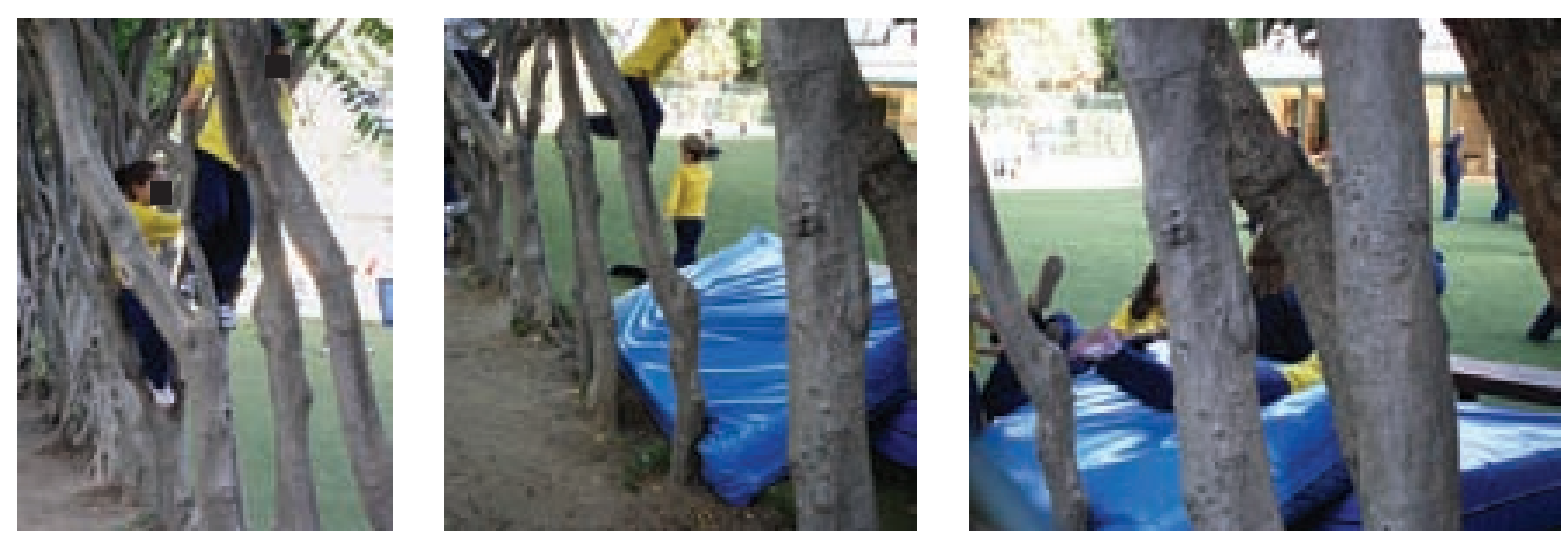

Sem dúvida, outros espaços e elementos da escola também oferecem desafios e possibilitam atividades sensório-motoras, como as árvores existentes no terreno e bancos e outros elementos disponibilizados pelos professores. Muitos dos desafios acabam sendo criados justamente pelas ações "transgressoras" das crianças, que tentam subir nas grades e mesas, ou no aproveitamento por estas de situações criadas ao acaso (pular das árvores para os colchões deixados pelo professor), pois as situações propostas pela escola ainda aparecem de forma muito pontual e isolada: a fileira de árvores ao longo de uma das bordas do terreno, ou o "canteiro" mesmas trampolins!
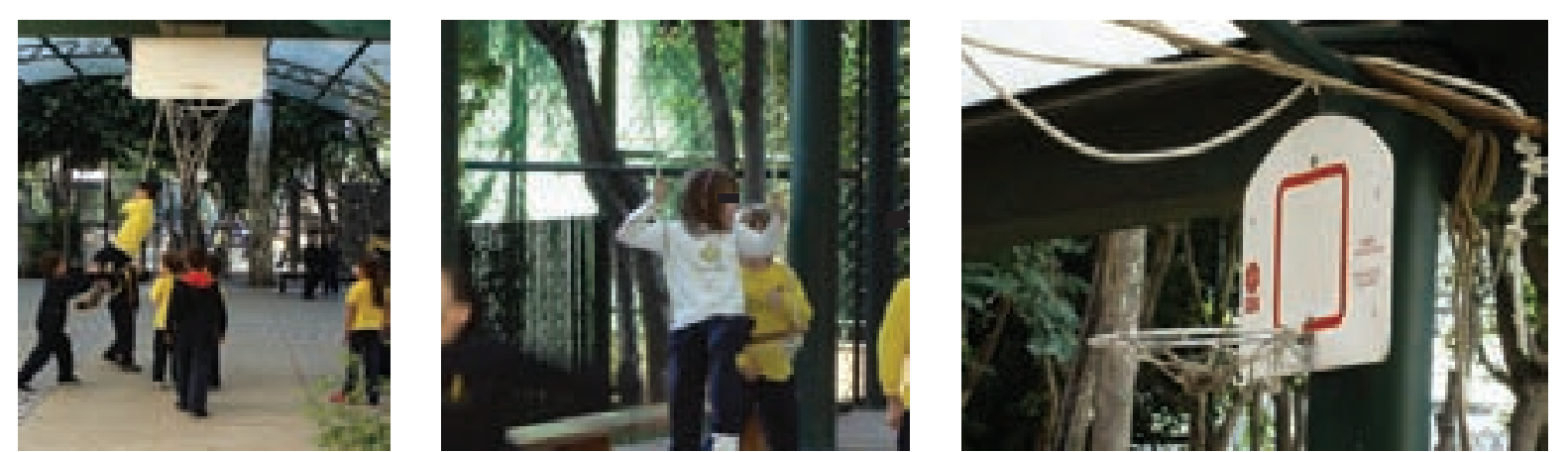

onde se encontra um conjunto pequeno de árvores

mais robustas, formando algumas áreas de sombra e pouca visibilidade, por exemplo.

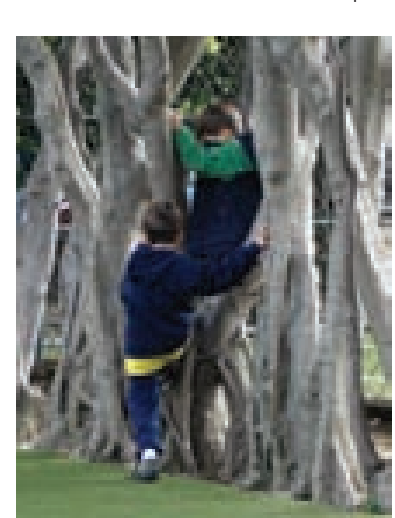

Árvores e grades como desafiadores emaranhados a serem escalados.

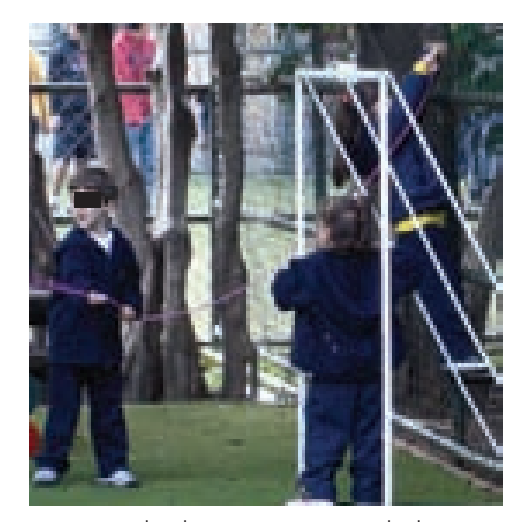

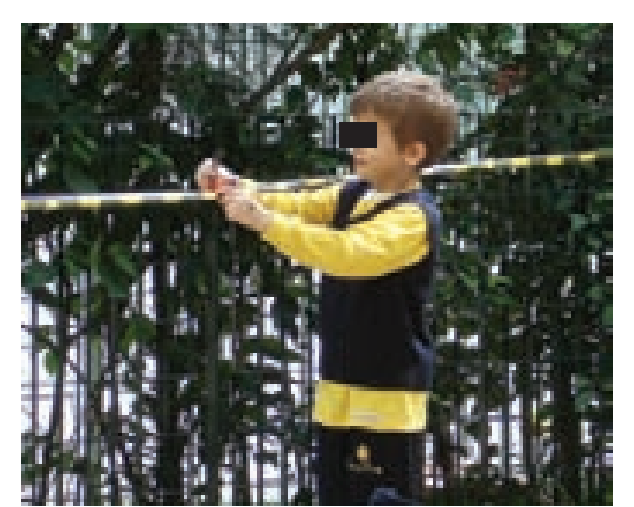

Bancos e faixas de obra que se transformam em casas, armários, e pistas de corrida no ar.

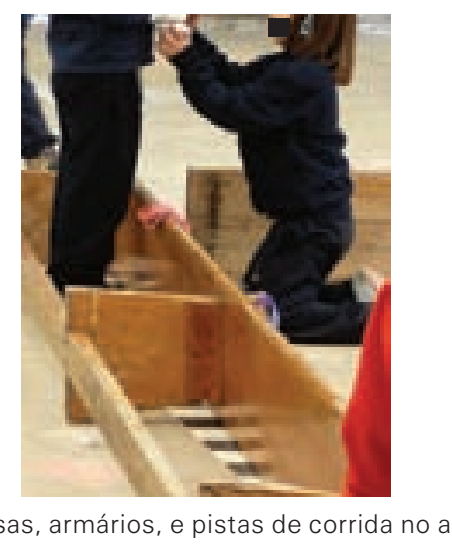


A diferenciação de pisos e o desnivelamento dos mesmos poderiam ser também uma interessante ferramenta para proporcionar desafios motores, criando pequenas dificuldades ao longo dos percursos das crianças (sem deixar de considerar a segurança necessária). No entanto, isso é pouco explorado na escola, aparecendo apenas na transição entre o gramado e o piso de terra e entre este e a quadra. O gramado, sendo artificial, apresenta superfícies regulares e bordas bem definidas. Já o piso de pedra do terraço-corredor e da quadra apresenta uma rugosidade e uma irregularidade maiores, mas mantêm o mesmo nível em toda a área. As mudanças, portanto, são só realmente sentidas pela diferença de maciez, rugosidade e atrito dos materiais e no pequeno desnivelamento que acontece na passagem dos três (gramado, terraço-corredor e quadra) pisos para o piso de terra e entre este e o parquinho, com piso de areia.

Além dos desafios motores, vários podem ser os elementos que estimulam os sentidos e a percepção da criança,

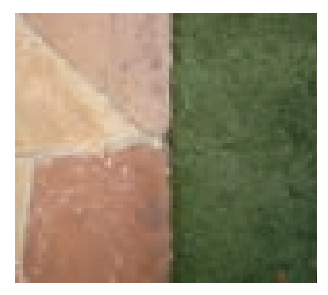

Junção terraço-corredor, gramado artificial e quadra.
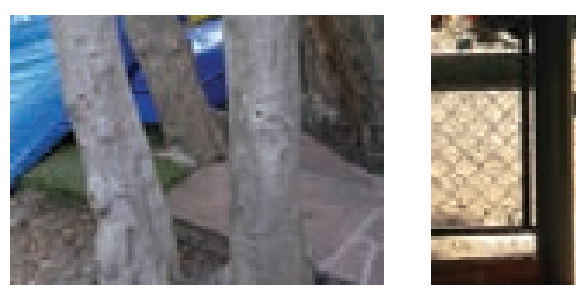

Piso de pedra e de areia.

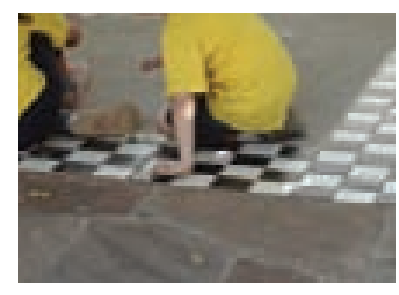

Pedra e azulejo na quadra. como a alternância entre espaços abertos e fechados, estreitos e largos, altos e baixos; o jogo entre visibilidade/ não visibilidade, acesso/restrição, contato/separação; a diferenciação de acabamentos, fechamentos e coberturas, a variação das nuanças de luz/sombra, transparência e opacidade, entre outras coisas.

Até mesmo a natureza, a vegetação de forma geral, pode passar a ser equipamento, quando também integrada aos brinquedos, mobiliários, equipamentos ou mesmo cercados e muros, criando assim situações "híbridas" e de inter-relação entre artificial e natural, construído e existente. No Santa Cruz, porém, ainda acontece de forma tímida essa integração entre natureza e elementos artificiais e/ou construídos industrialmente. Faz-se bastante uso da madeira em equipamentos, mobiliário e brinquedos, em que esta aparece sob diferentes aspectos e acabamentos; porém, o jogo entre natural e artificial, ou o reaproveitamento de materiais recicláveis, sucatas, etc. acaba ficando restrito às atividades em aula e ateliê.
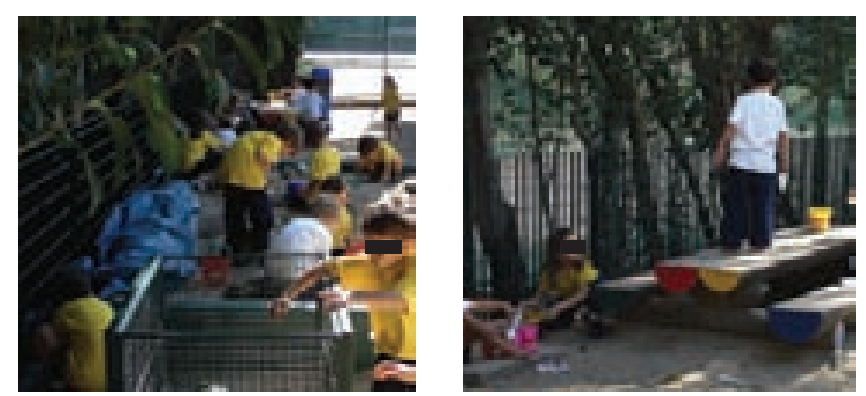

No parquinho, a natureza fica de fundo, contornando externamente área, sem dialogar diretamente com os equipamentos.

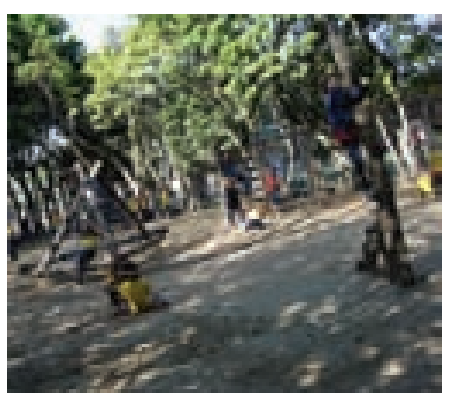




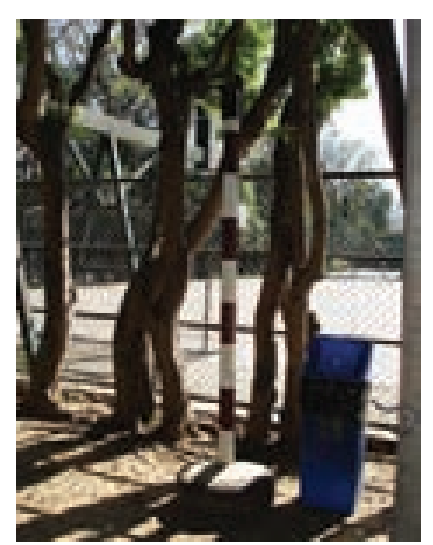

Ainda no parquinho, a cesta de basquete, isolada das árvores, com um suporte independente; a idéia do "cesto", ou do desafio, poderia ser explorada nas próprias árvores.

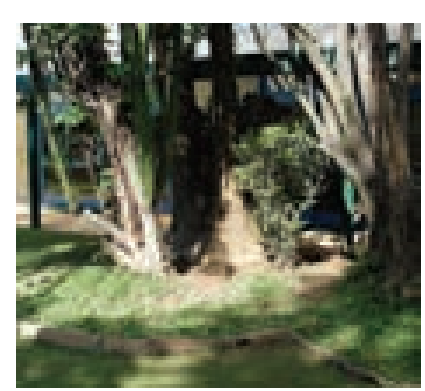

"Cantinho das árvores": um pouco mais integrado aos espaço-ambientes da escola, ainda encontra-se claramente contid "canteiro", delimitado por pedra lapidadas.
lanteiro",

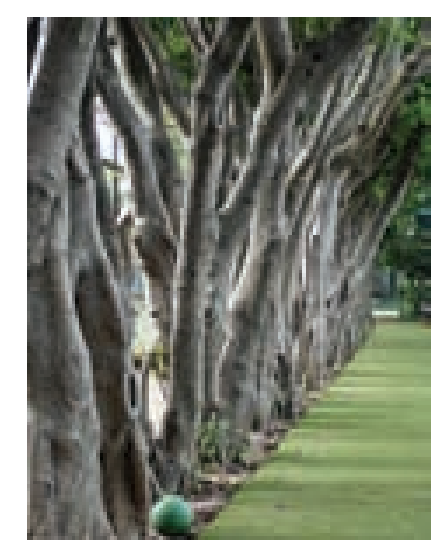

Uma fileira de árvores disposta ao longo do gramado. toda a vegetação encontra-se nas bordas das áreas do gramado, da quadra ou do parquinho; raramente integra-se a elas, apenas as "acompanham" e as ambientam.

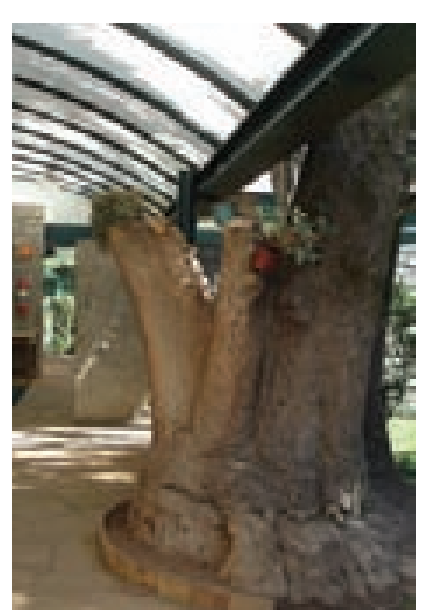

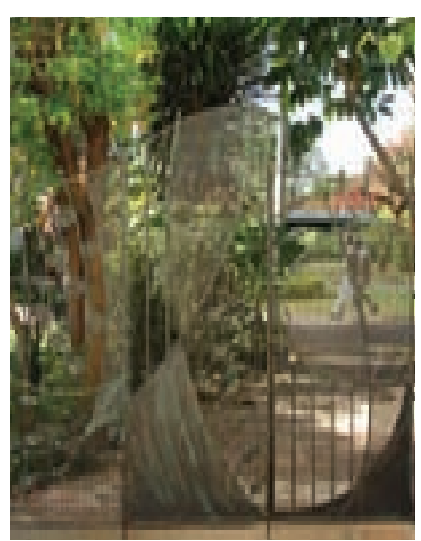

A natureza como pano de fundo, e referência visual para o trabalho orgânico fortemente presente na arquitetura-ambientação da escola (na foto, portão projetado a partir das referências de Gaudí e da natureza).

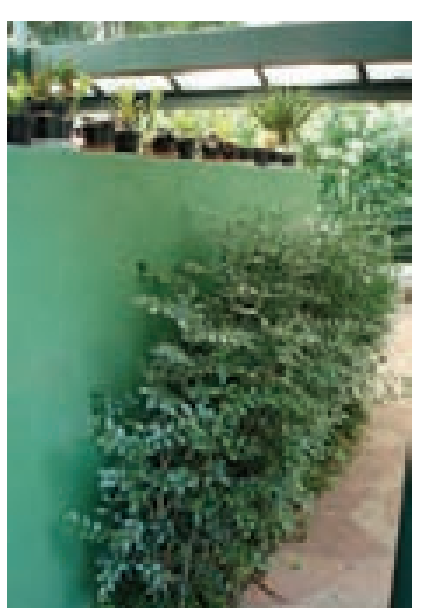

A combinação de elementos naturais e artificiais ou de proveniências diferentes é importante, pois resulta em uma maior variedade de possibilidades de construções e composições, e enriquece o repertório das crianças e dos usuários da escola em geral, levando para as experiências do dia-a-dia uma variedade de materiais, cores, texturas, formatos, acabamentos, encaixes, estruturas, odores, temperaturas, etc. E pode ainda fomentar a discussão sobre recursos da Terra, a proveniência dos mesmos, o ciclo de vida de cada material, e sobre os fenômenos físicos em geral.

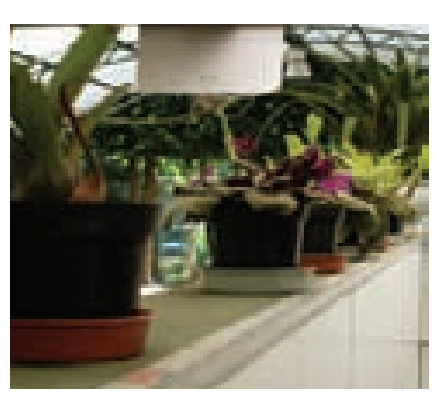

Canteiros e vasos de flores: a ve getação tem seu lugar definido na paisagem da escola: sempre junto a bordas do terreno ou a equipamentos que delimitam áreas diferentes ou de transição. 

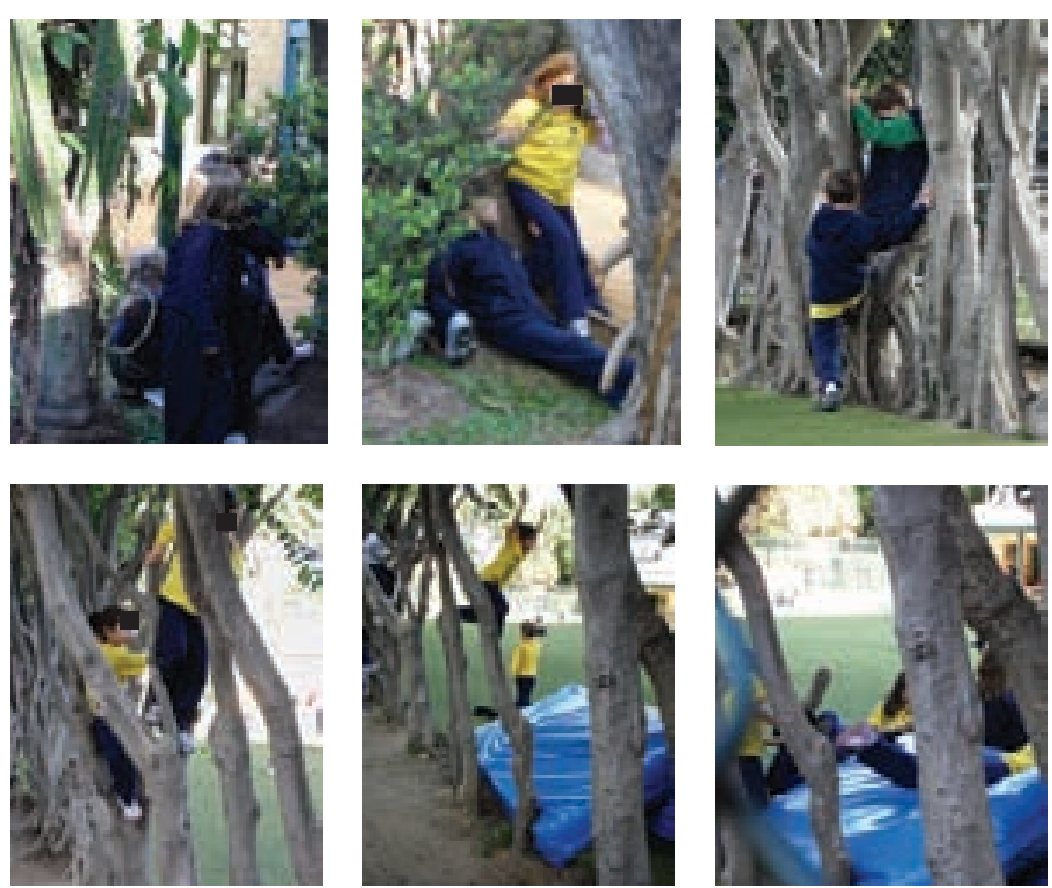

A natureza é um rico elemento a ser explorado pelas crianças. Nos seus galhos e plantas irregulares e mutantes, há sempre algo novo a ser descoberto.
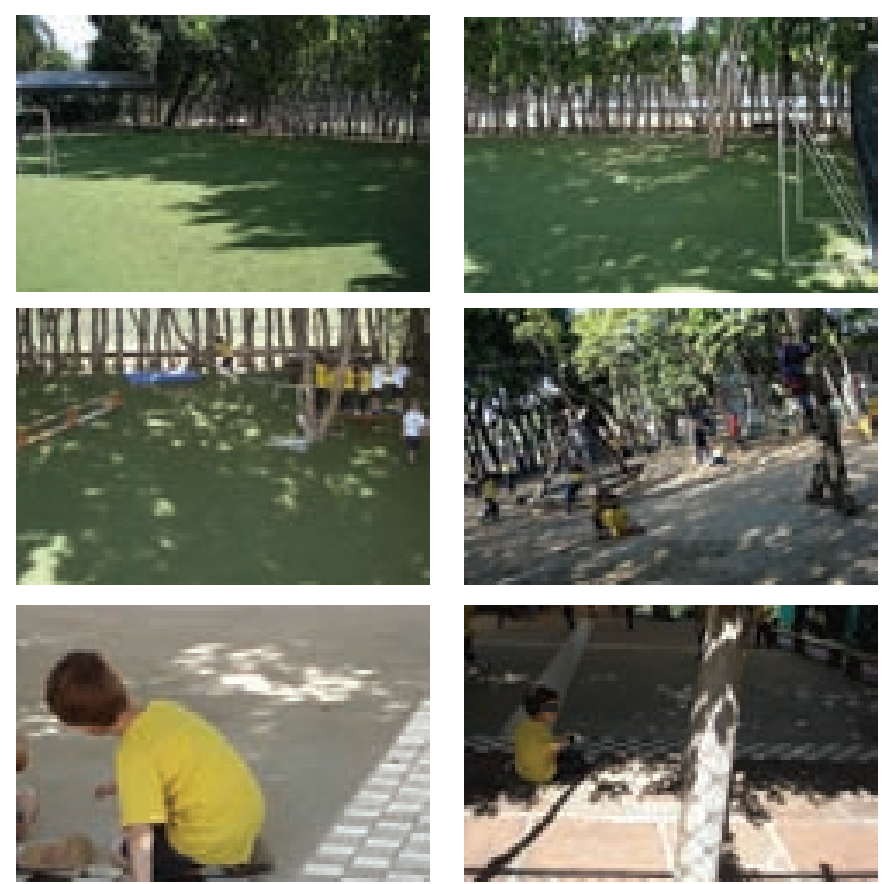

Os diferentes jogos de sombra e luz criam ambientes e sensações diferentes, assim como formam interessantes desenhos.

Além de "equipamentos", as árvores e plantas podem também ser exploradas de forma a criar diferentes ambientes, trabalhando escalas, aberturas/ fechamentos, luminosidade/ sombreamento diversos, por exemplo. Um aspecto interessante é o efeito que surge quando folhas e plantas caem das árvores e depositam-se sobre as coberturas translúcidas dos corredores externos. Esse jogo, assim como o que acontece quando as plantas se entre laçam e se mesclam com as estruturas metálicas vazadas que acompanham as rampas, por exemplo, é um simples e enriquecedor modo de transformar os ambientes, pois possibilita a formação de diferentes "paisagens" que mudam conforme o tempo, ora permitindo maior luminosidade ou visibilidade, ora criando ambientes mais fechados ou mais sombreados, mais ou menos "cheirosos", mais ou menos "texturizados", etc. 

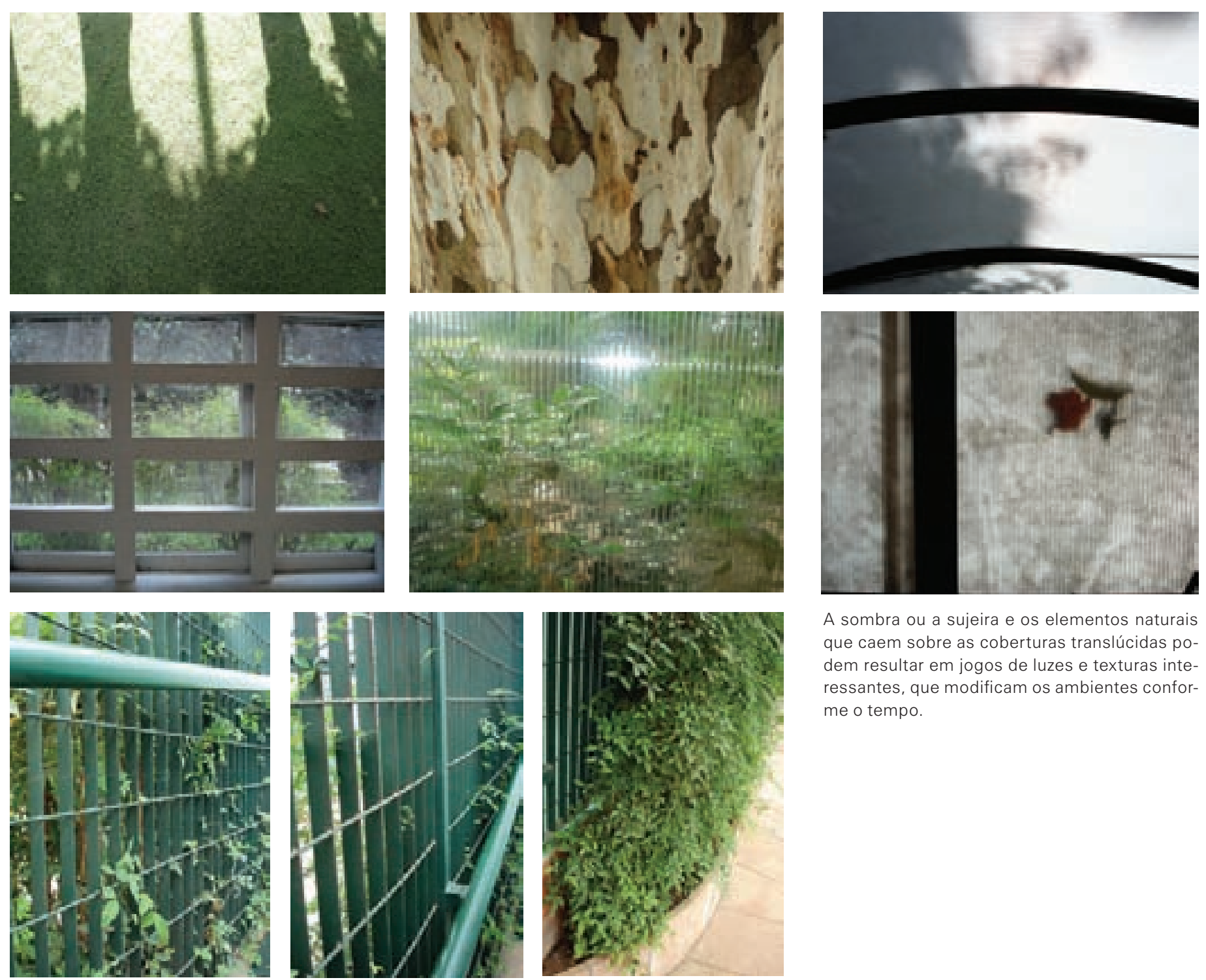

A sombra ou a sujeira e os elementos naturais que caem sobre as coberturas translúcidas podem resultar em jogos de luzes e texturas interessantes, que modificam os ambientes conforme o tempo.

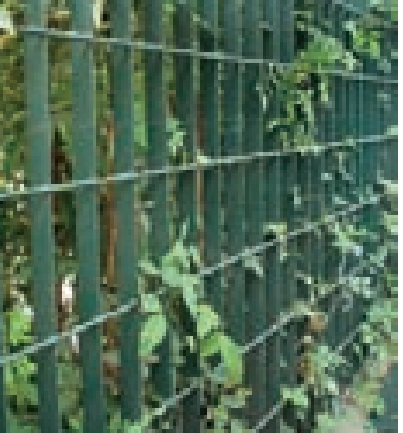

Riqueza de texturas, cores e luzes, ampliada com a mescla de elementos naturais e artificiais; criação de diferentes ambientações e sensações por meio do jogo de transparências, de elementos vazados e elementos fechados e opacos; avanço ou contenção da natureza, criando texturas, ampliando ou reduzindo/confinando ambientes e passagens. O trabalho com a vegetação pode criar diversidade e enriquecer o ambiente da escola. 
De um modo geral, portanto, podemos constatar que desafios físico-motores, assim como estímulos sensoriais (visuais e táteis, principalmente) estão presentes na escola. Porém, percebemos que estes se encontram na maior parte das vezes delimitados, isolados em áreas específicas e previamente direcionados: o gramado é um campo aberto, sem cantos nem esconderijos; as árvores encontram-se alinhadas; os equipamentos como ponte, trepatrepa, etc. estão concentrados em um "parquinho" fechado. Todo o espaço é facilmente visualizado, compreendido e apreendido rapidamente, e poucas são as surpresas que se pode encontrar. Já se sabe onde estão os desafios, as barreiras, as fronteiras.

A importância de criar um ambiente escolar mais rico e complexo parece, então, ter aparecido mais claramente como intuito da equipe da escola na proposta de seus espaços internos. De modo diferente do espaço externo, para os espaços do edifício da escola foi desenvolvido um projeto de ambientação.

Inspirado no trabalho dos arquitetos Antoni Gaudi (catalão) e Friedensreich Hundertwasser ${ }^{2}$ (austríaco), o projeto de ambientação, desenvolvido pelo arquiteto J.C.
Serroni em diálogo com a diretora da escola, procurava fugir ao padrão mais comumente usado nas escolas, com paredes de cores frias e linhas retas. O uso das cores apareceu, então, segundo a diretora, como uma forma de criar um espaço que estimulasse a criatividade, permitindo a vivência, por parte das crianças principalmente, de uma liberdade de traçado e de forma, e de um universo inusitado. Pretendia-se criar a "surpresa", romper a previsibilidade por meio do jogo lúdico, combinando diversidade e surpresa com precisão e organização (Plano Diretor 2007 p.22). Por isso, então, as referências de Gaudi e Hundertwasser e, conseqüentemente, do trabalho de mosaicos e de formas orgânicas.

Além das salas, as quais analisaremos detalhadamente em tópico a seguir, o corredor superior e todos os banheiros foram "ambientados" a partir desse conceito. No corredor, apenas as janelas tiveram seus batentes rodeados de mosaicos. Já nos banheiros, o trabalho de cores e formas se espalhou por quase todas as superfícies, indo do chão até as paredes, até uma altura acima da estatura máxima das crianças (com exceção do piso interno aos boxes, revestidos de azulejos em cores neutras).
2 Friedrich Stowasser, mais conhecido pelo nome de Friedensreich Hundertwasser, era pintor e arquiteto, tendo exercido grande influência na arquitetura orgânica moderna.
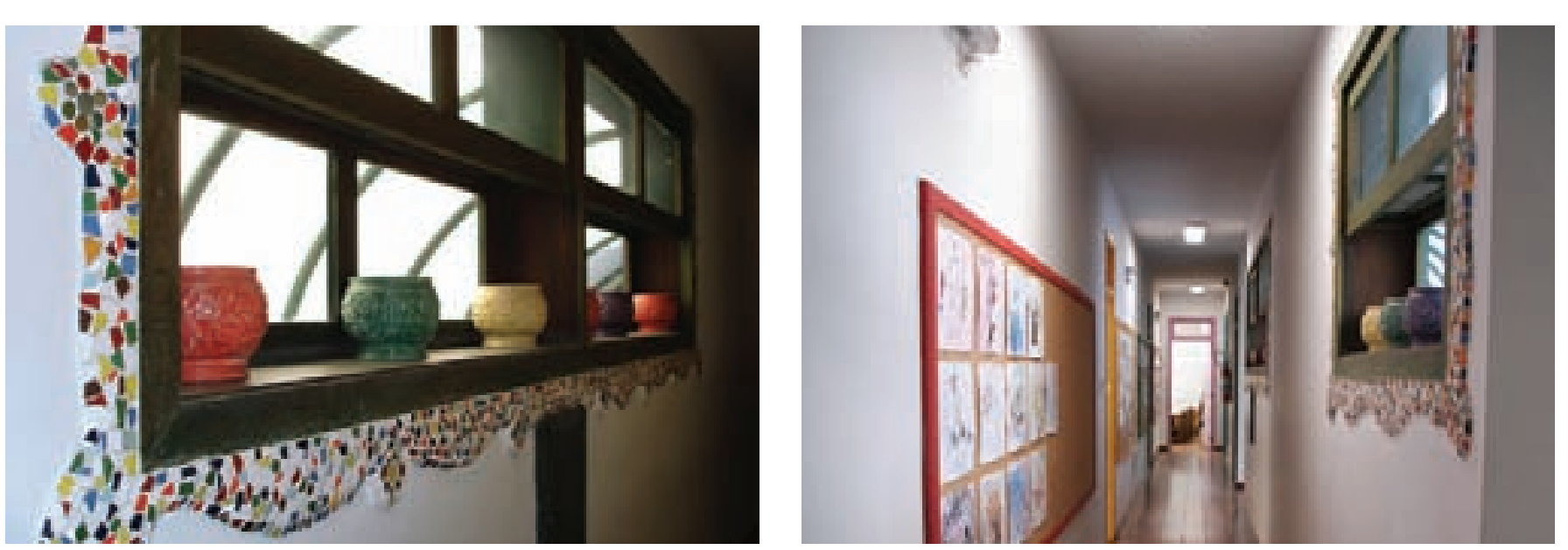

Batentes rodeados pelo trabalho de mosaicos, compondo também com o jogo de vasos coloridos. 
Cada banheiro foi trabalhado mesclando a cor branca com mais uma ou duas cores semelhantes, em suas diferentes tonalidades, o que pode ser interessante para auxiliar na identificação dos mesmos pelas crianças. Junto ao mosaico de cacos, foram fixadas também pequenas peças figurativas em forma de peixes, que se destacam em alto relevo ao longo da linha limítrofe do mosaico na parede. Nos banheiros externos, no piso térreo, foi criado um espaço intermediário, com três pias, semi-fechado por duas paredes baixas (acima da estatura das crianças), trabalhadas com a mesma linguagem, mesclando uma pintura manchada com o jogo de cores do mosaico.
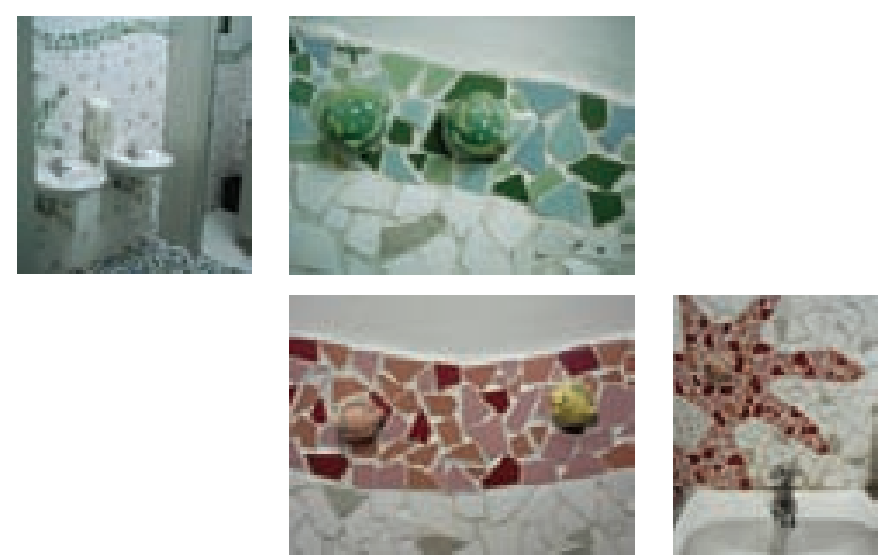

Banheiros internos: diferenciação de cor entre meninos e meninas trabalhada nas peças de mosaico, que formam figuras orgânicas lembrando formas da fauna e da flora marítimas.
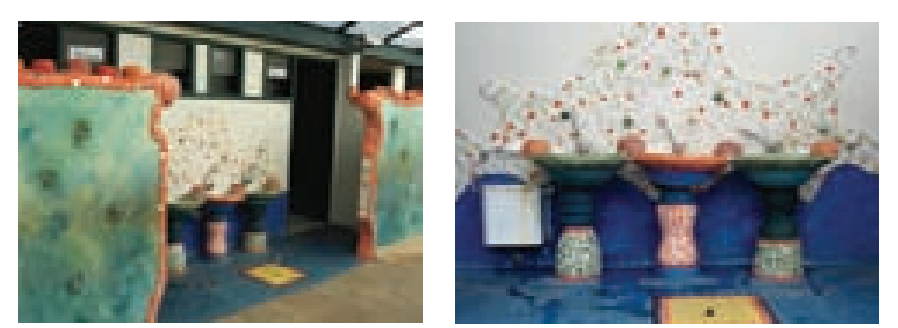

Banheiros externos: com dois anteparos que criam um ambiente intermediário, com as pias, e que marcam, juntamente com o piso, a passagem para um "outro universo", da fantasia e do lúdico.
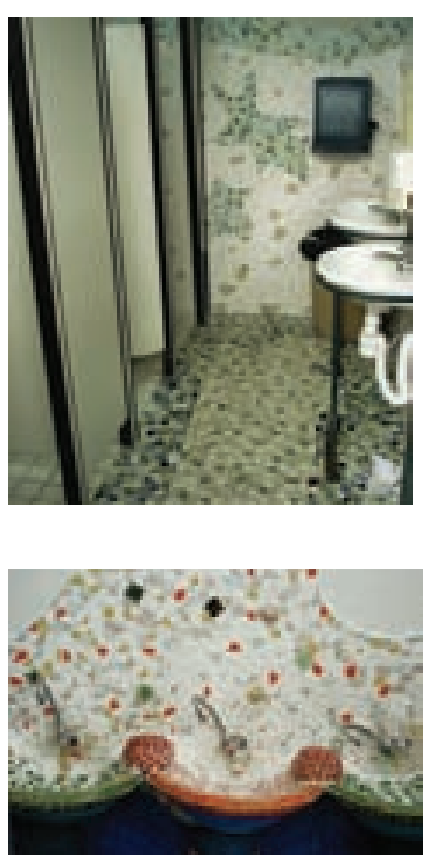

Detalhe dos banheiros externos: trabalho de mosaico mesclado com pintura manchada, que traz, em diálogo com o piso, o universo da água (e a sensação de se entrar nele), por meio das cores azul e verde e suas diferentes tonalidades.

De forma geral, podemos observar que, ainda que tenha existido uma preocupação em criar diversidade de referências visuais e de atividades, o projeto da Escola Infantil Santa Cruz acabou resultando em uma pequena complexidade ambiental. A preocupação com o espaço existe e é visível, porém, como a própria escola coloca, este é apenas um "habitat" da educação proposta. Tem-se a consciência da importância deste no processo de desenvolvimento da criança e procura-se trabalhá-lo de forma a estimulá-la. No entanto, os ambientes resultantes acabam limitando-se a dar suporte às atividades, e constituem-se principalmente como referência visual para as mesmas. 

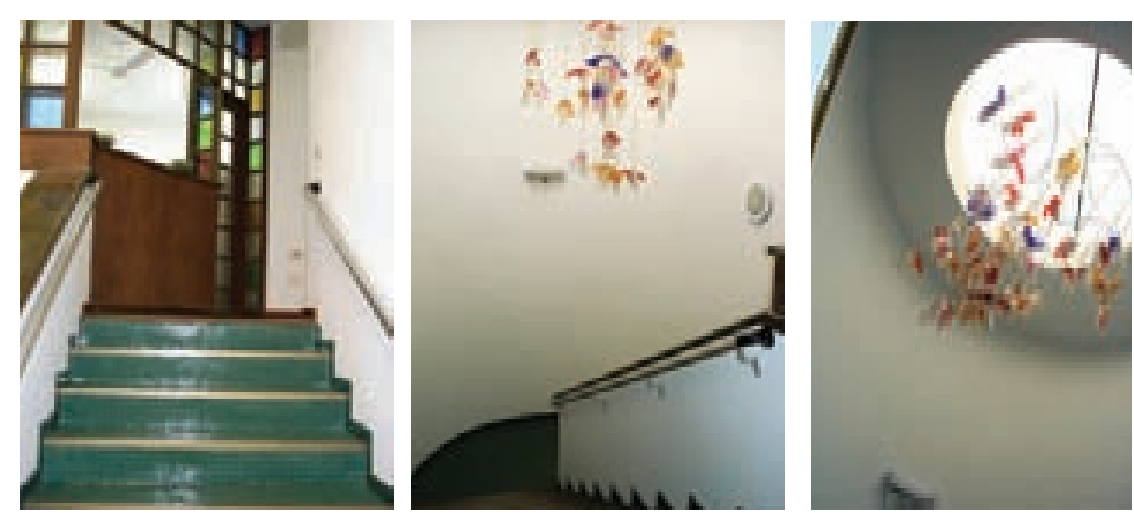

Escada interna: considerado apenas espaço de passagem, esse ambiente, assim como as rampas, acabou não sendo trabalhado pelo arquiteto com a linguagem de mosaicos. Porém apesar do contraste com o restante do edifício, com paredes brancas, sem intervenção alguma, seja das crianças seja dos professores, neste espaço foram explorados alguns princípios, como o jogo de cores e materiais, no piso da escala (madeira lisa-borracha texturizada), no fechamento da área de apoio (na foto à equerda, na parte superior), feito a partir da composição entre madeira e vidro transparente, colorido e incolor, e no móbile fixado sob a elementos acabam perdendo força, pois são pouco vivenciados pelas crianças. Ao mesmo tempo em que proporcionam um "silêncio" e uma quebra de ritmo na explosão de cores e formas de mosaicos, parecem constituir um ambiente à parte, e secundário em relação às salas de aula.
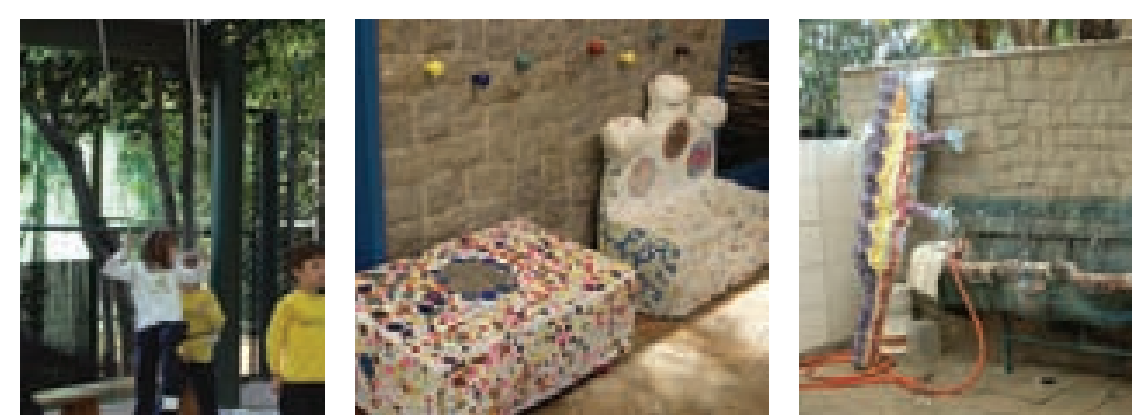

Brinquedos à disposição das crianças durante o horário de recreio: fantasias e materiais da aula de educação física, como bancos e cordas, são apropriados pelas crianças de formas diversas; aqui já podemos observar uma maior intervenção das crianças no espaço e uma maior liberdade de manipulação e de re-interpretação das funções dos objetos e equipamen tos; ao lado, objetos projetados e feitos com as crianças: forte referência à linguagem visual presente nos espaços da escola.
A interferência das crianças no espaço acaba se dando, então, essencialmente nos momentos em que ali desenvolvem algum tipo de atividade (livre ou orientada), porém aquela não se mantém presente, a não ser por meio de algumas peças produzidas nas aulas de artes, como bancos, mesas e alguns outros objetos, que passam a fazer parte do ambiente da escola. Estes geralmente acabam reproduzindo linguagens semelhantes às referências predominantes na escola (mosaicos)

Os materiais e instrumentos fornecidos pelos professores poderiam talvez instigar ou ao menos possibilitar uma maior transformação dos espaços, mas isso acontece de forma relativamente limitada, pois são pouco diversificados e permitem poucas variações na sua manipulação ou apropriação.
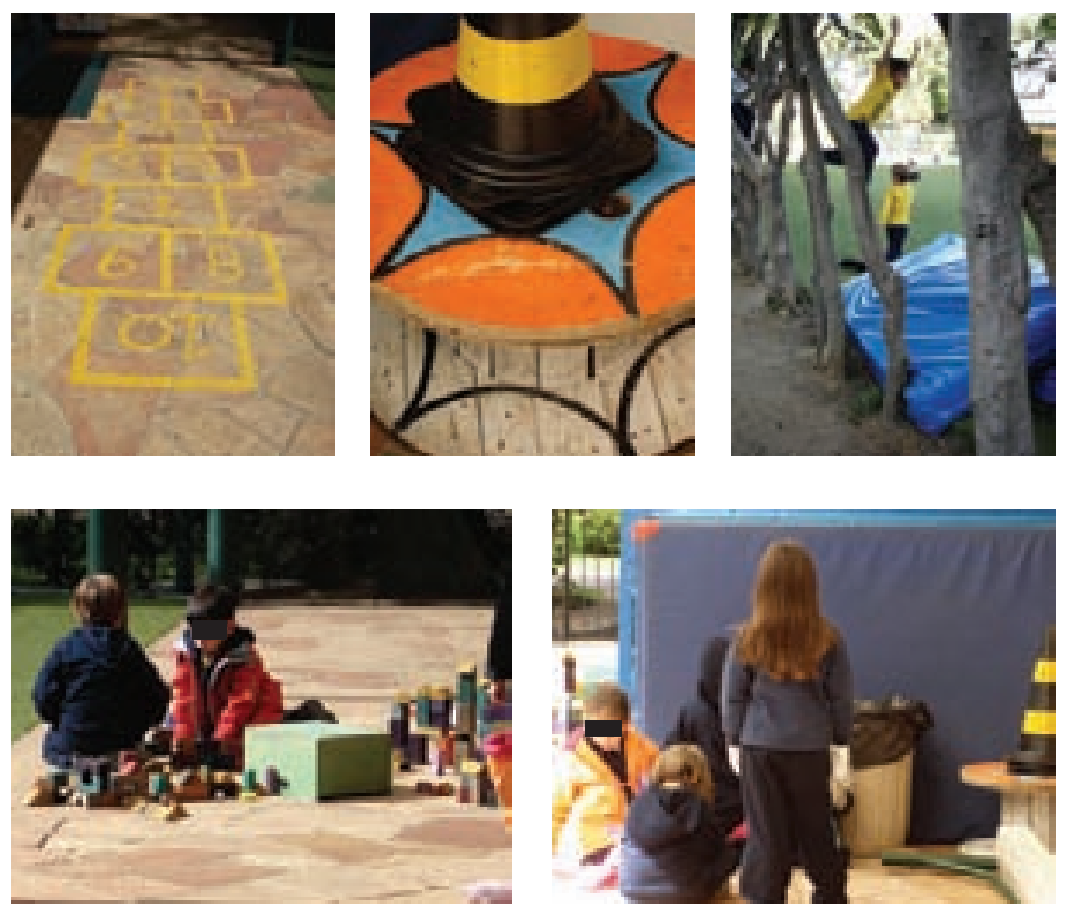

Brinquedos à disposição das crianças durante o horário de recreio: jogos de construção, amarelinhas pintadas no chão, materiais da aula de educação física, que são apropriados pelas crianças; não há, porém, a extrapolação dos limites dos próprios brinquedos, não acontecendo a interação e a integração com o espaço ou mesmo com outros briquedos e equipamentos ao redor. 

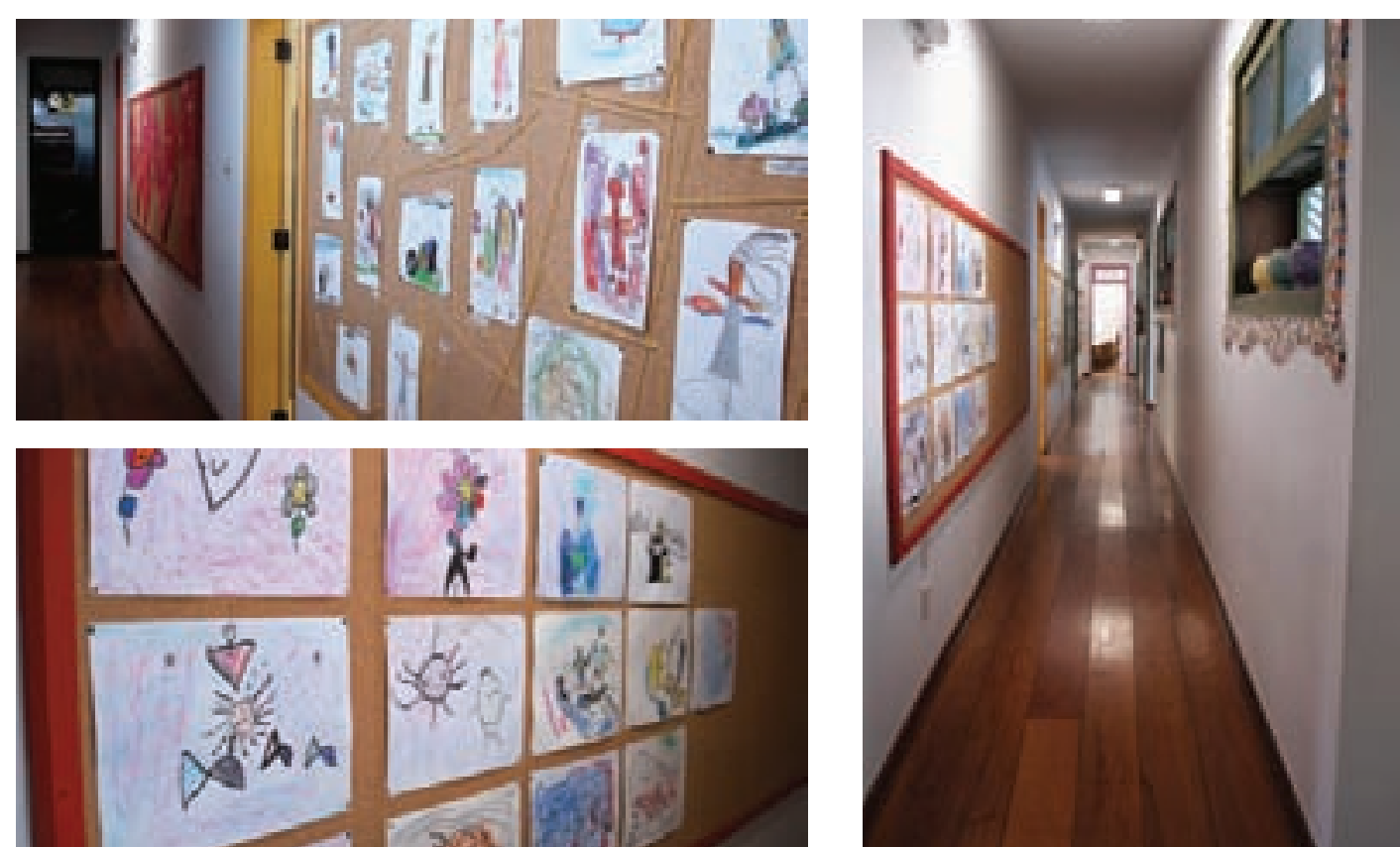

Corredor das salas de aula: cada sala tem o seu quadro, pintado da mesma cor da sala, onde ficam expostos os trabalhos de cada turma; corredor estreito e altura dos murais prejudicam sua contemplação dos mesmos.
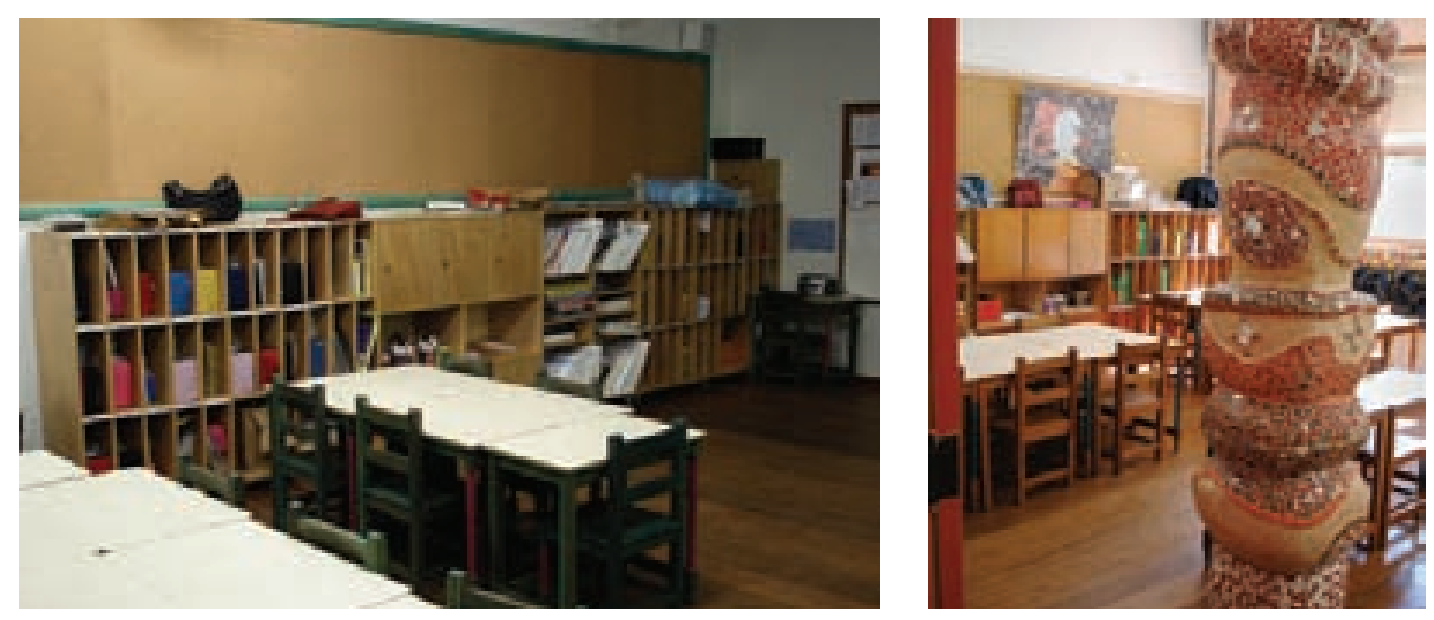

Desenhos e trabalhos feitos pelas crianças ao longo do ano letivo também encontram-se espalhados pelos corredores e pelas salas dos professores, da coordenação e da diretoria, valorizando essa produção e manifestação expressiva. Porém, acabam ficando restritos aos espaços já previstos para os mesmos, como quadros e painéis, muitas vezes, inclusive, fixados em alturas fora do alcance do olhar das crianças (como no corredor do piso superior, que é prejudicado também por ser estreito).

Quando colocados próximos ao chão, ou em uma escala diferente - como, por exemplo, acontece na situação que vemos na página ao lado - chamam a atenção das crianças, que, atraídas, ficam a observar e a comentar cada detalhe dos trabalhos.

Nas salas de aula, quadros também foram instalados em alturas muito acima do nível do olho da criança; trabalhos só podem ser observados de longe, e não podem ser tocados ou manipulados pelas crianças.

AMBIENTE ESCOLAR INFANTIL CAP 4 PROJETOS NO BRASIL 


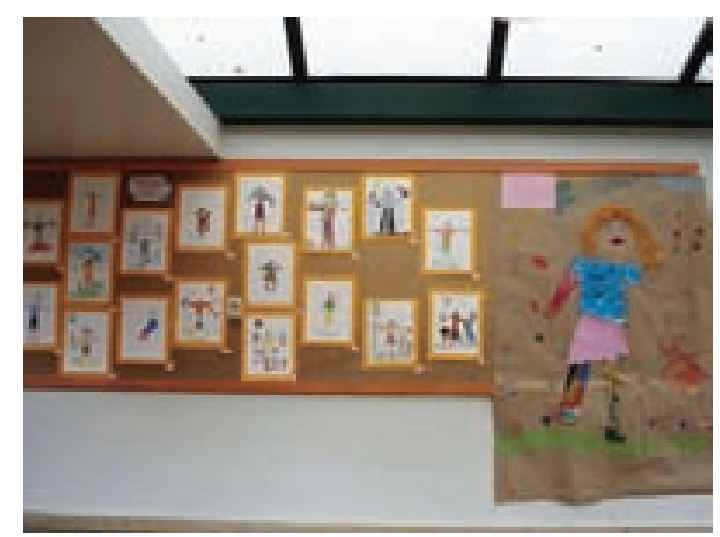

Uma situação um pouco inusitada: um trabalho em outra escala, extrapolando os limites do mural: chama a atenção de todos, tanto pelo tamanho quanto pela ocupação no espaço (além de ficar a uma altura mais propícia à observação pelas crianças).

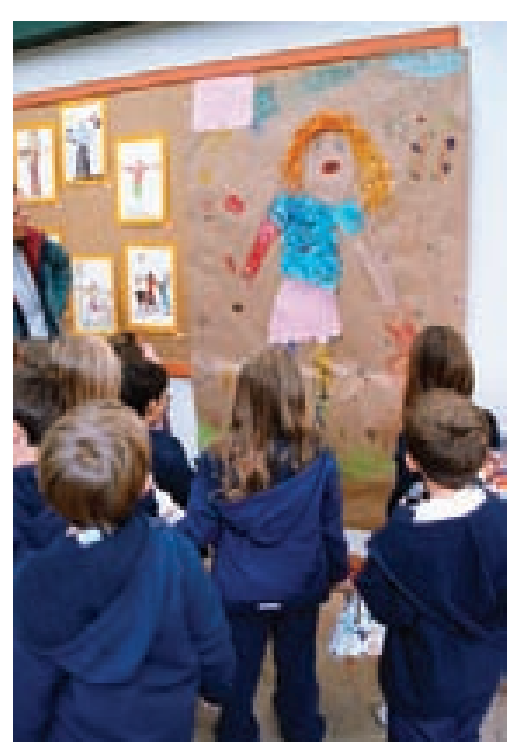

A quebra de ritmo, o jogo do inesperado, a introdução de surpresas no dia-a-dia dos usuários deste espaço, principalmente no das crianças, são fundamentais para que a experiência vivida ali não se torne monótona e não se estabeleça uma relação automática com os ambientes e elementos da escola.

Por isso, um lugar que se proponha não apenas a "cuidar" deve ir além da funcionalidade, da adequação e da segurança. E, se busca o "conhecer", deve procurar oportunidades para que as crianças exerçam a autonomia e a responsabilidade por meio de uma atitude ativa. E esta só pode ser acontecer se houver a possibilidade, e mais, o estímulo à apropriação e transformação dos ambientes pelas próprias crianças, individualmente ou em coletividade, independentemente ou em conjunto com os professores. Só assim o ambiente da escola deixará de ser apenas um suporte paras as atividades didático-pedagógicas e passará a constituir uma estrutura de oportunidades para o desenvolvimento das mesmas.

\section{Salas de aula}

[análise de: relação com demais espaços da escola; elementos estruturais; formato; dimensões; organização espacial e das atividades; materiais, cores, texturas de pisos, paredes; iluminação; decoração; flexibilidade; mobiliário, equipamentos, objetos e brinquedos]

As salas de aula da Escola Infantil Santa Cruz apresentam formatos e tamanhos semelhantes, e uma área generosa para o desenvolvimento das atividades pelas crianças e professores.

Em função de questões estruturais (adaptação a partir de um projeto de residência), em algumas das salas de aula no piso superior foi necessária a manutenção das colunas de sustentação que se encontravam fora do eixo das paredes. Diante de tal inevitável situação, a diretoria da escola, junto ao arquiteto, decidiu incorporá-las como elementos lúdicos no espaço das salas (referência a projeto do arquiteto Hunterwasser). Ao perceber que as colunas se destacavam no conjunto destes ambientes, decidiu-se adotá-las como elementos marcantes em todas as salas de aula, trabalhando-as de forma irregular e cobrindo-as com um trabalho de mosaicos (semelhante ao dos corredores e banheiros, mostrado anteriormente).

Cada sala, então, ganhou uma ambientação semelhante, porém diferenciada nas cores. Procurou-se distribuir as cores complementares nos mosaicos, a fim de impedir que uma sala tivesse uma única cor, mas buscou-se ambientá-las de forma que uma das cores predominasse e passasse, então, a identificar não só o espaço como também a turma que aí viesse a ocupá-la durante o ano.

Todas as salas foram projetadas da mesma forma para que não houvesse diferença entre elas (apenas na cor predominante), nem mesmo em relação à presença da coluna. Apenas na sala azul (última sala construída, alguns anos depois da reforma inicial), a coluna, criada apenas como marco (sem função estrutural), foi descolada do miolo para a lateral do ambiente, sendo construída como "meia-coluna" acoplada à parede. 

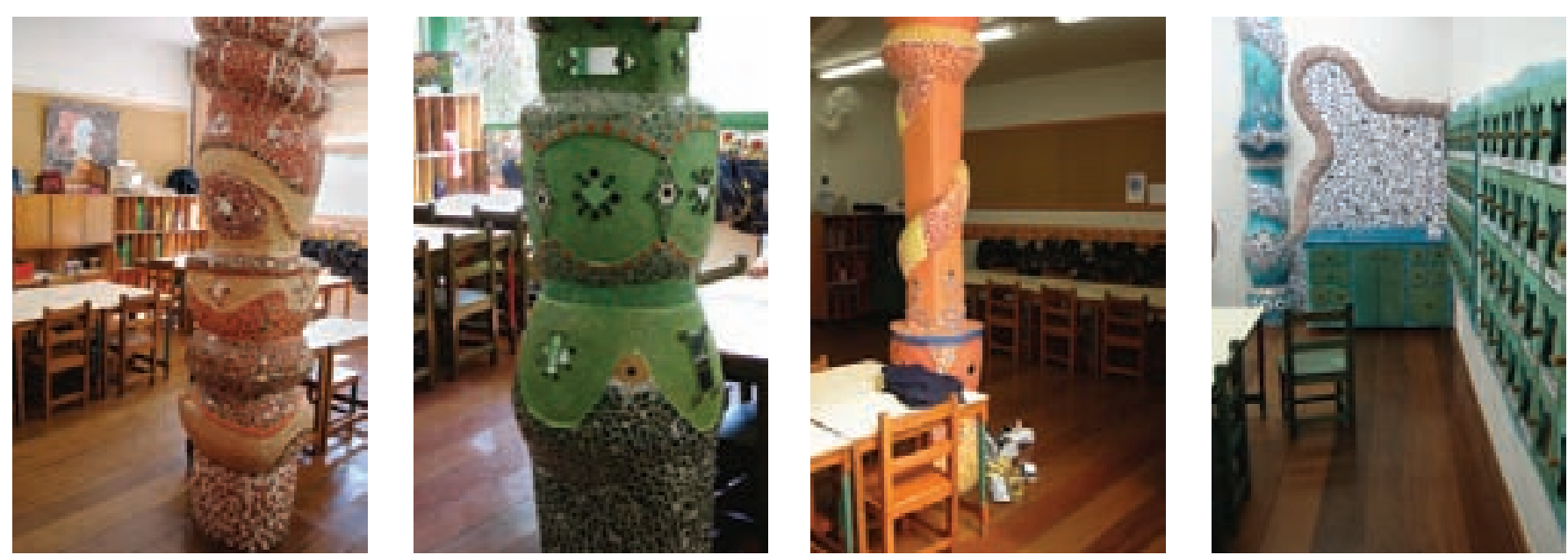

Salas de aula, caracterizadas pelas cores do jogo de mosaicos, e marcadas, cada uma por uma coluna diferente, mas semelhante. Acima, na penúltima foto, a sala turquesa: última sala a ser construída, acabou deslocando a coluna (falsa) para o canto, a fim de não prejudicar as atividades.

Apesar de a coluna se constituir como um obstáculo ao uso do espaço de algumas salas, buscou-se tirar proveito do mesmo em um primeiro momento, transformando-a em um elemento lúdico. A partir do momento que ela passou a ser replicada, porém, perderam-se o ineditismo da proposta e a força e identidade de cada situação. Este mesmo princípio - o fazer uso de obstáculos e a criação de novas situações provocadoras - poderia ter norteado uma série de soluções, porém teria sido mais enriquecedor se trabalhado de forma individual em cada uma das salas, criando um contexto único e diferenciado para cada uma delas. A coluna deslocada para o canto da sala mostra, ao contrário, o papel apenas visual e simbólico que esta passou a exercer no conjunto dos ambientes.

Apesar da presença da coluna, os espaços das salas de aula ainda são bem generosos e permitem o desenvolvimento de várias e diversas atividades ao mesmo tempo e ao longo do período escolar. Professores e crianças podem reorganizar esse espaço de diferentes maneiras fim de atender melhor as necessidades de cada momento.
Todo o mobiliário é adequado ao tamanho das crianças e, por ser leve, pode ser transportado por elas mesmas. Alguns equipamentos, inclusive, como o móvel da TV, por exemplo, apresentam rodinhas com o objetivo de possibilitar o seu uso em diferentes pontos da sala.

As salas apresentam formato retangular, concentrando os armários, lousas e demais equipamentos ao longo das paredes, e deixando a área central livre, apenas com as mesas e cadeiras das crianças. Os professores, no entanto, procuram trabalhar com a idéia de "cantos", onde atividades diferentes são desenvolvidas ao mesmo tempo. Essa divisão, por não existir concretamente (por meio de divisórias ou disposição dos móveis) acaba sendo feita, então, apenas pelo arranjo das cadeiras e mesas, deixando-as mais ou menos configuradas ou liberando mais ou menos espaço livre em função de cada atividade proposta.

A própria coluna acaba se constituindo como um elemento de marcação e é utilizada pelos professores como divisor de áreas de atividades, servindo, freqüentemente, como ponto de apoio para organização das mesas.
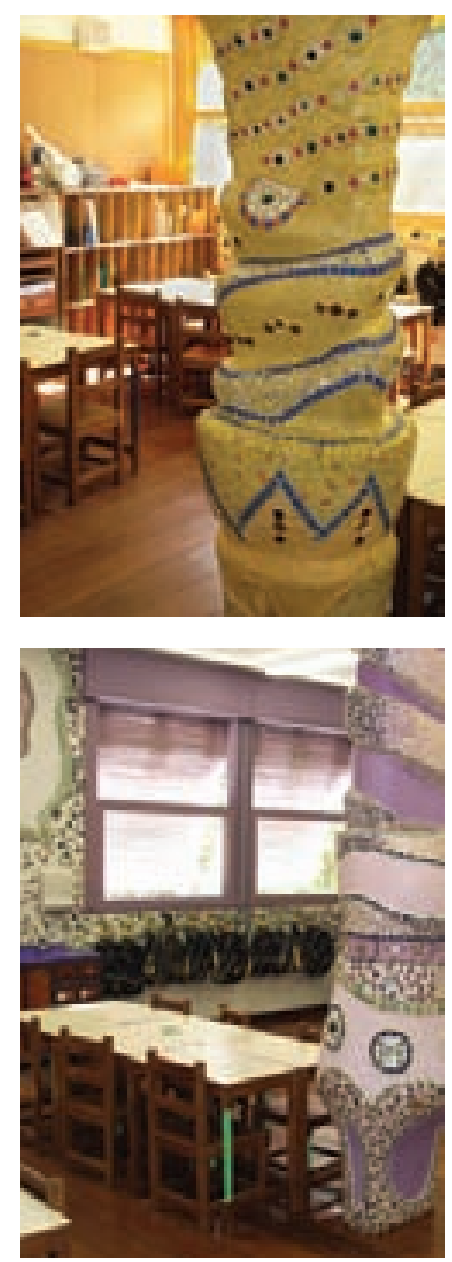

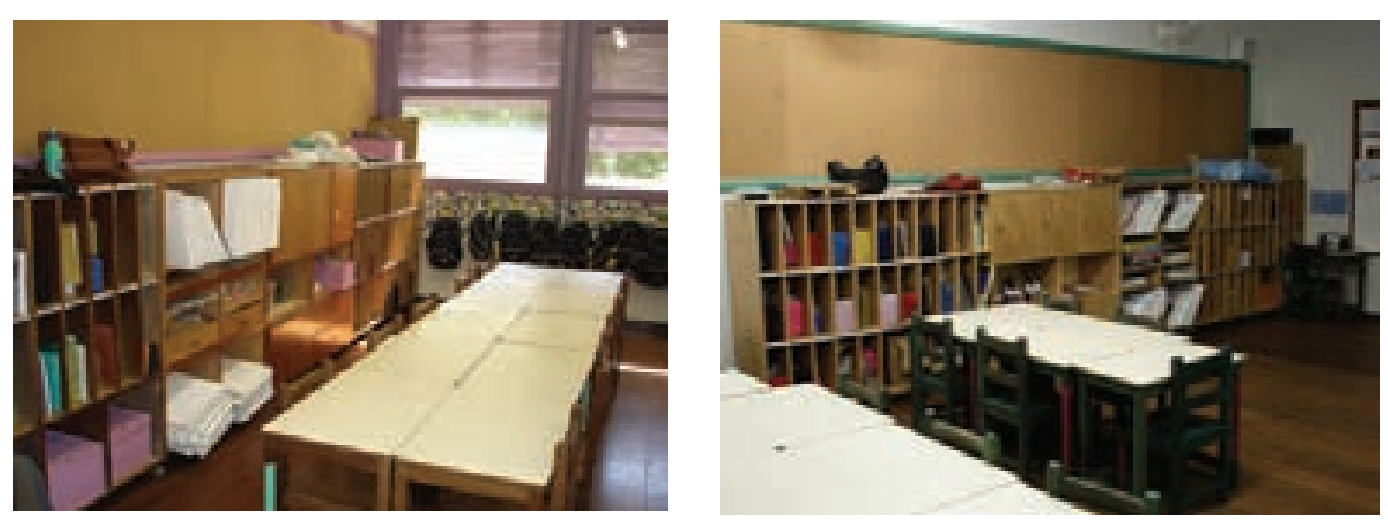

Armários e estantes ao longo das paredes e mesas organizadas em números e posições variadas, segundo as atividades e intenções dos professores e das crianças.
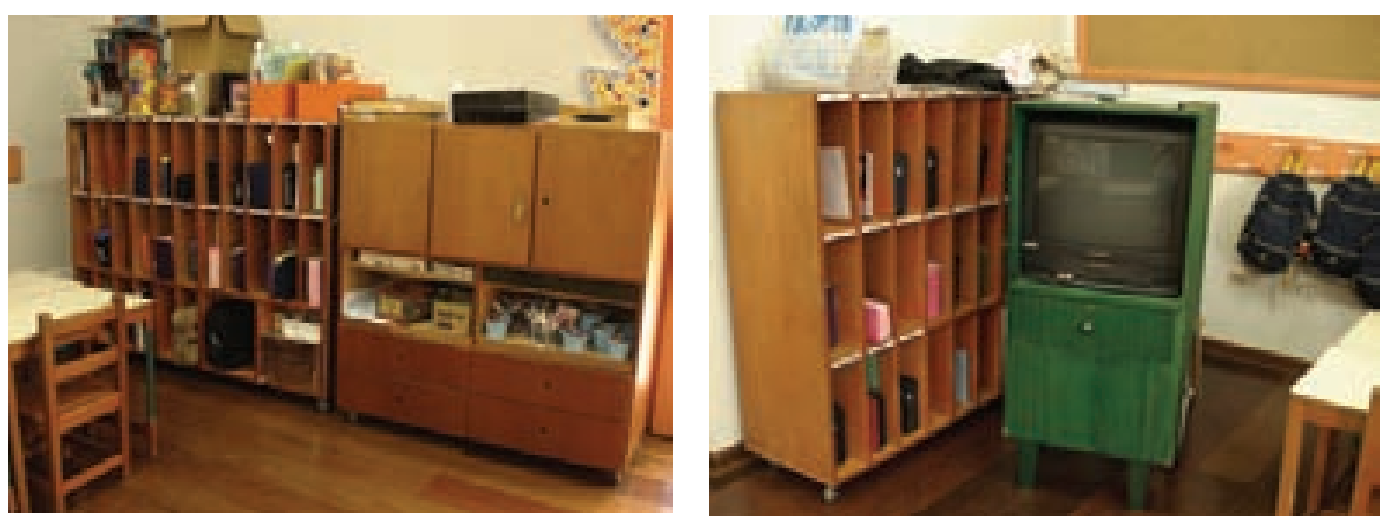

Armários, estantes e outros móveis, como o da TV: todos com rodinhas, permitindo o seu deslocamento e a reorganização das salas a qualquer momento; há uma alternância entre nichos abertos e fechados, definindo o que pode ou não ser acessado e manipulado pelas crianças.

Os nichos mais estreitos são os espaços reservados para cada criança individualmente, conforme podemos ver na foto à extrema direita: nichos identificados com os nomes das crianças, onde cada uma guarda os seus pertences.

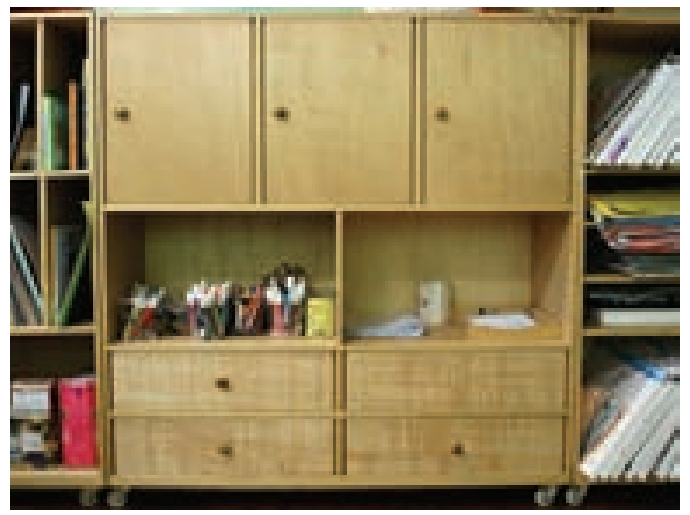

Além das cadeiras e mesas e dos armários para os materiais utilizados no dia-a-dia, existem também em todas as salas os armários das crianças. Cada uma delas tem um nicho aberto onde pode colocar seu estojo, sua pasta e alguns trabalhos. O espaço não é muito grande mas a idéia é interessante para criar em cada criança um sentimento de identidade, de pertencimento à classe e ao mesmo tempo, incubi-la da responsabilidade de cuida do seu "cantinho", sem deixar muita bagunça ou invadir o espaço do outro.
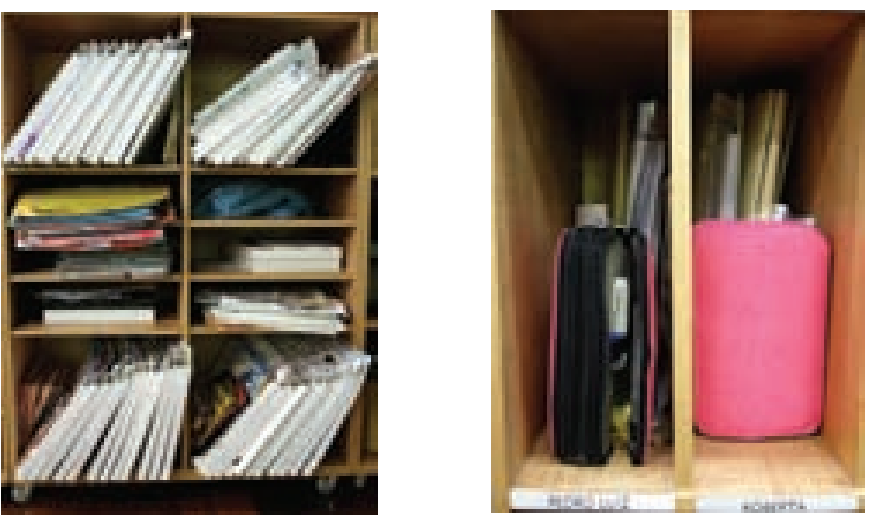
Outra maneira que a escola encontrou de fomentar o vínculo da criança com o espaço da classe foi criando um mural com "armarinhos-retratos" onde as fotos de todos são colocadas lado a lado, juntamente com os respectivos nomes. Dessa forma, todos podem se ver e ver aos outros colegas, além de visualizarem e, aos poucos, aprenderem a grafia de seus nomes. Talvez esse jogo de reconhecimento acabe se esgotando com o tempo e perdendo interesse pelas crianças, pois, depois de feitas as descobertas, acabam-se as novidades. Mas, independentemente disso, os "armarinhos-retratos" podem se transforma em interessantes "esconderijos" para pertences, brinquedos e objetos de cada criança. É o espaço onde ela pode guardar o que quiser sem que ninguém mais possa ver.. ou, como nas escolas da Reggio Emilia, pode ainda fazer o papel de caixa de mensagens, onde as crianças podem trocar objetos e bilhetes entre si... Não nos foi possível
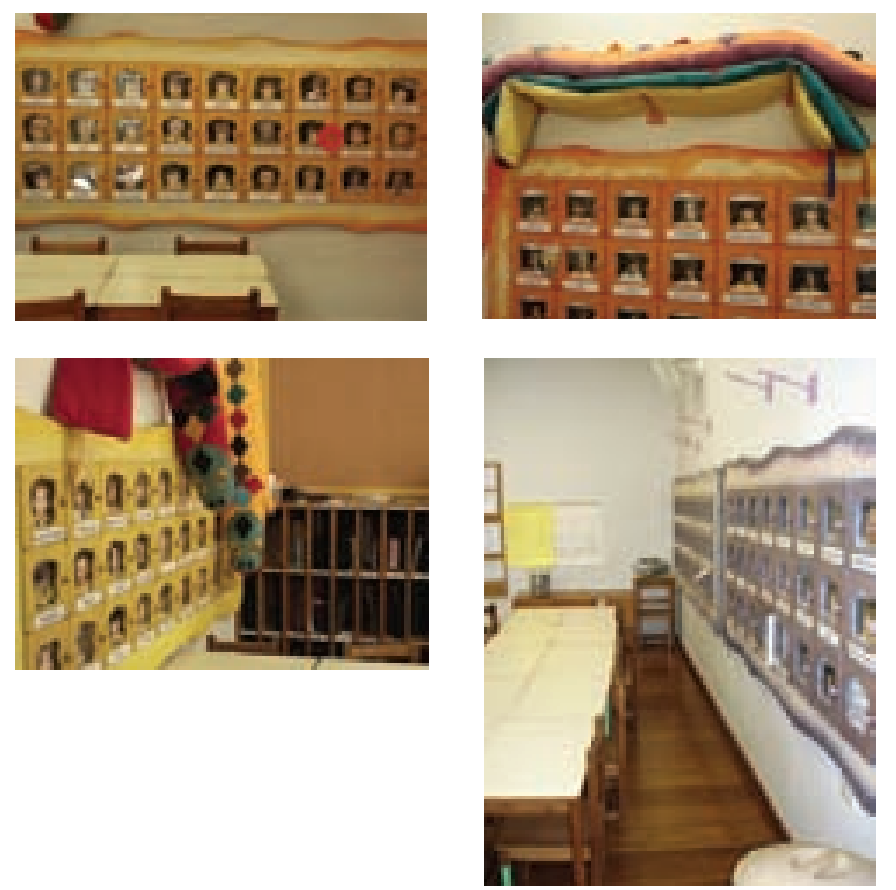

observar como de fato acontece a apropriação destes elementos, mas aí poderia se constituir um grande vínculo da criança com sua sala, seus colegas e a escola de forma geral, dando espaço para a fantasia de cada uma.

Ainda um outro meio de construir a identidade e estabelecer o vínculo das crianças com suas classes é por meio da exposição de seus trabalhos no ambiente. Há, em todas as classes painéis onde são fixados desenhos e projetos das crianças, mas, assim como os painéis externos, localizados nos corredores, encontram-se instalados muito acima da linha de olho das crianças, só podendo ser vistos de longe, além de nunca possibilitarem que os trabalhos sejam tocados ou mesmo fixados pelas próprias crianças. O posicionamento baixo dos painéis, como podemos observar, pode ser mais um elemento de estímulo ao respeito, à responsabilidade e à noção de coletividade, pois requer que as crianças não estraguem o que está
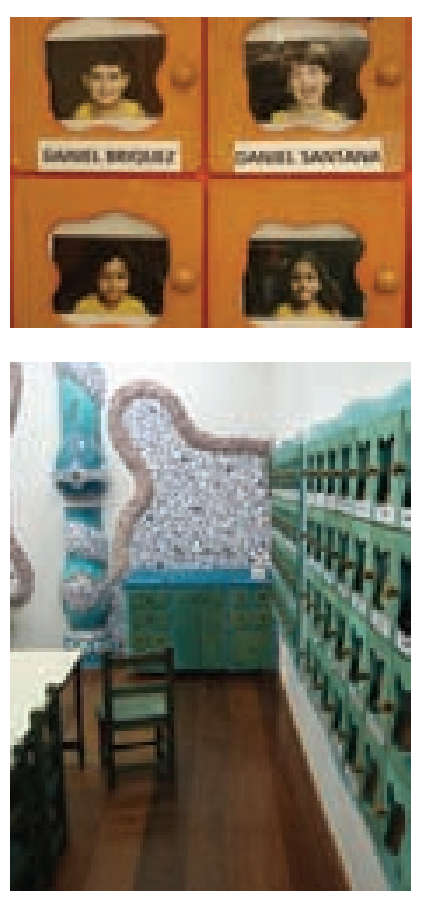

Os "armarinhos-retratos": incorporados na ambientação das salas, estes poderiam extrapolar a idéia de armário, de instrumento para o reconhecimento de si e dos colegas e de aprendizagem da grafia dos nomes, e se transformar em "esconderijos", "caixas de mensagens", "caixas de supresas", e tudo o mais que as crianças quisessem. 
sendo exposto, além de Ihes permitir organizar, ou pelo menos fixar, o conjunto de materiais (exige um trabalho conjunto de orientação do professor).

A proposta de expor os trabalhos das crianças pode extrapolar a idéia de painéis e murais e integrar-se aos ambientes tanto das salas de aula quanto da escola como um todo. Reservar um espaço externo a cada sala para mostrar à escola (crianças, professores, coordenadores/ diretores, funcionários e pais) o que está sendo desenvolvido por cada turma e poder ver o conjunto de propostas e manifestações acontecendo naquele universo é uma forma de valorizar as crianças e suas turmas e de fortalecer a auto-estima. No entanto, essa iniciativa poderia ser enriquecida com o incentivo à integração desses trabalhos ao próprio espaço da escola, por vezes criando até mesmo novos ambientes e extrapolando a idéia de "exposição" e de espaço oficialmente programado para a mesma.
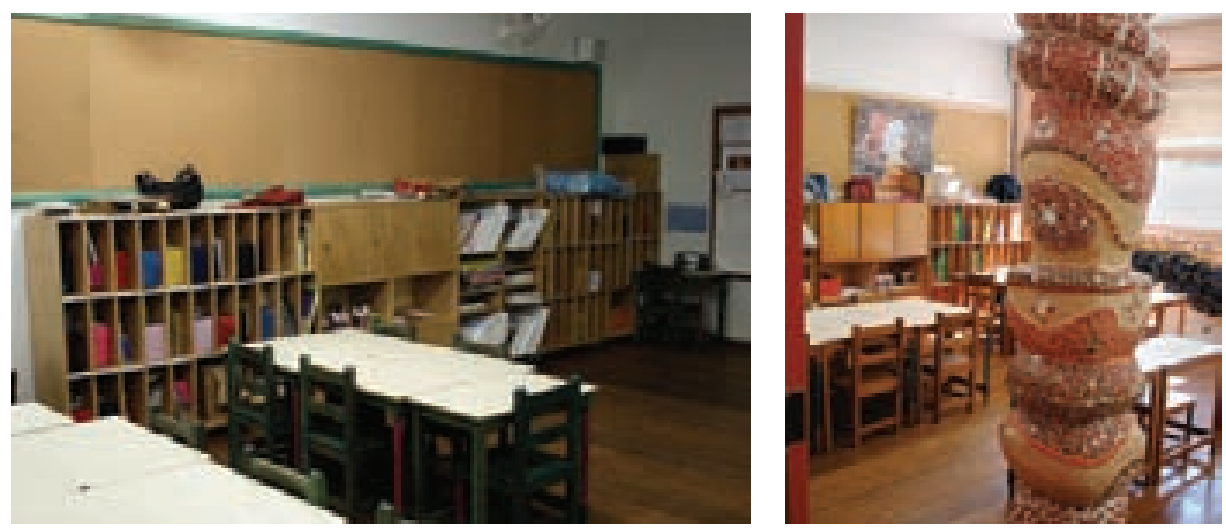

Painéis dentro das classes -nem sempre utilizados, ficando muitas vezes vazios; poderiam ser meIhor aproveitados se fossem mais baixos, ficando ao alcance das crianças, e disponíveis para intervenções de naturezas variadas (não apenas para exposição dos trabalhos).
Com relação aos materiais constituintes e presentes nas salas, observamos a intenção de criar ambientes aconchegantes e fluidos, que remetessem à idéia de natureza, organicidade, naturalidade. Em função disso, o piso escolhido foi o de madeira (escolha do diretor do colégio), quente, e, para as paredes e colunas, como já comentado, uma mescla entre uma cor neutra, a branca (parede lisa), e o trabalho de mosaicos, que varia de sala para sala. Como todo o mobiliário, as esquadrias e batentes foram construídos em madeira e pintados na cor predominante correspondente à cada sala.

De modo geral, os elementos das salas foram projetados de forma neutra (uso predominante da madeira natural), e o que se sobressai no conjunto é o trabalho dos mosaicos. Todas as salas possuem o mesmo layout, contando inclusive como uma área molhada, ou seja, uma pia para as crianças se lavarem depois de atividades com tinta, cola, etc. Esta área acaba concentrando boa parte do arranjo de mosaicos, constituindo um segundo ponto de referência do ambiente (além da coluna). Em geral, localizada entre as janelas, a pia possui todo o seu entorno preenchido por cacos que se espalham pela parede formando desenhos irregulares e manchas com contornos orgânicos. Juntamente com os pés de suporte do armário da pia, feitos em forma de "bichos", os mosaicos criam um ambiente de fantasia e ludicidade. A visão geral que se tem das salas, portanto, é dada principalmente por este trabalho plástico.

Por um lado, ao ser construída a partir de cacos coloridos, formando manchas heterogêneas e irregulares, esta ambientação cria zonas de indefinição que confundem a visão e podem esconder surpresas que vão sendo descobertas com o tempo e com a apropriação do espaço (elementos diferentes, como espelhos, como os "bichos" que sustentam as pias, ou mesmo objetos em relevo, como os peixes dos banheiros, já comentados). Por parecer homogênea, só releva os seus detalhes com muita aproximação e atenção, o que pode ser uma interessante maneira de cativar o usuário (as crianças, principalmente), que passa 

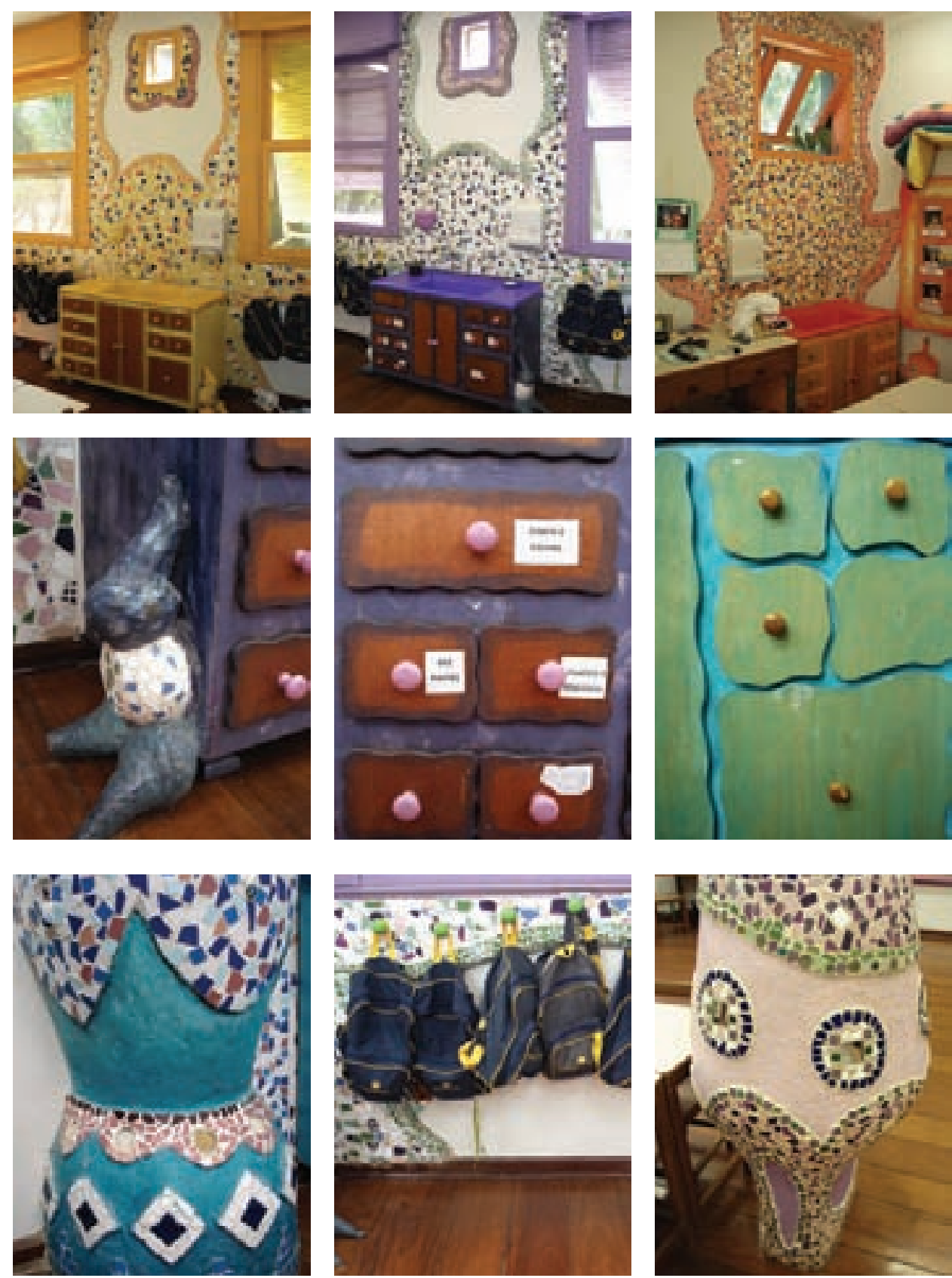

a buscar outras surpresas, ou, pelo menos, a ficar mais atento às nuanças dos ambientes.

Por outro lado, a aplicação do mesmo padrão de trabaIho e layout em todas as salas (e corredores e banheiros) as torna repetitivas e, portanto, desinteressantes uma vez que já se conhece uma primeira. Ainda que os contornos sejam diferentes, que o desdobramento da coluna mude, e que as cores sejam outras, são todas variações sutis do mesmo tema. A possibilidade de ampliação do repertório das crianças, portanto, fica restrita a um mesmo universo.

Além do trabalho dos mosaicos nas paredes e colunas e do uso predominante da madeira no piso e no mobiliário, pouco se explora em termos de materiais. Em função da forte presença plástica dos cacos, acaba-se deixando de lado outros elementos que poderiam ser explorados, como jogo de luz, transparências/opacidades, ou mesmo outros objetos e materiais que poderiam contribuir para a construção de ambientes diversificados e mais personalizados por cada turma.

Um dos elementos que parece ser explorado em alguns momentos é a janela. Tendo uma persiana de enrolar, pode ser manipulada de diversas formas: aberta em diferentes posições na vertical, deixando passar um maior ou menor facho de luz, ou pode ainda ser deslocada em direção à área externa (na horizontal), aumentando ainda mais as possibilidades de controle de luminosidade na sala. Pode-se, então, fazer uso desse jogo não só para adequar o ambiente à melhor intensidade de luz, como também para explorar o próprio fenômeno da propagação da luz, e dos efeitos possíveis decorrentes disso.

Forte presença da área molhada das salas, que se destaca pelo trabaIho de mosaicos, em contraste com a parede branca; um primeiro olhar para este trabalho não nos permite notar os detalhes de sua composição; aqui, a complexidade do trabalho só é percebida numa escala bem pequena, se perdendo na grande escala, em que a heterogeneidade dos elementos compositivos do mosaico é percebida como uma mancha homogênea e pouco diferenciada. 

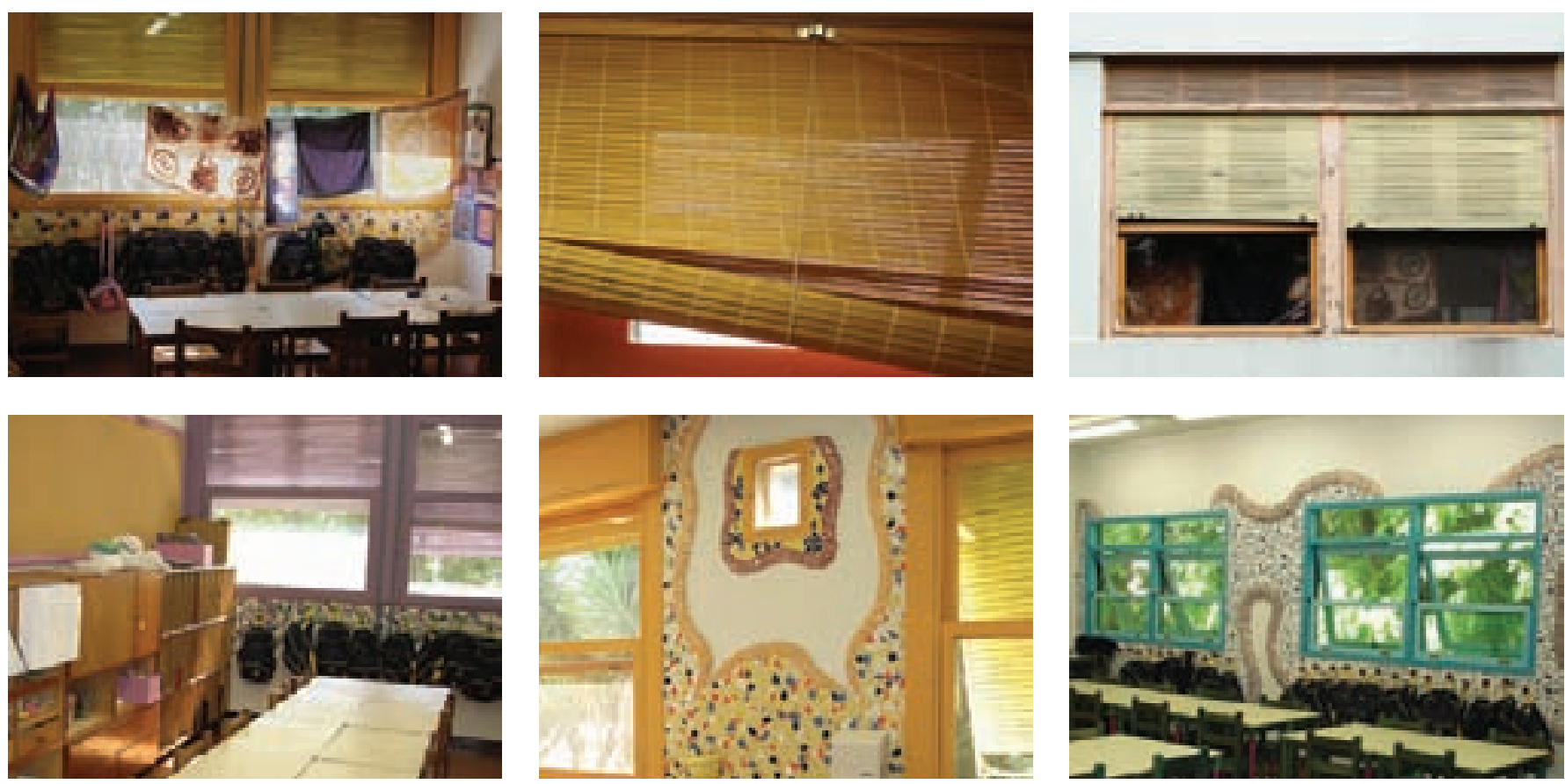

As persianas de enrolar ou as cortinas, no caso da sala laranja, e as diferentes intensidades de luz; esta pode ser ainda mais explorada como elemento de ambientação e investigação por meio de sua filtragem, através de tecidos, como vemos nas primeiras fotos, ou papéis, plásticos, e mesmo pinturas feitas pelas crianças, experimentando o jogo de transparência, opacidade, translucidez, e os efeitos de sombras, cores, etc.

Outro elemento que chama a atenção é um artifício utilizado pelo arquiteto ao projetar as mesas e cadeiras usadas pelas crianças: pintar apenas uma das pernas de cada peça. Ao fazer isso, cria um ponto focal que desvia e direciona o olhar do usuário, que tem então sua atenção captada por um elemento de surpresa. De que maneira isso será absorvido pelo usuário não nos cabe aqui analisar. De alguma forma, porém, capta a sua atenção e provoca o início de um processo de percepção mais atenta. Mais uma vez, talvez se tenha pecado pelo excesso e pela repetição: é sempre a mesma perna (lado direito das mesas e lado esquerdo das cadeiras) e a pintura é aplicada em todas as peças, sem exceção. Perde-se a oportunidade de se aguçar um pouco mais o instinto por descoberta próprio das crianças
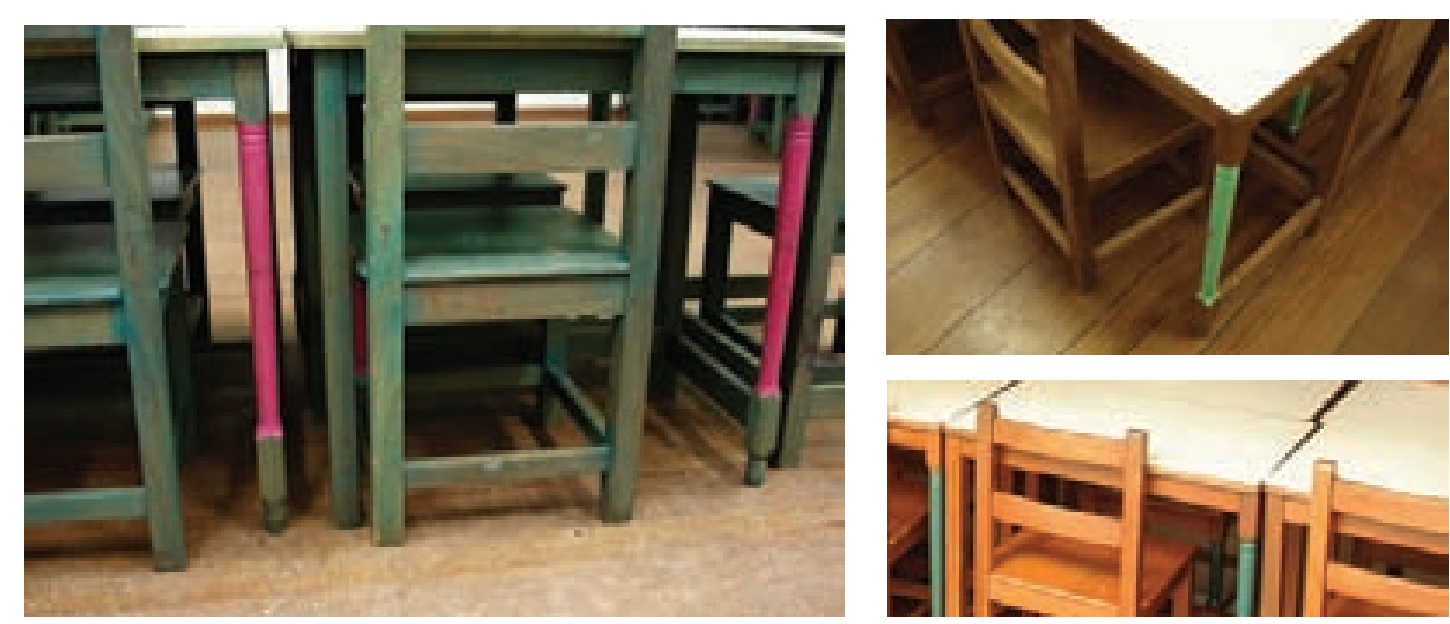
Pode-se dizer, porém, que, em função do já marcante trabalho dos mosaicos, a opção por não criar mais "brincadeiras", surpresas ou jogos de diferenciação tenha sido proposital, a fim de não criar mais ruídos e desequilíbrios (visuais) que desestabilizariam demais a sensação de conforto e segurança dos ambientes da escola (principalmente das salas, onde estes requisitos são importantes). O dinamismo e a vibração do trabalho fortemente presente dos mosaicos são assim contrabalanceados com a quase neutralidade dos objetos e equipamentos.

\section{Atividades, usos e funções}

Apesar de desenvolver atividades de artes e expressão dentro das salas de aula, a escola oferece espaços próprios para a prática dessas atividades complementares, como a sala de artes e a sala de jogos dramáticos (música, teatro, etc.).

Ainda apresentando o trabalho de mosaicos em algumas de suas partes ou peças, estas salas, porém, são projetadas de maneira a criar ambientes mais neutros, talvez por se acreditar que nelas a intervenção das crianças possa ser maior.

A sala de jogos dramáticos é trabalhada predominantemente com madeira na cor natural (com proteção acústica). As cores do ambiente aparecem, assim, principalmente nos objetos manuseados pelas crianças, como livros, fantasias e instrumentos (além da presença da coluna de mosaicos que, porém, fica localizada bem lateralmente). Alguns objetos apresentam contornos e texturas orgânicas, dialogando com a linguagem dos mosaicos, como o espelho e a caixa de fantasias, mas não se constituem como elementos marcantes no ambiente em geral.

Nesta sala também existem cantos, alguns um pouco mais delineados do que nas salas de aula, como a "biblioteca" ou estante de livros, e a área do piano. Há, inclusive, uma divisória retrátil utilizada para dividir o ambiente quando necessário.

Já na sala de artes, bem menor, a cor se faz mais presente, mesmo sem os trabalhos das crianças. O verde é
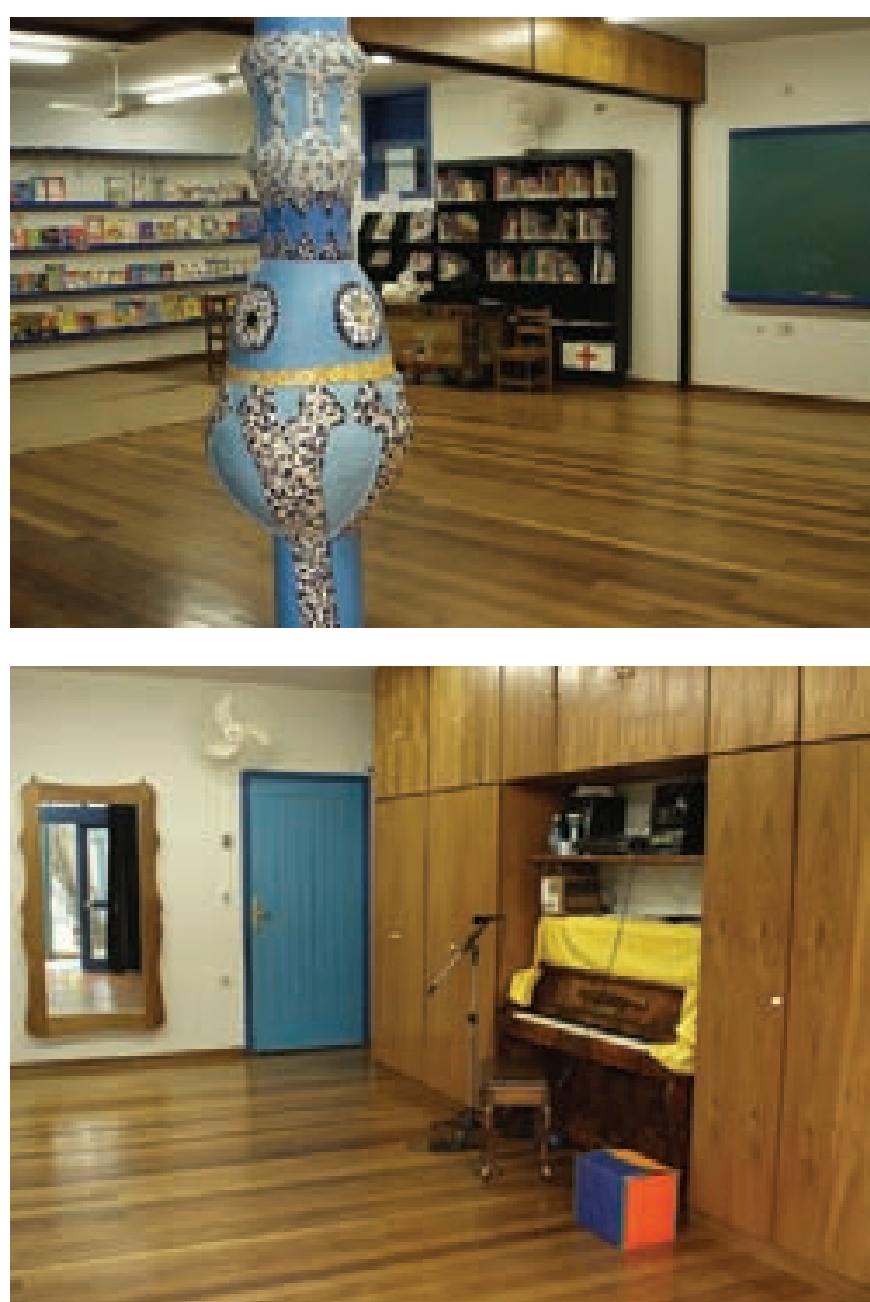

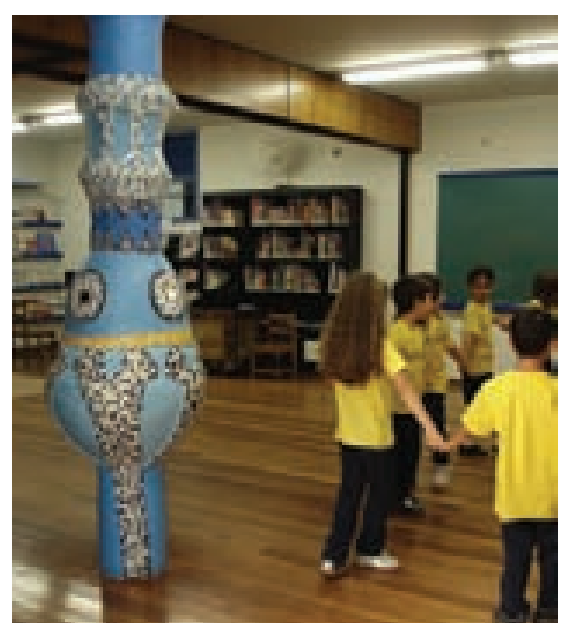

Área da bilbioteca ao fundo, com as estantes e algumas poucas mesas e cadeiras; a estrutura no meio da sala permite que se deslize uma divisória nesse eixo, separando a sala em dois ambientes; ao lado, o outro canto da sala constitui-se como o canto da música, onde se encontram os instrumentos musicais, os quais, porém, podem ser deslocados para outras partes do ambiente (com exceção do piano); como nas salas de aula, os móveis encontram-se todos ao longo das paredes, deixando a área central livre para as atividades: coluna de mosaicos também marca presença nesse ambiente; os "cantos" criados aí, no entanto, não chegam a constituir ambientes propriamente ditos, apenas pontos de referência para a organização da sala. 
adotado como cor predominante, estando presente em vários elementos, como prateleiras, armários, bordas e esquadrias. Ainda que quebrado pela presença das mesas e paredes brancas, acaba contaminando fortemente o ambiente. E é ainda complementado pelo trabalho de mosaicos no piso, onde também se faz presente em um jogo com tonalidades diferentes do azul.

Por ser um lugar onde se deve explorar a criatividade, a sala de artes acaba "admitindo" maiores "informalidades", "desordens" e "sujeiras". Ainda assim, a presença das crianças só se dá quando estão ali desenvolvendo alguma atividade ou quando seus trabalhos estão secando no varal. Não se vêem objetos, maquetes, projetos em geral pendurados pelo teto ou na parede, simplesmente como produções livres ou mesmo decoração, criando atmosferas diferentes e/ou marcando a construção de seus espaços.
Com relação às áreas de uso coletivo da escola, estas são abertas e interligadas (com exceção do parquinho, que é cercado por grades), permitindo usos diversificados. Em função da diferenciação dos pisos, porém, como já comentado, as atividades acabam sendo quase que direcionadas: futebol, corda, corrida e cambalhota no gramado; brinquedos, conversa no terraço; corrida, basquete e casinha na quadra.

É importante que se tenha consciência da força de um piso no direcionamento, ou mesmo sugestão, da atividade ou do percurso. Até as faixas de azulejo compostas com as pedras do piso da quadra acabam influenciando as brincadeiras das crianças, que inconscientemente se apegam aos eixos estabelecidos (e também são utilizadas pelos professores como pontos de encontro).
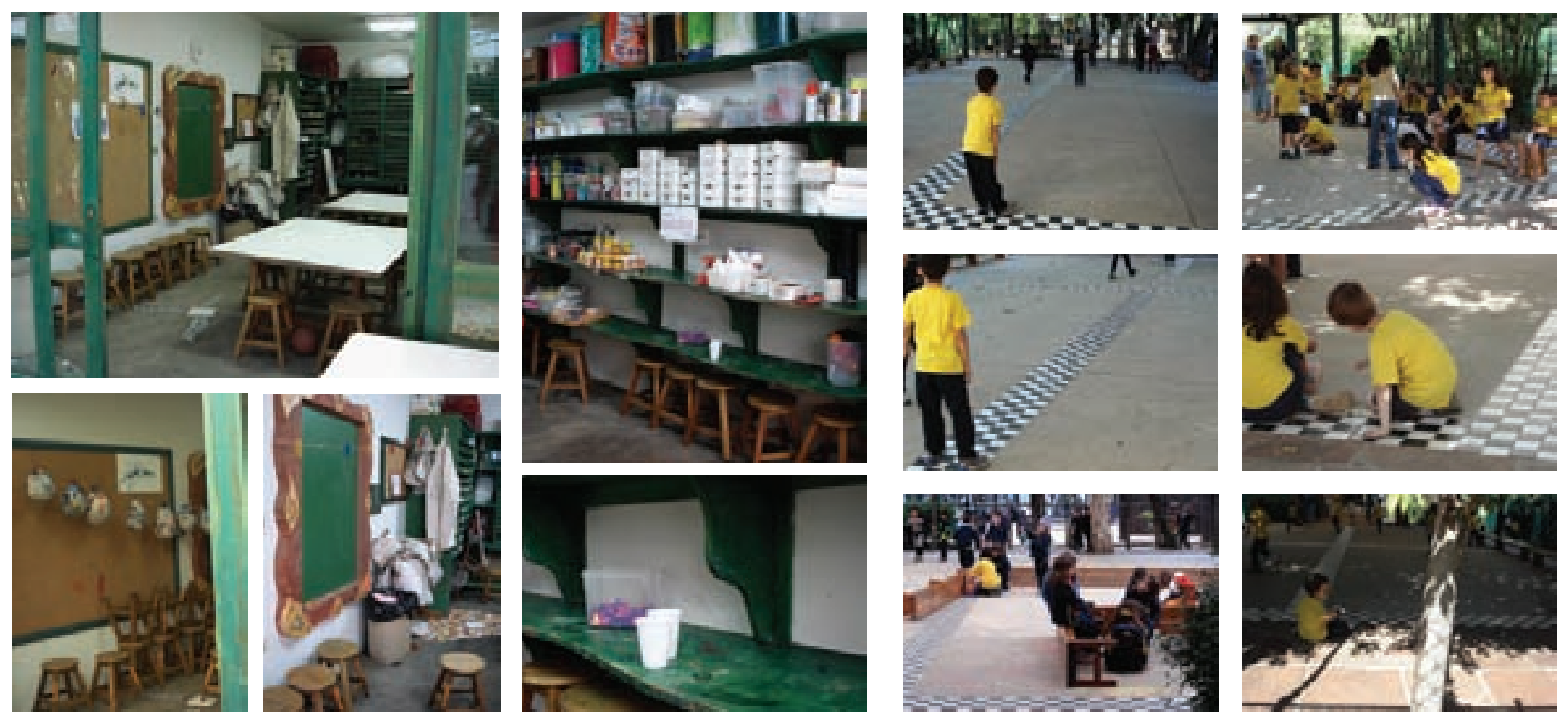


\section{Considerações finais}

Concebido em um momento em que a importância do ambiente escolar (desde a arquitetura até os equipamentos, mobiliários e brinquedos) ganhava força e era pesquisada e que experiências nesse sentido vinham sendo realizadas, o projeto da Escola Infantil do Santa Cruz procurou atentar para essa questão, fugindo dos padrões mais freqüentes de concepção desse espaço (paredes lisas, cores e pisos frios, etc.).

No entanto, ao entender o espaço como um "habitat" da educação, concebendo-o como "uma representação arquitetônica do aprender, do prazer, do respeito, do otimis mo, da invenção, da natureza" (Plano Diretor 2007 p.22) a escola propõe uma relação de contemplação, mais do que de interação, entre este e seus usuários. Concebe-o como suporte das atividades, e não como uma estrutura de oportunidades para o desenvolvimento das mesmas. Projeta-o como um ambiente cenográfico, estático, e não como um ambiente dinâmico, passível de transformação.

Sua ambientação e o trabalho de cores e mosaicos passam a ser referência para inúmeros projetos e atividades das crianças, mas constituem-se principalmente como objetos de estudo. Gaudí e a cidade de Barcelona (o contexto), assim como a coluna, o mosaico e as formas orgânicas, por exemplo, são temas de pesquisas e trabaIhos plásticos. O ambiente alimenta, assim, o estudo de cores, formas, composições. A partir da desconstrução dos desenhos encontrados nas colunas, pisos e paredes, as crianças fazem a reconstrução dos mesmos utilizando caquinhos de pedras, papéis coloridos, lápis de cor, etc. A observação de portões e colunas dá origem a outros desenhos, e composições são desenvolvidas a partir de desenhos de projetos conhecidos do arquiteto.

Sem dúvida, estas atividades enriquecem o repertório visual das crianças, assim como exercitam o olhar atento, a observação minuciosa, e provocam o despertar da sensibilidade e da expressividade artísticas, principalmente. Porém, trabalham com uma única referência, além de explorarem primordialmente os sentidos visual e tátil, em detrimento dos demais.

O ambiente passa a estimular ações práticas, e é entendido como uma fonte de pesquisa, observação, etc. constituindo-se assim em uma forma de motivação a uma atitude ativa por parte das crianças. No entanto, é estático e imutável, pois é fixo. Todo o projeto é construído por meio de elementos fixos, os quais não podem ser transformados nem pela equipe da escola nem tampouco pelas crianças, a não ser por meio de uma reforma arquitetônica. Praticamente inexistem elementos semi-fixos ou móveis que possam ser manipulados pelos usuários desse espaço, como, por exemplo, fechamentos/vedações, pinturas (a não ser na área em frente à sala de artes), entre outros, a não ser os próprios brinquedos das crianças, os trabalhos que são expostos, os jogos oferecidos pelos professores, etc

Não há, portanto, uma dinâmica de constante mudança e revisão da proposta ambiental, nem o incentivo à mesma por parte das crianças, o que seria interessante tanto para a criação de uma identidade própria de cada turma que passa pela escola, como também para a dinamização da mesma, evitando a monotonia ou a estagnação (sempre atentando para a necessidade de se manter um equilíbrio entre transformações e permanências, pois estas últimas são essenciais para a sensação de segurança e para o reconhecimento do espaço através de suas referências marcantes).

A ambientação sobrepõe-se à presença da criança. Ali, tudo parece ter seu lugar, havendo, portanto, pouco espaço para o "acaso", para o inusitado, para a apropriação espontânea: os espaços são abertos, sem cantos, com usos "sugeridos" ou quase predefinidos. 

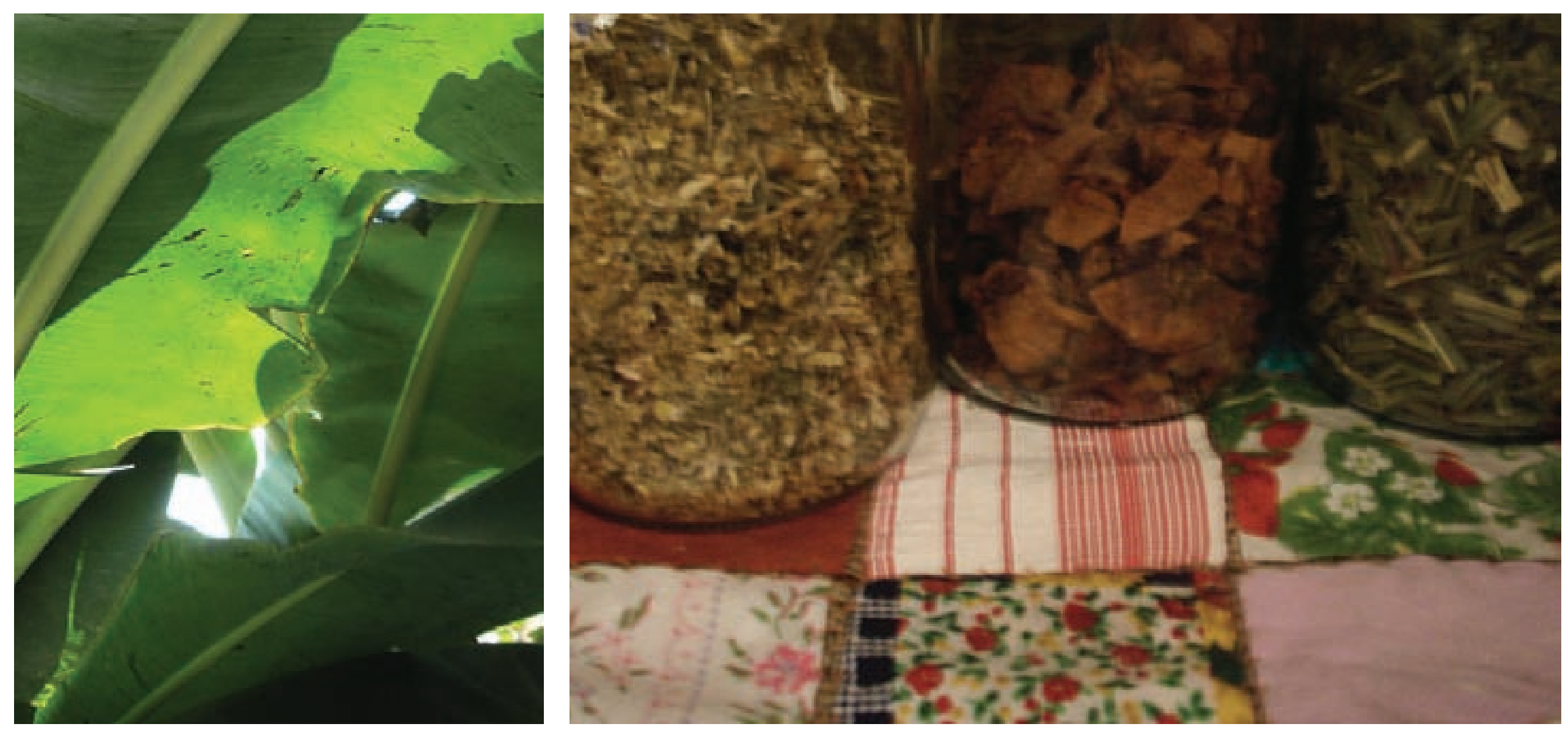


\title{
O projeto de escolas infantis da Pedagogia Waldorf
}

\author{
Escolas Waldorf Rudolf Steiner e Waldorf São Paulo
}

Projeto de arquitetura autoria desconhec

Local e Ano São Paulo, Brasil, 1956

Escola analisada educação infantil dos 2 aos 6 anos de idade

Total de crianças Rudolf Steiner: aprox. 78 crianças (só manhã) Waldorf São Paulo: não nos foi possível saber

Total de salas Rudolf Steiner: 3 salas de maternal e 3 de jardim (geralmente, 13 crianças por sala)

Waldorf São Paulo: 1 sala de maternal e 2 de jardim
Pelo fato de a pedagogia Waldorf ser, na cidade de São Paulo, seguida e adotada por um grande número de es colas, decidimos visitar e conhecer não só a primeira unidade, instalada no Alto da Boa Vista, mas também outras unidades menores, a fim de verificar como ocorre o desdobramento da proposta em diferentes situações. Para fins da discussão apresentada nessa dissertação, foram analisadas apenas duas, a Escola Waldorf Rudolf Steiner e Escola Waldorf São Paulo.

Infelizmente não nos foi possível acompanhar de perto a dinâmica do dia-a-dia das crianças em nenhuma das escolas visitadas. As observações e tomadas de fotos foram portanto, realizadas em dias e horários fora do período de atividades, não nos possibilitanto uma análise mais profunda sobre a relação estabelecida entre as crianças e seu ambiente escolar. Todo a discussão a seguir baseou-se na leitura de textos, em conversas com professoras e ex-professoras da escola sobre a pedagogia Waldorf, e na análise feita a partir de observações e fotos tiradas nos locais.

\section{A pedagogia Waldorf}

Fundada em 1919, na Alemanha, e chegando ao Brasil por intermédio da Escola Rudolf Steiner, em 1956, a pedagogia Waldorf procurou adaptar-se ao contexto socioeconômicocultural brasileiro, passando por transformações variadas como as que procuraram atender a nova Lei de Diretrizes e Bases da Educação Nacional (1996) sem deixar, porém. que sua essência e princípios básicos se perdessem.

Baseada na Antroposofia, a pedagogia Waldorf acredita na educação como um caminho no despertar dos sentidos e da sensibilidade do homem, com a conservação da sua plena consciência. Busca, assim, estimular o entusiasmo pelo aprendizado e o desenvolvimento saudável, com o aprimoramento das faculdades críticas e de julgamento (que surgem com a adolescência) (www.ewrs.com.br).

Contra uma educação que cada vez mais privilegia o desenvolvimento intelectual, a pedagogia Waldorf aponta negativamente a falta de atenção dada aos demais aspectos da formação do homem, os quais considera essenciais para o bem-estar e completude do mesmo: a vida de sentimentos (emoções, estética, sensibilidade social), a força de vontade (a habilidade de fazer as coisas acontecerem) e a natureza moral (discernimento entre certo e errado). A partir dessa reflexão, busca se distanciar do conceito 
biologista do ser humano e da visão materialista da educação, e trabalhar a formação daquele por meio do desenvolvimento físico, anímico e espiritual, cujo desdobramento concreto veremos a seguir.

\section{A Educação Infantil}

Segundo Rudolf Steiner, fundador desta pedagogia, a vida humana não decorre de forma linear, mas em ciclos de aproximadamente sete anos. A Infância, portanto, corresponde ao primeiro setênio (como são denominados os ciclos), período em que "o que realmente 'nasceu' foi o corpo físico" (Lanz 1990, p.32).

Durante os primeiros sete anos de vida, segundo Steiner, tudo na criança está relacionado com o organis mo e ela está entregue aos seus processos vitais (alimentação, metabolismo, sono, movimentos descontrolados). Por isso, ela é inconsciente ou apresenta uma consciência bastante reduzida, não chegando a construir a barreira entre si própria e o seu mundo, tal como acontece no adulto, por exemplo. Em conseqüência disso, a criança é permeável a todas as influências do ambiente e, por sua vez, transmite diretamente a esse mundo tudo o que se passa dentro dela, constituindo-se, assim, como um grande órgão sensório (Lanz 1990, p.35).

A pedagogia Waldorf considera esta permeabilidade da criança ao seu entorno um dado essencial para a com preensão desta no mundo e um elemento fundamental para a construção do processo educativo. Considera que as influências que emanam do mundo ambiente exercem efeitos profundos sobre a organização física e psíquica da criança, efeitos que se farão sentir durante a vida futura. Fica evidente, então, que o ambiente escolar exerce um papel bastante significativo em sua proposta educativa.

Entendendo que o ideal fosse que a criança, na idade pré-escolar, estivesse com a mãe, no ambiente familiar, brincando com seus irmãos e amigos, onde pudessem conviver com a natureza e com os afazeres diários da casa, o jardim de infância (incluindo-se aí o maternal) passa a ter como tarefa a criação, para as crianças, de um lar que elas não têm mais em casa.

Partindo desse princípio, o projeto do jardim de infância faz-se como uma reprodução da família e do ambiente familiar (da concepção de família e de lar apontada pela pedagogia): uma unidade fechada, com seu ambiente próprio, sob direção de uma orientadora (eventualmente duas). Deve haver uma pequena mistura de crianças de idades diferentes (turmas de 2 a 4 anos, no maternal, e turmas de 4 a 6 , no jardim), como irmãos em uma família, na qual os grandes têm maior responsabilidade e tarefas mais amplas, devendo, inclusive, cuidar dos mais novos. Cada grupo deve ter a sua sala, com seus espaços, brinquedos e materiais. O dia é dividido em períodos de várias atividades, com diversos deveres distribuídos entre as crianças: regar plantas, arrumar a sala, preparar a mesa para o lanche, guardar brinquedos, etc.

"Todo o ambiente de jardim-de-infância deve ser acoIhedor e aconchegante. Nenhum objeto deveria destoar da harmonia do ambiente, nenhuma caricatura tirada de desenhos animados ou de revistas em quadrinhos pode ser tolerada nesse pequeno santuário das crianças.

A criança deve adquirir confiança no mundo: cada objeto, pelo seu material, deve ser o que parece ser. Daí a exigência de materiais naturais: madeira, pedras, panos, etc. Nada de material plástico, sintético, símbolos de um mundo de mentira e de pseudo-valores.

Dessa solidez e desse aconchego nascem uma extraordinária segurança e confiança no mundo dos adultos, no mundo em geral: o mundo é bom! Este deveria ser o elemento básico do ambiente que constitui o fundamento de uma autêntica religiosidade da criança pequena" (Lanz 1990, p.97, grifos nossos).

Nos primeiros anos de vida, entregue ao seu entorno físico e ainda não distinguindo realidade e fantasia, a criança, inconscientemente, imita o que percebe ao seu redor (um pouco mais tarde, a imitação se tornará mais consciente). Imitação e exemplo são os motivos básicos de todo comportamento infantil, e, por isso, a pedagogia 
Waldorf acredita na importância de que neste ambiente acolhedor seja oferecida à criança uma série de situações e elementos carregados de significados para a imitação e para o brincar criativo.

Considerando, como apontamos anteriormente, que os sentidos são as "janelas do corpo para o mundo" (www.ewrs.com.br), pois é através destes que ela absorve e aprende a se relacionar com a realidade, educar, no primeiro setênio, constitui-se em permitir à criança exercitar seus sentidos. Todas as atividades do jardim devem atender ao desenvolvimento sensório. Atividades com areia, água, pintura, modelagem, etc., são então estimuladas, assim como a experimentação com e do corpo, dos seus movimentos, permitindo à criança moldar o seu pró prio processo e produto final, explorando os movimentos e impulsos oriundos de si própria para que ela se livre do condicionamento de ritmos, formas e barulho do mundo mecanizado de hoje (www.ewrs.com.br). O que não significa que as ocupações, individuais ou em grupo, sejam "passatempos" improvisados, mas, ao contrário, devem combinar espontaneidade com uma certa orientação.

Segundo a pedagogia, ambiente de fantasia e de espontaneidade não comporta nenhum aprendizado diri gido. Se o processo de amadurecimento do ser humano se realiza de forma endógena, orgânica, e se dá por meio do contato com o mundo, deve-se "sempre procurar manter o homem 'aberto' para o aprender - a especialização e a fixação são, em qualquer idade (...) um crime contra o desenvolvimento do ser humano em direção à sua imagem ideal" (Lanz 1990, p.34)

A seguir, procuraremos entender como estes conceitos e concepções da criança e de seu desenvolvimento são trabalhados no desenrolar do processo educativo Waldor e como são concretizados em seu ambiente escolar

\section{O espaço escolar como ambiente de aprendizagem} [dimensões física, funcional, temporal e relacional]

Com o intuito de resguardar as crianças pequenas (até seis anos) e garantir a sensação de acolhimento, segurança e confiança entendida pela pedagogia como essencial à criança no primeiro setênio da vida, os maternais e jardins de infância das escolas Waldorf são, no que parece ser em sua maioria, separados fisicamente do restante das unidades educacionais, como ensino fundamental e médio quando estes se localizam no mesmo terreno.

Com entrada externa independente (no caso da Waldorf São Paulo) ou não (Waldorf Rudolf Steiner), procura-se sempre delimitar claramente a área dos "pequenos". Na Escola Waldorf Rudolf Steiner, essa demarcação e separação são feitas por meio de elementos naturais, como cercas vivas e diferenciação de pisos (pedra-gramado), sendo permeável, principalmente em termos visuais, ao apresentar alturas baixas para o horizonte do adulto ou das crianças já um pouco maiores, e ao permitir, por entre as folhagens e vazios das cercas vivas, a visualização de parte do espaço pelas crianças menores. Já na Escola Waldorf São Paulo, a separação da área das crianças até seis anos é muito mais marcada, tanto pela estrutura organizacional da mesma, que se volta para pátios-praças in ternos e dá as costas para o restante da escola, como pelo fechamento de suas paredes e muros, que apresentam poucas aberturas permitindo a visualização das diferentes partes (que, quando existentes, em geral estão em alturas inacessíveis aos olhos dos pequenos).

É importante observar, nesse momento, que, enquanto as dependências da escola Rudolf Steiner, em sua maio parte, foram projetadas especificamente para o desenvolvimento do ensino Waldorf, a Escola São Paulo foi instalada em uma casa já existente, alugada, a partir da qual foram feitas adaptações (que continuam sendo feitas até hoje, com limitações, em função da situação de aluguel). A diversidade de condições, mesmo em função do tamanho do terreno e de sua inserção na cidade (a primeira no bairro 


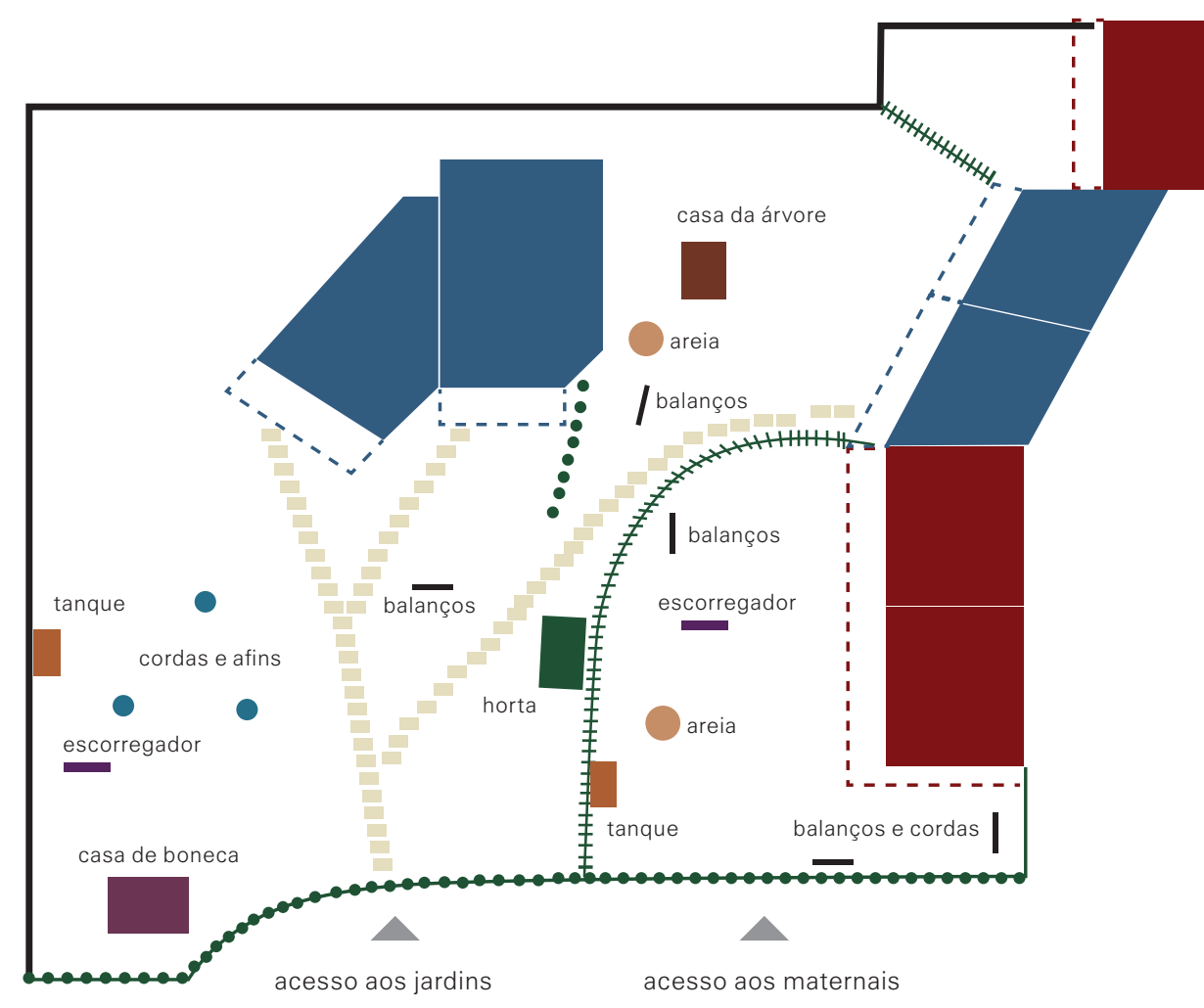

Planta esquemática da Escola Waldorf Rudolf Steiner, elaborada pelos autores com base nas observações realizadas em visita ao local (sem escala).

materna

jardim-de-infância

.. cerca-viva

\#+ cerca de madeira

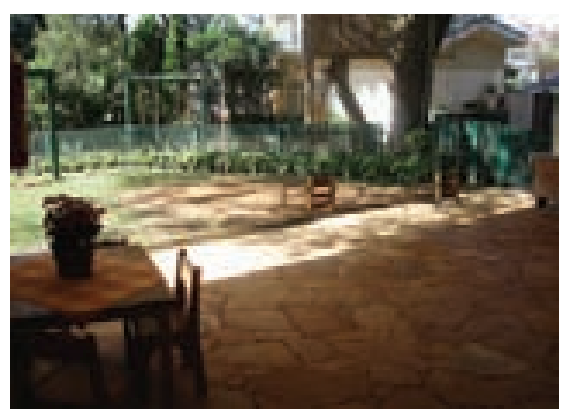

Vista a partir do terraço de um dos maternais, de onde pode se ver a cerca de madeira que separa a área de jardim dos maternais (2 a 4 anos) da dos jardins (4 a 6 anos). bloco de dois dos jardins ao fundo.

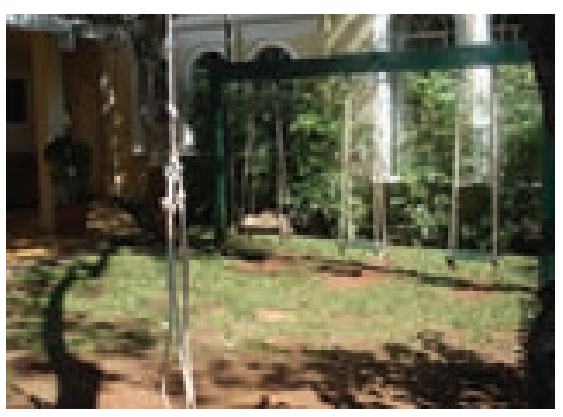

Cerca viva separando a área do jardim-de-inBloco de duas das turmas dos maternais $(2$ 4 anos), com terraços e área de jardim adjacente. este bloco abriga mais duas salas de jardins e uma de maternal, logo atrás destas duas primeiras observadas na foto. fância das demais dependências da escola.

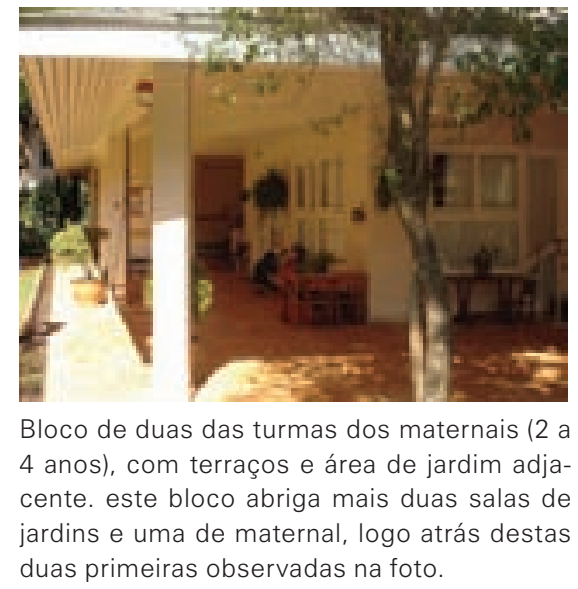

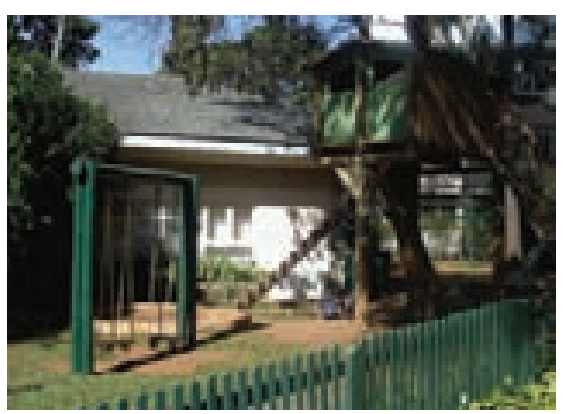

Área de jardim de duas das turmas de 4 a 6 anos, com bloco de mais duas turmas dessa idade ao fundo. em primeiro plano, cerca que separa área dos maternais e área dos jardins.

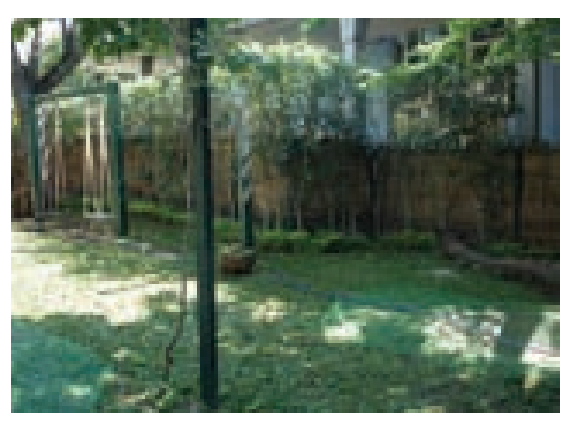

Cerca de bambuzinhos e vegetação separando a área do jardim-de-infância do acesso aos demais edifícios da escola (área de maior circulação).

pedra que dá acesso aos demais jardins 


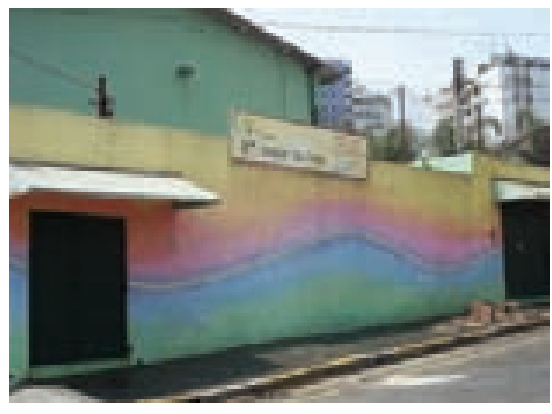

Acessos à Escola Waldorf São Paulo: à esquerda, portão para o jardim-de-infância; à direita para as demais dependências da escola.
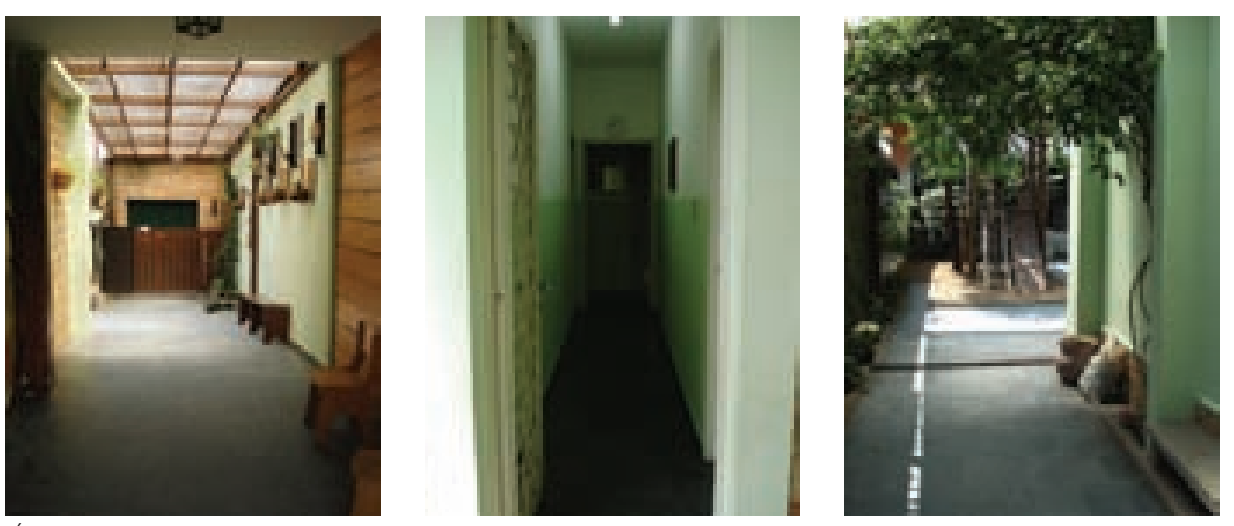

Áreas de circulação do jardim-de-infância: na foto à esquerda, o portão de entrada ao fundo e o corredor que dá acesso ao "parquinho", às salas dos jardins (corredor da foto central) e ao "pátio" e sala do maternal.

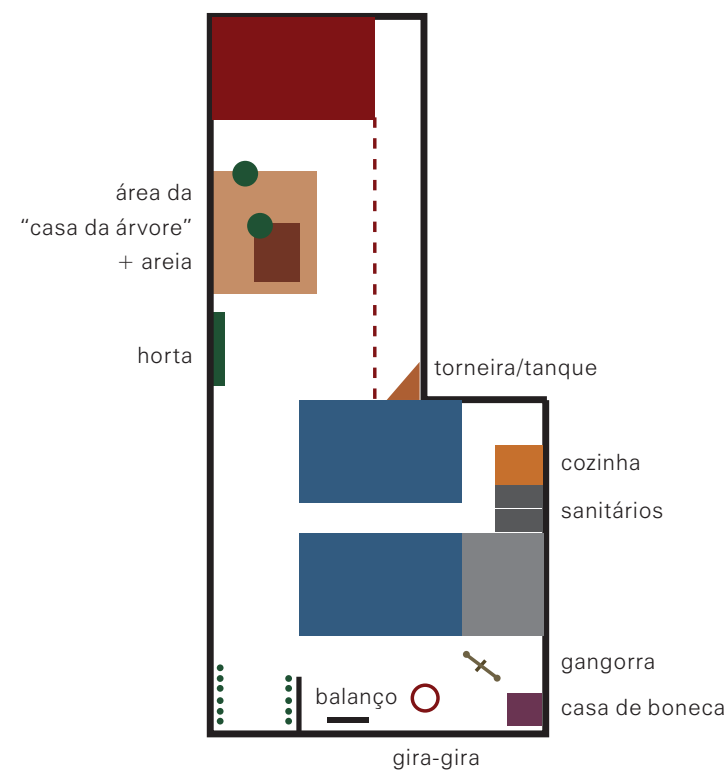

maternal

jardim-de-infância

... canteiros

- árvores

Planta esquemática da Escola Waldorf São Paulo, elaborada pelos autores com base nas observações realizadas em visita ao local (sem escala).

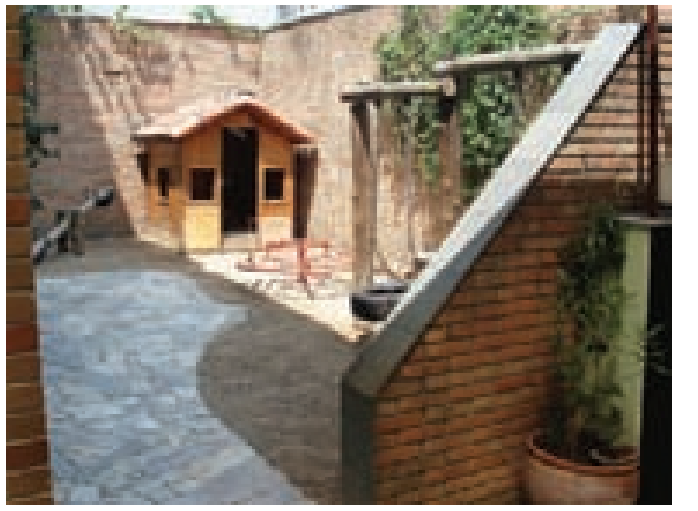

"Parquinho"; ao fundo, muro que separa área dos jardins dos demais edifícios da escola.

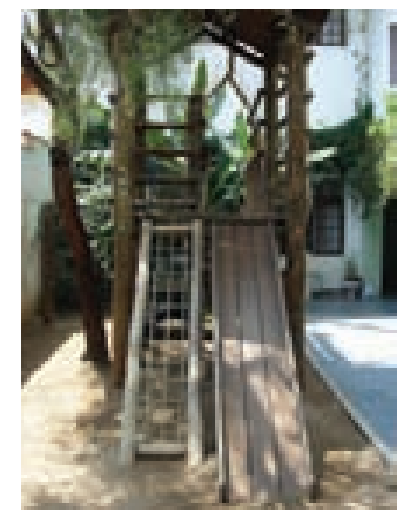

"Pátio", com sala do maternal ao fundo. 
Alto da Boa Vista, bairro residencial arborizado, com lotes grandes, e a segunda no bairro Vila Olímpia, fortemente urbanizado e com lotes bem menores), de fato impõe limites e dificulta o desdobramento da pedagogia nas suas condições ideais, principalmente em relação à importância do contato com a natureza e com os elementos de desafios dos espaços ao ar livre. Apesar de esta situação não ser vista como um empecilho ao desenvolvimento da mesma por parte da equipe da Escola São Paulo, que a considera até mesmo um desafio interessante para o grupo, podemos observar que alguns aspectos da proposta pedagógica deixam de ser explorados ou acabam perdendo o seu caráter particular e próprio do pensamento waldorfiano, como veremos ao longo dessa análise.

Em ambas as escolas, as turmas de maternal e jardim ficam em áreas separadas dentro da mesma parte do terreno delimitada para as crianças de dois a seis anos de idade (com exceção de uma nova sala para a nova turma de maternal na Waldorf Rudolf Steiner, que, em função do crescimento do número de crianças ingressantes, adaptou uma antiga sala de professores ao lado de um dos jardins de infância). Cada turma tem a sua própria sala, mesclando crianças de 2 a 3,5/4 e 4/4,5 a 6 anos. As crianças só mudam de sala quando passam da idade do maternal e devem ser encaminhadas para o jardim.

$\mathrm{Na}$ Rudolf Steiner, cuja realidade de projeto poderia ser considerada ideal, cada sala tem também uma área intermediária, o terraço, entre o ambiente fechado e a área externa, aberta e descoberta. Aí são desenvolvidas algumas poucas atividades, mas é utilizado principalmente nos momentos de transição entre as salas e os jardins e nos dias de chuva. Nem todas as escolas apresentam terraços, como é o caso da Waldorf São Paulo. Nesta, todas as salas têm algum ponto de contato com a área externa, mas nenhuma delas se volta diretamente para a mesma; esse contato se dá apenas por meio de suas janelas.

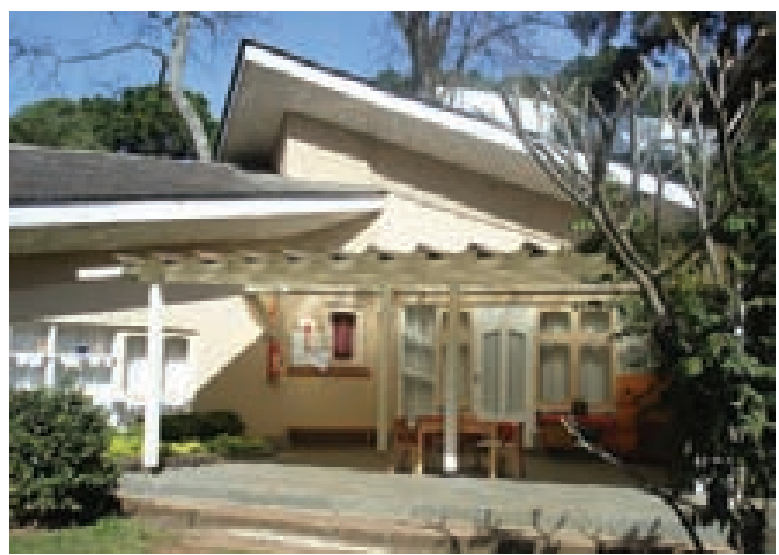

Rudolf Steiner (RS): terraço de uma das salas de jardins.

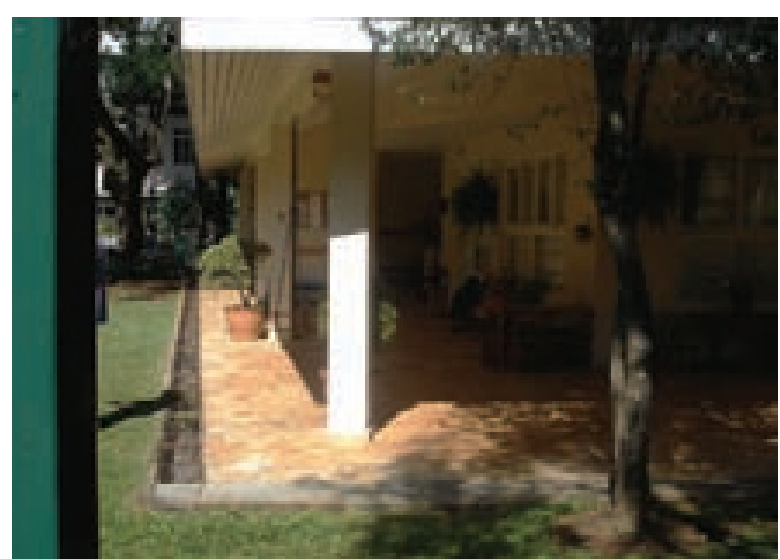

RS: terraço de duas das salas de maternal.

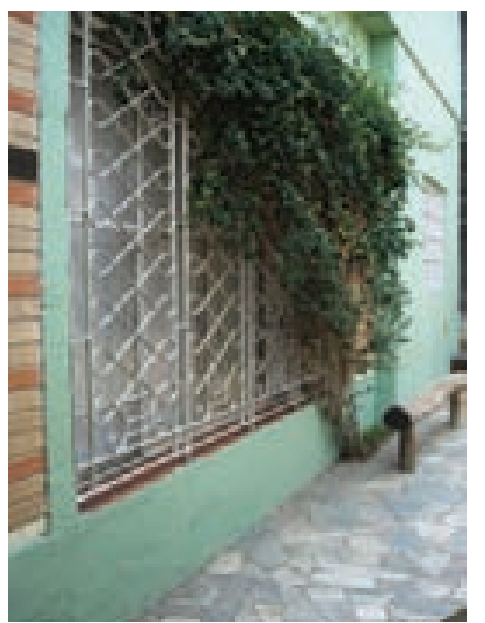

Waldorf São Paulo (WSP): janela de uma das salas de jardins, que dá para o "parquinho".

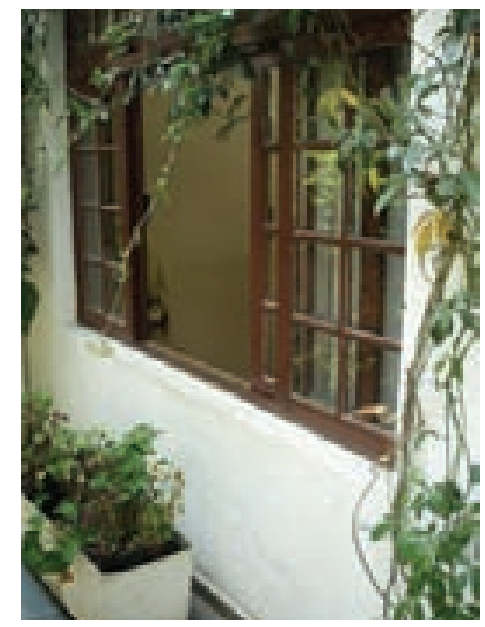

WSP: janela da sala de maternal, que dá para o "pátio".

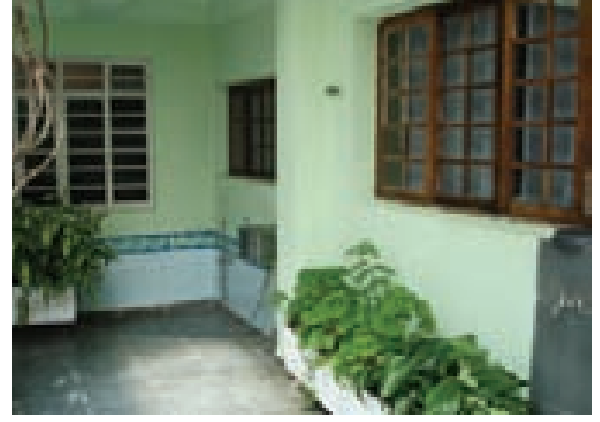

WSP: janela de outra das sala de jardins, que dá para o "pátio". 
Já a área externa parece existir em quase todas as escolas Waldorf, variando, porém, em sua tipologia. Na Rudolf Steiner, constitui-se de uma mescla de áreas gramadas com áreas de terra batida ou areia, abrigando equipamentos variados e uma horta. Na Escola São Paulo, inexistem os gramados, prevalecendo as áreas de areia e terra batida, com seus limites mais claros. Também equipamentos diversos e a horta estão presentes, ainda que em formatos diferentes. Em qualquer uma das situações parece que se procura trabalhar com os mesmos princípios que regem o conceito de espaço externo da pedagogia Waldorf: uma área de contato com a natureza, onde brinquedos, equipamentos, árvores e morros apresentam alguns obstáculos e desafios às crianças. As condições colocadas, os elementos e a maneira como estes são trabalhados e explorados resultam, porém, em ambientes bem diferentes.

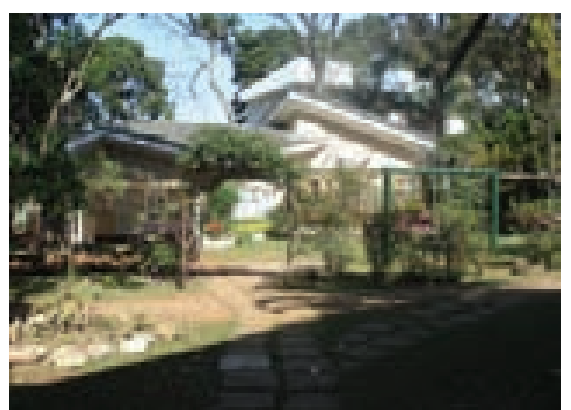

RS: área externa próxima a duas das salas de jardins; caminho de acesso às duas outras salas de jardins e aos maternais.

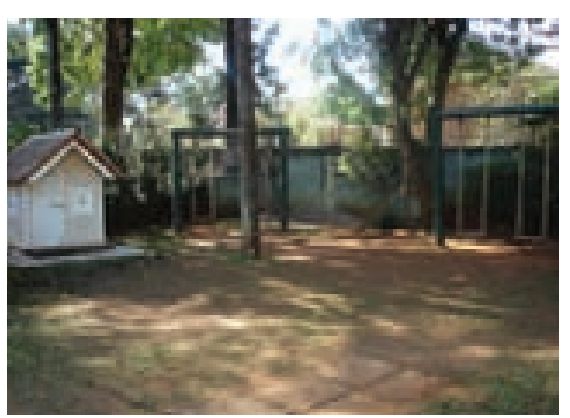

RS: área externa próxima a duas das salas de jardins; ao fundo, limite do terreno da escola com a rua externa.

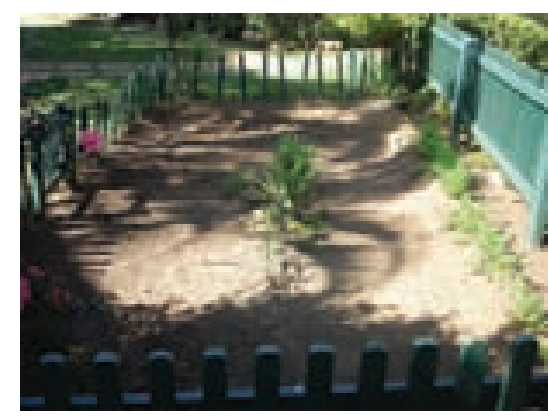

RS: horta (cultivada pelas turmas do ensino fundamental e usufruida pelo jardim-de infância).

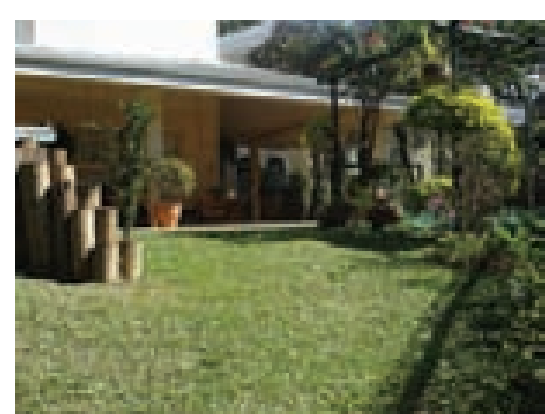

RS: jardim adjacente a duas das salas de maternal, ao fundo.

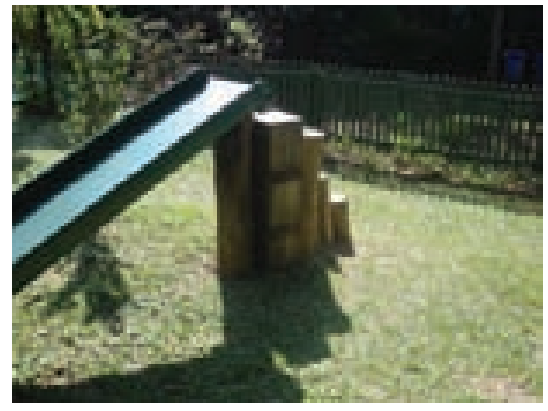

RS: acima, escorregador na área externa de duas das turmas de maternal; ao lado, tanque de areia da área externa de duas das salas de maternal; ao fundo, área dos jardins com casa da árvore.

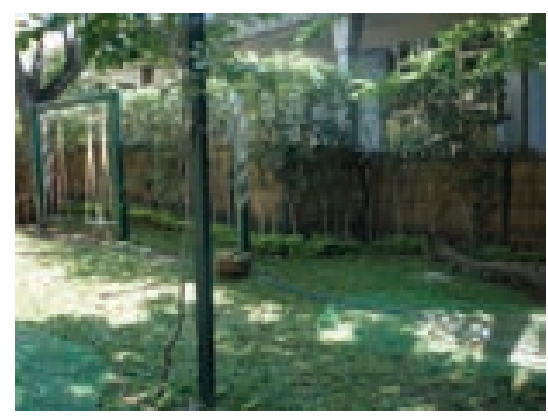

RS: área externa do jardim-de-infância e limite com demais edifícios da escola.

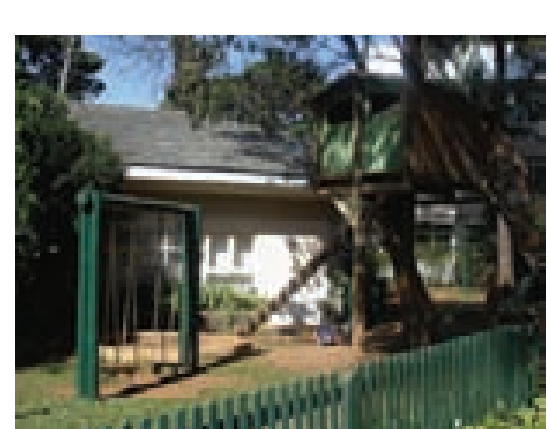

RS: área externa de duas das salas de jardins, com casa da árvore, tanque de areia balanço, etc.

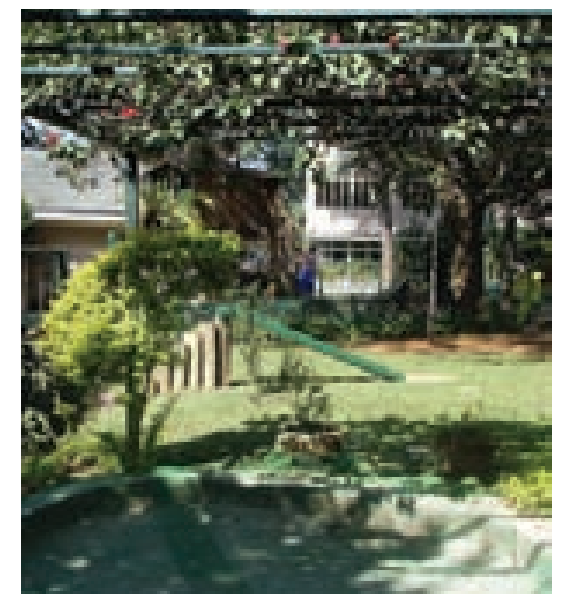




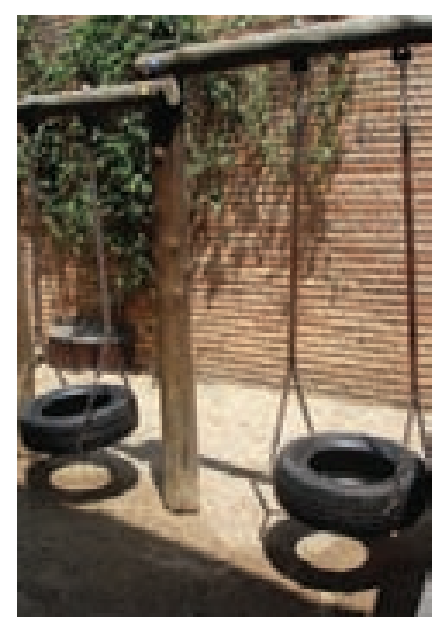

WSP: balanço de pneu.

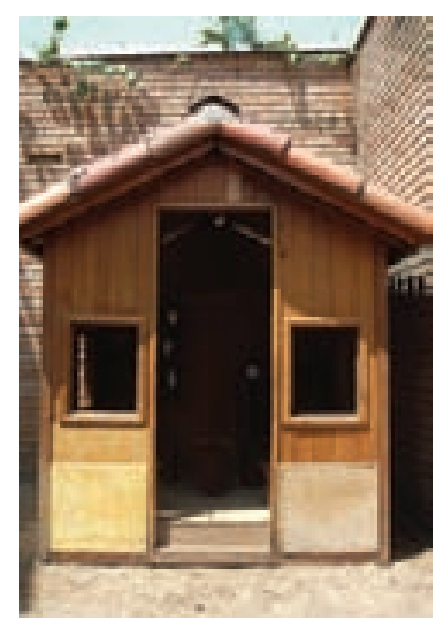

WSP: casinha de madeira, com utensílios reproduzindo uma casa de verdade (não segue o partido arquitetônico Waldorf).

A dinâmica do dia-a-dia das crianças é regida por um jogo de ritmos. Segundo a proposta pedagógica, deve-se criar ritmos que se repetem diariamente, semanalmente e anualmente, pois é por meio destes que a criança passa a ter uma idéia mais clara e um domínio - e, por conseguinte, uma sensação de segurança - do seu "caminho". A criança deve saber o que irá acontecer depois de cada atividade, portanto deve haver sempre uma programação das mesmas no cotidiano da escola.

A partir da alternância entre momentos e movimentos de contração e expansão, as escolas organizam as atividades do dia-a-dia, estabelecendo os seus ritmos:

- Ritmos diários (exemplos): desenho ou pintura música e poemas; brincar livre dentro da sala; culinária; modelagem; teatro; lanche; brincar no jardim; histórias de contos de fada ou teatro; etc

- Ritmo semanal: cada escola monta a sua própria programação, estabelecendo a cada dia da semana uma atividade diferente. Na Waldorf Rudolf Steiner, por exemplo, segunda é dia de desenho, terça é dia de trabalho com aquarela, quarta é dia de fazer pão e assim por diante.
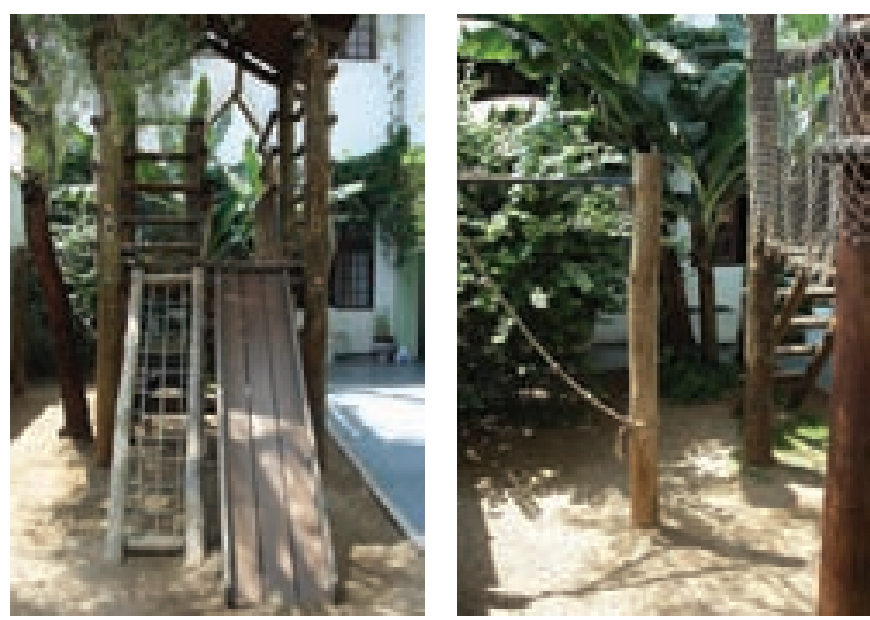

WSP."pátio", com área de terra, onde se encontram algumas árvores e o equipamento de madeira com múltiplos usos e funções; a área de terra é delimitada, dividindo o espaço do "pátio" com ums espécie de terraço semi-aberto, com piso de pedra.

- Ritmo mensal: em cada mês, um tema diferente é desenvolvido nas rodas de história e contos, de acordo com a época do ano.

- Ritmo anual: em cada estação ou período festivo do ano, faz-se um trabalho com as crianças, enfatizando suas características e peculiaridades, que, em geral, culminam em festas, como a Festa da Lanterna, Páscoa, Natal, Festa da Primavera.

O dia é, assim, dividido com períodos de atividades comuns, alternando com jogos e ocupações em que a criança brinca sozinha. O ambiente de cada sala, reproduzindo a casa, o lar, abriga, então, todas essas atividades, sendo organizado por "cantos": a cozinha, a "cabana" ou casinha, o "altar", etc. Dessa forma, brinquedos, materiais e equipamentos ficam à disposição para as crianças, que têm autonomia para utilizá-los. Apesar da existência dos cantos, há uma flexibilidade na organização das salas, que varia de acordo com os professores, as crianças, as escolas, e a dinâmica de atividades.

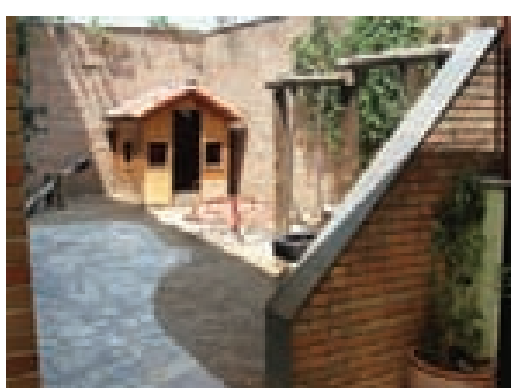

WSP: "parquinho", com casinha, balanço, gira-gira, etc., instalados sobre areia; piso quinho, delimitando áreas diferentes.

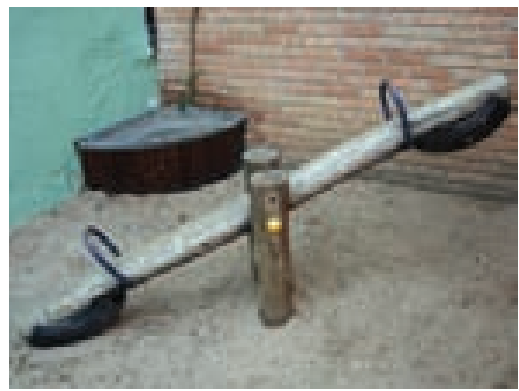

WSP: gangorra.

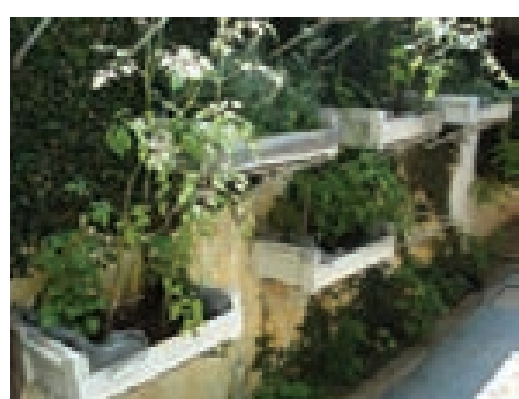

WSP: horta, localizada ao longo do final do corredor de acesso ao "pátio" (área mais aberta, com iluminação natural 
Nas escolas Waldorf, não há salas específicas para atividades como música, artes ou outras do gênero. Dentro do raciocínio de que a criança deve se sentir protegida nos primeiros anos de vida e deve ter na escola uma extensão do lar, acredita-se que tudo deva ser desenvolvido dentro do mesmo espaço. São as salas de cada turma e os jardins externos que constituem, então, o ambiente das escolas que seguem esta proposta.

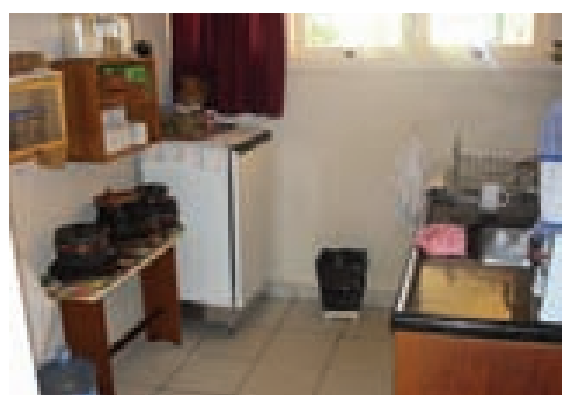

RS: cozinha.

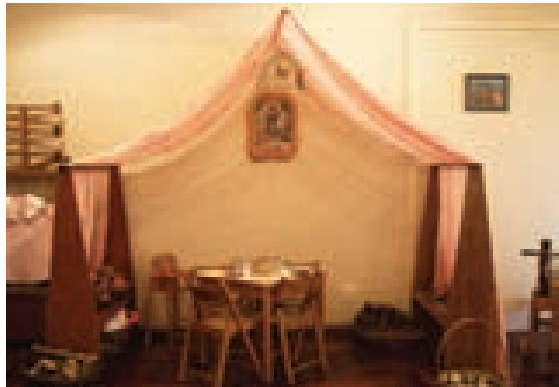

RS: casa-cabana

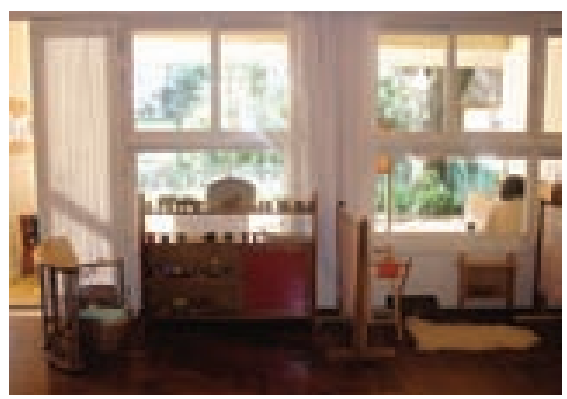

RS: estante com brinquedos, canto, cavaletes e panos para criar cabanas.

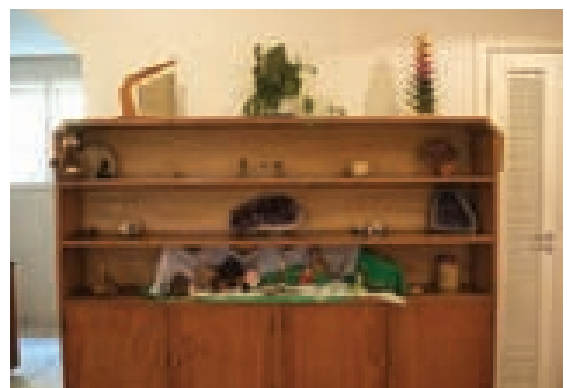

RS: "altar", canto dedicado ao tema do período

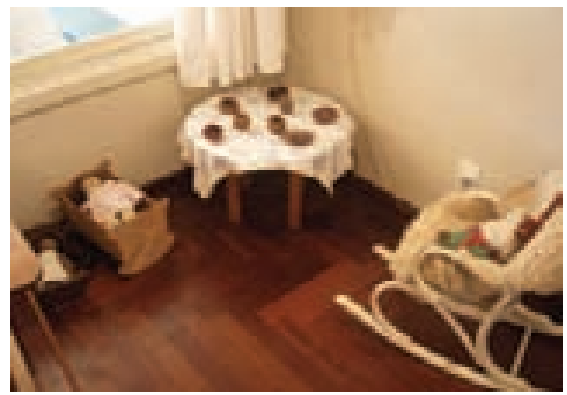

RS: canto das bonecas

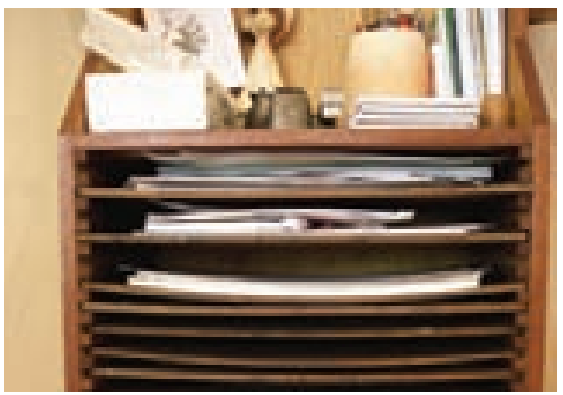

RS: material para aquarela e desenho com cera de abelha.

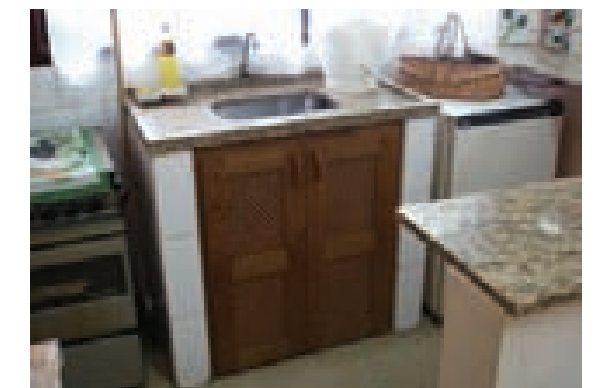

WSP: cozinha

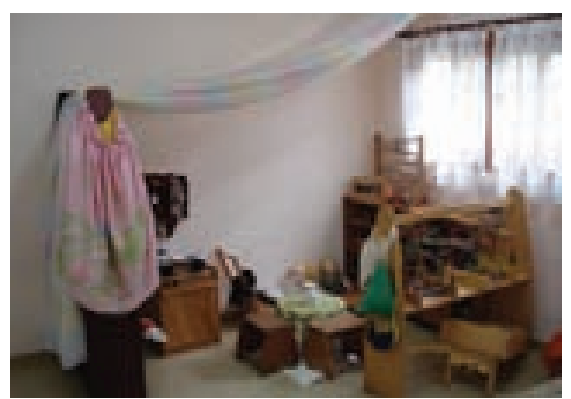

WSP: casa-cabana

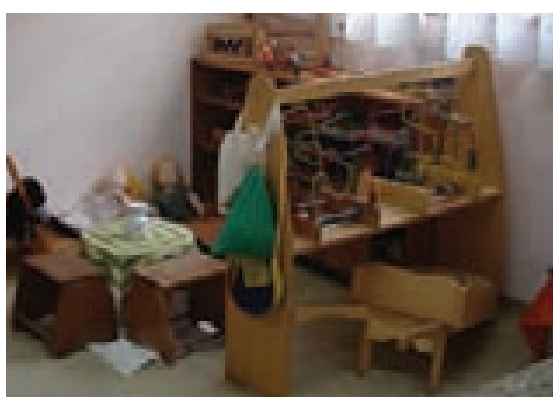

WSP: estante com brinquedos, canto, cavaletes e panos para criar cabanas.

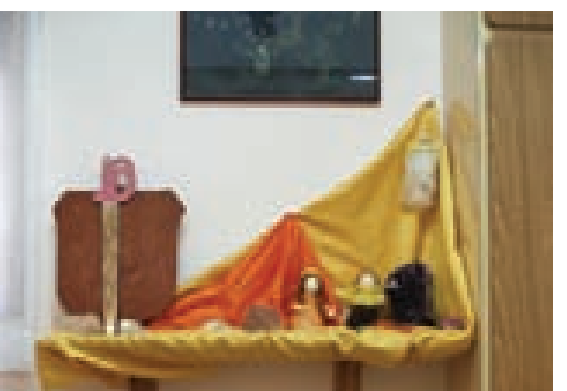

WSP: "altar", canto dedicado ao tema do período

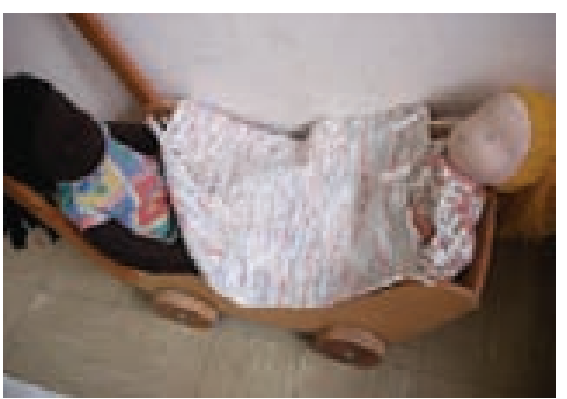

WSP: canto das bonecas.

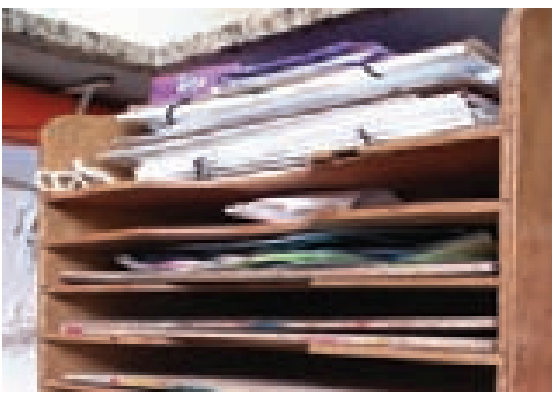

WSP: material para aquarela e desenho com cera de abelha. 
O ambiente escolar como estrutura de oportunidades para o processo de aprendizagem

\section{A. Organização espacial e campo visua}

Como mencionado anteriormente, as escolas Waldorf procuram estabelecer uma relação de interação entre as salas e os jardins ou áreas externas. Este princípio, porém, ainda que constituindo uma orientação na organização espacial das escolas, é desdobrado de formas bem diversas, resultando em relações, fluxos, dinâmicas, e, enfim, ambientes bastante diferentes.

$\mathrm{Na}$ escola Rudolf Steiner, todas as salas voltam-se diretamente para os jardins, tendo os terraços como áreas de transição. Todas têm vista para o conjunto de jardins, ainda que estes tenham alguns cantos e áreas mais reservadas e escondidas. Nenhuma sala encontra-se de frente para a outra, e a maior parte delas tem o seu próprio terraço, independente ou separado da sala vizinha por paredes (com exceção de duas das salas de maternal, que apresentam um terraço contínuo, dividido apenas por uma meiaparede). Os jardins das turmas de maternal são separados por pequenas cercas de madeira dos jardins das turmas de jardim-de-infância, e cada uma das turmas tem o seu próprio canto, mesmo que compartilhem uma mesma área.

Se por um lado, a organização em torno dos jardins cria uma unidade e define bem a área destinada às crianças de 2 a 6 anos, garantindo a sensação de segurança e criando uma espécie de "comunidade", por outro, acaba não se constituindo como um local de reunião ou de coletividade, em função das separações e disposições físicas. Ainda que permeáveis visualmente, as cercas vivas e "portões" de madeira que separam os jardins dos maternais e os jardins dos jardins-de-infância impedem a integração entre as turmas, que brincam separadamente em seus espaços próprios.

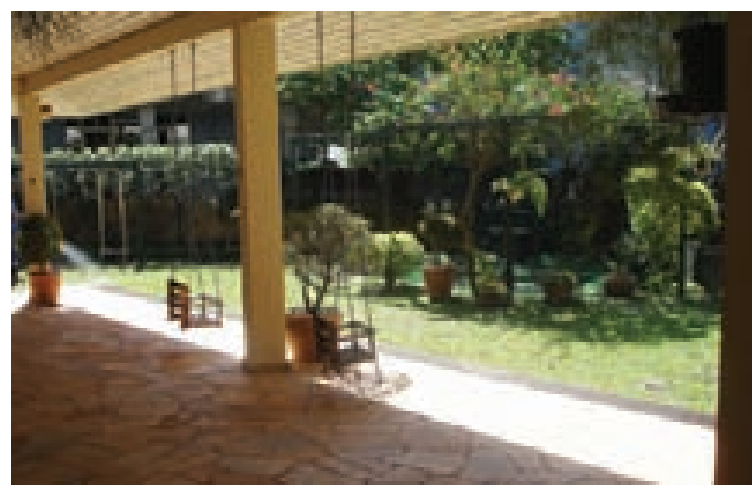

RS: vista do jardim a partir do terraço de duas das salas do maternal: campo relativamente aberto, com cerca viva mais alta ao fundo, separando a área do jardim-de-infância das demais dependências das escola.

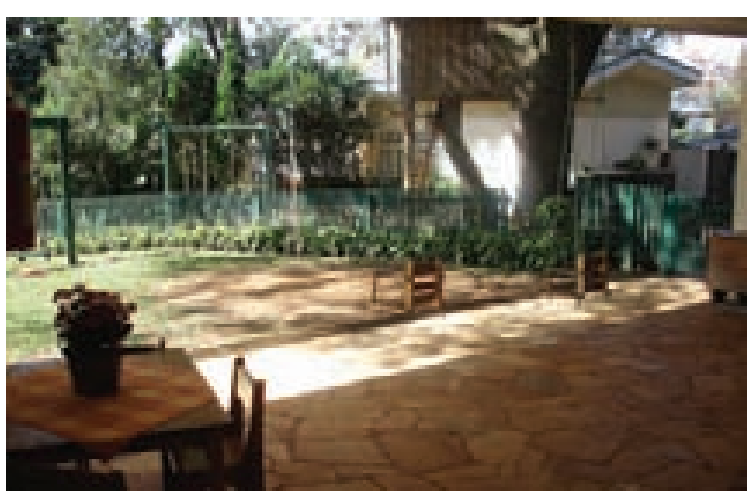

RS: vista do outro lado do jardim a partir do terraço de duas das salas do maternal; campo visual mais aberto do que na foto ao lado, com cerca de madeira ao fundo, dividindo maternal e jardins (4-6anos)

RS: possível soltar as crianças nos jardins de cada turma sem que se perca vista das mesmas, o que, no entanto, reduz o jogo entre cheios e vazios, cantos mais intimistas e cantos mais abertos, etc., ainda que não cheguem a constituir grandes gramados abertos e contínuos, como na escola Santa Cruz. As surpresas e descobertas acabam ficando mais por conta da diversidade, variação e imprevisibilidade da natureza do que propriamente pela organização do espaço e das relações estabelecidas entre esta e os elementos construídos pela escola.

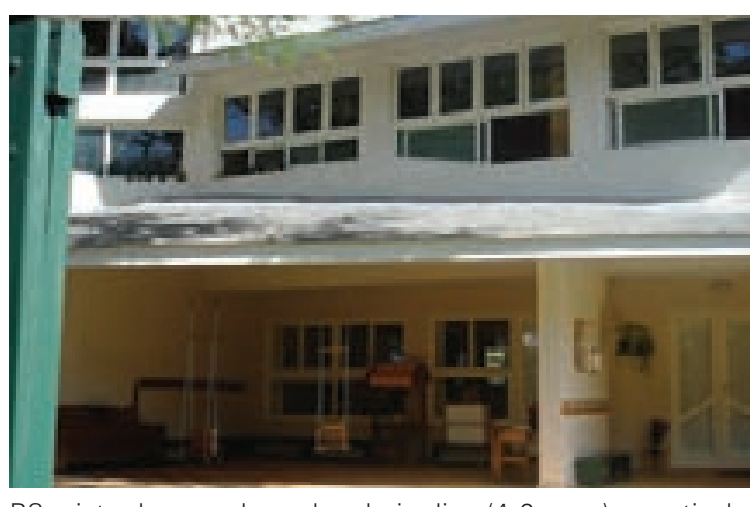

RS: vista de uma das salas de jardins (4-6 anos) a partir do jardim: terraço próprio, separado das demais turmas.

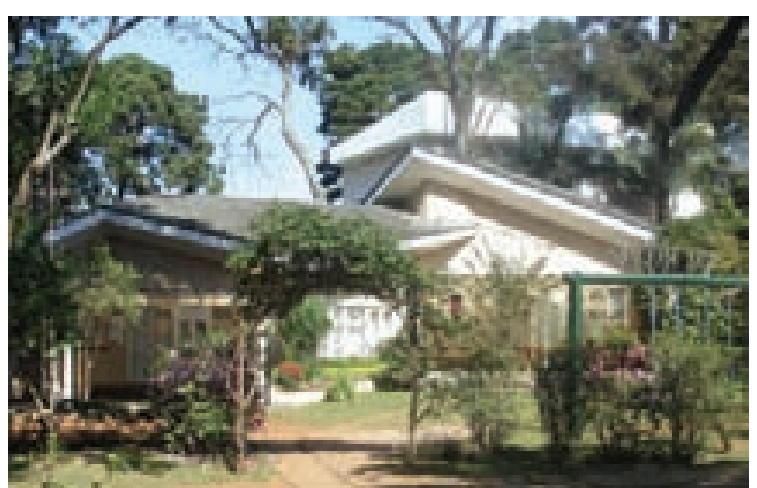

RS: vista de duas das salas de jardins (4-6 anos) a partir do jardim adjacente a elas: terraços próprios, separados pelo arranjo das salas no terreno; área de jardim comum, com entrada marcada por "arco natural", mas salas voltam-se para direções diferentes.

Rudolf Steiner: é interessante e rica a idéia de pensar em um conjunto de ambientes com privacidades e aberturas diferentes para cada turma, trabalhando a percepção entre espaço e os conceitos de relação social, coletividade, intimidade, etc.. Porém, parece que o espaço de coletividade acaba ficando enfraquecido pela ausência de uma centralidade e pela impossibilidade de vencimento dos obstáculos (cercas, etc.) pelas crianças independentemente das professoras, o que parece ser fruto da preocupação com a segurança das mesmas, já observada como princípio da proposta pedagógica. 
$\mathrm{Na}$ Escola São Paulo, a separação é ainda maior em função da distância de localização existente entre o pátioparquinho próximo às salas dos jardins-de-infância e o pátio-praça próximo à sala de maternal. Estes pátios acabam definindo a organização espacial da escola, criando dois núcleos separados, que se comunicam por um corredor coberto. Nenhuma das salas, porém, como já comentado, volta-se diretamente para os pátios. A comunicação entre os mesmos se dá apenas pelas janelas. Apesar de, em sua maioria, baixas, as janelas não permitem a saída das crianças diretamente para os parquinhos, que devem, então, ser acessados pelo corredor interno do edifício (com exceção da sala do maternal, cuja porta se volta para a lateral de uma espécie de corredor-terraço, semi-aberto).
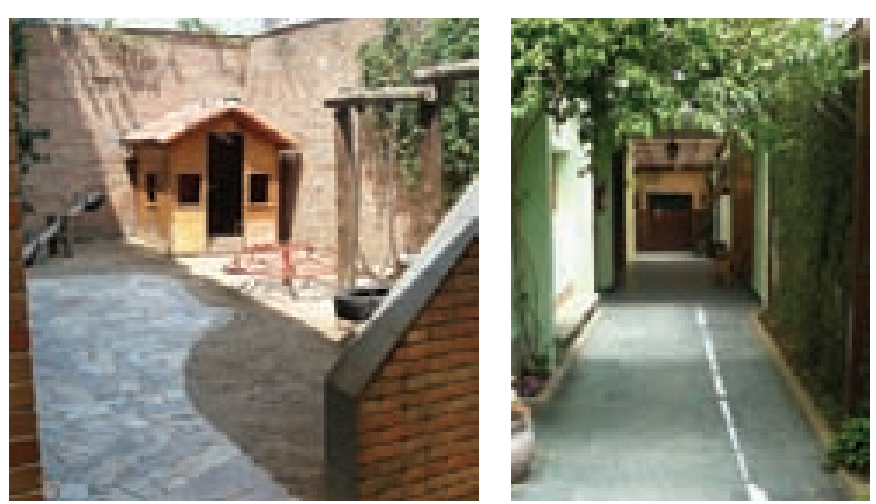

WSP: contato "indireto" das salas com as áreas abertas; restrição do movimento e da troca independente e espontânea entre as crianças e o meio externo.
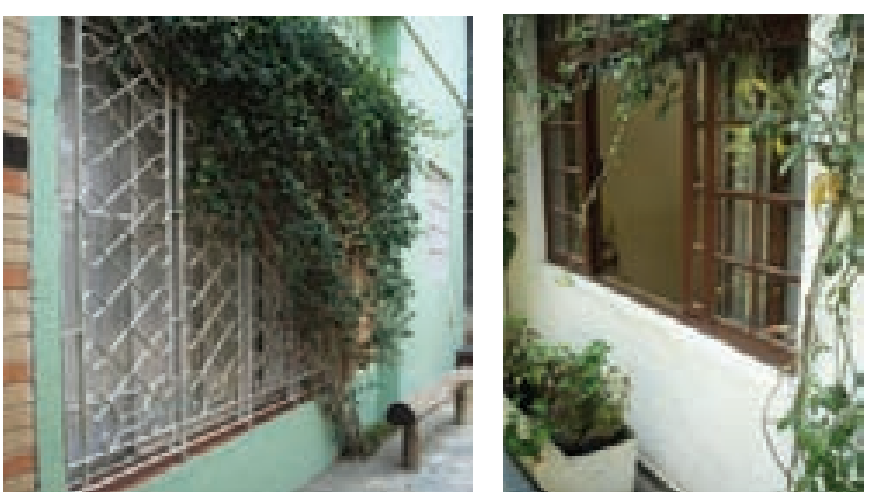

Nessa situação, os pátios-parquinhos-praças deixam de ser exclusivos de uma ou outra turma, não existindo tampouco os cantos, como na escola Rudolf Steiner. Se, por um lado, isso pode permitir uma maior integração entre as turmas e uma maior noção de coletividade, por outro, não chega a constituir um convite à reunião, como na Escola Viva, pois dilui a força de um núcleo único (a "praçona") ou de uma referência principal (como o gramado na escola infantil Santa Cruz).

Tanto na escola Rudolf Steiner como na Escola São Paulo, o perímetro (a área de circulação) das crianças é bastante restrito. Na primeira, as crianças freqüentam apenas a própria sala e o jardim contíguo à mesma. $\mathrm{Na}$ segunda, ironicamente, pelo próprio fato de ser menor, o

WSP: à equerda, vista do "parquinho" a partir do corredor de acesso da escola e de ligação entre todas as salas e os ambientes externos: a área é bem delimitada por muros, só havendo esta abertura de acesso; muros altos e opacos, confinando o espaço e o campo visual, e restringindo os movimentos, descobertas e a autonomia das crianças; à direita, graduação de intensidade de luz e abertura na passagem das salas para as áreas externas.
WSP: área um pouco menos confinada que o "parquinho", o "pátio" apresenta muros mais baixos, uma alternância enterra descoberta, além de vegetação variada, apesar de tímida (pouca), que dá maior movimento e diversidade ao ambiente, além de criar nichos e possibilidades de percursos variados. tre o terraço semi-coberto e a área de 
que resultou na distribuição da área de jardim-pátio em duas partes separadas, as crianças acabam circulando por uma área um pouco maior e mais diversificada. Em ambas as escolas as situações parecem favorecer a autonomia das crianças, desde que definidos os limites das áreas que utilizam, o que, infelizmente, porém, não nos foi possível observar em função da impossibilidade de acompanhar o dia-a-dia das mesmas.

Na Escola São Paulo, os pátios-parquinhos separados passam, então, a constituir referências importantes para a compreensão do espaço da escola por parte das crianças. Com uma área externa e uma circulação mais recortadas que a Rudolf Steiner, a escola apresenta uma alternância mais marcada de campos visuais, e os pátios, sendo as únicas áreas descobertas e mais amplas, acabam tornando-se elementos significativos para a noção de localização das crianças e para o estabelecimento das relações de in teração, hierarquia, e mesmo de separação, próprios da dinâmica da escola.

Apesar de marcadas, as alternâncias de campos visuais são relativamente poucas, ocorrendo principalmente nas transições entre sala e corredor ou terraço, corredor interno e corredor externo e entre este e o pátio-parquinho ou páeo-praça. Internamente ao edifício principal, as mudanças são as mais fortes: de salas amplas e iluminadas, entra-se em um corredor estreito e relativamente escuro. $\mathrm{O}$ acesso aos banheiros, externos às salas em função das restrições apresentadas pela casa alugada, também se dá pelo corredor estreito, apresentando pouca luminosidade e visibilidade em função da largura e distribuição da área de circulação. Saindo do corredor em direção à área externa, passa-se por uma área de transição, o corredor externo, semi-aberto, mais largo e iluminado. A cobertura nesse percurso externo reforça essa sensação de transição, passando de uma laje opaca para um material translúcido, até abrir-se para os pátios descobertos.

Estas mudanças de campos visuais, luminosidades e temperaturas, em função dos fechamentos e aberturas existentes e da maior ou menor penetração dos raios
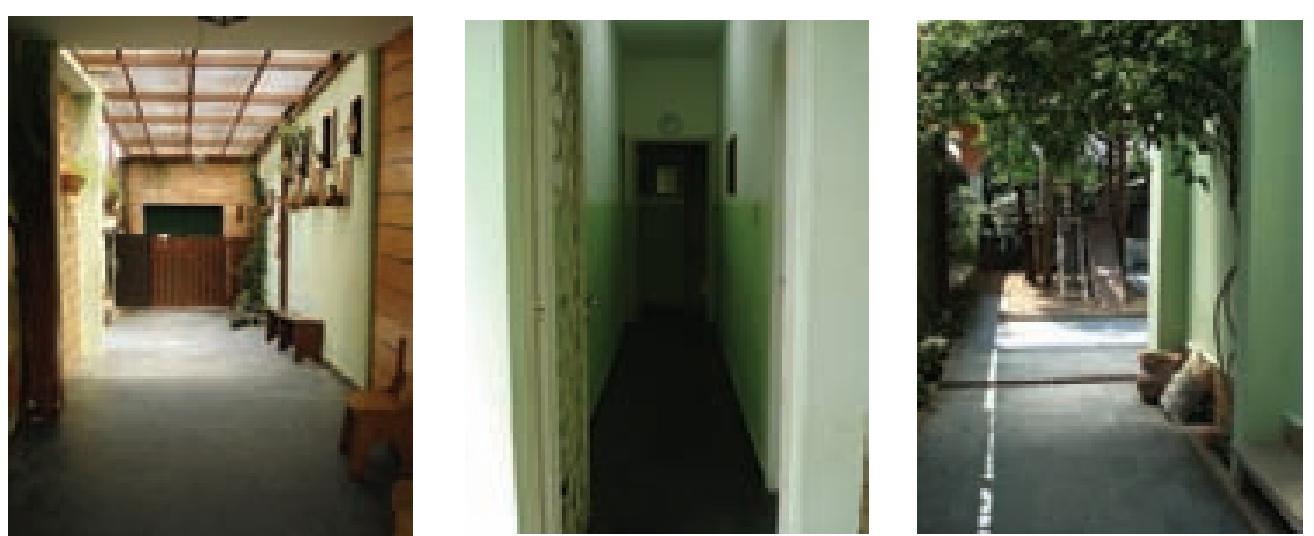

Mudanças de campos visuais e luminosidade, criando sensações diferentes, que passam a construir percepção dos diferentes ambientes e suas relações.
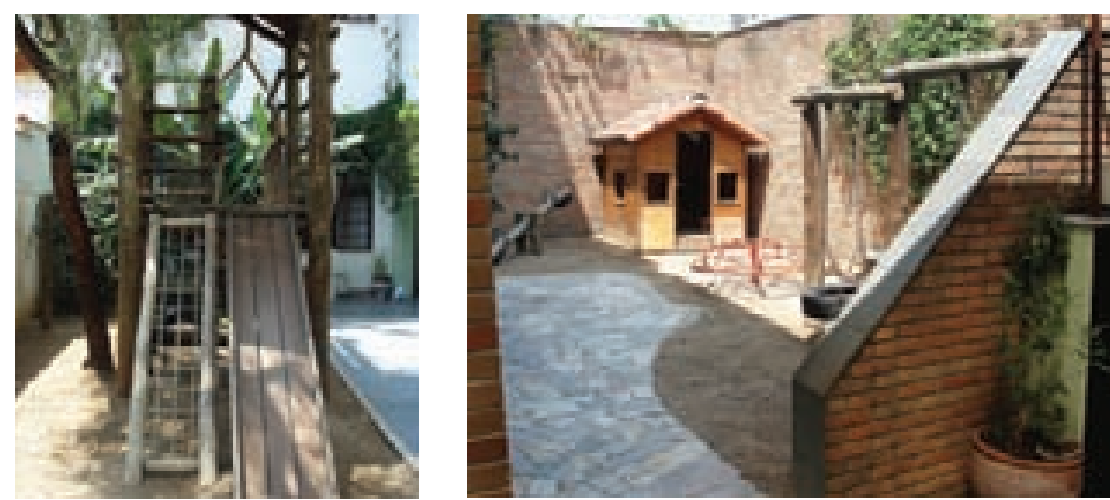

solares, influencia, mesmo que inconscientemente, as sensações e sentimentos das crianças e de todos os usuários da escola em relação a cada um de seus espaços e ambientes. Um corredor estreito e mal iluminado, por exemplo, pode criar uma sensação ruim quando deixa-se a área externa e adentra-se o edifício onde se encontram as salas. Ao mesmo tempo, e por outro lado, a passagem deste mesmo corredor para as salas amplas e bem iluminadas pode trazer justamente a sensação contrária, fazendo com que as crianças passem a identificar aquelas como ambientes acolhedores e confortáveis. 
Ainda, as mudanças nos campos visuais, conjugadas a uma série de outros elementos e relações, podem ser interessantes para criar expectativas e surpresas, quebrando a monotonia do espaço que é freqüentado todos os dias da semana ao longo de vários anos. Na Escola São Paulo, as mudanças ocorrem, porém são dadas pelos elementos fixos da arquitetura e, portanto, deixam de provocar expectativas quando seus percursos passam a ficar conhecidos.

Já na Rudolf Steiner, com jardins adjacentes às salas de cada turma, os campos visuais das áreas circunscritas para o uso de cada uma das turmas são mais abertos e menos variados. A alternância de campos visuais acaba acontecendo de fato quando se considera a área dos jardins e maternais como um todo, em função das cercasvivas, da vegetação e da disposição irregular dos edifícios-salas, os quais criam ambientes e cantos diferentes, maiores ou menores, mais abertos ou mais fechados, enfim, com campos visuais mais amplos ou mais estreitos. Estas mudanças se dão principalmente para as crianças pois as cercas vivas são em geral baixas para o olho de um adulto. Enquanto as primeiras encontram-se em meio a um campo recortado, o segundo tem a visão do todo, podendo controlar muitos dos ambientes e cantos a partir de um único ponto.
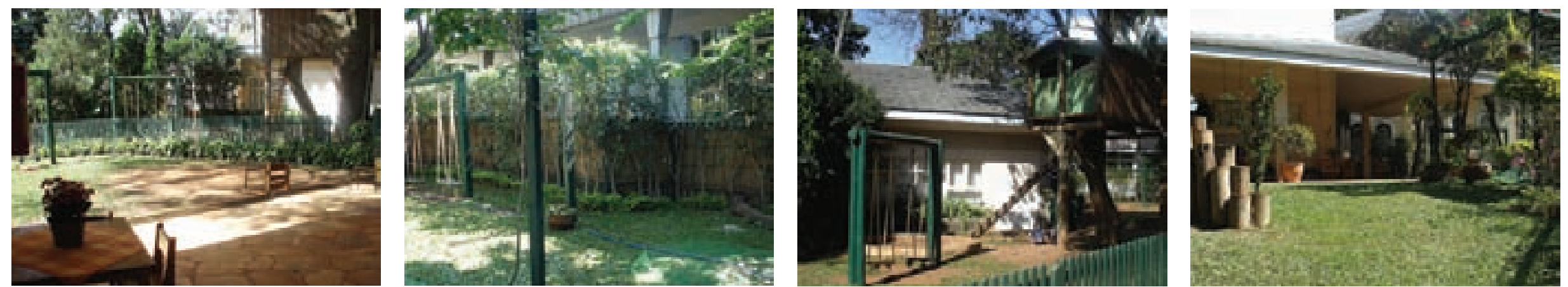

RS: predominância de campos visuais mais abertos, mas
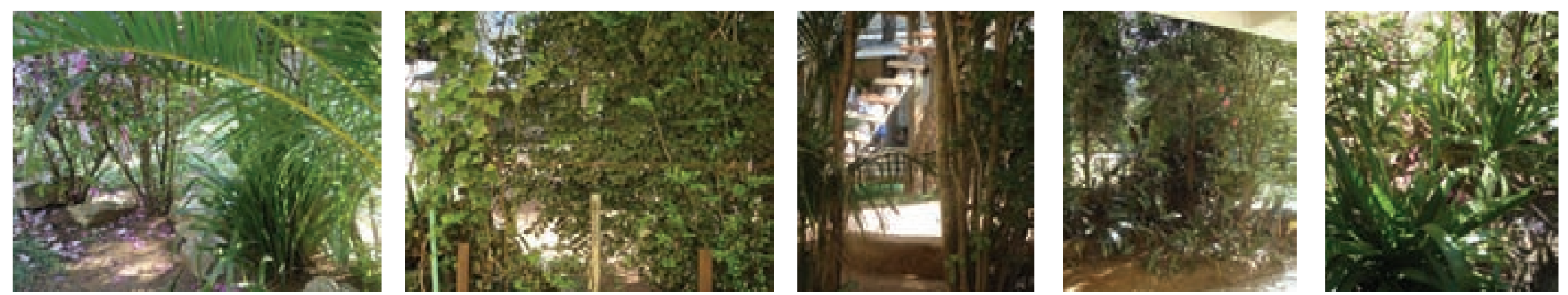

com presença de nichos, barreiras visuais e irregularidades variadas, que criam complexidade e enriquecem o ambiente. 
Este princípio de organização e de composição de elementos é um interessante artifício para que se garanta a liberdade de circulação e descoberta pelas crianças sem que estas saiam da vista dos professores, diferentemente do que acontece na escola infantil Santa Cruz, por exemplo, onde, a fim de garantir o controle visual das crianças, cria-se um grande campo aberto (composto pela quadra e pelo gramado), onde praticamente inexistem os espaços e cantos de esconderijo, descoberta e desafios.

Ao restringir as áreas de uso dos jardins para cada uma das turmas, mesmo a escola Rudolf Steiner perde a chance de oferecer um mais rico ambiente de aprendizagem e desenvolvimento para as crianças. Percebe-se que há uma mudança de complexidade na passagem das áreas de jardins destinadas aos maternais (menos complexas, campos visuais mais abertos) para as áreas dos jardins-deinfância (mais complexas, campos visuais variados). Isto pode ser interessante, pois cria uma situação de mais fácil domínio pelas crianças quando menores, construindo uma sensação de familiaridade com o espaço da escola, a qual dá mais segurança para a exploração de um ambiente mais complexo em um segundo momento da vida das mesmas. No entanto, a delimitação de cantos para as salas (que se percebe, inclusive, pela repetição dos mesmos brinquedos em frente a cada grupo de duas delas) reduz as possibilidades de surpresas e descobertas ao longo dos dois anos que a criança freqüenta estes espaços. Se a idéia dos cantos é instituir e construir referências e elementos de identificação para cada uma das turmas, será que os terraços de cada sala não poderiam exercer este papel, já que constituem justamente espaços de transição entre os ambientes mais privativos, as salas, e os ambientes mais coletivos? Não seriam, assim, todos os espaços da escola mais aproveitados e explorados, uma vez que nos pareceu, pelas conversas com professoras, que os terraços são pouco utilizados, a não ser como áreas de transição?

De maneira geral, podemos observar que, de fato, a organização espacial das escolas Waldorf é estruturada de forma a reforçar os conceitos de segurança e acolhi- mento considerados importantes para o desenvolvimento da criança no seu primeiro setênio. Desde a conformação das salas como reproduções da casa familiar, até a disposição e delimitação dos jardins como quintais adjacentes às casas e "varandas", há a intenção de uma educação mais protetora. Até mesmo os banheiros, sendo internos à cada sala, fecham a idéia de uma composição mais compacta, voltada para si, que dá autonomia e liberdade à criança, contanto que dentro de um campo claramente definido.

\section{B. Clima e recursos do ambiente, arquitetura, materiais,}

\section{equipamentos e brinquedos}

Também localizadas numa região de clima tropical, como a Escola Viva e a Escola Infantil Santa Cruz, as escolas Waldorf analisadas procuram ter boa parte de suas áreas externas descobertas, promovendo uma maior interação das crianças com a natureza (o que, como nos demais casos, restringe a área de lazer nos dias de chuva).

Na Rudolf Steiner, apesar da orientação de cantos específicos para cada turma ou grupo de turmas, não ocorre uma delimitação de espaços e funções, como ocorre na escola Santa Cruz (parquinho, quadra, gramado), por exemplo, ou mesmo, de forma diferente, na Escola São Paulo, com a separação dos dois pátios. Na primeira, tanques de areia, balanços, casa da árvore, escorregadores, cordas e outros equipamentos estão espalhados pelos jardins sem que haja uma demarcação das "áreas de equipamentos", ou do "parquinho". Há uma integração de todos esses elementos, inclusive em relação à vegetação, que se mescla aos brinquedos, criando desafios a partir da exploração de seus troncos e galhos de árvores, ou criando esconderijos a partir do jogo de suas plantas. Não havendo uma delimitação ou demarcação clara para cada área de atividade específica, a criança se depara com elementos diferentes por cada local onde ela passa, o que proporciona um dinamismo e dificulta o estabelecimento de uma relação automática e programada desta com o ambiente escolar. Além disso, a mescla de equipamentos de finalidade "predefinidas" (escorregador, balanço, etc.) e 

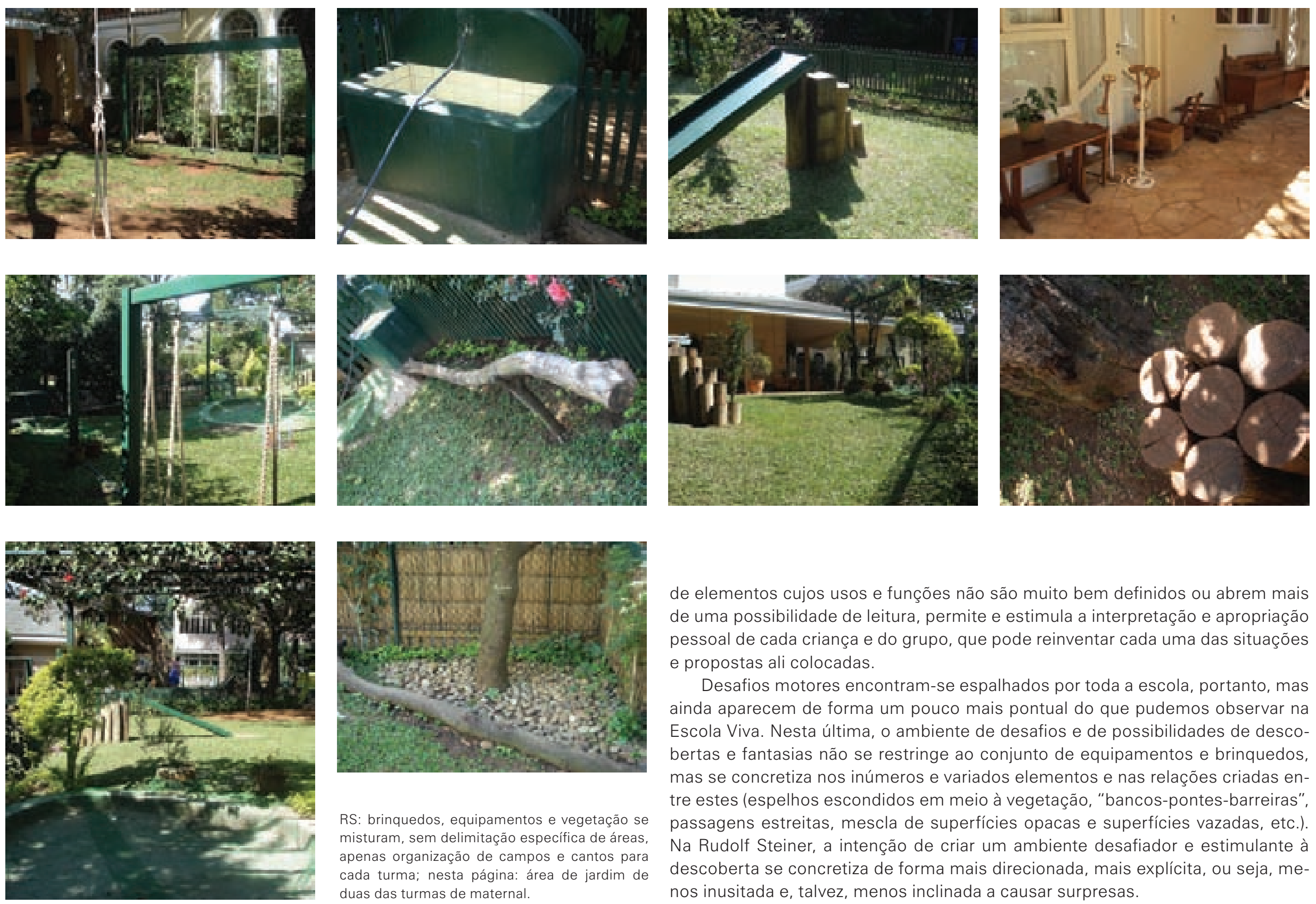

de elementos cujos usos e funções não são muito bem definidos ou abrem mais de uma possibilidade de leitura, permite e estimula a interpretação e apropriação pessoal de cada criança e do grupo, que pode reinventar cada uma das situações e propostas ali colocadas.

Desafios motores encontram-se espalhados por toda a escola, portanto, mas ainda aparecem de forma um pouco mais pontual do que pudemos observar na Escola Viva. Nesta última, o ambiente de desafios e de possibilidades de descobertas e fantasias não se restringe ao conjunto de equipamentos e brinquedos, mas se concretiza nos inúmeros e variados elementos e nas relações criadas entre estes (espelhos escondidos em meio à vegetação "bancos-pontes-barreiras",

RS: brinquedos, equipamentos e vegetação se misturam, sem delimitação específica de áreas, apenas organização de campos e cantos para cada turma; nesta página: área de jardim de duas das turmas de maternal. Na Rudolf Steiner, a intenção de criar um ambiente desafiador e estimulante à descoberta se concretiza de forma mais direcionada, mais explícita, ou seja, menos inusitada e, talvez, menos inclinada a causar surpresas. 

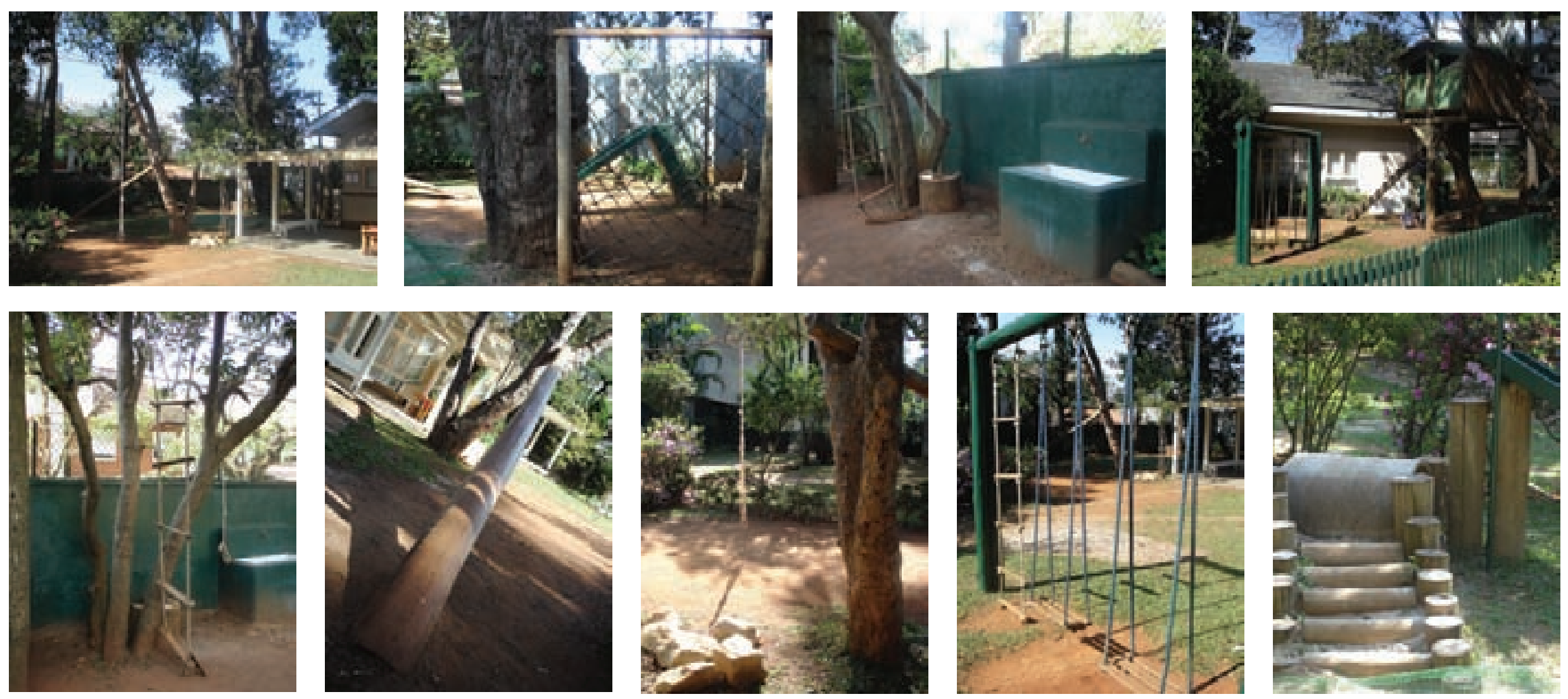

A riqueza deste ambiente se dá principalmente pela diversidade de seus elementos naturais e pela natural integração, inter-relação e interferência que se permite que se estabeleçam entre eles; pela declividade do terreno; pelo respeito à naturalidade da reação dos materiais utilizados e dos próprios elementos da natureza às condições de tempo e clima; enfim, pela abertura, apropriação e proveito que se faz em relação ao desenvolvimento natural das coisas. Sombras, áreas de gramado, áreas de terra batida, pedras, raízes, tocos de madeira, etc., tudo se mistura intencionalmente, como projeto, mas sem que haja con- trole de suas manifestações e transformações ao longo do tempo. Ao contrário, são estas transformações, elementos de experimentação das crianças durante os anos que freqüentam a escola.

Seguindo esse princípio, podemos notar também que se permite uma irregularidade, uma variação e um desnivelamento dos pisos da escola. Algumas vezes mais direcionado, outras tímido, e outras ao acaso, esse jogo é utilizado tanto para delimitar áreas de usos e funções diferentes, como também para oferecer diferentes desafios (de equilíbrio e outros) e possibilidades variadas de brincadeiras.
RS. nesta página, área de tudas das turmas de jardim de infância: alguns brinquedos e equipamentos são os mesmos dos das turmas de maternal, e outros são diferentes, apresentando maiores desafios às crianças mais velhas. 

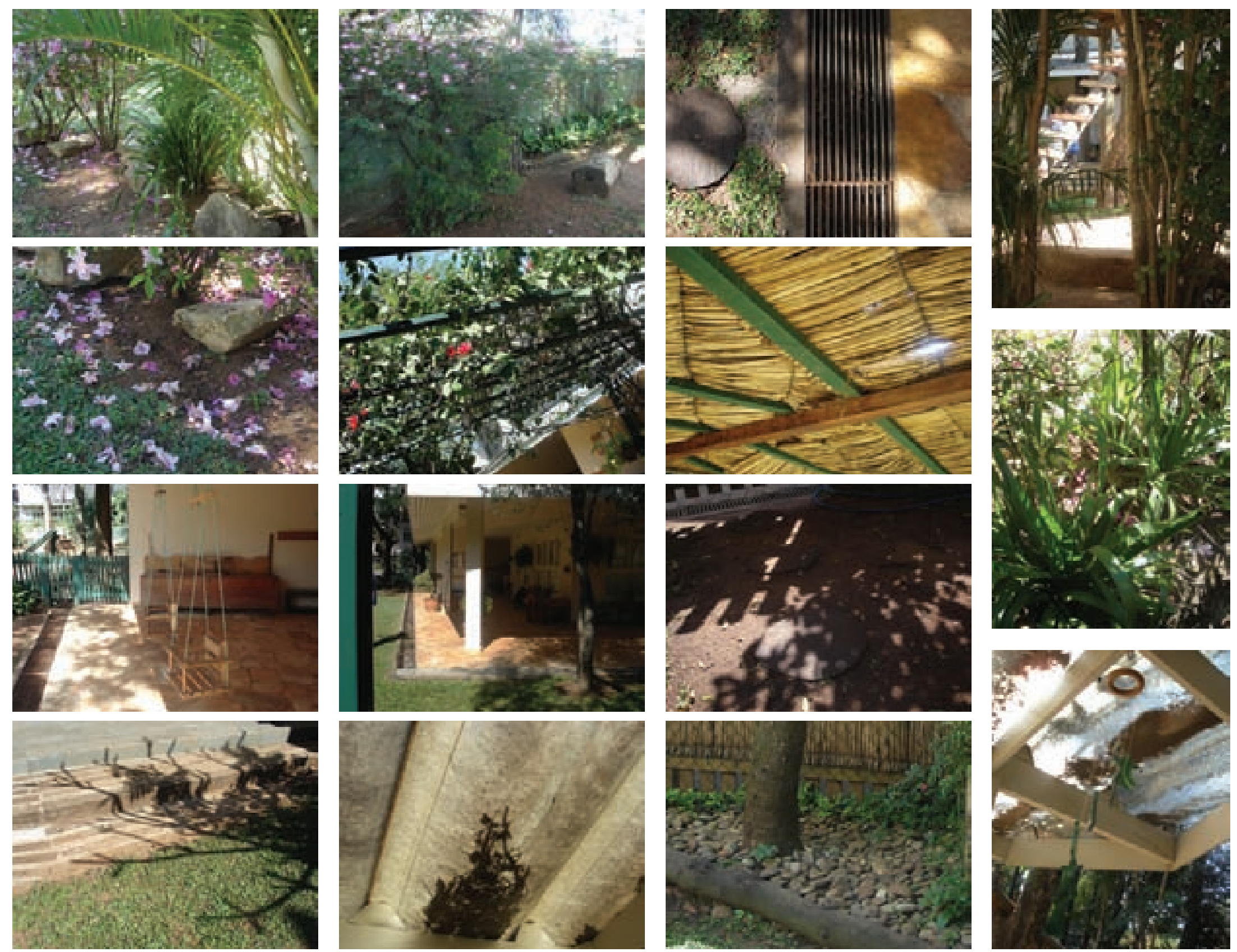
De modo geral, defendendo a idéia de que o mundo apresentado às crianças nessa primeira fase da vida deve ser "verdadeiro", a escola procura trabalhar apenas com materiais naturais. Isso pode ser percebido na escolha dos alimentos e brinquedos oferecidos às crianças, dos equipamentos existentes nos jardins externos. Não há, portanto, uma mescla de materiais artificiais e naturais. Plásticos, metais e pinturas (a não ser com pigmentos naturais), por exemplo, são evitados e, por isso, todos os equipamentos externos são construídos utilizando-se principalmente madeira e cordas de fibras naturais (pelo menos nas partes em maior contato com as crianças). Em função da dificuldade de encontrar equipamentos e brinquedos que sigam todos os princípios colocados pela pedagogia Waldorf, muitas vezes a escola produz os seus próprios materiais didáticos, ou acaba cedendo a algumas das exigências da mesma. Quando possível, no entanto, a diversidade de materiais é explorada a partir da diversidade da própria natureza, por meio de elementos de proveniências e características variadas.

Na Escola São Paulo, ainda que procurando seguir os mesmos princípios da pedagogia Waldorf, os ambientes externos resultam bem diferentes. Como já mencionado, a separação da área externa em dois pátios, e um corredor de ligação, acaba justamente delimitando áreas com usos mais específicos, ou pelo menos mais direcionados: um deles configurado mais como um parquinho, com piso predominantemente de areia, balanço, gangorra e casinha, e outro mais como pátio, com uma área perimetral semicoberta de piso de pedra, e outra descoberta, com piso de terra e equipamento de madeira (mescla de vários usos).

Todo o espaço externo da escola, portanto, assim como os seus cantos, brinquedos e equipamentos, são facilmente desvendados pelas crianças e sua percepção se esgota em poucos olhares. Os desafios são pontuais e os elementos disponíveis para brincadeiras pouco variados, flexíveis ou polivalentes. Como na Rudolf Steiner, o que enriquece o ambiente, criando um pouco mais de complexidade, são os elementos da vegetação, principalmente na área próxima ao maternal (o "pátio"). Ali, trepadeiras, algumas poucas árvores variadas e uma bananeira quebram a regularidade, a organização e a definição dos espaços e elementos ao redor, criando nichos, sombras, percursos irregulares, texturas, e possibilitando o surgimento de situações inusitadas, ou pelo menos variantes, em função das épocas e climas do ano.

Porém, diferentemente da Rudolf Steiner, essa complexidade fica restrita a uma determinada área. A vegetação ou os elementos da natureza, que, no pátio, criam diversidade, por exemplo, ficam restritos a vasos e canteiros ao longo do corredor externo. Ainda que não sejam fixos, como acontece com a maior parte da área destinada à vegetação na escola Santa Cruz, estes elementos parecem não ser manipulados para a transformação do ambiente nem tampouco explorados pelas crianças (a não ser as hortas, cuidadas por elas ao longo do ano).

A maior parte dos brinquedos e equipamentos sugere fortemente usos mais específicos, como a gangorra, o balanço e a casinha, e o conceito de trabalhar com o máximo de coisas e brinquedos menos "prontos", de usos e funções menos definidas, colocado pela pedagogia Waldorf, acaba se enfraquecendo na construção e organização dos ambientes externos da escola.

Como veremos a seguir, grande parte dos conceitos e da essência desta pedagogia se realiza mais fortemente dentro das salas, reprodução dos lares familiares.

WSP: brinquedos e equipamentos de usos predefinidos (o que não im pede novas leituras e apropriações por parte das crianças, porém de forma relativamente limitada).
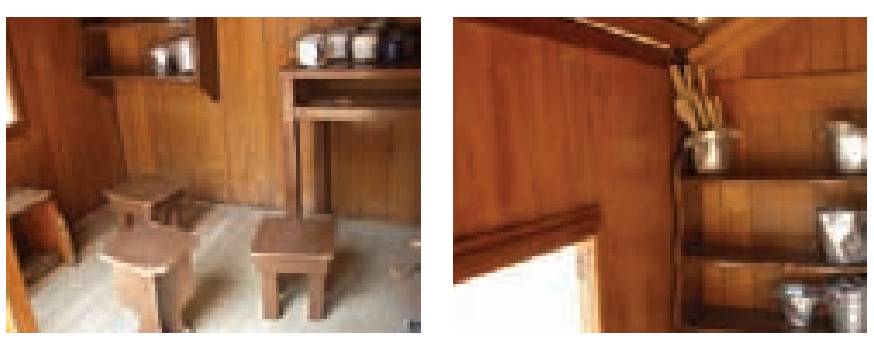
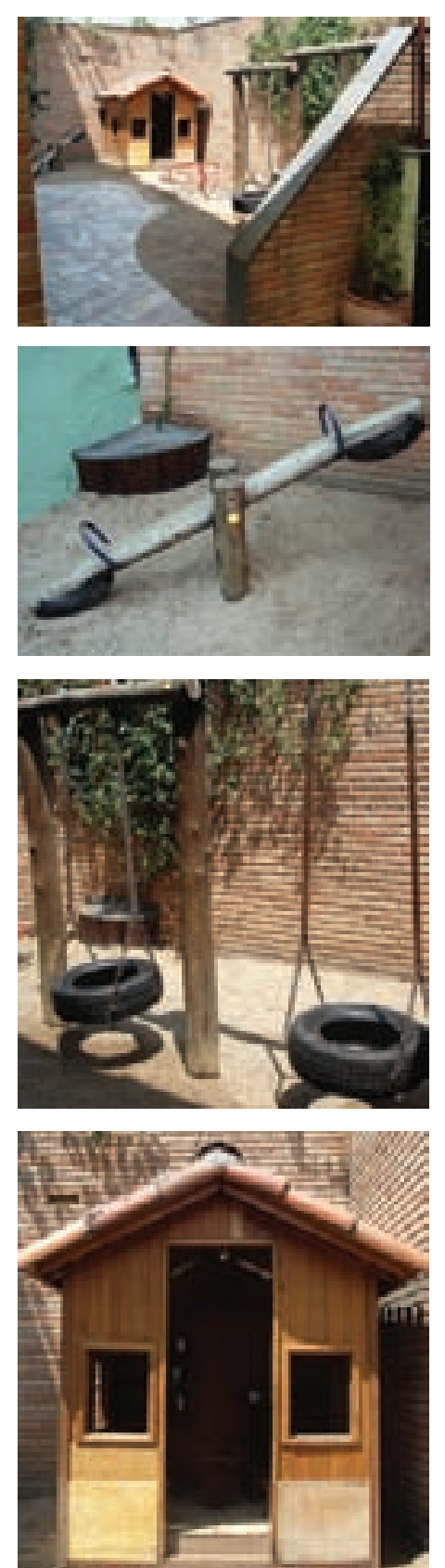

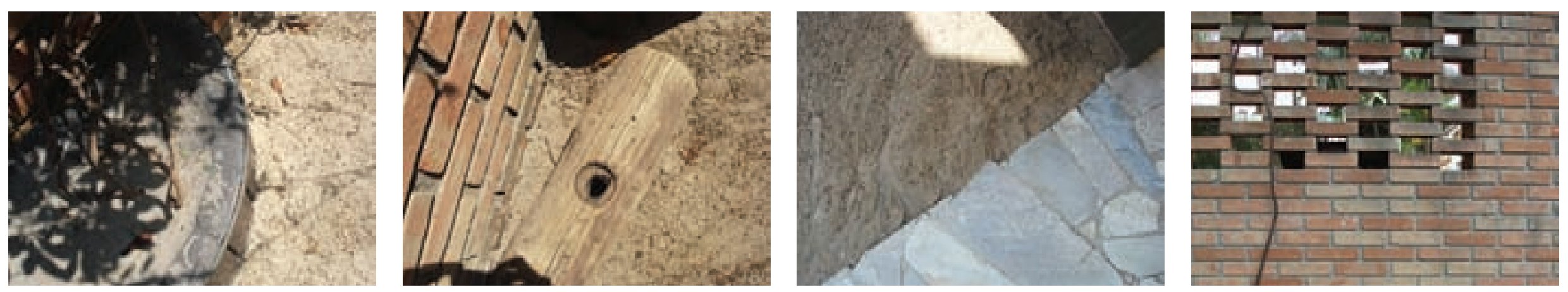

WSP: sombras, texturas, variações de luz,
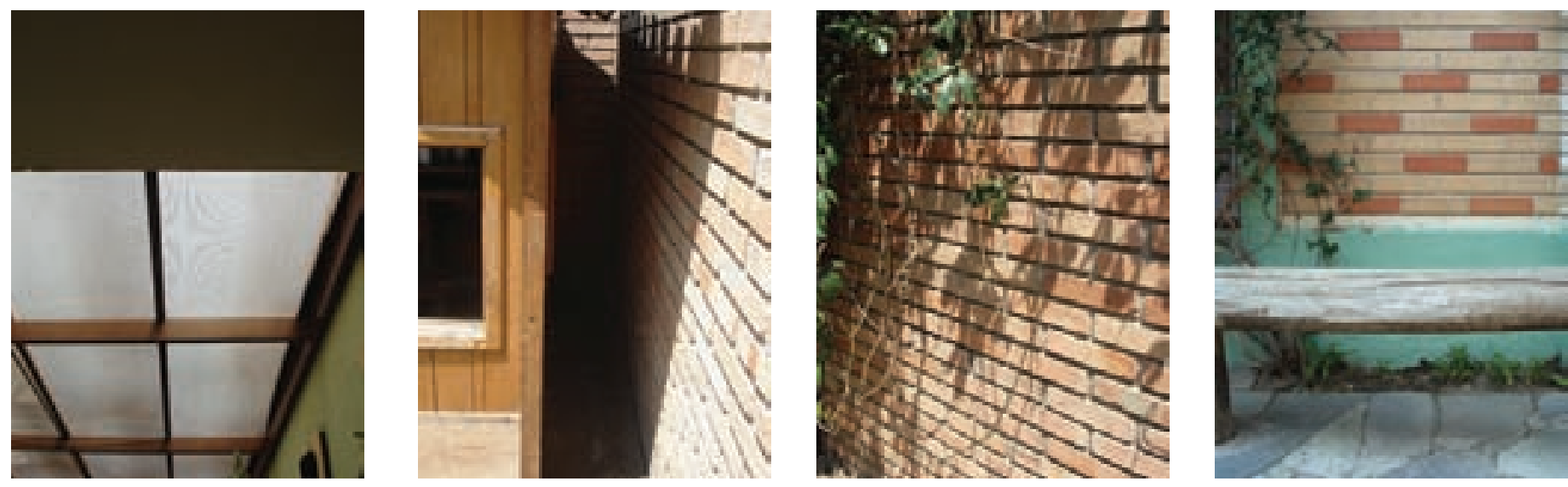

WSP: vegetação e manifestações/ intervenções das crianças têm seus locais predefinidos e suas áreas delimitadas.
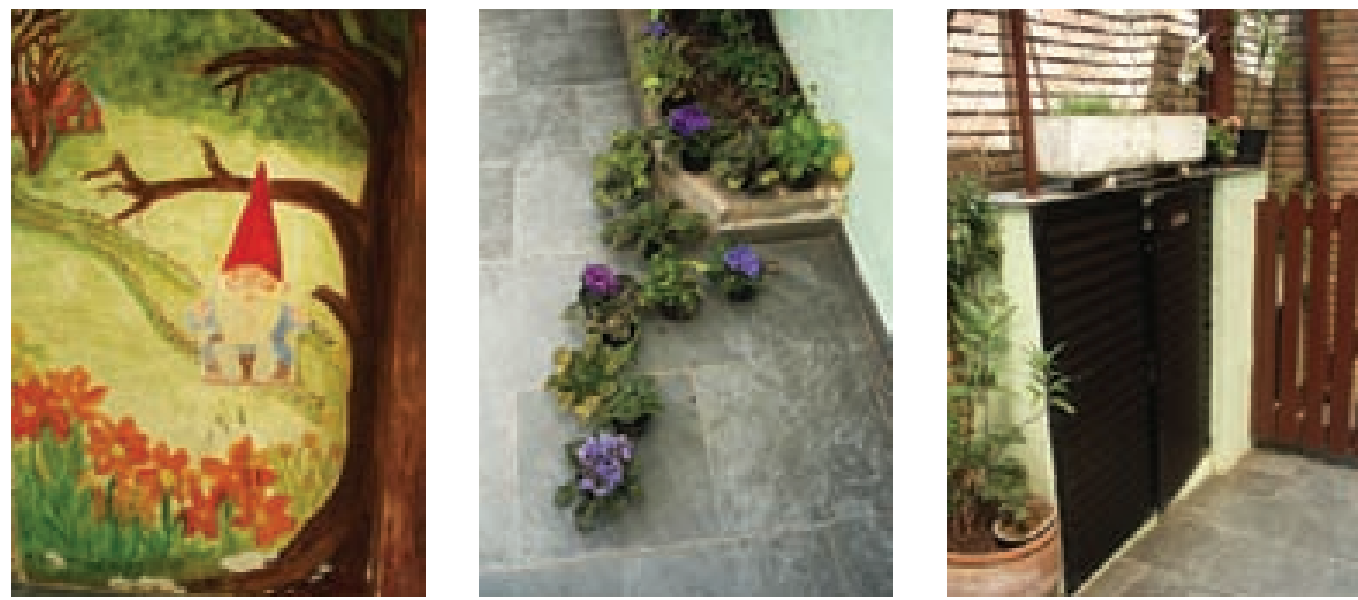

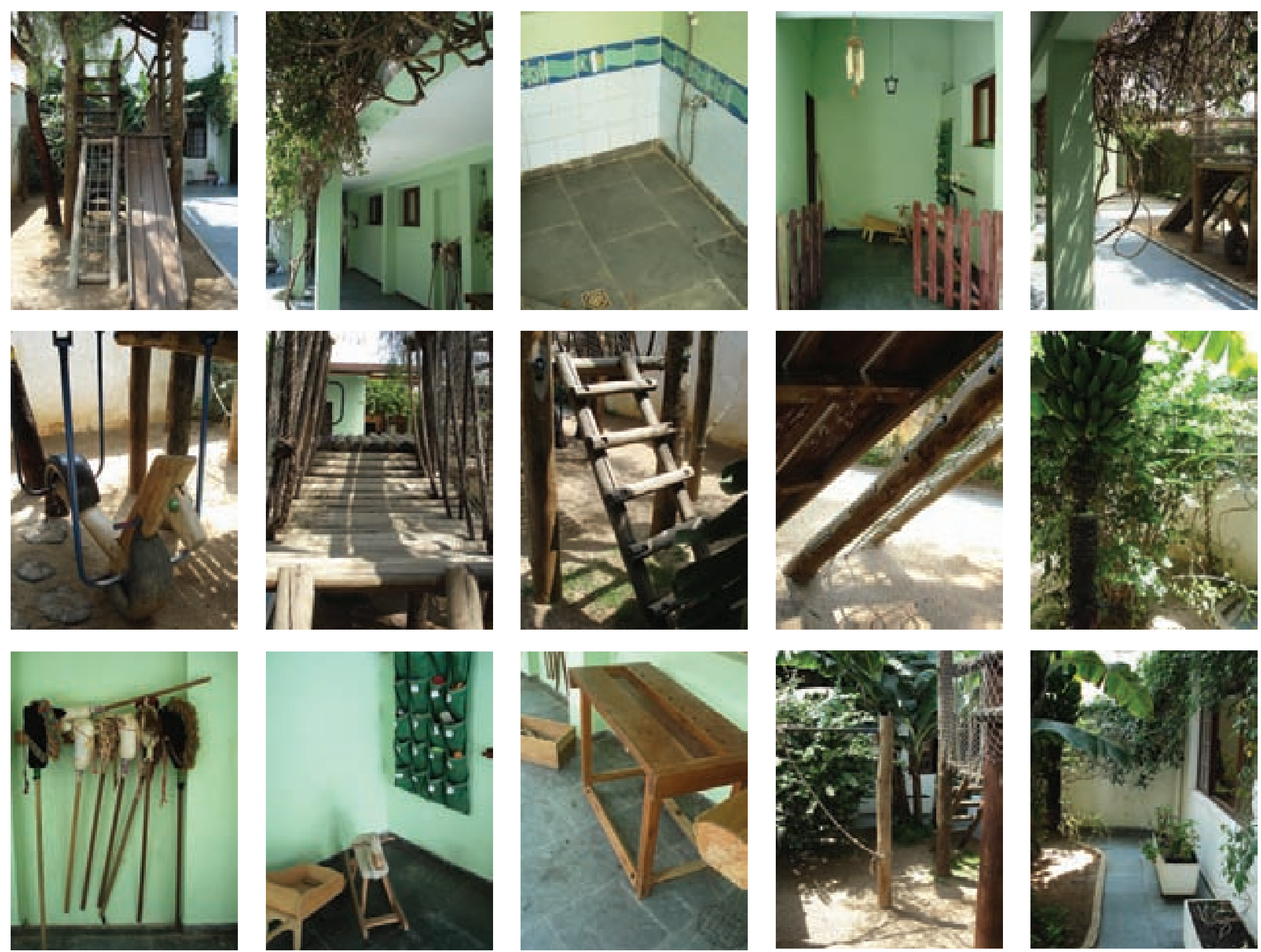

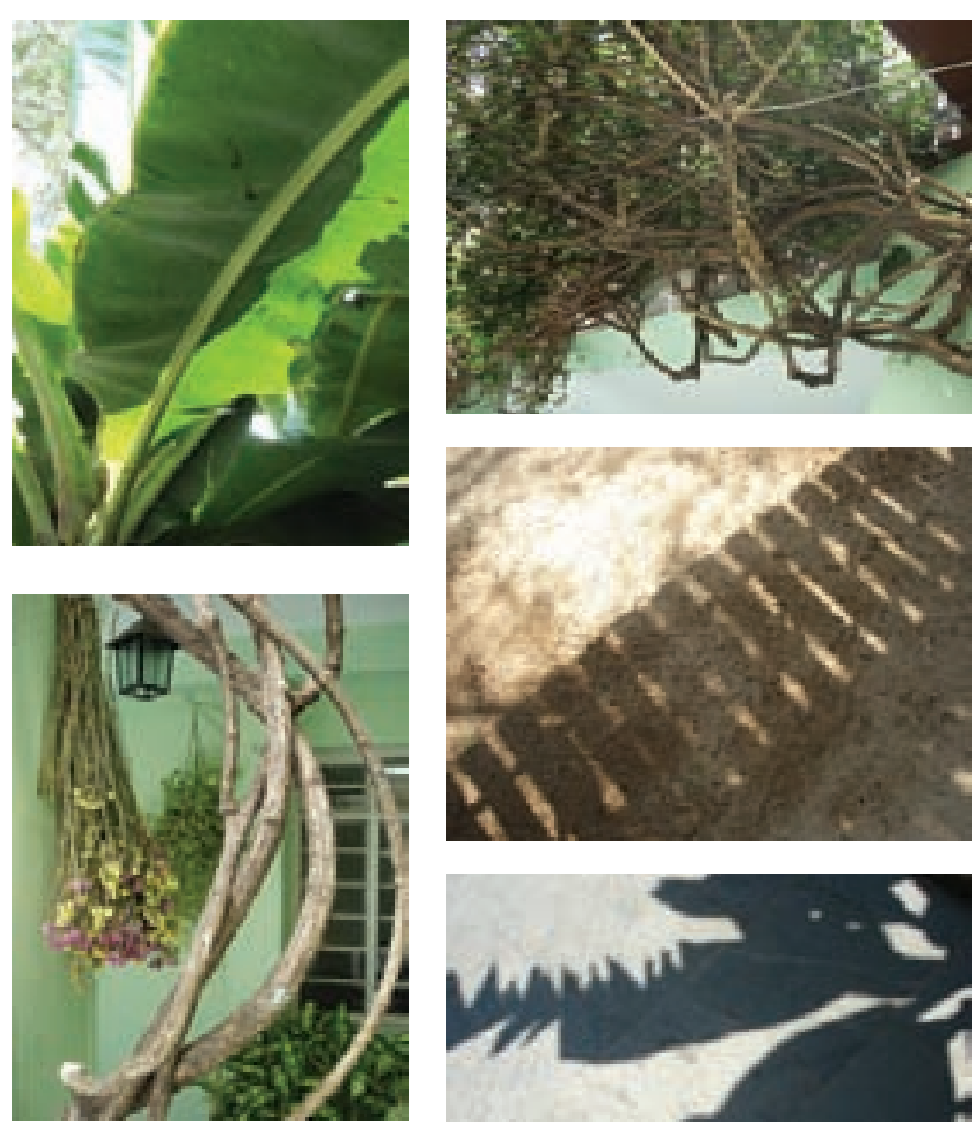

WSP (nesta e na página anterior): facilmente desvendável e com poucos ambientes a serem explorados, a escola, porém, tem seus cantos e esconderijos e dá espaço para fenômenos físicos que podem enriquecer a vivência das crianças. Os encontros entre equipamentos e vegetação, ou os espaços "entre" esta e o edifício, ou "entre" os próprios elementos dos equipamentos e mobiliários, além de outros tantos "espaços entre", por exemplo, podem dar margem a variadas interpretações e apropriações, criando novas situações no que pode parecer um espaço já esgotado de possibilidades de vivências.

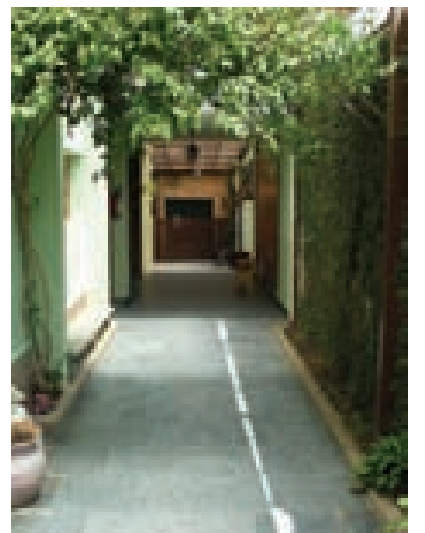

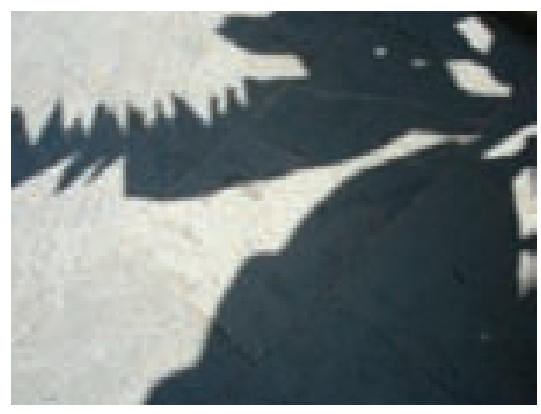

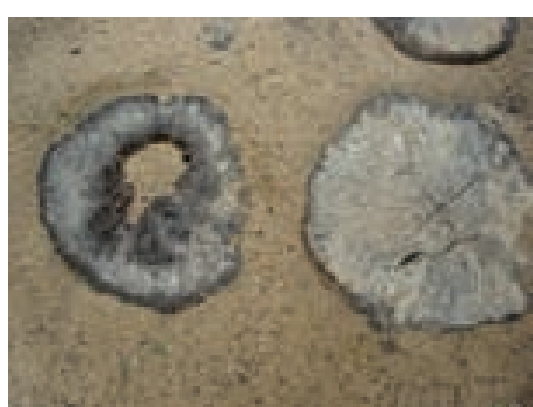

C. Salas de aula

[análise de: relação com demais espaços da escola; elementos estrutuais; formato; dimensões; organização espacial e das atividades; materiais, cores, texturas de pisos, paredes; iluminação; decoração; flexibilidade; mobiliário, equipamentos, objetos e brinquedos]

As salas das escolas Waldorf em geral tendem a ser quadradas, sendo recortadas pela área da cozinha e pelo espaço do banheiro, quando este se localiza no seu interior, situação considerada ideal e que acontece na escola Rudolf Steiner (mas não na Escola São Paulo, onde os banheiros são coletivos, externos às salas). Os tamanhos variam um pouco entre as salas da mesma escola e principalmente entre escolas diferentes, em função da área do terreno e da organização espacial da escola como um todo, mas parece ser uma preocupação da proposta pedagógica que estas sejam amplas e permitam, assim, a organização em cantos diversos, incluindo aí a cozinha, ambiente indispensável em uma sala Waldorf.

Como já mencionado, apesar da existência de terraços, áreas intermediárias entre as salas fechadas, e o espaço aberto e descoberto da área do jardim-de-infância (novamente, considerada situação ideal, presente na escola Rudolf Steiner), é praticamente no ambiente da sala que acontece a maior parte das atividades com as crian ças, pouco se usufruindo destas áreas semi-cobertas, semi-abertas, semi-privativas.

Toda a concepção do ambiente das salas, portanto, parte de importantes fundamentos e princípios da pedagogia Waldorf: a reprodução do lar e da figura materna construindo um ambiente seguro e acolhedor; a idéia de que o mundo apresentado às crianças no primeiro setênio deve ser verdadeiro; e o valor da vivência, através da qual o mundo deve ser experimentado naturalmente, sem abstrações iniciais. Estes foram os três princípios que mais identificamos como construtores dos ambientes observados, com a ressalva de que não nos foi possível acompanhar de fato as relações que aí se estabelecem no dia-adia das escolas. 
Contra a idéia de apresentar logo cedo os problemas do mundo à criança, suas restrições e regras rígidas, então, a arquitetura das escolas Waldorf apresenta um caráter muito peculiar, em que são evitados ao máximo os ângulos retos. Edifícios, mobiliários, brinquedos, etc. têm, sempre que possível, formas e cantos arredondados, de maneira a não restringir o uso, a apropriação, a circulação da criança, o que despertaria a consciência e a preocupação na mesma.

Tudo deve ser o mais natural possível. As formas sem ângulos retos, então, fazem parte também da preocupação com a construção de um ambiente de aspecto mais natural, mais próximo das leis que regem a natureza, sem a intervenção racionalista do homem'. E se o mundo apresentado às crianças em seus primeiros anos de vida deve ser o mais verdadeiro possível, os materiais presentes no ambiente de aprendizagem devem seguir, portanto, este mesmo princípio. Por isso, não são encontrados nos ambientes que seguem a pedagogia Waldorf brinquedos ou quaisquer elementos de plástico, por exemplo. A madeira natural, de preferência sem pintura alguma, é o material predominante nos brinquedos, móveis e pisos, assim como a lã de carneiro, o algodão, o giz de cera de abelha (com coloração natural também), além de todos os demais materiais próprios dos elementos da natureza que são levados para dentro da sala e que se transformam em brinquedos diversos nas mãos das crianças: tocos de madeira, pinhas, pedras, conchas, cascas das mais variadas frutas e frutos, entre outros.

As paredes são pintadas de branco ou de cores quentes bem claras, com acabamento liso, sem textura, o que faz com que reflitam as cores do ambiente, a luz solar, e o jogo desta com a cor das cortinas. A iluminação natural é bastante valorizada, o que pode ser observado pela existência de grandes aberturas em quase todas as salas visitadas (com exceção de uma sala de jardim da Escola São Paulo, que ficou prejudicada com janelas menores e mais altas). Em geral, as janelas (pelo menos parte delas) são baixas, permitindo a visualização da área externa por parte das crianças, o que reforça a busca de integração com o mundo natural.

Há um interessante controle de luz - realizado, porém, principalmente pelas professoras - por meio do jogo entre luz natural e artificial, fazendo-se uso das cortinas, translúcidas na maior parte dos casos, que filtram os raios de formas diferentes, criando ambientes diversos e variados conforme a intensidade, incidência e tonalidade da luz solar. A escolha das cortinas, em alguns casos, como ficou claro na escola Rudolf Steiner é feita pelas próprias professoras e acaba se constituindo um forte elemento de caracterização do ambiente construído em cada sala. Cortinas na cor vinho, por exemplo, utilizadas em uma das salas de maternal desta escola, quando fechadas, além de escurecerem mais o ambiente, criam a sensação de um espaço menor em relação a uma segunda sala de mesmo tamanho e organização espacial, que, porém, utiliza cortinas brancas em suas janelas.

Na escola Rudolf Steiner, onde a arquitetura é típica da pedagogia Waldorf, seguindo novamente o princípio de evitar os ângulos retos, os tetos também são trabalhados a partir de planos diagonais, o que cria um movimento e chega a influenciar levemente até mesmo a iluminação, que passa a ser instalada em planos de ângulos variados, direcionando a luz, portanto, de forma diferente que em um plano reto convencional. As luzes são amarelas, embutidas e pontuais, não sendo utilizadas lâmpadas fluorescentes penduradas externamente ao forro, como comumente acontece na escolas, com o intuito de criar um ambiente mais quente e acolhedor do que o resultante do uso de luzes frias ${ }^{2}$. Os pés-direitos, variando de escola para escola, são em geral relativamente altos, mas acabam não passando a sensação de distância excessiva em função do jogo de movimento criado pelos planos diagonais.
1 É por este mesmo motivo que a pedagogia não se propõe a trabalhar com projetos junto às crianças, pois acredita-se que o conhecimento deve ser construído primeiramente pela experiência e pela vivência concreta sem a formulação consciente e abstrata dos fenômenos da natureza e da vida.

${ }^{2}$ Caberia aqui uma avaliação em relação ao conforto e eficiência desta iluminação em função das atividades desenvolvidas, lembrando que não se propõem aqui aulas de escrita ou ocupações do gênero, que requerem concentração e foco de leitura. 

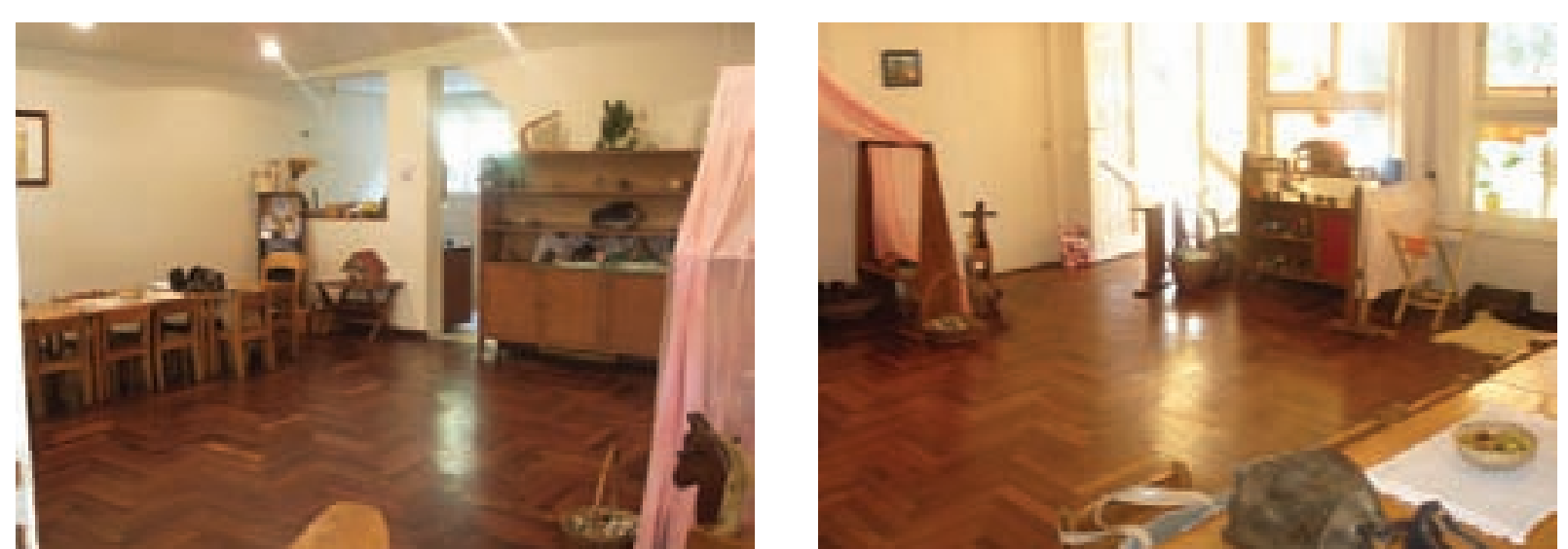

RS: sala de uma das turmas de maternal: área ampla, quadrada, recortada pela cozinha (atrás do balcão) e pelo banheiro (parede ao fundo, ao lado da cozinha); grandes aberturas para entrada da luz natural (de ambos os lados, na maior parte das salas da escola Rudolf Steiner, o que não acontece na Escola São Paulo, no entanto).
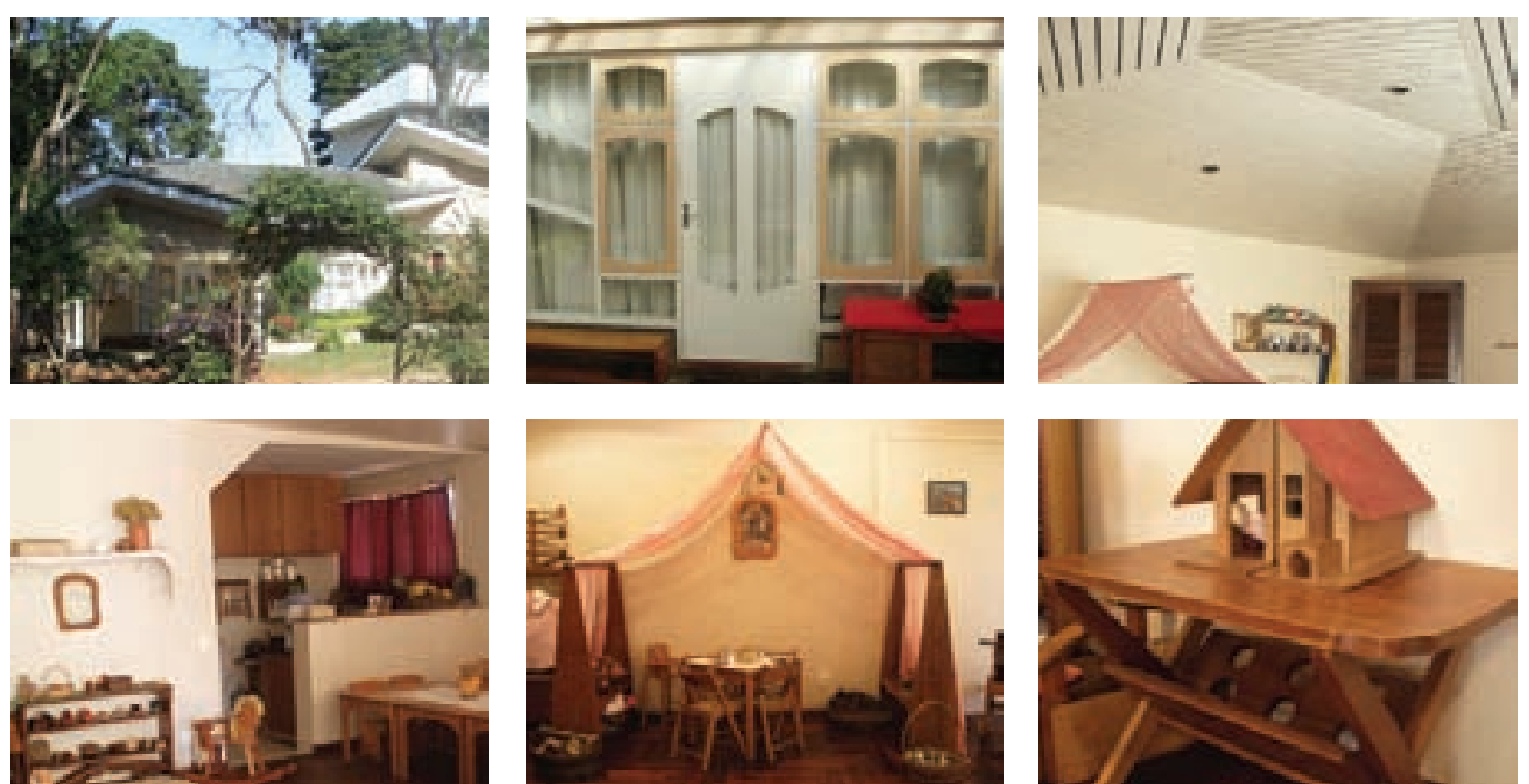

RS: arquitetura até o mobiliário: planos chanfrados e diagonais nas portas e janelas, no teto, nas aberturas e divisões de ambientes, nas peças de mesas, suportes, brinquedos etc. 

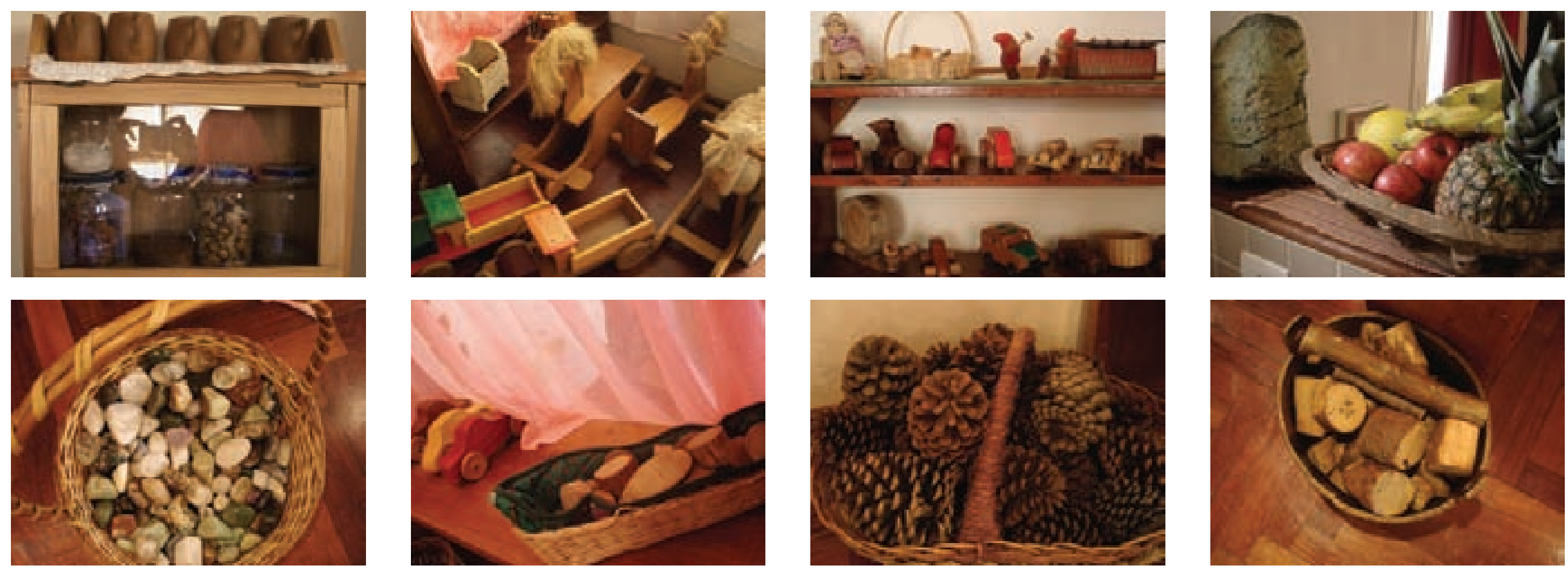

RS: a busca de apresentar um mundo o mais "natural" e "verdadeiro" possível: brinquedos de madeira, de preferência sem pintura, frutas, sementes grãos, pedras, tocos de madeira, pinhas, cascas de frutos, tecidos de algodão, tigelas e potes de barro, piso e mobiliário em madeira, etc.
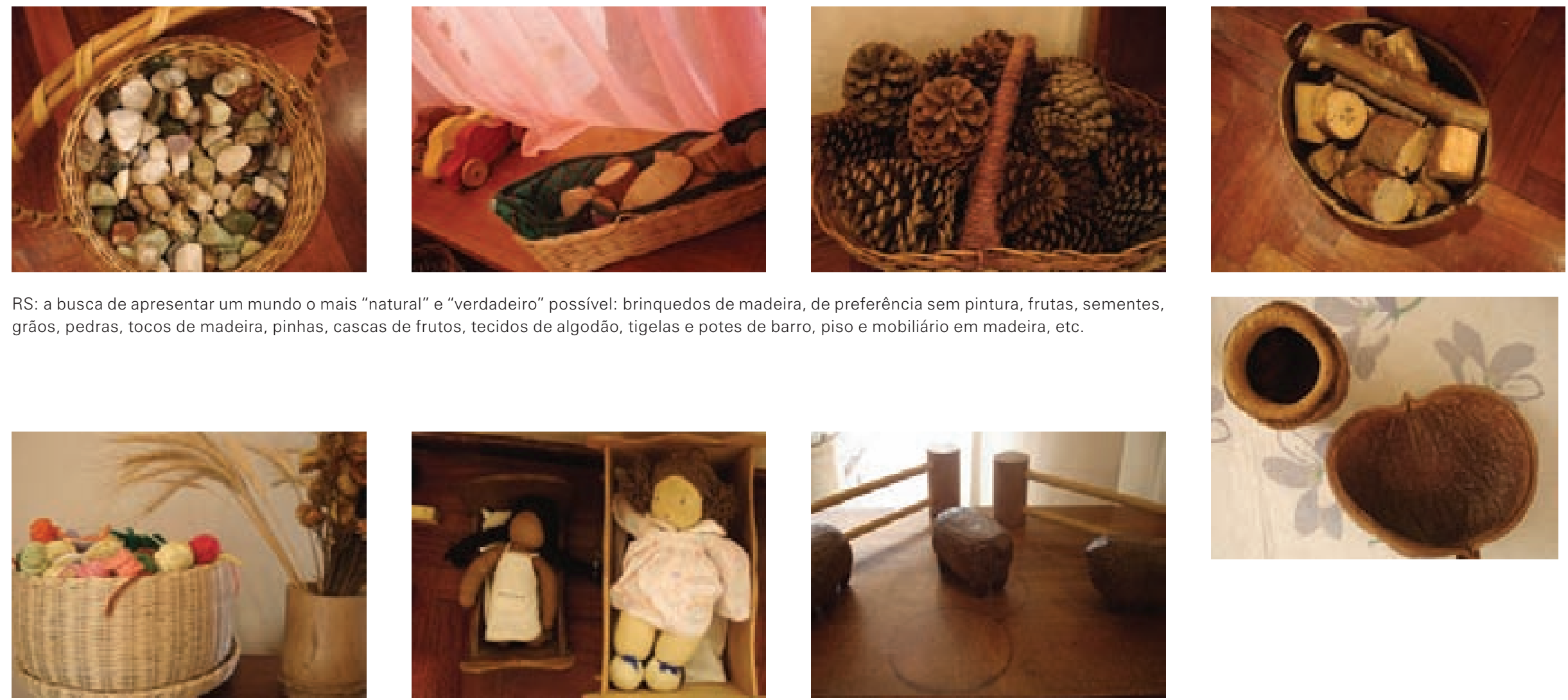

RS: "Natural" e "verdadeiro" nos fios de lã de carneiro, bonecas feitas com tecidos e enchimento natural, de preferência sem rosto ou quaisquer outros traços mais marcantes (o que nem sempre é possível, como se vê na foto acima, mas procura-se sempre trabalhar com bonecas de pano com pouca definição) e "bichos" de madeira sem uma forma muito definida e detalhada, mas sugerida...

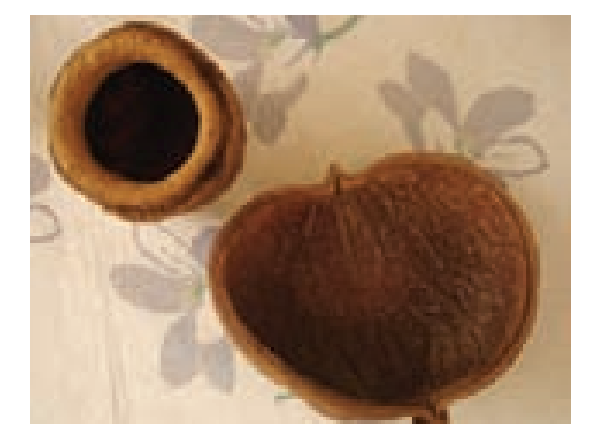


Já na Escola São Paulo, encontramos uma situação diferente. Estando instalada em uma casa alugada, a escola não teve desenvolvido um projeto específico, que seguisse o partido waldorfiano. Cabe ressaltar que, ainda que muitas fossem as limitações nesse sentido, poderiam ter sido criados ali artifícios que explorassem os mesmos princípios arquitetônicos a fim de criar o ambiente considerado mais propício e estimulante para o desenvolvimento da criança nessa fase da vida. Utilizando-se de elementos semi-fixos e móveis, como tecidos, papéis e inúmeros outros, poder-se-ia levar o movimento, o ritmo, o jogo de luz, enfim, a quebra da rigidez e da racionalidade buscadas pela proposta pedagógica.
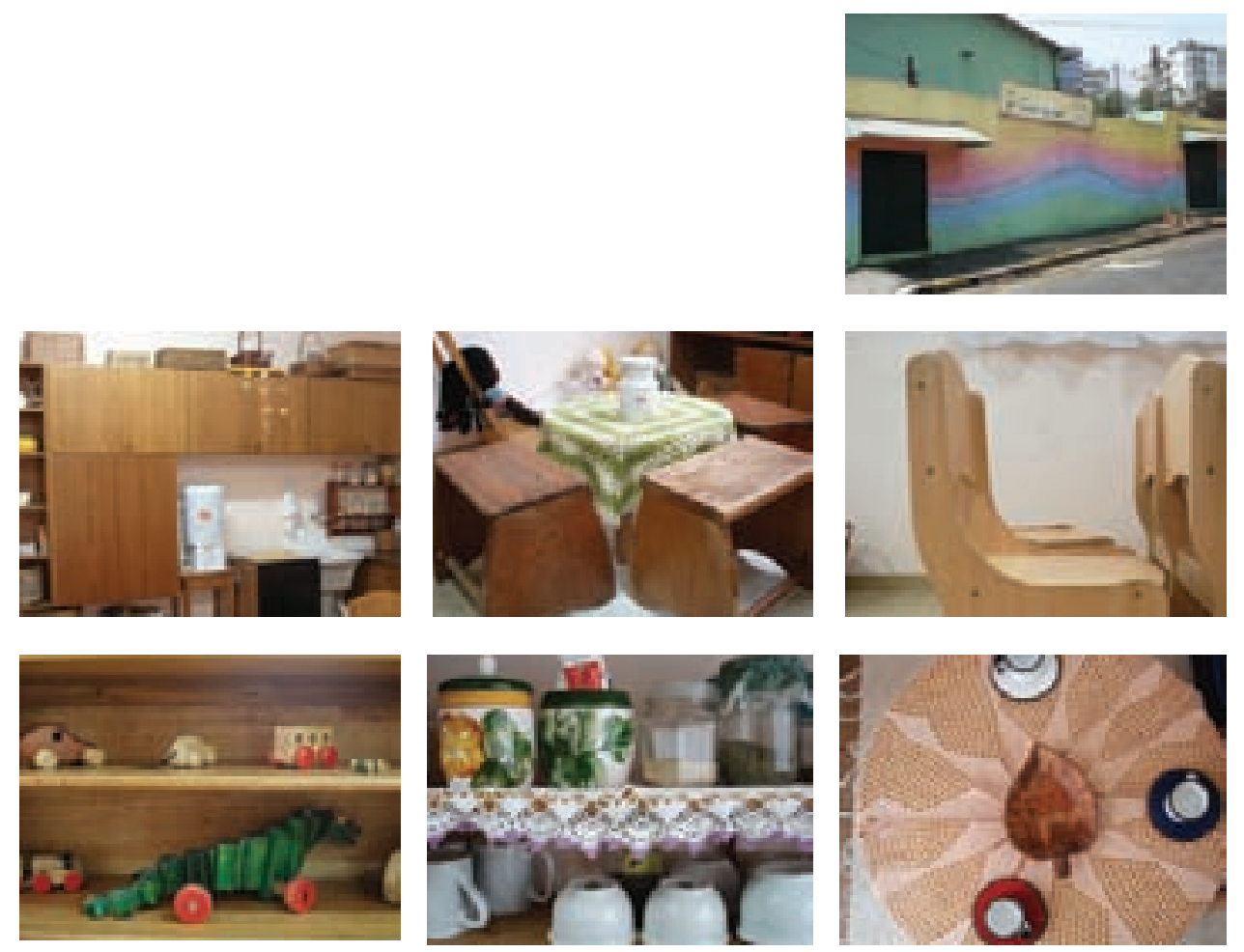

WSP: a mesma busca do "natural" e "verdadeiro" no mobiliário e nos brinquedos da Escola São Paulo.
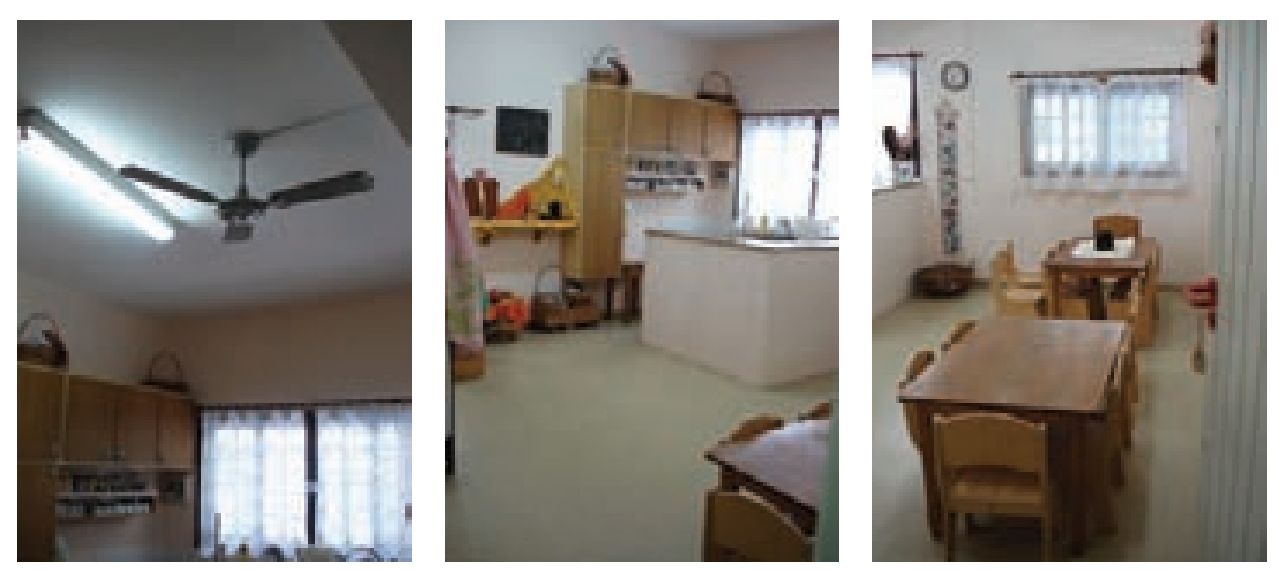

Ao lado, fachada da escola, fazendo alusão a uma pintura em aquarela; acima, interior de uma das salas de jardins: quebra com os princípios da arquitetura Waldorf e com a busca de aproximação a um mundo mais "verdadeiro e natural" (piso frio, teto plano, iluminação branca e fria, ausência de vegetação em diálogo com o edifício - apenas no "pátio" e no "parquinho"- ou de elementos que quebrem a rigidez dos elementos construídos já existentes).
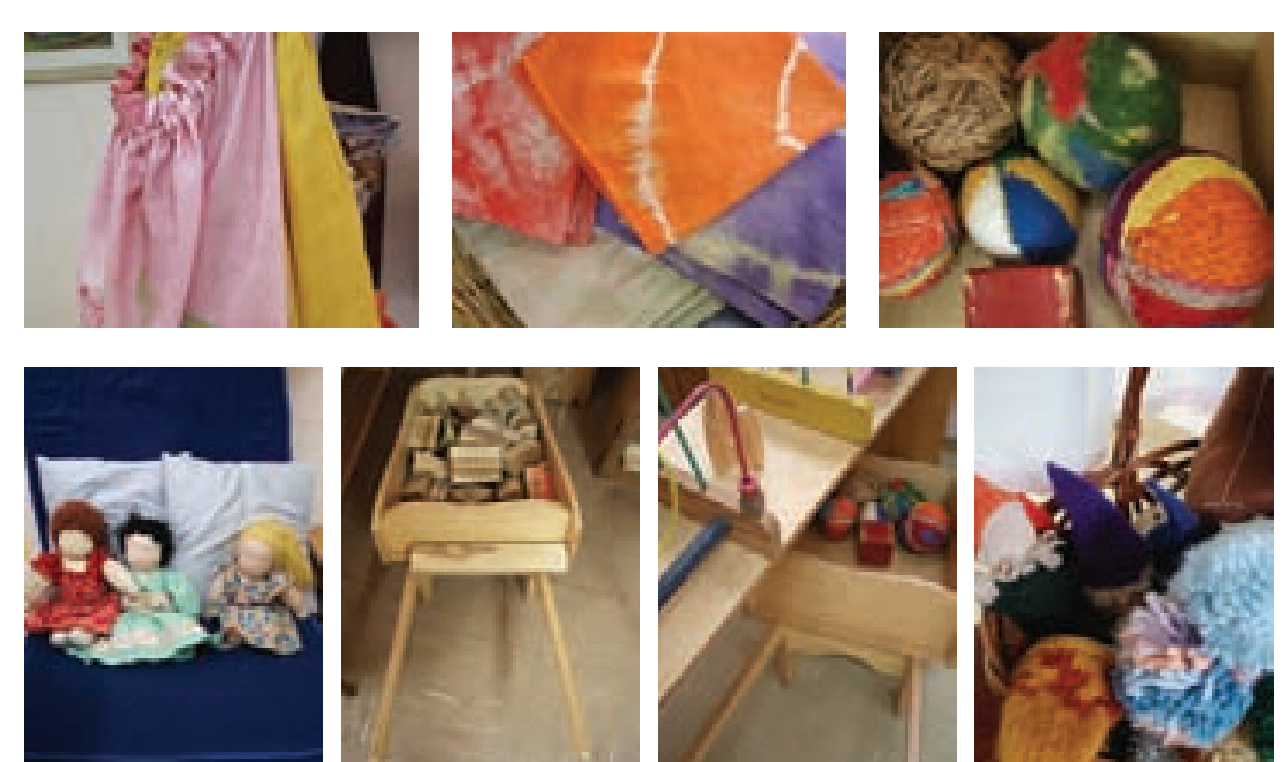
Ainda na busca de que as crianças conheçam o mundo através de vivências concretas, mas sempre em um ambiente seguro, acolhedor, familiar (tanto no sentido da família quanto no sentido do não estranhamento), a pedagogia acredita que as atividades primárias, as artes e os trabalhos manuais e artesanais são importantes ao longo de todo desenvolvimento do homem, o que se concretiza, no jardim-de-infância, nas atividades de cozinha/panificação, construção, arrumação da casa, aquarela, desenho com giz de cera, etc.

Para abrigar, dar suporte e possibilitar estas diversas atividades, então, o ambiente da sala das crianças é or ganizado por cantos, os quais são flexíveis e podem ser transformados tanto pelas professoras quanto pelas crianças. De uma forma geral, porém, observou-se que todas as salas visitadas apresentaram os mesmos cantos, estando estes apenas localizados em pontos diferentes das salas em cada uma das situações (ver fotos p.173). Apesar da liberdade e da flexibilidade que parecem ser permitidas na construção destes ambientes, não ocorre de fato uma recriação dos mesmos a partir dos princípios colocados pela pedagogia. Há uma caracterização bastante forte do que constitui uma sala Waldorf, o que pode ser identificado em todas as escolas visitadas. A particularidade e a identidade de cada uma acabam sendo construídas sutilmente pelos diferentes brinquedos, panos e outros elementos móveis (termo cunhado por Amos Rapoport, no seu livro Aspectos humanos da forma urbana. Ver capítulo 2).

Podemos observar que esta identidade, porém, parece construída, pelo que nos foi possível observar, principalmente pelas professoras (em conjunto com a comunidade de pais, muitas vezes), uma vez que são elas que escoIhem os brinquedos e demais elementos que farão parte do ambiente da sala. Não se vêem trabalhos ou quaisque intervenções produzidas pelas próprias crianças. Tudo o que é feito pelas crianças é guardado e posteriormente entregue aos pais, pois acredita-se que as crianças não identifiquem o que é produzido por elas depois que já o fizeram. A intenção é valorizar o momento em que as coisas estão sendo realizadas e vivenciadas, e não o produto das mesmas.

Se um dos fortes princípios que orientam a pedagogia Waldorf é a busca de construção de um ambiente acolhedor e familiar (nos dois sentidos apontados acima), podemos nos perguntar se não seria importante a participação das crianças na construção de uma identidade própria deste ambiente onde ela passa alguns dos primeiros anos de sua vida. Se a intervenção por meio de trabalhos, como acontece, por exemplo, na Escola Viva, onde as crianças produzem objetos que viram cortinas, ou fazem intervenções nos pisos, vidros e outros elementos da arquitetura e do espaço da escola, ou, de forma semelhante mas diferente, como acontece nas escolas da Reggio Emilia, na Itália, não é um caminho que faça sentido dentro da pedagogia aqui colocada, perde-se a oportunidade de se explorar mais fortemente esta construção por meio dos brinquedos e equipamentos disponibilizados para as crianças.

Ainda que haja a intenção de que as crianças tenham autonomia na transformação dos espaços, podendo deslocar o mobiliário existente em cada sala, isso não parece acontecer de fato, pois as peças são pesadas e não propiciam ou facilitam o seu manuseio (a não ser pelas professoras). Com relação aos brinquedos, a intenção de que estes sejam o menos "prontos, acabados" possível, e mais "sugestivos", a fim de cultivar a criatividade da criança, já pode ser percebida pela ausência de rostos em algumas bonecas, ou pela indefinição de formas e traços em alguns bichos de madeira, ou ainda pelo uso de tocos de madeira e outros elementos da natureza em sua forma original, como já comentado. No entanto, ainda que dêem espaço à imaginação da criança, e da transformação a partir desta, não chegam a permitir uma real transformação destes por meio de manipulação, montagem, desmontagem ou reconstrução. Ao se trabalhar apenas com a idéia de "ina- 
cabado", perde-se a oportunidade de levar a "polivalência" ao ambiente, que talvez permitisse uma maior e mais forte construção de identidade por parte das crianças.

A idéia de que a criança conheça o mundo através da vivência acaba, então, se realizando mais por meio da experimentação do que pela experimentação transformadora. Mas, nesse sentido, não podemos deixar de apontar a riqueza da proposta quanto ao estímulo e à ênfase dada ao desenvolvimento e ao refinamento não apenas dos cinco, mas dos doze sentidos existentes segundo a Antroposofia, ciência espiritual a partir da qual se desenvolve a pedagogia Waldorf.

O paladar é aguçado por meio das experimentações na cozinha (o doce, o salgado, o azedo, etc.), assim como o olfato; a audição, além da experimentação do próprio corpo como um todo, é explorada nas aulas de música e dança, e por meio de todo o trabalho de alternância de ritmos proposto pela pedagogia; o tato é vivido nos diferentes materiais dos objetos, equipamentos, alimentos e tudo o que está ao redor da criança dentro do universo em que ela vive, e assim por diante.

\section{Atividades, usos e funções}

Como já observado, é nos ambientes das salas de cada turma que se desenvolve a grande parte das atividades das crianças durante o jardim-de-infância. Mesmo atividades como música e artes, que em muitas escolas são realizadas em ambientes separados, acontecem, nas escolas Waldorf, dentro das "salas-casas". A idéia é justamente não fragmentar o conhecimento e a vivência do mundo e fazer com que as crianças o entendam como um todo único, ainda que complexo e diversificado.

O jardim é o quintal da casa, e por isso também acaba se constituindo como o espaço de lazer, de experiência e de experimentação livre proporcionado pela riqueza e complexidade da natureza, que pode ser vista como um grande laboratório a ser explorado (quando de fato existe esta riqueza, o que não acontece, por exemplo, na Escola São Paulo). Em que medida, porém, este jardim é desbravado pelas crianças e professoras e em que medida seus elementos são explorados, e levados, por exemplo, para as salas como insumos à fantasia das crianças, não nos fo possível observar. Os materiais encontrados dentro das salas de cada turma, como pinhas, pedras, conchas, etc., nos pareceu retirados de outros ambientes que não dos jardins pertencentes ao espaço da escola. A curiosidade e o prazer de conhecer e de experimentar poderiam ser muito mais estimulados nas crianças se estes materiais fossem descobertos e lapidados (transformados) por elas mesmas, sendo então complementados por outros vindos de outras proveniências.

Mais do que constituir um espaço de coletividade então, estas áreas externas parecem ser mais utilizadas como momentos de integração à natureza e de liberdade de experimentação e de movimento. Mesmo que os espaços das escolas pudessem propiciar esse encontro, delimitações físicas (cercas vivas e portões, na Rudolf Steiner, por exemplo), programações e controles acabam não sugerindo e até mesmo impedindo de certa maneira a mistura das diferentes turmas do jardim-de-infância.

Podemos observar, assim, que, desde a organização espacial até a organização das atividades, dos usos e funções dos espaços e ambientes, tudo acontece de forma a garantir uma proteção acolhedora e intimista à criança. O desenvolvimento desta se dá por meio da vivência do mundo, mas a escola deve assegurar que este seja verdadeiro e o mais natural possível nestes primeiros anos de vida, assim como o entende a pedagogia e a ciência na qual está baseada. 


\section{Considerações finais}

A análise das escolas acima permitiu-nos observar a existência, por parte da pedagogia Waldorf, de uma forte preocupação com o ambiente onde se desenvolve o processo de educação, e uma busca de coerência entre este e os princípios que a regem.

O entendimento da educação como um caminho no despertar natural dos sentidos e da sensibilidade do homem é claramente visível na ênfase dada à experimentação e à vivência pelos sentidos: na cozinha, na panificação, na aquarela, no desenho com cera de abelha, na argila etc. A idéia de um desenvolvimento saudável, em um ambiente acolhedor, aconchegante, seguro e confiáve também, como já comentado, está presente na organização do espaço, no controle dos campos visuais, das áreas utilizadas por cada turma e em vários elementos que constroem os ambientes Waldorf. A convivência com a natureza e os afazeres diários de casa reforçam todos esses objetivos. Percebe-se uma coerência e uma consciência da inter-relação entre proposta e ambiente pedagógicos. E reconhece-se facilmente uma escola que segue a pedagogia Waldorf, principalmente por suas salas, reproduções de uma idéia própria de lar familiar.

A atenção voltada para a reprodução deste ambiente porém, acaba se sobrepondo algumas vezes à consciência da dimensão da escola como um todo, que então é perdida ou reduzida na construção dos demais ambientes, como é o caso da Escola São Paulo, por exemplo.
A forte imagem da construção deste lar faz ainda com que, mesmo havendo flexibilidade para a elaboração e a organização da sala pelos professores, não haja desdobramentos muito diversos de uma sala para a outra em uma mesma escola ou mesmo entre escolas diferentes. Percebe-se uma diferença de riqueza e complexidade em função dos brinquedos e materiais apresentados, porém não em relação aos tipos de elementos e de relações estabelecidas e construídas entre estes: as bonecas, as cabanas, os brinquedos (estes um pouco mais diversificados), os materiais, etc. apresentam pouca variação de uma sala para a outra, ou mesmo de uma turma de maternal para uma turma de jardim, além de constituírem quase sempre o mesmo jogo de objetos.

A simples reprodução da idéia do lar, no entanto, está longe de constituir a construção de um ambiente escolar regido pelos princípios da pedagogia Waldorf. Nesse sentido, se o estabelecimento de parâmetros e a definição de exemplos para a construção de ambientes Waldorf garantem, por um lado, a adequação dos mesmos, por outro, podem restringir a criatividade de desdobramento dos princípios e objetivos da proposta, como de fato acontece.

Existindo esta forte referência visual, pudemos observar, por exemplo, que, diante de condições adversas ou limitantes para o desenvolvimento da arquitetura ou do ambiente físico "ideal" de forma geral, abre-se mão de detalhes importantes para a construção do ambiente de 
aprendizagem, ou deixa-se de apresentar novas soluções para os mesmos fins (como é o caso da Escola São Paulo já mencionado), pois acredita-se que o essencial está garantido na estruturação do espaço, quando sabemos que a complexidade e, conseqüentemente, a riqueza de um ambiente se constrói nas suas diferentes escalas.

A riqueza da proposta Waldorf, percebida principalmente na escola Rudolf Steiner, está justamente além da idéia de construção de um lar seguro e aconchegante, onde são desenvolvidos os afazeres do dia-a-dia. A riqueza da experiência que nos pareceu ser vivida ali pelas crianças (infelizmente não possível de constatar, apenas de intuir, pela percepção e sugestão dos ambientes visitados) está na exploração dos seus diversos sentidos, como olfato, paladar, tato, etc., por meio das atividades, brinquedos, materiais e vivências (não como experiências dirigidas, como na pedagogia Montessori, por exemplo) e no desenvolvimento da sua sensibilidade. E está também, seguindo este mesmo princípio, na forte presença da natureza "in natura", sem canteiros delimitados, sem grandes gramados previsíveis, percursos definidos, dando espaço para a diversidade e para a imprevisibilidade próprias deste universo.

Negando o aprendizado dirigido, propõe-se um rico processo de aprendizagem por meio do contato direto com o mundo. No entanto, esta negação acaba sendo excessiva quando deixa de abrir espaço para a polivalência (além da flexibilidade), ou para o estímulo à curiosidade e ao aprendizado por meio da sugestão, da provocação positiva, e da criação de desafios. Há espaço para a fantasia, mas o inusitado, a surpresa parecem só poder existir na natureza, e não nos elementos construídos pelo homem. Perde-se talvez aqui a oportunidade de desdobramentos diversos dos princípios colocados pela pedagogia Waldorf, que acabam reduzidos a poucas formas, estruturas e atividades. 



\section{AMBIENTE ESCOLAR INFANTIL: \\ ESTRUTURAÇÃO DE OPORTUNIDADES PARA O DESENVOLVIMENTO DA CRIANÇA}

Com exceção dos Parques Infantis e das EMEls/ CEDEC, os quais não foram extensivamente analisados, tendo sido trazidos para a discussão mais para o levantamento de questões conceituais e socioculturais do que propriamente de projeto questões que serão retomadas mais à frente, ao longo desse mesmo capítulo.

2 É importante lembrar aqui que nem todas as escolas puderam ser visitadas, sendo utilizadas para a construção dos diagramas, nestes casos,

fotografias retiradas de publicações e outras fontes, o que impediu que fosse feito um recorte e uma seleção de imagens unicamente a partir do olhar do pesquisador, que atendesse os seus

objetivos e critérios.

${ }^{3}$ Consideradas as especificidades dos contextos, com a ciência de que não se reproduzem experiências, mas se reflete sobre princípios e realizações, e se projeta a partir da realidade e situação locais.
Retomaremos aqui os projetos e experiência analisadas por meio de diagramas de referências perceptivas ${ }^{1}$, que servirão de ponto de partida para uma reflexão mais ampla sobre o ambiente escolar infantil de forma geral.

Diagrama de referências perceptivas é, para fins deste trabalho, um conjunto de imagens que procura representar a essência dos ambientes analisados (sob o enfoque colocado pela pesquisa em questão), detectada nas suas características físicas, e nas situações, fenônemos e relações ali estabelecidas. Ou seja, é um quadro que funciona como base de sustentação icônica daquilo que, ao longo do trabalho, é considerado como "princípio" de unidade na diversidade de cada uma das escolas ${ }^{2}$

Apesar de visual, o diagrama procura fazer referência a vivências e processos sensoriais de todos os tipos; por meio de imagens da arquitetura, do mobiliário, dos equipamentos, da natureza, e, quando possível, da interação das crianças com estes elementos de cada escola, buscamos evidenciar os aspectos mais fortes de cada experiência, que podem ser vivenciados não só através de um único, mas de vários sentidos. Imagens da natureza, por exemplo, não apenas apresentam um retrato visual da presença desta no ambiente escolar, como procuram detectar e remeter a experiências táteis, visuais, olfativas e/ou auditivas vividas (ou passíveis de serem vividas) pelas crianças.

Ainda que não possamos representar de fato a experiência e a complexidade de cada ambiente por meio de imagens apenas, perceberemos que estas já nos dão uma boa indicação de que tipo de proposta se coloca em cada uma das escolas. Se ao longo das análises nos capítulos anteriores, procuramos completar as imagens por meio de explicações e narrativas, neste capítulo pretendemos que os diagramas falem por si só (o que não significa que apresentem uma única possibilidade de leitura; pelo contrário, admitem múltiplos eixos de interpretação).

Veremos que, por mais que tenhamos procurado construir diagramas a partir de um fio condutor e uma lógica única, cada uma das experiências escolares nos conduziu e nos permitiu uma seleção de imagens específicas e próprias da concretização de cada um dos discursos apresentados. É a partir destas diferenças perceptivas, que estão também relacionadas com os parâmetros de análise postos no capítulo 2 (e utilizados como base para a análise individual das escolas), que podemos notar mais claramente a diferença entre caminhos construídos para o ambiente escolar infantil.

Mais do que avaliar as escolas aqui apresentadas ou compará-las, no entanto, o objetivo deste trabalho é extrair destas experiências, abordagens, proposições, enfim, elementos para reflexão sobre o projeto de ambientes escolares infantis (e não só infantis ou escolares) ${ }^{3}$.

Comecemos com os diagramas de referências perceptivas que vemos a seguir. 


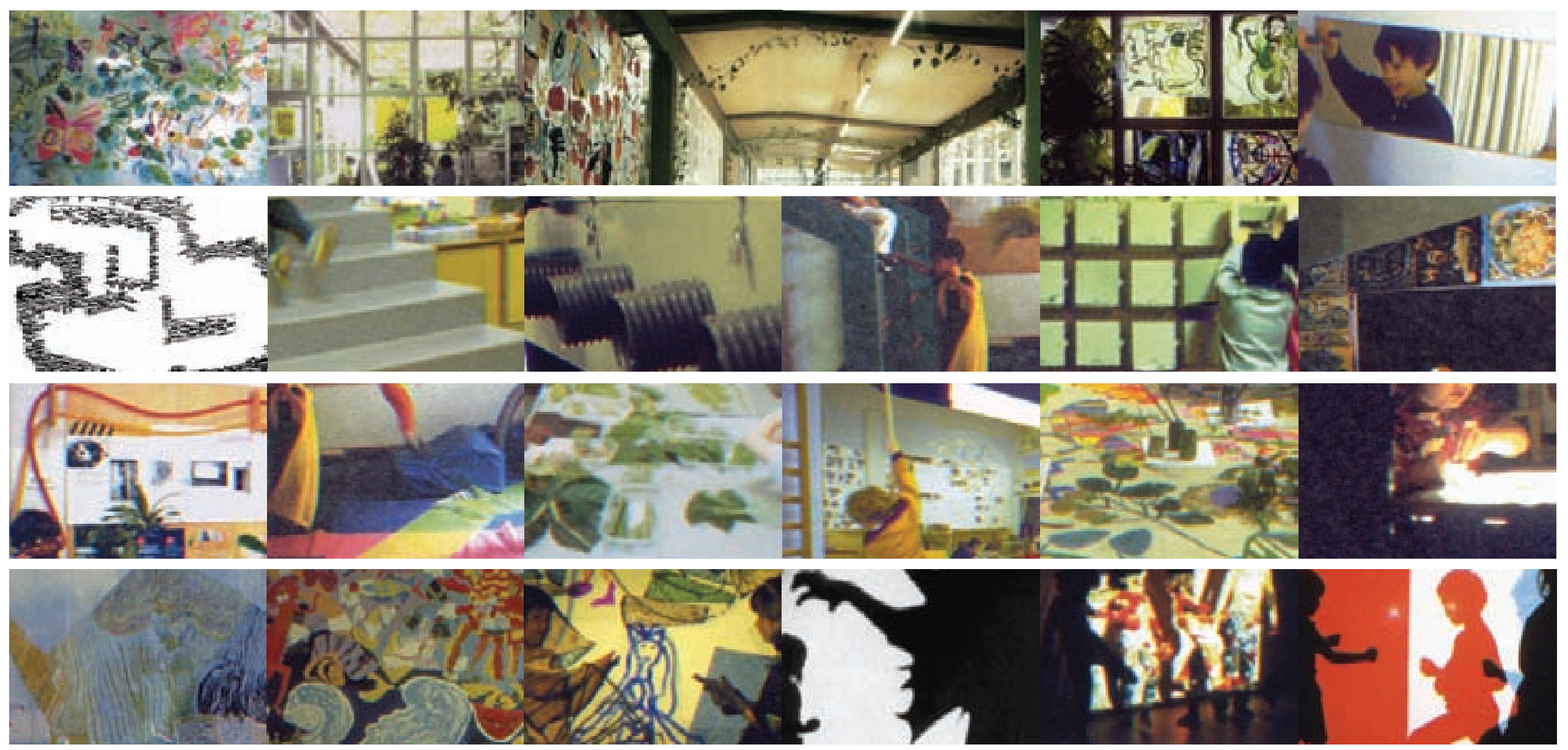




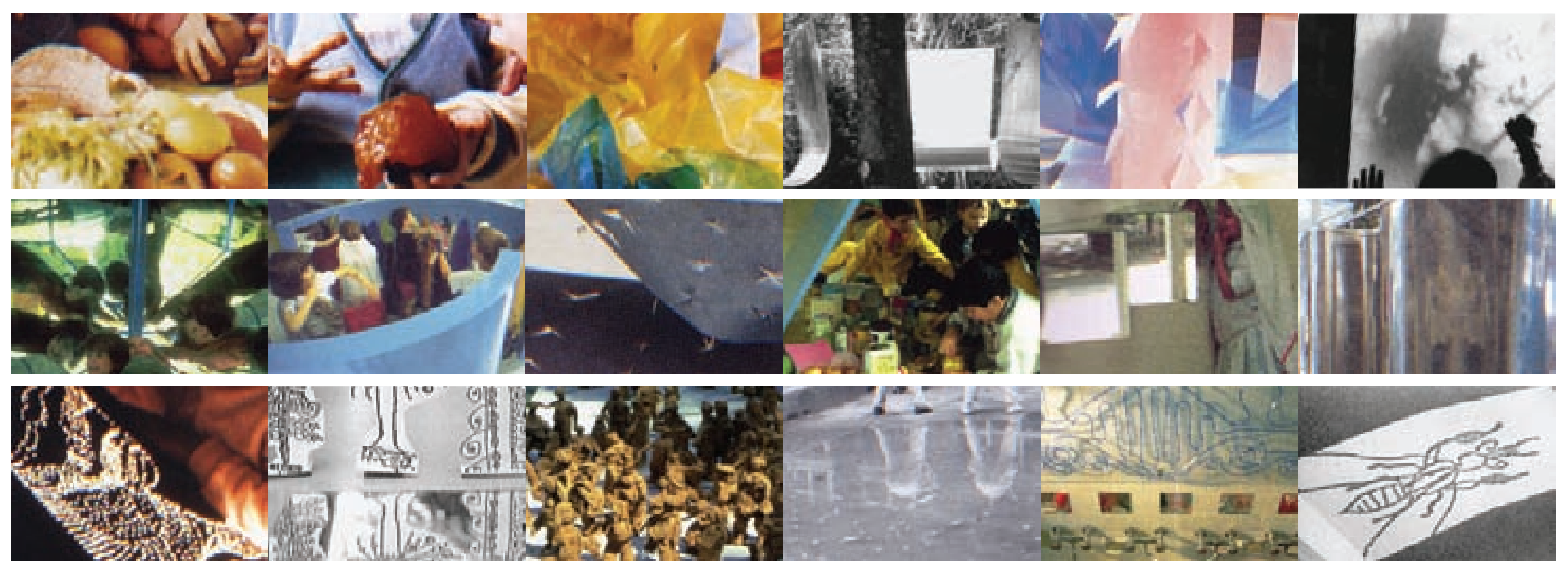


DELFTSE MONTESSORISCHOOL diagrama de referências perceptivas
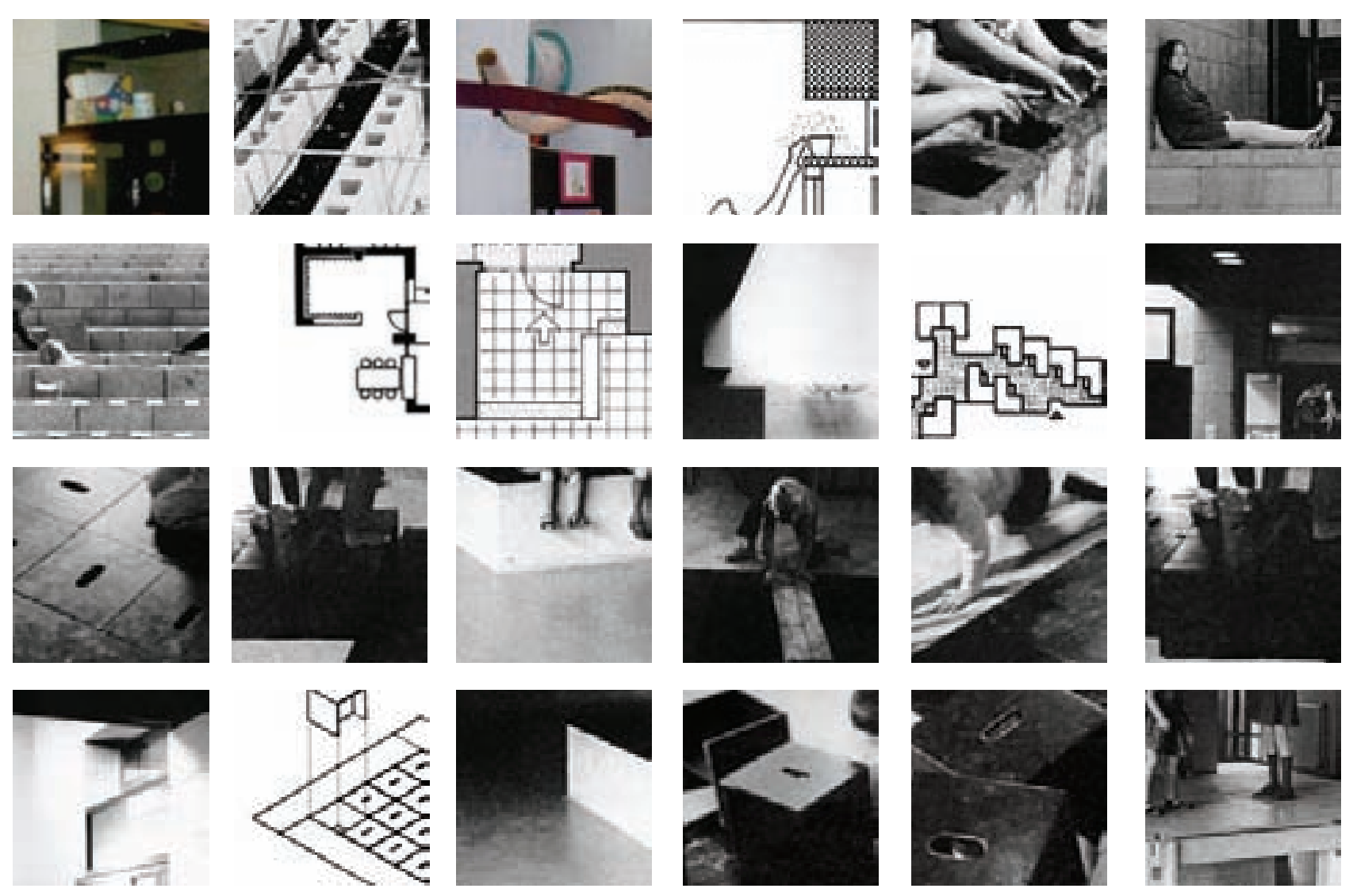
ESCOLA VIVA diagrama de referências perceptivas
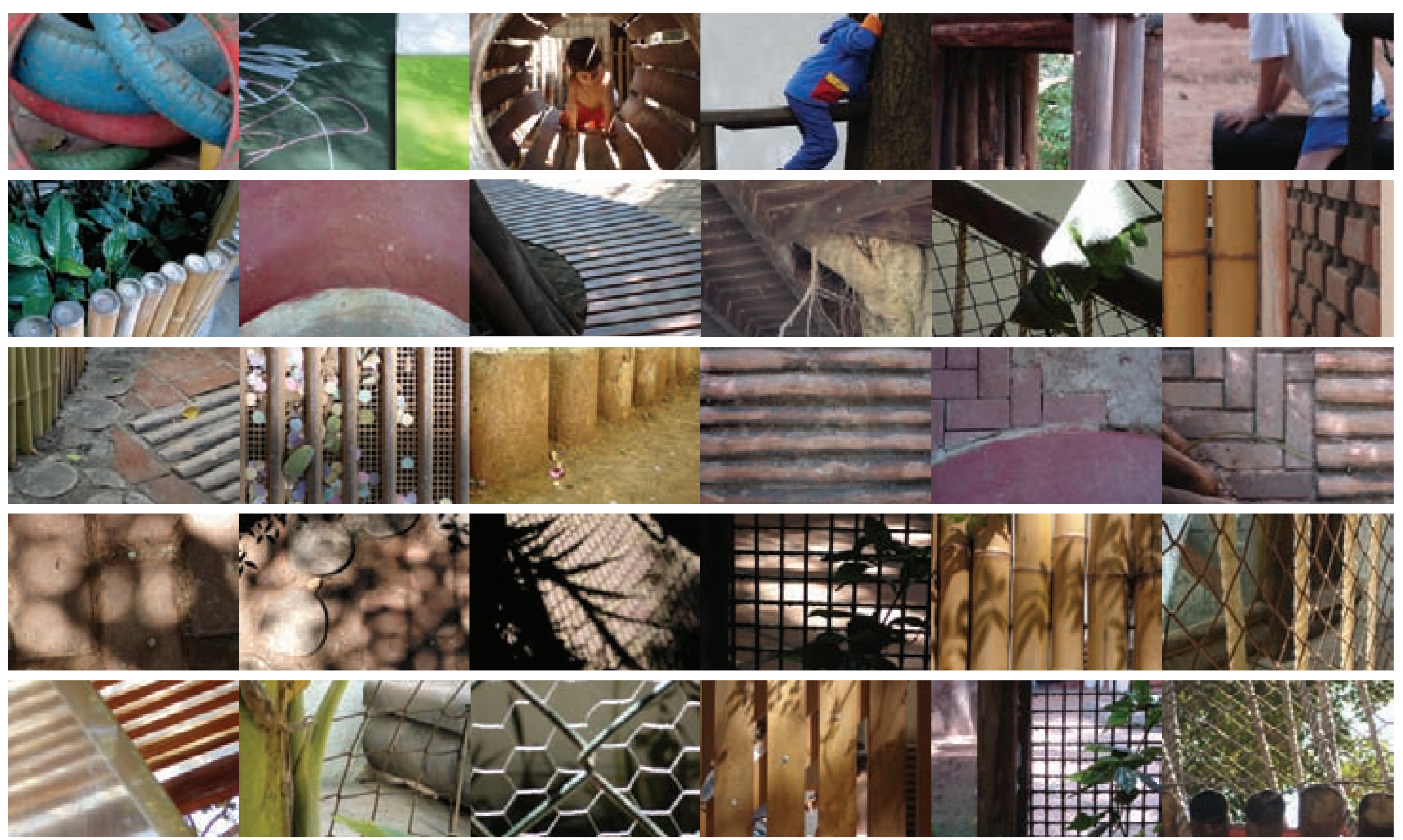

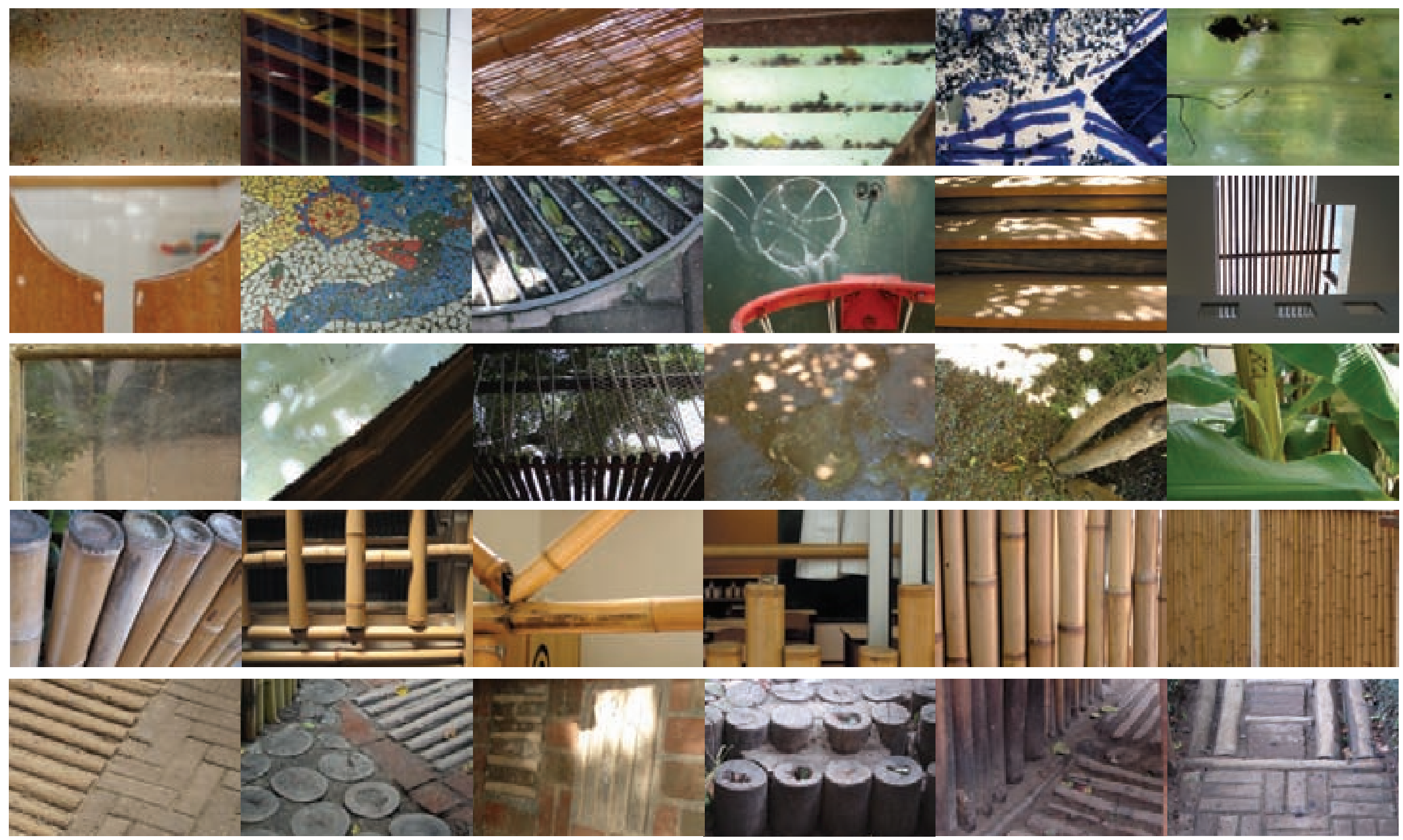


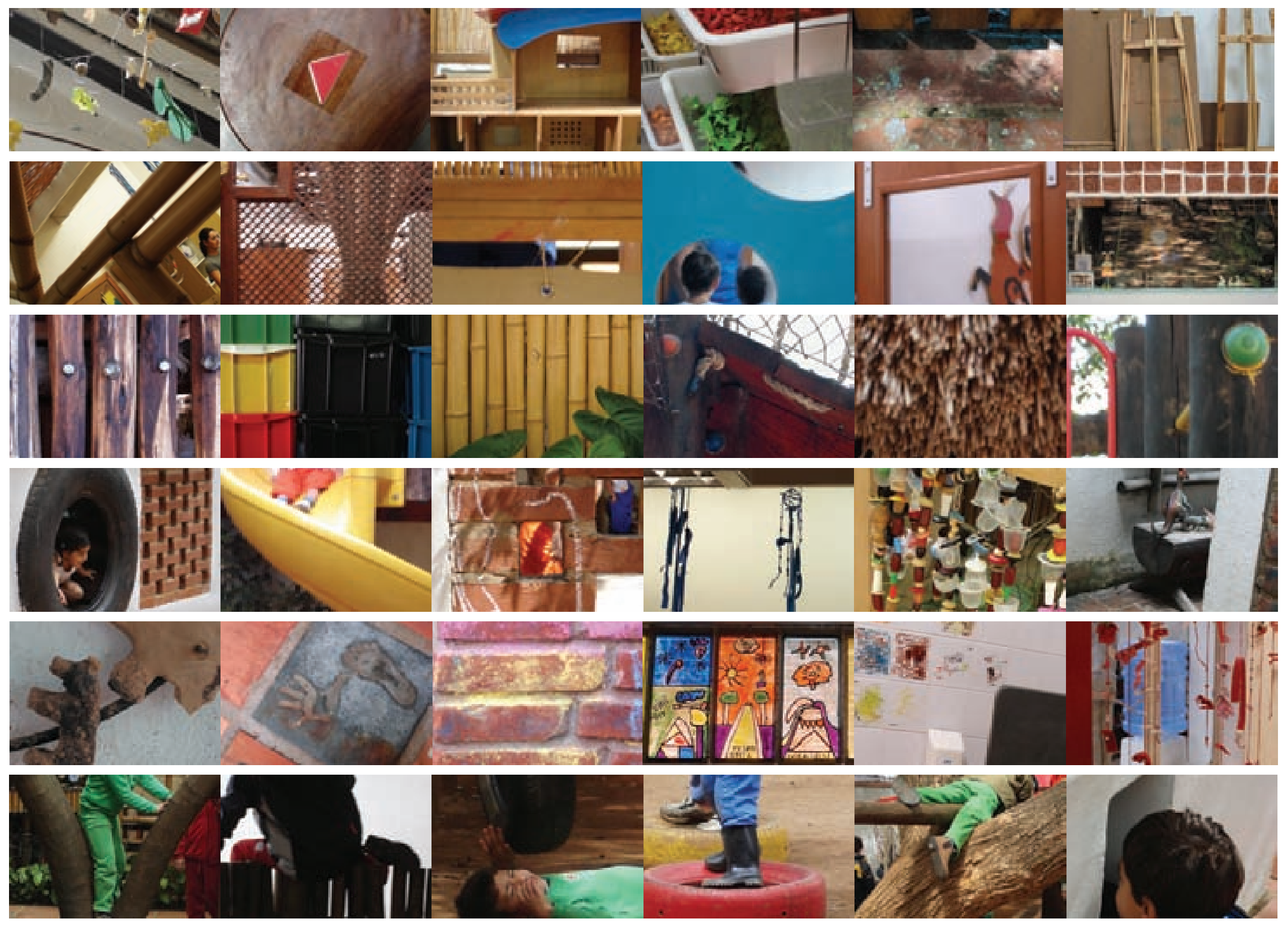



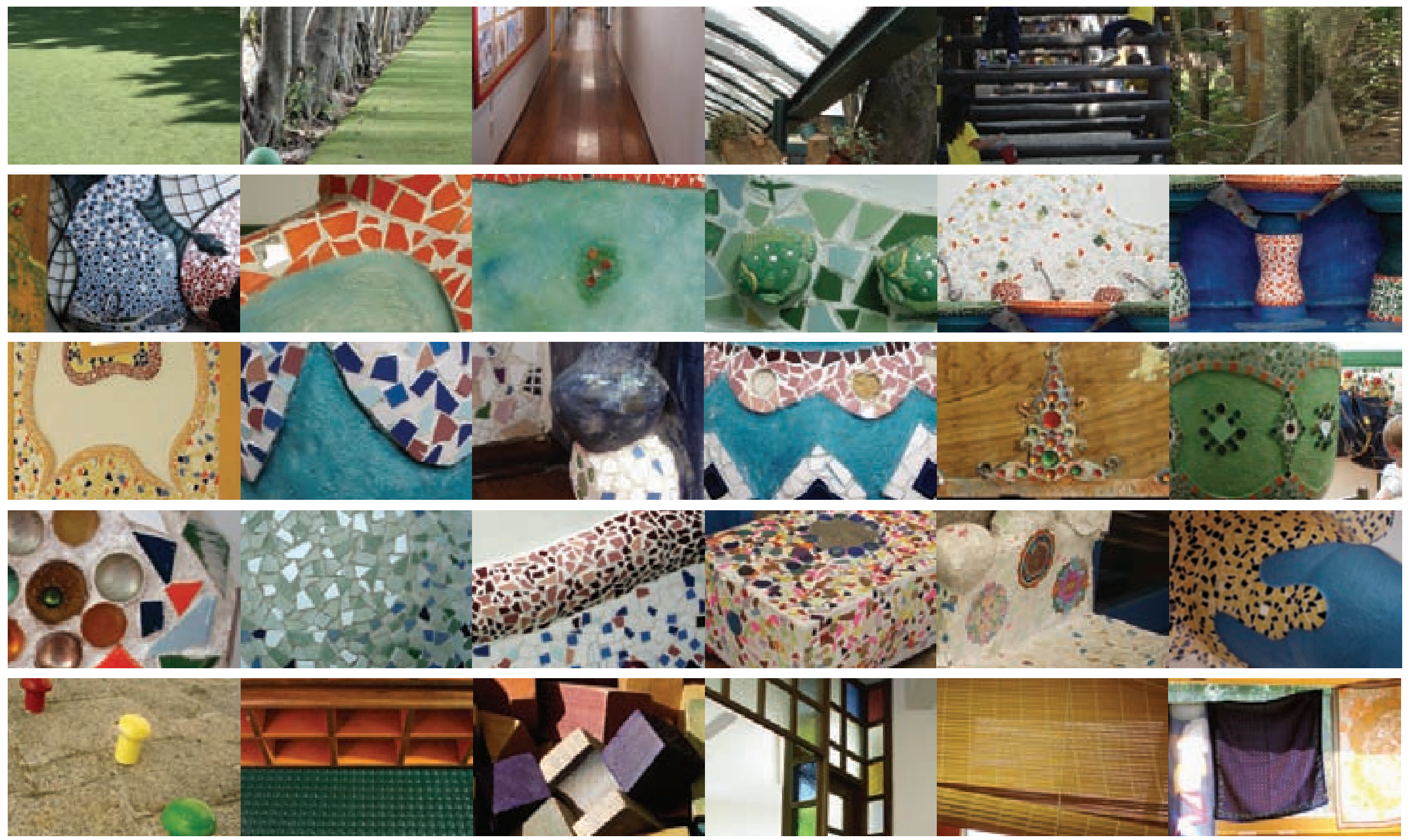

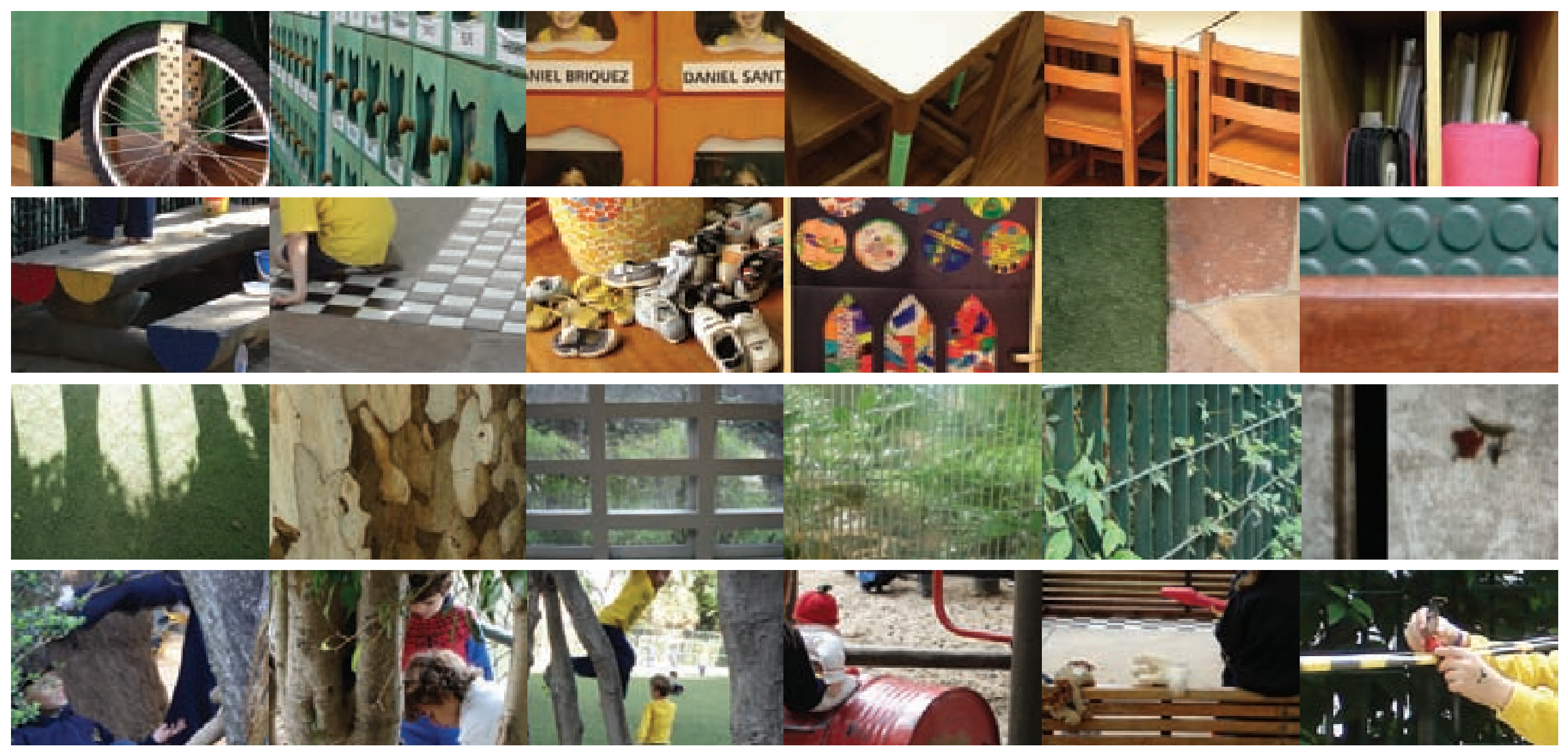

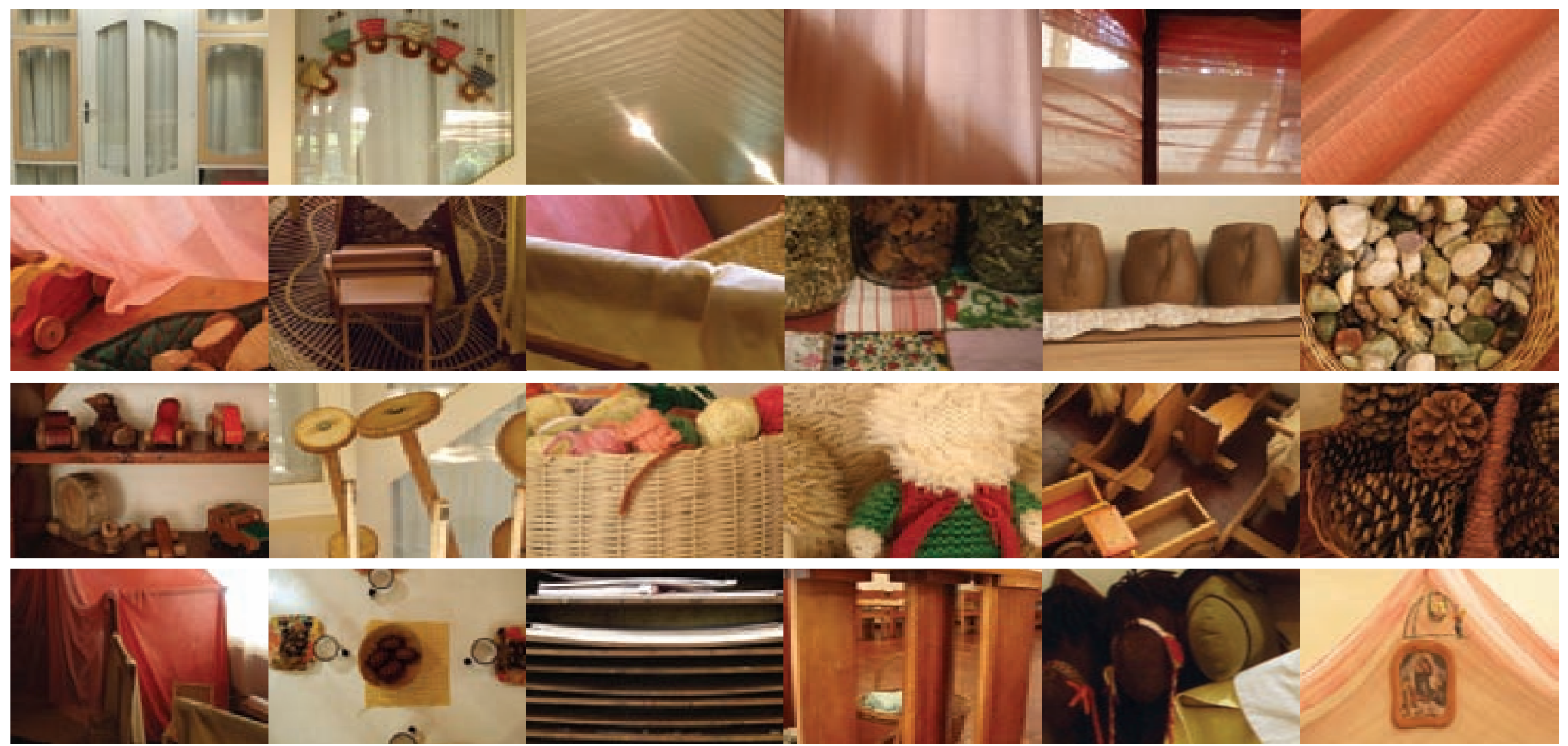

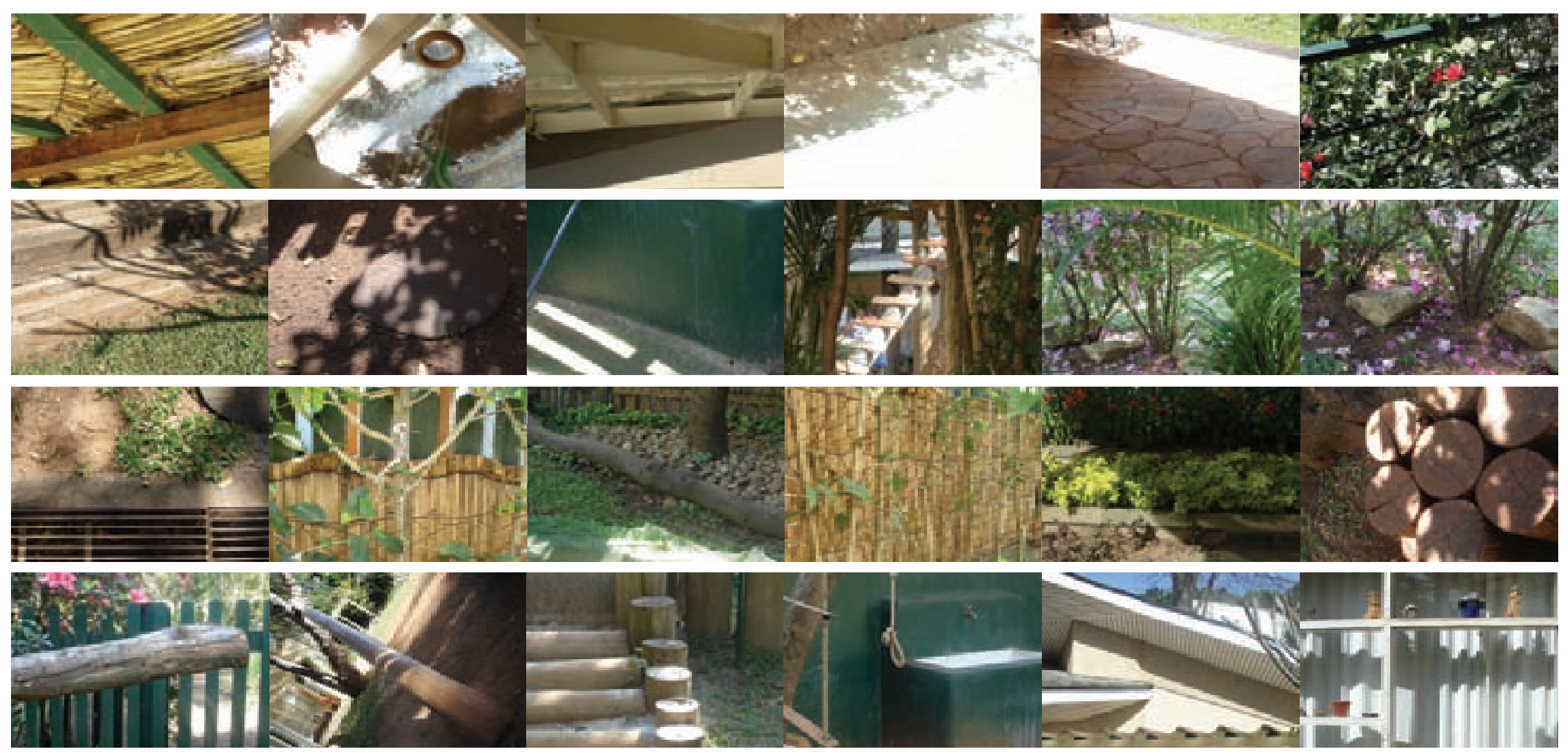


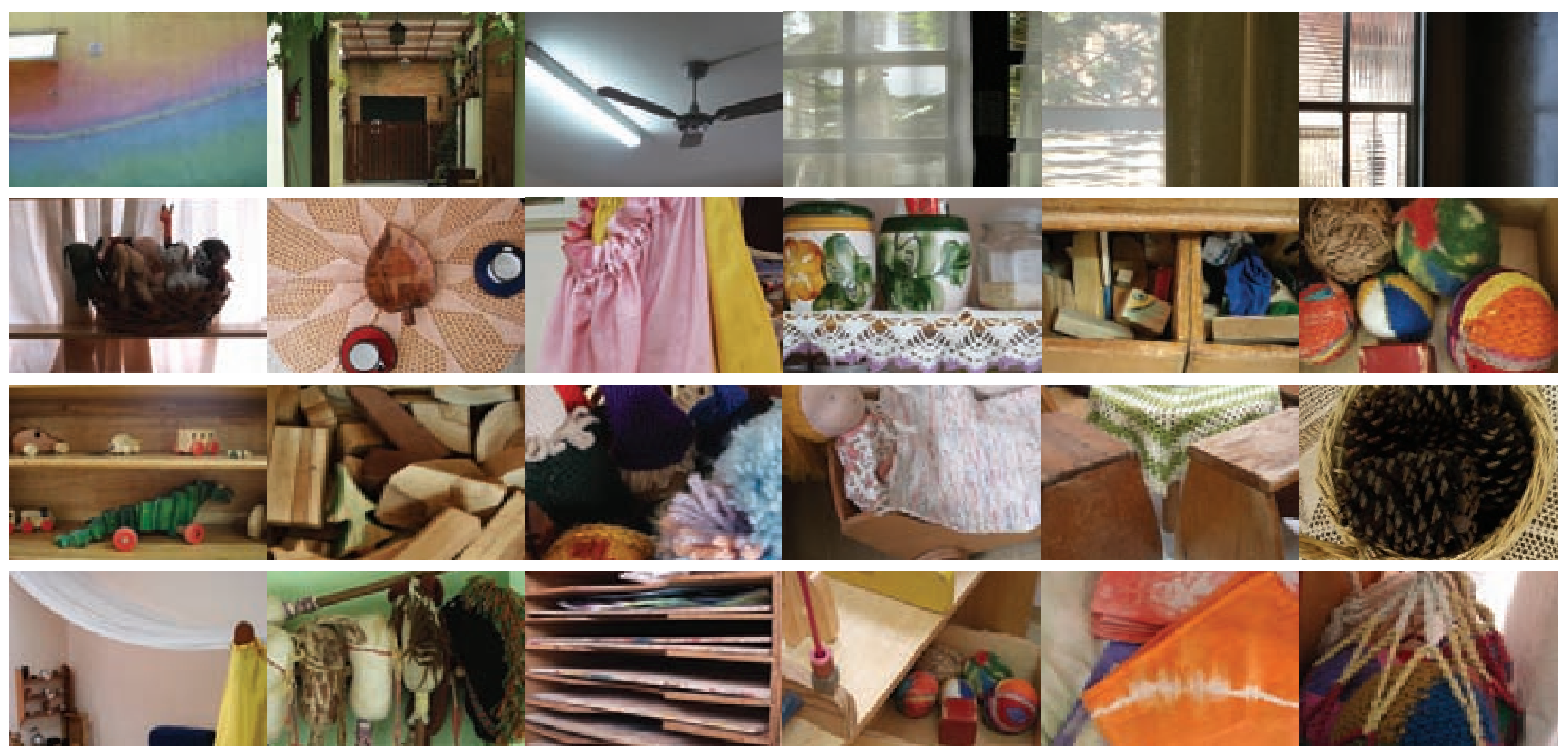




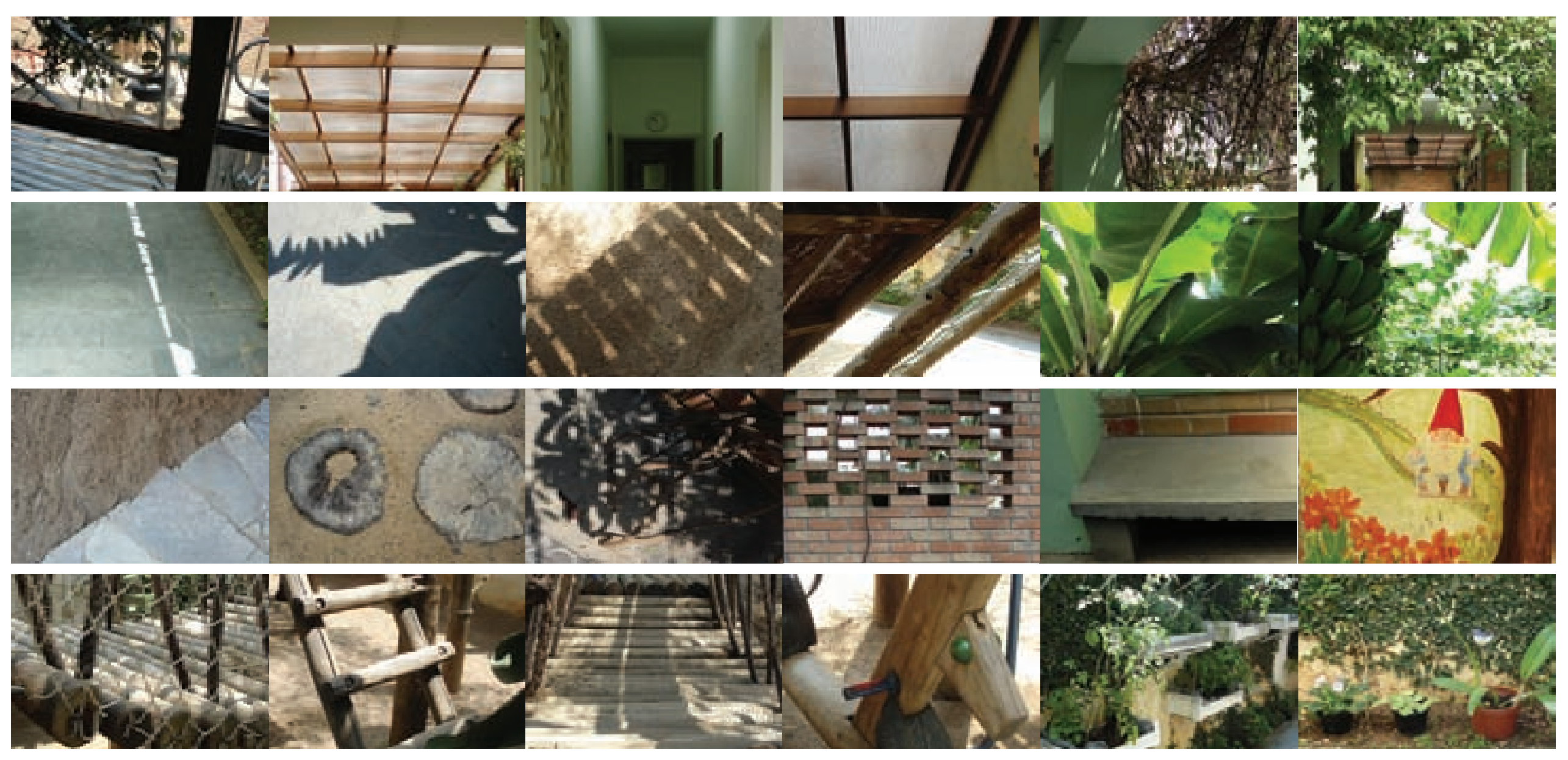


Podemos notar que cada uma das escolas apresenta um diagrama de referências muito próprio, o que acontece não só em função de suas características físicas e linguagens, mas também, e até mesmo antes destas, em função de suas concepções e lógicas estruturais.

Se no diagrama da Delftse Montessorischool o que vemos predominar é o jogo de formas e a lógica de construção dos elementos do ambiente escolar, no diagrama das escolas de Reggio Emilia são os materiais e os experimentos e experimentações realizadas pelas crianças que ficam em evidência. Já no conjunto da Escola Viva, da escola infantil do Santa Cruz e das escolas Waldorf, se também vemos os materiais de forma predominante, estes aparecem, no entanto, principalmente na arquitetura, no mobiliário, nos equipamentos e no espaço, cada um à sua maneira, sendo menores as referências à transformação e/ou experimentação dos mesmos pelas crianças.

Isso já nos mostra a existência de diferentes princípios de concepção e estruturação de projeto, os quais vimos desdobrados nas análises individuais de cada escola e que procuraremos rever e compreender de forma um pouco mais clara neste capítulo.

Tendo estes princípios como eixos norteadores, podemos observar também, a partir destes diagramas, os diversos tipos de elementos que compõem o ambiente escolar infantil e os diferentes níveis em que este pode ser pensado e trabalhado. Como ficou mais evidente na análise das escolas reggianas, podemos considerar que o ambiente pode ser estruturado a partir de grupos de elementos de naturezas e escalas diferentes, os quais podem ser mais ou menos explorados, de modo mais ou menos integrado.

A análise destes grupos e das relações entre eles definidos aqui como espaço e arquitetura; mobiliário e equipamentos maiores; equipamentos e instrumentos menores fixos e semi-fixos; e materiais e instrumentos menores, em geral móveis (que podem ser transformados pelas crianças) - nos servirá, então, neste capítulo, como guia para a compreensão dos projetos e para o encaminhamento da reflexão sobre o que consideramos importante ter em conta no desenvolvimento de qualquer projeto de ambiente deste tipo. É importante lembrar que estes elementos estão (ou deveriam estar) intrinsecamente ligados, sendo feita aqui a separação dos mesmos em "categorias" apenas para fins de análise e compreensão. Todo ambiente deve ser entendido no seu todo, por meio das relações entre os seus componentes, e não apenas pelos componentes por si só.

Voltando o olhar para a Delftse Montessorischool, a primeira escola analisada, notamos que a proposta do arquiteto é de extrapolar os limites dos "materiais" montessorianos e levar a idéia de autonomia e descoberta, pretendida pela exploração destes, para o espaço da escola como um todo. Percebe-se, no entanto, que, de um lado, pelas características da pedagogia Montessori, e, de outro, pela natureza formalista-estruturalista do trabalho do arquiteto, esta transposição de conceitos acaba sendo realizada também, assim como acontece nos "materiais", de forma pontual: no podium, na depressão, na malha de blocos de tijolo, enfim, em equipamentos e mobiliários isolados. Se há uma preocupação por parte de Hertzberger em trabalhar o ambiente em diferentes níveis, sua estruturação acaba se dando, porém, fundamentalmente na escala da arquitetura, do mobiliário e dos grandes equipamentos, pouco se relacionando com as atividades e exercícios desenvolvidos pelas crianças por meio dos "materiais" montessorianos, equipamentos e instrumentos menores e móveis (que também parecem ter suas explorações e finalidades esgotadas em si mesmas). O partido formal de Hertzberger acaba, assim, levando não tanto à conformação de um ambiente, ou um "laboratório de experimentações" (como é colocado pela proposta reggiana), onde elementos fixos, semi-fixos e móveis estão em constante interação e transformando-se uns aos outros, mas se concretiza como um espaço onde estas podem acontecer, de forma localizada.

Não podemos deixar de apontar, no entanto, riquezas na proposta de Hertzberger, tendo em mente que estas estão não tanto nas relações estabelecidas entre os 
elementos do ambiente escolar (e por isso, as suas limitações), mas no princípio de construção formal destes, principalmente dos equipamentos e mobiliários, que abrem possibilidades de interações diferentes com os usuários.

Ainda que o arquiteto trabalhe a partir de um rigor formal (euclidiano), cuja precisão e alta definição de linguagem acabem estabelecendo alguns limites à intervenção infantil (cujas possibilidades se esgotam a partir de um determinado momento), é interessante refletir sobre o conceito de polivalência que ali se coloca. A ambigüidade de forma proposta por Hertzberger, que, segundo ele, é o que dá o caráter polivalente aos seus objetos, não apenas permite que a organização e o uso dos espaços sejam modificados - o que acontece quando estes são pensados apenas a partir do conceito de flexibilidade - mas possibilita também que os próprios elementos sejam apropriados de formas diferentes, ganhando papéis e usos diversos, e criando situações, cenários e ambientes variados. Conforme a posição em que são dispostos e utilizados os objetos, conforme a combinação que se faz entre eles, ou, ainda, conforme o arranjo que se faz destes no espaço, novas relações são estabelecidas, seguindo a imaginação das crianças e/ou dos professores, e, às vezes, até mesmo, os surpreendendo com resultantes inesperadas.

Este princípio de polivalência a partir da ambigüidade da forma, apesar de enriquecedor da experiência ambiental $^{3}$, não é muito encontrado nos projetos para ambientes escolares infantis, não tendo sido observado, pelo menos não de forma marcante, nos demais projetos analisados.

Nas escolas Waldorf, com uma proposta que, em um primeiro momento, pode parecer semelhante, procura-se produzir (quando feitos pelos próprios pais, professores ou fornecedores próprios) objetos, principalmente brinquedos, de modo a não definir claramente suas formas ou delinear completamente seus elementos constituintes. Com a intenção de que as crianças possam interpretá-los de maneira o mais livre possível, muitos dos bonecos e bonecas não têm olhos, boca ou nariz, animais de madeira não têm seus detalhes entalhados, e assim por diante. Estes objetos, porém, não chegam a ser propriamente polivalentes em suas estruturas não assumindo formas diferentes conforme são apropriados, posicionados ou combinados; apenas permitem mais de uma interpretação, dada pela imaginação das crianças em cada momento específico (o que também é interessante, só menos provocador a intervenções e ações construtivas), uma vez que não há ambigüidade de formas, e sim, incompletude das mesmas.

Assim como acontece nas escolas Waldorf, a idéia de polivalência acaba sendo em geral explorada mais pela indefinição de usos e funções do que pelo trabalho de formas (ambígüas). Na Escola Viva, por exemplo, a polivalência observada nos equipamentos externos (principalmente) também se dá pela não definição de formas de apropriação específicas. Constituídos por tocos de madeira e combinados entre si e com elementos da natureza ou da arquitetura, estes equipamentos apenas possibilitam ou sugerem alguns usos, sem delimitá-los.

Já, de modo um pouco diferente, nas escolas de Reggio Emilia, a polivalência do ambiente é resultante das relações estabelecidas entre seus elementos constituintes. Não está nem na forma dos objetos, equipamentos ou mobiliários, nem tampouco apenas na indefinição ou na incompletude formal dos mesmos, mas está na possibilidade de transformação proporcionada principalmente pelos elementos móveis em combinação, intersecção ou interação com os elementos fixos e semi-fixos. Na relação entre a neutralidade da arquitetura, então passível de receber uma segunda pele, com a diversidade de materiais e instrumentos disponíveis, os quais, conforme a manipulação de suas características ou de seus estados, podem surtir efeitos diferentes, surge a capacidade do ambiente de tomar diferentes formas e servir a diferentes usos.

Um simples objeto como um projetor, cuja função básica é projetar luz, ao ser oferecido às crianças e aos professores, pode ser apropriado e ter seu uso direcionado das mais diferentes formas: pode possibilitar a projeção de luz na parede, no teto, no vidro ou em uma tela; pode proporcionar maiores ou menores projeções, mais ou menos constrói na relação com o universo ao seu redor. desenvolvendo-se à medida que investiga, compreende e transforma o mundo e a si mesma. 
intensas, mais ou menos coloridas; pode ter sua luz filtrada ou não; pode servir para projeções puras e diretas, ou pode ser utilizado para a criação de fusões entre imagens, objetos, pessoas, texturas e tudo o mais; enfim, pode ser utilizado para criar ambientes e situações as mais variadas. Assim como papéis, tecidos, tintas, plásticos e outros materiais podem ser utilizados para inúmeras intervenções nos vidros da arquitetura, interferindo na luz, nas cores, nas sombras, e em muitos outros aspectos do ambiente em que se inserem, influindo, inclusive, nas sensações e percepções daqueles que por ali passam ou ficam.

Retomando a noção de estrutura do ambiente, apresentada no início do texto, aqui podemos observar e destacar um outro rico princípio de construção do ambiente escolar infantil, também nem sempre lembrado em projetos deste tipo (diferente do projeto de Hertzberger, o que não significa que sejam excludentes e que não possam ser complementares): o jogo de equilíbrio e interação entre elementos fixos, semi-fixos e móveis, com suas diferentes capacidades de abrigar ou possibilitar transformações, estabelecendo uma relação entre legibilidade e clareza, na grande escala de percepção, e complexidade, na pequena. Um ambiente que se pretenda enriquecedor da experiência diária da criança e do processo de desenvolvimento desta tende a contrabalancear a segurança de suas partes estáticas por meio da diversificação de suas partes dinâmicas, sem cair no caos nem tampouco na monotonia.

Fortemente presente nas escolas reggianas, essa diversidade dos elementos semi-fixos e móveis (equipamentos e instrumentos menores e materiais principalmente), que permitem a manipulação das crianças de forma a estabelecer relações de interação e transformação do espaço e da arquitetura, é pouco presente nas demais escolas analisadas, ou, quando existente, é pouco explorada pelas crianças em conjunto com os professores.

No Santa Cruz, não foi muito observada, parecendo ser poucos e pouco variados os objetos e instrumentos disponibilizados para as crianças brincarem, criarem e modificarem os espaços e situações que vivenciam. Nas horas de recreio, a maioria dos elementos a elas oferecidos tem funções e usos relativamente predefinidos, como bolas, cordas e colchões - o que não impede que estes sejam apropriados de formas diferentes pelas mesmas, mas de forma limitada -, e, durante as atividades em salas, parece haver um direcionamento maior para trabalhos e projetos que se esgotam neles próprios, sem que haja interação ou investigação do universo ao redor. A diversidade do ambiente, interno principalmente, acaba construída essencialmente na heterogeneidade do trabalho de mosaico proposto pelo projeto de ambientação, o qual, porém, é fixo, perdendo, assim, sua riqueza e se transformando em homogeneidade quando é repetido de forma muito similar em quase todos os ambientes, sem permitir qualquer intervenção ou transformação por parte das crianças e/ou dos professores.

Já na Escola Viva e na Waldorf Rudolf Steiner, percebemos uma procura maior em se trabalhar a diversidade dos elementos móveis e semi-fixos na construção da complexidade de seus ambientes (na pequena escala) ${ }^{3}$, mas ainda de forma não tão ricamente explorada como nas escolas reggianas.

Na primeira proposta, esta diversidade existe fundamentalmente em suas áreas externas, e é pouco trabaIhada no interior das salas, ou mesmo nas atividades e projetos desenvolvidos pelas crianças, as quais exploram e/ou estabelecem relações de forma ainda tímida com os recursos existentes nos espaços externos da escola. E na segunda proposta, se estimula mais a vivência e a percepção sensorial pontuais (do cheiro, da cor, da textura, etc.) do que propriamente a experimentação transformadora das relações existentes nos ambientes.

Se na Escola Viva há, por um lado, um menor direcionamento da exploração sensorial nas atividades desenvolvidas no dia-a-dia com as crianças, e um não aproveitamento da potencialidade máxima dos recursos de seus ambientes, há, por outro lado, um interessante dinamismo na transformação dos seus ambientes tanto no curto quanto - e parece que principalmente - no médio e no
3 Sem deixar de manter o equilíbrio com a legibilidade do conjunto de seus espaços, apesar de esta, na Escola Viva, se perder algumas vezes em função da expansão e da construção irregular dos edifícios. 
longo prazos. Apesar de pouco investigarem o universo ao seu redor, as crianças e os professores da Escola Viva, além de o modificarem no seu dia-a-dia por meio de apropriações diversas, desenvolvem, ao longo do ano, projetos que aí se inserem, alterando os ambientes tanto internos quanto externos com o passar do tempo.

A dinâmica de transformação (relação espaço-tempo) é, assim, mais um ponto interessante e importante a se discutido no projeto e na construção de ambientes escolares infantis, uma vez que a complexidade destes está diretamente relacionada com a idéia de expectativas violadas e diferenças perceptíveis, ou seja, com as variações dentro de uma ordem - pois são as mudanças de estímulos que são percebidas, e não os estímulos por si só. Especialmente se tratando de crianças, como vimos no capítulo 2, para que estas sejam provocadas e estimuladas a buscar novas maneiras de adaptação e de comportamentos e ações bem-sucedidas, o meio deve romper o seu equilíbrio por meio de constantes estimulações (diferenças perceptivas). Deve, portanto, apresentar novas informações que coloquem o organismo em estado de alerta (Rapoport 1978, p.172; Pignatari 1977, p.58), o que pressupõe mudanças ao longo do tempo.

$\mathrm{Na}$ Escola Viva, isso parece acontecer de forma constante, tanto por parte da diretoria em diálogo com arquitetos e profissionais da área, como por parte de seus usuários em geral. Não só são realizadas mudanças diárias e semanais através de projetos mutantes e temporários, como também são produzidas transformações mensais, semestrais ou anuais nos elementos fixos e semi-fixos, por meio de reformas projetadas ou acompanhadas por arquitetos e de projetos mais duradouros desenvolvidos pelas crianças em conjunto com os professores (intervenções em vidros e pisos, produção de painéis e/ou objetos de decoração, etc.)

Nas escolas reggianas, se por um lado há um movimento de constante exploração e transformação temporária dos ambientes, por outro, parece haver poucas alterações nos seus elementos fixos ou semi-fixos. Dando grande atenção à história de sua experiência, a proposta reggiana parece procurar preservar e querer comunicar muito do que já foi feito e descoberto, às vezes dando menos espaço para que novas conquistas e realizações se manifestem também de maneira um pouco mais duradou ras nos seus ambientes. Painéis sobre atividades e projetos antigos, assim como intervenções em grande escala realizadas por grupos de crianças em um dado momento, são muitas vezes mantidos de forma fixa nas escolas, não sendo substituídos nem tampouco convivendo com outros mais recentes.

Nas demais escolas, os conceitos de segurança e de constância parecem predominar, principalmente nas escolas Waldorf, onde se considera que, dada a complexidade do mundo exterior, cabe à escola reconstruir a idéia de "la familiar", acolhedor, com menos desequilíbrios.

Nesta proposta, ao mesmo tempo que acolhimento e proteção são marcantes, não se deixa, porém, de promover e incentivar o que talvez possa ser considerado um dos aspectos mais ricos da experiência waldorfiana e mais um princípio fundamental para a construção de ambientes escolares infantis: a vivência do mundo (sem fazer juízo aqui de que mundo é considerado por esta) através dos sentidos - que, segundo esta pedagogia, não são apenas cinco, mas doze.

Mais um princípio, portanto, que podemos ressaltar para a reflexão sobre o projeto de ambientes escolares, e que podemos ver ser desdobrado sob formas variadas nas diferentes escolas aqui apresentadas: a polissensorialidade das experiências e explorações propostas, tendo como conceito norteador a natureza polivalente da percepção.

Este princípio é também fortemente considerado e trabalhado nas escolas reggianas, e considerado, porém talvez um pouco menos trabalhado, na Escola Viva. Na escola projetada por Hertzberger, a exploração sensorial parece acontecer pontualmente e de forma direcionada nas atividades realizadas com os "materiais" montessorianos, e, no Santa Cruz, parecem predominar os estímulos visuais e táteis, em detrimento dos demais. 
Como pudemos observar ao longo desta dissertação, inúmeros são os mecanismos e princípios de construção de ambientes escolares infantis. Neste capítulo, procuramos recuperar e destacar alguns deles, os quais acreditamos que, junto aos elementos de projeto que apontamos duran te as análises (organização espacial, campo visual, recursos do ambiente, formato e dimensão das salas, materiais texturas, etc.), talvez possam sugerir caminhos de criação e construção de complexidade e riqueza ambiental.

Fica claro, aqui, que pressupomos a complexidade como um aspecto fundamental no desenvolvimento de projetos de ambientes, principalmente escolares, onde um dos seus papéis é justamente o de proporcionar possibilidades de aumento de repertório, permitindo assim o desenvolvimento do conhecimento, do vocabulário e da compreensão da relação entre as coisas ${ }^{4}$.

Como comentamos, mais do que avaliar as propostas aqui apresentadas, ou colocar alguma delas como modelo a ser seguido, então, pretendemos com este trabalho observar mais de perto experiências concretas, extraindo destas elementos e questões para a reflexão sobre projetos de ambientes educativos (sob o ponto de vista da arquitetura e do design), e chamando, assim, a atenção para a importância e representatividade das escolhas soluções ambientais físicas na construção das vivências de aprendizagem das crianças.

Este trabalho procura de alguma forma questionar a usual primazia do espaço em detrimento do ambiente. feita tanto por parte de arquitetos como de educadores. Além de desconsiderar todas as questões aqui colocadas em relação à importância da complexidade ambiental para o desenvolvimento infantil, este olhar voltado unicamente para o espaço acaba muitas vezes se colocando como obstáculo ou mesmo desculpa para que medidas concretas de melhoria nas escolas sejam realizadas.

Principalmente no Brasil, a discussão em torno desse tema se mostra ainda muito atrasada, e se faz urgente colocá-lo em pauta sob novos enfoques ou de forma mais efetiva. Na rede pública, especialmente, ainda estamos nos debatendo sobre questões de infra-estutura básica, e, na rede privada, muitos dos discursos e discussões ficam no âmbito teórico ou abstrato. Ainda que estejamos inseridos em um contexto de grandes dificuldades, sejam elas políticas, econômicas ou de outra natureza, é importante que mudemos a abordagem da problemática. Diante da realidade atual, é preciso repensar a função social da escola. Como discutimos no segundo capítulo, hoje exige-se pensar além dos conteúdos formativos da etapa da infância, questionando-se qual a verdadeira contribuição da Educação Infantil para o desenvolvimento do indivíduo como um todo, por completo. Exige-se perceber que a infância não se restringe à fase dos 0 aos 7 anos apenas, e que é essencial que se dê continuidade ao processo de formação da criança quando esta passa da pré-escola para o Ensino Fundamental, tomando-a como ser social e não como "aluno" a ser "preenchido" e "completado".

Nesse novo contexto, a escola infantil deve construir uma proposta aberta, em diálogo com o seu tempo, com a nova sociedade e com o novo papel social que exerce hoje a criança na comunidade. Não podemos mais pensar a escola e, conseqüentemente, seu ambiente, apenas como espaços de ensino (muito menos tão-somente de assistência, acolhimento ou lazer), mas devemos concebê-la para além disso, como ambiente de aprendizagem, de tro$\mathrm{ca}$, de experimentação e de desenvolvimento, individual e coletivo, da condição humana e da cidadania.

Não podemos mais manter, portanto, o isolamento entre arquitetura-urbanismo-design e pedagogia, sociologia, psicologia, e áreas afins. Como diz Ana Beatriz Goulart, "Arquitetura e o Urbanismo só reencontrarão seu sentido, significado e papel social, tanto no contexto do debate sobre a Educação Infantil, quanto em outro mais amplo, o da Cultura e Educação brasileiras, caso nos disponhamos a superar o monólogo dominante nesta prática (do qual os não lugares - lugares que não têm nenhum significado, segundo Marc Augé - são oriundos) e passemos a dialogar com outras áreas do conhecimento e, a partir disso, rever nossos princípios e padrões de produção de conhecimento
${ }^{4}$ A complexidade de um ambiente está relacionada com as variações dentro de uma ordem, ou seja, com as diferenças percebidas. A informação admissível depende dos estímulos que se detectam como variáveis dentro de um sistema de expectativas: são as mudanças nos estímulos que são percebidas, e não os estímulos por si só (Gibson 1968; Rapoport e Hawkes 1970; Rapoport 1978). 
${ }^{5}$ Entendemos que nos cabe questionar qual o grau de abertura que o partido formal que adotamos em um determinado projeto apresenta em relação à intervenção (marcas, índices) das crianças, bem como em relação à capacidade de reprocessar esses sinais. As análises que fazemos das escolas estruturam-se em parte sobre esta reflexão, que pode ser entendida, sob o olhar da semiótica, a partir do que Décio Pignatari aponta com os "três tipos de montagem" do universo icônico: montagem (sintática), colagem (semântica) e bricolagem (pragmática). Ver PIGNATARI, Décio. "Semiótica da montagem". In: Revista Através no 1 , São Paulo, Martins Fontes, 1982, pp.168-169. e de lugares, na dimensão dos objetos arquitetônicos e urbanos". "O que proponho é que, a partir do pensar-fazer arquitetura e do pensar-fazer pedagogia, olhemos para a questão do projeto e implantação do lugar pedagógico da infância, em todas as dimensões possíveis, para todas as infâncias. É um caminho de mão dupla, onde arquiteturas se educam nas pedagogias e pedagogias se espacializam no projeto e nas suas arquiteturas" (Faria 2007, p.99).

Estamos nesse momento lidando com novos valores e novos entendimentos sobre o desenvolvimento infantil. $\mathrm{O}$ que se coloca hoje, mais do que nunca, é a importância de se promover a identidade pessoal, e a infância é o momento crucial para desenvolvimento do potencial do indivíduo. A realidade de hoje cada vez mais exige que se pense em "um projeto educativo que ative e valorize não só a capacidade crítica, comunicativa e relacional das crianças, mas sua capacidade projetiva e criativa, a partir da sua vontade de fazer coisas" (Dolto 1998).

E, uma vez que a identidade pessoal está intrinsecamente ligada à noção de identidade de lugar (Oliveira 2007, p.107), é importante que o ambiente infantil seja planejado para dar oportunidade para as crianças desenvolverem sua individualidade, permitindo-Ihes ter seus próprios objetos, personalizar seu espaço e, sempre que possível, participar nas decisões sobre a organização do mesmo. Devemos partir do princípio e trabalhar com mecanismos que considerem a participação das crianças nesse processo. Pois só quando permitirmos e oferecermos às crianças condições de experimentarem autonomamente a exploração, a ocupação e a transformação dos lugares, é que elas poderão de fato se desenvolver cognitiva, social e fisicamente.

Devemos sempre, então, nos perguntar, assim como á fazia Mayumi Souza Lima, se estamos projetando e construindo ambientes "para a criança, com a criança ou da criança". Pois "é preciso deixar o espaço suficientemente pensado para estimular a curiosidade e a imaginação da criança, mas incompleto o bastante para que ela se aproprie e transforme este espaço através da sua própria ação" (Mayumi 1989 p.72).
A personalização de espaços e objetos é fundamental no desenvolvimento da identidade pessoal. Portanto, talvez devamos projetar ambientes em que as crianças possam re-significar, transformar, propor, recriar, explorar e modificar o que foi planejado. O que significa, entre outras coisas, dar espaço para o imprevisto (não a improvisação) e possibilitar o convívio das mais variadas diferenças.

Isso implica considerar todas as dimensões humanas potencializadas nas crianças: o imaginário, o lúdico, o artístico, o afetivo, o cognitivo, etc. (Faria 2005, p.74), e considerar, portanto, a plurissensorialidade das mesmas. Se o processo de descoberta diária do mundo, como vimos nos capítulos anteriores, se dá, na criança especialmente, por meio das experiências sensoriais que esta vive, provocadas por constantes estimulações e novas informações que coloquem o organismo em estado de alerta, o pro cesso de ensino-aprendizagem deve ser fundamentado e estruturado na lógica do encantamento e da descoberta (Faria 2005), procurando-se estimular a curiosidade e garantir o espaço para as suas investigações.

Como diz Ana Beatriz Goulart, "é necessário transformarmos a curiosidade num verbo e conjugá-lo diariamente, sem deixar que as incertezas interrompam esse caminho. (...) Se procurarmos garantir um cotidiano em festa, em contentamento engajado, comprometemo-nos em ampliar a dimensão criativa, criadora e estética do dia-a-dia de meninos e meninas, bem como daqueles que com eles e elas trabalham. Desenho, brincadeira, todas as formas de expressão das crianças tornam-se grandes, e agigantam-se, proporcionando que o prazer das descobertas, das elaborações, torne-se alegria e se constitua como um currículo que não engesse a todos, adultos e crianças, ao transformarem seu cotidiano em antecipação da escolarização, gradeado por muros invisíveis que se tornam tão claros quando percebemos o conhecimento fragmentar-se em áreas que pouco ou nada dialogam entre si" (Faria 2007, p.120)

Talvez possamos fazer com que os ambientes escolares infantis, mais do que dêem suporte ao processo de 
ensino-aprendizagem, possibilitem o aumento de repertório daqueles que o utilizam, alimentando o imaginário das crianças, dos professores e dos demais usuários, e dando condições e proporcionando oportunidades para o desenvolvimento de novos olhares, e para a capacidade de transformação e criação de novos universos ${ }^{6}$. É fundamental que projetemos ambientes que, mais do que atendam necessidades, possibilitem transformações e, conseqüentemente, a construção de identidades pessoais.

Diante da realidade atual, da sociedade da informação, da comunicação e da tecnologia, em que espaço e tempo ganham novas dimensões, em que valores e visões de mundo são questionados, e em que não há mais espaço para verdades e certezas absolutas, percebe-se cada vez mais que precisamos formar cidadãos criativos, que saibam experimentar, investigar, questionar, analisar e projetar, e que não tenham receio do outro, da diferença, do novo, do desconhecido. Em um mundo instável, em constante transformação, cada vez mais intensas e maiores, é preciso saber lidar com a realidade de forma versátil, consciente, responsável e criativa.

E a escola de uma forma geral talvez deva, assim, estar aberta a experiências, à multidimensionalidade e à polivalência das áreas de conhecimento, e, assim, estar em permanente transformação e construção. Sem deixar de se furtar à responsabilidade de pensar a questão pública, é importante, ainda, que procure se integrar à comunidade e à cidade, criando e fortalecendo laços de relação com outras instâncias, o que já temos visto acontecer em alguns lugares do mundo, por meio do que se conhece hoje como o lema da "cidade educadora", onde a escola desenvolve um trabalho formativo vinculado ao trabalho que é realizado por outros agentes de formação (família, município, instituições culturais, etc.). Uma questão que vem sendo debatida globalmente e que merece ainda novas e mais profundas investigações e reflexões.

Diante de tudo isso, portanto, parece que, mais do que nunca, cabe a nós retomar e refletir sobre a idéia de "arquitetura do lugar", como colocava Mayumi Souza Lima, ou de "projeto do lugar", como defendem hoje pensadores e pesquisadores como Vicente del Rio, Robert Sommer, Ana Beatriz Goulart, entre outros ${ }^{7}$. Sem se contrapor ou negar os processos socioeconômicos, culturais e tecnológicos que estamos vivendo ultimamente, ao contrário, tendo em consideração todos estes movimentos que vêm transformando, entre inúmeras outras coisas, a maneira como concebemos e vivenciamos os espaços, sejam eles nossas casas ou nossa cidade, e o modo como construimos e estabelecemos nossos laços e noções de identidade, é fundamental que reflitamos sobre o significado e o papel do contexto e das culturas locais e a importância destes para o desenvolvimento de projetos de arquitetura e ambientes em geral ${ }^{8}$.
${ }^{6}$ Ambiente escolar e proposta educativa devem estar em sintonia, potencializando-se um ao outro de forma a criar oportunidades ricas de vivência e de crescimento. Mais do que os resultados, são os processos investigativos e criativos que têm significado para o desenvolvimento do indivíduo, e por isso não podemos desconsiderar a grande importância do papel do professor como estimulador e facilitador da aprendizagem.

7 Ver Projeto do Lugar: colaboração entre psicologia, arquitetura e urbanismo, livro organizado por Vivente del Rio, Cristiane Rose Duarte e Paulo Afonso Rheingantz.

${ }^{8}$ Como nos mostram, no caso dos ambientes escolares infantis vistos ao longo deste trabalho, experiências como a de Reggio Emilia, a dos Parques Infantis, a das EMEIs/CEDEC, entre outras, tanto no que diz respeito ao envolvimento da comunidade na construção dos espaços educativos, quanto com relação à disponibilidade e características dos recursos disponiveis para a mesma. 


\section{CRÉDITOS DAS IMAGENS}

Muitas das imagens reproduzidas nesta dissertação foram extraídas da internet e de publicações que não se encontravam em bom estado de conservação. Apesar de terem recebido tratamento digital, não nos foi possível al-

cançar em todas elas a qualidade desejada.

ACERVO TATIANA MACHADO. Páginas: 102, 106-109, 111-125, 127-132, 134, 136-161, 164, 168-177, 179-185, 187-189 $201-209$

ACERVO ESCOLA INFANTIL SANTA CRUZ. Páginas: 135 ACERVO ESCOLA VIVA. Páginas: 105.

CEPPI, Giulio e ZINI, Michele. Bambini, Spazi, Relazioni. Metaprogetto di ambiente per l'infanzia. Regiio Children Domus Academy Research Center, Reggio Children e Comune di Reggio Emilia - Nidi e Scuole dell'infanzia, 1998. Páginas:58, 64, 66, 68, 70-72, 74-75, 77-85, 198-199.

HERTZBERGER, Herman. Lições de Arquitetura. Trad. Carlos Eduardo Lima Machado. São Paulo: Martins Fontes, 1996. Páginas: 38, 41, 44-46, 48, 53-56, 200.

LIMA, Mayumi Souza. Arquitetura e Educação. São Paulo: Nobel, 1995. Páginas: 98, 100.

NIEMEYER, Carlos Augusto da Costa Niemeyer. Parques Infantis de São Paulo: lazer como expressão de cidadania São Paulo: Anablume, 2002. Páginas: 94-95.

Uma contribuição para a pesquisa em História do Paisagismo: os Parques Infantis e as ressonâncias da tipologia Reform Park em São Paulo. Artigo publicado na Revista Paisagens em Debate, Revista eletrônica da áre de Paisagem e Ambiente, FAU USP. São Paulo, Novembro de 2005. Páginas: 95.

REGGIO CHILDREN. Advisories. Municipality of Reggio Emilia Infant-toddler Centers amd Preschools, 2002. Páginas: 63-69, 73, 76-77, 79-80, 82, 84-85, 198-199

REGGIO CHILDREN. The Hundred Languages of Children Catalogue of the exhibit, 1996. Reggio Emilia, Itália. Páginas:58, 67, 70-75, 77-85, 198-199.

http://www.montessoridelft.nl . Páginas: 42, 48, 52-56.

http:// www.montessorienfrance.com. Páginas: 40, 51. 


\section{BIBLIOGRAFIA}

ALMEIDA, Elvira de. Arte lúdica. São Paulo, Edusp/ FAPESP, 1977

ALVES, Rubens; DIMENSTEIN, Gilberto. Fomos maus alunos. Papirus Editora. Campinas, SP, 2003

BEARD, Ruth M. Como a criança pensa: a psicologia de Piaget e suas aplicações educacionais. Trad. Aydano Arruda. 119a ed. São Paulo: IBRASA, 1999

BENCOSTA, Marcus Levy Albino (org.). História da Educação, Arquitetura e Espaço Escolar. São Paulo: Cortez, 2005.

BENEVENTO, Márcia Maria. Espaço de Relacionamento: a presença do lúdico nas atividades de recreação Dissertação de mestrado. São Paulo: FAUUSP, 1999.

BENJAMIN, Walter. Reflexões sobre a cirança, o brinquedo e a educação. Trad. Marcos Vinicius Mazzari. São Paulo: Duas Cidades; Editora 34, 2002

BERGEIJK, Herman Van e Deborah Hauptmann. Notations of Herman Hertzberger. Netherlands: NAi Publishers, 1998.

BRANDÃO, Carlos Rodrigues. O que é educação. São Paulo: Editora Brasiliense, 2006

BRASÍLIA Lei de Diretrizes e Bases da Educação Nacional 9394, de 20 de dezembro de 1996.

BULLIVANT, Lucy. The currencies of childhood. In: Kid Size. The material of childhood. Milan: Skira editore, 1997 pp. 13-24.

Caderno Temático de Formação II - Educação Infantil. Construindo a Pedagogia da Infância no Município de São Paulo. São Paulo, Janeiro de 2004.

CAMPOS, Maria Malta. Educação Infantil. Disponível em www.aomestre.com.br/raio x/66 educ inf.htm: Acesso em abril de 2007
CARNEIRO, Maria Ângela Barbato. A educação infantil, as políticas públicas e o Banco Mundial. In: Revista PUC Viva, n²1. São Paulo, 2004.

CARVAlHO, Mara I. Campos de; e RUBiAnO, Márcia R. Bonagamba. Organização do Espaço em Instituições Préescolares. In: Educação Infantil: muitos olhares. $7^{\mathrm{a}} \mathrm{ed}$ São Paulo: Cortez Editora, 2007

CASTRO, Fabíola Fiúza Malerbi de Castro. Relação espaçoaprendizado: uma análise do ambiente pré-escolar Dissertação de mestrado. São Paulo: FAUUSP, 2000.

CEPPI, Giulio e ZINI, Michele. Bambini, Spazi, Relazioni. Metaprogetto di ambiente per l'infanzia. Regiio Children Domus Academy Research Center, Reggio Children Comune di Reggio Emilia - Nidi e Scuole dell'infanzia, 1998.

CONESP. Relatório Jardim Fortaleza. Guarulhos, 1984

DEL RIO, Vicente; DUARTE, Rose e RHEINGANTZ, Paulo Afonso (orgs.). Projeto do lugar: colaboração entre psicologia arquitetura e urbanismo. Rio de Janeiro: Contra Capa Livraria/PROARQ, 2002

DOLTO, Françoise. L'enfant dans la ville. Éditions Gallimard, Paris, 1998.

EDWARDS, Carolyn; GANDINI, Lella e FORMAN, George. As cem linguagens da criança: a abordagem de Reggio Emilia na educação da primeira infância. Trad. Dayse Batista. Porto Alegre: Artmed, 1999.

FARIA, Ana Lúcia Goulart de e PALHARES, Marina Silveira (orgs.). Educação infantil pós-LDB: rumos e desafios. $5^{a}$ ed. Campinas, SP: Autores Associados, 2005. Coleção polêmicas do nosso tempo. 
FARIA, Ana Lúcia Goulart de, MELLO, Suely Amaral (orgs.) Territórios da infância: linguagens, tempos e relações para uma pedagogia para as crianças pequenas. Araraquara, SP: Junqueira\&Marin, 2007.

FARIA, Ana Lúcia Goulart de. A contribuição dos parques infantis de Mário de Andrade para a construção de uma pedagogia da educação infantil. Artigo revisto e ampliado do trabalho apresentado no IV Simpósio Latino-Americano de Atenção à Criança de 0 a 6 anos e no II Simpósio Nacional de Educação Infantil, Brasília novembro de 1996. In: Revista Educação \& Sociedade, ano XX, nº9, Dezembro de 1999.

FARIA, Ana Lúcia Goulart de. Direito à infância: Mário de Andrade e os parques infantis para as crianças de família operária da cidade de São Paulo (1935-1938) Tese de Doutorado. São Paulo: FEUUSP, 1996.

. O espaço físico como um dos elementos fundamentais para uma Pedagogia da Educação Infantil. In: Educação infantil pós-LDB: rumos e desafios. Ana Lúcia Goulart de Faria e Marina Silveira Palhares (orgs.). $5^{\mathrm{a}}$ ed. Campinas, SP: Autores Associados, 2005. Coleção polêmicas do nosso tempo).

Educação pré-escolar e cultura. $2^{\mathrm{a}}$ ed. Campinas: Cortez Editora, 2002.

FERRARA, Lucrecia D'Alessio. Design em Espaços. São Paulo: Edições Rosari, 2002. Coleção Textos Design.

FORNEIRO, Lina I. A organização dos espaços na educação infantil. In: ZABALZA, Miguel. Qualidade em educação infantil. Trad. Beatriz Affonso Neves. Porto Alegre: ArtMed 1998, pp.229-281.

FREIRE, Paulo. Education for critical consciousness. Crossroad Publishing Company, 1974

Pedagogia da Autonomia: saberes necessários à prática educativa. São Paulo: Paz e Terra, 1996 (Coleção Leitura).

FREYBERGER, Adriana. O Espaço do Brincar. Dissertação de Mestrado. São Paulo: FAUUSP 2000.

A construção do ambiente educativo. Tese de Doutorado. São Paulo: FEUSP 2005.

GIBSON, James J. La percepción del mundo visual. Ediciones Infinito, Buenos Aires, 1974.
HALL, Edward T. A dimensão oculta. São Paulo: Martins Fontes, 2005.

HERTZBERGER, Herman. Lições de Arquitetura. Trad. Carlos Eduardo Lima Machado. São Paulo: Martins Fontes, 1996.

KISHIMOTO, Tizuko M. Escolarização e brincadeira na educação infantil. Texto extraído do site da Faculdade de Educação da USP, Laboratório de brinquedos e materiais pedagógicos (www.fe.usp.br/laboratorios/labrimp/escola.htm).

LANZ, Rudolf. A Pedagogia Waldorf: caminho para um ensino mais humano. $5^{a}$ ed. São Paulo: Antroposófica, 1990.

LIMA, Mayumi Souza. A cidade e a criança. São Paulo: Nobel, 1989. Coleção Cidade Aberta.

Arquitetura e Educação. São Paulo: Nobel, 1995.

Centro de desenvolvimento de equipamentos urbanos e comunitarios : escolas - manual do usuario São Paulo: Emurb-Cedec, 1992.

MAZZILLI, Clice Sanjar. Arquitetura Lúdica: criança, projeto e linguagem. Tese de Doutorado. São Paulo: FAUUSP 2003.

Ministério da Educação. Secretaria de Educação Básica. Parâmetros Básicos de Infra-estrutura para Instituições de Educação Infantil. Brasília, DF: MEC/SEB, 2006.

MIRANDA, Angélica. Arquitetura e educação: juntas por uma educação infantil melhor. In: Revista Criança do Professor de educação infantil, $n^{\circ} 43$. Rio de Janeiro, RJ: agosto de 2007. Ministério da Educação.

MUNARI, Bruno Das coisas nascem coisas. Trad. José Manuel de Vasconcelos. São Paulo: Martins Fontes, 1998.

Design e Comunicação visual: contribuição para uma metodologia didática. Trad. Daniel Santana. São Paulo: Martins Fontes, 1997.

NIEMEYER, Carlos Augusto da Costa Niemeyer. Parques Infantis de São Paulo: lazer como expressão de cidadania. São Paulo: Anablume, 2002.

Uma contribuição para a pesquisa em História do Paisagismo: os Parques Infantise as ressonâncias datipologia Reform Park em São Paulo. Artigo publicado na Revista Paisagens em Debate, revista eletrônica da área de Paisagem e Ambiente, FAUUSP. São Paulo, Novembro de 2005. 
OLDIGES, Jutta. Maria Montessori's concept of the prepared environment: 'the interior as a living world of learning'. In: Kid Size. The material of childhood. Milan: Skira editore, 1997, pp.175-182.

OLIVEIRA, Zilma Moraes R. de (org.). Educação infantil: muitos olhares. $7^{\mathrm{a}}$ ed. São Paulo: Cortez, 2007.

PIGNATARI, Décio. Informação. Linguagem. Comunicação São Paulo: Perspectiva, $8^{\mathrm{a}}$ ed., 1977.

PIGNATARI, Décio. Semiótica da montagem. In. Ver. Através $n^{\circ}$ 1., São Paulo, Martins Fontes, 1982

RAPOPORT, Amos and HAWKES, RoN. The perception of urban complexity. Artigo publicado no Journal of the American Institute of Planners, March 1970

RAPOPORT, Amos and KANTOR, Robert E. Complexity and Ambiguity in Environmental Design. Artigo publicado no Journal of the American Institute of Planners, July 1967, pp. 210-221.

RAPOPORT, Amos. Aspectos humanos de la forma urbana: hacia una confrontación de las Ciencias Sociales con el diseño de la forma urbana. Trad. Josep Muntañola i Thornberg. Barcelona, Gustavo Gili, 1978 (Colección Arquitectura/Perspectivas).

REGGIO CHILDREN. Advisories. Municipality of Reggio Emilia Infant-toddler Centers amd Preschools, 2002.

REGGIO CHILDREN. Brochura de apresentação do Centro internazionale per la difesa e la promozione dei diritti e delle potenzialità dei bambini e delle bambine, s/d.

REGGIO CHILDREN. Rechild. Reggio Children Newsletter. Dezembro de 2005.

REGGIO CHILDREN. Rechild. Reggio Children Newsletter. Outubro de 2001

REGGIO CHILDREN. The Hundred Languages of Children Catalogue of the exhibit, 1996. Reggio Emilia, Itália.

REGGIO COMUNE. Scuole e Nidi d'Infanzia. Istituzione de Comune di Reggio Emilia. Reggio Comune. Notiziario quindicinale dell'Amministrazione Comunale di Reggio Emilia. $n^{\circ}$ 10. Dezembro 2005

RINALDI, Carla e VECCHI, Vea. Atelier ${ }^{3}$. Arredi per l'infanzia Reggio Emilia: Reggio Children, 2005
ROMÃO, Flavia Fernanda. A dimensão espacial da escola de educação infantil enquanto ambiente de desenvolvimento humano e pedagógico. Memoria apresentado ao Curso de Pedagogia/PROESF. Faculdade de Educação, Universidade Estadual de Campinas. Americana 2006.

SAYÃO, Suely; AQUINO, Julio Groppa. Em defesa da escola. Papirus Editora. Campinas, SP, 2004

SANTA CRUZ, Colégio. Plano Diretor 2007. São Paulo, 2007.

TOMIE OHTAKE. Folder da exposição As 100 Linguagens da Criança, A educação para a infância em Reggio Emilia realizada no Instituto Tomie Ohtake, em São Paulo, SP entre os dias 15 e 30 de setembro de 2007.

TURINO, Célio. Educação não formal, jogo e brincadeira. In Cadernos Cenpec. $2^{a}$ ed. São Paulo, SP: Cortez Editora: CENPEC, 2006.

VITRA DESIGN MUSEUM. Kid Size. The material of childhood. Milan: Skira editore, 1997

ZABALZA, Miguel A. Didática de la Educación infantil. Madrid: Narcea, 1987

ZABALZA, Miguel A. Qualidade em educação infantil. Trad. Beatriz Affonso Neves. - Porto Alegre: ArtMed, 1998.

Sites na internet

http:// www.montessori.edu

http:// www.montessori.it

http:// www.montessorienfrance.com

http://www.montessoridelft.nl

http://navir.asso.free.fr/

http://www.escolacarlitos.com.br/

http://www.escoladavila.com.br/

http://www.ewrs.com.br

http://www.highscope.org

http://www.santacruz.g12.br/

http://www.summerhillschool.co.uk

http://www.vitruvius.com.br/ac/ac003/ac003 3.asp

http://www.waldorf.com.br

http://zerosei.comune.re.it 